Special Distribution

Issued: December 1977

\title{
Radiological Survey and Decontamination of the Former Main Technical Area (TA-1) at Los Alamos, New Mexico
}

\author{
Compiled by
}

A. John Ahlquist

Alan K. Stoker

Linda K. Trocki 


\section{CONTENTS}

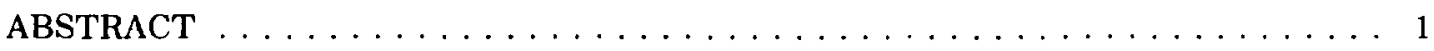

EXECUTIVE SUMMARY $\ldots \ldots \ldots \ldots \ldots \ldots \ldots \ldots$

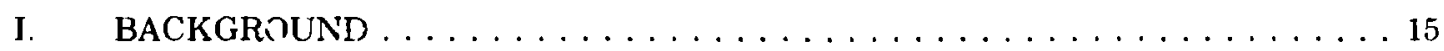

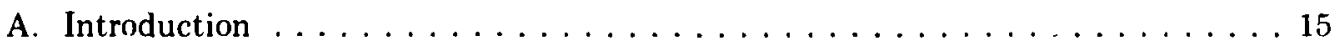

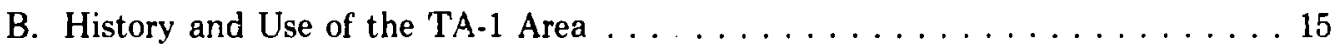

II. SURVEY, EXPLOPATION, AND DECONTAMINATION:

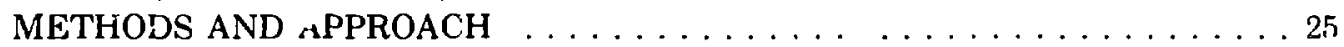

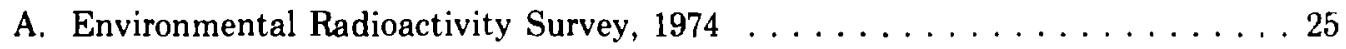

B. Intensive Exploration and Investigation, $1975-1976 \ldots \ldots \ldots \ldots \ldots$

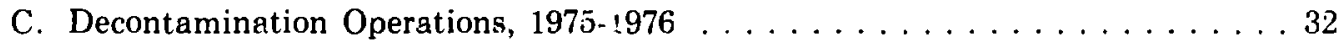

III. RESULTS OF EXPLORATORY AND DECONTAMINATION OPERATIOIS _. 37

A. Genera! 'TA-1 Area $\ldots \ldots \ldots \ldots \ldots \ldots \ldots \ldots \ldots \ldots$

B. Ares vith Plutonium as Principal Contaminant $\ldots \ldots \ldots \ldots \ldots \ldots$

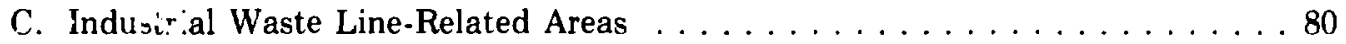

D. Areas with Uranium as the Principal Contaminant $\ldots \ldots \ldots \ldots \ldots$

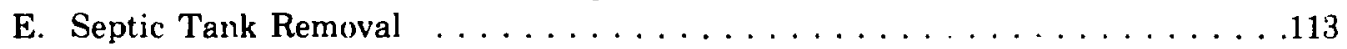

F. Developed Areas with Contamination Potential . . . . . . . . . . . .118

G. Coniamination Remaining on ERDA Property Adjacent to TA - $1 \ldots \ldots$. . . . 122

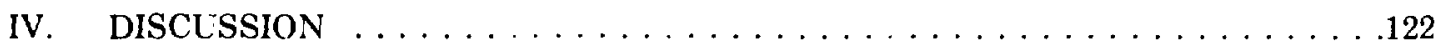

APPENDIX A. Summary of Records Search and Discussions with

L.ASL Personnel Concerning Buildings and Drain Lines in TA.1

Where Radioactive Materials Were Processed . . . . . . . . . . . . . . . . . 124

APPENDIX B. Structure Identification, Removal Date, and

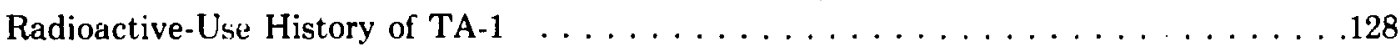

APPENDIX C. Letter Describing TA-1 Contamination Status and

H-Division Recommendations, January $13,1960 \ldots \ldots \ldots \ldots \ldots$

APPENDIX D. Instrumentation and Methods Used in the 1974 Survey . . . . . . . .147

APPENDIX E. Radiochemical Data from 1974 Envi

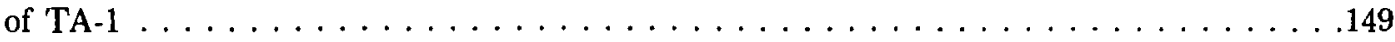

APPENDIX F. Radiological Instrumentation Used During TA-1 Cleanup . . . . . . . . 164 
APPENDIX G. Dicailed Results of Environmental Air Sampling . . . . . . . . . . 174

ACKNOWLEDGMENTS . . . . . . . . . . . . . . . . . . . . . . . . . . . 179

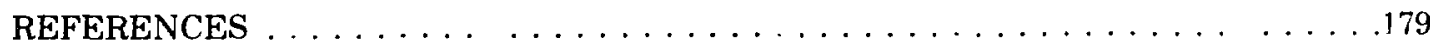

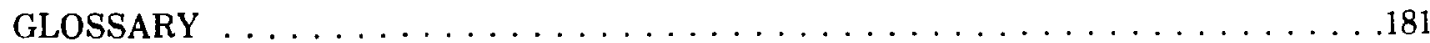

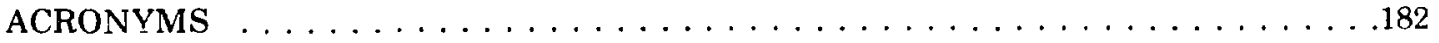

\section{TABLES}

Summary of Surface Sampling Results from 1974 Survey $\ldots \ldots \ldots \ldots \ldots$

I. Buildings at TA-1 That Housed Operations Involving

Radioactive Contamination Potential . . . . . . . . . . . . . . . . . 20

II. Summary of Surface Sampling Results from 1974 Survey . . . . . . . . . . 29

III. Meetings at Which As-Low-As-Practicable Detontamination

Was Determined . . . . . . . . . . . . . . . . . . . . . . . . 39

IV. Material Removed from Major TA-1 Excavations $\ldots \ldots \ldots \ldots$

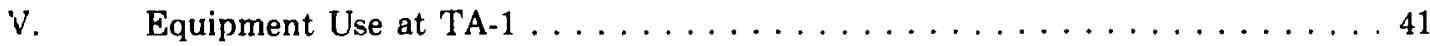

VI. Equipment Use for TA-1 Associated Projects $\ldots \ldots \ldots \ldots \ldots \ldots$

VII. Zia Personnel Charges to the TA-1 Project $\ldots \ldots \ldots \ldots \ldots \ldots \ldots$

VIII. Manpower Supplied by LASL for TA-1 Survey and

Decontamination . . . . . . . . . . . . . . . . . . . 44

IX. Funding and Cost Allocations for TA-1 Project, $1975-1976 \ldots \ldots \ldots$

X. Laboratory Analysis Results of General-Area Samples . . . . . . . . . 45

XI. Results of Radiochemical Analyses of Selected Soil

Samples from D-Building Area . . . . . . . . . . . . . . . . 61

XII. Tritium Concentrations in Soil Moisture from LASL

1973-1976 Environmental Sampling . . . . . . . . . . . . . . 66

XIII. Radiochemistry Results for Selected Survey Samples

Near Septic Tank $138 \ldots \ldots \ldots \ldots \ldots \ldots$. . . . . . . . . . . . . . . . . 
XIV. Plutonium Chemistry Results for Postcleanup Samples

from Area of Septic Tank $138 \ldots \ldots \ldots \ldots 2$

XV. Radiochemistry Results from $\mathrm{H}-\mathrm{Theta}$ Area $\ldots \ldots \ldots \ldots$

XVI. Radiochemistry Results from Sigma-Building Area . . . . . . . . . . . . 107

XVII. Radiochemistry Results from TU Building Area $\ldots \ldots \ldots \ldots \ldots \ldots \ldots \ldots$

XVIII. Survey and Decontamination Results $\ldots \ldots \ldots \ldots \ldots \ldots \ldots \ldots \ldots$

XIX. Summary and Disposition of Septic Tanks from TA-1

Cleanup Operations . . . . . . . . . . . . . . . . . . . . . . . . .119

XX. Sampling Rer: u'ts from Excavations for Removal of

Uncontaminated Septic Tanks . . . . . . . . . . . . . . . . . 120

E-1. Gross-Alpha and -Beta Activities in Soil $\ldots \ldots \ldots \ldots \ldots \ldots$

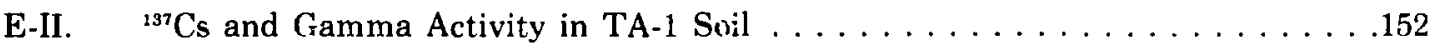

E-liï. Plutonium Activity in TA-1 Soil $\ldots \ldots \ldots \ldots \ldots \ldots \ldots \ldots \ldots$

E-IV. Plutonium in Soil of TA-1 Drilling Samples $\ldots \ldots \ldots \ldots \ldots \ldots$

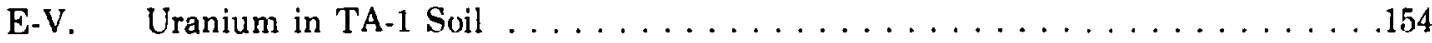

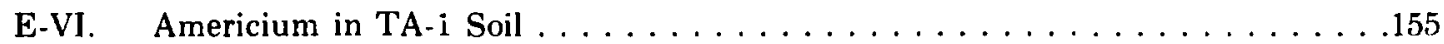

E-VII. Radium in TA-1 Soil $\ldots \ldots \ldots \ldots \ldots \ldots \ldots \ldots \ldots \ldots$

E-VIII. Beryllium in Soil $\ldots \ldots \ldots \ldots \ldots \ldots \ldots \ldots \ldots \ldots \ldots \ldots \ldots \ldots \ldots$

E-IX. Plutoniur in TA-1 Vegetation $\ldots \ldots \ldots \ldots \ldots \ldots \ldots \ldots \ldots \ldots \ldots \ldots \ldots \ldots \ldots$

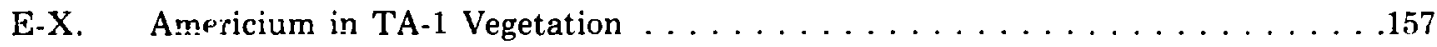

E-XI. ${ }^{137} \mathrm{Cs}$ in TA-1 Vegetation $\ldots \ldots \ldots \ldots \ldots \ldots \ldots \ldots \ldots$

E-XII. Uranium in TA-1 Vegetation $\ldots \ldots \ldots \ldots \ldots \ldots \ldots \ldots$

E-XIII. Gross-Gamma Field Measurements . . . . . . . . . . . . . . . . . . .1:9

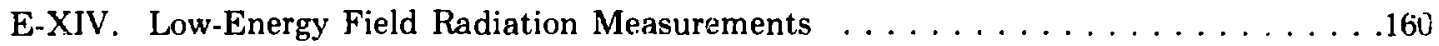

E-XV. Depth Distributions of Plutonium in Soil $\ldots \ldots \ldots \ldots \ldots \ldots \ldots$

G-I. Gross-Alpha and -Beta Air-Sarnpling Results $\ldots \ldots \ldots \ldots \ldots \ldots$

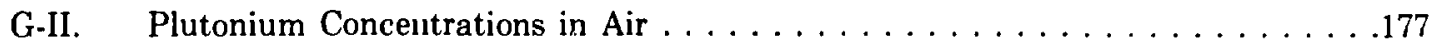




\section{FIGURES}

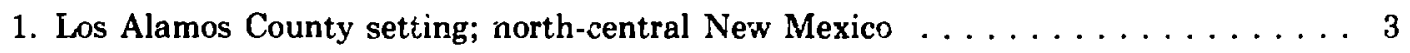

2. Views of TA-1 $\ldots \ldots \ldots \ldots \ldots \ldots \ldots \ldots \ldots \ldots \ldots \ldots \ldots \ldots$

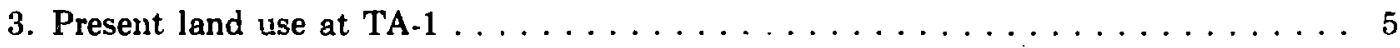

4. Former TA-1 areas with high potential for contamination, $1974 \ldots \ldots \ldots$

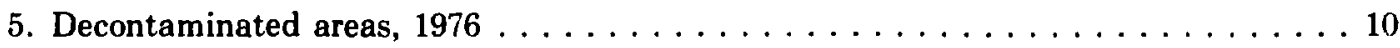

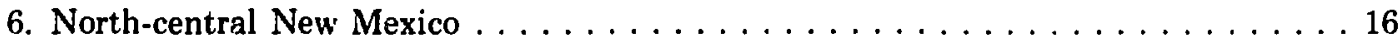

7. Aerial view of the Los Alamos Ranch School, $1935 \ldots \ldots \ldots \ldots \ldots$

8. TA-1, circa $1955 \ldots \ldots \ldots \ldots \ldots \ldots \ldots \ldots \ldots \ldots \ldots \ldots \ldots$ [back pocket]

9. Part of TA-1 (mostly south of Ashley Pond), $1958 \ldots \ldots \ldots \ldots$

10. TA-1 acid waste lines and extension ic Pueblo Canyon

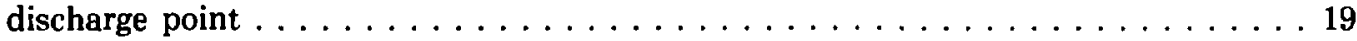

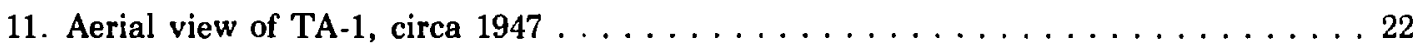

12. Spray-painting being used to fix contamination $\ldots \ldots \ldots \ldots \ldots \ldots$

13. D-Building outline, indicating 1954 soil-sampling results $\ldots \ldots \ldots \ldots$

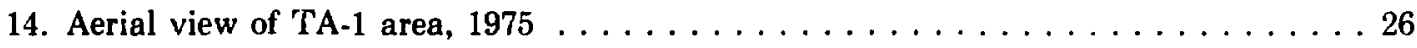

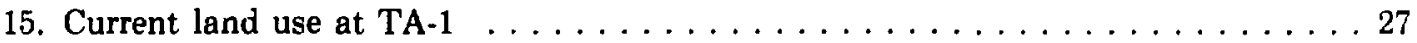

16. Location and concentration of ${ }^{239} \mathrm{Pu}(\geq 1 \mathrm{pCi} / \mathrm{g})$ and total uranium $(\geq 5 \mu \mathrm{g} / \mathrm{g})$ in $\mathrm{TA}-1$ soil $\ldots \ldots \ldots \ldots \ldots \ldots \ldots \ldots$

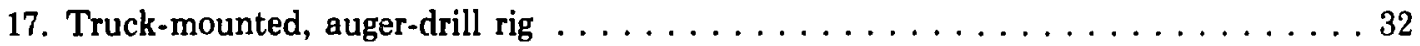

18. Excavation of TA-1 land by backhoe $\ldots \ldots \ldots \ldots \ldots \ldots$

19. Crawle tractor with bulldozer blade on front and ripper

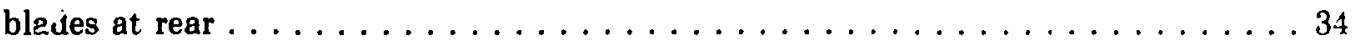

20. Field surveying with the portable phoswich $\ldots \ldots \ldots \ldots \ldots$

21. Front-end loader scooping up soil $\ldots \ldots \ldots \ldots \ldots \ldots \ldots \ldots \ldots \ldots \ldots \ldots \ldots \ldots$

22. Front-end loader scooping up soil from a stockpile $\ldots \ldots \ldots \ldots \ldots$ 
23. Soil being loaded into a dump truck from a front-end loader

24. Phoswich-surveying of a loaded, tarpaulin-covered truck 38

25. Contaminated pipe shards found below ground surface near Sigma Building

26. Summary of genera!-area survey results at TA-1 [back pocket]

27. Profiles of general-area auger holes 46

28. Relative locations of Building D-2 and Septıc Tank $137 \ldots \ldots \ldots \ldots$

29. Cross section of the Septic Tank 137 excavation 48

30. Sampling points and activity on east wall of Septic Tank 137 excavation

31. Locations of sanitary-sewer and drain lines in area of Building D-2 as indicated on engineering drawings

32. Operational areas in D Building 50

33. Original demolition instructions for D Building, 1954 51

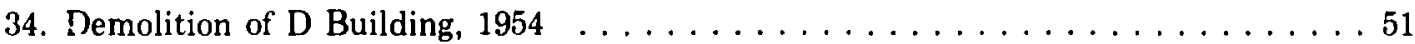

35. Trenci locations, Building D-2 area survey $\ldots \ldots \ldots \ldots \ldots \ldots \ldots \ldots \ldots \ldots \ldots$

36. Trenches $1 \mathrm{~A}, 1 \mathrm{~B}$, and $1 \mathrm{C}$ in Building $\mathrm{D}-2$ area, with soilsampling results

37. Cross section of D-2 Trench 3 , witl sampling results $\ldots \ldots \ldots \ldots$

38. Cross section of D-2 Trench 4 , with sampling results $\ldots \ldots \ldots \ldots \ldots$

39. Cross section of $\mathrm{D}-2$ Trunch 5 , with sampling results $\ldots \ldots \ldots \ldots \ldots$

40. Cross section of D-2 Trench 6 , with sampling results $\ldots \ldots \ldots \ldots$

41. Cross section of $\mathrm{D}-2$ Trench 7 , with sampling results $\ldots \ldots \ldots \ldots \ldots$

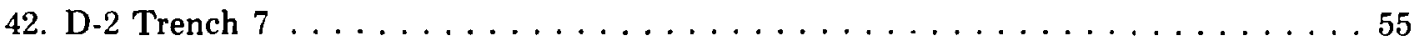

43. Nc: th end of the west wall of D-2 Trench 7, showing

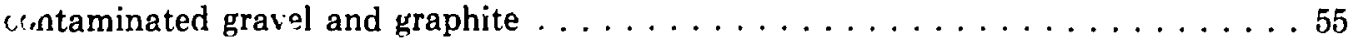

44. Cross section of D-2 Trench 8 , with sampling results $\ldots \ldots \ldots \ldots$ 
45. Trench-sampling results for Trench 1 for $\mathrm{D}$-Building

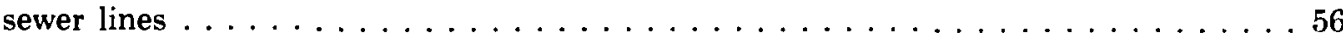

46. Survey detail in D-Building area $\ldots \ldots \ldots \ldots \ldots$

47. Cross sections of D-Building area drill holes having gross-

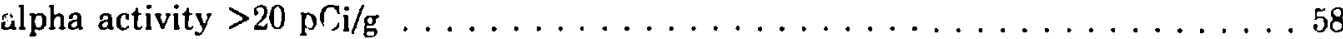

48. Cross sections of D-Building area drill holes having gross-

alpha activity $>20 \mathrm{pCi} / \mathrm{g}$

49. Cross sections of drill holes in D-Building area and northwest of D-Building area hiving gross-alpha activity $>20 \mathrm{pCi} / \mathrm{g} \ldots \ldots 60$

50. D-Building area drill holes $\ldots \ldots \ldots \ldots \ldots \ldots \ldots$

51. Cross sections of D-Building area drill holes, showing depth and magnitude of tritium in soil moisture $\ldots \ldots \ldots \ldots \ldots$

52. Cross sections of D-Building area drill holes, showing depth and magnitude of tritium in soil moisture 65

53. Tritiuin results from the vicinity of the Los Alamos Inn $\ldots \ldots \ldots \ldots$

54. D-2 area excavation and sempling results, December $5,1975 \ldots \ldots \ldots$

55. D-2 area excavation and sampling results, December $19,1975 \ldots \ldots \ldots$

56. Deep trench excavation in the D-2 area drainage channel $\ldots \ldots \ldots \ldots$

57. D-2 excavation and sampling results, January $19,1976 \ldots \ldots \ldots \ldots$

58. Final sampling results in D and D-2 areas prior to

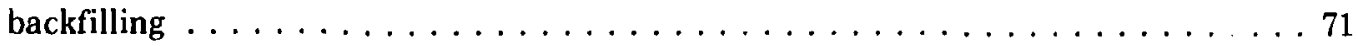

59. D-Building acid-sewer trench prior to backfilling $\ldots \ldots \ldots \ldots \ldots \ldots$

60. Locations of $\mathrm{D}$ and $\mathrm{D}-2$ excavation and trench profiles

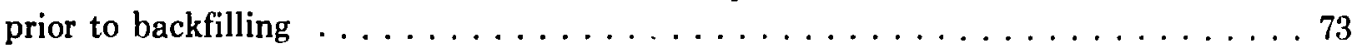

61. Contour map of $\mathrm{D}$ and $\mathrm{D}-2$ excavations prior to backfilling $\ldots \ldots \ldots \ldots$

62. Contour map of final grading in the $\mathrm{D}$ and $\mathrm{D}-2$ areas $\ldots \ldots \ldots \ldots$

63. Initia! excavation north and west of D Building, with

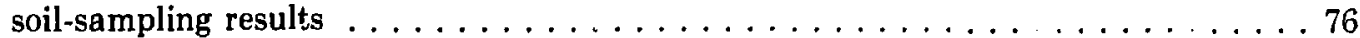

64. Follow-up excavations north and west of D Building, with follow-up soil-sainpling results 
65. Trench and pit in the excavation north and west of $D$

Building, with soil-sampling results

66. Trench and pit in the excavation north and west of $D$

Building, with foliow-up soil-sampling results $\ldots \ldots \ldots \ldots \ldots$

67. Soil-sampling survey in area of Se

68. Cross section of Trench 1 in area of Septic Tank $138 \ldots \ldots \ldots \ldots$

69. Cross section of Trench 5 in area of Septic Tank $138 \ldots \ldots \ldots \ldots \ldots$

70. Soil-sampling survey detail of Sept ${ }^{i c}$ Tank 138 excavation $\ldots \ldots \ldots \ldots \ldots$

71. Postdecontamination detail of Septis: Tank 138 excavation $\ldots \ldots \ldots \ldots$

72. Septic Tank 138 excavation before backfilling $\ldots \ldots \ldots \ldots$

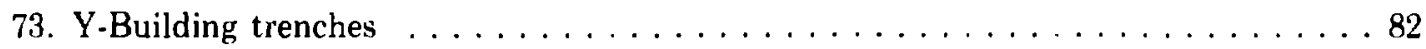

74. Initial survey results in the $\mathrm{H}$-Theta area $\ldots \ldots \ldots \ldots$

75. Cross section of $\mathrm{H}$-Theta Trench 1 , with sampling results $\ldots \ldots \ldots$

76. Cross section of $\mathrm{H}$-Theta Trench 2 , with sampling results $\ldots \ldots \ldots$

77. Sampling results from $\mathrm{H}-\mathrm{Thet}$ 'Trench $3 \ldots \ldots \ldots \ldots$

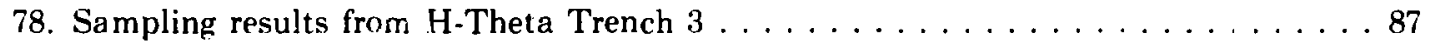

79. Soil-sampling results frum expanded $\mathrm{H}$-Tha a Trench 3

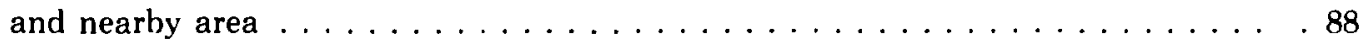

80. Schematic of concrete-encased pipe found north of $\mathrm{H}$ Building $\ldots \ldots \ldots 8$

81. Initial survey results from keyway excavation north of

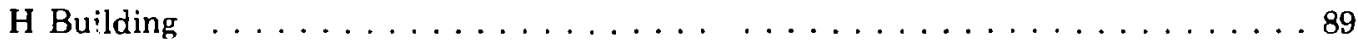

82. Concrete-encased acid-sewer lateral after removal from

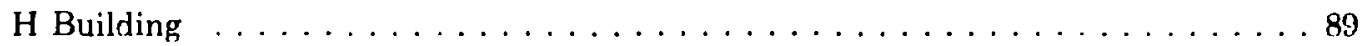

83. Keyway excavation just north of $\mathrm{H}$ and Theta Buildings $\ldots \ldots \ldots$. . . . 89

84. Acid-sewer trench from the H-Theta keyway excavation $\ldots \ldots \ldots \ldots$

85. Acid-sewer trench from the H-Theta keyway excavation $\ldots \ldots \ldots \ldots$

86. Survey results from west wall of keyway excavatior $\ldots \ldots \ldots \ldots \ldots \ldots$ 
87. Postdecontamination survey results from west wall of keyway ercavation

88. Postdiecontamination sampiing results from keyway excavation

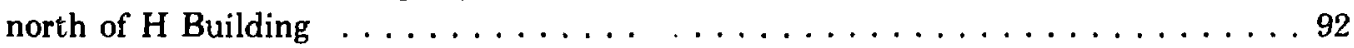

89. Survey locations and results from south of Sigma Building and in the $\mathrm{H}$-Theta surface drainage area

90. Soil-sampling results from around storm drain in $\mathrm{H}$-Theta drainage area

91. Final sampling results from H-Theta surface drainage area

92. Locations of acid-sewer lines from $\mathrm{D}$ Building to Trinity $\mathrm{Dr} . \ldots \ldots 6$

93. Locations of eariy exploratory trenches behind Taco Bell and Exxon station

94. Acid-sewer trench on undeveloped land south of Trinity Drive

95. Section $A B$ of acid-sewer trench, with initial soil-sampling results

96. Section $\mathrm{AB}$ of acid-sewer trench, with final sampling results in areas where the excavation was enlarged

97. Section BC of acid-sewer trench, with initial soil-sampling results

98. Section $\mathrm{BC}$ of acid-sewer trench, with final sampling results in areas where the excavation was enlarged

99. Section $D G$ of acid-sewer trench, with initial soil-sampling results.

100. Section DG of acid-sewer trench, with final sampli'g results from areas where the excavation was enlarged

101. Section GH of acid-sewer trench, with initial soil-sampling results

102. Section GH of acid-sewer trench, with final sampling results from areas where the excavation was enlarged

103. Pipes and steam tunnel in acid-sewer trench near $Q$ Building .102 


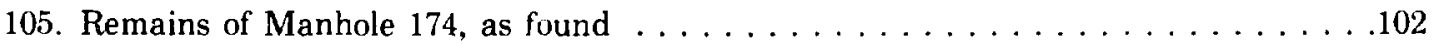

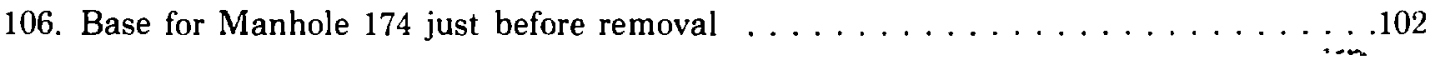

107. Trench locations along western portion of acid-sewer line,

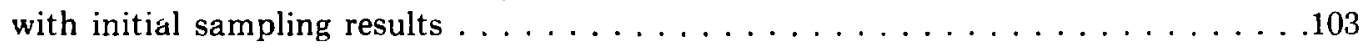

108. Cross section of Trench $3 \mathrm{~A}$, with initial soil-samplirg

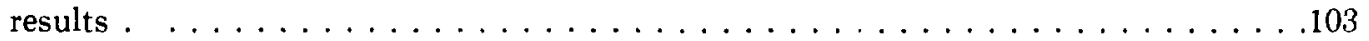

i09. Cross section of Trench $3 A$, with final soil-sampling results $\ldots \ldots \ldots \ldots$

110. Excavation around Phoswich Survey Point $8 \ldots \ldots \ldots \ldots \ldots$

111. Cross section of trench excavation around Phoswich Survey

Point 8 , with final soil-sampling results $\ldots \ldots \ldots \ldots \ldots \ldots \ldots$

112. Location and postdecontamination soil-sampling results of

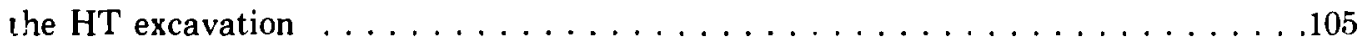

113. Sigma-Building trench and soil survey locations and

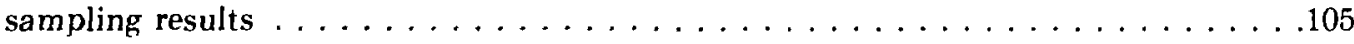

114. Cross section of Sigma Trench 2 and soil-sampling results $\ldots \ldots \ldots \ldots$

115. Sigma-Building excavation locations and postdecontamination

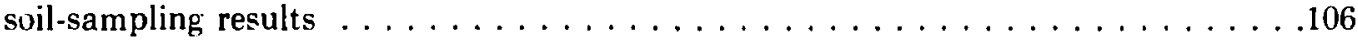

116. Soil-sampling survey results from Delta-Building area $\ldots \ldots \ldots \ldots$. . . . 108

117. Cross section of Delta Trench 1 and soil-sampling results $\ldots \ldots \ldots \ldots$

118. Cracks in tuff in pit excavation south of Warehouse $19 \ldots \ldots \ldots \ldots$

119. Lncation and final soil-sampling results of the Warehouse

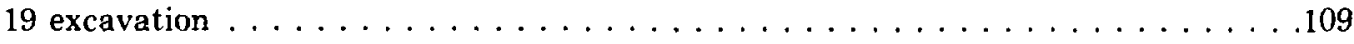

120. Soil-sampling results from TU-Building area $\ldots \ldots \ldots \ldots \ldots \ldots \ldots$

121. Excavation and postdecontamination soil-sampling results at

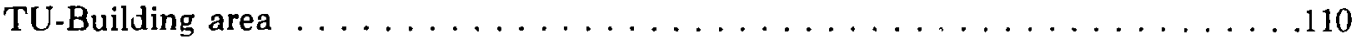

122. Profiles of TU-area land surface after excavation and after

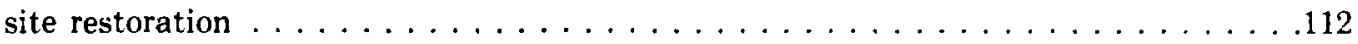

123. Depth profiles and soil-sampling results from TU-RD

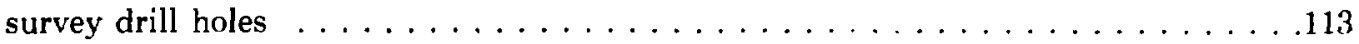


124. Septic Tank 140 excavation locations and postdecontamination soil-sampling results

125. Trench and pit soil-sampling results; postdecontamination

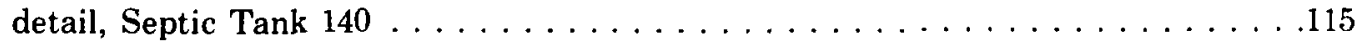

126. Locations of soil-sampling surveys in warehouse area $\ldots \ldots \ldots \ldots \ldots \ldots \ldots$

127. Excavation locations and postdecontamination soil-sampling

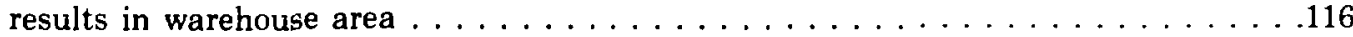

128. Locations of contamination located in March-April 1976

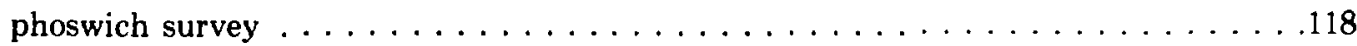

129. Septic Tank 276 trench and excavation locations $\ldots \ldots \ldots \ldots \ldots \ldots \ldots \ldots$

D-1. Experimentally determined response curve of Ludlum Mudel 12S count-rate meter detector as a function of photon energy $\ldots \ldots \ldots \ldots \ldots \ldots \ldots$

D.2. Response of an RSS-111 monitor as a function of incident

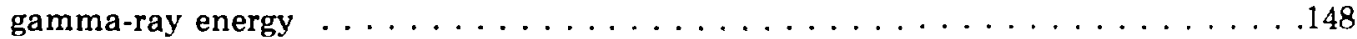

G-1. Air samplers in TA-1 area during decontamination operations $\ldots \ldots \ldots \ldots$

G-2. Plutonium concentrations in air measured during TA-1

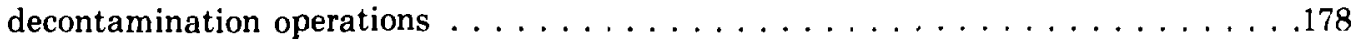




\title{
RADIOLOGICAL SURVEY AND DECONTAMINATION \\ OF THE FORMER MAIN TECHNICAL AREA \\ (TA-1) AT LOS ALAMOS, NEW MEXICO
}

Compiled by

A. John Ahlquist

Alan K. Stoker

Linda $\mathrm{K}$. Trocki

\begin{abstract}
A radiological survey was conducted on the undeveloped portions of the site of the former Main Technical Area (TA-1) of the Los Alamos Scientific Laboratory in north-central New Mexico. Between 1943 and 1965, research work on nuclear weapons was carried out in TA-1. The area was decontaminated and demolished in stages, and beginning in 1966 the land was given to Los Alamos County or sold to private interests. The survey disclosed traces of radioactive contamination undetected or considered insignificant during original demolition in the 1950 s and 1960 s. The remaining contamination was removed in 1975 and 1976 to levels considered to pose no health or safety hazards and, further, to the lowest levels considered practicable.

Methods used in the survey included measurement techniques for detecting alpha emitters such as uranium and plutonium, extensive surface and subsurface soil sampling, and use of conventional health physics instrumentation to provide detailed information on $\sim 16$ hectares (40 acres) of land. As a result of the decontamination efforts, $\sim 15000 \mathrm{~m}^{3}$ of contaminated or potentially contaminated material was removed to an approved radioactive waste disposal site on ERDA property. Full details of the methods, findings, decision criteria, and as-left conditions are documented. (ERDA was succeeded by the Department of Energy (DOE) in October 1977.)
\end{abstract}




\section{EXECUTIVE SIJMMARY}

This report describes the radiological survey and decontamination efforts conducted betwcen 1974 and 1976 on $\sim 16$ bectares (40 acres) of land in the townsite of Los Alamos, New Mexico (Fig. 1). In 1943 the land became the site of nuclear weapons research and development for the Manhattan Engineer District and subsequently the Atomic Energy Commission (AEC). The building complex (Fig. 2) housing the research work came to be known as Technical Area One (TA-i) because it was the first research facility of the Los Alamos Scientific Laboratory (LASL). The Laboratory was operated by the University of California, which in 1947 continued its responsibility under contract to the newly formed AEC.

Radioactive materials, including uranium, plutonium, and fission products, were used at TA-1 during the development of the technology for atomic (fission) explosives and thermonuclear (fusion) devices. The work resulted in varying degrees of radioactive contamination of some of the buildings, waste-handling systems, and land. In the $1950 \mathrm{~s}$, research work was gradually moved from TA-1, immediately adjacent to the townsite, to new laboratory facilities across a major canyon from the townsite. The new facilities permitted consolidation of central laboratory buildings and greater physical separation of the laboratory from residential and commerciai areas (Fig. 1). When vacated, the obsolete TA-1 facilities were decontaminated and demolished. Major operations to remove structures began in 1954 and continued intermittently through 1965. In 1966 the land occupied by TA-1 was given to Los Alamos County or sold to private interests because it lay in a central area useful to the future development of the townsite, and residual radioactive contamination was not considered hazardous. Development of public facilities and commercial establishments began shortly after disposal and still continues (Fig. 3).

By 1971, increased concern over radioactive contamination at extremely low, but detectable, levels led the $\mathrm{AEC}$ to request more modern and sensitive radiological surveys of various former AEC lands released to the public, including the remaining undeveloped portion of TA-1. ERDA has the requisite authority to decontaminate any sites or facilities in order to protect health and to minimize danger to life or property where the contamination is a result of activity authorized by the Atomic Energy Act of 1954, as amended. 'The Administrator (formerly, the Commission) is authorized pursuant to Sec. 161.i of the Act to prescribe such regulations or orders as he may deem necessary to govern any such activity.

Field work for the TA-1 survey began in 1974 and led to extensive exploratory excavation and decontamination efforts which continued through August 1976. The work started under AEC auspices, but was completed under the auspices of the US Energy Research and Deveiopment Administration (ERDA), to which most of the nonlicensing and nonregulatory responsibilities of the $A E C$ were transferred in January 1975.

Survey work in 1974 included field measurements of $\mathrm{x}$ and gamma radiation and collection of soil and vegetation samples at 55 points on the undeveloped land formerly occupied by TA-1. At one or more of the sampling locations, concentrations of radioactive contaninants in soil were higher than was consistent with northern New Mexico regional background samples (see accompanying table).

The maximum values raised no significant health or safety questions and most values were small fractions of the maxima. For example, 5 of 55 analyses for ${ }^{299} \mathrm{Pu}$ showed $>10 \mathrm{pCi} / \mathrm{g}$ of activity, two showed $>100 \mathrm{pCi} / \mathrm{g}$, and the maximum was $224 \mathrm{pCi} / \mathrm{g}$.

The maximum ${ }^{299} \mathrm{Pu}$ concentration $(224 \mathrm{pCi} / \mathrm{g})$ was found in a sample collected on ERDA property near the outlet of a septic tank which served a structure used as a laundry for contaminated clothing during 1944 and 1945. To confirm the source of this apparently minimal contamination, the septic tank was excavated in August 1975. It was of different construction and condition than old engineering records had shown. A sample of sludge from the tank contained $114 \mathrm{pCi} / \mathrm{g}$ of ${ }^{239} \mathrm{Pu}$. While the tank was being removed, a pocket of ${ }^{239} \mathrm{P}_{11 \text {-contaminated }}$ material was discovered in the excavation about 1.3 m ( $4 \mathrm{ft}$ ) below the surface on ERDA property just at the property line. Radiochemical analyses showed as much as $125000 \mathrm{pCi} / \mathrm{g}$ of early-1945 Hanford plutonium in a sample from the pocket. In addition, 


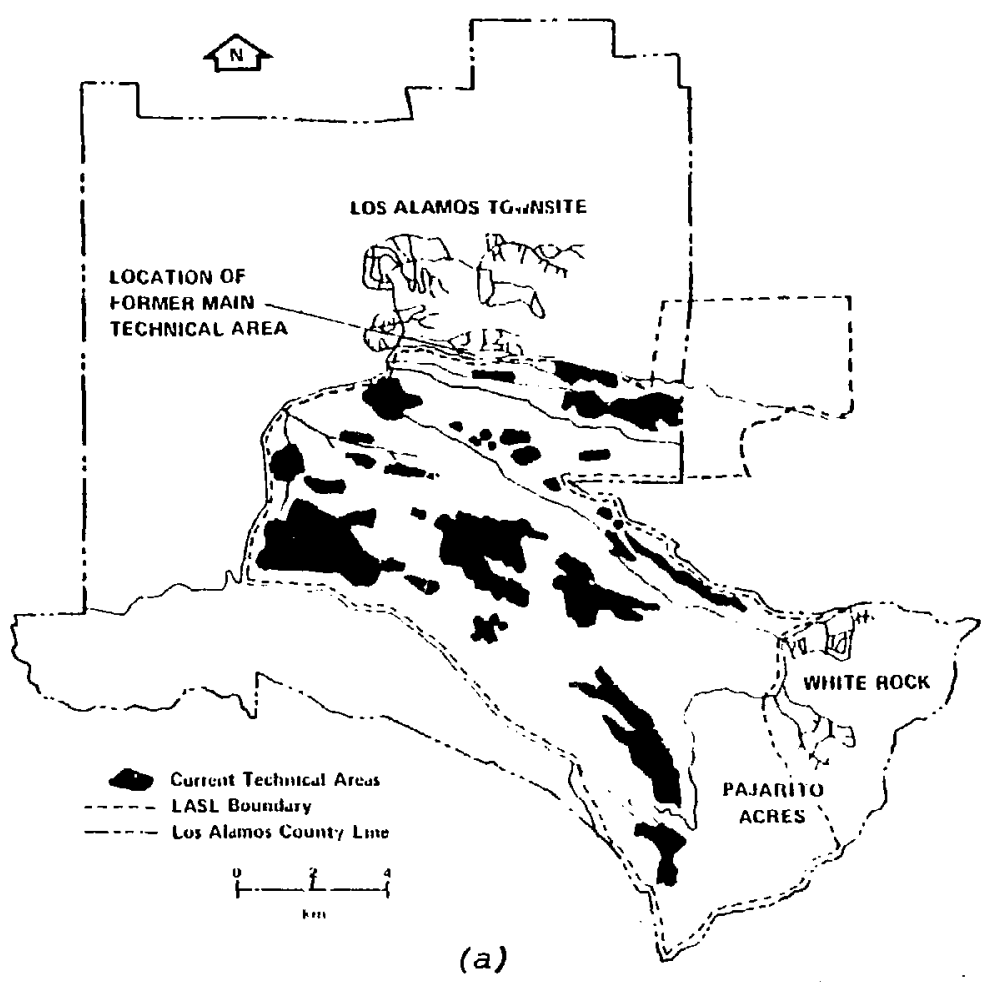

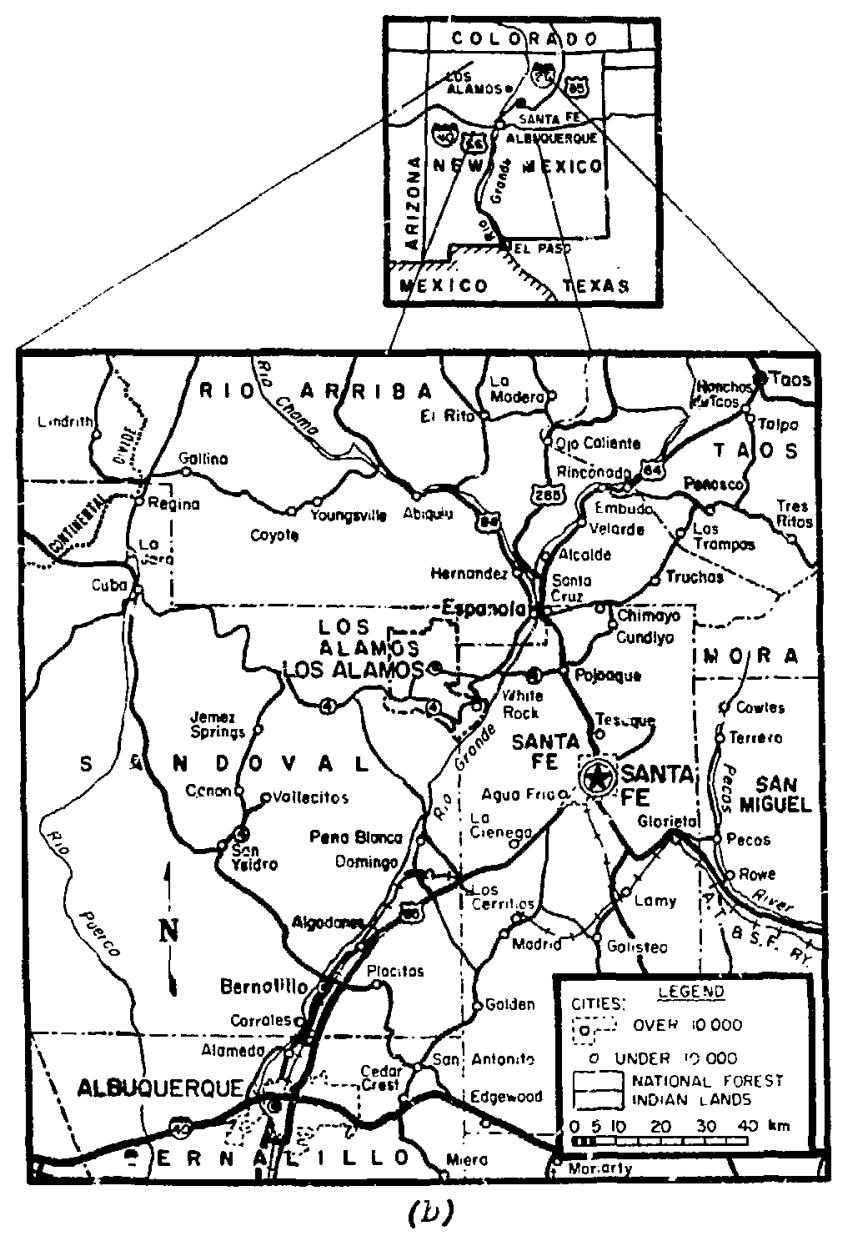

Fig. 1.

(1a) Los Alamos County setting. LASL is located primarily in Los Alamos County, with an eastern extension into Santa Fe County. The technical areas (shaded) are scattered throughout the reservation, most of them being on relatively flat mesa tops. The Los Alamos townsite and the residential areas of White Rock and Pajarito Acres adjoin the LASL boundary to the rith and southeast. (1b) North-central New Mexico. 

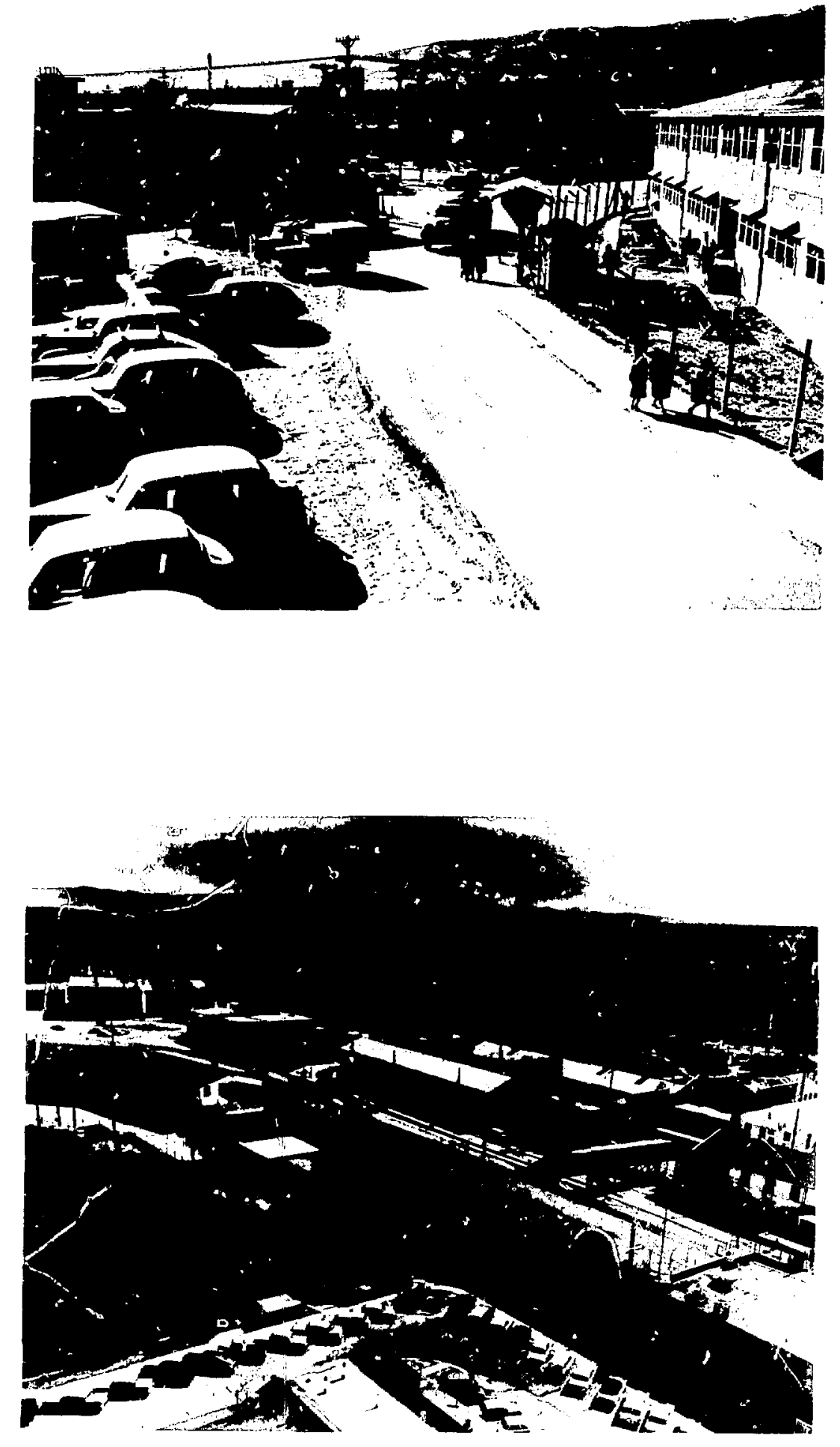

Fig. 2.

Views of TA-1. 


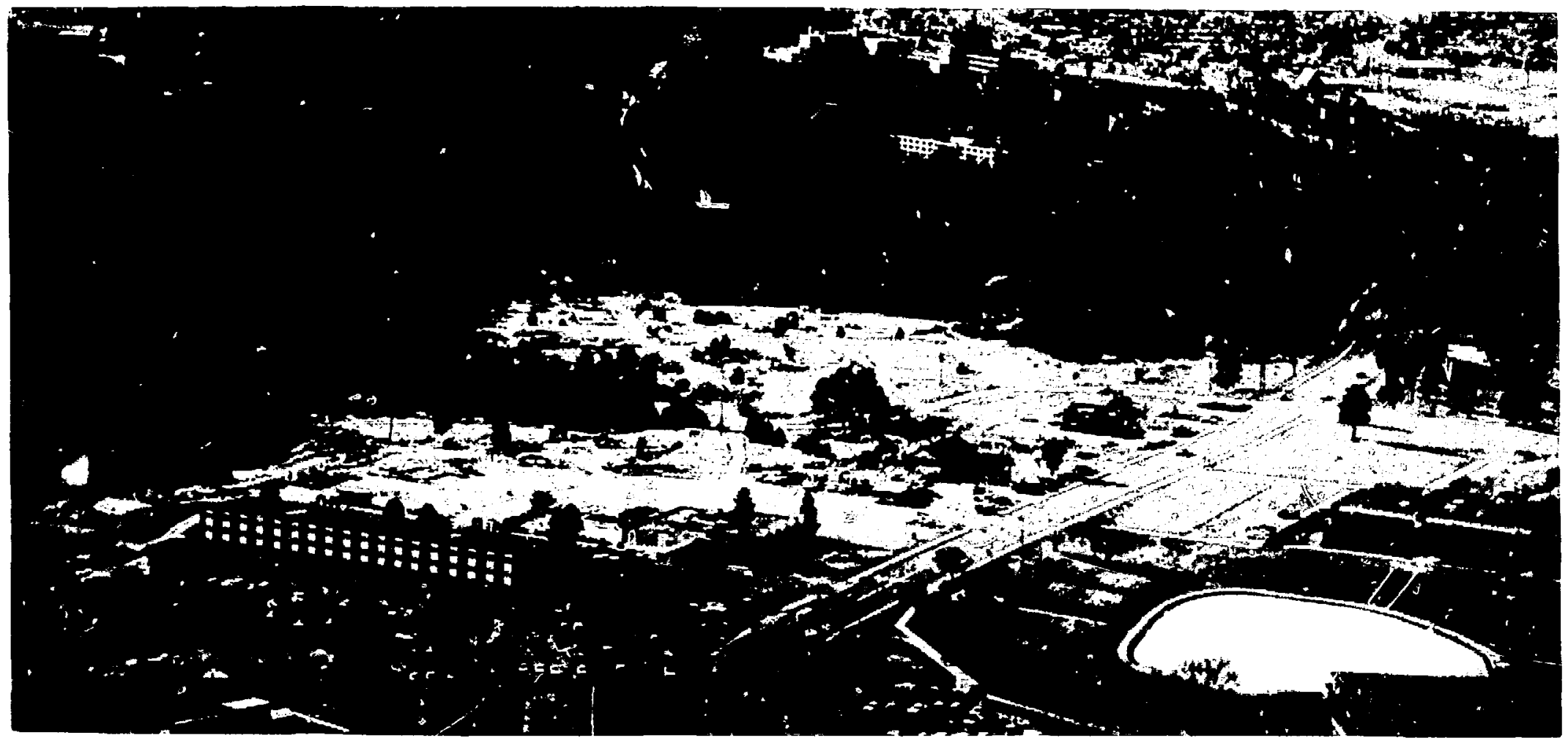

Fig. 3.

Present land use at TA-1. A January 1976 aerial view of the area occupied by TA-1, looking westward. Trinity Drive extends from lower center to upper right. To the right of Trinity are Ashley Pond and the Los Alamos County Community Building. Just above the lower bend in Trinity Drive is the main building of the Los Alamos Inn, wit? the Inn's guest rooms and several office buildings extending toward the left edge of the picture. Beyond the Inn on Trinity are the Gulf station, Taco Bell food service, the Exxon station. and the long, pitched roofs of apartment buildings. TA-1 exploration and decontamination activities were carried out in the open area to the left of the commercial establishments. Remnants of TA-1 roads and foundation slabs are visitie in the open area. 


\begin{tabular}{|c|c|c|c|c|c|}
\hline Contaminant & Units & $\begin{array}{c}\text { No. of } \\
\text { Samples }\end{array}$ & Range & Median & Average \\
\hline \multicolumn{6}{|c|}{ All TA-1 Locations } \\
\hline Gross alpha & $\mathrm{pCi} / \mathrm{g}$ & 51 & 1.1 to 23.9 & 2.8 & 3.6 \\
\hline${ }^{239} \mathrm{Pu}$ & $\mathrm{pCi} / \mathrm{g}$ & 55 & 0.11 to 224 & 0.25 & 8.7 \\
\hline Uranium & $\mu \mathrm{g} / \mathrm{g}$ & 45 & 1.6 to 55 & 6.2 & 8.7 \\
\hline${ }^{241} \mathrm{Am}$ & $\mathrm{pCi} / \mathrm{g}$ & 20 & -0.12 to & 0.07 & 0.33 \\
\hline${ }^{226} \mathrm{Ra}$ & $\mathrm{pCi} / \mathrm{g}$ & 13 & 0.8 to 5.2 & 2.1 & 2.1 \\
\hline${ }^{197} \mathrm{Cs}$ & $\mathrm{pCi} / \mathrm{g}$ & 51 & 0.26 to 12.5 & 0.89 & 1.4 \\
\hline Beryllium & $\mu \mathrm{g} / \mathrm{g}$ & 6 & 0.86 to 2.9 & 1.2 & 1.5 \\
\hline
\end{tabular}

Northern New Mexico Reference Locations

$\begin{array}{llllll}\text { Gross alpha } & \mathrm{pCi} / \mathrm{g} & 7 & 1.8 \text { to } 4.0 & 2.6 & 2.6 \\ { }^{239} \mathrm{Pu} & \mathrm{pCi} / \mathrm{g} & 7 & 0.010 \text { to } 0.034 & 0.025 & 0.024 \\ \text { Uranium } & \mu \mathrm{g} / \mathrm{g} & 7 & 1.4 \text { to } 2.9 & 1.7 & 2.0 \\ & & & & & \\ { }^{241} \mathrm{Am} & \mathrm{pCi} / \mathrm{g} & 7 & -0.47 \text { to } 0.11 & 0.01 & -0.06 \\ { }^{228} \mathrm{Ra} & \mathrm{pCi} / \mathrm{g} & 7 & 1.6 \text { to } 3.9 & 2.3 & 2.3 \\ { }^{139} \mathrm{Cs} & \mathrm{pCi} / \mathrm{g} & 7 & 1.2 \text { to } 2.5 & 1.7 & 1.8 \\ \text { Beryllium } & \mu \mathrm{g} / \mathrm{g} & 7 & 0.58 \text { to } 1.2 & 1.0 & 0.96\end{array}$

a pipe fragment contaminated to $4000 \mathrm{c} / \mathrm{min}$, as detected by a portable alpha survey instrument, was found on the surface nearby (Fig. 4).

These unexpected findings forced a reappraisal of the significance of earlier survey results. The discovery of even a small soil volume containing as much as $125000 \mathrm{pCi} / \mathrm{g}$ of ${ }^{239} \mathrm{Pu}$, the presence of alpha-contaminated debris on the surface, the discrepancies between old records and actual conditions, and the possibility that the 55-point survey may have missed other significant contamination all combined to emphasize the need for additional sampling and exploratory excavation to define the extent of contamination remaining at TA-1.

The additional sampling and exploratory work and decontamination work got under way in September 1975 after the general problem and plan for field work had been presented to property owners and the press at a public meeting.

The plan for exploration had several objectives:

- The entire remaining undevaloped portion of the TA-1 area was to be surveyed in detail with por- table instruments to identify contamination on ary remairing debris, including foundations left in place or near-ground-surface contamination.

- A comprehensive soil-sampling program was to provide both surface and at-depth information with samples at closer spacing than used in the 1974 survey, with special emphesis on areas suspected of contamination.

- Exploratory excavations were to be made to obtain information on subsurface conditions, especially along the alignments of potentially contaminated waste lines, as well as to locate and remove any remaining septic tanks.

The plan for decontamination haci one principal objective: any contamination found by the exploratory efforts was to be removed to the lowest practicable levels.

Because of pressures imposed by some private property owners to begin new construction, the exploratory and decontamination operations were conducted concurrently. The basic approach was first to explore and define clearly the areas already 


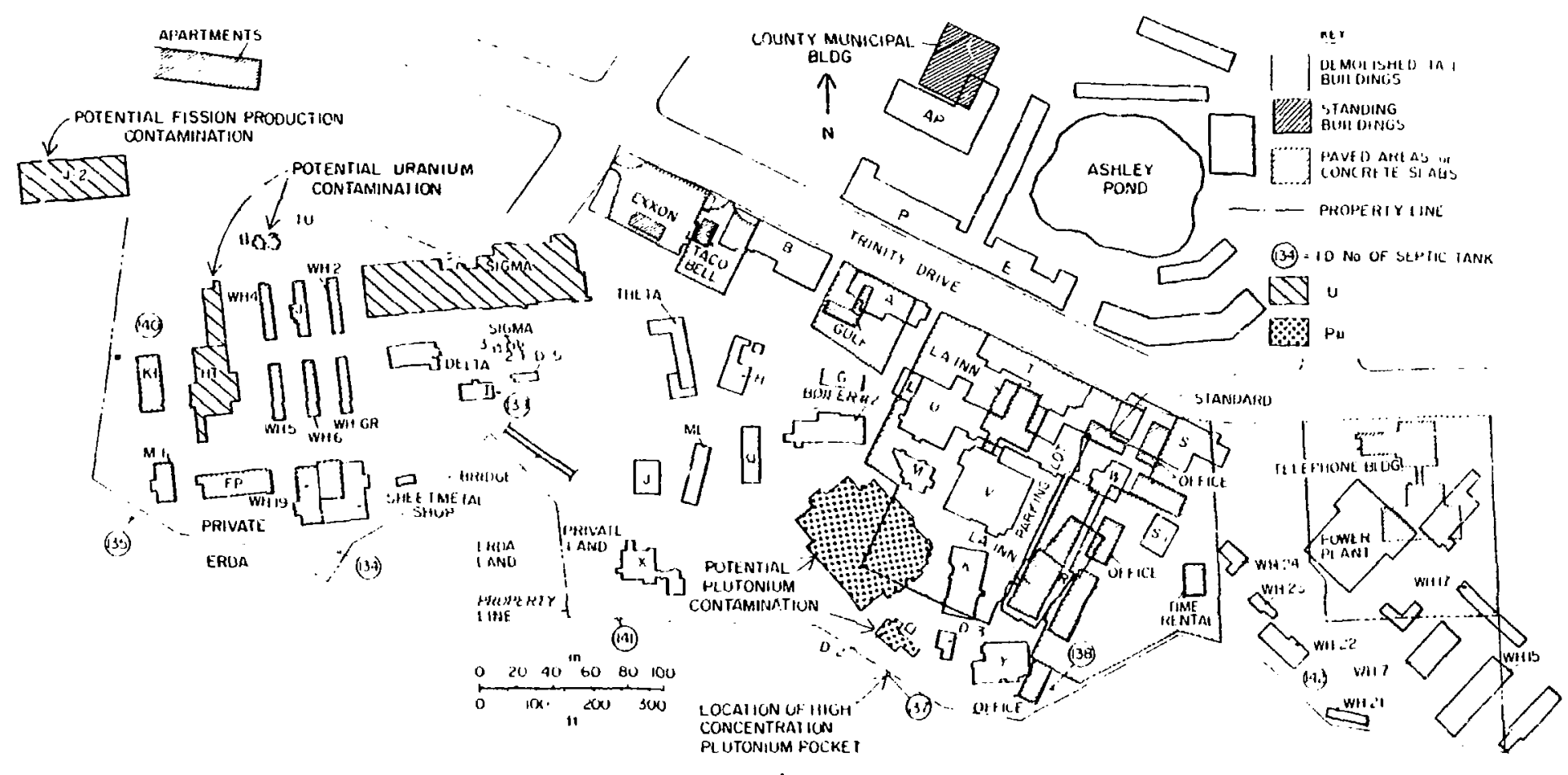

Fig. 4.

Former TA-1 areas with high poteni ial for contamination, 1974. 
known or suspected $t \omega$ be contaminateri. Genera!area investigations were to follow as rapidiy as progress permitted.

Five types of areas with the highest contamination potential were identified (1) on the basis of historical informaticn on building use, (2) records of the demolition and original decontamination operations conducted in the 1950 s and $1950 \mathrm{~s}$, (3) recollections of former TA-1 personnel, and (4) the findings of the 1974 survey. These areas are shown in Fig. 4 and can be described in the following general terms.

- Potential Plutonium Contamination Areas. Included were the vicinities of buildings housing plutonium chemistry and metallurgy research (D Building) and the laundry for contaminated clothing (D-2 Building).

- Potential Uranium Contamination Areas. Included were the vicinities of buildings housing casting and machining operations of uranium (Sigma Building), machining and recovery of urarium (TU Building), and heat treatment and machining of uranium (HT Building).

- Potential Fission-Product Contamination Areas. Included was the vicinity of the building housing radiochemistry research on weapons test debris ( $\mathrm{J}-2$ Building).

- Industrial Waste Sewer Alignment. Included were locations of former main acid-sewer lines extending from $\mathrm{D}$ Building in the eastern portion of TA-1 and the main line extending from J-2 Building in the western portion.

- Septic Tanks. Included were twelve septic tanks recorded to have been abandoned in place and considered potentially contaminated because of the findings at Septic Tank 137, which had served the contaminated laundry (D-2 Building).

As a result of the exploratory efforts, decontamination was required for additional areas, which initially were thought to have a low probability of contamination or none at all.

A variety of instruments and sampling techniques was used in the exploratory work. Conventional portable survey instruments, including alpha airionization detectors, beta-gamma GM-tube detectors, thin-window GM detectors, and FIDLER detectors, were used to monitor debris, land surfaces, exploratory trenches, and excavations. Two phoswich detectors were adapted for field use to provide better sensitivity to the low-energy $x$ rays associated with radioactive decay of plutonium. They were also more sensitive in detecting radiation from uranium and cesium thar ${ }_{1}$ were conventional survey instruments.

A quick method used to determine gross-alpha activity in soil samples provided lower limits of detection for alpha contamination than was possible with survey instrumeits. The technique employed a zinc sulfide $(\mathrm{ZnS})$ detector that could detect alpha activity $\sim 20 \mathrm{pCi} / \mathrm{g}$ rbove natural alpha hackground, with minimal sample preparation and short counting times. This technique was used extensively for exploratory work and as guidance for decontamination excavations and for documentation of final conditions.

Samples for exploratory purposes included surface samples from the top few centimeters of soil. core samples obtained by driving a plastic pipe as far as $40 \mathrm{~cm}$ into the gr.sund, cuttings obtained from 10-cm-diam holes drilled with a truck-mounted auger rig to depths as great as $10 \mathrm{~m}$, and grab samples scraped from sides or bottoms of exploratory trenches or pits. All samples were subjected to grossalpha analysis by two $\mathrm{ZnS}$ detector systems located in a laboratory trailer parked at the site. Selected samples were analyzed with $x$ - or gamma-ray spectroscopy equipment (also located in the trailer) for qualitative identification of isotopes or were submitted to LASL analytical laboratories for more extensive radiochemical analysis.

The exploratory survey and sampling work continued from September 1975 through August 1976. When exploration activities indicated that decontamination was necessary, excavation would start as soon as possible and the exploratory efforts would be focused on another suspect area. Once most suspicious areas had been evaluated, exploratory work continued on the remaining areas. In some instances, the decontamination work resulted in the need to explore adjacent areas in nore detail. Thus, the exploratory and the decontamination efforts were interactive and each often required several iterations before all probable significant contamination had been found and removed to the limits of practicability.

Approximately 8000 samples were collected for exploratory and documentation purposes. All were analyzed for gross-alpha activity and several hundred underwent additional laboratory analyses. 
The results of the exploratory efforts can be inferred in general terms from i ig. 5 , which delineates the locations of decontamination excavations. The areas to be excavated werc determined by instrumental survey or sampling. Results of the exploratory sampling are shown in greater detail in Figs. 26, 35, 46, and 128, which show the type, location, and summary results of exploratory samples taken before substantial excavations were begun. These figures indicate the extent and density of sampling conducted throughout TA-1; the full results are discussed in the body of the report. Although the figures do not show the overall portable-instrument survey results directly, they do represent the positive findings in that samples were taken from those locations where survey instruments had detected above-background conditions. About midway in the field work, the sensitive phoswich instruments were used to surve the entire undeveloped area and did identify 1.7 previously unsuspeited areas having as much as $980 \mathrm{pCi} / \mathrm{g}$ of gross-alpha contamination. The phoswich was also used to survey the readily accessible land in the developed area north of Trinity Drive around Ashley Pond and the County Building; no contamination was detected.

Decontamination operations were conducted with equipment ranging in size from hand shovels to bulldozers. The excavation techniques depended on the type and level of contamination and its location and distribution. The smallest spots or spots, with high concentrations were excavated by handshoveling the contaminated soil into plastic hags. Small areas were removed directly to dump trucks by backhoe and front-end loader. For large areas, a crawler tractor equipped with ripper blades broke up the material, which was then pushed into stockpiles by the bulldozer blade. A front-end loader put the material into dump trucks which hauled it to the solid radioactive waste disposal area $\sim 12.5$ $\mathrm{km}$ (7.5 miles) away on ERDA-controlled Laboratory property.

The following precautions were taken to prevent the spread of contamination:

- The most highly contaminated muterial-soil, sewer lines, or other debris-was excavated with shovels or by careful use of a backhoe.

- Water sprays were used extensively to suppress dust suspension during excavation by heavy equip- ment and during ripping and truck-loading opera tions.

- Dump-truck beds were lined with plastic before being loaded; the load was covered by the plastic and secured by tarpaulins tied over the load.

- Workers wore protective clothing whenever contact with contamination was a possibility.

- Extensive health physics monitoring was conducted throughout the decontamination. Personnel monitoring and air monitoring within the work area showed that no workers received any significant exposure.

- Loaded trucks were monitored before leaving the work area.

- Work areas were fenced in to preclude entry by the public during decontamination operations.

Decontamination in a given area would proceed until contamination was no longer detectable by portable instruments. Then surface soil samples would be collected and analyzed for gross-alpha activity by the $\mathrm{ZnS}$ detectors. If measurable activity remained, additional material would be removed iteratively until no contamination could be identified or until a conscious decision was made that residual contamination was as low as practicable. The decisions involved factors that varied from area to area, including:

- The particular containment involved.

- The location of the contaminant.

- The ability to detect different types of radioactivity in field situations.

- The cost of further effcrts in terms of time, money, or immediate physical hazards to personnel.

In practice, the LASL Health-Division personnel overseeing the field operations applied professional judgment in directing the day-to-day operations. At regular intervals they presented the data and made recommendations on decontamination progress to the Operational Safety personnel of ERDA's Los Alamos Office (LAAO) and Albuquerque Operations Office (ALO). The ERDA persornel reviewed the information and recommendations and those from ALO made the final decisions conierning whether decontamination had proceeded as far as was practicable. The most significant factors contributing to these decisions are summarized in the following brief descriptions of the areas where decontamination operations were carried out (more details are given in the body of the report). 


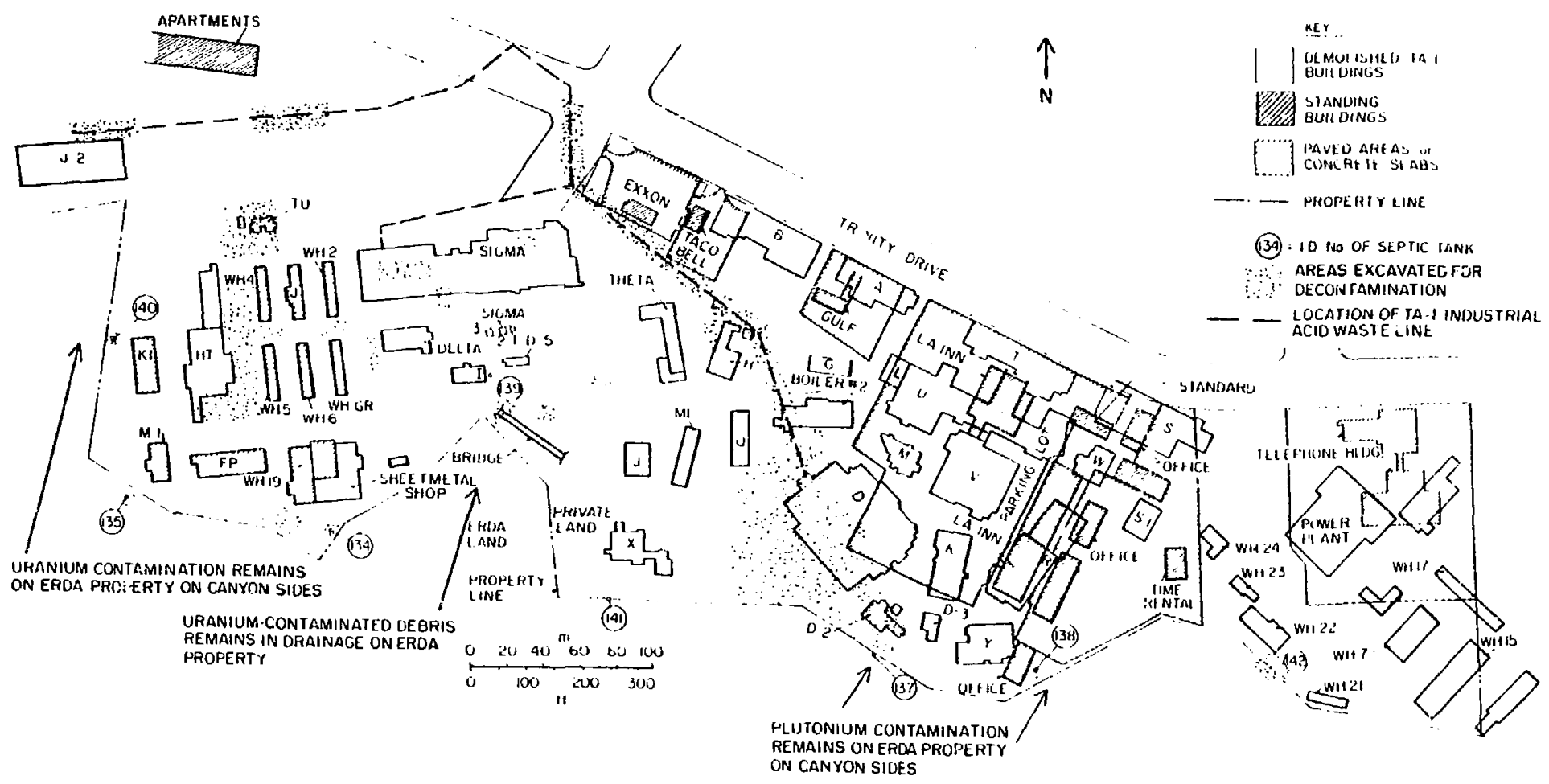

Fig. 5.

Decontaminated areas, 1976. 
Decontamination operations are discussed according to the principal type of contamination or, in the case of waste lines and septic tanks, the type of structure.

\section{Areas with Plutonium as the Principal Contaminant}

Septic Tank for Buiding D-2. The initial disrovery of plutonium contamination $>100000 \mathrm{pCi} / \mathrm{g}$ (described earlier) occurred during excavation to remove Septic Tank 137, which served Building D. 2, where contaminated clothing was laundered. Contaminated soil near the tank was removed as part of the overall decontamination near Building D-2.

Vicinities of Buildings $D$ and D-2. The areas formerly occupied by the plutoniurn chemistry and metallurgy research building (D Building) and the laundry for contaminated clothing (D-2 Building) had many contaminated areas with gros 3 -alpha concentrations in the thousands of $\mathrm{pCi} / \mathrm{g}$. Most of the contamiration was ${ }^{29 \theta} \mathrm{Pu}$. The highest levels, usually associated with contaminated waste line locations, were $>100000 \mathrm{pCi} / \mathrm{g}$. Soil and rock were reıno:ed to depths as great as $4.6 \mathrm{~m}$, and irum one parking-lot corner an area $\sim 225 \mathrm{~m}^{2}$ arid $\sim 6 \mathrm{~m}$ deep was excavated.

The total volume of material removed, including that from natural drainage channels on ERDA land, was $\sim 7600 \mathrm{~m}^{3}$. The soil removed from the parking lot included some that had shown tritiurn concentrations in soil moisture as high as $690 \mathrm{pCi} / \mathrm{m} \ell$ (about 2 orders of magnitude greater than is typical for northern New ivexico, but no more than $23 \%$ of that suggested by the guids.lines for drinking water). Tritium contaminatior. was not identified in any other areas. Factors contributing to the decision that decontamination in these areas was complete included (1) the absence of phoswich-detectable activity, (2) the presence of $<20 \mathrm{pCi} / \mathrm{g}$ of gross-alpha activity in a majority of final samples taken from a $3-\mathrm{m}$ grid, with no samples from private land having $>120 \mathrm{pCi} / \mathrm{g}$, and (3) the fact that most of the excavations had reached previously undisturbed rock. Some contamination remains on ERDA property on the hillside south of the former D.2 Building.
Area to the North and West of $D$ Building. Extensive sampling in an area about $30 \mathrm{~m}$ wide by $40 \mathrm{r}$ ling to the north and west of D Building confirmed the presence of spotty, shallow, gross alpha contamination at concentrations up to $\sim 200 \mathrm{pCi} / \mathrm{g}$, some of which was identified radiochemically as plutunium. A 0.6-m-deep layer of soil was removed, along with a sewer pipe having assnciated grossalpha contamination as high as $340 \mathrm{pCi} / \mathrm{g}$. About $1300 \mathrm{~m}^{3}$ of material were removed from north and west of D Building. Factors contributing to the decision that decontamination was complete included (1) the absence of phoswich-detectable activity, (2) the presence of $<.20 \mathrm{pCi} / \mathrm{g}$ gross-alpha activity in all final soil samples taken from a 3-m grid, and (3) the fact that most of the excavation had reached previously undisturbed rock.

Septic Tank 138. This septic tank, located under a shed of an existing office building, was not known to be connected with any contaminated source. The tank itself was not contaminated, but soil around it had gross-alpha contamination as high as $\sim 300$ $\mathrm{pCi} / \mathrm{g}$. The tank and surrounding soil were removed. Factors contributing to the decision that the private property associated with Septic Tank 138 had been decontaminated included (1) the absence of phoswich-cieiertable artivity, (2) no final soil samples with plutonium activity $>100 \mathrm{pCi} / \mathrm{g}$, and (3) the fact that remaining contamination was at depth in an essentially inaccessible location. Additional contamination remains on the hillside on ERDA land below the location of the tank's outlet pipe.

\section{Areas Related to Former Industrial Waste Line Locations}

Vicinity of Buildings $\mathbf{H}$ and Theta. Records indicating an overflow of the industrial waste line near Building $\mathrm{H}$ prompted exploratory sampling which disclosed gross-alpha activity (primarily plutonium) as high as $\sim 200 \mathrm{pCi} / \mathrm{g}$. Gradually increasing levels of contamination persisted through several iterations of excavation, each leading closer to the alignment of the former main industrial waste line north of Building $\mathrm{H}$. Ultimately, two sections of highly contaminated, concrete-encased pipe which had served as lateral connections to the main line 
were located. Approxinately $470 \mathrm{~m}^{3}$ of contaminated material were removed, including some from the location of the main industrial waste line trench and some from several shallow excavations in a natural drainage course extending southwesterly from the vicinity of Buildings $\mathrm{H}$ and Theta toward the former location of Bailey Bridge. Factors contributing to the decision that the area had been decontaminated included (1) the absence of any phoswich-detectable activity and (2) the presence of $<20 \mathrm{pC}$ :/g of gross-alpha activity in the majority of final soil samples.

Eastern Portion of Main Industrial Waste Line Alignment. The contamination associated with the main ir.uustrial waste line near Buildings $H$ and Theta and that found during excavations around D Building led to a thorough excavation around the line. The trench was decontaminated from the vicinity of $\mathrm{D}$ Building to Trinity Drive, just north of Sigma Building. Contamination existed through the trench at levels sometimes as high as $\sim 1200 \mathrm{pCi} / \mathrm{g}$ of gross-alpha activity. One intact manhoie and two bases of manhole structures were fonnd; all were contaminated and all were removeci. About $1100 \mathrm{~m}^{3}$ of material were removed. Factors contributing to the decisiun that the area was decontaminated included (1) the presence of $<20 \mathrm{pCi} / \mathrm{g}$ of gross-alpha activity in the majority of final soil samples and (2) the fact that contaminated debris had been removed.

\section{Western Portion of Main Industrial Waste Line} Alignment. Exploration near the location of Building J-2, which has been used for radiochemistry on weapon test debris, located a portion of industrial waste line in place. $\mathrm{A} \sim 37$-m-long section of contaminated pipe was removed. Factors contributing to the decision that this area had been decontaminated included (1) the absence of phoswich-detectable activity, (2) the presence of $<20 \mathrm{pCi} / \mathrm{g}$ and no more than $45 \mathrm{pCi} / \mathrm{g}$ of gross-alpha activity in the majority of final soil samples, and (3) the fact that the remaining activity was at depth. A spot of surface contamination, identified as ${ }^{137} \mathrm{Cs}$, was found at the approximate location of a known leak in the industrial waste line that had led from Building J-2 toward Trinity Drive. Contaminated soil was removed from $\sim 40 \mathrm{~m}$ of the trench, in- cluding one area where the trench was made wider and was deepened to $\sim 3.7 \mathrm{~m}$ in an attempt tu removed cesium-contaminated material that followed a vertical fracture in inte rock. About 440 $\mathrm{m}^{2}$ of material were removed. Factors contributing to the decision that the area was decontaminated included (1) the absence of phoswich-detectable activicy in all portions of the trench except the fracture and (2) the fact that remaining contamination was of limited dimensions and at depth.

\section{Areas with Uranium as the Principal Contaminant}

Vicinity of Building HT. Contamination south of the former HT Building, once used for heat treat ment and machining of uranium, was located by in. strumental survey. An area about $19 \mathrm{~m}$ wide by $22 \mathrm{~m}$ long and as deep as $80 \mathrm{~cm}$ was excavated. About 27 $\mathrm{m}^{3}$ of soil were removed. Factors contributing to the decision that the area had been decontaminated included (1) the absence of phoswich-detectable activity and (2) the presence of $<20 \mathrm{pCi} / \mathrm{g}$ of grossalpha activity in all final soil samples.

Vicinity of Sigma Building. Three small contaminated ars:-, were found within the outline of Sigma Buildi:ıg, which had been used for uranium and thorium machining, casting, and powder metallurgy. The discovery of pipe shards contaminated to levels of 100 to $200 \mathrm{mR} / \mathrm{h}$ and other explorations led to the excavation of $\sim 50 \mathrm{~m}^{3}$ of soil from two areas. Factors contributing to the decision that these two areas had been decontaminated in. cluded (1) the absence of phoswich-detectable activity and (2) the presence of $<20 \mathrm{pCi} / \mathrm{g}$ of grossalpha activity in all but one of 20 final soil samples. Soil-sampling led to the discovery of the third contaminated area, at the south edge of the outline, having gross-alpha concentrations as hish as 46 $\mathrm{pCi} / \mathrm{g}$ (one sample contained $\sim 7 \mathrm{pCi} / \mathrm{g}$ of plutonium). Approximately $96 \mathrm{~m}^{3}$ of soil were removed. Factors contributing to the decision that the area had been decontaminated included (1) the absence of phoswich-detectable activity and (2) the presence of $<20 \mathrm{pCi} / \mathrm{g}$ of gross-alpha activity in all but one final soil sample. 
Vicinity of Building Delta. Near Building Delta, which had been used as a meeting place and for a time as a laboratory using fission-product tracers, a small surface spot of uranium contamination was identified by sampling and was removed. Additional sampling disciosed no further contamination. Factors contributing to the decision that no decontamination was necessary included (1) the absence of phoswich-detectable activity and (2) the fact that resuits from additional sampiing indicated only the possibility of some random low levels of uranium.

Vicinity of Warehouse 19. Instrumentai surveys identified a uranium-contaminated area soutl of Warehouse 19, a warehouse not known to have contained radioactive materials. Digging near the surface exposed colored spots of uranium oxide. Approximately $300 \mathrm{~m}^{3}$ of material were removed. Factors contributing to the decision that the area had been decontaminated included (1) the absence of phoswich-detectable activity and (2) the fact that final soil samples showed no gross-alpha activity greater than $64 \mathrm{pCi} / \mathrm{g}$.

Vicinity of Building TU. On the basis of the 1974 survey, uranium contamination was suspected near the location of TU Building, where uranium had been processed, and an adjacent structure (TU-1) where uranium storage and recovery operations took place. Instrumental survey and exploration confirmed the contamination, including some spots of colored uranium oxide. In iterative excavations $\sim 2800 \mathrm{~m}^{3}$ of material were removed. In one small area of the excavation a $\sim 3-\mathrm{m}$-deep pit was dug in an at tempt to follow two thin veins of uranium contamination. Factors contributing to the decision that decontamination in the area was complete included (1) the absence of phoswich-detectable activity, except in the veins, (2) the presence of $<20$ $\mathrm{pCi} / \mathrm{g}$ gross-alpha activity in all but one of the 30 final soil samples, (3) the depth and small dimensions of the veins, and (4) the fact that additional drill-hole sampling in the vicinity of the veins indicated no contamination greater than $\sim 100 \mathrm{pCi} / \mathrm{g}$.

Septic Tank for Building HT. Exploratory sampling of the contents oi Septic Tank 140, which had served the uranium heat-lreatment and machining facility (HT), indicated the presence of uranium contamination. The tank and its inlet and outlet lunes were removed, and associated contaminated soil was excavated. About $27 \mathrm{~m}^{3}$ of material were removed. Factors contributing to the decision that decontamination on private lands near this tank was complete included (1) the absence of phoswichdetectable activity and (2) the presence of $<20$ pCi/g of gross-alpha activity in all but 5 of the 56 final soil samples. Some uranium contamination remains on ERDA property on the hillside west of the end of the out!et. pipe.

General Warehouse Area. Some uraniumcontaminated areas were discovered by phoswich survey in the vicinity of the six warehouse locations east of Building HT. Along the western edge of the warehouse area, uranium-oxide contamination was found in a drainage course. Between the two westernmost warehouse locations, a $15.3-\mathrm{kg}$ cylinder of normal uranium was unearthed. Ultimately, $\sim 270 \mathrm{~m}^{3}$ of soil were removed from the warehouse area. Factors contributing to the decision that the warehouse area decontamination was complete included (1) the absence of phosivich-detectable activity and (2) the presence of $<20 \mathrm{pCi} / \mathrm{g}$ of grossalpha activity in all but 2 of the 69 final soil samples.

\section{Miscellaneous Small Areas}

The phoswich survey located several small, suspicious areas, but exploratory digging (mostly hand-shoveling) failed to unearth any significant contamination. Factors contributing to the decision that these areas required no "urther decontamination included (1) the absence of phoswich-detectable activity and (2) the presence of $<90 \mathrm{pCi} / \mathrm{g}$ of gross-alpha activity in final soil samples.

\section{Other Excavations}

Seven uncontaminated septic tanks were located and removed. One septic tank, thought to have been left in place, was not located.

Approximately $15000 \mathrm{~m}^{3}$ of material were removed from all TA-1 excavations and buried at the LASL solid radioactive waste disposal site. 
The total equivalent costs for the project were $\$ 769000$. This included a $\$ 418000$ direct allocation from ERDA and a $\$ 351000$ assessment of LASL technical programs. The LASL assessment included the equivalent cost of 141 man-months of exploration, project management, analytical work, and documentation.

\section{Conclusion}

Although it is impossible to give absolute assurance that all contamination has been found, all likely sources of contamination in the undeveloped portion of the former TA-1 area have been investigated. All contamination found was removed to the lowest levels practicable on the basis of the high cost of further action and the insignificant health and safety benefits anticipated. In the future, contamination might be found, but it is highly unlikely that any health hazard would be encountered. On the basis of the experience gained during these operations, any remaining pockets of contaminated soil probably would be greatly diluted by construction activities.

Some contaminated spots may exist in the previously developed portions of the TA-1 area, but it is unlikely that they could cause any concern because they are virtually inaccessible and also would probably have been diluted by any earthwork associated with the construction of new buildings and improvements.

No samples were taken from already developed portions of the TA-1 area so that existing rildings or improvements would not be disturbed. A phoswich survey conducted on the developed, but readily accessible, county-owned land north of Trinity Drive around Ashley Pond showed no evidence of contamination. Some contamination remains on ERDA property adjacent to the former TA-1 area, but the possibility of inadvertent public entry into these areas has been redured by the construction of a fence along the property line. 


\section{BACKGR̃uUND}

\section{A. Introduction}

In 1974, 1975, and 1976 the Los Alamos Scientific Laboratory (LASL), at the instigation of and with the support of the Atomic Energy Commission (AEC) and later the Energy Research and Development Admi-istration (ERDA), carried out surveys and decontamination operations on land in the townsite of Los Alamos, New Mexico, that had been the site of the main technical area of the Laboratory during the development of the atomic bomb and for some years thereafter. Later, the Laboratory facilities were relocated, leaving empty this desirable land near the center of town. Sale of the property began in 1966 .

This report details the operations and findings of the survey and decontamination of that land.

\section{B. History and Use of the TA-1 Area}

The site for Project $\mathrm{Y}$ was selected in November 1942 for the development, assembly, and testing of the atomic bomb. An isolated site was essential because the new project was to be the most secret of the US Army's entire Manhattan Engineer District. The Los Alamos Rasich School, located on the Pajarito Platcau on the east slope of the Jemez Mountains in north-central New Mexico (Fig. 6) was isolated and offered 54 buildings, as well as adequate cleared land on which to construct new facilities (Fig. 7). About 1460 hectares (3600 acres) of school land and other private holdings were purchased by the War Department through direct negotiation or after condemnation. Nearly 18600 additional hectares ( 46000 acres) were acquired by permit ırom other government agencies.

A construction contract for laboratory buildings and temporary housing was let in December 1942. In January 1943, the University of Califorria was selected to operate the new Laboratory, and a formal nonprofit contract was soon drawn with the Manhattan Engineer District. By early spring, large pieces of borrowed equipment were being installed and scientists were arriving. At first, technical facilities were constructed mainly on $\sim 16$ hectares (40 acres) near the Ranch School-around Ashley
Pond and along the south side of Trinity Drive-and this area was then known as the Main Technical Area. By mid-1945, when the first nuclear weapons were detonated, the layout of the Main Technical Area was essentially as shown in Fig. 8 (back pocket of this report).

The Technical Area buildings were constructed hurriedly to avoid delaying the scientific and engineering efforts; work sometimes started before plans were completed. The original technical buildings were of a military mobilization type with exteriors of drop siding or asbestos cement shingles, pitched roofs covered with asphalt shingles, and interiors of gypsum-board sheathing (Fig. 9). Some exteriors were of triple-seal gypsum-board siding nailed to the studs, and the interiors had a single layer of the siding. Most buildings had autumatic sprinkler systems; some had complete airconditioning systems and were dustproof. Sanitary wastes went to septic tanks placed around the perimeter of the Technical Area. Industrial waste lines, known as acid sewers, served buildings in which laboratory or process chemistry and radiochenistry wastes were produced. Ultimately, all the industrial waste flowed into a main acid sewer that extended north to a discharge point in Pueblo Canyon (Fig. 10). (The discharge area was first decontaminated in the 1960s and currently is being resur veyed as a separate project.)

Between March 1943 dnd the end of July 1945, much of the theoretical, experimental, and production work involving radioactive materials essential to the development of the first atomic bombs took place in th:e Technical Area buildings. During the next several years, much of the work involved im. provement and evaluation of nuclear explosives, including construction of devices for field tests.

In early 1947, the Laboratory became known as the Los Alamos Scientific Laboratory, to be operated by the University of California for the newly created AEC. After 1949, as the Laboratory expanded, technical activities were gradually relocated to the south, across Los Alamos Canyon, where major new facilities were consolidated and research areas became separate from the residential and community areas. During this expansion, the Main Technical Area became known as Technical Area-1 (TA-1). 


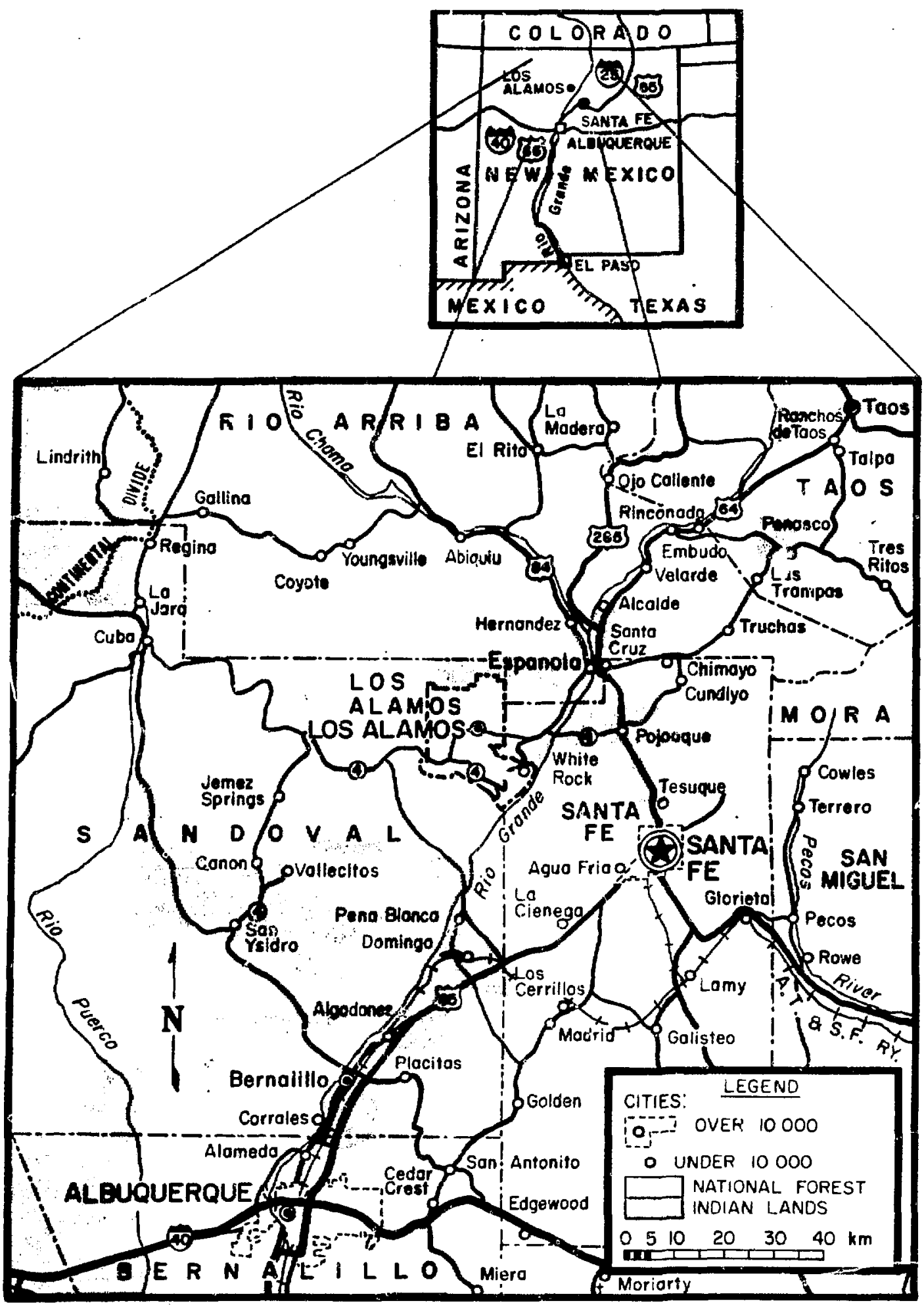

Fig. 6.

North-central New Mexico. 


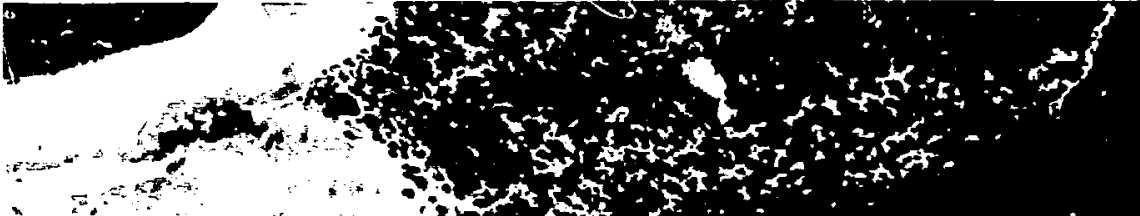

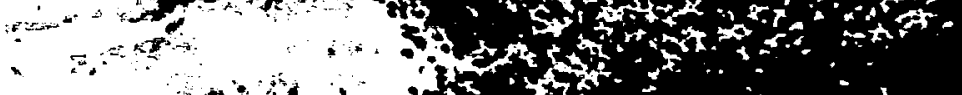

Ito

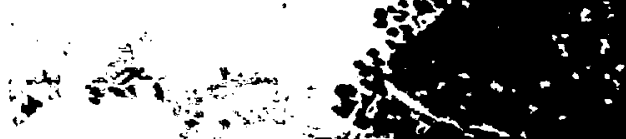

$\therefore$

(1)

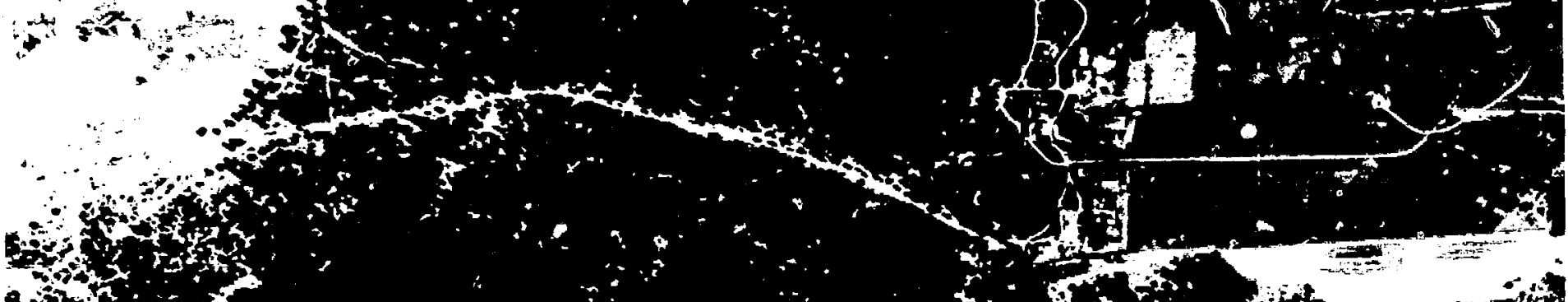
$\theta+2 x^{2}+2$

$\rightarrow x+x$

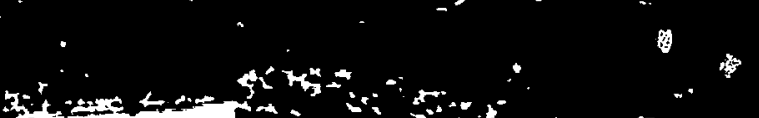

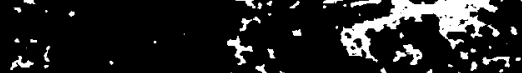

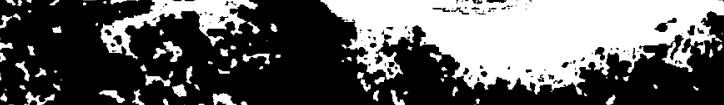

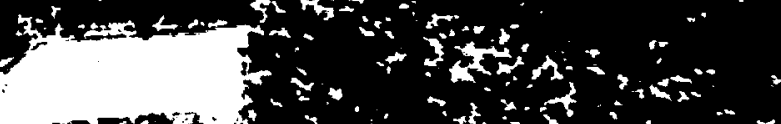

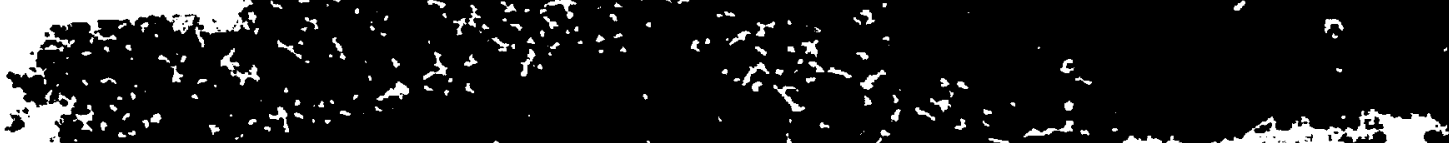

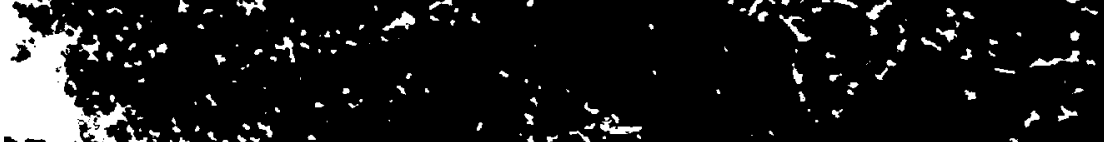


Fig. 8.

[Figure is in back pocket of this report.]

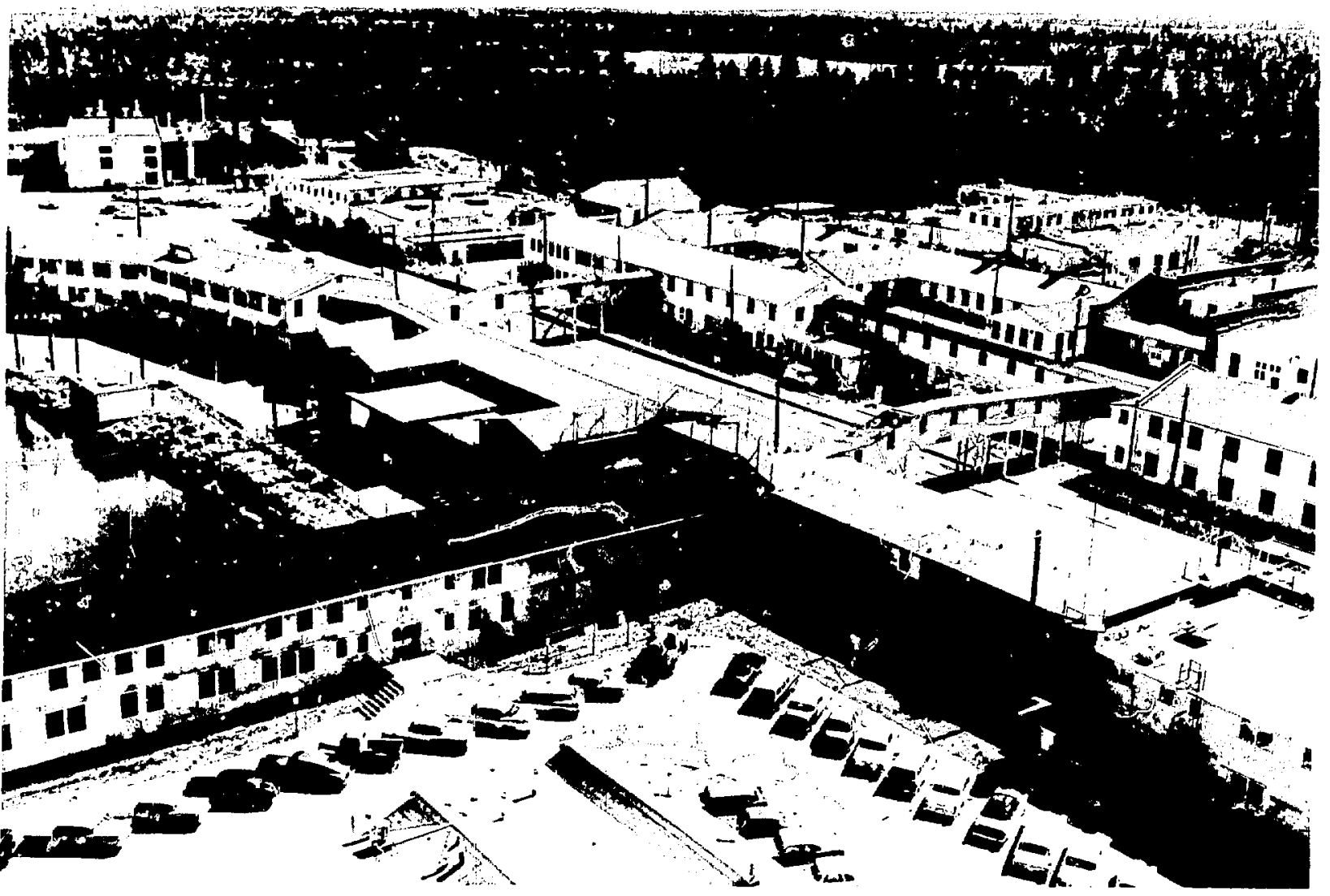

Fig. 9.

Part of TA-1 (mostly south of Ashley Pond), 1958. 


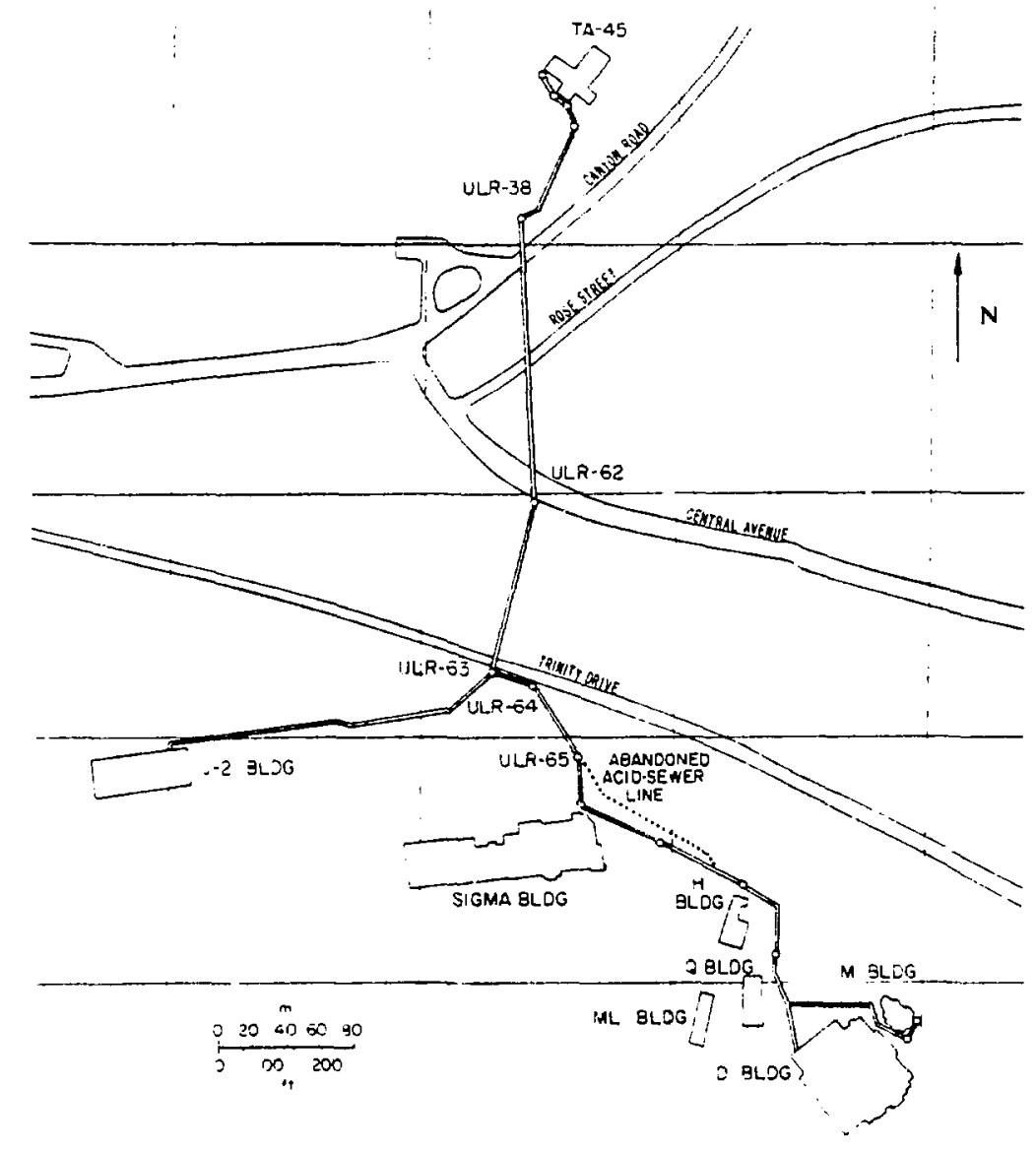

Fig. 10 .

TA-I acid waste lines and extension to Pueblo Canyon discharge point (upper center).

At the time of the new Laboratory construction in $195 \mathrm{C}$ and 1951 , the thermonuclear, or fusion, weapon was being developed. Throughout the $1950 \mathrm{~s}$ the Laboratory devoted most of its efforts to developing a family of fission weapons ranging from artillery shells to large strategic weapons. Many prototype devices were tested at the Nevada Test Site, and dehris and samples were returned to Los Alamos for radiochemical analysis.

Portions of all these activities were carried out in TA-1 facilities, and some continued there until 1965 , when the last buildings were demolished. These tasks resulted in varying degrees of radioactive contamination to the equipment, buildings, waste collection systems, and land at TA-1. The TA-1 buildings in which radioactive materials were processed, in which accidental contamination was known to have occurred, and which were connected to the industrial waste collection lines are listed in Table I according to the four materials likely to have contributed to contamination: uranium, plutonium, fission products, and radium. (Appendix A contains brief historical descriptions of structure contamination, as developed from records and from conversations with TA-1 personnel.)

Radioactive materials were used in other buildings, but records show that they were sealed sources or in forms such as foils that would not be expected to result in contamination. Some of these buildings are identified in Appendix B, along with a list of TA-1 structures by number, date of removal (or other disposition), and notes about radioactive 


\section{BUILDINGS AT TA-1 THAT HOUSED DFERATIONS INVOLVING RADIOACTIVE CONTANINATION POTENTIAL}

\section{Principal Operations}

Facilities Housing Plutonium Operations

Plutonium chemistry, metailurgy, and processing

Contaminated laundry and glassware decontamination; later used as electronics shop and for decontaminatiun of equipment from $D$ Building

Storage vault

Medical iaboratory, urine assay; latur used for radiochemical processing

\section{Facilitiea Housing Uranium Operations}

Lrarium machining

Cranium and graphite pile. leak-testing of radium sources

Heat treatment and machining of normal and enriched uranium

Storage of uranium

Processing, soetallurgy, and recovery ot enriched uranium

Casting and machining of normal and enriched uranium

Machining of normal uranium (tuballoy)

Recovery of enriched uraniura, storage

Machine shop for uranium and beryllium
Building

Designation

Other Radioactive Materials Present

D

$D \cdot 2$

Enriched uranium

D.5

Cranium

MI Artericium, curium

\section{Facilities Housing Fistion-Product O peretiong}

Radiochemistry on weapons test debri3, processing of plutonium

\section{Facilities Housing Radium Operatinns}

Storage and processing of radium sources

o

Calibration operationg with radium sources

Q

Thorium

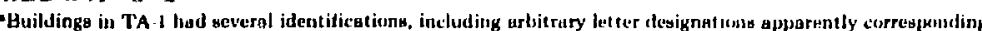

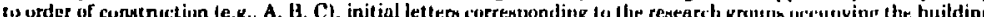
(te.t) Tur Tureticath. tinlonilisy rluep--tubaltuy

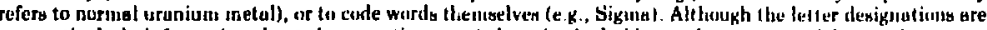

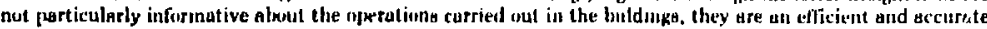

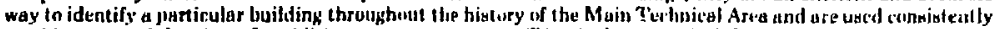
on old mays and drawinge. In addition, every meruiture at T'A.I had a numericul designation of the furw TA.1.

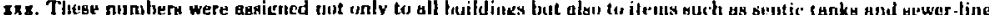

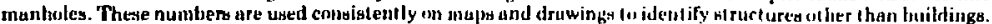


materials known to have been used there or that were mentioned in surveys conducted at the time of the original TA-1 demolition and disposal.

As new, more permanent facilities became available, research work was moved out of TA-1. Once vacated, the old structures were surveyed by health physics personnel, decontaminated as necessary, and removed or demolished. Uncontaminated materials were salvaged. Highly contaminated materials were removed to solid radioactive waste disposal sites on AEC-controlled land. Materials with low levels of contamination were disposed of in various ways, including burial at the site.

There were two major periods of demolition and decontamination at T.4-1. First, the eastern portion of the area was razed (Fig. 11) between 1953 and late 1959. This included all of the technical area east of a fence line running approximately north-south $\sim 30$ m ( $\sim 100 \mathrm{ft}$ ) west of $\mathrm{H}$ Building (Fig. 8). Second, the remaining western portion and most of the reinaining acid-sewer lines extending north from TA-1 were removed during 1964 and 1965. (See Appendix B for dates of structure removal.) A memorandum summarizing a records search completed in 1973 indicates that in the decontamination and demolition of buildings the superstructures were removed first. ${ }^{1}$ In some cases, the concrete slab or foundation walls were then removed; in other cases, depending on location and the lack of significant contamination, the large concrete slabs and foundations were left in place. In the final stages, acid-sewer lines and any contaminated senitary-sewage iines were removed.

According to Ref. 1, all activity detectable with portable alpha or beta-gamma survey instruments was removed from the eastern area. This led to the conclusiun stated in a 1959 clearance letter that "to the best of our knowledge, no radioactive contamination remains in TA-1 north or south of Trinity, east of the north-south exclusion fence..."2 That statement must be tempered by the knowledge that the survey instruments then in use had detection limits significantly higher than levels attributable to natural background. The beta-gamma survey instruments were GM-tube devices that could detect $\sim 1 \mathrm{nCi} / \mathrm{cm}^{2}$ under ideal conditions; the alpha survey instruments were Pewee propcrtional counters that could detect $\sim 16 \mathrm{dis} / \mathrm{min} / \mathrm{cm}^{2}$ under ideal conditions.
Some historical information also exists regarding the decontamination and demolition of the main facility (D Building) in which plutoniuın chemistry and processing were periormed. Because of the concern over potential plutonium hazards, D Building was subjected to a carefully planned, 9-month decontamination effort that constituted the most elaborate cleanup undertaken at TA-1. We sum. marize these efforts here to indicate the care and the techniqure employ، . to remove a seriously contaminateu buildir: and to indicate what contamination was known to remain.

Contaminated equipment, such as gloveboxes, hoods, and laboratory benches, was removed first and either decontaminated for use elsewhere or sealed and buried at the controlled solid radioactive waste site. Uncontaminated portions of the building were torn down first, followed by the roof and frame walls of the contaminated portions. A section of the roof or wall was cut with an air-driven saw. Paint was sprayed on the section to immobilize any surface alpha contamination, and a water spray controlled any dust stirred up while the section was being cut and lifted away by crane to a flatbed truck. The debris on the truck was covered with a layer of cheesecloth and spray-painted again (Fig. 12). Finally, tarpaulins were tied over the load for the journey to the specially prepared solid radioactive waste disposal pit. Smaller debris and the rubble from demolition of concrete floors and foundations were transported in dump trucks. All trucks carrying contaminated material were escorted to the disposal site by health physics personnel with monitoring equipment. Each truck was washed down before returning for its next load.

Throughout the operation workers wore full protective clothing and respirator masks. Suppliedair suits were worn for work in one particularly contaminated area.

Throughout the operation the air was sampled in the vicinity of the demolition and in residential areas as far as $2.4 \mathrm{~km}$ (1.5 miles) away. No significant contamination was attributable to the operation (averages for the period were $<1 \mathrm{dis} / \mathrm{min} / \mathrm{m}^{3}$ of gross-alphn activity).

After the site had been cleaned of all rubble and debris, eight surface soil samples and eight subsurface soil samples were analyzed for plutonium. The 


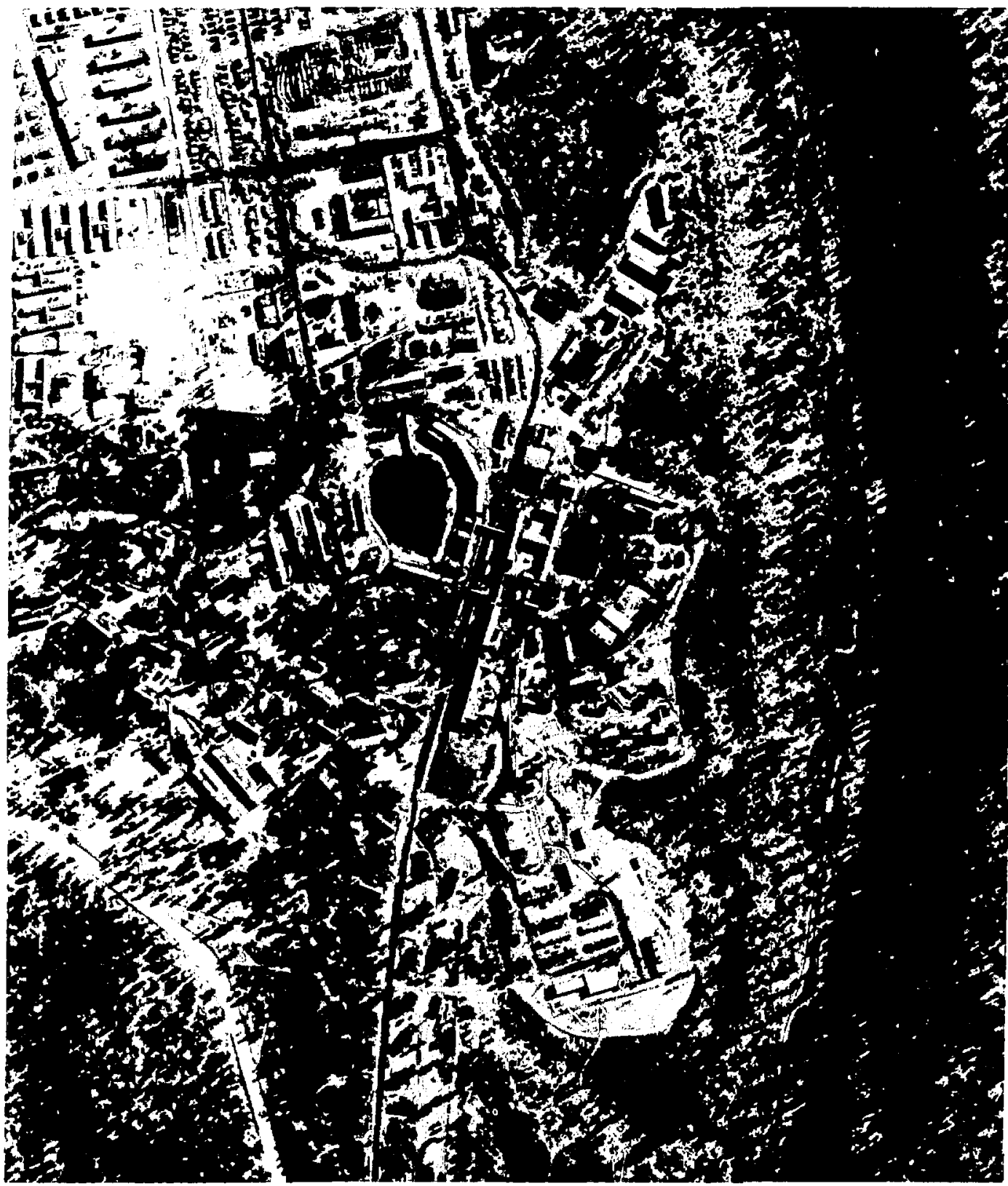




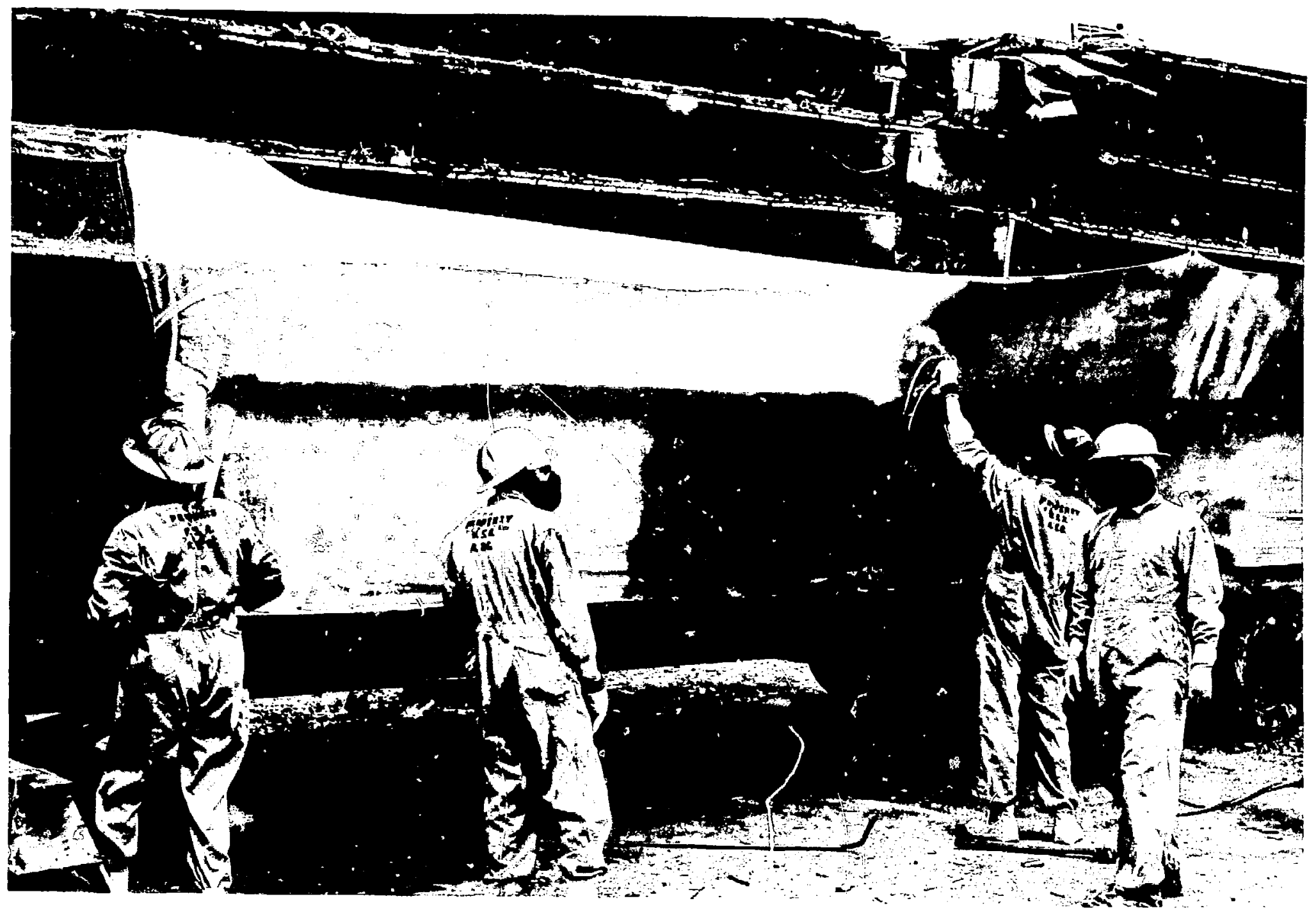

Fig. 12 
surface samples contained 3.6 to $140 \mathrm{pCi} / \mathrm{g}$ of plutonium; the samples from $\sim 2-m(\sim 6-\mathrm{ft})$ depth contained 3.6 to $33 \mathrm{pCi} / \mathrm{g}$. Then a $0.3-\mathrm{m}(1-\mathrm{ft})$ layer of soil was removed from the building site. Another eight surface samples taken from the southern part of the area were anulyzed for plutonium. This set of samples contained 28 to $242 \mathrm{pCi} / \mathrm{g}$ of plutonium (Fig. 13). The entire site was oiled to prevent the remaining dirt from blowing, ${ }^{3-6}$ and the area eventually was backfilled with clean soil and brought to grade (see Appendix A).

This, then, is the background against which the administration of LASL's Health Division recommended to the AEC in January 1960 the utilization or sale of the eastern portion of the TA-1 land (see Appendix $\mathrm{C}$ ). The reasoning was that any remaining radioactive materials were present in such small quantities or were so widely dispersed that they would in no way constitute a health hazard. The recommendation and reasoning were extended to include the ultimate clcanup of the western portion of TA-1.

The western portion was cleaned by December 1 , 1965 (Ref. 1), by procedures similar to those used for the eastern portion, although cement slabs and foundations were handled somewhat differently. Slabs or foundations of structures thought to be uncontaminated were monitored and left in place. Concrete from structures with actual or potential contamination were monitored with alpha survey meters. If the levels were $>2500 \mathrm{c} / \mathrm{min}$, the material was taken to the solid radioactive waste disposal area. This $2510-\mathrm{c} / \mathrm{min}$ level corresponds to $\geq 83$ $\mathrm{dis} / \mathrm{min} / \mathrm{cm}^{2}$, a lower limit of detection that applies

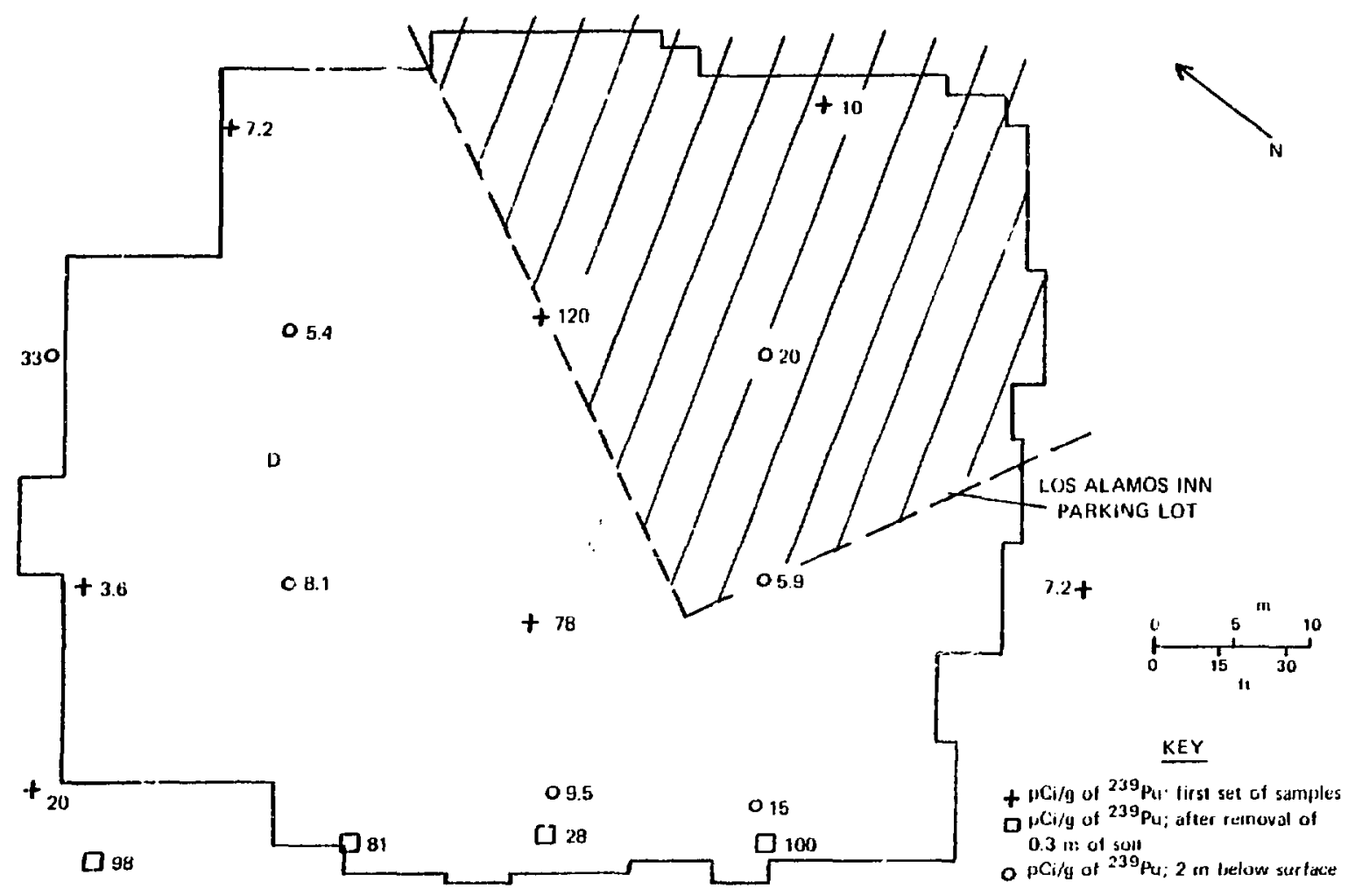

$\begin{array}{lllll}\square 52 & \square_{30} & \square^{49} & \square_{242} & 3.60\end{array}$

Fig. 13.

L-Building cutline, indicating 1954 soil-sampling results. 
to thin, uniform, dry alpha contamination spread over a flat, nonporous surface. Any departure from these ideal conditions will raise the detection level significantly. Material with $<2500 \mathrm{c} / \mathrm{min}$ of surface alpha contamination was bulldozed or was trucked to the drainage area crussed by Bailey Bridge (Fig. 8), dumped there, and in time was covered witl dirt. Most of the concrete put into this drainage area was considered uncontaminated; any contamination was from either normal or slightly enriched uraniurn. ${ }^{1}$

During the demolition and cleanup of the western portion of TA-1, the AEC took additional steps to release residential and community facilities from Federal control. Sale of government housing began in late 1965. A new County Municipal Building was constructed on that part of the former TA-1 area just west of Ashley Pond, and in mid-1967 it was turned over to Los Alamns County along with other puiblic-use lands, roads, buildings, and the utility systems. Sale of commercial properties, which included those parts of the former TA-1 area south of Trinity Drive, began in 1966 and by 1974 that land was occupied by gasoline stations, fast-food outlets, a motel, and several office buildings (Figs. 14 and 15). Undeveloped portions of the former TA-1 area, by then in private ownership, were being considered for townhouses, condominiums, and a new motel. The new survey efforts began at this time.

\section{SURVEY, EXPLORATION, AND DECON- TAMINATION: METHODS AND APPROACH}

Increased official and public concern over lowlevel radioactive contamination-including virtually any levels higher than those from naturally present radioactivity or worldwide fallout from nuclear weapons testing-led the AEC in late 1971 to request record searches and environmental radioactivity surveys of certain lands formerly used for or associated with nuclear research..$^{7,8}$ The lands in the Los Alamos area included some being considered for disposal as excess and some, such as TA1, already removed from Federal control. These surveys were carried out by personnel in LASL's Health Division. In early 1974, after completion of other, higher priority survevs and preliminary record searches relating to $\mathrm{iA}-1$, field sampling and measurement were initiated at TA-1.

\section{A. Linvironmental Radioactivity Survey, 1974}

The 1974 survey was undertaken to provide up-todate information on any radioactivity in excess of background (from natural or fallout radioactivity) on the remaining undeveloped lands once occupied by TA-1.

Fifty-five sulvey points were established throughout the undeveloped portion of the TA-1 area. Twency-six of these points were at the intersections of a reference grid having $\sim 76-\mathrm{m}$ intervals. The other 29 points were in areas considered to have a high contamination potential. These points included locations within or adjacent to the uutlines of former buildings, as well as locations in channels receiving major portions of runoff from the area (details in Sec. III.A and Appendix D). Seven additional survey points were established at 'ocations in north-central New Mexico, 30 to $80 \mathrm{~km}$ from Los Alamos, to provide background reference information. From March through July 1974, x- and gamma-radiation measurements were made at each survey point, and environrrental samples were collected.

Field measurements of $x$ and gamma radiation were made with a portable count-rate meter, a highpressure ionization chamber, and a special detector/multichannel analyzer system. The portable count-rate meter and the high-pressure ionization chamber could measure gross-gamma activity down to natural b.ackground levels. The special detector (FIDLER), crupled to a field-portable six-channel analyzer, could detect the low-energy $x$ rays associated with the radioactive decay of plutonium and americium. (Appendix D gives instrumentation details.)

Gross-gamma measurements at the TA-1 survey locations were within the range measured at the background reference locations, except for three points in drainage channels where topography alone was considered responsible for the slightly higher readings (Appendix $E$ has all data). The low-energy radiation measurements gave no indication of plutonium or americium above the detection limits of the instrument. Under ideal laboratory conditions the instrument was calibrated to detect $0.1 \mu \mathrm{Ci} / \mathrm{m}^{2}$ of ${ }^{239} \mathrm{Pu}$ and $0.05 \mu \mathrm{Ci} / \mathrm{m}^{2}$ of ${ }^{241} \mathrm{Am}$ uniformly dis. tributed on a flat surface. The field limits of detec. tion would be higher by an unknown factor because of shielding effects for any contamination below the 


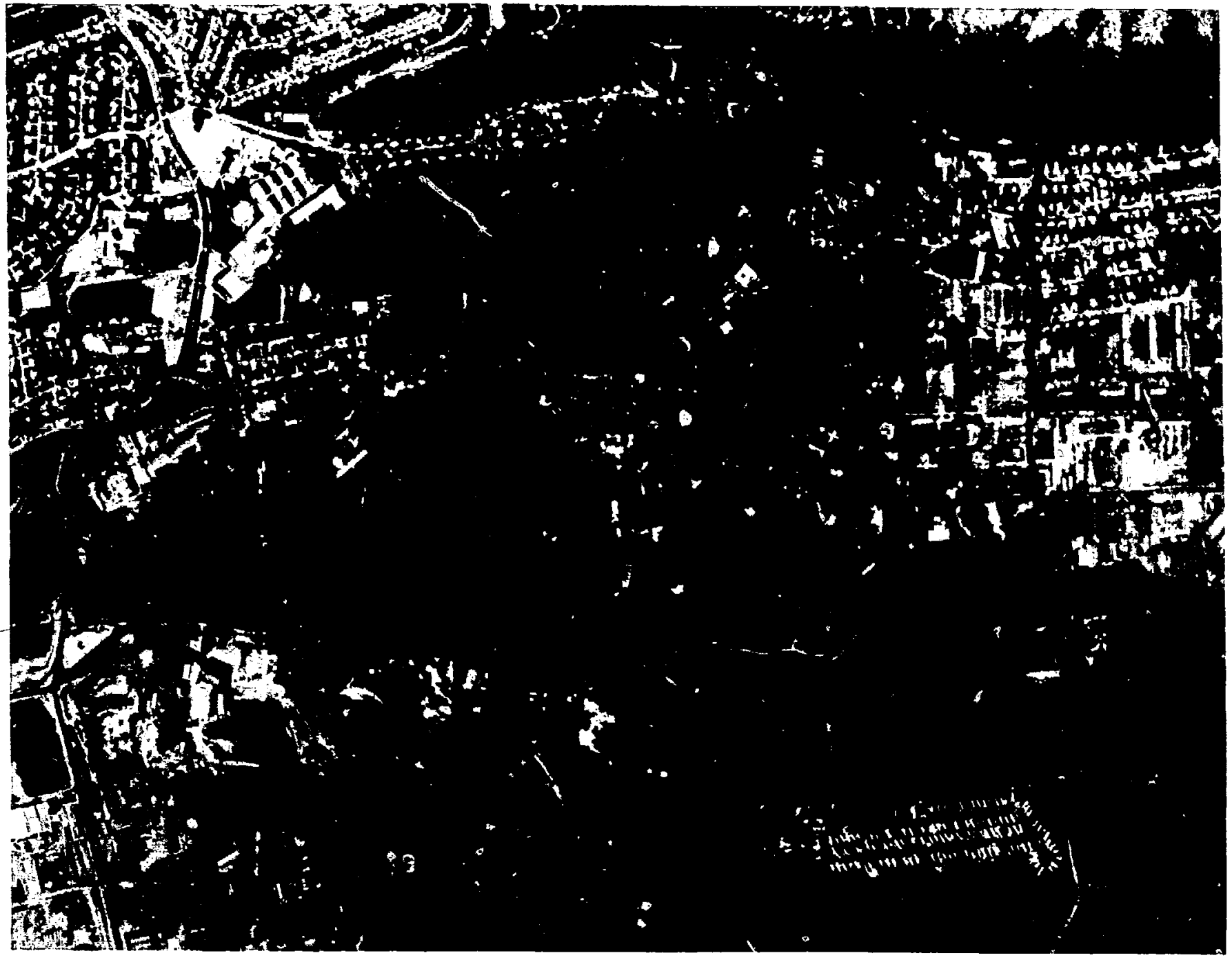




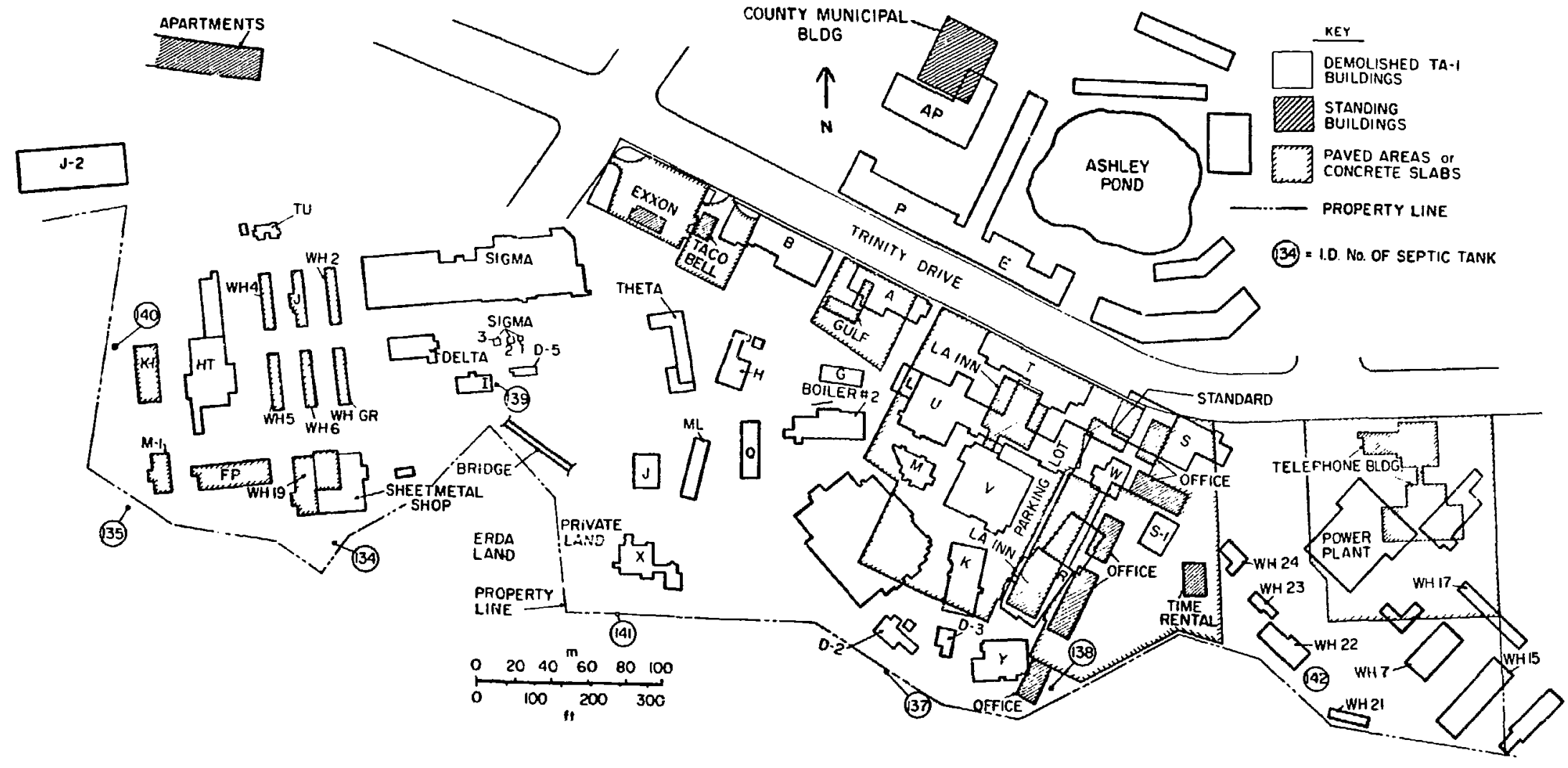

Fig. 15.

Current land use at TA-1. 
topmost surface, the probable nonuniform distribution, and uneven topography (Appendix D).

Environmental samples collected at each survey point included surface soil, a soil core, vegetation, and, at three points, the cuttings from a drilled hole. Surface soil samples were composited from five plugs $(5.1 \mathrm{~cm}$ deep and $7.6 \mathrm{~cm}$ in diameter) taken from the corners and center of a square with $10-\mathrm{m}$ sides. The soil core was collected in a $2.5-\mathrm{cm}$-diam plastic pipe driven $\sim 45 \mathrm{~cm}$ into the ground. Vegetation samples consisted of several hundred grams of native grasses. Auger-drill cuttings were removed in $60-\mathrm{cm}$ increments to a depth of $\sim 4 \mathrm{~m}$ at three locations near the former plutonium processing building (D Building).

The surface soil samples were analyzed for grossalpha and -beta activity, plutonium $\left({ }^{238} \mathrm{Pu}\right.$ and ${ }^{239} \mathrm{Pu}$ ), uranium (total), cesiun $\left({ }^{137} \mathrm{Cs}\right)$, and grossgamma activity. Selected samples from areas with high contamination potential were analyzed for americium $\left({ }^{241} \mathrm{Am}\right)$, radium $\left({ }^{228} \mathrm{Ra}\right)$, and beryllium, as considered appropriate on the basis of historical information. Soil core and vegetation samples were ansiyzed only from those locations at which significant surface soil contamination was found. The laboratory analyses were completed by April 1975 . (Appendixes $\mathrm{D}$ and $\mathrm{E}$ give details of analytical methods and results.)

The results of surface soil analyses are summarized in Table II. Concentrations higher than regional background levels were found at one or more of the TA-1 survey points for all of the contaminants except radium and beryllium. The most significant results were those for plutonium, uranium, and cesium/gross-gamma (Fig. 16). As could be expected from historical information (Sec. I.A and Table I), the highest levels of plutonium contamination were found in the eastern purtion of TA-1, especially in the vicinity of D Building and the contaminated-clothing laundry (Building D-2). The highest levels of uranium contamination were in the western portion of TA-1, especially near buildings in which uranium operations were performed (Buildings Sigma, TU, and HT). Maximum uranium levels were found in samples from the drainage channel (south of Building J-2 and west of Building HT on ERDA property) which carries much of the surface runoff from the western part of TA-1. Some elevated uranium values were also found in samples from the drainage channel, south of Sigma Building, into which uraniumcontaminated rubble had been placed during demolition of ivuildings in the western part of TA-1 (Sec. I.B). The samples exhibiting significantly above-background ${ }^{197} \mathrm{Cs}$ or gross-gamma activity came from points near the alignment of the acidsewer line serving Building J-2, where large quantities of fission products were handled.

The data from this survey were neither surprising nor indicative of any health or safety problems. The types, levels, and locations of contamination were consistent with expectations based on historical information. Even the maximum values of plutonium ( 100 to $200 \mathrm{pCi} / \mathrm{g}$ ) were not considered high enough or widespread enough to raise the question of health or safety hazards.

Nevertheless, the likely source of the highest ${ }^{238} \mathrm{Pu}$ contamination was investigated. It was located immediately downslope from the outlet from a septic tank which had served the laundry (Building D-2, Fig. 16). The tank had been left in place after the outlet line was monitored and found fres of contamination during the cleanup of TA-1's eastern portion. ${ }^{9}$ Records indicated that it was a rectangular concrete tank filled with dirt, but when found on the property line separating ERDA land from private land it turned out to be a cylindrical metal tank containing water and sludge. Radiochemical analysis of the contents showed $0.01 \mathrm{pCi} / \mathrm{g}$ of ${ }^{239} \mathrm{Pu}$ in the water and $114 \mathrm{pCi} / \mathrm{g}$ in the sludge, results consistent with the concentration found in the original surface sample past the end of the outlet pipe and below the detection limit of portable survey instruments. After the tank was removed on August 11, 1975, some contaminated soil was found in the pit. During additional excavation, a pocket of contamination was found $\sim 1.3 \mathrm{~m}$ below the surface on ERDA land just south of the property line. Radiochemical analysis of a sample from this pocket showed a maximum concentration of $125000 \mathrm{pCi} / \mathrm{g}$ of early-1945 Hanford plutonium. (Additional details are given in Sec. III.B.1.) During a postexcavation survey, a pipe fragment contaminated to levels easily detected by portable aipha survey instruments was found on the ground surface nearby.

These unexpected findings brought into que:tion the significance of the 1974 survey results. Whereas the survey had not indicuted any major amounts or 
TABLE II

SUMMARY OF SURFACE SAMPLING RESULTS FROM 1974 SURVEY

\begin{tabular}{|c|c|c|c|c|c|}
\hline Contaminant & Units & $\begin{array}{c}\text { No. of } \\
\text { Samples }\end{array}$ & Range & Median & Averag \\
\hline \multicolumn{6}{|c|}{ All TA-1 Locations } \\
\hline Gross alpha & $\mathrm{pCi} / \mathrm{g}$ & 51 & 1.1 to 23.9 & 2.8 & 3.6 \\
\hline${ }^{299} \mathrm{Pu}$ & $\mathrm{pCi} / \mathrm{g}$ & 55 & 0.11 to 224 & 0.25 & 8.7 \\
\hline Uranium & $\mu \mathrm{g} / \mathrm{g}$ & 45 & 1.6 to 55 & 6.2 & 8.7 \\
\hline${ }^{24 !} \mathrm{An} \cdot$ & pCi/g & 20 & -0.12 to & 0.07 & 0.33 \\
\hline${ }^{220} \mathrm{Ra}$ & $\mathrm{pCi} / \mathrm{g}$ & 13 & 0.8 to 5.2 & 2.1 & 2.1 \\
\hline${ }^{187} \mathrm{Cs}$ & $\mathrm{pCi} / \mathrm{g}$ & 51 & 0.26 to 12.5 & 0.89 & 1.4 \\
\hline Beryllium & $\mu \mathrm{g} / \mathrm{g}$ & 6 & 0.86 to 2.9 & 1.2 & 1.5 \\
\hline
\end{tabular}

Northern New Mexico Reference Locations

$\begin{array}{lllllll}\text { Gross alpha } & \mathrm{pCi} / \mathrm{g} & 7 & 1.8 \text { to } 4.0 & 2.6 & 2.6 \\ { }^{280} \mathrm{Pu} & \mathrm{pCi} / \mathrm{g} & 7 & 0.010 \text { to } 0.034 & 0.025 & 0.024 \\ \text { Uranium } & \mu \mathrm{g} / \mathrm{g} & 7 & 1.4 \text { to } 2.9 & 1.7 & 2.0 \\ & & & & & \\ { }^{201} \mathrm{Am} & \mathrm{pCi} / \mathrm{g} & 7 & -0.47 \text { to } 0.11 & 0.01 & -0.06 \\ { }^{220} \mathrm{Ra} & \mathrm{pCi} / \mathrm{g} & 7 & 1.6 \text { to } 3.9 & 2.3 & 2.3 \\ { }^{187} \mathrm{Cs} & \mathrm{pCi} / \mathrm{g} & 7 & 1.2 \text { to } 2.5 & 1.7 & 1.8 \\ \text { Beryllium } & \mu \mathrm{g} / \mathrm{g} & 7 & 0.58 \text { to } 1.2 & 1.0 & 0.96\end{array}$

high concentrations of contamination, there was now evidence that the relatively large spacing between samples, the shallowness of samples, or the inability of instruments to detect subsurface contamination resulted in failure to identify other, more significant contamination in the TA-1 area. These suspicions were heightened by the discovery of the contaminated pipe fragment on private land and the discrepancy in records about the construction and contents of the septic tank. A more intensive sampling, survey, and exploratory program was necessary to achieve the desired level of confidence about the presence or absence of contamination.

\section{B. Intensive Exploration and Investigation, 1975-1976}

An intensive exploratory effort was initiated after the discoveries of contamination near the laundry
(Building D-2). The investigation was meant to provide the best practicable assurance that all significant contamination would be identified. Also, any contamination found was to be removed to the lowest practicable level.

ERDA has the authority to decontaminate any sites or facilities in order to protect health and to minimize danger to life or property where the contamination is a result of activity authorized by the Atomic Energy Act of 1954, as amended. 'The Administrator (formerly, the Commission) is authorized pursuant to Sec. 161.i of the Act to prescribe such regulations or orders as he may deem necessary to govern any such activity.

The problem and the plan were explained at a public meeting on September 5, 1975, and property owners gave permission to conduct the work. The investigative efforts included: 


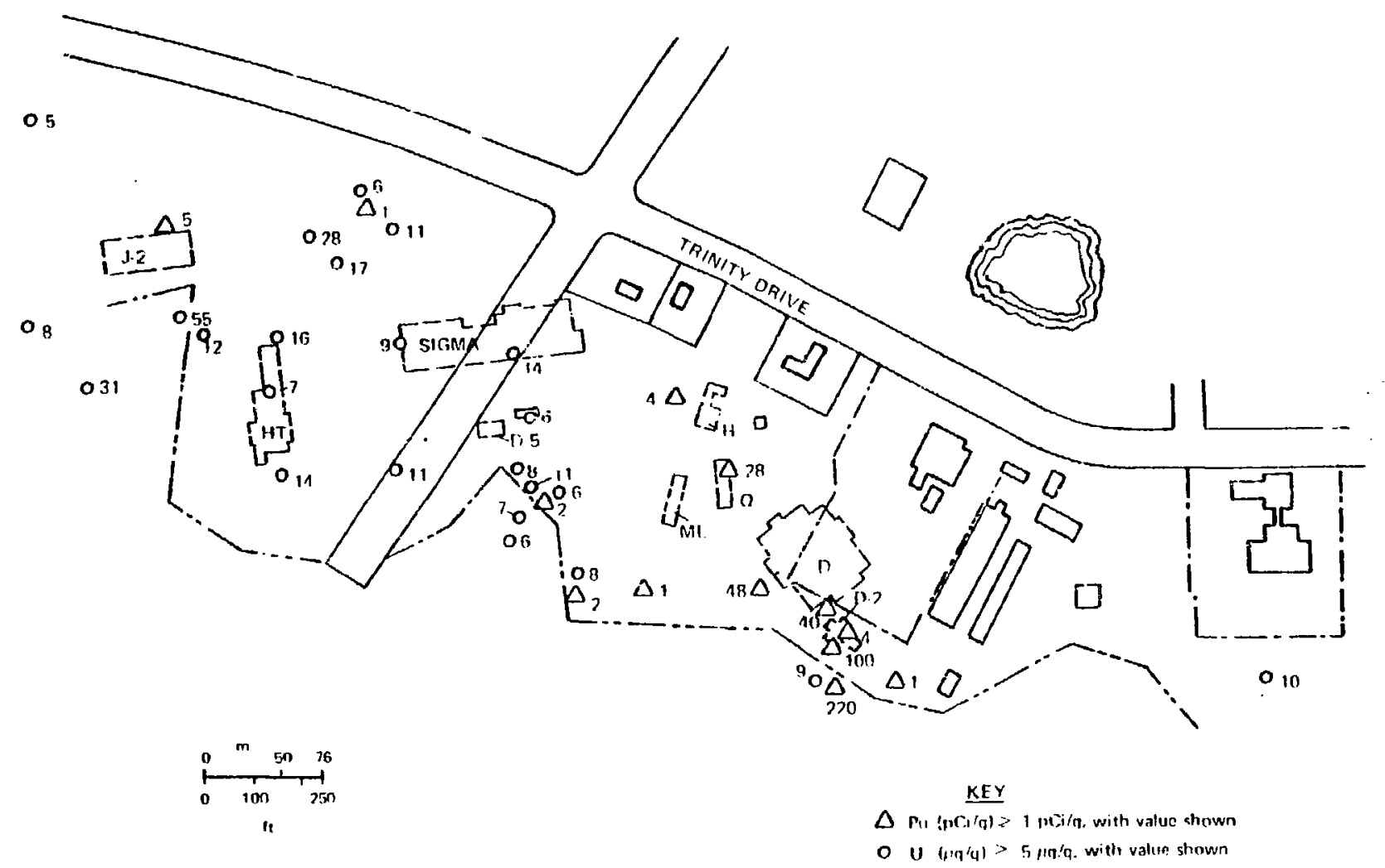

Fig. 16.

Location and concentration of ${ }^{239} \mathrm{Pu}(\geq 1 \mathrm{pCi} / \mathrm{g})$ and total uranium $(\geq 5 \mu \mathrm{g} / \mathrm{g})$ in $\mathrm{TA}-1$ soil (1974 Environmental Radioactivity Survey). 
- An extensive survey made with portable instruments to identify any major near-surface contamination or any major contamination of debris from demolition.

- A sampling program to obtain additional surface samples, core samples, and drill-cutting samples, with emphasis on areas suspected of being contaminated and including adequat $€$ random samples.

- Exploratory trenching to obtain information on subsurface conditions, especially where there might be contaminated sewer lines.

- Excavation to determine the presence and possible contamination of any septic tanks and the removal of all such tanks.

- Intensive search for additional records, engineering drawings, routine reports, and other historical inticrmation, including personal memories of people who worked at TA-1, that might turn up clues to contamination sources.

The first exploratory efforts were directed towaid defining the extent of those areas already known to be contaminated; for example, the area around the laundry (Building D-2) and the areas around buildings where uranium operations had been carried out (Buildings HT and Sigma). Decontamination operations were carried out at the same time to make efficient use of available personnel, instruments, and equipment. In many cases, exploratory and decontamination tasks were irdistinguishable hecause cleanup of wise contaminated area would often lead to the discovery of a previously unlocated contamination. Details of the exploratory firclings and the decontamination operations are described by area in Sec. III. An overview of tools and techniques, as well as the scope of the exploratory efforts is given in this section (II.B). An overview of the methods and extent of the decontamination roperations is given in Sec. II.C.

1. Instrumental Surveys. Among the portable survey instruments used for rapid identification of contamination on debris or near the ground surface were conventional alpha air-ionization detectors, beta-gamma GM-tube detectors, thin-window GM detectors, and FIDLER detectors (details in Appen$\operatorname{dix}$ F). They were used by health physics monitors or supervisory personnel for exploratory surveys over large land areas, evaluation of possible contamina- tion on debris, detection of contamination in exploratory trenches, and guiding excavation operations in contaminated areas.

Two special field versions of a phoswich detector were constructed to better detect the low-energy $x$ and gamma radiation associated with the radioactive decay of plutonium, uranium, and americium (the instruments are described in Appendix F). The phoswich detector was also more sensitive in detecting ${ }^{137} \mathrm{Cs}$ than were conventional survey instruments. The two phoswich detectors were not available until after the intensive exploration and decontamination operations were under way. Their first use was to guide excavation and decontamination operations; later, they were used to resurvey the

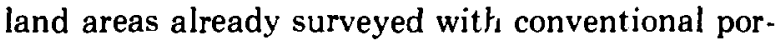
table equipment. The phoswich was also used to survey exploratory excavatious.

2. Soil Sampling and Analysis. Exploratory surface and subsurface soil samples were collected in four ways: (1) surface samples were scooped from the top tew centirneters of a $\sim 100-\mathrm{cm}^{2}$ area; (2) core samples were collected by driving a $2.5-\mathrm{cm}$-diam plastic pipe as far as $40 \mathrm{~cm}$ into the ground-the dejth depending on soil texture; (3) cuttings from $10 \mathrm{~cm}$-diam holes drilled by a truck-mounted augerdrill iig (Fig. 17) were collected at 60 - to $150-\mathrm{cm}$ intervals at depths ranging to $\sim 10 \mathrm{~m}$; and (4) grab samples were scooped from the sides or bottoms of exploratory trenches or pits at intervals chosen according to the expectations for potential contamination and indications from portable survey instruinents (Appendix F).

All soil sampies were given a rapid gross-alpha analysis by a zinc-sulfide ( $\mathrm{ZnS})$ detector system that had an operational detection limit of $\sim 2.0 \mathrm{pCi} / \mathrm{g}$ above natural alpha background (Appendix F). Two such detector systems were locaied in a field laboratory trailer parked at the site during most of the field worh. Also available in the trailer were a FIDLER and a shielded phoswich detector, both connected to a multichannel analyzer to permit qualitative identification of isotopes. LASL analytical laboratories performed radiochemical, mass spectrographic, elemental, or instrumental analyses on selected samples to make a detailed isotopic evaluation, confirm the type and level of contamination, or identify unknown contamination, 


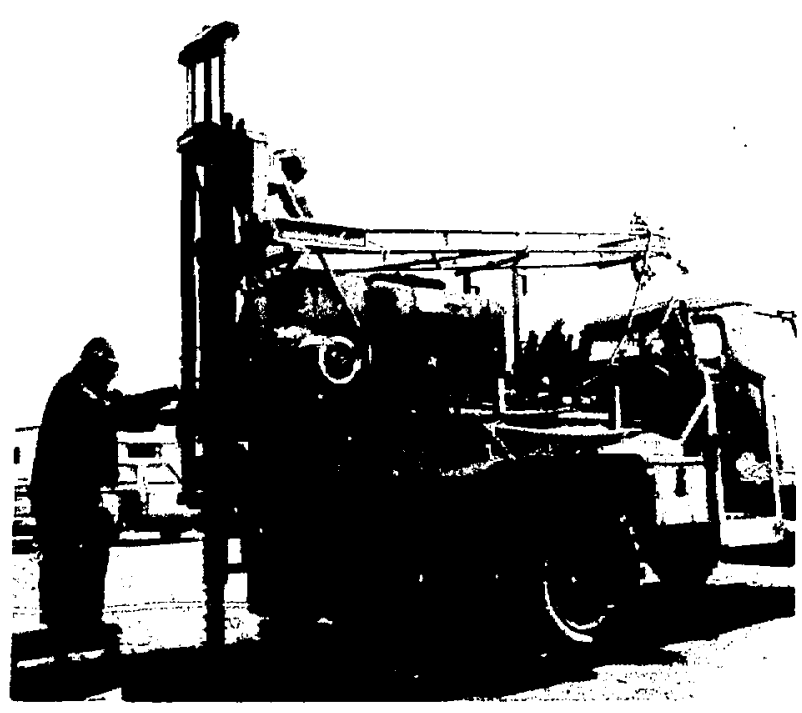

Fig. 17.

Truck-mounted, auger-drill rig.

as appropriate. (The most frequently used radiochemical methods are described in Appendix D.)

3. Scope of Exploration. The exploratory surveying and the sampling went on from September 1975 through August 1976. At first, efforts involved thorough exploration of areas suspected of contamination on the basis of historical information or as a result of the 1974 survey. This exploration included instrumental surveys of any remaining debris, foundations, or slabs and the ground area around a suspected structure. In some cases, trenches were dug to check on the presence of any contaminated waste lines, and exploratory excavations were made to locate the remaining septic tanks. Any such excavations were monitored with the survey instruments. Surface soil and grab samples from the trenches or excavations then underwent gross-alpha analysis. If the field-instrument surveys indicated any contamination, extra samples were often collected. If the initial samples indicated a level of contamination that might require removal, additional samples were often taken in an attempt to define the extent of required excavation. Sometimes samples were submitted for radiochemical analysis before a decision was made about supplementary samples.
If an area required decontamination, the excavation was guided initially by survey instruments. After contamination had been removed to levels below the field instruments' detection capabilities, required additional sampling often disclosed portions of the area needing additional cleanup or adjacent areas with contamination not detectable by the portable instruments. Details of such exploratory findings and iterative efforts are described later by area.

In addition to the investigations of specific areas, exploratory surveying and sampling were conducted throughout the TA-1 area to provide a closer spacing of data than was available from the 55-point, 1974 survey. This exploration was conducted concurrently with decontamination work as time permitted. In some cases, extra samples were taken to fill in information between areas already intensively sampled or to check on possible spread of contamination by water or sediment transport. Exploration of the TA-1 area included taking samples from the surface, as well as at depth, by means of cuttings from shallow (as deep as $\sim 1 \mathrm{~m}$ ) auger holes. Another phase of this exploration was the phoswich resurvey of the entire undeveloped portion of the TA-1 area, including areas previously surveyed with conventional instruments. A number of spots of previously undetected contamination were identified.

\section{Decontamination Operations, 1975-1976}

Decontamination and cleanup activities depended on the type of contamirant, its concentration, areal extent, and depth, and on the topographic situation. The timing of efforts depended upon the availability of adequate details about the contamination, the availability of manpower and equipment, the need for periodic review to determine whether decontamination had reached practicable limits, and the pressures exerted by private property owners who wanted to build on the land. Day-to-day field work was supervised by Health Division and Engineering Department personnel. Heavy equipment, trucks, laborers, teamsters, and equipment operators were supplied by Zia Co., ERDA's Los Alamos support-services contractor. 
1. Decontamination Methods. Essentially all decontamination work involved the removal of soil or tuff, the soft volcanic rock making up much of the mesa tops in the Los Alam 'ss area. Some debris, including pipes, clay-tile sewer lines, septic tanks, concrete, and various building materials, was also removed, but its volume was insignificant in comparison to that of the soil and rock. All contaminated material was taker to the controlled solid radioactive waste disposell area, which accommodates the routine cintaminated wastes froin Laboratory operations.

Smail, isolated spots of contamination or spots with high concentrations were carefully handshoveled into plastic bags to minimize the spread of contamination.

A backhoe excavated areas having a potential for high levels of contamination, such as lines found in place, the course of old trenches for contaminated waste lines, and septic tanks found in place, as well as difficult locations such as deep excavations and stcep slopes. In such areas, the buckets of material were monitored to determine progress. Contaminated soil removed by backhoe was loaded directly into a dump truck (Fig. 18).

Heavy equipment was used in large areas where contamination was relatively widesuread but lowlevel, as determined by exploratory sampling and monitoring. A crawler tractor equipped with backmounted ripper blades broke up the soil or tuff to depths as great as $1 \mathrm{~m}$ (Fig. 19). The area was monitored to identify any uncovered, high contamination levels that would require nandexcavation (Fig. 20). The broken material then was pushed by bulldozer into a stockpile, from which it was loaded into dump trucks by a front-end loader (Figs. 21-23). Throughout all excavation and loading operations that might result in suspended dust, water sprays were used extensively to wet the exposed earth and preclude airborne contamination.

Dump trucks hauled contaminated or potentially contaminated material to the Laboratory's solid radioactive waste disposal site $\sim 12.5 \mathrm{~km}$ away. The truck-beds were lined with plastic sheets to prevent loss of material in transit. For material from uranium-contaninated areas, only the tailgate was lined; for material from plutonium-contaminated areas, the entire truck bed was lined with plastic sheeting large enough to fold over the load. All truckloads were covered with canvas tarpaulins $w !: ~ h$ were tied to prevent the dirt from blowing. As a loaded truck left the work area, the tires and the ledges on the truck-ived were phoswich-monitored to assure that contamination was not tracked out (Fig. 24). A load ticket carried by each driver gave the nature of the load's contamination to ensure proper disposition at the disposal site. A health physics monitor in a second vehicle having radio communication with the truck driver escorted to the disposal site any truck known to be carrying appreciably contaminated material.

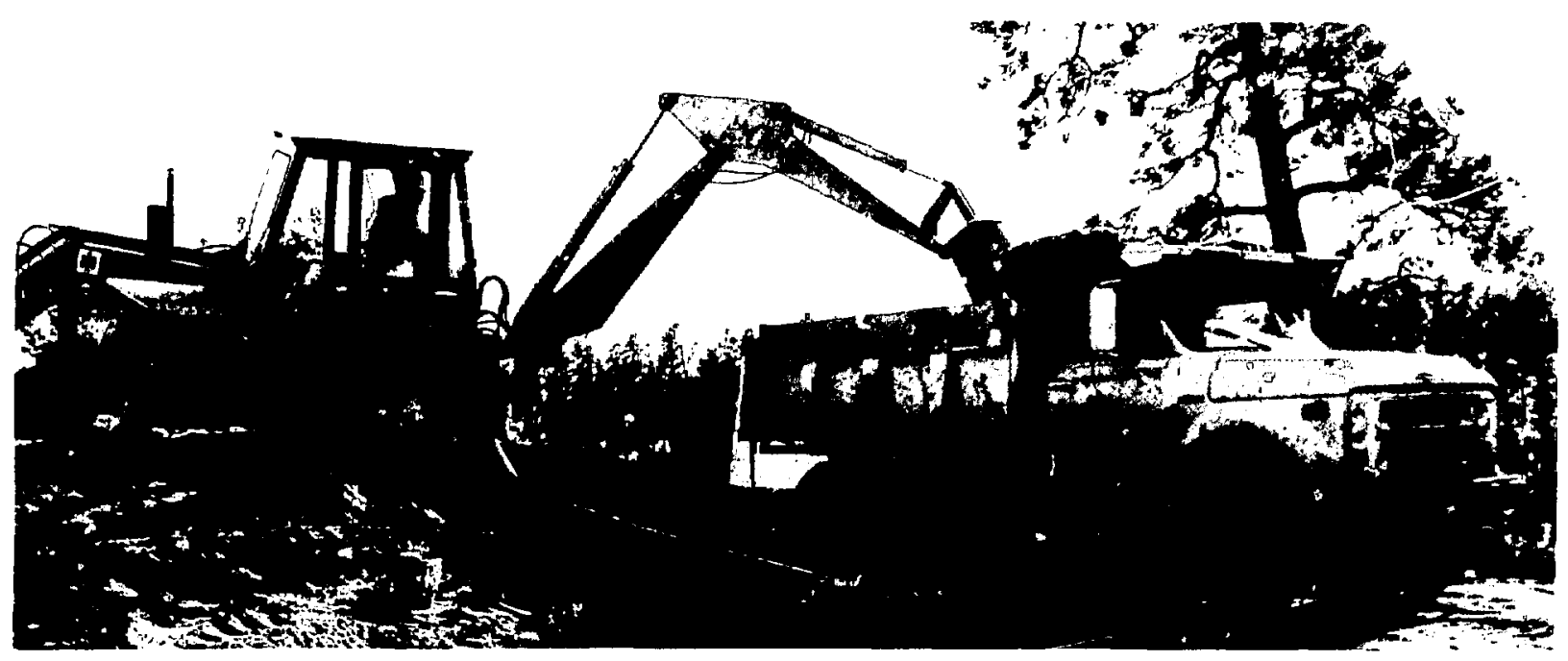

Fig. 18.

Excavation of TA-1 land by backhoe. Soil is loaded directly into a dump truck. 


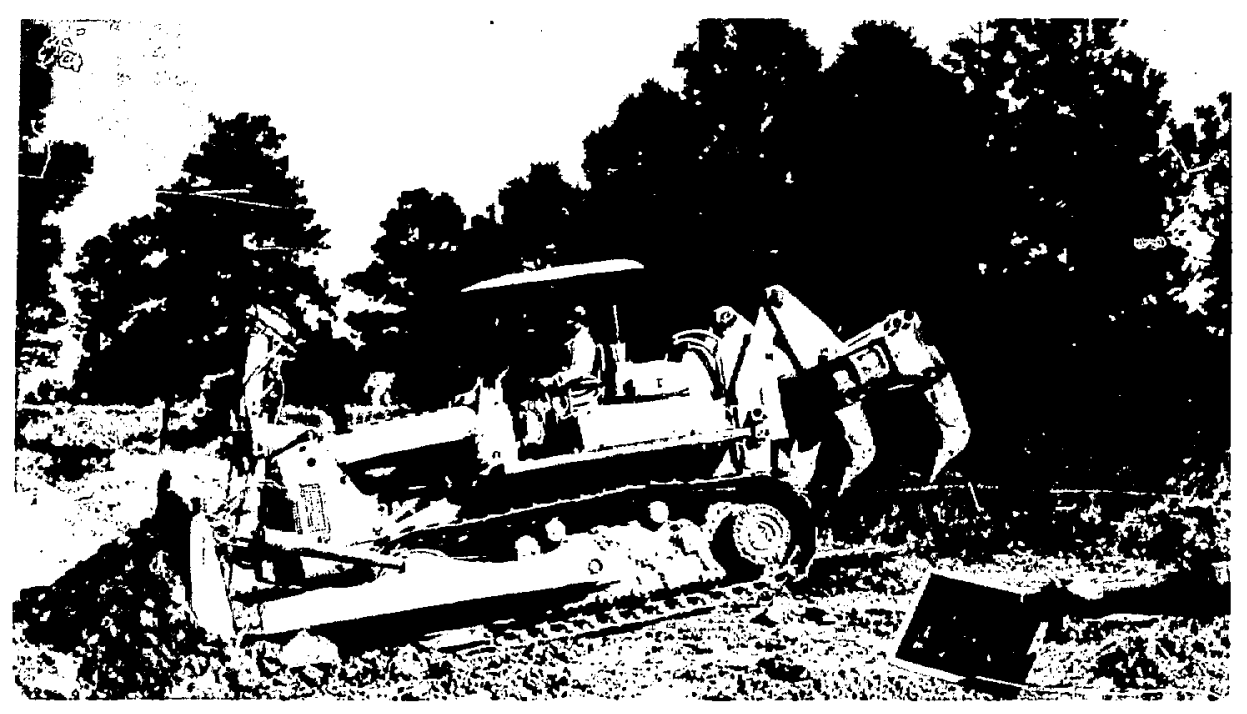

Fig. 19.

Crawler tractor with bulldozer blade on front and ripper blades at rear.

2. Extent of Required Decontamination. The basic premise of the decontamination operations was that all contamination found was to be removed to the lowest practicable levels. The rationale, together with certain elements of radiation protection philosophy, is discussed in Sec. IV, but the operational steps taken to implement the as-low-aspracticable philosophy are described here.

Decontamination operations proceeded by appropriate methods until contamination was no longer detectable by portable instruments (the field phoswich had the best sensitivity). Often the excavation would be iterative because removal of contaminated soil would expose additional contamination. Surface samples were collected at about 3- to 6-m intervals on a grid pattern and the $\mathrm{ZnS}$ detector system analyzed them for gross-alpha activity. If measurable activity remained (the $\mathrm{ZnS}$ detector limit was $\sim 20 \mathrm{pCi} / \mathrm{g}$ above natural alpha background), material was removed by additional excavation until no further contamination could be identified by field methods or until a decision was made that residual contamination was as low as practicable.

Among the factors involved in determining complete decontamination are:

- The particular contaminant involved,

- The location of the contaminant,
- The ability to detect different types of radioactivity in field situations, and

- The cost of further efforts to reduce levels in terms of time, money, or physical hazards to personnel.

In practice, the Health Division personnel overseeing the field operation used professional judgment in directing the day-to-day operations. LASL personnel regularly presented data and recommendations on decontamination progress to the Operational Safety personnel of ERDA's Albuquerque Operations Office (ALO), and ALO personnel made the final decisions about whether decontamination to levels as low as practicable had been achieved. These decisions were usually made at meetings held in Los Alamos in conjunction with onsite inspections by ALO personnel. Table III lists these meetings, indicating the areas being considered and the personnel representing LASL as well as ERDA's ALO and Los Alamos Area Office (LAAO).

\section{Related Support Operations}

a. Health Physics Protection. Throughout all decontamination operations, workers were monitored to ensure against unnecessary exposure. 


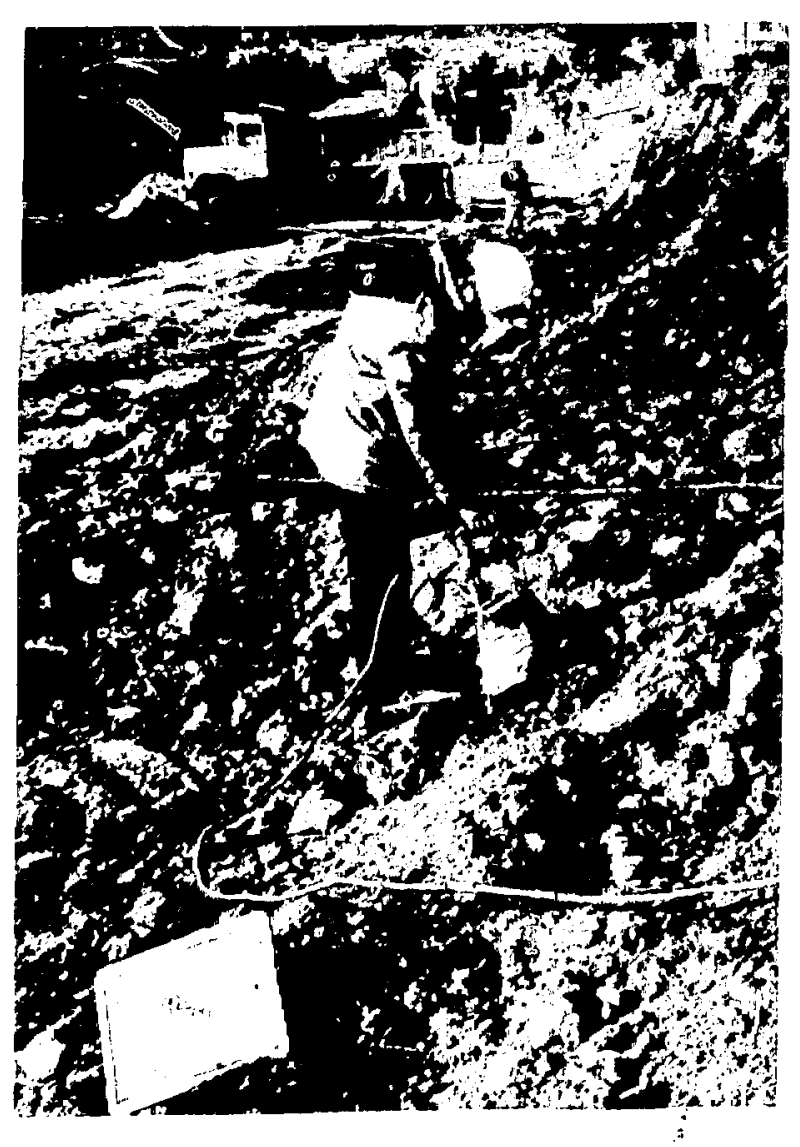

Fig. 20.

Field surieying with the portable phoswich.

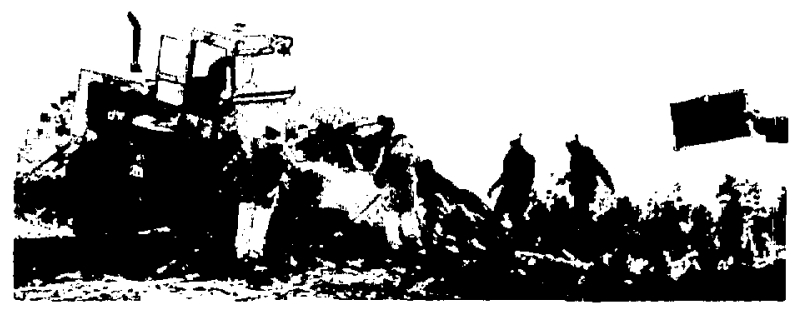

Fig. 21.

Front-end loader scooping up soil.
All personnel who did removal work wore anticontamination clothing-coveralls, gloves, footwear, and head coverings.

All workers also wore personnel dosimeters (film badges). Specific personnel exposures cannot be aitributed to TA-1 because workers were not there exclusively; however, 10 months of film-badge readings on the 50 people most active in the project showed a maximum exposure of 0.14 rem (of 500 badges analyzed, 20 had positive readings).

Air was sampled throughout the workday in the immediate vicinity of decontamination operations, and the air filters were analyzed daily. Of 242 air samples, 33 had positive, long-lived, gross-alpha activity. The maximum concentration in any one filter was $3.6 \times 10^{-19}$, found after a 6 -h work period near the drain trench of Building D-2.

Daily nose swipes were taken from workers in contaminated areas, but no activity was found in any of 1705 swipes. All workers who might be exposed to plutonium were given urinalyses; 20 urinalyses out side the routine urinalysis program were performed for TA.1 workers. No urinalysis indicated exposure.

In summary, no worker received any significant exposure as a result of the TA-1 decontamination project.

b. Environmental Monitoring. Continuous airsampling stations were established at three commercial establishments close to the major plutonium decontamination operations. Grossalpha and -beta measurements were made on the samples, as were radiochemical analyses for plutoniuin. The gross-alpha and -beta measurements did not differ significantly from those taken from the environmental air-sampling network. In several instances, plutonium values were somewhat higher than air-sampling network values for that time of year. The maximum value of $463 \times 10^{-18}$ $\mu \mathrm{Ci} / \mathrm{cm}^{3}(0.8 \%$ of the Radioactivity Concentration Guide ( $R C G$ ) for the individual in an uncontrolled area) for a 2-wk period approximates the maximum (for a 6-wk period) measured by the air-sampling network during 1973 through 1975. (Appendix G contains details of the measurements.)

c. Protective Fencing. Temporary fences were constructed to protect the publir; from areas with a 


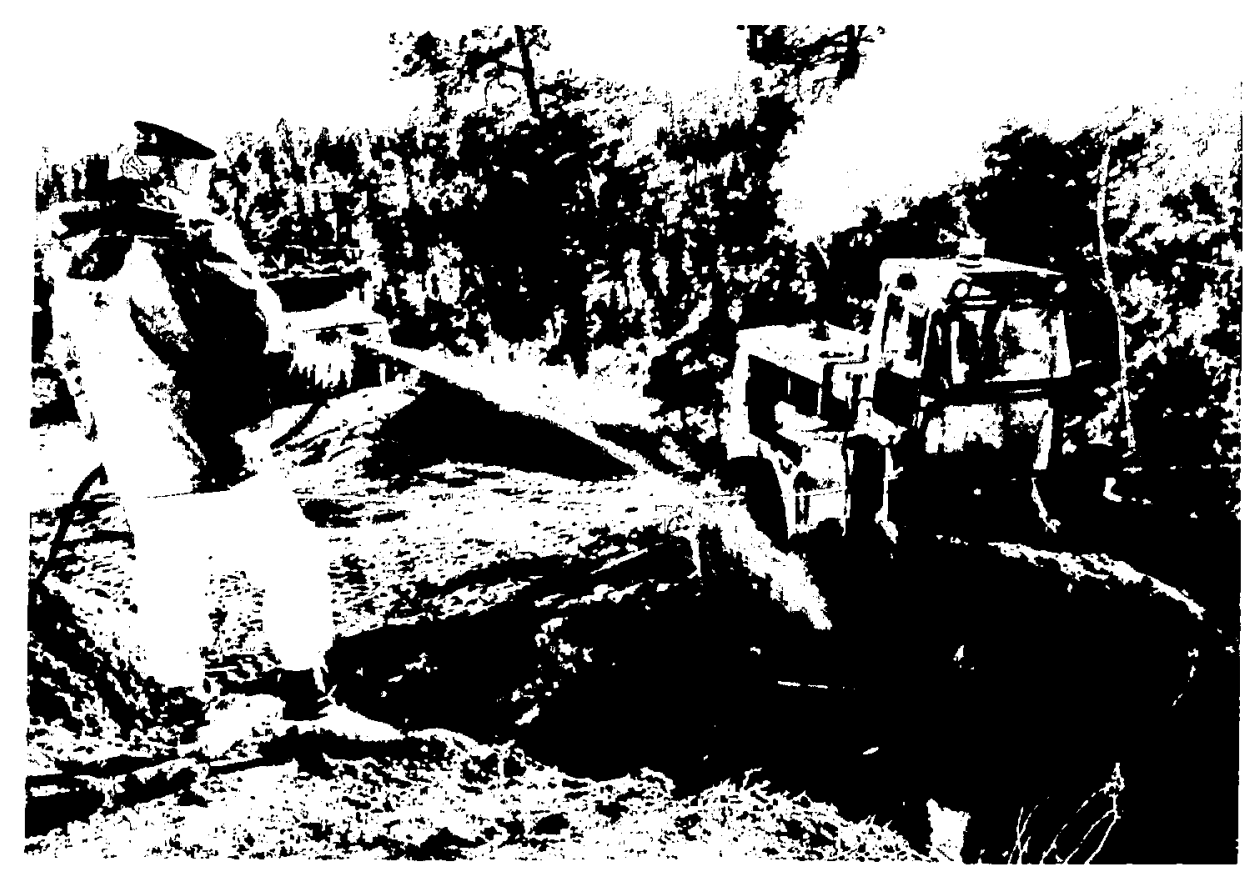

Fig. 22.

Front-end loader scooping up soil from a stockpile. Note method of water-sp ying.

potential for significant contamination or where excavations were deep. Permanent, chain-link fencing, $1200 \mathrm{~m}$ long and $2.4 \mathrm{~m}$ high, ererted along the property line between ERDA land (to the south) and private land (to the north) still separates the public from areas where contamination related to TA.1 may remain.

d. Restoration of Excavated Areas. Areas excavated fol decontamination purposes were restored as soon as decontamination was deemed complete. Clean fill and soil were hauled from new construction sites, placed in the excavations, and compacted, and the surface was worked to approximate the original contours. The areas were drilled with fertilizer and five species of native grasses and were stabilized with straw and an asphalt emulsion to aid germination. In one ERDA location south of the Los Alamos Inn parking lot, a retaining wall of boulders was built to stabilize the new fill. To prevent erosion of the new fill by runoff from the lot, an asphalt drainage channel was constructed from the west side of the parking lot toward the south onto ERDA property.
4. Level of Effort. The intensive exploratory efforts and the decontamination operations at TA-1 lasted $\sim 1 \mathrm{yr}$ and $\sim 15000 \mathrm{~m}^{3}$ of contaminated and potentially contaminated material were removed to LASL's solid radioactive waste disposal site. About 8000 soil samples were analyzed for gross-alpha activity, and several hundred of those underwent additional analyses. Table IV gives the amount of soil removed each month from each of the excavation aress.

The extensive decontamination operations began in mid-October 1975, after $\sim 1$ month of exploratory effort. Until late February 1976, work proceeded in the vicinity of Buildings D and D-2, Warehouse 19 , Building TU, Sigma Building, and Septic Tanks 138 and 140 . During this time, about 14 LASL staff and technicians and 24 support-contractor personnel (supervisors, laborers, heavy-equipment operators, and truck drivers) were involved full-time. By the end of February 1976, budgetary limitations forced temporary curtailment of support-contractor help.

During March end April, report writing started, exploratory sampling continued, and the entire area was surveyed by phoswich detector. About eight 


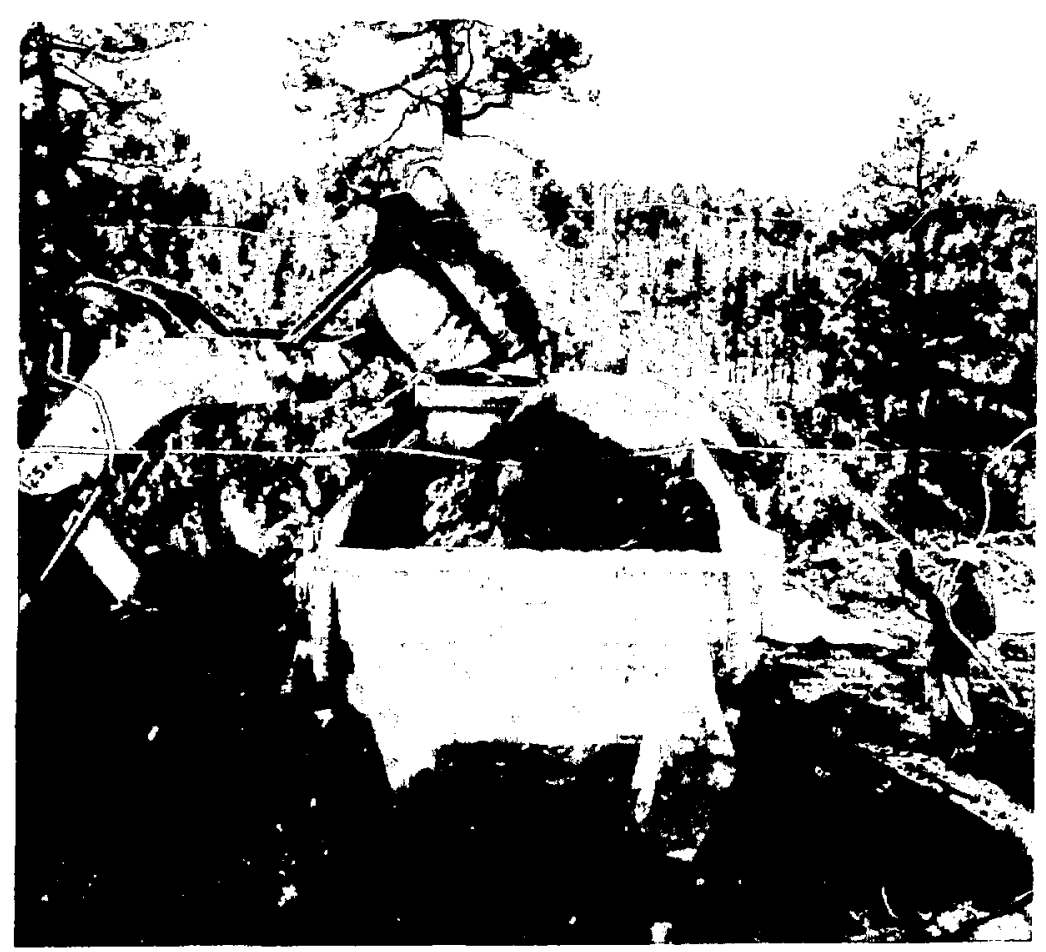

Fig. 23.

Soil being loaded into a dump truck from a front-end loader. Note method of water spraying. For most of the operation, plastic sheeting used in the dump trucks was twice the width of the plastic shown here.

full-time LASL staff and tichnicians were involved. During a 3 -wk period a small support-contractor crew build the permanent fence along the property line.

In May, additional funding permitted resumption of those decontamination operations requiring the support contractor. Work was undertaken in the area to the nort: and west of D Building, along the entire eastern portion of the former industrial waste line location, and in some parts of the western portion, in the vicinity of the general warehouses, Sigma Building, and several small, isolated locations. These operations and all remaining exploratory work were finished in early August 1976; all site-restoration was finished by mid-August. Between May and August, about 9 L.ASL staff and technicians and 11 support-contractor personnel worked full-time on the operation.

Tables V-VIII summarize the equipment, time, and manpower charged to the TA-1 decontamina- tion project; costs are summarized in Table IX. Funding came from a special ERDA allocation and from LASL technical-program assessment via charges to a Laboratory-wide overhead account.

\section{RESULTS OF EXPLORATORY AND DECONTAMINATION OPERATIONS}

\section{A. General TA-1 Area}

Information on the condition of the general TA-1 area came from three main sources: (1) the Fall 1975 survey of TA-1 made with conventional radiation monitoring instruments and the concurrent monitoring of debris being removed from the area; (2) a combination of sampling results from 1974 and the field operations of 1975 and 1976; and (3) the phoswich survey conducted in March and April 1976. 


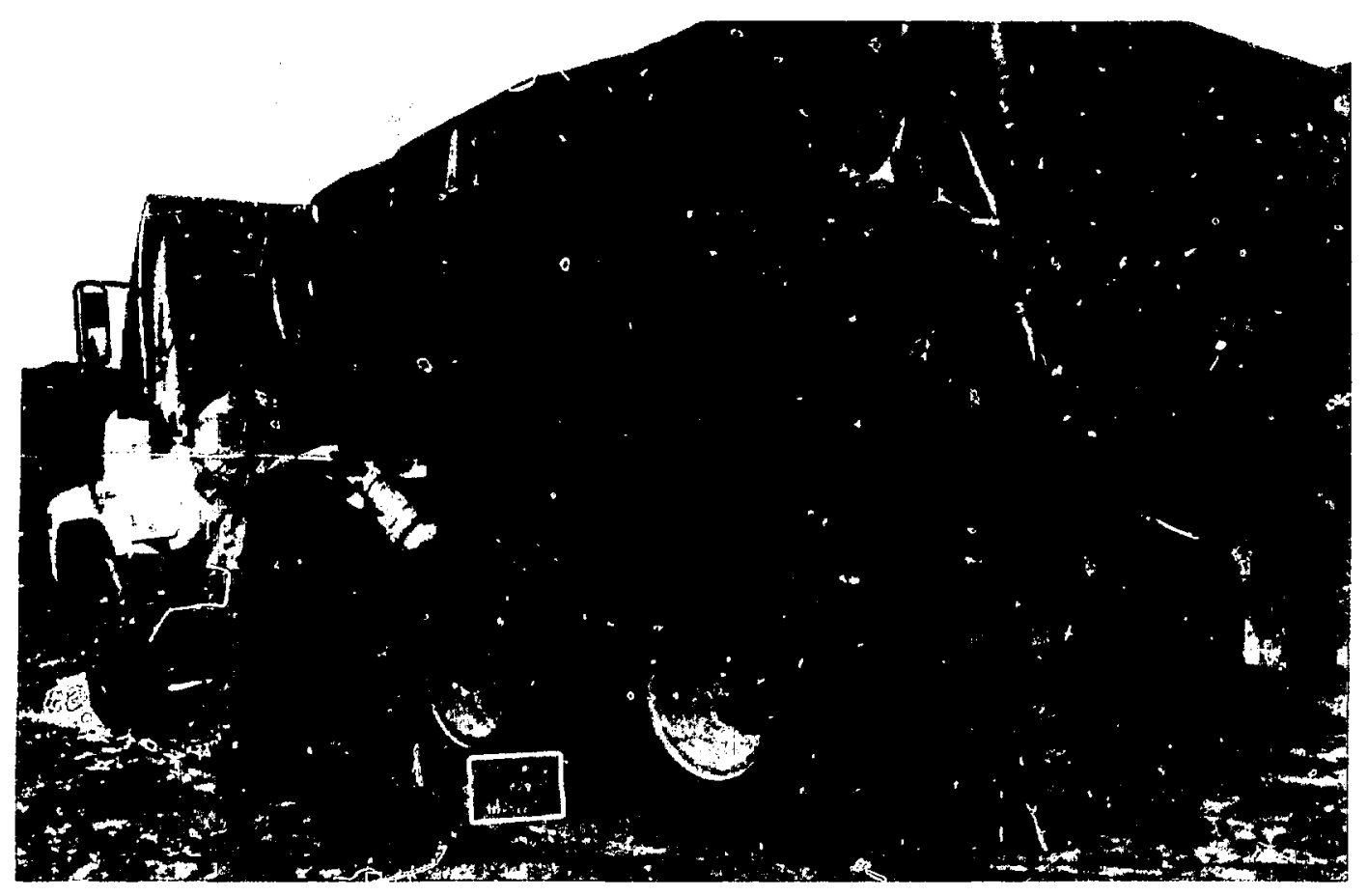

Fig. 24.

Phoswich-surveying of a loaded, tarpaulin-covered truck before load is taken to waste disposal area.

1. Survey and Debris Cleanup. At the start of field operations in September 1975, a survey of TA-1 was conducted with conventional, portable, radiation-detection instruments in conjunction with a cleanup of small surface debris. It was more efficient to remove all small debris than to survey each piece. Debris, such as pipe shards and random other pieces, were surveyed with alpha airionization and GM beta-gamma survey instruments (see Appendix F).

Large objects, such as pieces of concrete, too heavy for two men to lift safely into a truck, were monitored with alpha and beta-gamma survey instruments. All such large objects were free of detectable contamination and were sprayed with green paint to so iden ify them. Of the 50 metric tons of material taken to the radioactive waste dump, an estimated $50 \mathrm{~kg}$ had contamination levels detectable by portable survey instruments. The bulk of the contaminated material was uraniumcontaminated soil, although the highest activity was associated with pipe shards. The highest activity found in this survey came from uranium contamination on pipe shards found just below the ground surface in the area of Sigma Building. These shards (Fig. 25) showed an activity of 100 to $200 \mathrm{mR} / \mathrm{h}$ (open-window) on a GM survey meter and $>10000$ c/min on an alpha survey meter.

During this survey and cleanup, areas with abovebackground radiation were discovered. Some, including locations near the former $\mathrm{HT}$ and $\mathrm{TU}$ Buildings, were areas that ultimately required decontamination.

2. General-Area Sampling. Three categories of sampling results are discussed in this section: (1) surface and shallow auger-hole samples taken to augment the 1974 survey; (2) randomly chosen, deep, auger-hole samples; and (3) surface and shallow auger-hole samples from water drainage channels. All sarnple locations are given in Fig. 26 (back pocket of this report). 


\section{MEFTINGS AT WHICH AS-IOW-AS-PRACTICABLE (ALAP) DECONTAMILATION WAS DETERMINES}

\begin{tabular}{|c|c|c|c|c|c|}
\hline \multirow{2}{*}{$\begin{array}{l}\text { Neeting } \\
\text { Date }\end{array}$} & \multirow[b]{2}{*}{ Areas Designated AIAP } & \multicolumn{4}{|c|}{ Personnel Present (by Affiliation) } \\
\hline & & ALO & LAAO & IASL & $\mathrm{Zia}$ \\
\hline $11 / 4 / 75$ & HT; Warthouse 19 & $\begin{array}{l}\text { Rocider, } \\
\text { Miller }\end{array}$ & Crismon & $\begin{array}{l}\text { Jordan. Siephens, Myers, } \\
\text { Siniquist, Bayhurst }\end{array}$ & Thomas \\
\hline $11 / 25 / 75$ & $\begin{array}{l}\text { Major portion of } \mathrm{Tl} \text {; } \\
\text { Sigma areas } 1 \text { and } 2 \text {; } \\
\text { Delta }\end{array}$ & $\begin{array}{l}\text { Roeder, } \\
\text { Werkema }\end{array}$ & Crismon & $\begin{array}{l}\text { Bayhurst, Stoker, Jordan, } \\
\text { Smale, Ahlquist }\end{array}$ & \\
\hline $\begin{array}{l}12 / 4 / 75 \\
\text { (at ALO) }\end{array}$ & Septic Tank 138 & $\begin{array}{l}\text { Roser, Roeder, } \\
\text { Burke, Werkema, } \\
\text { Miller }\end{array}$ & $\begin{array}{l}\text { Braziel, } \\
\text { Crismon }\end{array}$ & Jordan & \\
\hline $1 / 6 / 76$ & $\begin{array}{l}\text { Easturn part of D-:; } \\
\text { deip trench, D-2 }\end{array}$ & $\begin{array}{l}\text { Roeder, } \\
\text { Miller }\end{array}$ & $\begin{array}{l}\text { Braziel, } \\
\text { Crismon }\end{array}$ & $\begin{array}{l}\text { Jordwn, IRedman, Ahlquist, } \\
\text { Smale, d'urtymun, } \\
\text { Gunderson, Api }\end{array}$ & \\
\hline $1 / 20 / 76$ & $\begin{array}{l}\text { Five areas in D and } \\
\mathrm{D}-2\end{array}$ & $\begin{array}{l}\text { Roeder, } \\
\text { Miller }\end{array}$ & $\begin{array}{l}\text { Crimusun, } \\
\text { Valencia }\end{array}$ & $\begin{array}{l}\text { Simale, Ablquist, Stuker, } \\
\text { Gunderson }\end{array}$ & \\
\hline $1 / 30 / 76$ & $\begin{array}{l}\text { Balance of D and D.2; } \\
\text { Septic'Tank } 140\end{array}$ & $\begin{array}{l}\text { Clark, } \\
\text { Charnuff, } \\
\text { iloeder }\end{array}$ & $\begin{array}{l}\text { Braziel, } \\
\text { Cismon. } \\
\text { Giscuere. } \\
\text { Warren }\end{array}$ & $\begin{array}{l}\text { Bradhhaw, Brusne, Stephens, } \\
\text { Jurdan, Sundberg, Healy, } \\
\text { Mrers. Baylhurst, Garde, } \\
\text { Stoker. Apt, Dummer, } \\
\text { Ahlquist }\end{array}$ & \\
\hline $4 / 23 / 76$ & Balance of TU & Roeder & $\begin{array}{l}\text { Crismon, } \\
\text { Braziel }\end{array}$ & $\begin{array}{l}\text { Stoker, Johnson, Ahlquist, } \\
\text { Jordan }\end{array}$ & \\
\hline $6 / 8 ; 76$ & $\begin{array}{l}\text { Northwest of } D \text {; ware. } \\
\text { he sse area; part of } \\
\text { H-']het a drainage }\end{array}$ & $\begin{array}{l}\text { Miller, } \\
\text { Roeder }\end{array}$ & $\begin{array}{l}\text { Braziei, } \\
\text { Crisinom, } \\
\text { Warren }\end{array}$ & $\begin{array}{l}\text { Iordan, Stoker, Ahlquist, } \\
\text { Simale, Dummer }\end{array}$ & \\
\hline $7 / 28 / 76$ & $\begin{array}{l}\text { Balance of J-2; acid } \\
\text { sewer; acid-sewer } \\
\text { trench from D to MH } \\
17 \cdot ; \text { H -Theta; Sigma } \\
\text { area } 3 ; \text { acidi-sewer } \\
\text { trench from } \mathrm{NH} 174 \text { to } \\
\text { ULIR } 65\end{array}$ & $\begin{array}{l}\text { Werkems, } \\
\text { Rueder }\end{array}$ & $\begin{array}{l}\text { Crimmon, } \\
\text { Braziel }\end{array}$ & $\begin{array}{l}\text { Jordan. Healy, Stuaic, Garde, } \\
\text { Trucki, Ahlugist, Bayhurst, } \\
\text { Stoker }\end{array}$ & \\
\hline
\end{tabular}

a. Samples to Augment the 1974 Survey. One group of seven surface-composite samples was collected from around former Buildings $\mathrm{K}-1, \mathrm{M}-1$, FP, Theta-1, the Sheet Metal Shop, and the warehouse area (Fig. 26). Three of the six areas had a history of radioactive use. Buildiıg M-1 had been used for lithium and ${ }^{238} \mathrm{U}$ machining; ${ }^{238} \mathrm{U}$ spills had cecurred on the Sheet Metal Shop floor; and the JDivision Annex in the warehouse area had contained
${ }^{220}$ Ra dust from a source storage pig. All seven composite samples showed $<20 \mathrm{pCi} / \mathrm{g}$ gross-alpha activity, and no decontamination was considered necessary.

In the warehouse area, samples were taken from nine shallow ( $<1-m$-deep) auger holes. All samples showed $<20 \mathrm{pCi} / \mathrm{g}$ of gross-alpha content, with the exception of sample WR-RD-6 which was collected south of Warehouse GR and which had $50 \mathrm{pCi} / \mathrm{g}$ of 
TABLE IV

MATERIAL REMOVED FROM MAJOR TA-1 EXCAVATIONS

(Approximate soil volume removed $\left(m^{3}\right)$ by month)

\begin{abstract}
Location"
Areas with Plutonium as

Principal Contaminant
\end{abstract}

Vicinity of D and D-2

Area northwest of D

Septic Tank 138

27

\begin{tabular}{ccc}
\multicolumn{1}{c}{1975} \\
\hline Aug Sept Oct Nov Dec
\end{tabular}

Industrial Waste Line Related Areas

Vicinity of fi and Thete

Eustern portion of acid

sewer

Western portion of acid

sewer

Areas with Uranium es

Principal Contaminant

Vicinity of $\mathrm{HT}$

Vicinity of Sigma

Vicinity of Warehouse 19

Vicinity of TU

Septic Tank 140

General warehouse area

Miscellaneous spots

- Desiknations are the historic TA-1 building identifiers used on mapa.

-An additional $28 \mathrm{~m}^{2}$ were removed during August 1977.

2

Jan Fob Mar Apr May June July Aug Total

2212

1322

$\begin{array}{rrrr}230 & 11 & & 46 f_{1} \\ 830 & 294 & & 1124\end{array}$

$294 \quad 145$

\begin{tabular}{rrr}
59 & 37 & 27 \\
& & 150 \\
& 300 \\
& 2815 \\
21 & 268 \\
& & 385 \\
& & 43 \\
\cline { 2 - 2 } & & $14982^{\circ}$
\end{tabular}


TABLE V

EQUIPMENT USE AT TA-1

(In hours)

\begin{tabular}{|c|c|c|c|c|c|c|c|c|c|c|c|c|c|}
\hline \multirow[b]{2}{*}{ Equipment } & \multicolumn{4}{|c|}{1975} & \multicolumn{8}{|c|}{1976} & \multirow[b]{2}{*}{ Total } \\
\hline & Sept & Oct & Nov & $\overline{\text { Dec }}$ & Jan & Feb & Mar & Apr & May & June & July & Aug & \\
\hline Backhoe & 28 & 87 & 84 & 26 & 68 & 11 & & & 39 & 105 & 56 & 22 & 526 \\
\hline Dump truck, large & & & 140 & 480 & 517 & 386 & & & & & & & 1523 \\
\hline Dump truck, small & 89 & 201 & 710 & 439 & 549.5 & 260 & 4 & 48 & 432 & 724 & 381 & 88 & 3925.5 \\
\hline Water truck & 3 & 47 & 107 & 122 & 117 & 63 & & 11 & 136 & 197 & 98 & 32 & 933 \\
\hline Compressor & 17 & 43 & 21 & 50 & 14 & 39 & & & & 6 & 1 & & 191 \\
\hline Bulldozer & & 3 & 70 & 39 & 83 & 74 & & & 44 & 36 & 18 & & 367 \\
\hline Front-end loader & & 47 & 160 & 164 & 181 & 147 & & 22 & 62 & 96 & 61 & 13 & 953 \\
\hline Blade & & & 9 & 2 & & 22 & & & & & & & 33 \\
\hline Scraper & & & & 2 & & 40 & & & & & & & 42 \\
\hline Roller & & & & & 11 & 85 & & & & 2 & & & 98 \\
\hline Miscellaneous & 12 & 5. & 9 & 13.5 & 31 & 31 & 30 & & 3 & 18 & 7 & 16 & 175.5 \\
\hline Total & 149 & 433 & 1310 & 1337.5 & 1571.5 & 1158 & 34 & 81 & 716 & 1184 & 622 & 171 & 8767 \\
\hline
\end{tabular}




\section{TABLE VI}

\section{EQUUIPMENT USE FOR TA-1 ASSOCIATED PROJECTS} (In hours)

Equipment
Bulldozer
Scraper
Blade
Welder
Mixer
Compressor
Miscellaneous
"Built at TA-5.

\section{New Waste}

D:sposal Pits ${ }^{\mathrm{a}}$

114

156

11

11
30

28

73

Fence

1 gross alpha, probably associated with the urarium contamination near the Delta-Building area (see Sec. III.D.3). Sample WR-RD-6 contained 0.01 $\mathrm{pCi} / \mathrm{g}{ }^{239} \mathrm{Pu}$ (Table $\mathrm{X}$ ), a level within the range of fallout background.

The former $J$ Building had been a physics laboratory in which ${ }^{3} \mathrm{H}$ and ${ }^{239} \mathrm{U}$ had been hand!ed and which was alpha-contaminated. The former $\mathrm{X}$ Building was a cyclotron. The area between $\mathrm{J}$ and $\mathrm{X}$ Buildings and the former D 8 Building was sampied to augment results from samples $1-11$ and $1-6$ from the 1974 survey $\left[2\right.$ and $1 \mathrm{pCi} / \mathrm{g}{ }^{299} \mathrm{Pu}$. respectively isee Appendix E)l, with 7 shallow auger holes drilled for exploratory purposes. Because these auger-hole samples all had $<20 \mathrm{pCi} / \mathrm{g}$ gross alpha, no decontamination was considered necessary.

b. Deep Auger-Hole Samples. In an attempt to gain additional information from random sites about any contamination at depth, the T.A-1 area was divided into 76 - by $76-\mathrm{m}$ quadrants. A drill site was selected in each of 10 quadrants where intensive sampling had never been done. Profiles of augerhole sampless are shown in Fig. 27. Analytic results for plutonsur, and uranium in selected auger-hole samples are given in Table $\mathrm{X}$ with the prefix "RD." (For cleanup details of the plutonium-associated contamination in auger hole RD-13, see Sec. LI.C.1.) Aiter consideration of the depths, levels, and types of contamination in the other auger holes in Fig. 27, it was decided decontamination was not necessary.

c. Water-Druinage Area Samples. Surface contamination could be removed and repositioned by water in drainage channels at TA-1. For that reason, samples were taken from 68 locations in the water channels. Of 42 samples from the surface and 26 trom shallow auger holes ( $\leq 1 \mathrm{~m}$ deep) drilled in the channels, 7 locations (9 samples) with $>20 \mathrm{pCi} / \mathrm{g}$ gross-alpha contamination were identified.

Analytical radiochemistry results for uranium and plutonium in these nine samples are shown in Table X with the prefix "WD." Samples WD-RD-12 were associated with the uranium contamination near the former Delta Building. Sample WD-RD-25, from $25 \mathrm{~m}$ west of the Theta-Building area, and sample WD-RS-13 from south of $\mathrm{H}$ Building had little or no plutcnium or uranium contamination. On the basis of analytic results from these three samples and other samples from each hole having grossalpha activity $<20 \mathrm{pCi} / \mathrm{g}$, the areas were judged to require no furt her decontamination. WD-RD-2 samole results indicated elevated (above the surrounding area) concentrations of uranium. These samples were taken from the drainage channel north of 'TU and the Paint Shop. Other area samples (such as AS-1) did not have these elevated uranium concentrations. Beraise the elevated concentration seemed limited in: extent and was still well within the range of natural uranium in soil (or rock), the arca was judged to require no further decontamination.

However, the presence of ${ }^{238} \mathrm{Pu}$ in samples from two locations in the Railey Bridge area (WD-RS-42 and -RD-23) led to two sinall decontamination operations in that area, which is part of the H-Theta drainage (see Sec. III.C.1). Radioch?mical analysis of sample WD-RD-10 (6.8 pCi/g $\left.{ }^{298} \mathrm{Pu}\right)$ focused attention on tne south-central to southwest part of the former Sigma Building. Eight subsequent saliples fron this area indicated a small region of contamination which was removed (see Sec. III.D.2).

3. Phoswich Survey. During late March and early April 1976, when major decontamination operations were curtailed, a phoswich survey was made of all undeveloped portions of the TA-1 area, 
TABITE VII

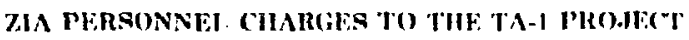

(In man-hours)

\begin{tabular}{|c|c|c|c|c|c|c|c|c|c|c|c|c|c|}
\hline \multirow[b]{2}{*}{ Personncl } & \multicolumn{4}{|c|}{ CY 1975} & \multicolumn{8}{|c|}{ CY 1976} & \multirow[b]{2}{*}{ Total } \\
\hline & Sept & Oct & Nuy & Dre & Jen & Feh & Mar & Apr & May & June & $\sqrt{u y}$ & $\overline{\text { Aug }}$ & \\
\hline Operaturs & 53 & 185 & 417 & 362 & 499 & 55,4 & $5 x$ & 32 & 2015.5 & 307.5 & $18 ! n$ & 71 & $2413: 15$ \\
\hline Laborers & $i r n$ & 815 & 1495 & 2079.5 & 1594 & 445,5 & 226 & 9 & 694 & 939 & 501 & 114.4 & 111.564 .4 \\
\hline 'Tenunsters & 157 & 310 & $13: 19$ & lint: & 1550 & $9.9 \div \div .5$ & 35.5 & 66 & 682.5 & 1062.5 & $56: 3$ & 2.99 & 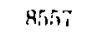 \\
\hline Carpenters & 100 & 31 & 28 & $r$ & $i 2$ & 23.5 & & & 3 & sin & & & int.5 \\
\hline 1.ine Shop & 81.5 & & & 27 & 11 & 17 & Ifi & & & & & & 1825 \\
\hline Flectricians & 67 & 4 & 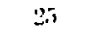 & sii & 5 & 12 & 67 & & & 29 & & & 296 \\
\hline Fitfers & $\sin$ & & 4 & 10,3 & (9) & 8 & 32 & & 18 & & & & $\$ 110$ \\
\hline Miscellaneous & 41.5 & 4.5 & 232 & 14 & 22 & $i 0$ & & & 2 & & 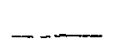 & 39 & ter. \\
\hline Monthly tortal & 1311 & 1349.5 & $\sin (4)$ & 4108.5 & .38 .37 & 2635.3 & $\$ 12.5$ & 194 & 1 for: & 2187 & 1105.5 & 75.3 & \\
\hline (unulative total & 1:11! & $26 f 00.5$ & folfon 5 & 10258 & 14092 & \& & 17960 & 17351. & 18959 & $21: 3 \mid$ & $22 ; 11.5$ & 2.3294 .5 & \\
\hline
\end{tabular}


TABLE VIII

MANPOWER SUPPIIED BY LASL FOR TA-I SURVEY ANID DECONTAMINATION

(In man-monxhs)

\begin{tabular}{|c|c|c|c|c|c|c|c|c|c|c|c|c|c|c|c|c|c|}
\hline \multirow{2}{*}{ Group } & \multicolumn{4}{|c|}{ CY 1975} & \multicolumn{12}{|c|}{ CY 1976} & \multirow[b]{2}{*}{ Total } \\
\hline & Sept & (19: & Nov & Dec & Jan & Feb & Mar & Apr & May & June & July & Aur & Sept & Oct & Nov & Dec & \\
\hline \multicolumn{18}{|c|}{ Finvironmental Studies } \\
\hline Prufeasional & 2.0 & 20 & $2 . n$ & 25 & 2.5 & 2.5 & 2.5 & 2.5 & 2.5 & 2.5 & 2.5 & 2.5 & 1.9 & 1.5 & 2.5 & 1.0 & 35.4 \\
\hline Technician & 1.7 & 3.0 & 3.1 & 3.2 & 3.2 & 3.7 & 2.1 & 2.2 & 2.2 & 2.9 & $3 . i$ & 2.7 & 1.0 & 0.5 & 0.5 & 9.8 & 35.9 \\
\hline \multicolumn{18}{|l|}{ Henlt h Physirg } \\
\hline Professiomal & 1.5 & 1.8 & 2.5 & 2.0 & 2.3 & 0.8 & 0.5 & 1.0 & 1.0 & 1.0 & 1.0 & 1.0 & & & & & 16.4 \\
\hline 'Teclmician & 4.5 & 4.0 & 4.3 & 3.8 & 4.3 & 1.5 & 1.0 & 3.0 & 2.0 & 2.0 & 2.0 & 2.0 & & & & & 34.4 \\
\hline \multicolumn{18}{|l|}{ Construction } \\
\hline Prufugajonal & 0.1 & & & & & & & & & & & & & & & & 0.1 \\
\hline Foreman & 1.0 & 1.0 & 1.0) & 1.0 & 1.9 & 1.0 & 0.3 & 1.0 & 0.4 & 0.2 & 0.2 & 0.2 & & & & & R.3 \\
\hline Survey & 2.2 & 0.7 & 0.5 & 0.5 & 0.5 & 0.5 & & & & 0.1 & 0.1 & 0.1 & & & & & 5.2 \\
\hline \multicolumn{18}{|l|}{ Division Offires } \\
\hline P'rofessional & 0.3 & 0.2 & 0.6 & 0.8 & 0.6 & 0.6 & 0.3 & 0.3 & 0.3 & 0.3 & & & & & & & 4.3 \\
\hline 'lechnician & - & - & - & 0.5 & 0.4 & - & - & - & - & - & - & - & - & - & - & & 0.9 \\
\hline \multicolumn{18}{|l|}{ Tntal } \\
\hline Profegsional & 3.9 & 4.0 & 5.1 & 5.7 & 5.4 & 3.9 & 3.5 & 3.8 & 3.8 & 3.8 & 3.5 & 3.5 & 1.9 & 1.5 & 2.5 & 1.0 & 56.2 \\
\hline Other & 9.4 & 8.7 & 8.9 & 51.11 & 9.4 & 0.7 & $: 34$ & 6.2 & 4.6 & 5.2 & 5.4 & 5.1 & 1.0 & 0.5 & 0.5 & 0.8 & 8.4 .7 \\
\hline
\end{tabular}

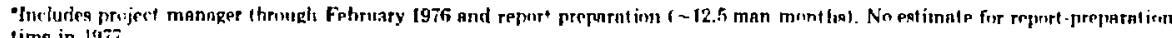
time in linit. 
TABLE IX

FUNDING AND COST ALLOCATIONS FOR

TA-1 PKOJECT, 1975-76

(In kilodollars)

Cost Categories $^{\mathrm{B}}$

Personnel Equipment Materials Overhead Total

ERDA allocation

192

75

84

67

$\$ 18$

LASL program

assessment

$\frac{240}{432} \quad \frac{16}{91}-\frac{14}{98} \quad \frac{81}{148} \quad \frac{351}{769}$

'Total

"Cost breakdowns are approximate.

TABLE X

\section{LABORATORY ANALYSIS RESULTS OF GENERAL-AKEA SAMPLES}

\begin{tabular}{|c|c|c|c|c|c|}
\hline $\begin{array}{l}\text { Sample Location } \\
\text { Identification }\end{array}$ & $\begin{array}{c}\text { Depth } \\
\text { (m) }\end{array}$ & $\begin{array}{l}{ }^{239} \mathbf{P} \mathbf{u}^{\mathrm{a}} \\
(\mathrm{pC} \mathbf{C} / \mathbf{g})\end{array}$ & $\begin{array}{c}\text { Total } \\
\text { Uranium } \\
(\mu \mathrm{g} / \mathrm{g}) \\
\end{array}$ & $\begin{array}{c}\text { Laboratory } \\
\text { Gross Alpha } \\
\text { (pCi/g) }\end{array}$ & $\begin{array}{c}\text { Laboratory } \\
\text { Gross Beta } \\
\text { (pCi/g) }\end{array}$ \\
\hline WR-RD-6 & 0 to 0.03 & 0.01 & & & \\
\hline RD-1 & 0.61 to 1.2 & 0.06 & 1.8 & & \\
\hline RD-2 & 0 to 0.61 & 0.05 & 3.7 & & \\
\hline RD-6 & 0 to 0.61 & 0.007 & 2.7 & & \\
\hline RD-7 & 1.8 to 2.4 & 0.01 & 1.4 & & \\
\hline RD-13 & $0 \quad$ to 0.61 & 4.6 & 0.17 & & \\
\hline WD-RS-13 & Surface & 0.01 & 2.3 & 4.6 & 3.7 \\
\hline WD-RS-42 & Surface & 1.0 & 3.4 & 1.3 & 8.0 \\
\hline WD-RD-2 & 0.30 to 0.61 & 0.19 & 58 & 51 & 35 \\
\hline WD-RD-2 & 0.61 to 0.76 & 0.21 & 60 & 35 & 34 \\
\hline WD-RD-10 & 0.30 to 0.61 & 6.8 & 2.9 & 10 & 5.7 \\
\hline WD-RD-12 & 0 to 0.30 & 0.09 & 8.6 & 8.3 & 8.8 \\
\hline WD-R! 12 & 0.46 & 0.003 & 2.5 & 4.4 & 3.3 \\
\hline WD-RD-23 & 0.30 to 0.61 & 4.6 & 26 & 10 & 15 \\
\hline WD-RD-25 & 0 to 0.30 & 0.33 & 2.2 & 4.6 & 4.0 \\
\hline
\end{tabular}

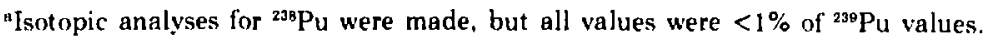




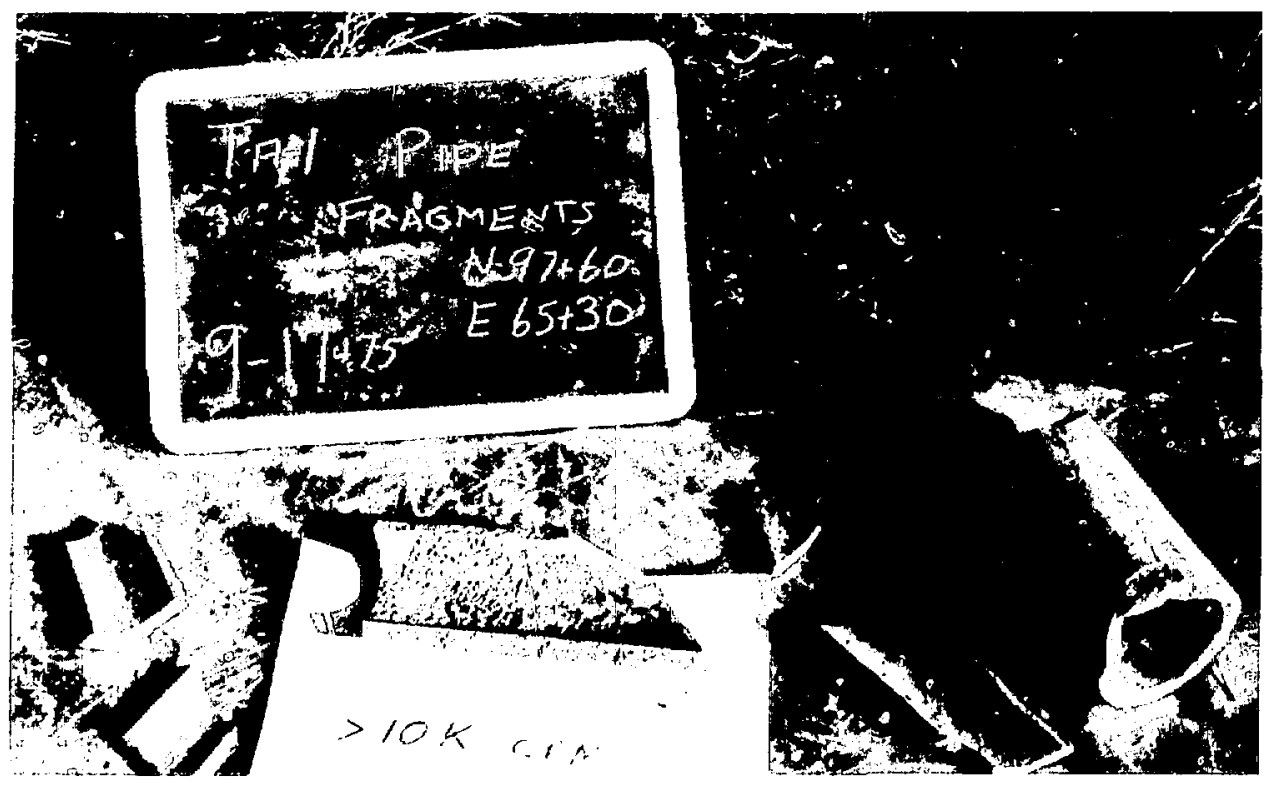

Fig. 25.

Contaminated pipe shards found just belriw the ground surface near Sigma Building.

Fig. 26.

[Figure is in hack pocket of this report.]
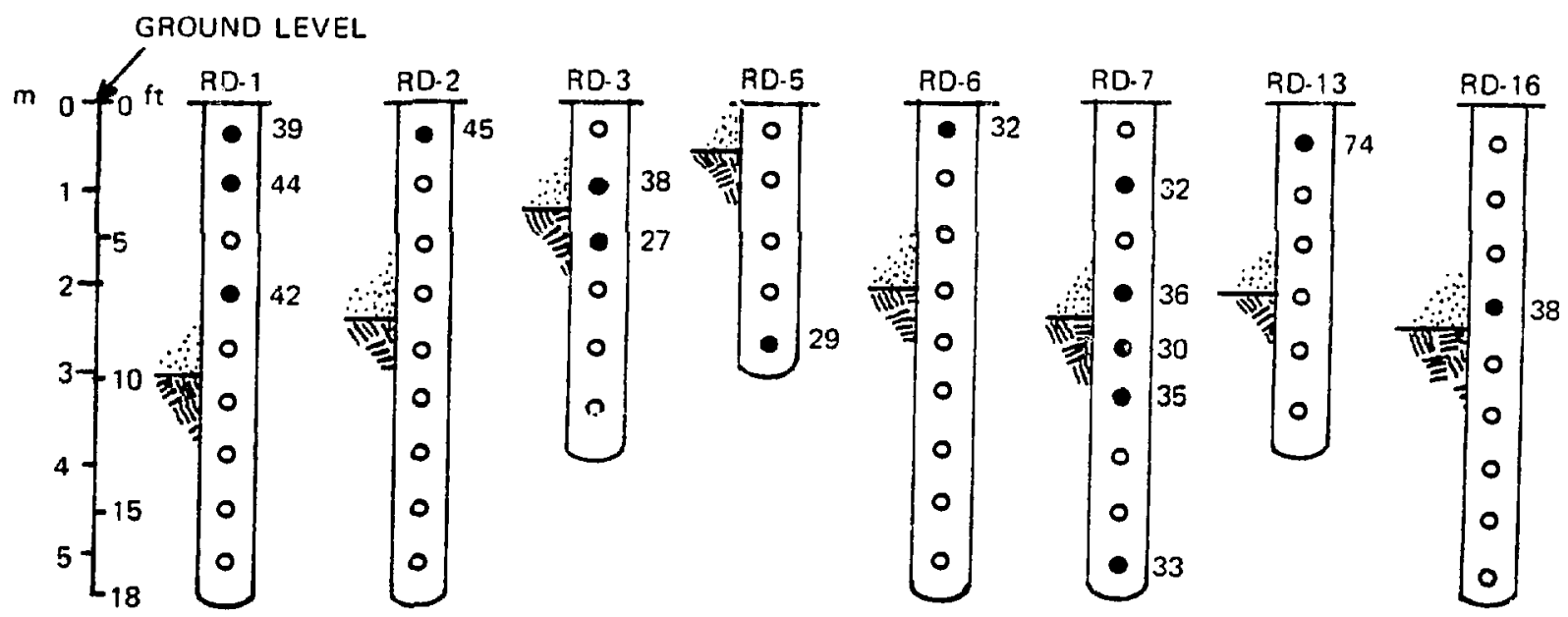

O Grab sample, Gross - $\alpha \leqslant 20 \mathrm{pCi} / \mathrm{g}$

- Grab sample, Gross - $\alpha>20 \mathrm{pci} / \mathrm{g}$, with value shown

min Fill

隄紫Tuff

Fig. 27.

Profiles of general-area auger holes; profiles depicted for all holes yielding at least one sample with $>20 \mathrm{pCi} / \mathrm{g}$ gross-alpha activity. 
excepting areas already decontaminated. The phoswich was not available for field use until after the first survey and debris cleanup were completed. but it had greater sensitivity than other portable instruments and was the obvious choice for a close survey to preclude omission of any seriously contaminated locations. This survey was directed in the field by seriior-level supervisory personnel.

As a result of this survey, $1 \%$ locations required further investigation. Soil samples from each suspect location were analyzed for gross alpha. Samples from 12 of the locations had gross-alpha activity $>20 \mathrm{pCi}$ 'g and ranging as high as $980 \mathrm{pCi} / \mathrm{g}$. $\mathrm{X}$ - and gamma-ray spectral analyses were used in an attempt at qualitative icientification of the contaninants. (Analytic resuits from the 17 locations are given in Sec. III.D.8, where the decontamination efforts are also detailed.)

The rest of the undeveloped portion of the TA-1 area (south of Trinity Drive) had no contamination detectable by the phoswich. However, because the phoswich's response is greatest for surface contamination and declines markedly for subsurface contamination, the survey lends confidence to the conclusion that no significant surface contaminatirn remains, but is not so conclusive about subsurface contamination.

The phoswich survey also included the area north of Trinity Drive. Buildings formerly in that aiea had been mainly office buildings. for those engaged in theoretical activities, personnel work, and supply and property matters. However, three buildings had contained radioactive materials. Building 126 (a library and then a laboratory area) had a leakin: ${ }^{80} \mathrm{Sr}$ source that caused surface contamination in the building (radioactive materials were not usually handled there). Sealed sources such as ${ }^{210} \mathrm{Po}$ and ${ }^{137} \mathrm{Cs}$ were handled in Gamma Building, where one contamination incident involving ${ }^{137} \mathrm{Cs}$ occurred. Contamination from these incidents had been cleaned up without problem. Weapon components were assembled and stored in Building Gamma-1 (the former ice house for the Ranch School), but no significant contamination would be likely there because of the solid form of materials handled. In any event, any contamination would be well mixed by now and widely distributed because the area has since been extensively landscaped and developed. The phoswich survey covered all the present grassy area bounded on the south and north by Trinity Drive and Central Avenue, respectively, and on the west and east by Oppenheimer Drive and 20th Street, respectively. (The area not covered by grass is occupied by buildings. narking lois, sidewalks. and a porid.) The rurvey south of Ashley Pond (where buildings Gamma and Gamma-1 had been) consisted of 50 -s counts at each intersect ion of a $5-m$ grid. A walking survey on a $10-\mathrm{m}$ grid was conducted north of the pond. Neither survey indicated activity above instrument background.

\section{B. Areas with Plutonium as Principa! Contaminant}

1. Septic Tank for Building D-2. Because the highest value $\left(224 \mathrm{pCi} / \mathrm{g}\right.$ ) of ${ }^{238} \mathrm{Pu}$ encountered in the 1974 survey was found immediately downslope fron the outlet line of Septic Tank 137, which served the contaminated-laundry (Building D-2\%, the septic tank was thoroughly investigated in August 1975. Records showed that the tank had been abandoned in place after its outfall line had been found free of contamination during the cleanup of the eastern portion of TA $1 .{ }^{9}$ Other records indicated that it would be a rectangular concrete tank filled with dirt. When located, on the property line separating ERDA from private lands (Fig. 28), it turned out to be a cylindrical metal tank containing water and sludge. Analysis of the contents showed $0.01 \mathrm{pCi} / \mathrm{g}$ of ${ }^{238} \mathrm{Pu}$ in the water and $114 \mathrm{pCi} / \mathrm{g}$ in the sludge-results consistent with the inability to detect this contamination with portable survey instruments. The tank was removed on August 11, 1975 , and as much as $850 \mathrm{pCi} / \mathrm{g}$ of gross-alpha activity was found in the surrounding soil. Excavations to remove this and lower level contamination uncovered scil that contained as much as $4000 \mathrm{pCi} / \mathrm{g}$ of g:oss-alrhha activity. A pocket of highly contam nater: soil and plant roots, initially showing $88^{\prime}, 00 \mu \mathrm{ji} / \mathrm{g}$ of gross alpha, was also found $\sim 1.2 \mathrm{~m}$ below ihe surface just south of the property line on ERDA land (Figs. 29 and 30). Radiochemical analysis of this heterogeneous sample showed a maximum of $125000 \mathrm{pCi} / \mathrm{g}$ of early-1945 Hanford plutonium. The sample also contained $986 \mathrm{pCi} / \mathrm{g}$ of ${ }^{241} \mathrm{Am}$ and $365 \mathrm{pCi} / \mathrm{g}$ of ${ }^{238} \mathrm{Pu}$. Gamma spectral analysis showed the ${ }^{241} \mathrm{Am}$ but no fission products or 


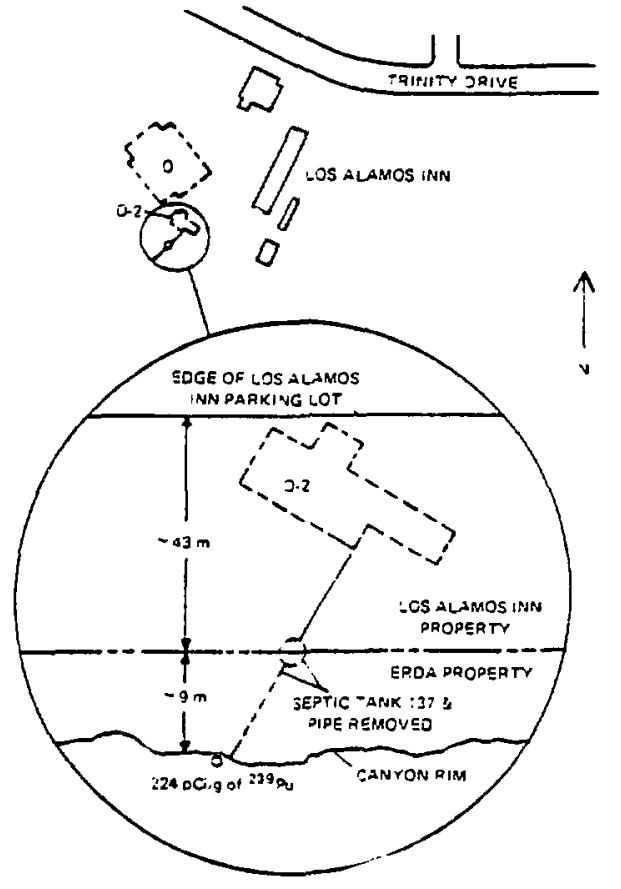

Fig. 28.

Relative locations of Building D-2 and Septic Tank 137.

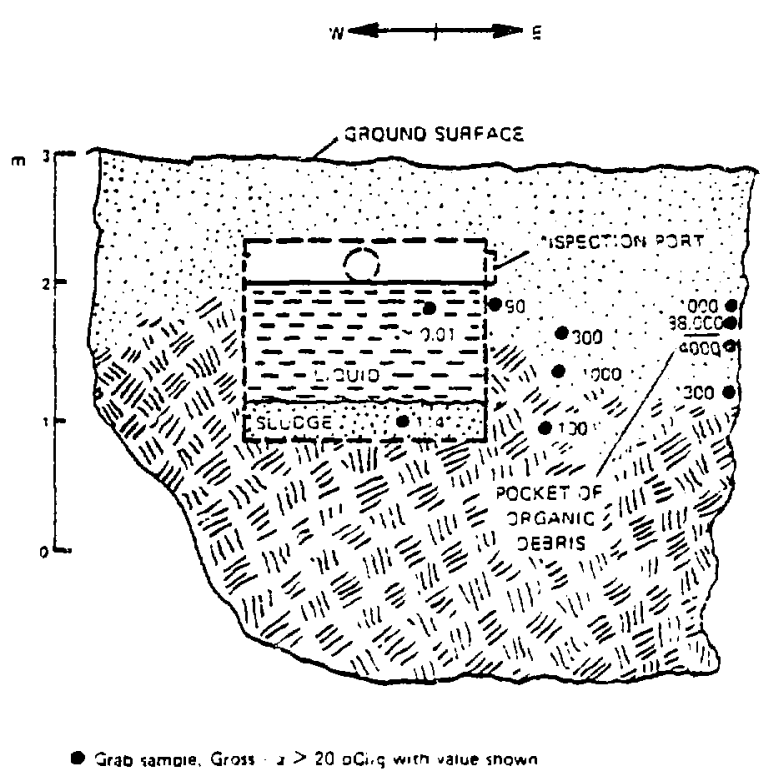

Fig. 29.

Cross section of the Septic Tank 137 excavation, indicating the east-west orientation (only) of contamination.

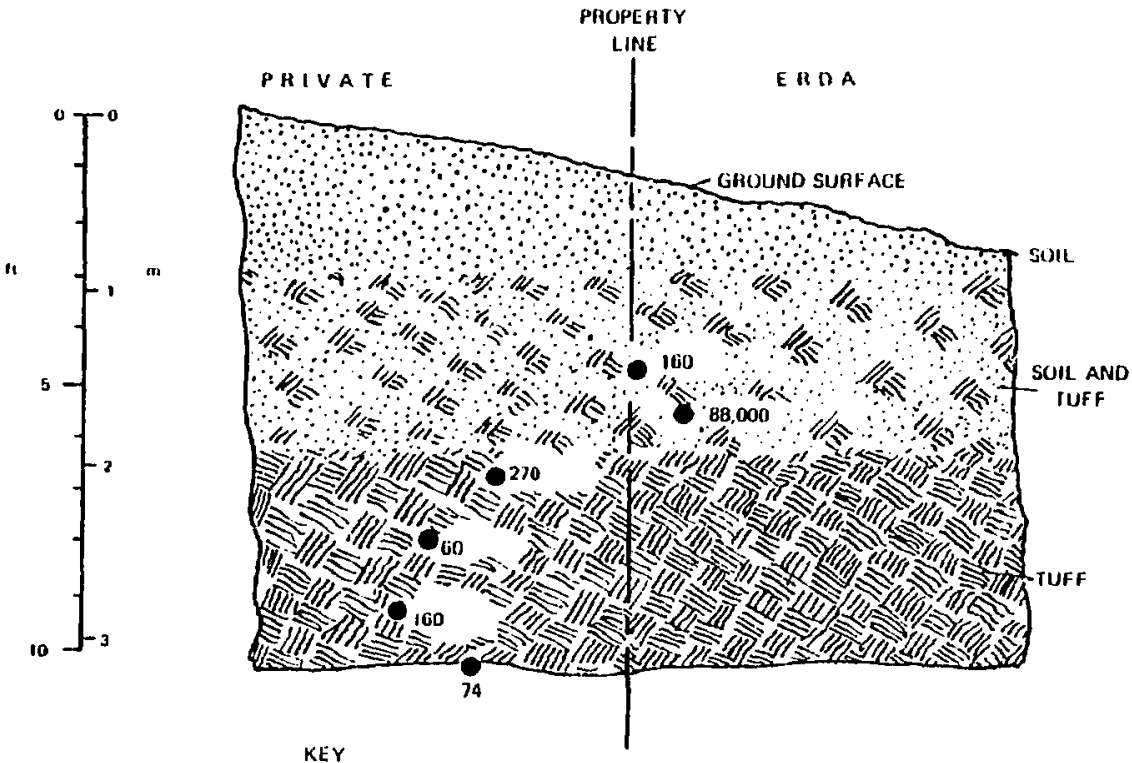

KEY

- Grab Sample, Gi coss - a $>20$ pCi/y,

with value sliown

Fig. 30.

Samping points and activity on east wall of Septic Tank 137 excavation. 
other isotopes in above-background concentrations. The excavation was backfilled intil a proper plan of action could be determined. During the backfill operations, a FIDLER stirvey of the entire area around the excavation located a pipe fragment contaminated to $4000 \mathrm{c} / \mathrm{min}$ on a portable alpha survey meter.

These findings led to a serious reappraisal of what constitutes an adequate survey and decontamination plan (see Sec. II.A). The surface debris and soil throughout the area around Building D-2, including that around Septic Tank 137, were subsequently removed.

\section{Vicinity of Buildings $D$ and D-2}

a. Exploration. The a:eas formerly occupied by the cheinistry and metallurgy building (D Building) where significant amounts of ${ }^{239} \mathrm{Pu}$ and ${ }^{236} \mathrm{U}$ were handled and the laundry for cont aminated clothing. rubber gloves, and respirators (Building D-2) required intensive investigation because of the contamination found during the excavation of Septic $i$ ank 137 which served the laundry, the finding of contaminated sewer lines in the D-2 area outline, and knowledge of past plutonium-handling operations in thest buildings.

One important clue came from the May 1945 monthly report for Group CM-12 (responsible for contaminated laundry and some health physics):

"The contaminated water discharge pipes draining behind the laundry have now been placed below the ground level with no open drain unil the pipes are past the south side of the (security patro!) road... The complete area behind the laundry has been covered with dirt to a depth of several inches to prevent spread of contamination."

Other records showed that Septic Tank 137 was not installed until 1947, well after the laundry had been moved out of TA-1 in late 1945. This explained why the area behind Building D-2 was more highly contaminated than the tank itself, and established a need to locate the drain lines. Engineering drawings indicated that these drain lines lay at the southeast end of Building D-2 (Ref. 10); Fig. 31 shows the D-2 area and the expected locations of the drain lines.
Former Manhattan District employees had identified the vario, 1 s operational areas in $D$ Building shown in rig. 32. Original demolition instructions (Fig. 33) indicated the general levels of building contamination. An area on the south wall was probably the most highly contaminated area in the building. The southwest side of $\mathrm{D}$ Building was elevated above the original sloping ground surface and was supported by wooden pillars on concrete footings. The area under the building was used for storage. Figure 34 shows demolition in progress on this portion of $D$ Building.

The D-Building area was surveyed by a combination of core, surface, and auger-drilling samples. As temporary work-fences were erected, the soil from the post holes was also analyzed.

Sampling was done in the D-2 area because of the 1974 survey results and the 1975 activities around. septic 'lank 137, and was accomplished primarily by trunching. Trenching was an efficient way to determine the boundaries of the necessary excavation, and was to proceed from areas with no expected contamination toward areas with higher contamination potential. The area to be trenched was surrounded by a temporary 2.44 -m-high chain-link fence, after which the shallow drain lines within the D-2 outline (discovered in Augut 1975) were removed to avoid breaking them and spreading contamination. The line removal formed Trenches $1 \mathrm{~A}$, $1 \mathrm{~B}$, and $1 \mathrm{C}$ shown in Fig. 35. Soil-sampling resulis from the three trenches are given in Fig. 36. 'The remaining trenches were then dug in numerical order as shown in Fig. 35 (there was no Tiench 2). Excavation was to the tuff-fill interface, whatever the depth. Several uncontaminated obstructions such as concrete footings were encountered but not removed. Trench 3 results are given in Fig. 37. Trench 4 was in two sections vecause the soil used to backfill the original Tank 137 excavation did not need to be excavated. The drain lines shown in Fig. 31 were not encountered. However, about $15 \mathrm{~m}$ northwest of the indicated location of these drain lines, two iron pipes (one of $10.2-\mathrm{cm}$ diam, the other of $15.2 \mathrm{~cm}$ diam) were found in the western portion of Trench 4. The soil in each pipe was highl: contaminated. At a joint in rhe 10.2-cm-diam phoswich read $>100000 \mathrm{c} / \mathrm{min}$. Gross-alpha activity in the tuff $20 \mathrm{~cm}$ below the $15.2-\mathrm{cm}$-diam pipe was 


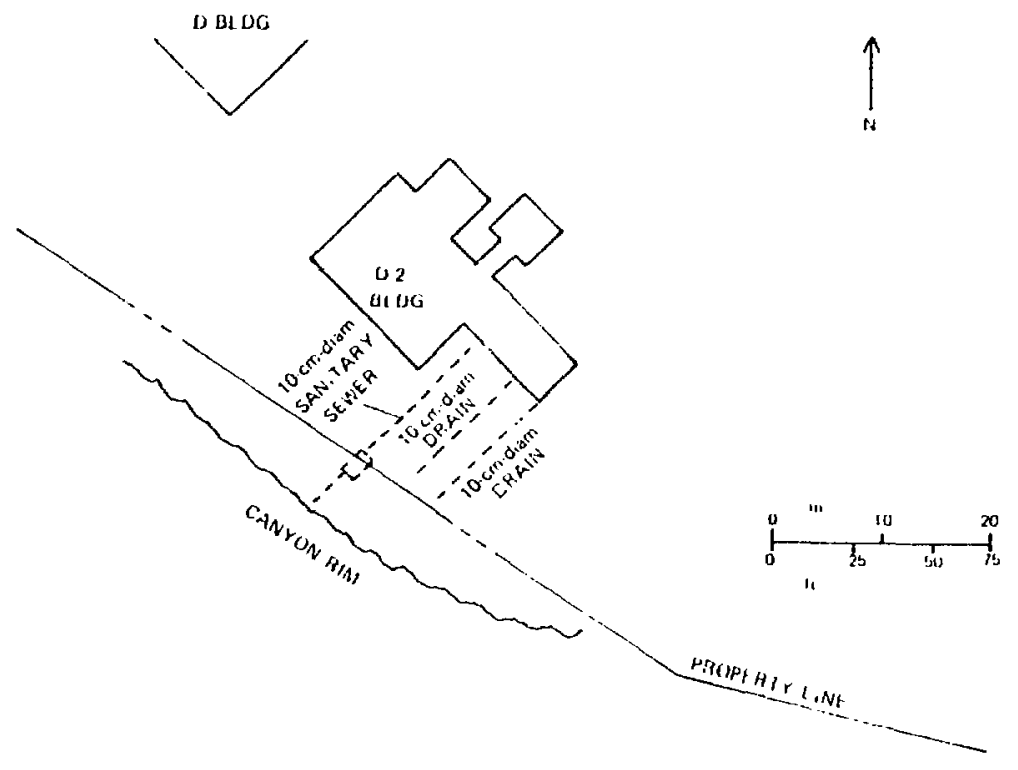

Fig. 31.

Locations of sanitary-sewer and drain lines in area of Building D-2 as indicated on engineering drawings.

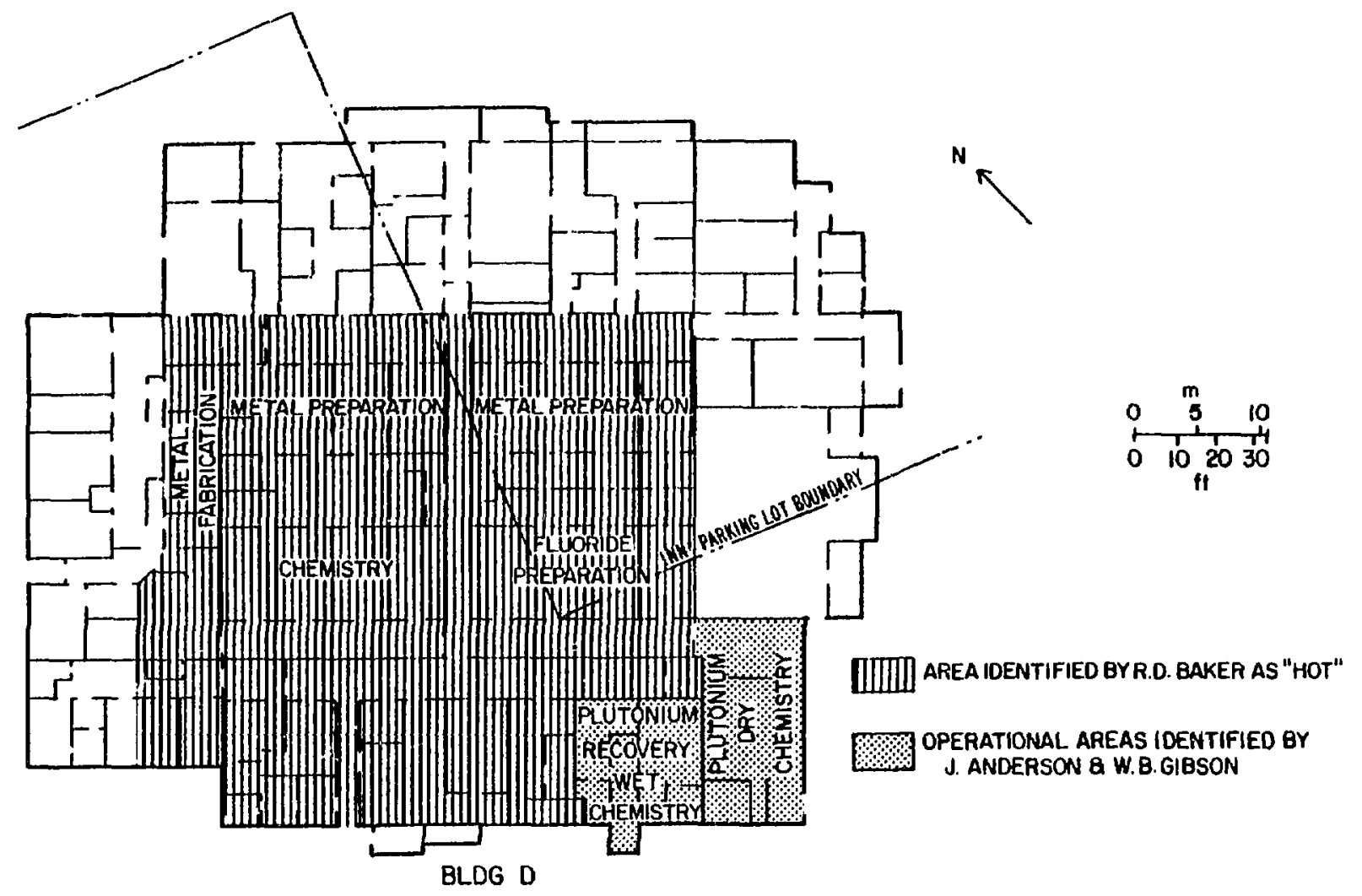

Fig. 32.

Opirational areas in $D$ Building. 


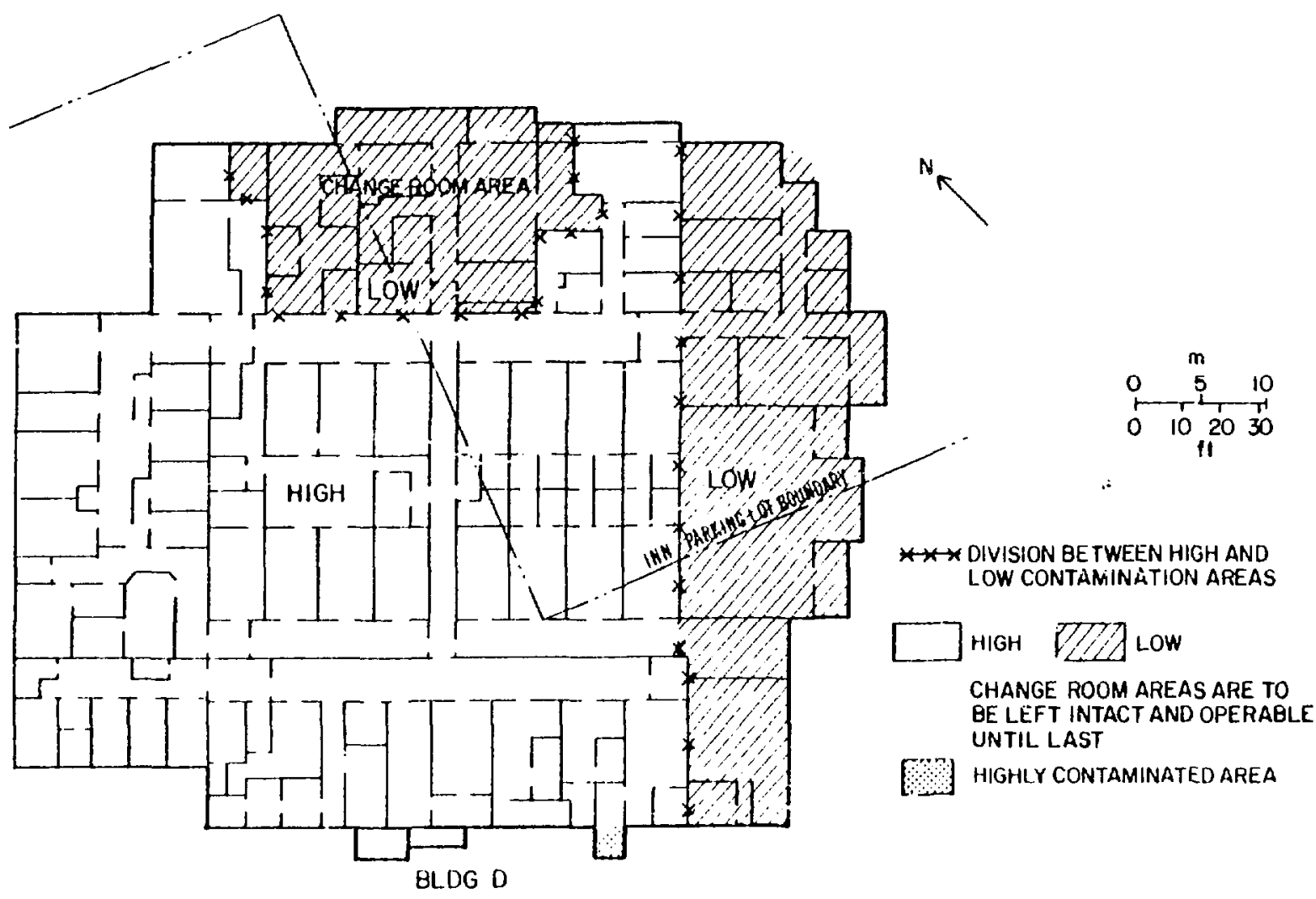

Fig. 33.

(Iriginal demolition instructions for $D$ Building, 1954 .

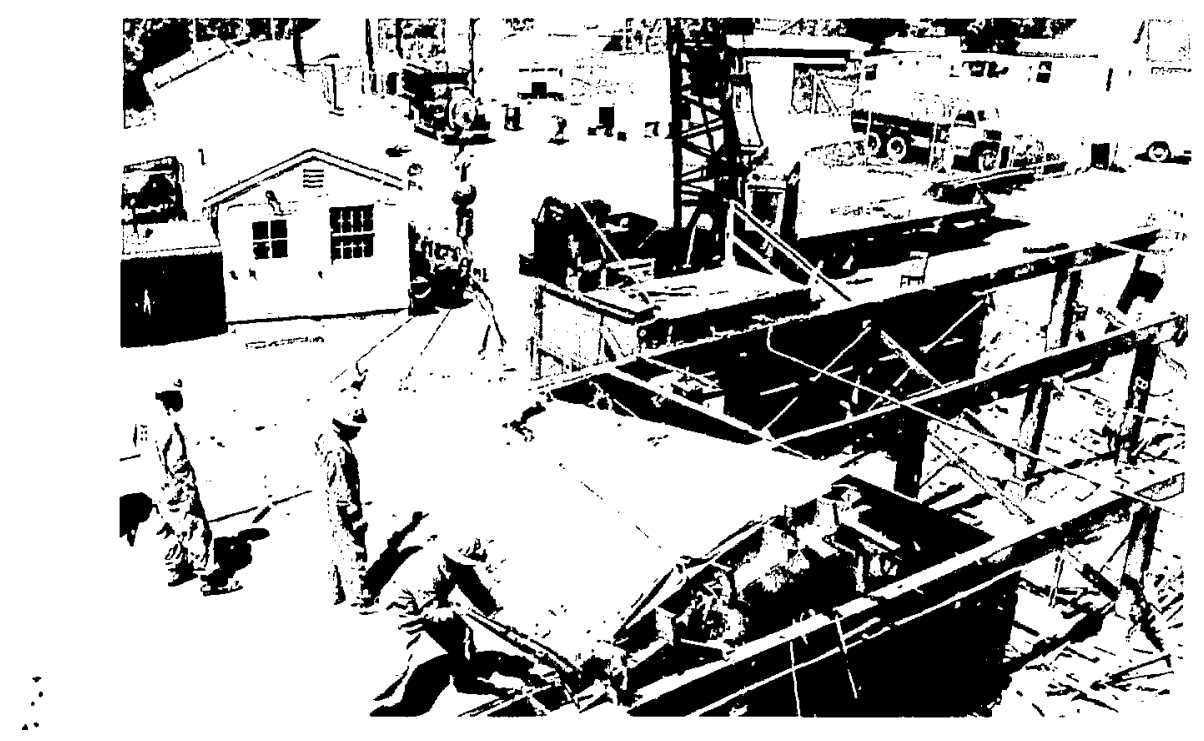

Fig. 34.

Demolition of $D$ Building, 1954. 


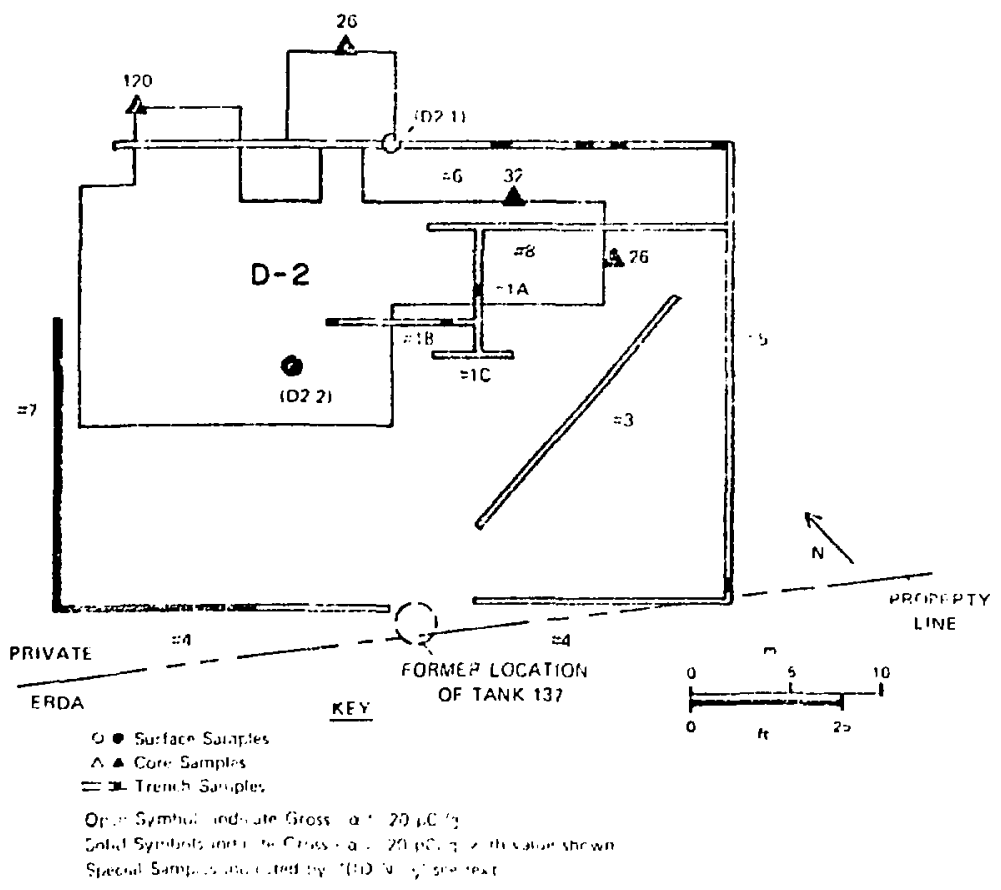

Fig. 35.

Trench locations, Building D-2 area survey.

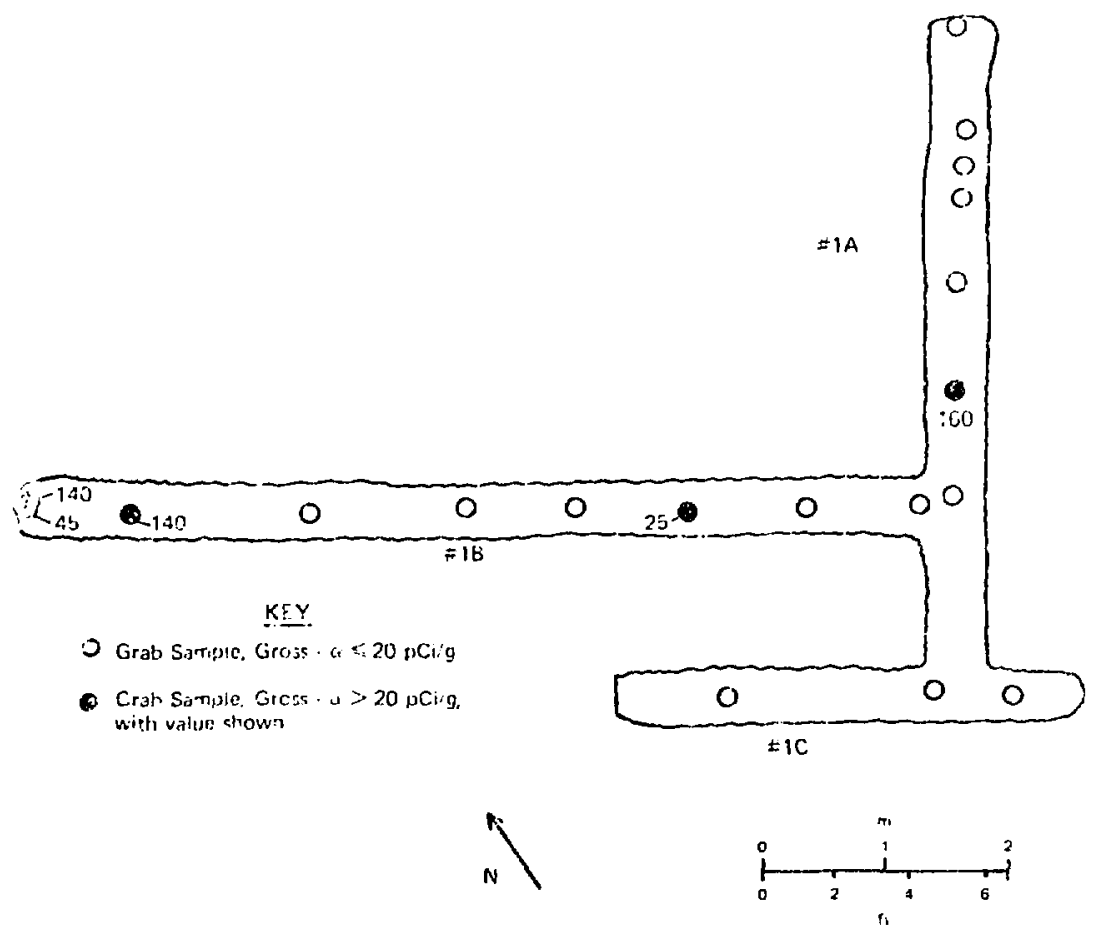

Fig. 36.

Trenches $1 A, 1 B$, and $1 C$ in the Building $D-2$ area, with soil-sampling results. 
$55000 \mathrm{pCi} / \mathrm{g}$. Soil-sampling results from Trench 4 are given in Fig. 38. The pips ends were carefully covered and reburied until their removal during the D.2 excavation.

Results from samples taken from Trenches 5 and 6 are given in Figs. 39 and 40 , respectively. Trench 7 was dug in an attrimpt to define the western edge of the D-2 contamination (results are given in Fig. 41 ). Contaminated rags, a brush, gravel, graphite, and oil soaked brass shavings were found at the northern end of Trench 7 . The end of a contaminated. 20.3cm-diam, vitrified clay-tile pipe evidently from $D$ Building was also uncovered there, and was considered the probable source of most of the contamination. Figures 42 and 43 show Trench 7 and a closeup of a contaminated area on the northwest bank. Contamination in the trench was spotty; a contaminated zone on one side did not necessarily have a corresponding zone on the other side.

Trench 8 was dug in an at tempt to further define the northeastern edge of the contamination. The trenc.. was only half as long as Trench 6 because of a backhoe breakdown. Trench 8 sampling results are given in Fig. 44.

To define the northwestern edge of the contamination, a trench was to be dug $6 \mathrm{~m}$ northwest of and parallel to Trench 7 . Contaminated asphalt found several centimeters below the surface may have been a consequence of the former practice of containing soil contamination by fixing it with asphalt. Surveys further toward the northwest in the D-Building area also located contaminated areas. These findings, coupled with results obtained from D-Building area sampling (discussed below) necessitated excavation of an area much larger than the D-2 Building outline and drainage areas.

Analysis of soil samples taken shortly after DBuilding demolition showed plutonium contamination in the D-Building outline. Contaminated soil was removed and the excavation was sampled. These samples had residual plutonium contamination ranging from 28 to $242 \mathrm{pCi} / \mathrm{g}$ (see Sec. I.B and Fig. 13). The area was then backfilled with clean soil to then-existing grade levels. Thus, it was expected that ${ }^{239} \mathrm{Pu}$ contamination would be found in and near the D-Building outline. Two D-Building sanitary-sewer lines were discovered to be contaminated. The lines were traced several meters north from their intersection with the trenches. A spot with gross-alpha activity to $15000 \mathrm{pCi} / \mathrm{g}$ was found in the tuff below one pipe joint. This pipe was covered over until later removal during the D-area excavalions. The trench-sampling results are given in Fig. 45. Locations of these trenches and overall results of expioratory sampling in the D-Building area are given in Fig. 46. Many core samples from the southwest side of D Building contained $>20$ $\mathrm{pCi} / \mathrm{g}$ of gross-alpha activity activity as high as $4700 \mathrm{pCi} / \mathrm{g}$ was found. The locations of those samples with highest activity corresponded reasonably well with the areas in D Building most likely to be highly contaminated (see Figs. 32 and 33 and Sec. I.B).

To assess possible contamination in that part of the D-Building outline under the Los Alamos Inn parking lot, a number of auger holes were drilled as deep as $10 \mathrm{~m}$ (Fig. 46). Because gross-alpha contamination was found in the extreme southwest corner of the lot, additional holes were drilled at increasingly close spacing to define its level and extent. Figures 47-49 show concentration and depth of contamination for those drill holes in which any sampled interval showed $>20 \mathrm{pCi} / \mathrm{g}$ of gross alpha. The D-Building area cross section shown in Fig. 50, drawn through the apparent center of contamination under the parking-lot corner, illustrates that contamination was first encountered at the tuff-fill interface under the parking lot. The tuff-fill interface corresponded reasonably well with the original grade under the portion of $D$ Building that was on stilts. South of the parking lot, however, most of the contamination was apparently in the fill material. During auger drilling, cuttings are spun to the surface; consequently, the measured amount of contamination in positive samples taken from below the first significant contamination is suspect because cuttings could become contaminated as they were pulled through the upper zone of contamination.

Radiochemistry performed on selected samples confirmed that essentially all gross-alpha activity found in the D-Building outline was ${ }^{239} \mathrm{Pu}$ (Table $\mathrm{XI}$ ).

Because samples from some of the drill holes seemed to contain a great deal of moisture, the soil moisture was analyzed for tritium (Figs. 51 and 52). Soil moisture in some of the auger samples contained amounts of tritium significantly above 


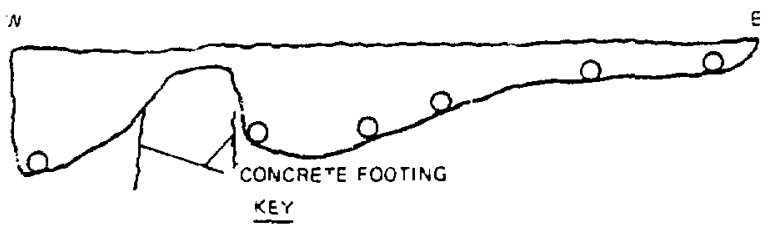

: Grao Sampie, Gross a 20 acig

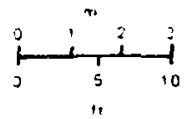

Fig. 37.

Cross section of D-2 Trench 3 (looking north), with sampling results.
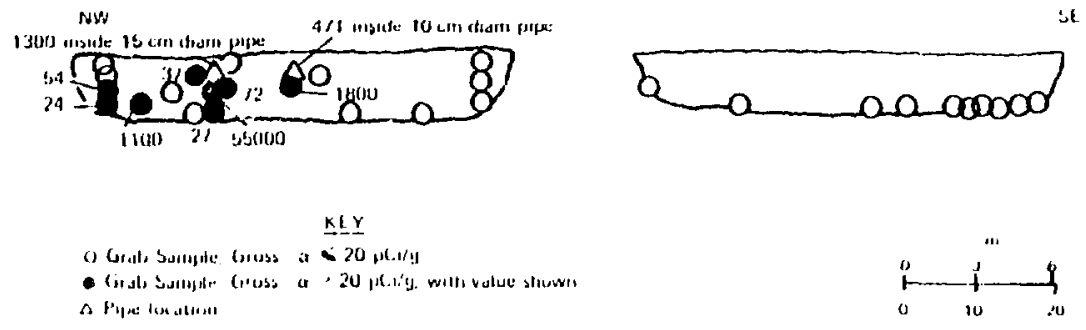

Fig. 38.

Cross section of D-2 Trench 4 (looking northeast), with sampling results.

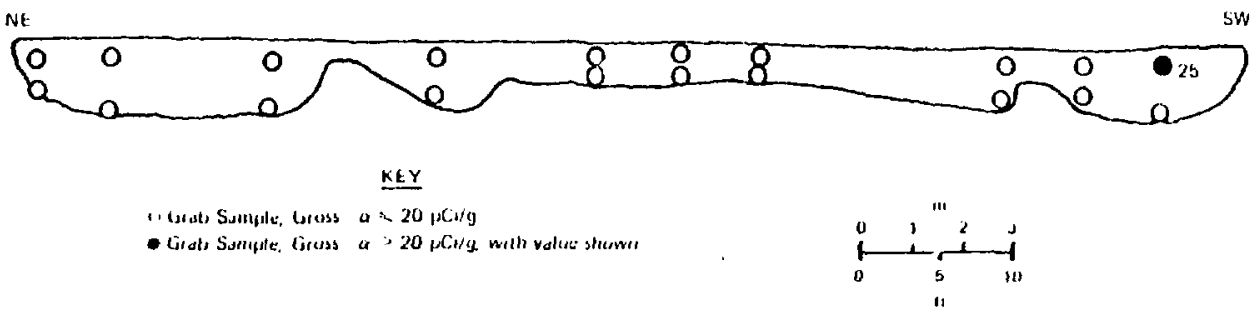

Fig. 39.

Cross section of D-2 Trench 5 (looking northwes,; with sampling results. 


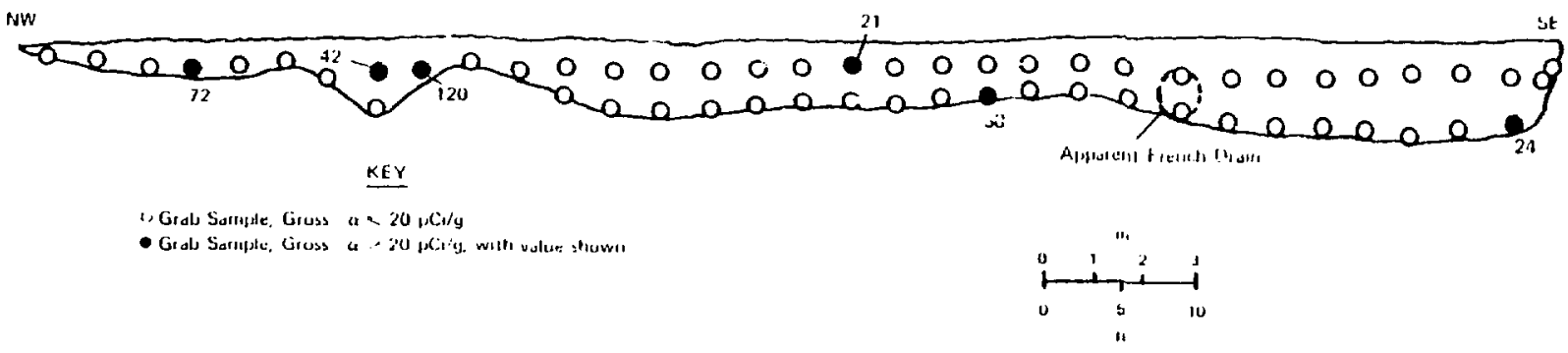

Fig. 40.

Cross section of D-2 Trench 6 (looking northeast), with sampling results.

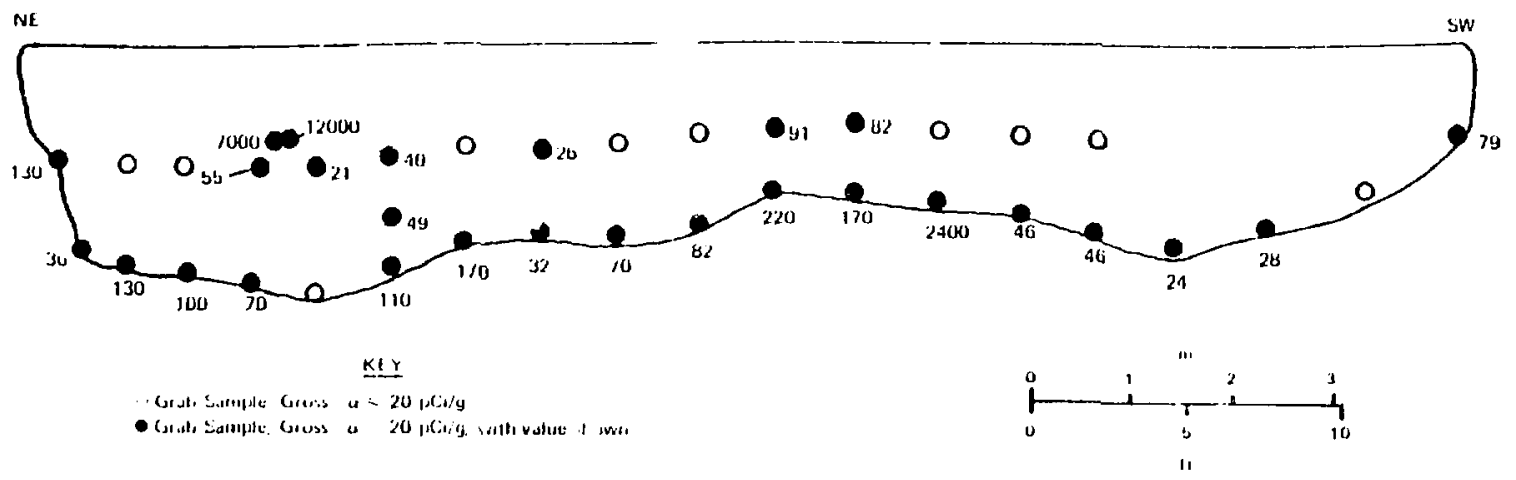

Fig. 41 .

Cross section of D-2 Trench 7 (looking northwest), with sampling results.

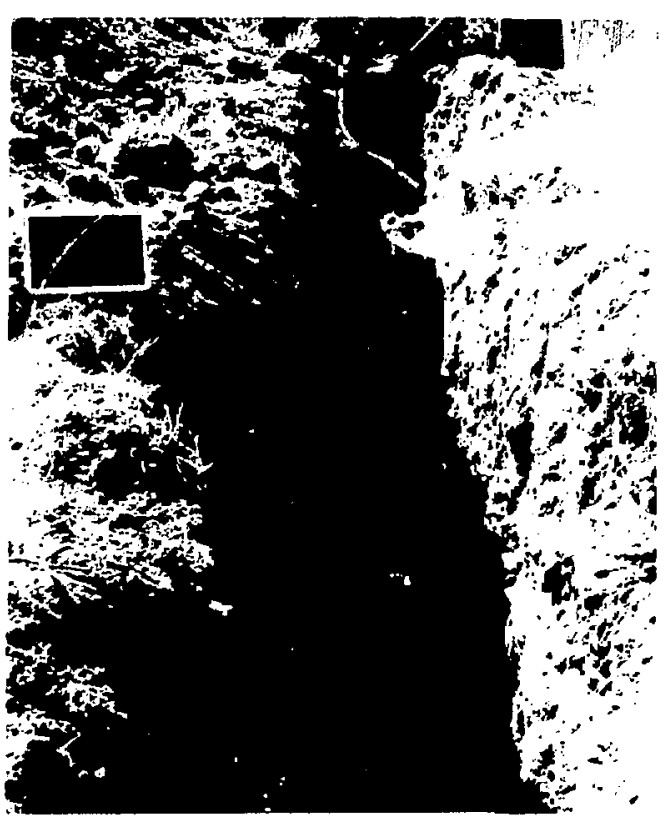

Fig. 42.

D-2 Trench 7, looking south.

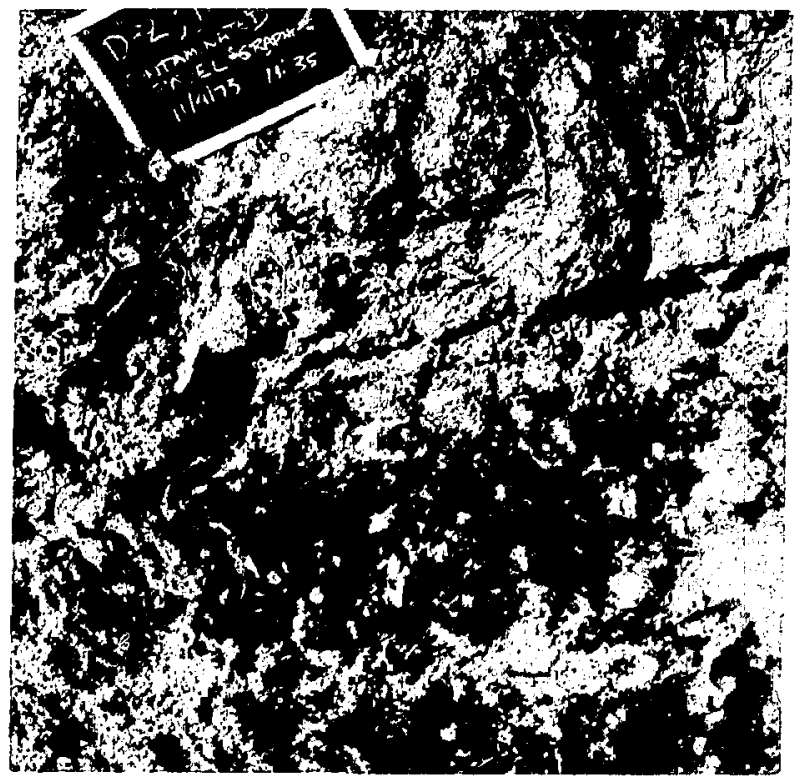

Fig. 43.

North end of the west wall of D.2 Trench 7, showing contaminated gravel and graphite. 


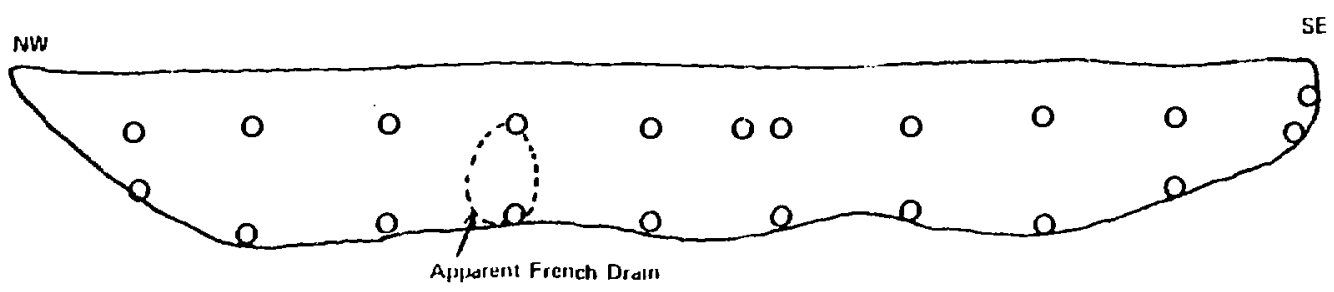

OGiab Samule. Gross $\quad \alpha=20 \mu \mathrm{KE} / \mathrm{g}$

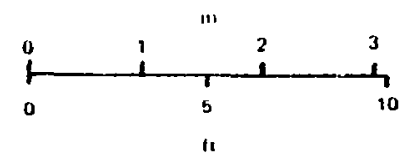

Fig. 44.

Cross section of D-2 Trench 8, with sampling results.

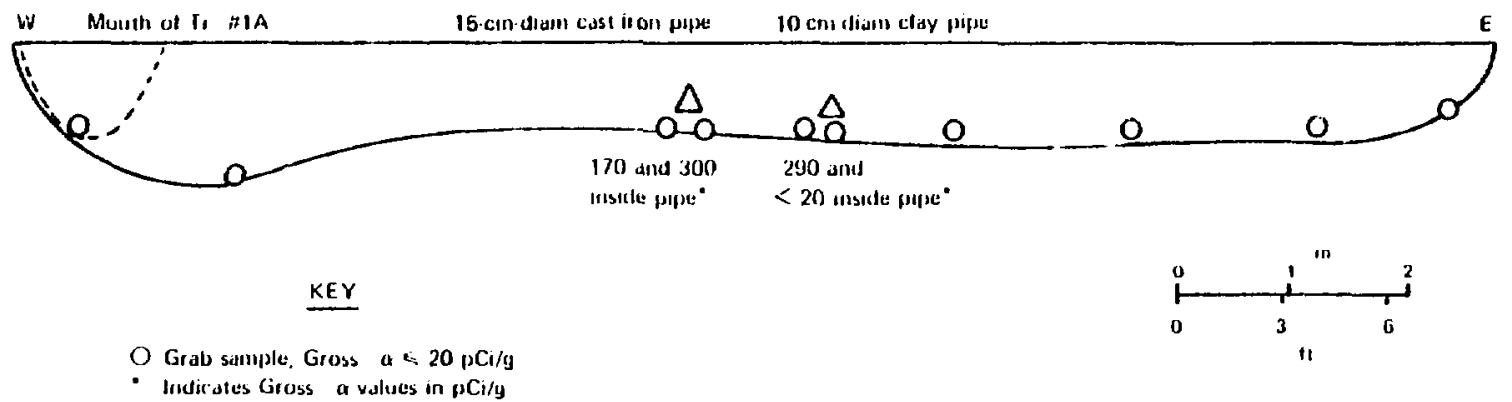

Fig. 45.

Trench-sampling results for Trench 1 for D-Building sewer lines.

background. Soil-moisture tritium results from the LASL inutine environmental surveillance program are given in Table XII and should be indicative of soil moisture in approximate equilibrium with present-day precipitation. Most higher level samples, such as D-58, D-59, D-66, and D-67, came from the southwest corner of the Lus Alamos Inn parking lot, which was ultimately excavated. The tritiated moisture in the southwest corner of the lot may have been moved there when debris from the areas of $U$ and $\mathrm{W}$ Buildings was bulldozed in that direction. Tritium had been handled in $U$ and $W$ Buildings, and a fire involving tritiated uranium hydride had occurred in a small courtyard between the two buildings. Commercial development precluded sample-hole drilling in the $\mathrm{U}$ and $\mathrm{W}$ areas, so soil moisture was sampled by collecting transpired water from trees near the Inn and several other locations in the D-Building area. No elevated tritium concentrations appeared (Fig. 53).
After the trenching near Building D-2, excavation efforts were planned to permit concurrent decontamination and sampling in the D-Building area according to the following guidelines.

- Known contaminated lines and hot-spot areas would be removed by backhoe. New hot spots uncovered by such excavation would be removed by hand to minimize the spread of contamination and the amount of airborne contaminated dust.

- Areas known to be contaminated at low to moderate levels would be ripped, bulldozed, and loaded (as described in Sec. II.C).

- A minimum of $0.6 \mathrm{~m}$ of soil or tuff in contaminated areas would be removed. The area then would be surveyed with the phoswich. If no phoswich-detectable activity remained, the area would be sampled and gross-alpha analyses would be done with the $\mathrm{ZnS}$ counter. On the basis of these results, a decision would be made to continue or stop decontamination of the area. 


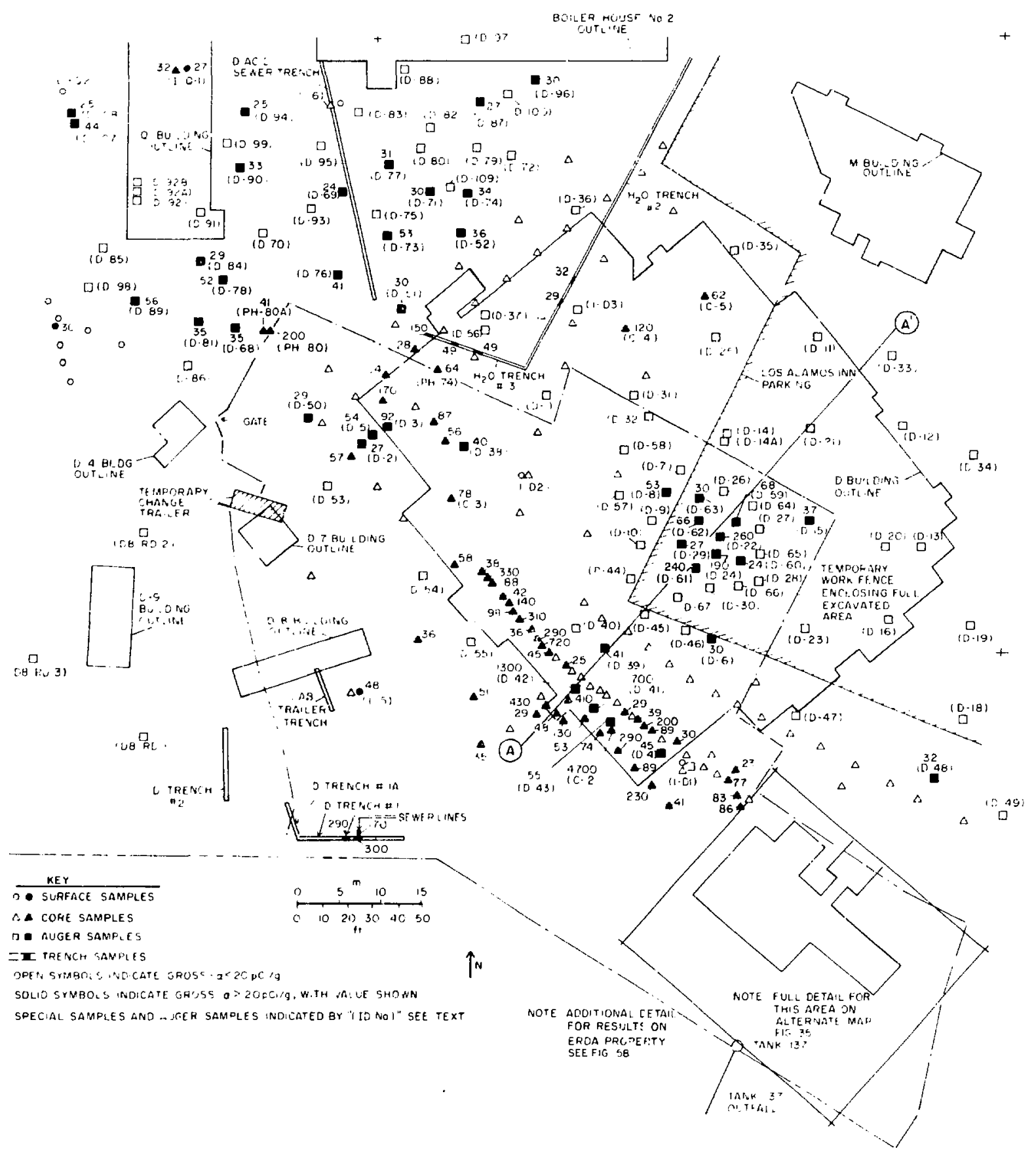

Fig. 46.

Survey detail in D-Building area, showing cross-section line $A A^{\prime}$ (see Fig. 49). 


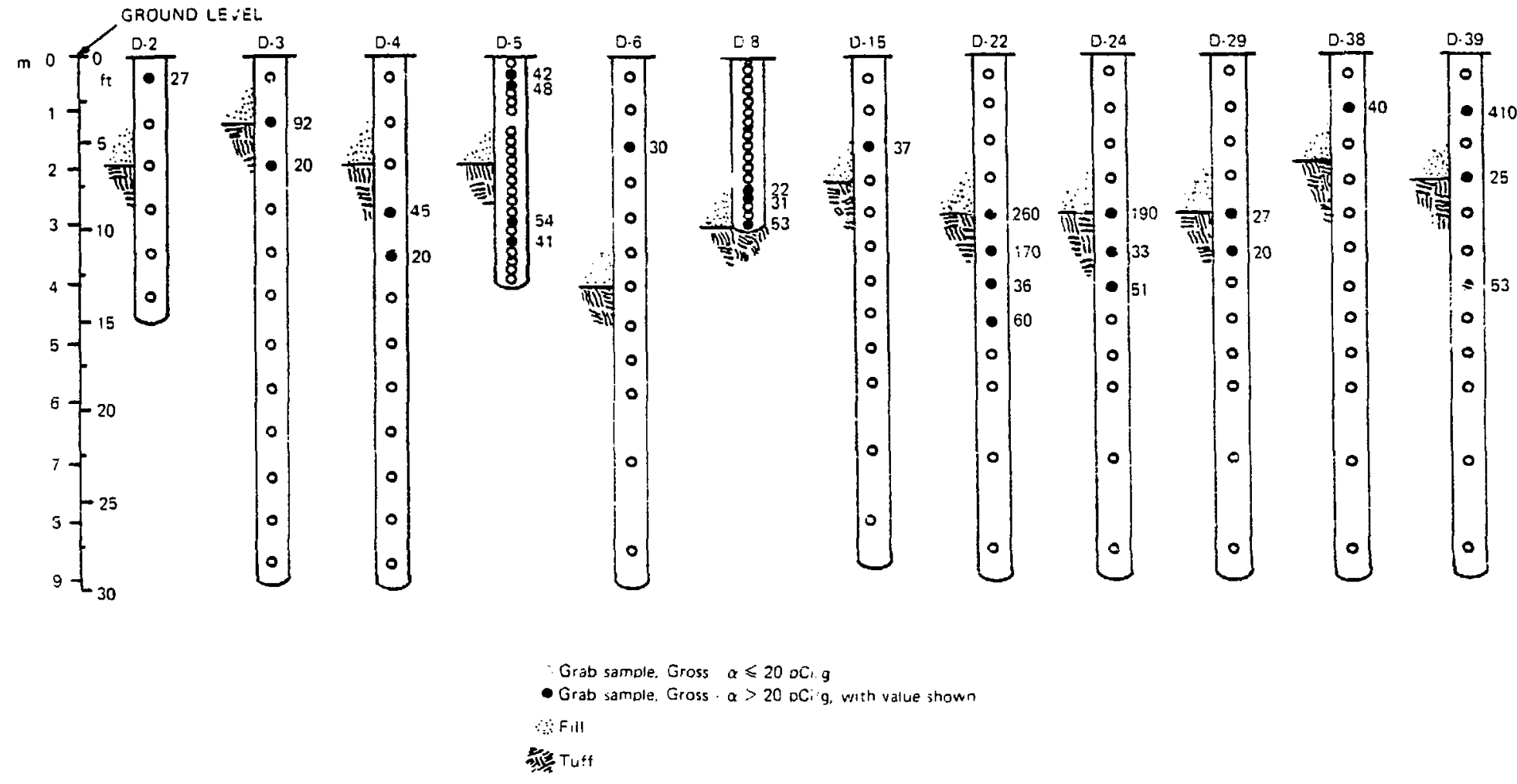

Fig. 47.

Cross sections of D-Building area drill holes having gross-alpha activity $>20 \mathrm{pCi} / \mathrm{g}$, showing depth and magnitude of the activity. 

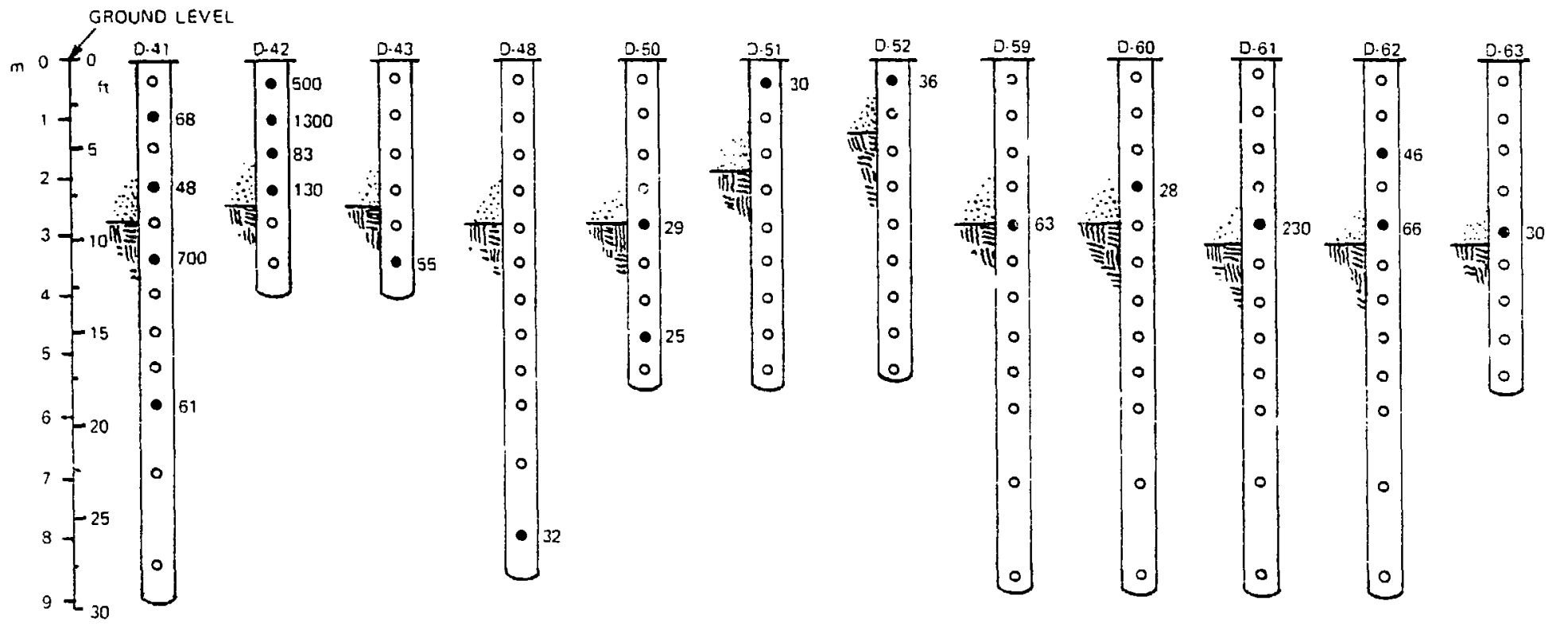

Fig. 48

Cross sections of D-Building area drill holes having gross-alpha activity $>20 \mathrm{pCi} / \mathrm{g}$, showing depth and magnitude of the activity. 

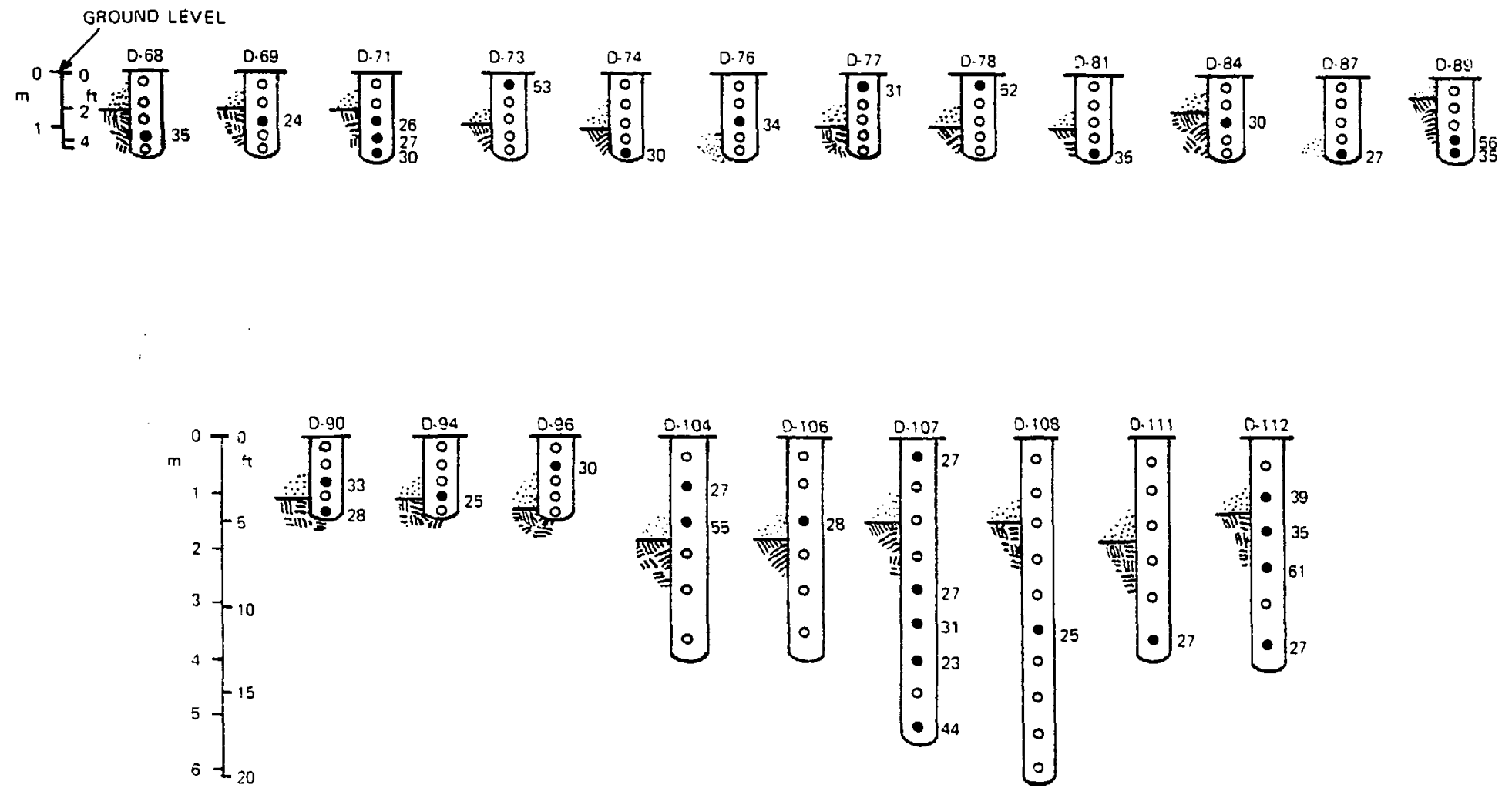

Grab sample, Gross $\alpha \leqslant 20 \mathrm{pCig}$

- Grab sampie. Gross $a>20$ pCi.g

with value shown

Fill

Not?

Fig. 49

Cross sections of drill holes in D-Building area and northwest of D-Building area having gross-alpha activity $>20 \mathrm{pCi} / \mathrm{g}$, showing depth and magnitude of the activity. 
TABLE XI

RESULTS OF RADIOCHEMICAL ANALYSES OF SELECTED SOIL SAMPLES FROM D-BUILDING AREA ${ }^{\mathrm{n}}$

\begin{tabular}{|c|c|c|c|c|c|}
\hline $\begin{array}{l}\text { Sample Location } \\
\text { Identification }\end{array}$ & $\begin{array}{l}\text { Depth } \\
\text { (m) }\end{array}$ & $\begin{array}{l}{ }^{230} \mathrm{Pu}^{\mathrm{b}} \\
(\mathrm{pCi} / \mathrm{g})\end{array}$ & $\begin{array}{l}\text { Laboratory } \\
\text { Gross Alpha } \\
\text { (pCi/g) }\end{array}$ & $\begin{array}{c}\text { Laboratory } \\
\text { Gross Beta } \\
\text { (pCi/g) }\end{array}$ & $\begin{array}{c}\text { Total } \\
\text { Uranium }\end{array}$ \\
\hline
\end{tabular}

Within D-Building Outline

$\begin{array}{llc}\text { C-2 } & \begin{array}{l}0 . \text { to } 0.05 \\ 0.15 \text { to } 0.20\end{array} & 3700 \\ & 0.40 \text { to } 0.60 & 5400 \\ & & \\ \text { C-3 } & 0.05 \text { to } 0.10 & 39 \\ \text { D2-RC-2 } & 0.10 \text { to } 0.15 & 0.64 \\ \text { D-4 } & 2.3 \text { to } 3 & 14 \\ \text { D-22 } & 2.4 \text { to } 3.0 & 150 \\ & 3.0 \text { to } 3.7 & 100 \\ \text { D-b! } & 2.4 \text { to } 3.0 & 210 \\ \text { D-62 } & 2.4 \text { to } 3.0 & 57\end{array}$

Northwest Corner Inside Fence

$\begin{array}{lll}\text { D-3 } 3 & 0.76 \text { to } 1.5 \quad 110\end{array}$

D-5 0.10 to $0.25 \quad 33$

0.25 to $0.46 \quad 19$

2.9 to $3.1 \quad 2.1$

3.2 to $3.4 \quad 0.3^{\prime} 7$

D-50 2.4 to $3.0 \quad 14$

$\begin{array}{llllll}\text { PH-74 } & 0 & \text { to } 0.76 & 46 & 4.5 & 4.2\end{array}$

$\begin{array}{llll}\text { PH-80 } & 0.45 & 6.4 & 3.1\end{array}$

$\begin{array}{ll}\text { PH-80 Resample } & 0.07\end{array}$

Water'Trench 27

No. 3. $20 \mathrm{ft}$

"See Fig. 46 for sample locations.

DIsotopic analyses were made for ${ }^{238} \mathrm{Pu}$ but all values were $<1 \%$ of the ${ }^{238} \mathrm{Pu}$ values. 
TABLE XI (cont)

\begin{tabular}{cccccc}
$\begin{array}{c}\text { Sample Location } \\
\text { Identification }\end{array}$ & $\begin{array}{c}\text { Depth } \\
(\mathrm{m})\end{array}$ & $\begin{array}{c}{ }^{239} \mathbf{P u}^{\mathrm{b}} \\
(\mathrm{pCi} / \mathrm{g})\end{array}$ & $\begin{array}{c}\text { Laboratory } \\
\text { Gross Alpha } \\
(\mathrm{pCi} / \mathrm{g})\end{array}$ & $\begin{array}{c}\text { Laboratory } \\
\text { Gross Beta } \\
(\mathrm{pCi} / \mathrm{g})\end{array}$ & $\begin{array}{c}\text { Total } \\
\text { Uranium }\end{array}$ \\
\hline
\end{tabular}

Northwest Corner Inside Fence (cont)

Water Trench

19

No. 3, $40 \mathrm{ft}$

Northeast of Building D-2
D-47
0.6 to 1.2
0.33
D-48
3.0 to 3.6
0.17
4.3 to 4.9
0.04
5.5 to 6.1
0.04
7.3 to 8.5
0.11

PH-15

61

$3.9 \mu \mathrm{g} / \mathrm{g}$

Northwest of D Building (outside fence)

$\begin{array}{lll}\text { C.4 } & 0 \text { to } 0.05 & 0.10 \\ & 0.10 \text { to } 0.15 & 0.61 \\ 0.20 \text { to } 0.58 & 0.67 \\ & & \\ & & \\ & 0.05 \text { to } 0.10 & 0.40 \\ & 0.15 \text { to } 0.20 & 0.75\end{array}$

D-51

0 to 0.60

18

6.6

D-52

0 to 0.60

1.4

16

4.5

0.60 to 1.2

6.6

D-73

0 to 0.30

67

4.1

$3 \mathrm{pCi} / \mathrm{g}$

D-77

0 to 0.30

0.016

1.2 to 1.4

0.010

D. 78

0 to 0.30

18

D.78 Resample

0 to 0.30

37

26

4.4

$3.9 \mathrm{pCi} / \mathrm{g}$

D-81

0.91 to 1.2

$<0.02 \mu \mathrm{g} / \mathrm{g}$

D-81 Resample

0.91 to 1.2

5.3

3.2

D-81

1.2 to 1.4

$0.42 \mu \mathrm{g} / \mathrm{g}$ 
TABLE XI (cont)

\begin{tabular}{|c|c|c|c|c|c|}
\hline $\begin{array}{l}\text { Sample Location } \\
\text { Idencification }\end{array}$ & $\begin{array}{c}\text { Depth } \\
(\mathbf{m})\end{array}$ & $\begin{array}{c}{ }^{2 * 0} \mathbf{P u}^{b} \\
(\mathrm{pCV} / \mathrm{g})\end{array}$ & $\begin{array}{c}\text { Laboratory } \\
\text { Gross Alpha } \\
\text { (pCi/g) }\end{array}$ & $\begin{array}{c}\text { Laboratory } \\
\text { Gross Beta } \\
\text { (pCi/g) }\end{array}$ & $\begin{array}{c}\text { Total } \\
\text { Uranium } \\
\end{array}$ \\
\hline \multicolumn{6}{|c|}{ Northwest of D Building (outside fence) (cont) } \\
\hline D-84 Resample & 0.60 to 0.91 & & 7.4 & 2.9 & \\
\hline D. $87^{c}$ & 1.2 to 1.4 & & & & $0.68 \mu \mathrm{g} / \mathrm{g}$ \\
\hline D-89 & 0.91 to 1.2 & 0.018 & & & \\
\hline D-89 Resample & 0.91 to 1.2 & 0.075 & 5.7 & 2.8 & $3.1 \mathrm{pCi} / \mathrm{g}$ \\
\hline D-89 & 1.2 to 1.4 & & 5.0 & 3.5 & \\
\hline D-90 & 0.60 to 0.91 & 0.32 & & & \\
\hline D-90 & 1.2 to 1.4 & 0.41 & & & \\
\hline D.94 & $\begin{array}{l}0.30 \text { to } 0.60 \\
0.91 \text { to } 1.2\end{array}$ & $\begin{array}{l}0.86 \\
0.21\end{array}$ & & & \\
\hline D-96 & $\begin{array}{l}0.30 \text { to } 0.60 \\
0.91 \text { to } 1.2\end{array}$ & $\begin{array}{l}0.03 \\
0.01\end{array}$ & & & \\
\hline D-104 & $\begin{array}{l}0.60 \text { to } 1.2^{\mathrm{c}} \\
1.2 \text { to } 1.8^{\mathrm{c}}\end{array}$ & & 7.9 & 1.7 & $\begin{array}{l}0.07 \mu \mathrm{g} / \mathrm{g} \\
0.15 \mu \mathrm{g} / \mathrm{g}\end{array}$ \\
\hline D-104 Resample & 1.2 to 1.8 & 0.04 & & & $2.8 \mathrm{pCi} / \mathrm{g}$ \\
\hline D-106 & 1.2 to 1.8 & & & & $0.24 \mu \mathrm{g} / \mathrm{g}$ \\
\hline D-107 & $\begin{array}{ll}0 & \text { to } 0.6^{\mathrm{c}} \\
3.0 & \text { to } 3.7^{\circ} \\
4.9 & \text { to } 5.5^{\mathrm{c}}\end{array}$ & & 4.1 & 2.2 & $\begin{array}{l}1.18 \mu \mathrm{g} / \mathrm{g} \\
1.79 \mu \mathrm{g} / \mathrm{g} \\
1.38 \mu \mathrm{g} / \mathrm{g}\end{array}$ \\
\hline D-112 & $\begin{array}{ll}0 & \text { to } 0.6^{c} \\
1.2 & \text { to } 1.8^{c}\end{array}$ & & & & $\begin{array}{l}2.20 \mu \mathrm{g} / \mathrm{g} \\
1.78 \mu \mathrm{g} / \mathrm{g}\end{array}$ \\
\hline D-112 Resample & $\begin{array}{l}1.2 \text { to } 1.8 \\
1.8 \text { to } 2.4^{\mathrm{c}} \\
3.0 \text { to } 4.0^{\mathrm{c}}\end{array}$ & 0.05 & 6.8 & 4.5 & $\begin{array}{l}2.7 \mathrm{pCi} / \mathrm{g} \\
1.38 \mu \mathrm{g} / \mathrm{g} \\
0.78 \mu \mathrm{g} / \mathrm{g}\end{array}$ \\
\hline
\end{tabular}

'Uranium isotopic analyses were made; all indicated normal uranium. 


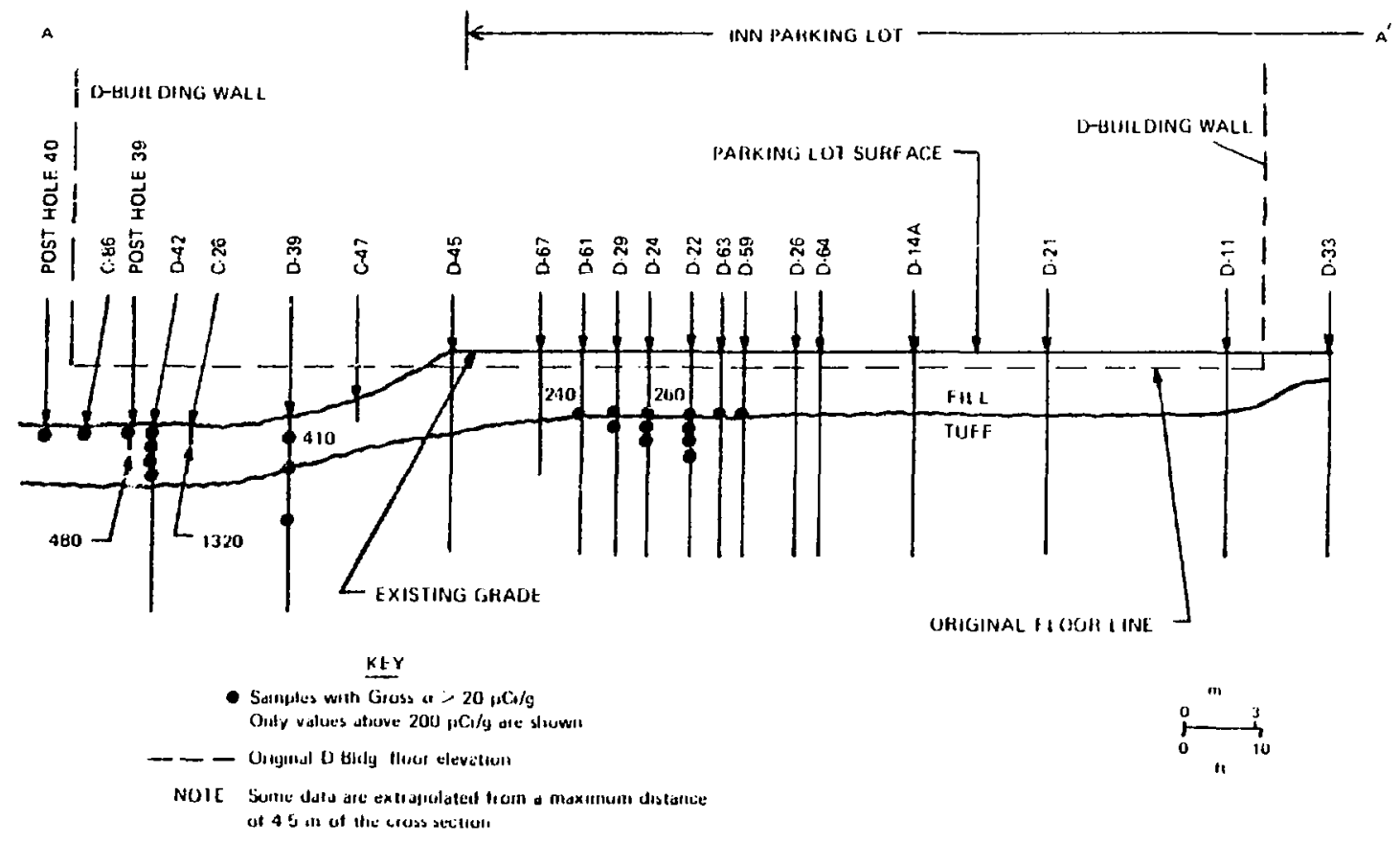

Fig. 50.

D-Building area drill holes from cross-section line $A A^{\prime}$ (looking northwest). (See Fig. 46.)

- The decision to continue would be made if a substantial proportion of positive samples came from an area that could be safely excavated with large equipment (and it generally could). If a localized hot spot existed, it would be removed by hand labor, backhoe, or front-end loader, as appropriate.

- A decision to stop decontamination would be made if a large proportion of samples had a grossalpha activity of $<20 \mathrm{pCi} / \mathrm{g}$ and if any positive samples were in the few tens of $\mathrm{pCi} / \mathrm{g}$. If repeated excavation did not appreciably lower concentrations of several hundred $\mathrm{pCi} / \mathrm{g}$ or less and if the excavation was in the tuff, a decision to stop could also be made.

b. Excavation. Most contamination found in the D and D-2 areas during explnration was associated in some way with contaminated sewer or drain lines. Thus, excavation began with the removal of these lines and hot spots by backhoe and hand labor. Debris and soil with activity $>10000 \mathrm{pCi} / \mathrm{g}$ were packaged in plastic-lined steel drums and sent to the on-site LASL retrievable storage facility (about 7 such drums were iilled). Soil with lower concentrations was buried in pits at the solid radioactive waste disposal site. The $15.2 \mathrm{~cm}$-diam iron pipe discovered in Trench 4 (Figs. 35 and 38) was $6.4 \mathrm{~m}$ long. and had welded joints. At its north end it sleeved over a 10.2-cm-dian: iron pipe. Apparently, this was a drain line that had been "extended" to the south side of the road in 1945 (see Sec. III.B.2.a). During removal of the contaminated $20.3-\mathrm{cm}$-diam line discovered in Trench 7 , an estimated $75000 \mathrm{pCi} / \mathrm{g}$ of activity (phoswich readings) were noted at a place where a pipe joint had leaked.

What seemed to be a French Drain-gravel-filled trench or pit for seepage-extended into the area south and east of the D-2 area outline (Figs. 40 and 44). No contamination was found in those parts of the French Drain encountered during exploration and excavation.

After drain-line removal and subsequent ripping, bulldozing, and loading operations, an area approximately $17 \mathrm{~m}$ wide by $38 \mathrm{~m}$ long by 0.6 to $2.8 \mathrm{~m}$ deep was excavated in the D-2 area. A 3.05-m grid for soil 


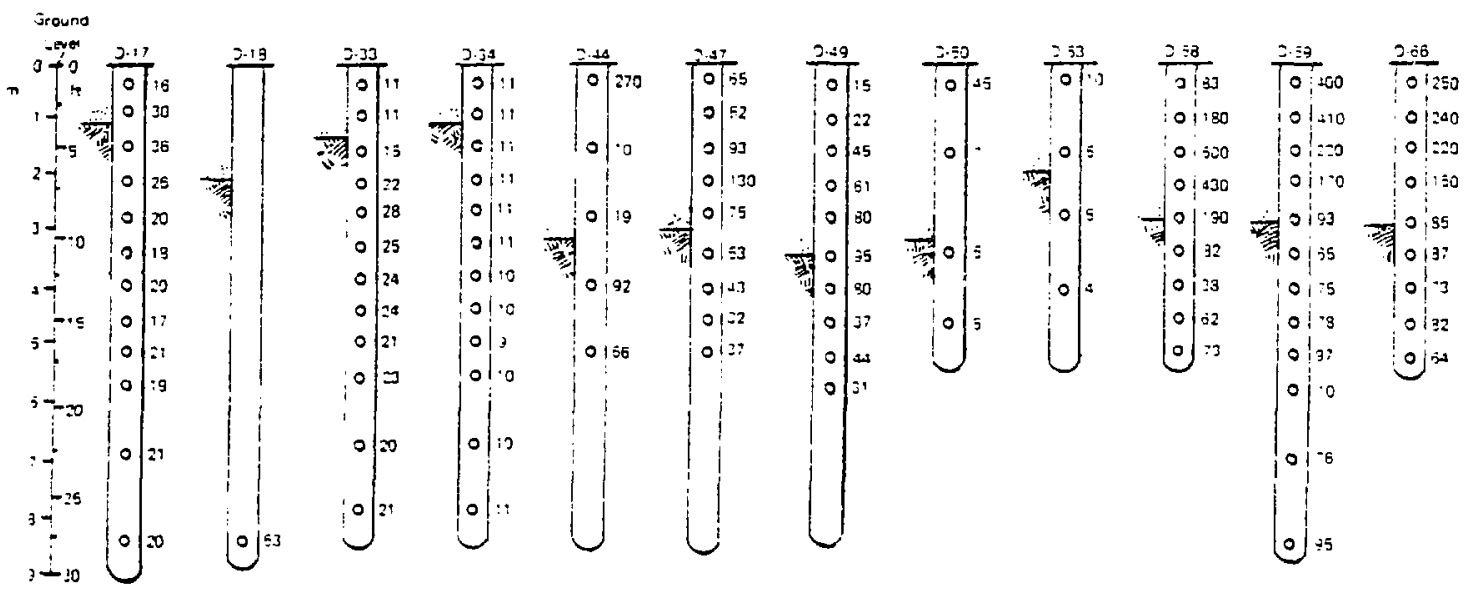

Fig. 51.

Cross sections of $D$-Building area drill holes, showing depth and magnitude of tritium in soil moisture.

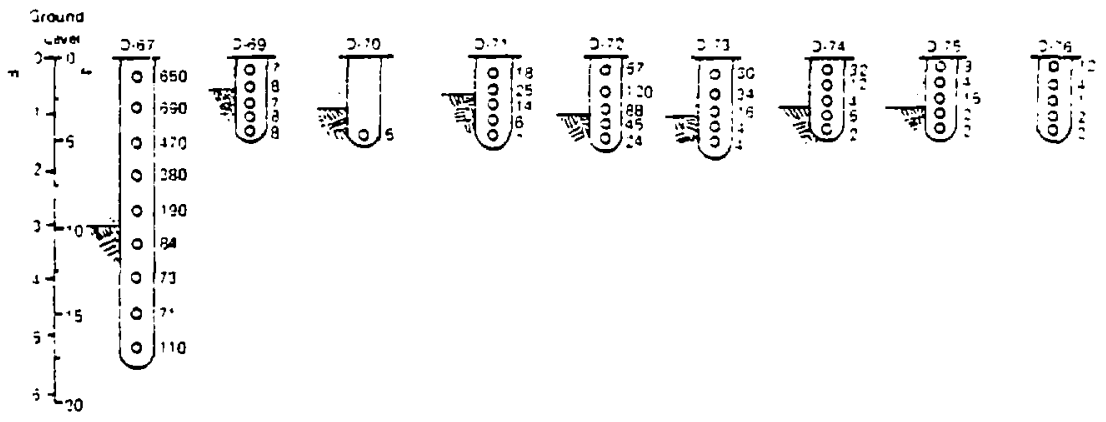

\footnotetext{
D Grab sample with tritium content in $\mathrm{oCi} / \mathrm{ml}$ at soil noisture $\because \because$ Fill

锩萑Tuft
}

Fig. 52.

Cross sections of D-Building area drill holes, showing depth and magnitude of tritium in soil moisture. 
TABLE XII

\section{TRITIUM CONCENTRATIONS IN SOIL MOISTURE FROM LASL 1973-1976 ENVIRONMENTAL SAMPLING (In $\mathrm{pCi} / \mathrm{m} \ell$ )}

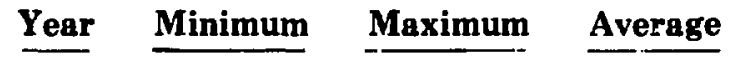

Soil Moisture

Off-site soils

1973

On-site soils

1973

Off-site soils

1974

On-site soils

1974

Off-site soils

1975

On-site soils

1975

1976

1976

2

5

0

-.-

1.9

3.0

1.4

3.5

On-site soils

Free Water

Mortandad Canyon

Liquid waste

disposal area

with known HTO
1973

1974
24

6

4
13
4.5
$\cdots$
$123^{\mathrm{a}}$
8.3
6.4
11

3

9

0.8

2.1

6.0

3.3

7.9

Uncontrolled Area Concentration Guide (ERDAM 0524) $3000 \mathrm{pCi} / \mathrm{m} \ell$

"A sample from the vicinity of a tritium processing facility had $123 \mathrm{pCi} / \mathrm{m} \ell$ of tritium. Of the other 8 samples, the maximum was $4.8 \mathrm{pCi} / \mathrm{m} \ell$.

sampling was established in the excavated area (known activity remained in the Tank 137 excavation). Results of grid-sample analyses and initial sampling from the natural drainage channels in the D-2 area are given in Fig. 54. At the ends of the drain-line locations, in the drainage channels, and in the Septic Tank 137 area, further excavation was required. In the western third of the grid, more than half the samples indicated activity $>20 \mathrm{pCi} / \mathrm{g}$, and another $0.6 \mathrm{~m}$ of soil was removed from the Septic Tank 137 location through the west edge of the grid. A deep trench was dug to attempt removal of high concentrations in the natural drainage channel below $t$ 1e drain lines west of Septic Tank 137. After these excavations, another set of soil samples was taker. (results are shown in Fig. 55). Comparison of
Figs. 54 and 55 indicates that spots with activity $\therefore 1000 \mathrm{pCi} / \mathrm{g}$ were removed, along with much of the activity in the western portion of the grid. However, the activity in the southeastern portion of the new grid (Fig. 55) was higher, and another $0.6 \mathrm{~m}$ of soil was removed, taking the soil level to 3 to $4.6 \mathrm{~m}$ below the original grade. If the activity continued to increase, more soil would be removed. If the activity remained constant or decreased, excavation would be stopped. Excavation of the deep trench had removed the soil with higher levels of activity. Thus, at a meeting on January 6, 1976 (Table III), the deep-trench excavation was considered to be decontaminated because (1) no phoswich-detectable activity remained in the trench; (2) most of the activity that did remain was on ERDA-owned and 


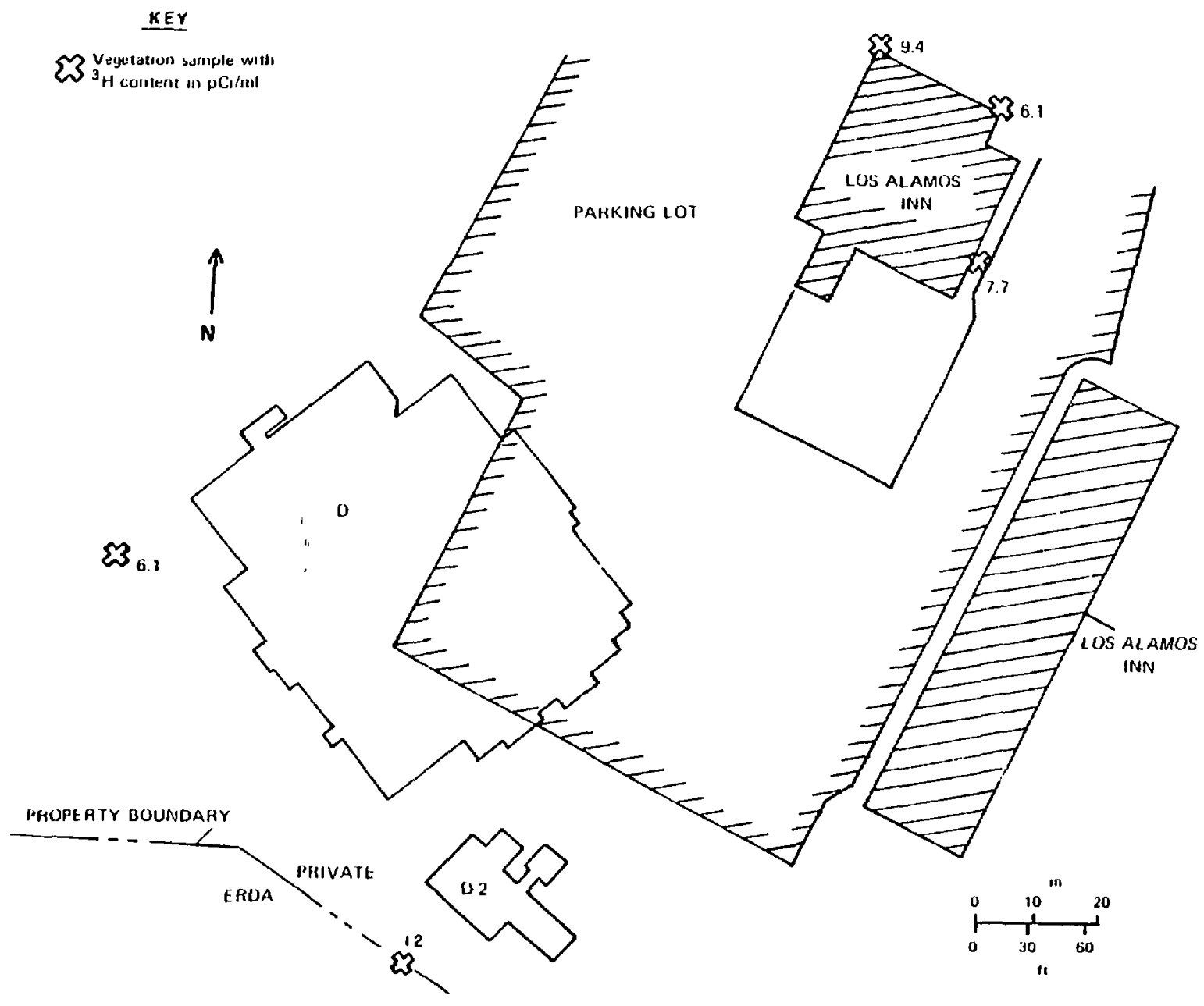

Fig. 53.

Tritium results from the vicinity of the Los Alamos Inn.

-controlled property; (3) steep terrain and the nearby canyon wall would have made excavation hazardous; and (4) most samples had gross-a'pha activity $<100 \mathrm{pCi} / g$. Figure 56 shows the north $\mathrm{t}$ nd of the deep trench before backfilling began. A chainlink fence now restricts public access to this hillside.

The next $0.6 \mathrm{~m}$ of soil in the grid area was removed and results of subsequent sampling are hown in Fig. 57. Comparison of Figs. 55 and 57 shows that the concentrations did not change appreciably, and soil removal was stopped. At a meeting on January 20, 1976 (Table III), this portion of the D-2 excavation was considered decontaminated because (1) no phoswich-detectable ac- tivity remained; (2) a number of samples had grossalpha activity $>20 \mathrm{pCi} / \mathrm{g}$ but the maximum was 110 $\mathrm{pCi} / \mathrm{g}$; and (3) the excavation was so deep in the tuff that a great deal of expensive soil removal would be necessary to improve results. Also, (1) the o-cavations were well below the drain pipes from I3iilding D-2; (2) the excavations were in undisturbeci tuff; and (3) the tuff had no apparent joints or cracks into which contaminated solutions would have leaked. Thus, major additional discoveries of contamination were unlikely. Possible reduction of small concentrations deep in the tuff along a property line did not justify the additional cost and physical hazards required to remove additional soil. 


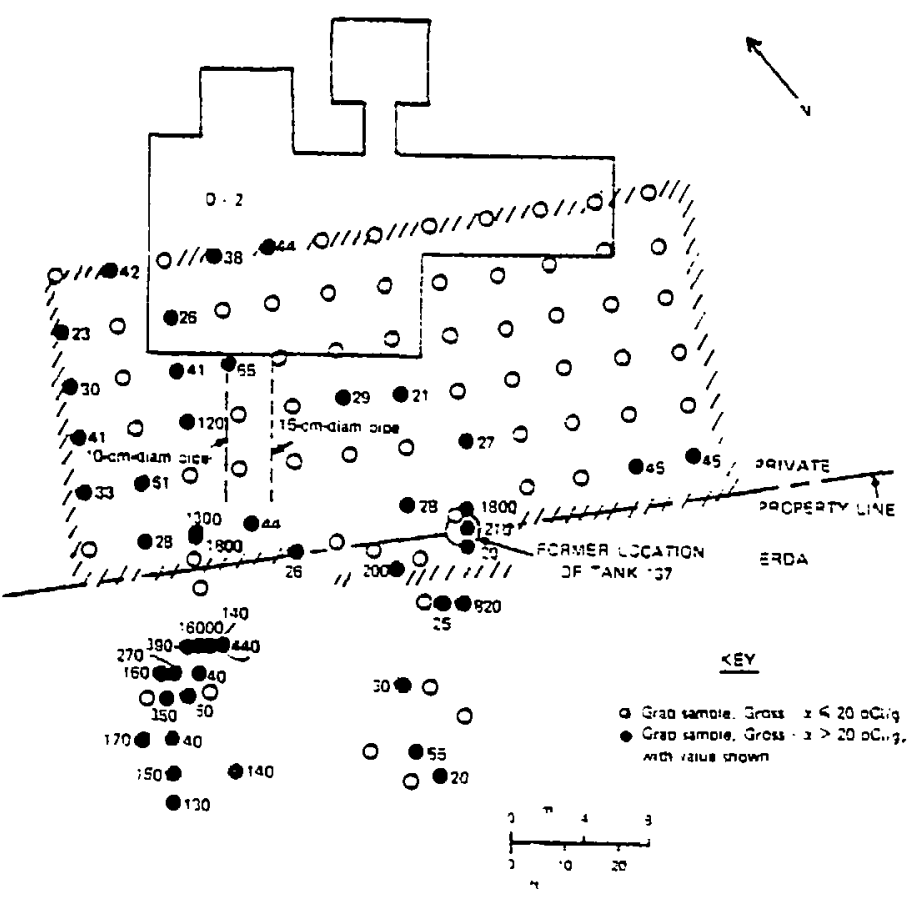

Fig. 54.

D.2 area excavation and sampling results, December 5, 1975.

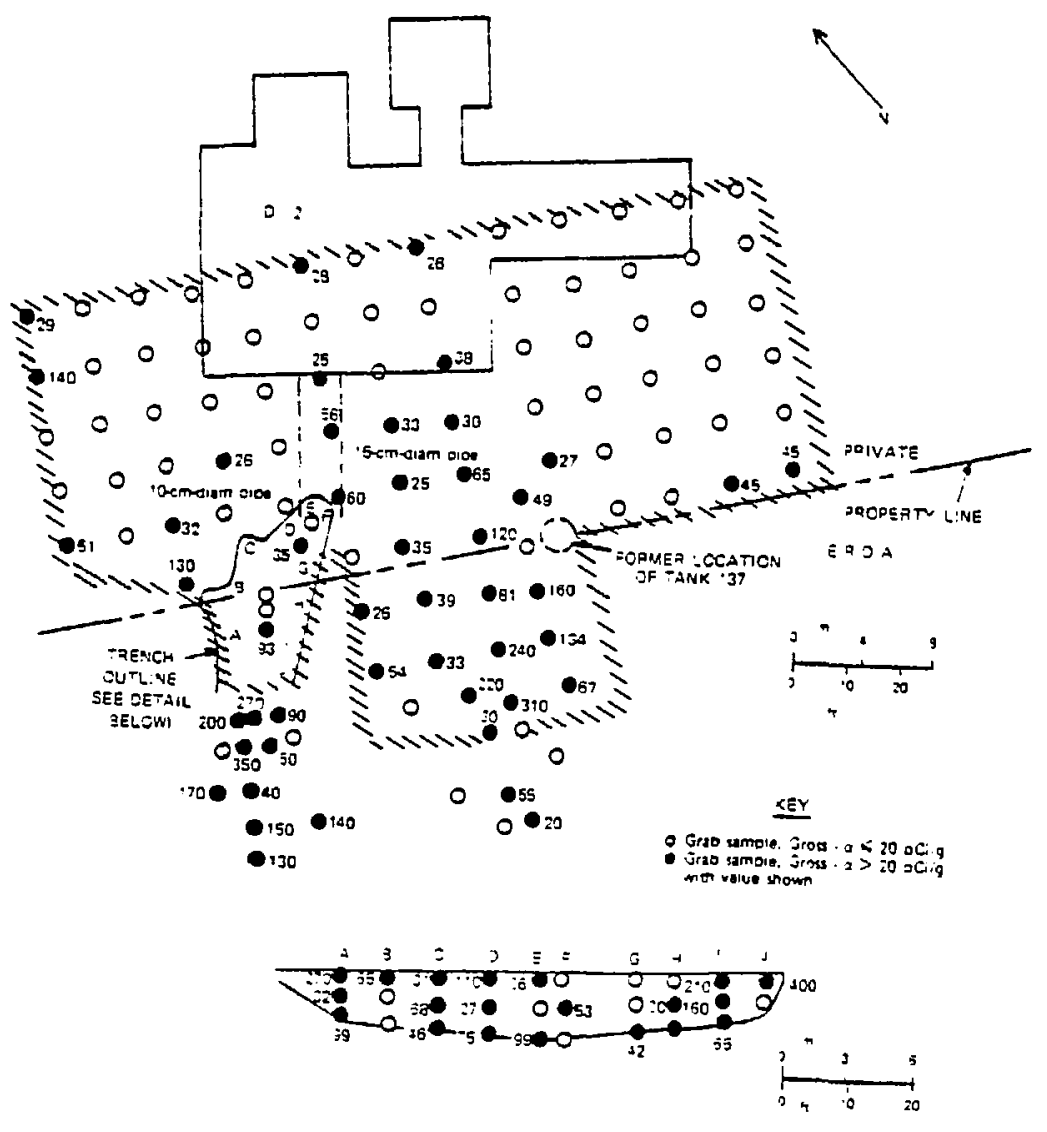

Fig. 55 .

D-2 area excavation and sampling results, December 19, 1975. 


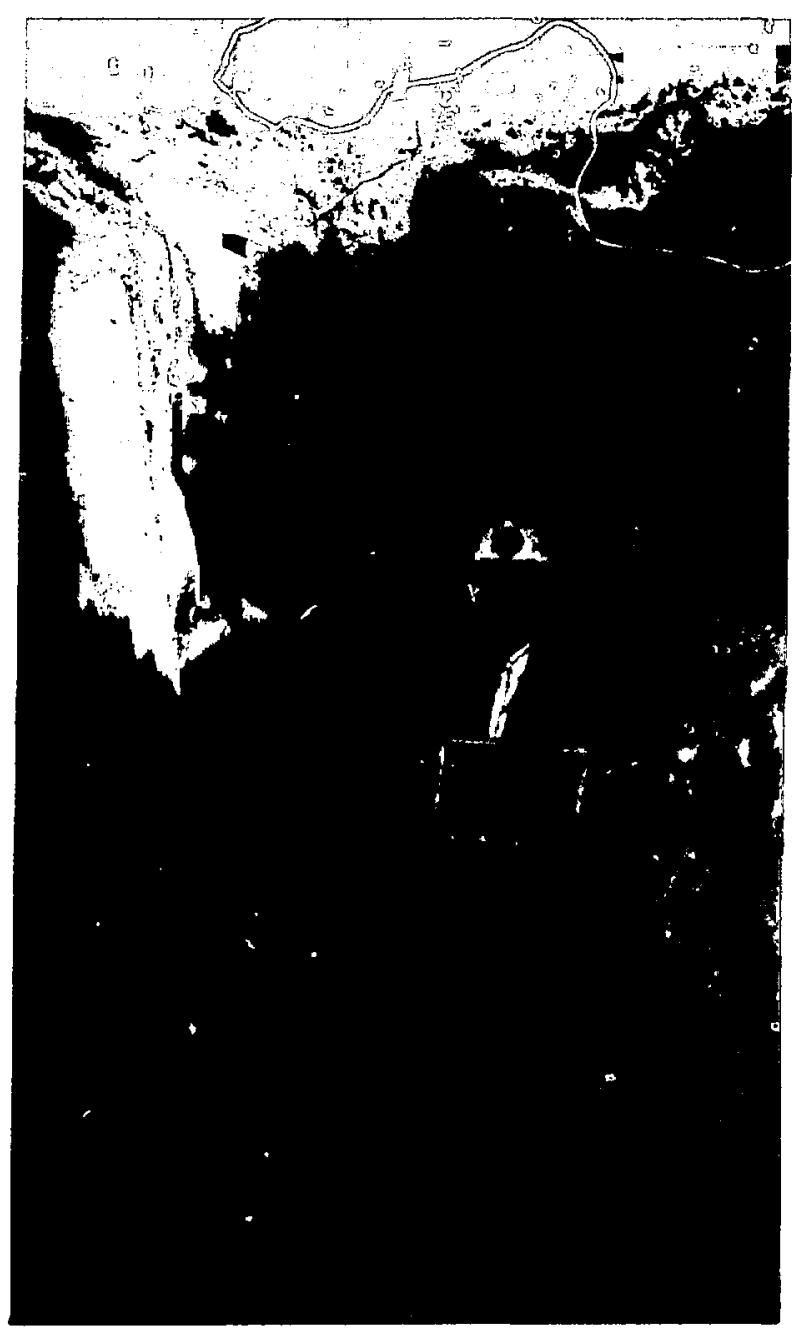

Fig. 56.

Deep trench excavation in the $D-2$ area drainage channel.

During these operations an $\sim 18$-m-tall pine tree on ERDA property in the drainage channel below Septic Tank 137 was removed because its shallow roots had been damaged by the excavation and because soil around the roots had $1400 \mathrm{pCi} / \mathrm{g}$ of gross-alpha activity.

The iterative steps of decontamination were discussed in detail here as an illustration of the process applied to most excavations in the TA-1 area. The results of each step will not usually be covered in other discussions because they do not contribute significantly to understanding the finai, as-left condition of the decontamination operations. However, the results of consecutive steps were crucial in determining day-to-day field operations and often contributed to decisions that decontamination was complete.

From 0.6 to $1.2 \mathrm{~m}$ of soil were removed from within the D-2 Building outline and from the area to the northwest where no trenches had been dug-an area close to the contaminated D-Building area. Near the D-2 outline the only significant contamination was a piece of pipe insulation which read $1500 \mathrm{c} / \mathrm{min}$ on the phoswich. Results of analyses of the final grid samples in this area are in Fig. 58.

Excavation for the D-Building area was done in the same way as for the D-2 area. Known contaminated lines and spots were removed by hand labor and backhoe; ripping, stockpiling, and loading served for the rest of the area. Because contamination appeared in auger cuttings at the tuff-fill interface in the southwest corner of the Los Alamos Inn parking lot, soil from beneath a 15.2 -m-wide by $15.2-\mathrm{m}$-long portion of the lot was removed to at least $0.6 \mathrm{~m}$ below the tuff-fill interface.

Contamination in these excavations was associated mainly with sewer lines and debris that were apparently left from the D-Building demolition. The contamination $(10000 \mathrm{c} / \mathrm{min}$ on the phoswich) beneath the Inn parking lot was apparently associated with steam-pipe insulation from 2.5$\mathrm{cm}$ - and $5.1-\mathrm{cm}$-diam steam pipes. Other contaminated debris included a concrete support pier (50000 $\mathrm{c} / \mathrm{min}$ on the phoswich) and rotten wood (20000 c/min on the phoswich). These were scattered, isolated spots and were not representative of the large volume of soi? removed. Once an excavated zone was surveyed and found to be below phoswich detection levels, partial soil sample grids were taken and further excavation was made, it necessary. Data for $3.05-\mathrm{m}$ sampling grids $v$ ere filled in later and for the most part represented the final results (Fig. 58).

Major contamination was associated with the sanitary-sewer line (D Outfall Trench in Fig. 58) and the trench associated with the former acidsewer line (D-Acid-Sewer Trench in Figs. 58 and 59).

Samples from the sanitary-sewer line trench had gross-alpha activity as high as $15000 \mathrm{pCi} / \mathrm{g}$ where a joint had leaked; phoswich-measured activity was as high as $10000 \mathrm{c} / \mathrm{min}$. This line went uphill to a level area and continued on the level for $4.6 \mathrm{~m}$. A 


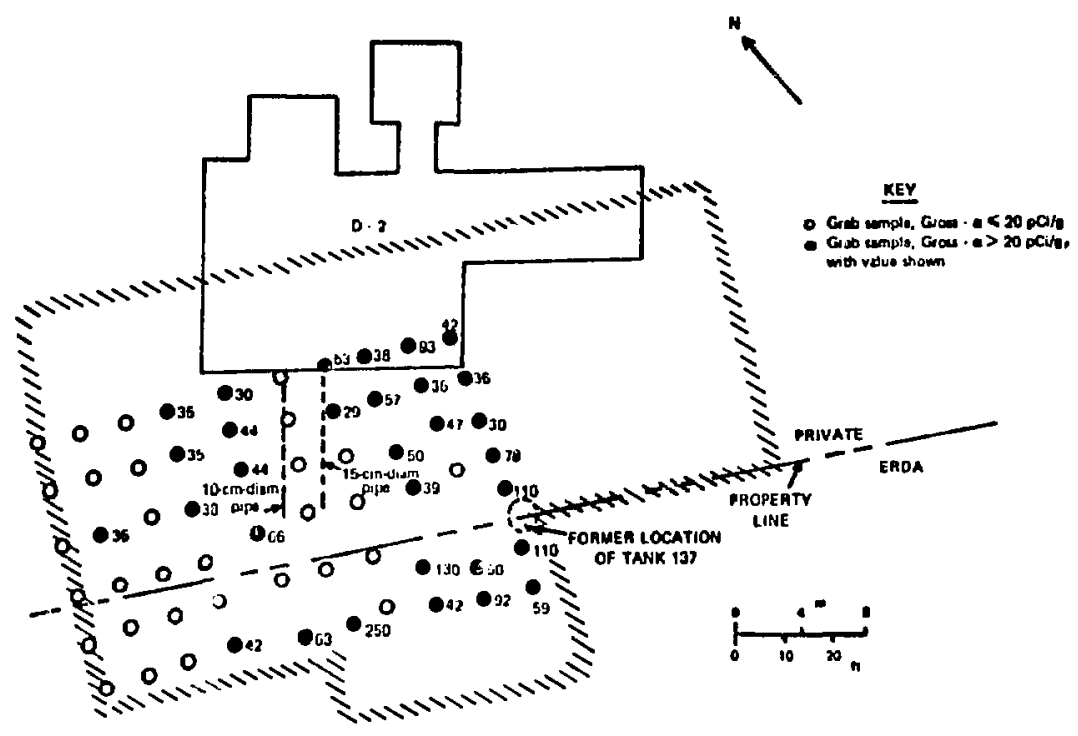

Fig. 5\%.

D-2 excavation and sampling results, danuary 19, 1976.

cross trench (Trench B in Figs. 60 and 61), dug to the north to see if the line continued, contained only a contaminated pipe shard.

The acid-sewer trench was contaminated with plutonium and uranium. Soil samples contained as much as $89600 \mathrm{pCi} / \mathrm{g}$ of gross-alpha activity. Some soil had phoswich-measured alpha activity of $>100000 \mathrm{pCi} / \mathrm{g}$. Among the items uncovered in the excavation were pipe shards, a test tube, small puddles of mercury, a filter, and a shovel without a handle. The trench was enlarged by $\sim 0.6$ to $1 \mathrm{~m}$ below and to either side of the original trench. Soil samples from the sides and bottom of this excavation indicated gross-alpha activity of $\sim 200 \mathrm{pCi} / \mathrm{g}$. An additional $1 \mathrm{~m}$ of soil was removed from the bottom and sides (Fig. 59 shows the final extent of the trench). Results of final sampling from the trench are included in Fig. 58.

During the D-area excavations, part of the old fire-main system (20.3-cm-diam cast-iron pipe) was uncovered and removed. The pipe, found in tuff, was in excellent condition even though it had been buried $>20$ yr without cathodic protection.

Final soil sampling results for D and D-2 areas are shown in Fig. 58. At meetings on January 6, 20, and 30,1976 (Table III), excavations in these two areas were determined to be decontaminated because (1) no phoswich-detectable activity remained; (2) the majority of soil samples had gross-alpha activity $<20 \mathrm{pCi} / \mathrm{g}$ - those having $>20 \mathrm{pCi} / \mathrm{g}$ on private land had activity $<120 \mathrm{pCi} / \mathrm{g}$; and (3) most excavations stopped in undisturbed tuff, which implied a low probability of finding further contaminated lines and debris.

As part of the final documentation, the elevation contours of the D and D-2 area excavations and trenches are presented in Figs. 60 and 61. Contours of the areas after backfilling and site restoration are given in Fig. 62.

3. Area North and West of $D$ Building. The area bounded roughly by $Q$ Building to the west, Boiler House No. 2 to the north, and extending into the D-Building area to the southeast was suspected of contamination on the basis of results of the 1974 survey and subsequent exploration (Fig. 46). Surface sample 1-Q-1 in the Q-Building outline (Fig. 46) had $27 \mathrm{pCi} / \mathrm{g}$ of ${ }^{239} \mathrm{Pu}$ (1974 survey) and samples from two post holes made for the temporary work fence around the $\mathrm{D}$-area excavation had gross-alpha levels as high as $200 \mathrm{pCi} / \mathrm{g}$; several samples from the trench dug for a temporary water line had grossalpha levels as high as $150 \mathrm{pCi} / \mathrm{g}$.

To define the contaminated area, samples from an extensive series of auger holes (Figs. 47-49) were analyzed-some radiochemically (Table XI). Many 


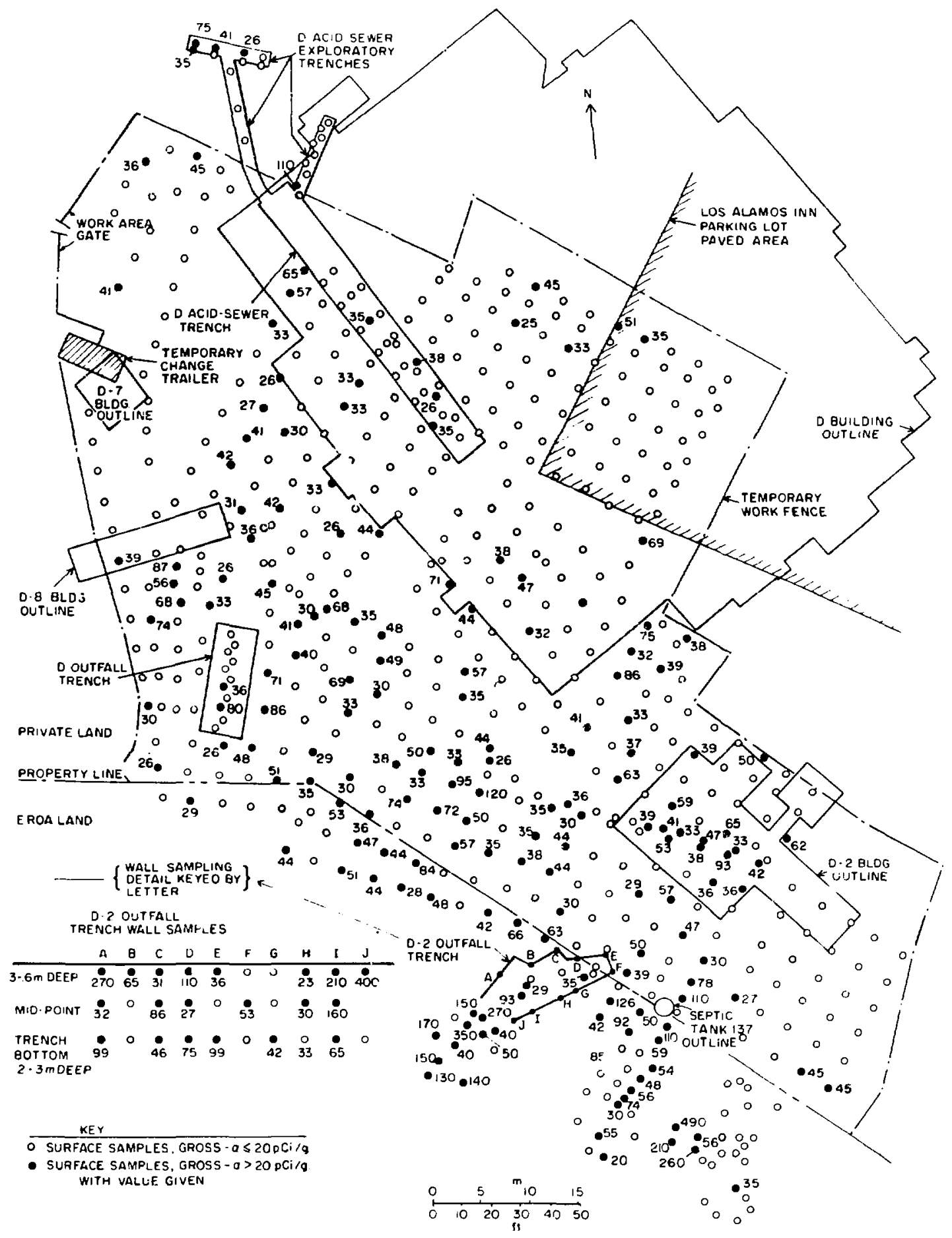

Fig. 58.

Final sampling results in $D$ and $D-2$ areas prior to bockfilling. 


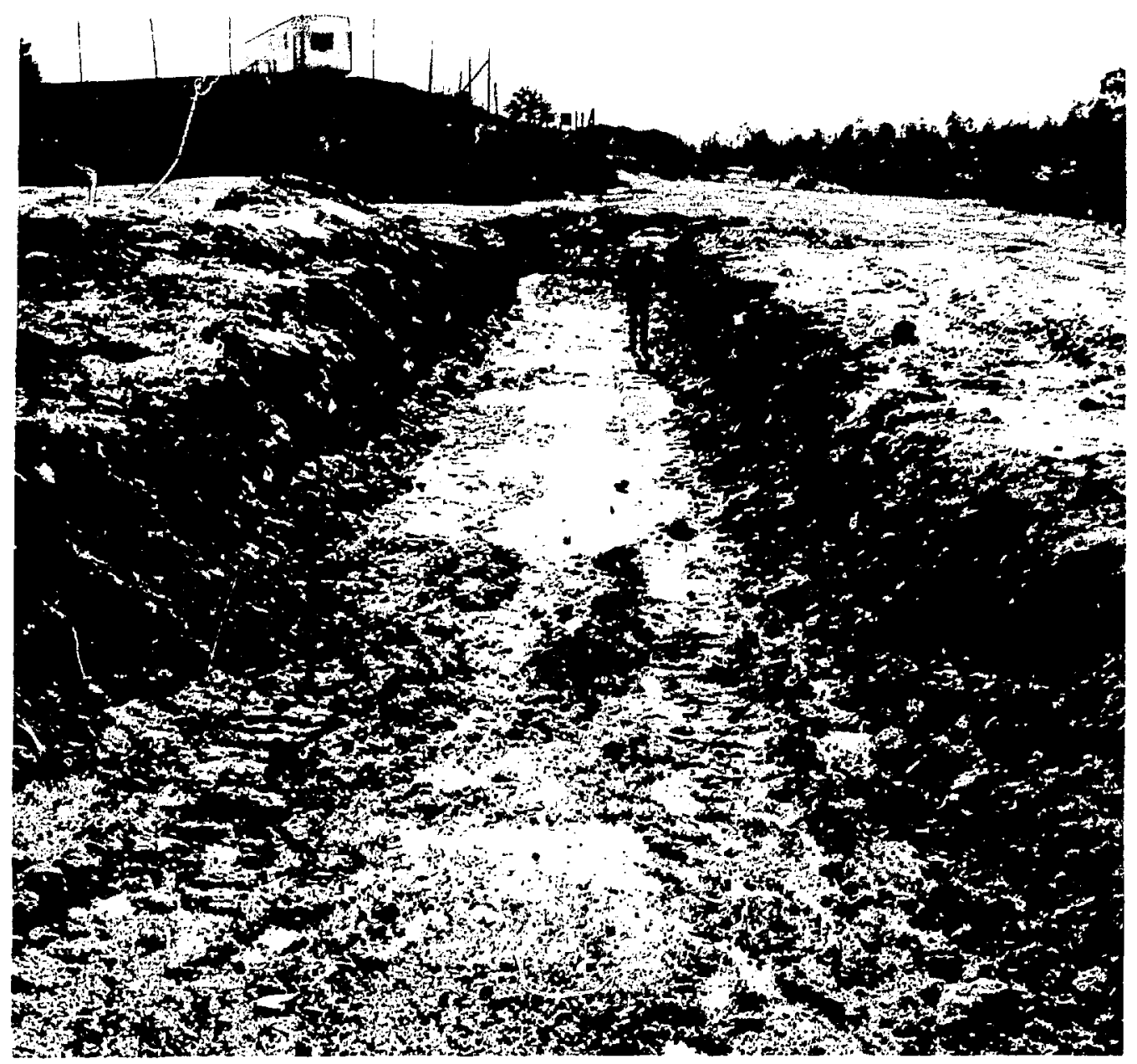

Fig. 59.

D-Building acid-sewer trench (looking ESE) prior to backfilling. (Called Trerch $A$ in Fig. 61.)

samples contained slightly elevated gross-alpha activity. Of those samples submitted for radiochemical analyses, the plutonium and uranium in many cases did not account completely for elevated gross-alpha activity, but in several cases the ${ }^{238} \mathrm{Pu}$ results generally agreed with the gross-alpha results, and known ${ }^{239} \mathrm{Pu}$ activity to $46 \mathrm{pCi} / \mathrm{g}$ was within 0.6 $m$ of the surface. The contamination was extremely irreguiar and of a low level, but nonetheless widespread; consequently, decontamination was attempted.
Because most of the samples with the highest activity came from within $0.6 \mathrm{~m}$ of the surface, an area about $30 \mathrm{~m}$ wide by $40 \mathrm{~m}$ long by $0.6 \mathrm{~m}$ deep was excavated initially. The location of this initial excavation and results from a $3.05-\mathrm{m}$ sample grid are given in Fig. 63. Further excavation was made in the areas having $>20 \mathrm{pCi} / \mathrm{g}$ activity and results from subsequent sampling are shown in Fig. 64. Phoswichdetectable activity was noted at one point under a vitrified clay-tile line discovered during excavation. The activity was associated with a small, buried tree 

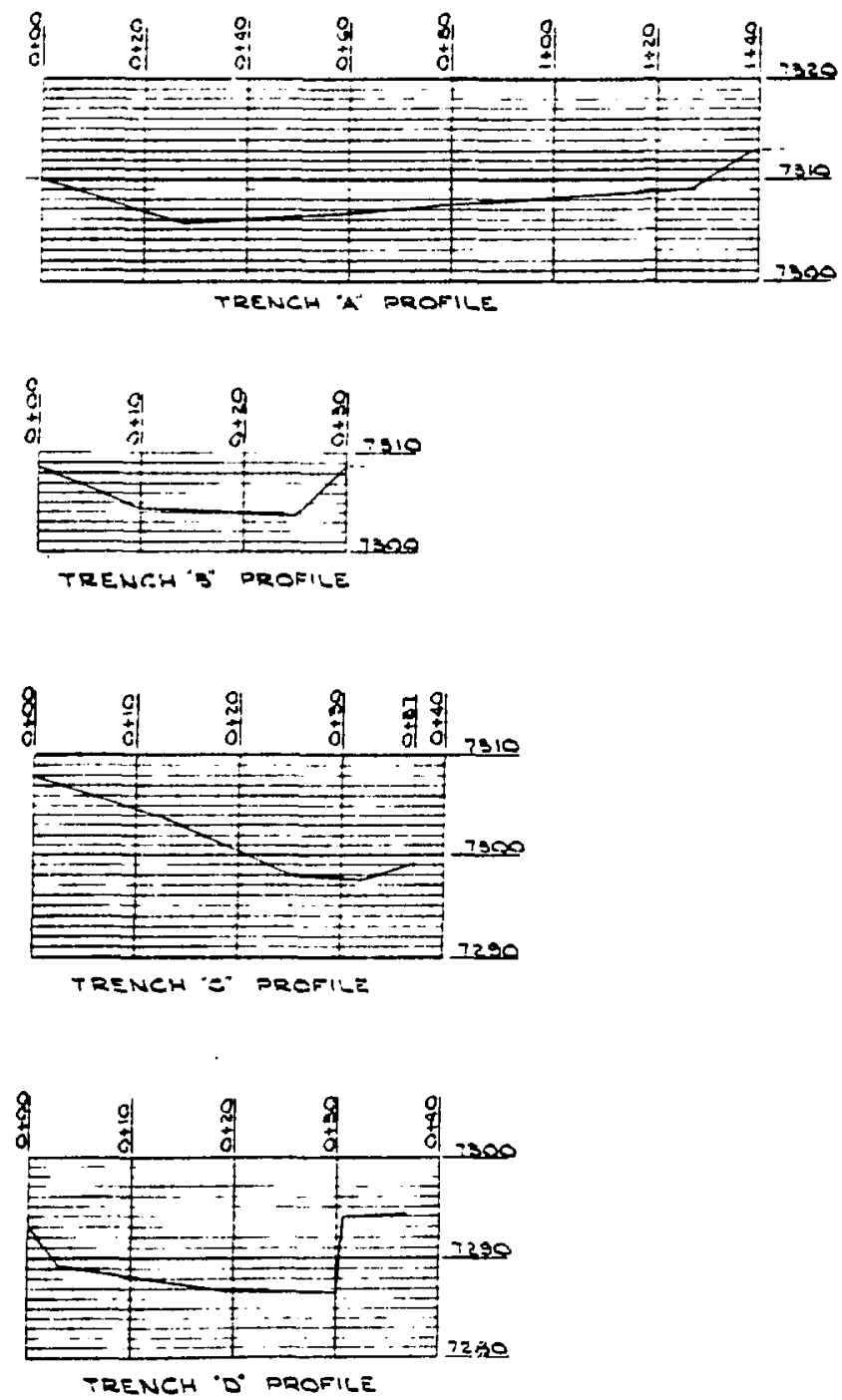

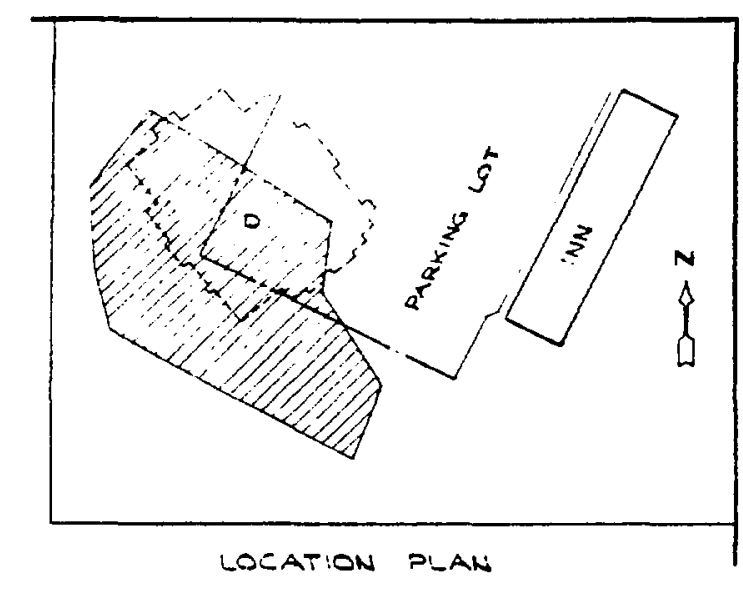

Fig. 60.

Locations of $D$ and $D-2$ excavation and trench profiles prior to backfilling. 


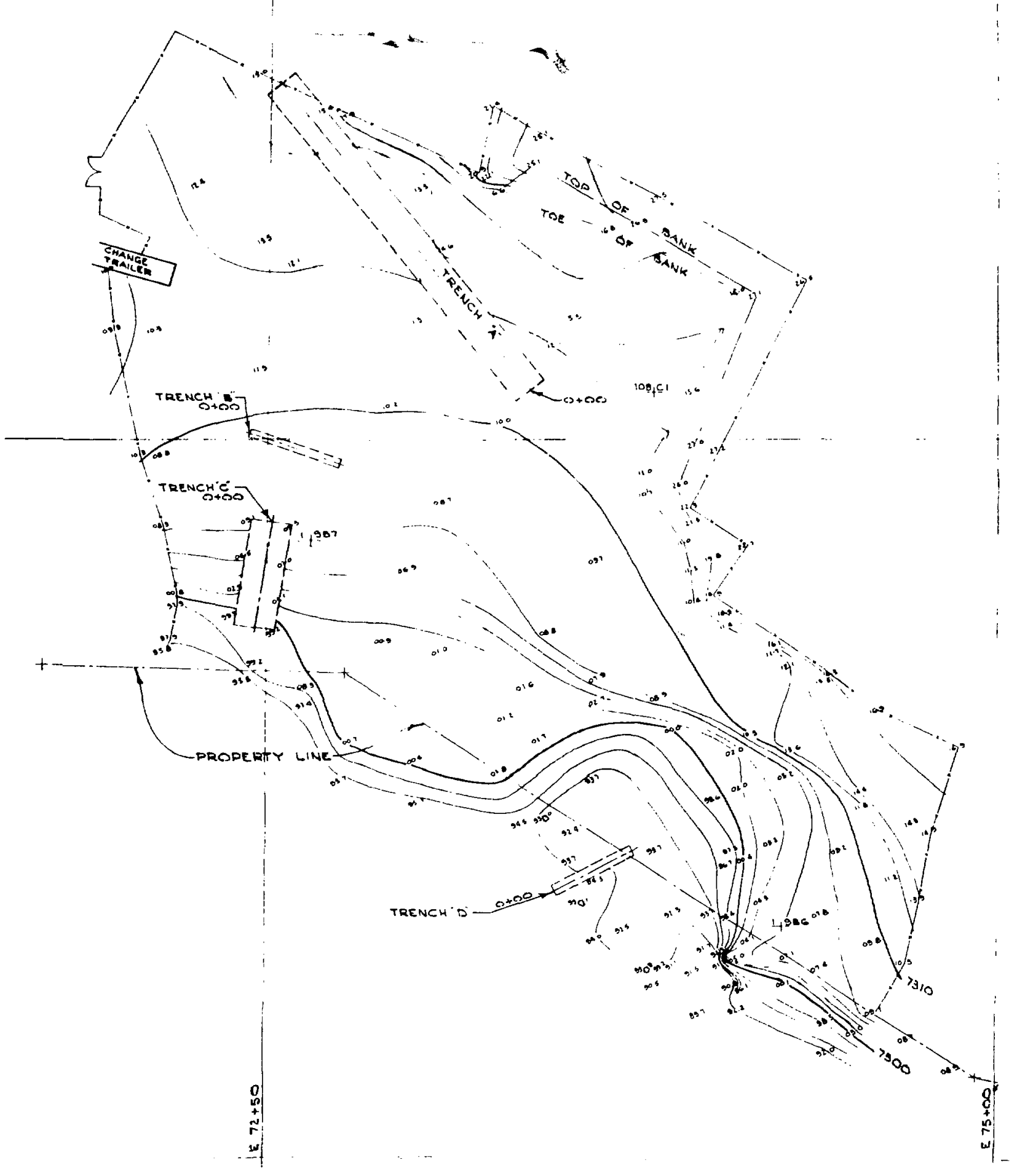

Fig. 61 .

Contour map of $D$ and $D-2$ excavations prior to backfilling. 


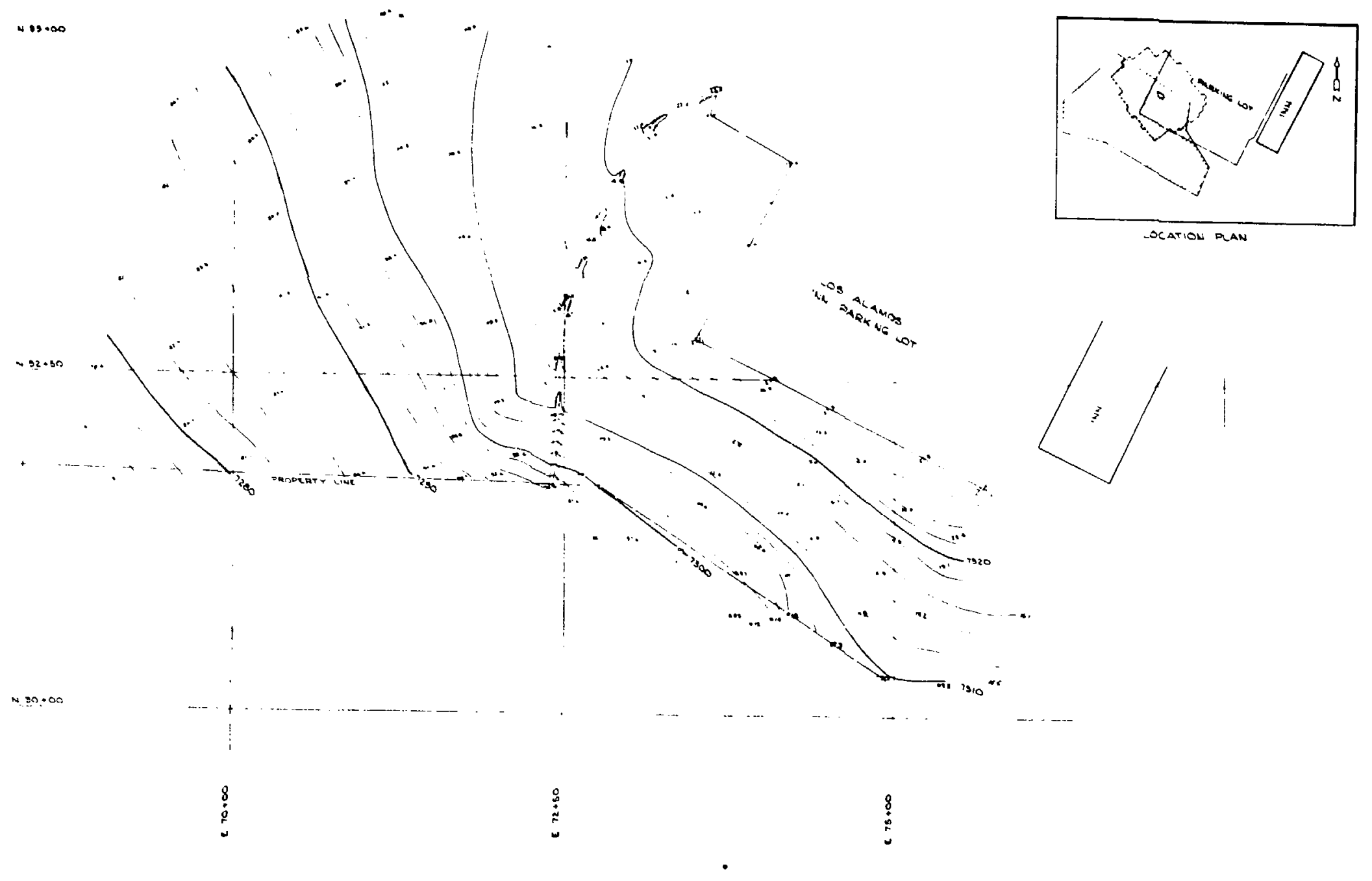

Fig. 62.

Contour map of final grading in the $D$ and $D-2$ areas. 


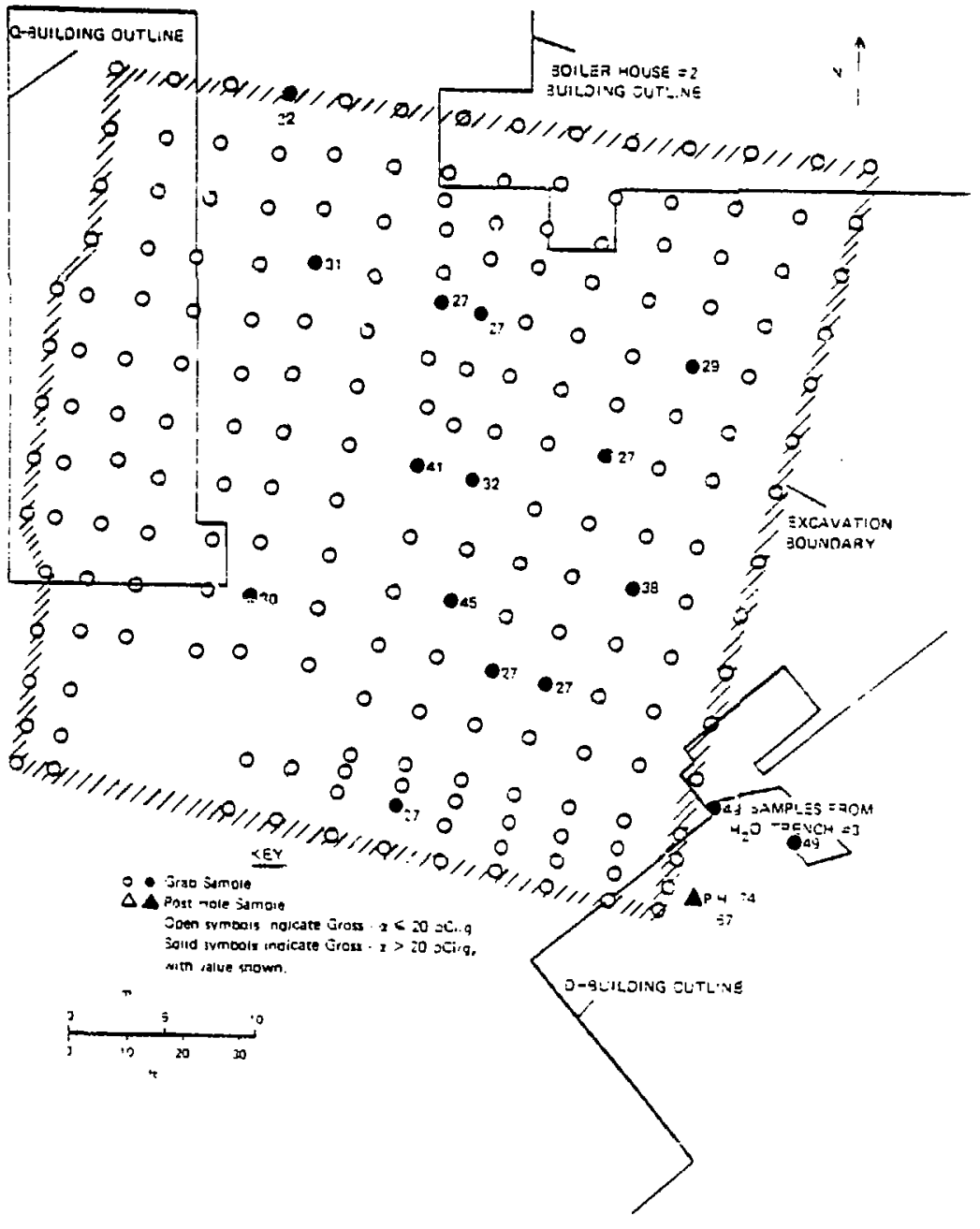

Fig. 63.

Initial excavation norih and west of $D$ Building, with soil-sumpling results.

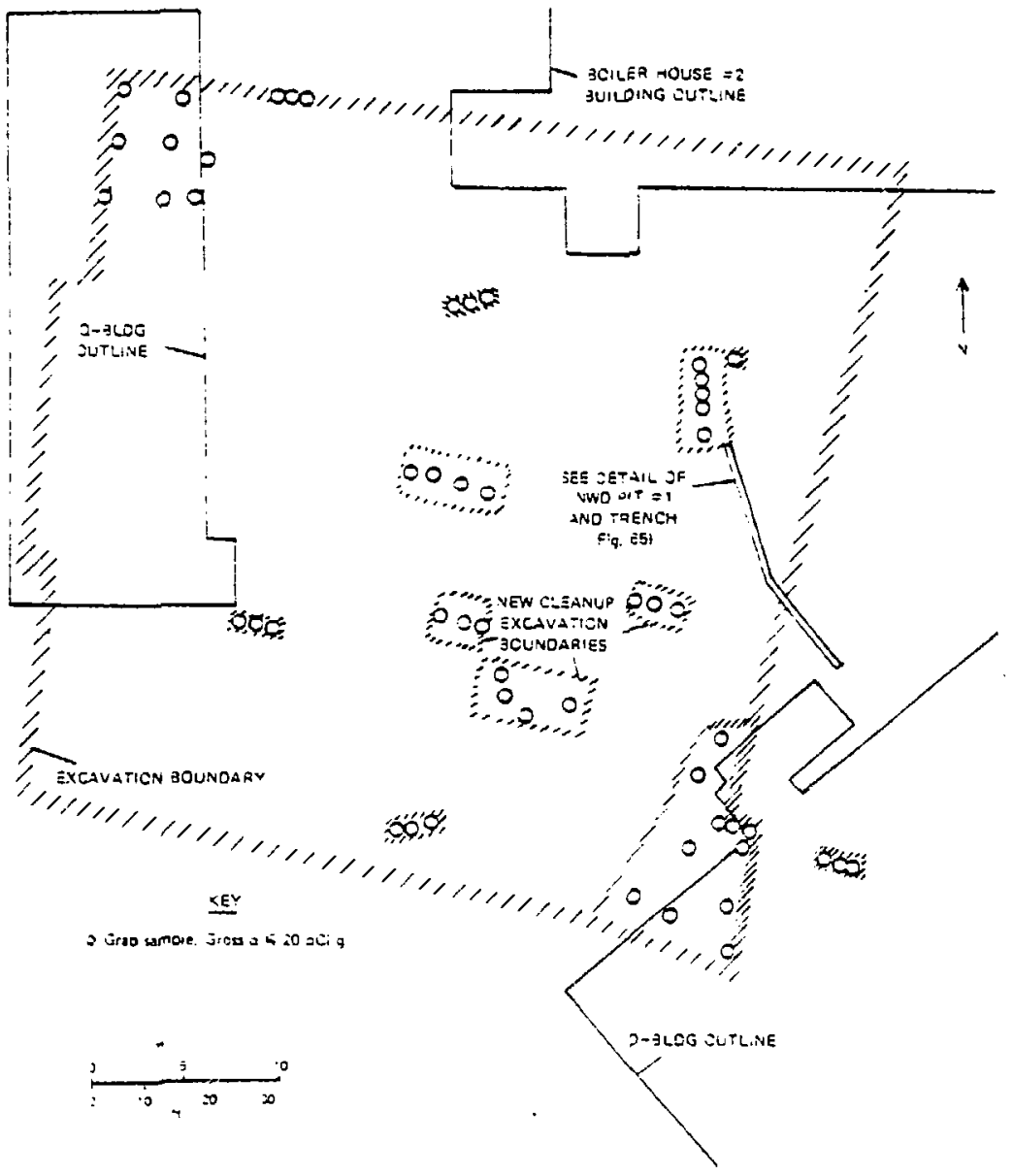

Fig. 64 .

Follow-up excavations north and west of $D$ Building, with follow-up soil-sampling results. 
trunk. Excavations around this trunk developed into Pit No. 1 (Fig. 64). Because as much as 340 $\mathrm{pCi} / \mathrm{g}$ of gross-alpha activity was observed near the clay-tile line, the entire line was removed. The initial and post-cleanup soil sampling results associated with the line removal are given in Figs. 65 and 66 , respectively.

The clay-tile line nearly corresponded to what was identified on engineering drawings ${ }^{10}$ as a sanitarysewer line coming from D Building; thus, the source of contamination was probably D Building. Several of the other areas requiring additional excavation corresponded approximately to the trench for the main acid-sewer line from D Building (see Sec. III.C.2 and Fig. 94). The cont amination found in the area nortb and west of $D$ Building may have resulted from the original decontamination and demolition of $D$ Building or from the removal of the building's main acid-sewer line.

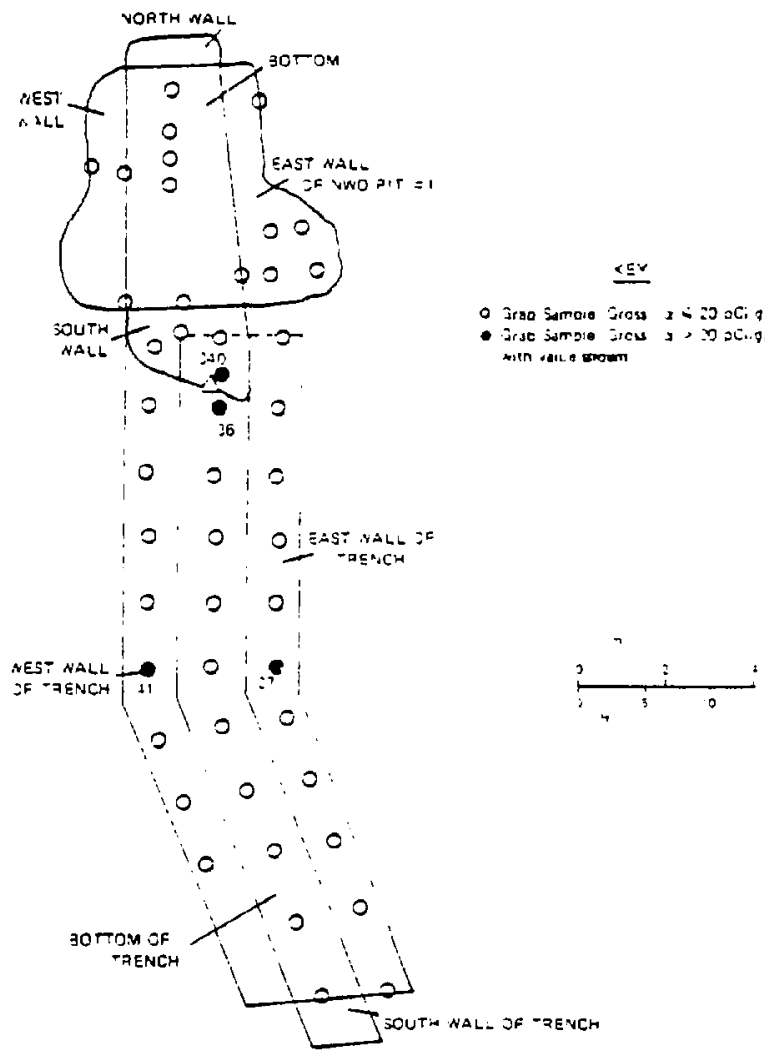

Fig. 65.

Flattened view of the trench and pit in the excavation north and west of $D$ Building, with soil-sampling results.
At a meeting on Jine 8, 1976 (Table 111), the area north and west of D Building was considered decontaminated because (1) no phoswich-detectable activity remained; (2) all 238 final documentation soil samples had activity $<20 \mathrm{pCi} / \mathrm{g}$; and (3) the excavation had been mainly in undisturbed tuff which made further discoveries of significant contamination unlikely.

4. Septic Tank 138. To find Septic Tank 138 , trenches were hand-dug to find the outfall line (samples were collected as work progressed). The trench locations and sampling results are shown in Figs. 67-69. (Trenches were numbered in order as each was dug.) Gross-alpha activity on all samples from Trenches 2, 3, and 4 was $<20 \mathrm{pCi} / \mathrm{g}$. Because samples from Trench 1 contained as much as 1100 $\mathrm{pCi} / \mathrm{g}$ of gross-alpha activity, a steep liticite on

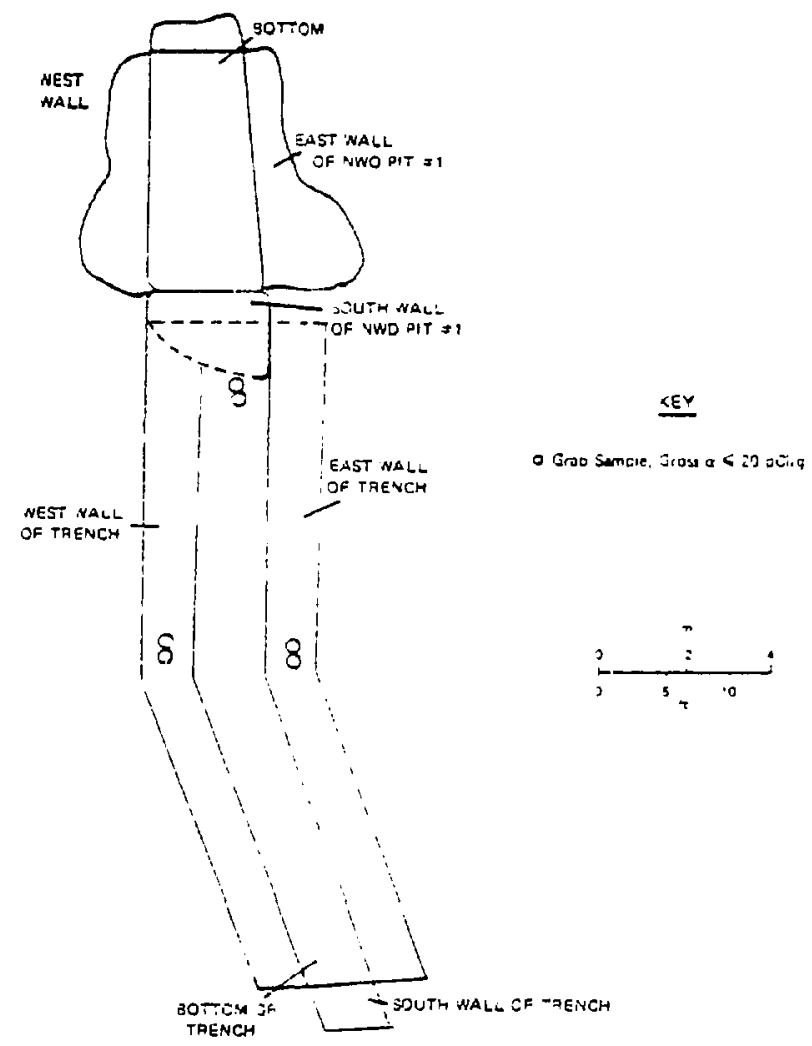

Fig. 66 .

Flatiened view of the trench and pit in the excavation north and west of $D$ Building. with follow-up soil-sampling results. 


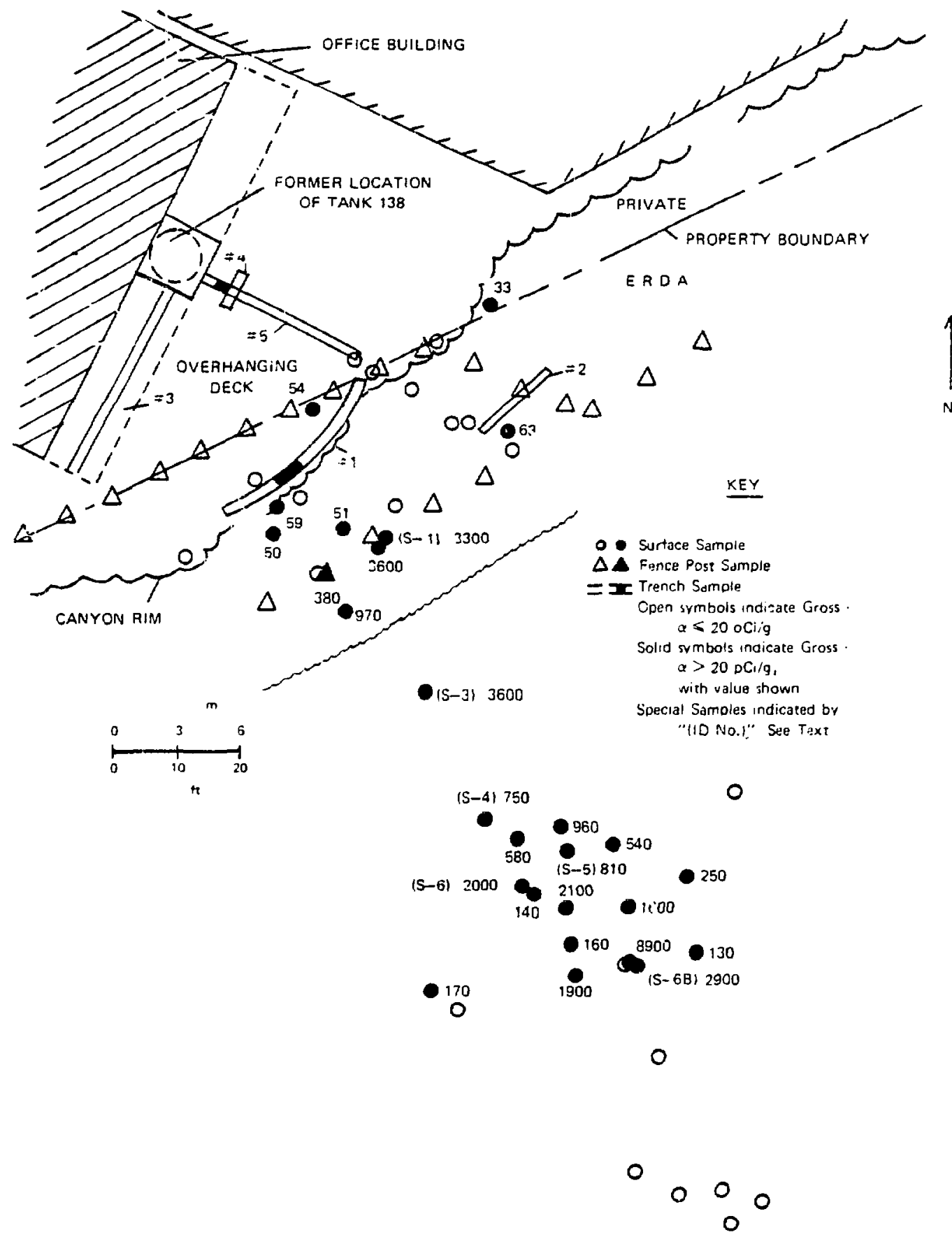

Fig. 67.

Soil-sampling survey in area of Septic Tank 138. 


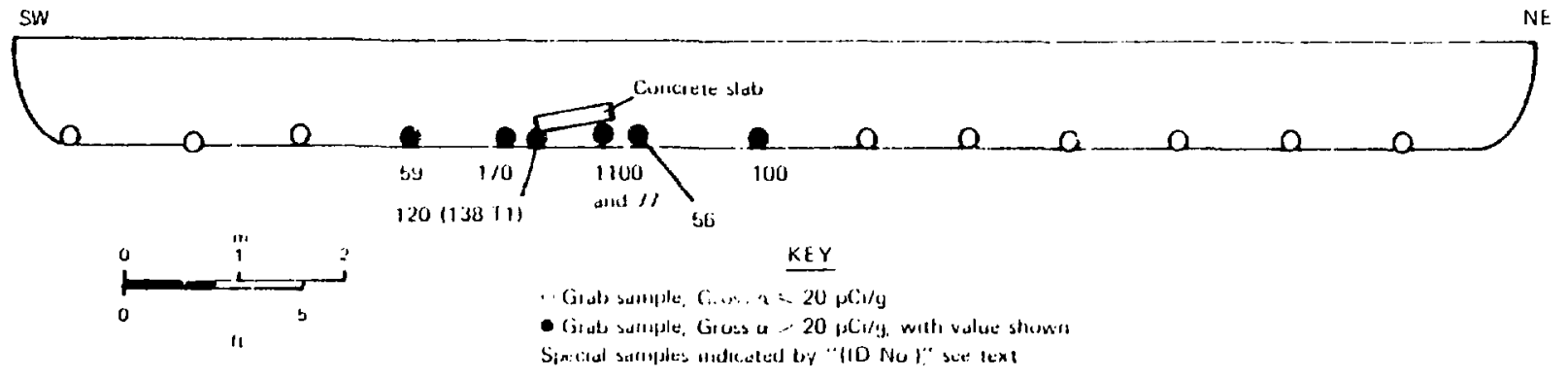

Fig. 68.

Cross section of Trench 1 in area of Septic Tani 138 (looking northwest).
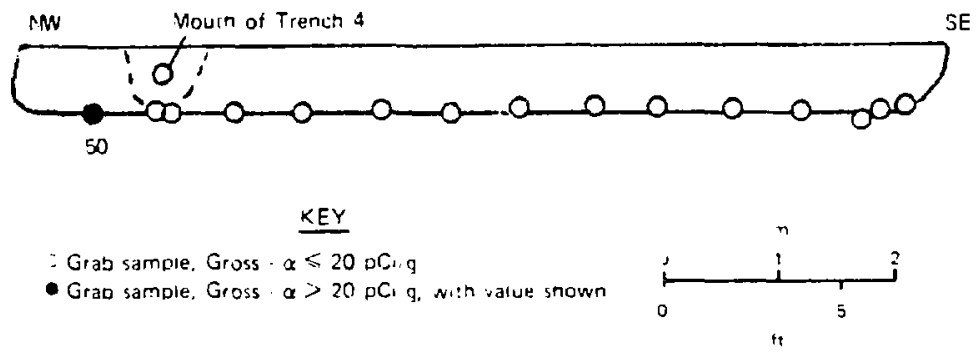

Fig. 69.

Cross section of Trench 5 in area of Septic Tank 138 (looking northeast).

ERDA land just below the trench was also investigated. Surface samples from this hillside showed gross-alpha activity as high as $3600 \mathrm{pCi} / \mathrm{g}$, confirmed by radiochemistry to be ${ }^{239} \mathrm{Pu}$ as shown in Table XIII. Follow-up sampling lower on the hillside, below a $15-\mathrm{m}$-high cliff, located gross-alpha activity to $8900 \mathrm{pCi} / \mathrm{g}$ (Fig. 67).

The outfall line from Tank 138 was finally located and followed (Trench 5) to Tank 138 below the floor of a storage shed attached to an office building. When the tank was removed (with the owner's permission), it held $\sim 0.6 \mathrm{~m}$ of uncontaminated sludge. Neither the outlet line nor broken pipe shards found at the inlet were contaminated. The inlet line is probably still in place under the office building; the portion leading to the tank evidently had been broken during building construction.

Although the tank contents were not contaminated, the soil around the tank was (Fig. 70). After some soil had been removed (remaining grossalpha activity concentrations are shown in Fig. 71), the hole was backfilled. Figure 72 shows the excava- tion, with a building jack left in place to provide support for the shed wall. The excavation was deeper along the eastern edge because activity had followed a clay-filled joint in that area. Radiochemical results are given in Table XIV for each of the soil samples meitioned in Fig. 71. The ${ }^{239} \mathrm{Pu}$ activity indicated in Table XIV is within a factor of 2 of the gross-alpha activity measured by the $\mathrm{ZnS}$ detector system.

The reason for the contamination around Septic Tank 138 is not known. In an attempt to discover a possible source, Trenches $\mathrm{Y} 1, \mathrm{Y} 2$, and $\mathrm{Y} 2 \mathrm{~A}$ were dug upslope of the 138 pit. Locations of the trenches are given in Fig. 73. Former sewer and storm drains were found in those $\mathrm{Y}$ trenches and one 0.31 -m-diam concrete pipe contained small puddles of elemental mercury which were removed, but no radioactivity was found.

Former TA-1 personnel who had worked in the vicinity could not identify a likely source for the contamination around Tank 138 and on the hillside below. Considerably more ${ }^{137} \mathrm{Cs}$ was associated with 
TABLE XIII

\section{RADIOCHEMISTRY RESULTS FOR SELECTED SURVEY SAMPLES NEAR SEPTIC TANK 138 \\ (In $\mathrm{pCi} / \mathrm{g}$ )}

\begin{tabular}{|c|c|c|c|c|}
\hline $\begin{array}{c}\text { Sample } \\
\text { Identification }\end{array}$ & $\begin{array}{c}\mathrm{ZnS} \\
\text { Gross Alpha }\end{array}$ & ${ }^{23 \theta} \mathbf{P} \mathbf{u}^{\mathbf{a}}$ & ${ }^{241} \mathrm{Am}$ & ${ }^{137} \mathrm{Cs}$ \\
\hline $138-\mathrm{T} 1$ & 120 & 55 & $\cdots$ & $\cdots$ \\
\hline 138-T1 Resample & $\ldots$ & 58 & $\cdots$ &.- \\
\hline $7.6 \mathrm{~m}$ down - canyon & 3600 & 2830 & -.. & ... \\
\hline S-4 & 750 & 380 & 1.4 & 57 \\
\hline S-5 & 810 & 497 & 1.3 & 77 \\
\hline S-6 & 2000 & 549 & 2 & 161 \\
\hline S-6B & 2900 & 1870 & 3.3 & 399 \\
\hline S.7 & 32 & 14 & $\ldots$ & -.- \\
\hline S-8 & $<20$ & 1.2 & ... & $\ldots$ \\
\hline
\end{tabular}

this plutonium than with that from areas around Buildings $D$ and D-2, so it is unlikely that those areas were the sources. Also, the present grades on this hillside suggest that it was not downslope from D and D-2.

At a meeting on December 4, 1975 (Table III), that part of the excavation on private land was determined to be decontaminated because (1) no phoswich-detectable activity was present; (2) the maximum activity was $100 \mathrm{pCi} / \mathrm{g}$ of ${ }^{230} \mathrm{Pu}$; and (3) the activity was bound in tuff in a rather inaccessible location.

A fence installed along the property boundary (see Sec. II.C.3) prevents public access to the ramaining surface contanination on the ERDAcontrolled hillside.

\section{Industrial Waste Line-Related Areas}

1. Vicinity of Buildings $H$ and Theta. During the detailed search of historic records, a memo" was found which stated:

"... that the acid sewer had overflowed behind $\mathrm{H}$-Building and had run across the drive between $\mathrm{H}$ and Theta... When all contaminated soil that was possible to remove was taken away, a load of gravel and binder was spread to a depth of four inches over the area. The area was again monitored and found to run not over 50 $\mathrm{c} / \mathrm{m}$ as against the $10000 \mathrm{c} / \mathrm{m}$ to infinity count found to be there originally."

As a result of this memo, an intensive survey for contamination was made in the vicinity of Buildings $\mathrm{H}$ and Theta. ( $\mathrm{H}$ Building had been used for chemistry and ${ }^{210} \mathrm{Po}$ research; Theta Building was a warehouse.)

The initial effort included surface and auger-hole sampling, as well as two trenche.s, dug in an attempt to intercept the former trench for the acid-sewer lateral to the main acid-sewer line from $\mathrm{H}$ Building and to cut across the drainage channels between $\mathrm{H}$ and Theta Buildings. Locations and results of sampling are shown in Figs. 74-76. Radiochemical analyses (Table XV) indicated ${ }^{238} \mathrm{Pu}$ activity. Appendix $\mathrm{A}$ also indicates the potential for ${ }^{\circ 0} \mathrm{Sr}$ contamination-none was found in two surface samples or at five different depths from a core sample.

Because gross-alpha contamination up to 180 $\mathrm{pCi} / \mathrm{g}$ was found in the trenches and $210 \mathrm{pCi} / \mathrm{g}$ in an auger sampie, the survey was expanded. A north- 


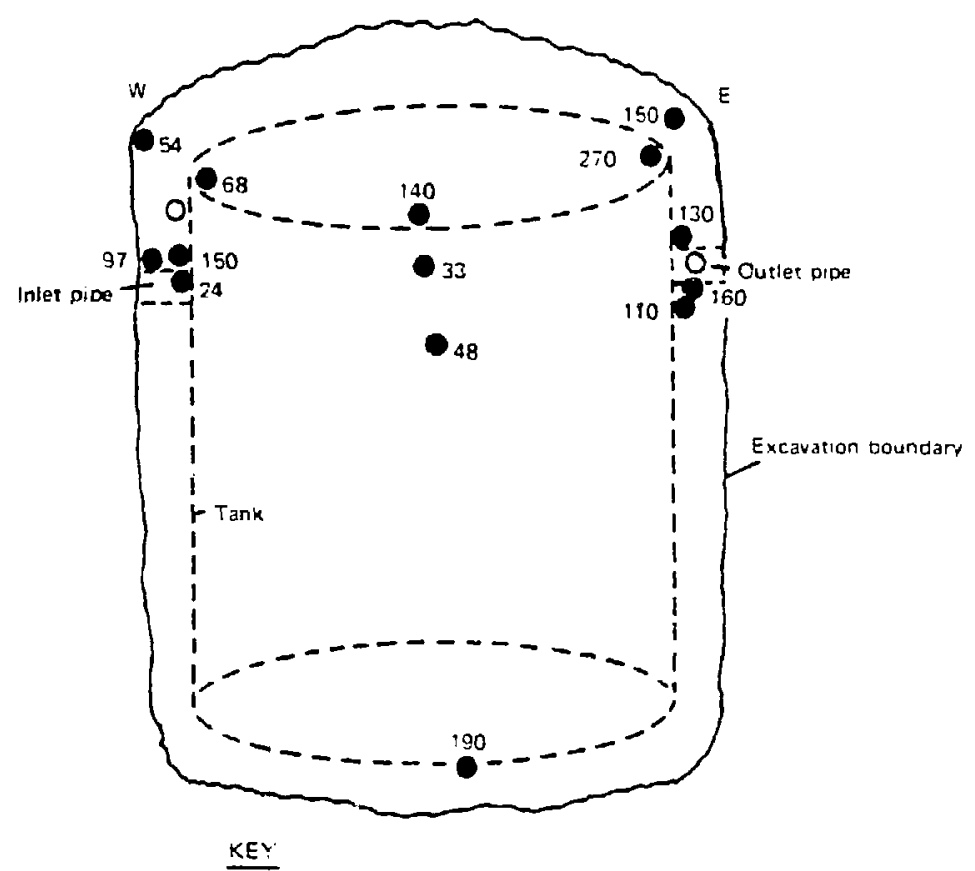

Grab sample, Gross a $\alpha 5200 \mathrm{C}$ - Grad sampe Gross a $a>20$ DCi $q$ with value shown

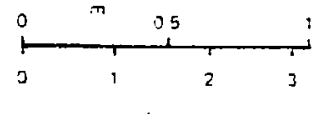

Fig. 70

Soil-sampling survey detail of Septic Tank 138 excavation.

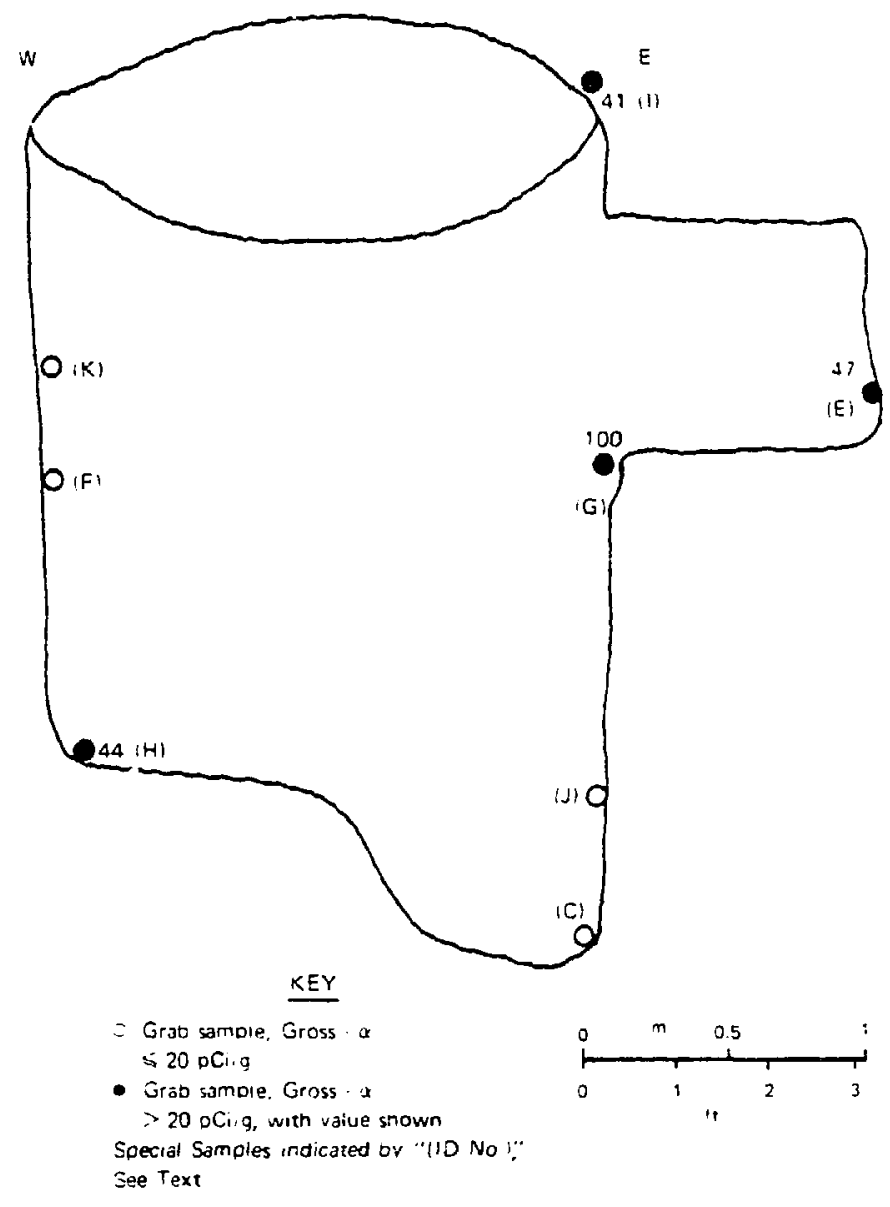

Fig. 71.

Postdecontamination detail of Septic Tank I38 excavation. Letters represent sample designations. 


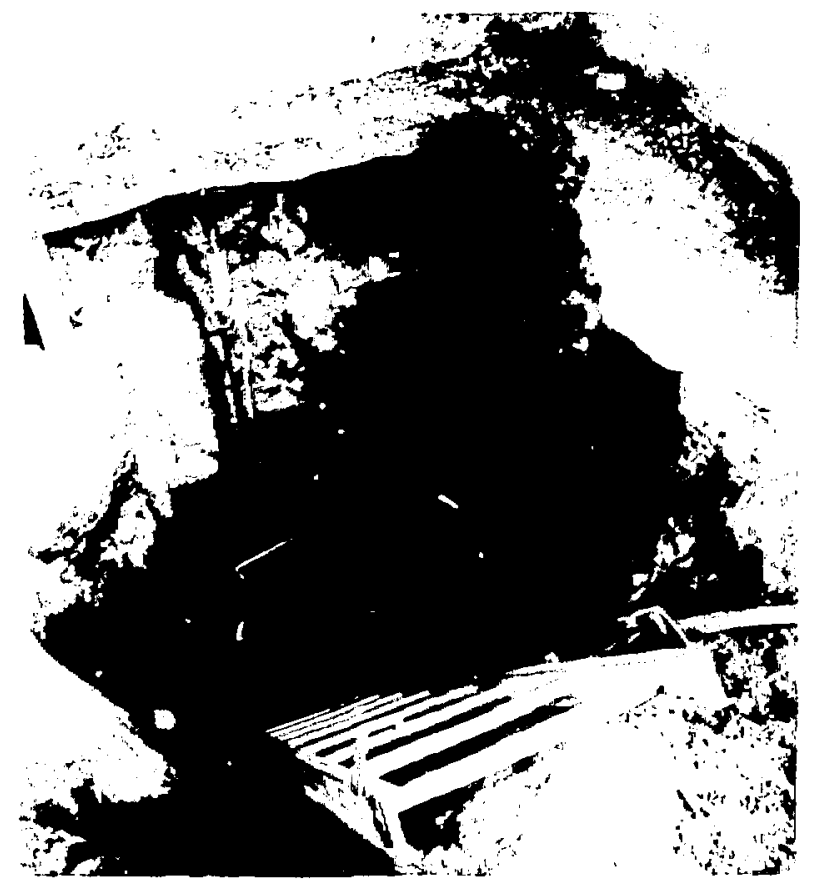

Fig. 72 .

Septic Tank 138 excavation before backfilling.

\section{TABLE XIV}

\section{PLUTONIUM CHEMISTRY RESULTS FOR POSTCLEANUP SAMPLES FROM AREA OF SEPTIC TANK 138}

(In $\mathrm{pCi} / \mathrm{g}$ )

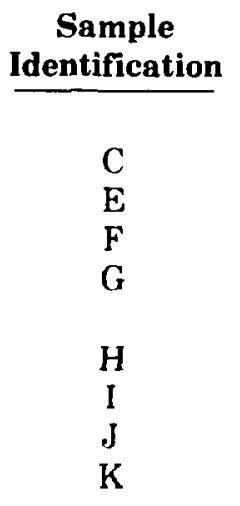

\begin{tabular}{|c|c|}
\hline $\begin{array}{c}\text { ZnS } \\
\text { Gross Alpha }\end{array}$ & ${ }^{23 \theta} \mathbf{P} \mathbf{u}^{\mathrm{B}}$ \\
\hline$<20$ & 29 \\
\hline 47 & 74 \\
\hline$<20$ & 22 \\
\hline 100 & 100 \\
\hline$<20$ & 47 \\
\hline 41 & 61 \\
\hline$<20$ & 7 \\
\hline$<20$ & 45 \\
\hline
\end{tabular}

"Isotopic analyses for ${ }^{23} \mathrm{P}$ u were made, hut all values were $<1 \%$ of the ${ }^{23}$ Pu values.

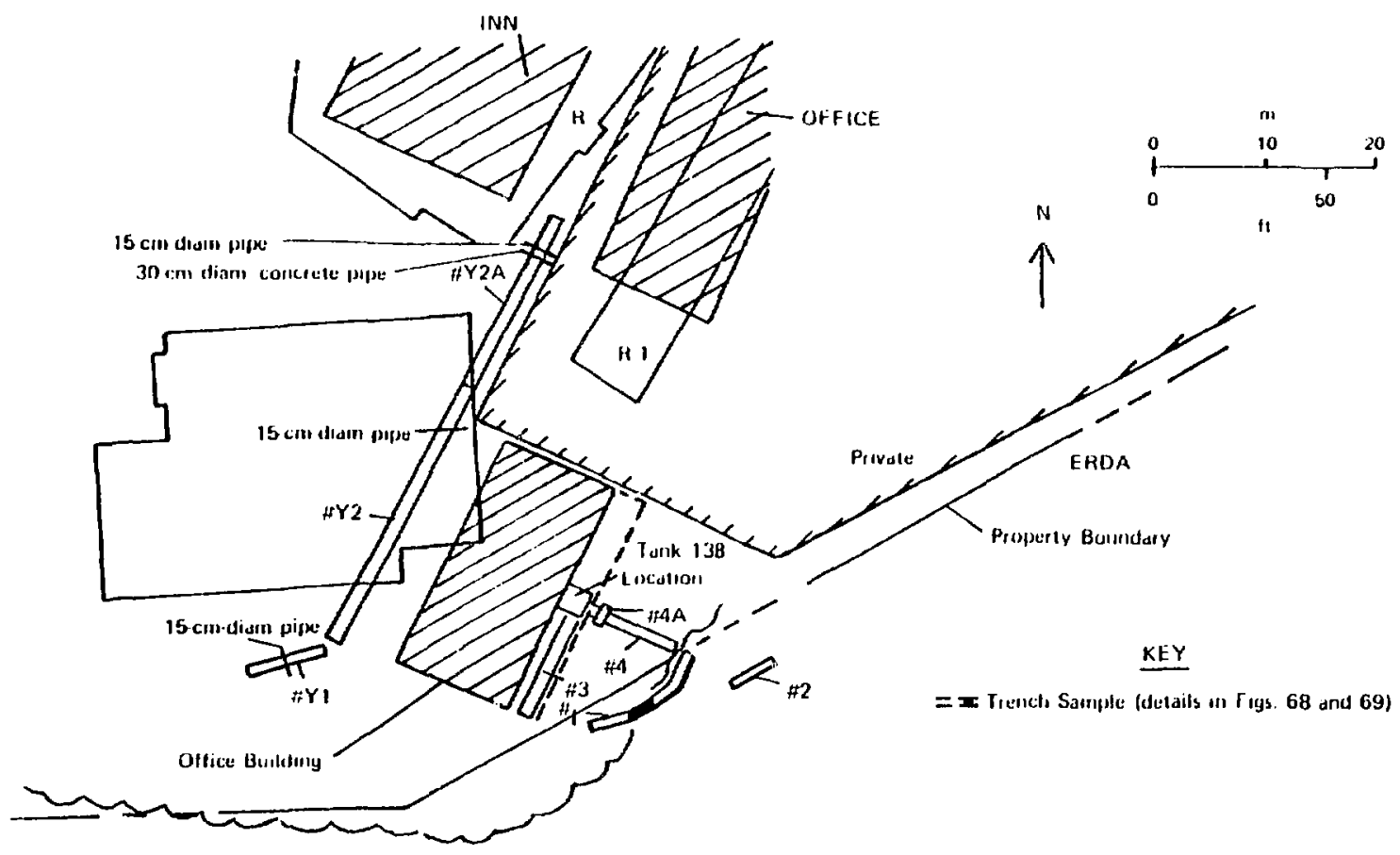

Fig. 73.

Y-Building trerches. 
south trench was dug roughly parallel to the west side of $\mathrm{H}$ Building and had two branches to the east. Figures 77 and 78 show the trench location and sampling results. Contamination, while not hirh, persisted in the trench. Despite further expansion of the trench and further surface-soil removal, grossalpha concentrations in the northeastern portion increased, as indicated in Fig. 79.

During the next iteration of excavation to remove this contaminated soil, a large chunk of concrete containing a contaminated $10.2-\mathrm{cm}$-diam iron line was uncovered. This concrete-encased pipe extended $\sim 7.6 \mathrm{~m}$ to the main acid-sewer trench and apparently had served as the junction between the main line and the line from $\mathrm{H}$ Building. Figure 80 is a schematic of the debris as found; the pipe's location is shown in Fig. 74. (Some records show that a manhole (TA-1-261) serving D Building was located at that spot.l

To remove the concrete a cut, known as a keyway, was made into the hillside north of the $\mathrm{H}$-Building outline. The soil in this keyway and in the main acid-sewer trench was cont aminated (Fig. 81). During excavations to remove the contamination in the kevway and the main trench, another chunk of concrete containing a contaminated $10.2-\mathrm{cm}$-diam iron pipe was found $\sim 3.8 \mathrm{~m}$ west of the first (Fig. 74). Figure 82 shows the concrete and pipe after removal. Apparently $\mathrm{H}$ Building had tu'v connections to the acid-sewer line. The second pipe was $\sim 1 \mathrm{~m}$ above the bottom of the main acid-sewer trench and probably once had a drop inlet to the main line. Figure 8:3 shows the excavation from which both concrete-encased pipes were removed. Figures 84 and 85 show different views of the acid-sewer trench excavations from the bottom of the keyway. Figures $86-88$ give details of the kevway survey.

At a meeting on July 28,1976 (Table III), the $\mathrm{H}$ Theta area was determined to be decontaminated because (1) no phoswich-detectable activity remained, and (2) the gross-alpha activity in the area (Figs. 79, 87, and 89 ) was almost entirely $<20$ $\mathrm{pCi} / \mathrm{g}$.

In the surface drainage areas from the $\mathrm{H}$. Theta area, a number of samples did have slightly elevated gross-alpha activity ( 34 to $74 \mathrm{pCi} / \mathrm{g}$ ) (Fig. 89). Also, a spot (No, 14) in this area showed activity during the phoswich survey (see Secs. II.B.1 and III.D.8 and Fig. 128). Because of the acid-sewer overflow which contained known ${ }^{2.39} P_{13}$ and the activity detected by the phoswich, these surface spots were excavated. Exploratory excavations unearthed a storm drain which was removed because of its potential for contamination (Fig. 901. The area around the only positive sample $(45 \mathrm{pCi} / \mathrm{g})$ was excavated. Results of radiochemical analyses are given in Table XV: final sumpling results for this area are in Fig. 91. At meetings on June 8 and Jul. 28, 1976 (Table III), the $\mathrm{H}$-Theta drainage area was determined to be decontaminated because (1) no phoswich-detectable activity remained, and (2) no activity >20 p( $\mathrm{i} / \mathrm{g}$ was detected in any of the excavations.

\section{Eastern Portion of Main Acid Sewer.}

Because of discrepancies between records and physical conditions, attempts began in September 1975 to verify that the main acid-sewer line connecting I'A-1 with the treatment plant at TA.45 had been removed during the original decontamination and demolition. As part of the effort, exploratory trenches were dug behind the Taco Bell and Exxon Station to verify that both lines in that area had been renoved (fig. 92). The various trench locations are shown in Fig. 94. To reach the original grade at the north ends of these trenches, it was necessary to dig thro'igh fill emplaced for construction of the Taco Bell arid Fxxon Station. Consequently, the trenches there were as deep as 5.2 in-the depth limit of the backhoe. In most cases, however, the backboe was able to dig to the tuff. No sewer pipe appeared in any of the trenches shown in Fig. 9:3. but portions of an old trench showed up at several places in the tuff where engineering drawings had indicated an acid-sewer line; therefore, the acid-sewer line probably had been removed.

After the discovery of substantial contamination in the acid-sewer trench during excavation of the D. Building outline in January 1976 (see Sec. III.B.2.b), further investigation was required. The first effort was an at tempt to foilow the D-Building acid-sewer trench (Fig. 58) to the expected intersection of that trench with the trench from $M$ Building, as shown in engineering drawings (Fig. 92). (As used hore, the term "acid-sewer trench" applies to the former location of the now-removed acid-sewer line.) Cross-trenching attempts to locate the continuation of the D-Building acid-sewer trench in the fill were 


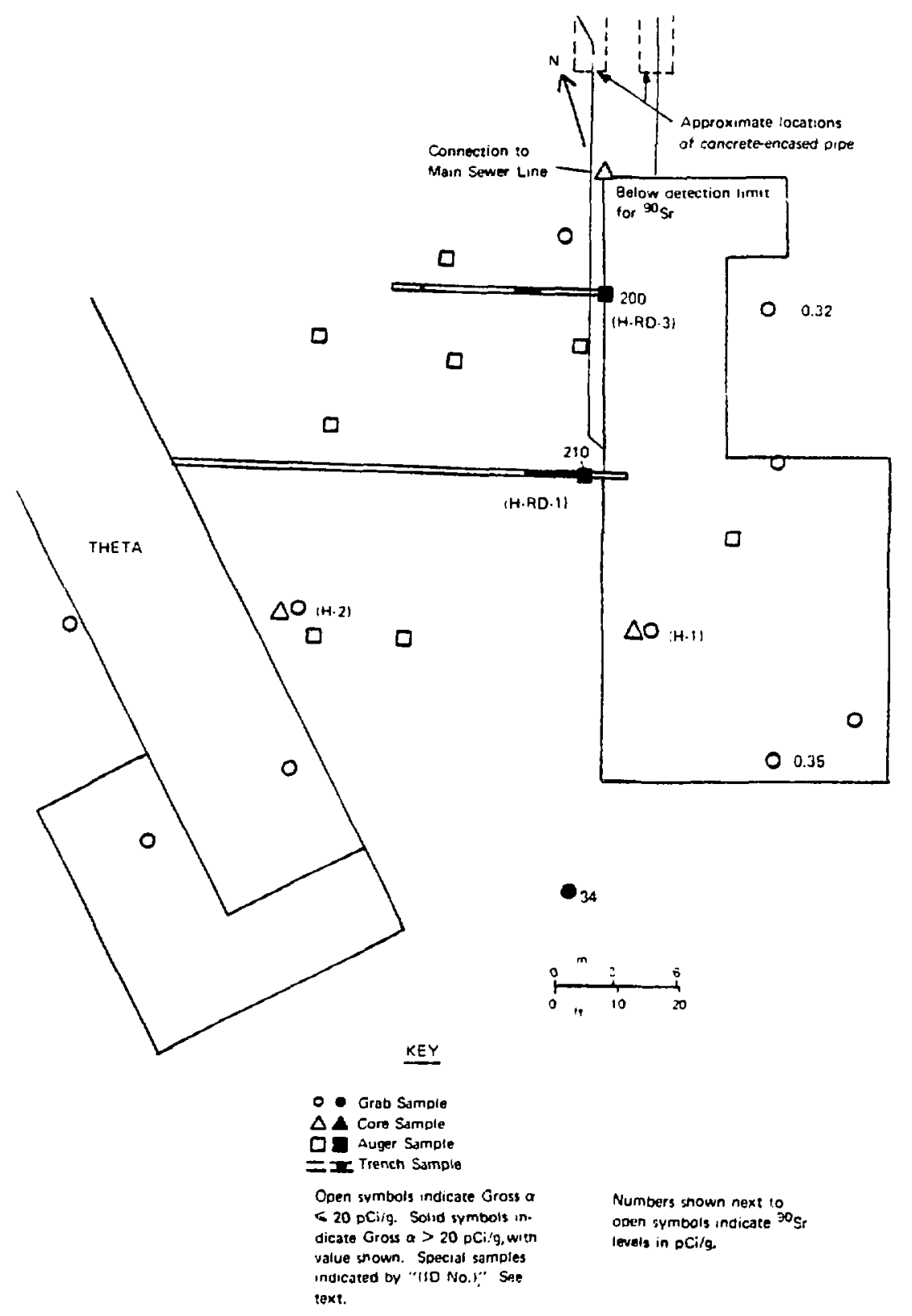

Fig. 74.

Initial survey results in the $H$-Theta area. 

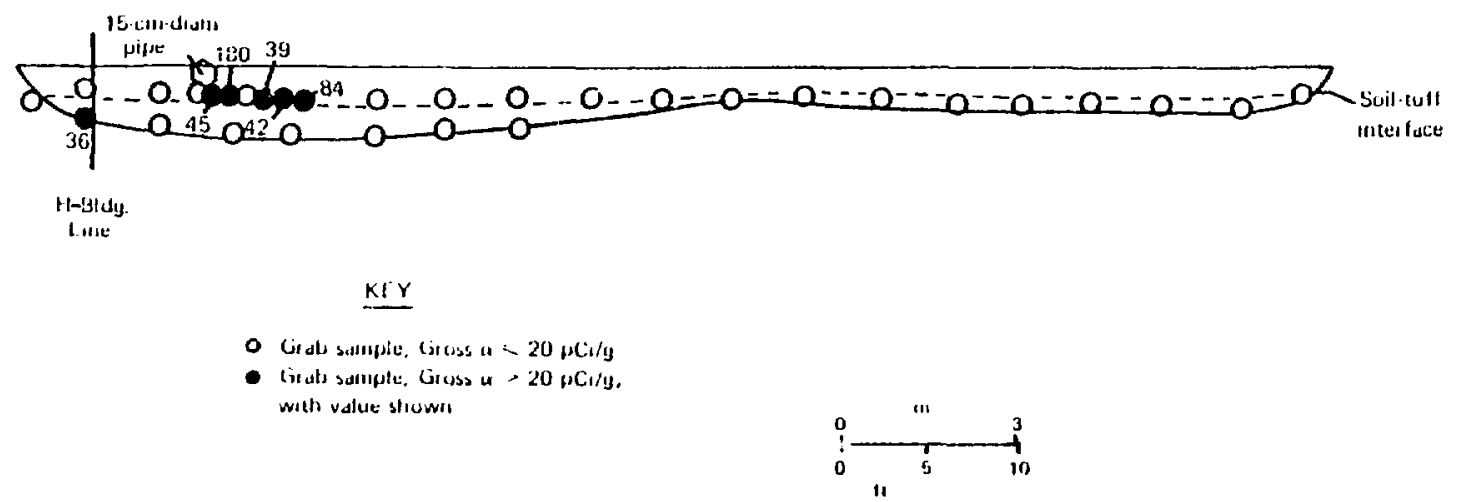

Fig. 75.

Cross section of $H$-Theta Trench 1 (looking south), with sampling results.
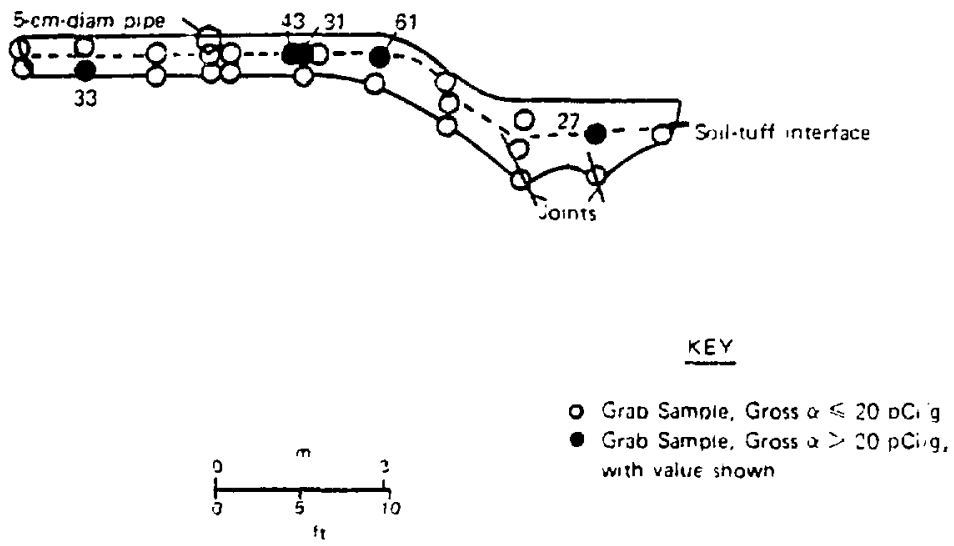

Fig. 76 .

Cross section of $H$-Theta Trench 2 (looking south), with sampling results.

unsuccessful, and the apparent course of an old trench was followed for $-33 \mathrm{~m}$ from the temporary work fence (Fig. 46). The approximate location of those trenches and the sampling results are shown in Figs. 46 and 58 . No significant contamination was found. The location of this trench corresponded approximately to the location indicated on engineering drawings for the main acid sewer leading from $D$ Building (Fig. 92). An uncontaminated, $\sim 1-\mathrm{m}-$ long piece of $20.3-\mathrm{cm}$-diam vitrified clay-tile pipe was found in this trench. The pipe was under an old asphalt road, which suggests that pipes below paved areas had not been removed during demolition and decontamination efforts in the 1960) [this corres ponds to similar findings in the vicinity of Building J.2 (see Sec. III.C..3)].

During February and May 1976, subsurface contamination found in the H-Theta area (see Sec. III.C.1) led to finds of highly contaminated laterals connecting with the main acid-sewer trench in that area (Segment CD in Fig. 94). Substantial alpha activity was also found in soil from the main trench in that area. These findings reopened the question of how to decontaminate the acid sewer. It was determined necessary to at tempt excavation of the entire trench from D Building to Trinity Drive (Fig. 94). The trench was followed in both directions from Segment $C D$. The locations and results of sampling 
TABLE XV

\section{RADIOCHEMISTRY RESULTS FROM H-THËTA AREA}

\begin{tabular}{|c|c|c|c|c|c|}
\hline $\begin{array}{c}\text { Sample } \\
\text { Identification }\end{array}$ & $\begin{array}{c}\text { Depth } \\
(\mathrm{m}) \\
\end{array}$ & $\begin{array}{c}\text { Laboratory } \\
\text { Gross Alpha } \\
\text { (pCi/g) }\end{array}$ & $\begin{array}{c}\text { Laboratory } \\
\text { Gross Beta } \\
\text { (pCi/g) }\end{array}$ & $\begin{array}{c}{ }^{239} \mathbf{P u}^{\mathrm{a}} \\
(\mathrm{pCi} / \mathrm{g})\end{array}$ & $\begin{array}{c}\text { Total } \\
\text { Uranium } \\
(\mu \mathrm{g} / \mathrm{g}) \\
\end{array}$ \\
\hline$\overline{\mathrm{H}-\mathrm{RD}-1^{\mathrm{b}}}$ & $\overline{0 \text { to } 0.30}$ & 450 & & 3.2 & 3.4 \\
\hline H-RD-3 & 0 to 0.31 & 0.10 & 0.30 & 240 & 3.5 \\
\hline H Trench 1 & & 7.2 & 4.1 & 130 & 4.2 \\
\hline H Trench 2 & & 14 & 7.1 & 0.39 & 2.3 \\
\hline
\end{tabular}

${ }^{9}$ Isotopic analyses for ${ }^{298} \mathrm{Pu}$ were made, but all values were $<1 \%$ of the ${ }^{290} \mathrm{Pu}$ values.

${ }^{\circ}$ Alpha pulse analysis indicated that two-thirds of the gross-ulpha activity were due to uranium and its daughters and one-third was due to ${ }^{2 *} \mathrm{Pu}$ (Ref. 12).

(as-found and as-left) are given in Figs. 95-102. In most places an obvious trench was found in the tuff and was easy to follow with a backhoe.

The trench was cleaned out by backhoe to the apparent original bottom. Samples: from the sidewalls and bottom were taken for gross-alpha analysis. As the survey details show (Figs. 95, 97, 99, and 101), some contamination was found throughout most of the trench. The highest levels were in Segment DG (Fig. 9S), where individual samples had as much as $1200 \mathrm{pCi} / \mathrm{g}$ of activity. These samples were from the trench near the CD segment where the contaminated laterals from $\mathrm{H}$-Theta had been removed (see Sec. III.C.1). To remove contaminated soil from the DG segment, the trench was made considerably larger than the original. Most postcleanup samples (Fig. 100) from this segment were taken from the backhoe bucket because the size of the trench (1.5 tc $2.8 \mathrm{~m}$ wide and $2.4 \mathrm{~m}$ deep) and the instability of the fill material on the north wall made the trench hazardous to enter.

In the other trench segments, identified spots of contamination were removed by enlarging the excavation by a few scoops from the backhoe or by hand-shoveling. These locations were resampled for final documentation (Figs. 96, 98, 100, and 102). Thus known, localized spots of contamination were removed. As the trenching approached D Building it became apparent that the first trench dug toward the intersection with the M-Building acid sewer
(Fig. 46) had been dug in the wrong place. The acidsewer trench was traced continuously froin the $\mathbf{H}$ Theta area all the way to $D$ Building, thereby contributing to a feeling of confidence that it finally had been located and monitored.

Figure 103 shows some of the uncontaminated underground structures, such as steam tunnels, found near $Q$ Building. They are typical of underground structures found throughout TA-1. A special attempt was made to determine whether any of the $Q$ Building lateral connections to the main acid-sewer line remained. None was found.

During trenching in Ssegment DG, an intact manhole was found at $l_{\text {ue }}$ place from which acidsewer manhole TA-1-235 presumably had been removed long ago. (Some drawings indicated a cleanout at this location.) Historical records (Appencix ( ) indicated that this manhole was removed in 1965. The manhole was made of brick on a concrete base (Fig. 104). The inlet and outlet lines remaining in the base were highly contaminated, and the entire structure and associated contamination were removed. Because of these findings, the Jocations of two other identified st ructures (MH-174 and ULR-65) associated with the acid-sewer line were investigated. Except for several partial courses of brick and the concrete bases, these two structures had been removed. Pipe shards in the bases were contaminated. (The shards at MH-174 read $>10000$ c/min on the phoswich.) Figures 105 and 106 show 


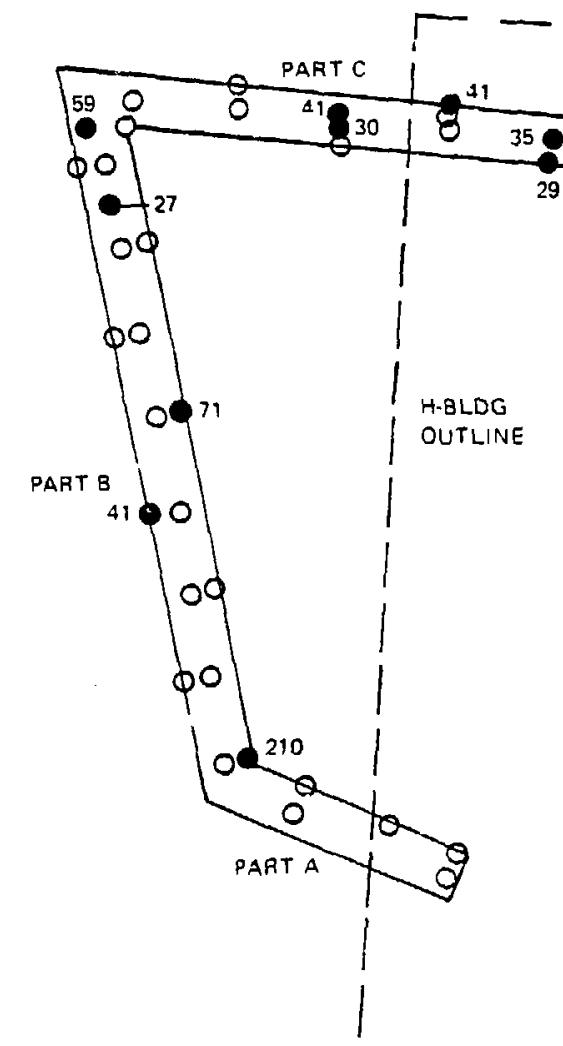

Fig. 77 .

Sampling results from $H$-Theta Trench 3.

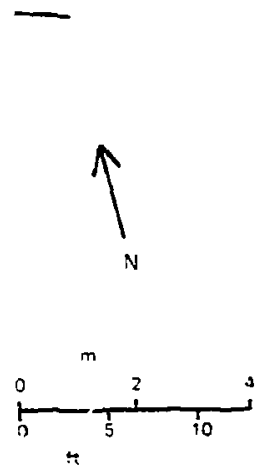

\section{KEY}

- Grab Sample Gross - $\alpha \leqslant 20$ oCi/g

- Grau Sample. Gross - $\alpha>2 \mathrm{C}$ oCi/g. with value shown

$$
\underline{K E Y}
$$

- Grab sample, Gross. $\alpha \leqslant 20 D C$ i:g

- Erab sam.ole, Gross-a> 20 ochig with ralue shown

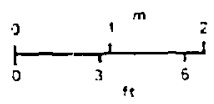

Fig. 78.

Sampiing results from $H$-Theta Trench 3 (see Fig. 77). 


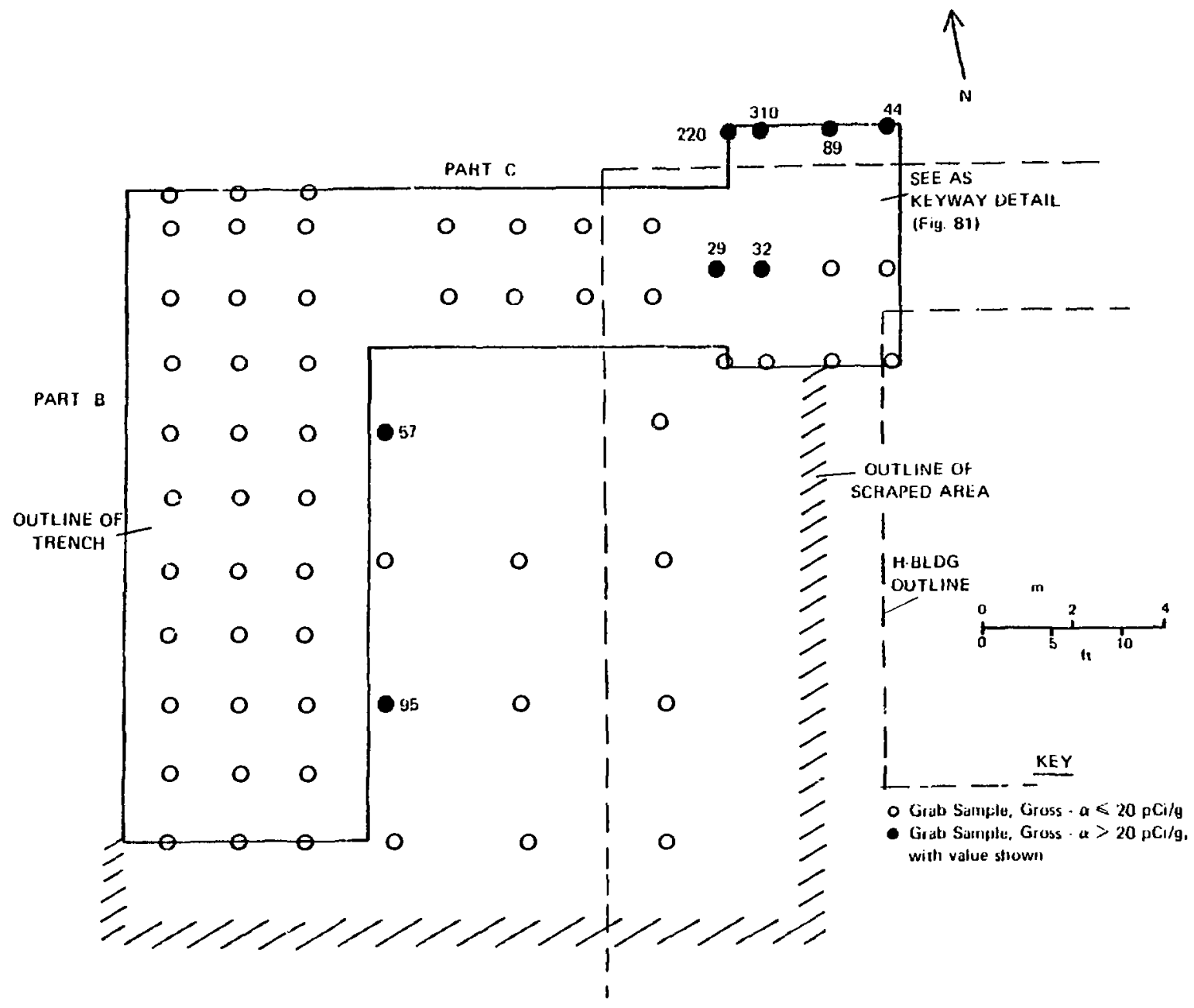

Fig. 79.

Soil-sampling results from expanded $H$-Theta Trench 3 and nearby aroa.

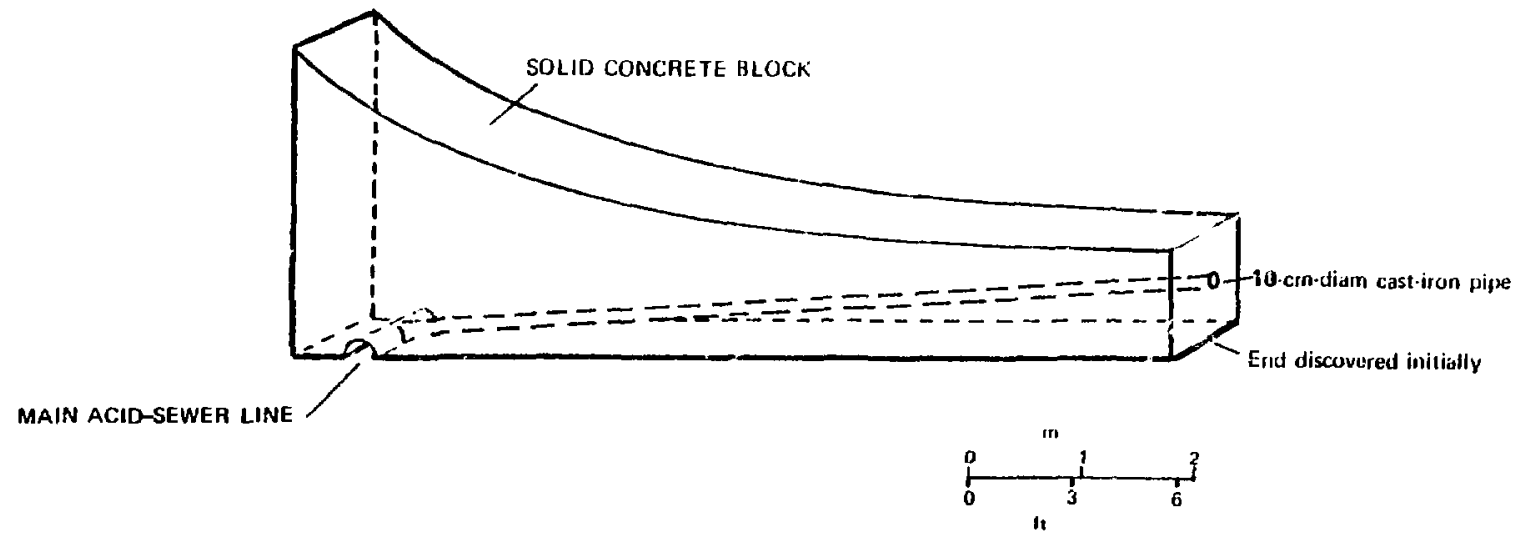

Fig. 80 .

Schematic of concrete-encased pipe found north of $H$ Building. 


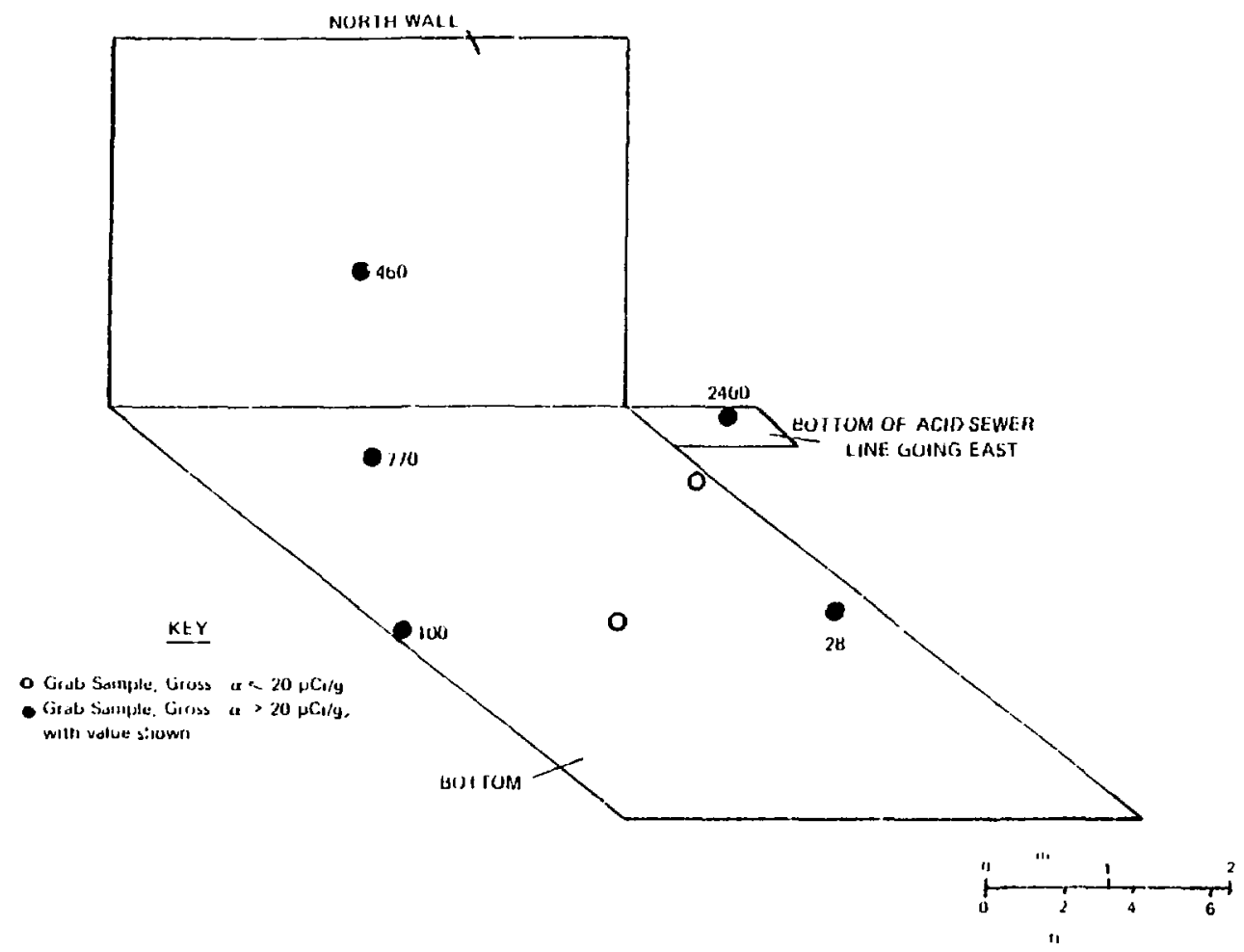

Fig. 81 .

Initial survey results from keyway excavation north of $H$ Building.

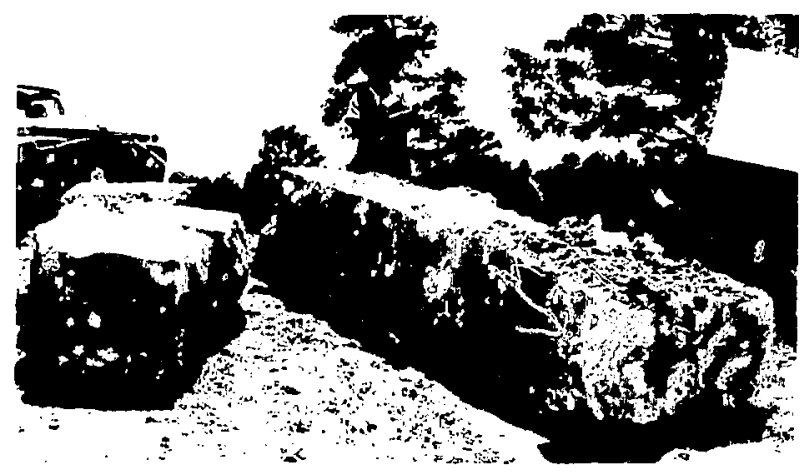

Fig. 82.

Concrete-encased acid-sewer lateral after removal from $H$ Building (the concrete was found intuct).

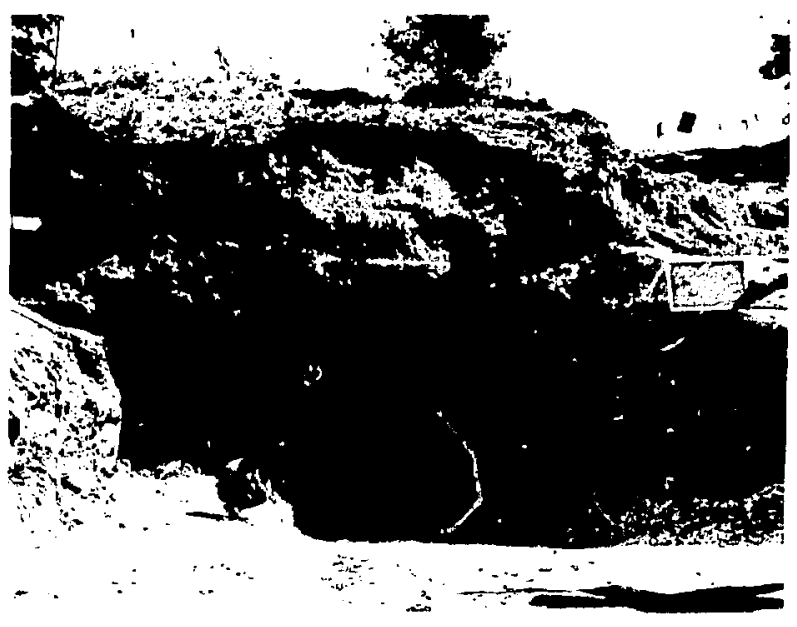

Fig. 83.

Keyway excavation just north of $H$ and Theta Buildings (looking north). 


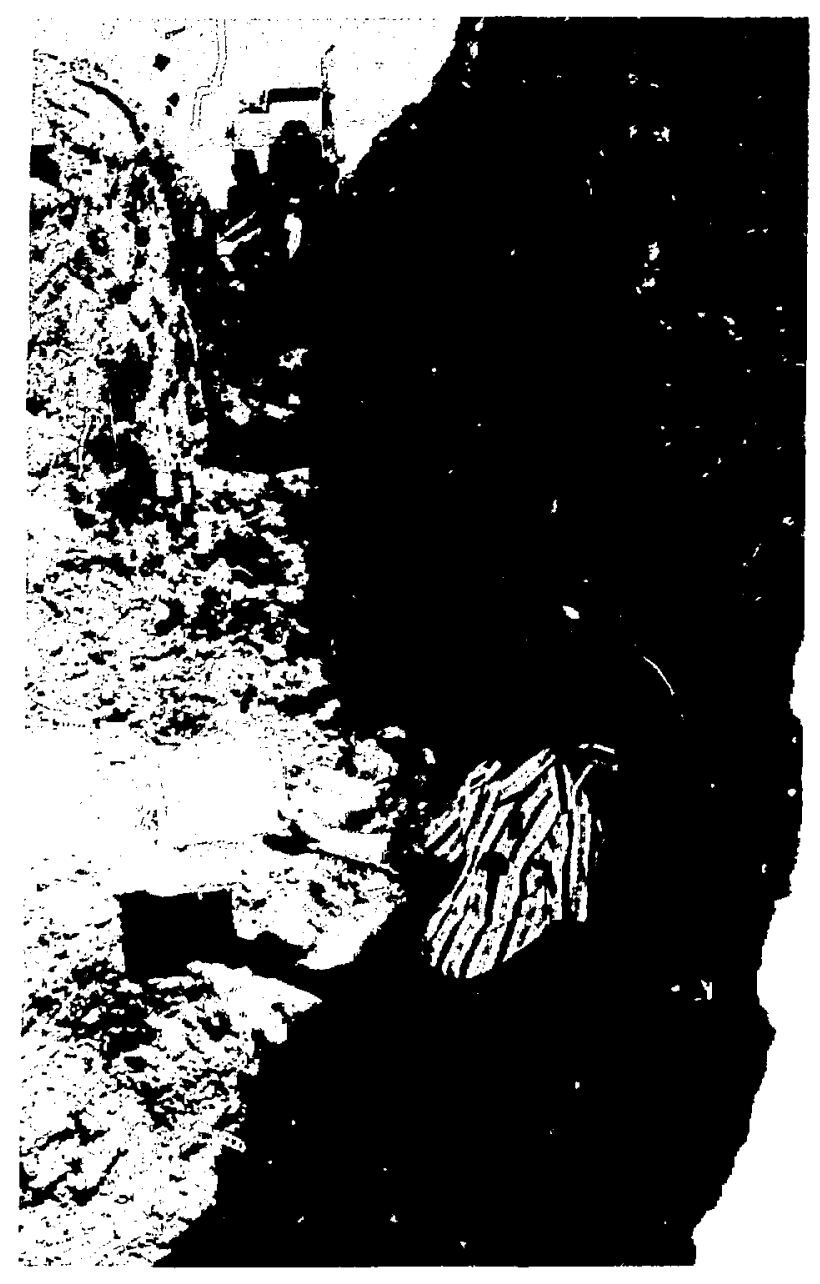

Fig. 84.

Acid-sewer trench from the $H$-Theta keyway excavation (looking west).

what remained of $\mathrm{MH}-174$. The brick, bases, and contaminated shards of MH-174 and ULR-65 were removed.

At a meeting on July 28, 1976 (Tak'e III), the acid-sewer excavations were determined to be decontaminated because (1) no phoswichdetectable activity remained in the trench; (2) most of the remaining gross-alyha activity in soil was $<20$ $\mathrm{pCi} / \mathrm{g}$ (maximum activity on a sample was 92 $\mathrm{pCi} / \mathrm{g}$ ); (3) all underground structures encountered in the trench had been monitored and those with detectable contamination had been removed; and (4) with the exception of a few laterals under developed portions of TA-1, the excavations in-

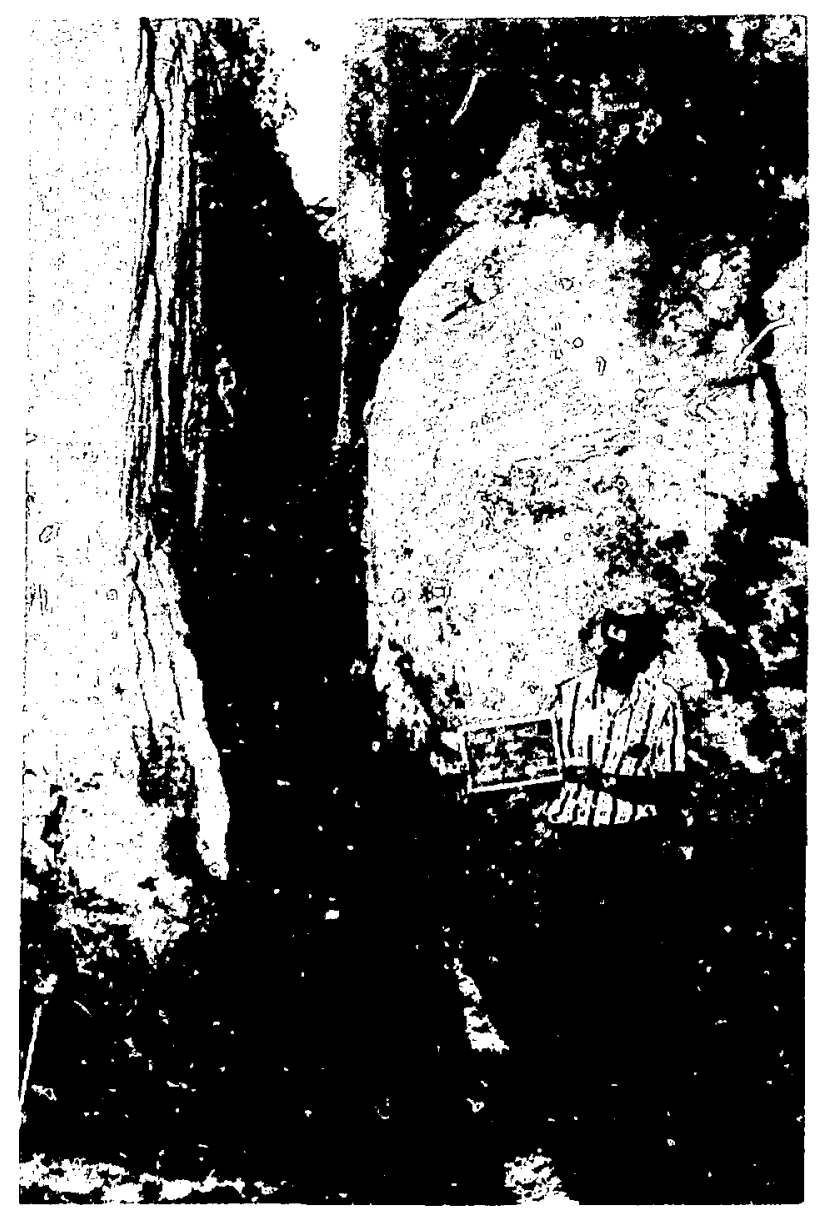

Fig. 85.

Acid-sewer trench from the $H$-Theta keyway excavation (looking east).

cluded all of the known acid-sewer trench south of Trinity Drive.

Any pipes found during trenching were broken open and surveyed. Most such pipes had been either water, sprinkler, or gas lines. One 20.3-cm-diam, cast-iron, fire-main line south of the Exxon Station held gasoline fumes-a leaking pump from an underground gasoline storage tank at the Exxon Station permitted gasoline to get into the abandoned fire-main lines. (Perhaps, during construction of the station, the fire-main line was broken during tank burial and sasoline entered through the broken section of the line.) After consultation with Exxon Corp., the Los Alamos Fire Department, and LASL 

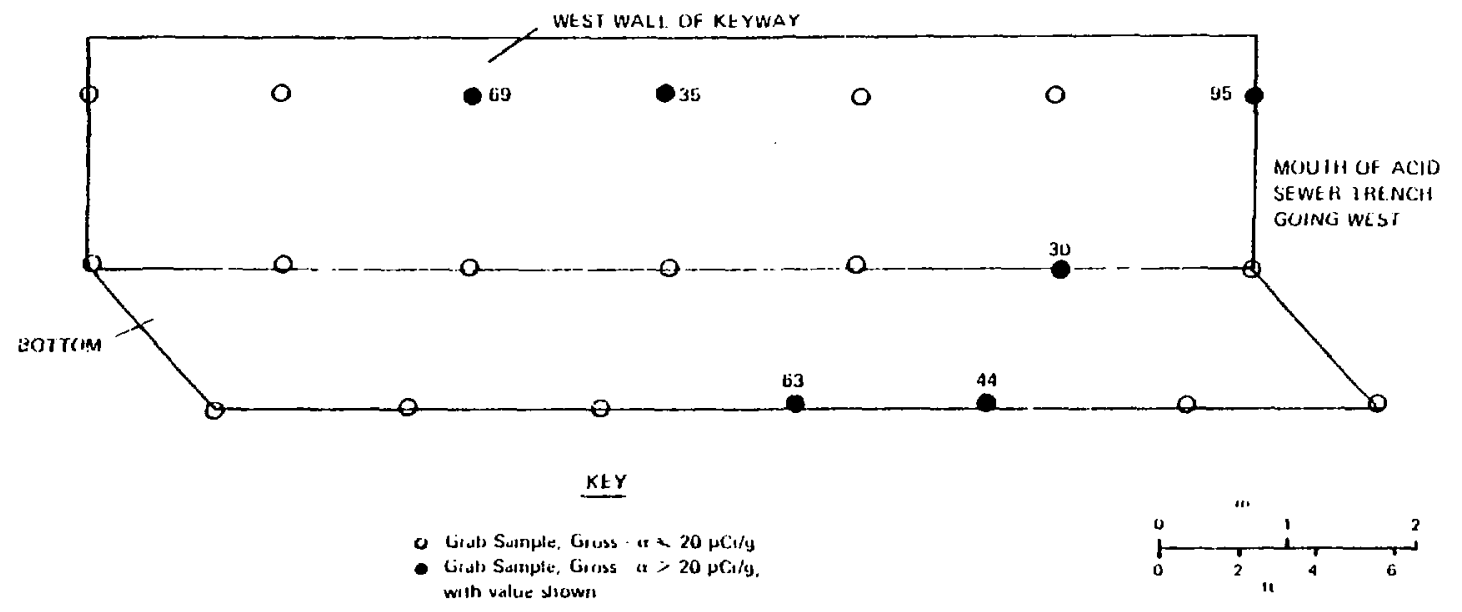

Fig. 86.

Survey results from west wall of kevway excavation (where a piece of concrete-encased pipe was found; see Fig. 82).

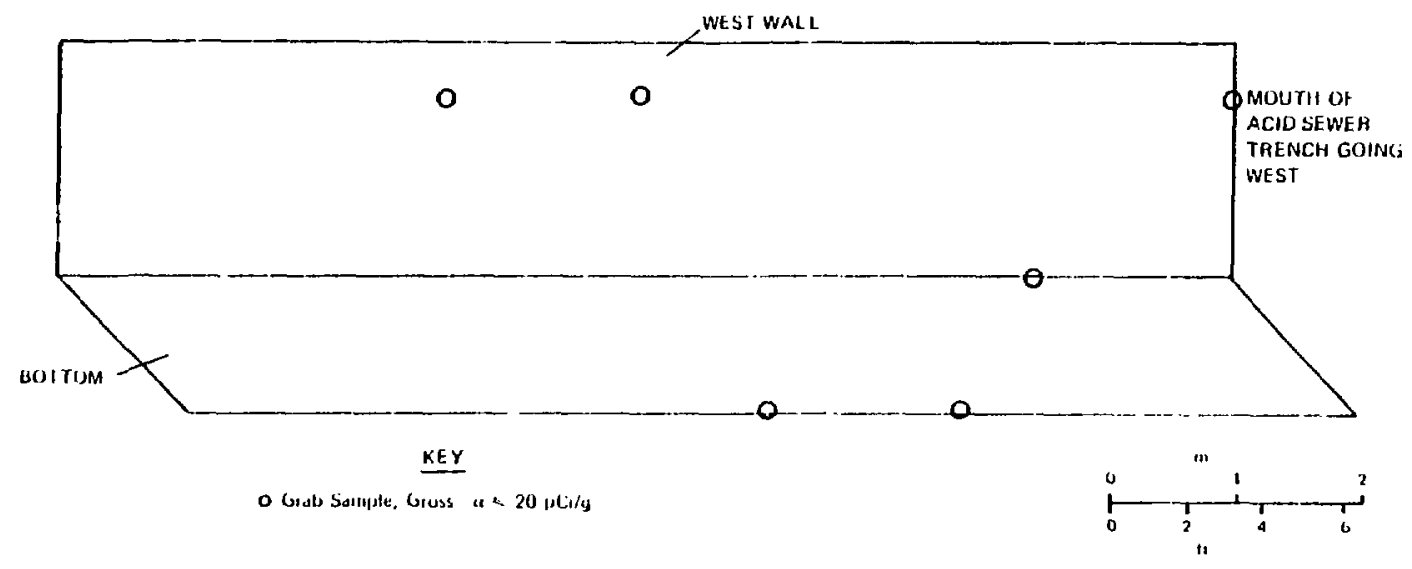

Fig. 87.

Postdecontamination survey results from west wall of keyway excavation.

safety and industrial hygiene groups, the line was cut and was removed for $\sim 3 \mathrm{~m}$, back to the Exxon property line where it was plugged with concrete. In the other direction, $\sim 150000 \ell$ of water were flushed through the line to reinove trapped vapors. A small amount of water surfuced through the Sheet Metal Shop slab in a riser for the building's sprinkler system. When the valve in the riser was shut off, no additional water appear. $\therefore$. After flushing. the line was checked several tinies for gasoline fumes, and after being found free of fumes was covered with dirt.
3. Western Portion of Main Acid Sewer. In the western portion of TA-1. an acid-sewer line ran from the Radiochemistry Building (J-2) to the main acid sewer (Fig. 92). Radiochemical analyses had been conducted in Building $J-2$ on weapon debris from tests in the South Pacific and Nevada. Thus, the primary effluents to the acid sewer from J-2 were mixed fission products (MFP). (Cesium-137 is the preduminant isotope remaining from these MFPs.)

As with the eastern portion of the acid sewer (see Sec. III.C.2), trenches (numbered 1, 2, 3, 3A, 5, and 7 in Fig. 107) were dug to verify that the acid-sewer 


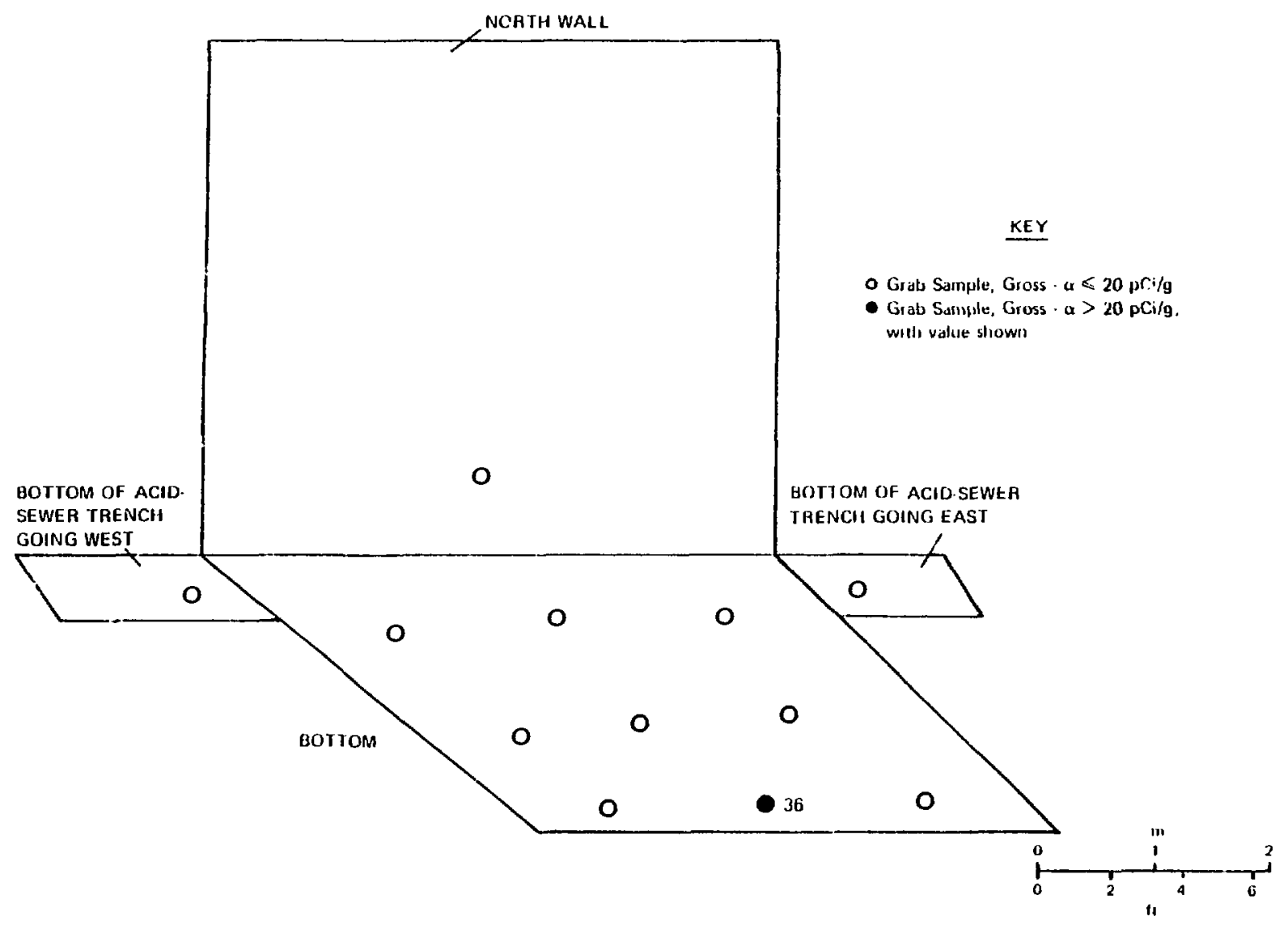

Fig. 88.

Postdecontamination sampling results from keyway excavation north of $H$ Building (see Fig.

81).

line had been removed. A 37-m-long section of 7.6cm-diam cast-iron line was found below a former parking lot and removed from Trench $3 \mathrm{~A}$. A phoswich survey indicated three areas of detectable activity in that trench (gamma spectroscopy showed it. to be predominantly ${ }^{137} \mathrm{Cs}$ ). Results of gross-alpha analyses on soil samples taken from below pipe joints as the line was removed are given in Fig. 108. The areas exhibiting gross-gamma activity were excavated until the phoswich readings were those of background ( $<200 \mathrm{pCi} / \mathrm{g}$ ). Areas with $>20 \mathrm{pCi} / \mathrm{g}$ gross-alpha activity also were excavated. A set of final-documentation samples was taken for future ar.aiysis and the tranch was backfilled for safety-it was directly behind the Trinity Village Apartments where a number of children live. Final sampling results are shown in Fig. 109.
Extensive sampling was also done in and near the J-2 Building outline to ensure no significant contamination. This included locating the former sanitary-sewer line, Trench 4 , which was uncontaminated (on the basis of soil samples and portable beta-gamma instrument survey) and a former pipe trench of concrete (intersected by Trench 6), which was uncontaminated fon the basis of portable betagamma insirumient survey). The trench location and surface sampling results are shown in Fig. 107. Radiochemical results from the 1974 survey are given in Appendix $\mathbb{E}$.

At a meeting on July 28,1976 (Table III), this portion of the acid-sewer line excavations near J-2 wis determined to be decontaminated uecause (1) $\mathrm{n}_{\mathrm{t}}$ phoswich-detectable activity remained; (2) of the 16 soil samples from Trench $3 \mathrm{~A}, 3$ had activity $>20$ 


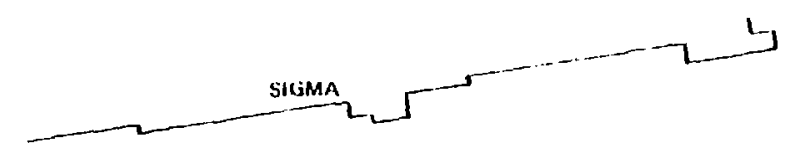

o

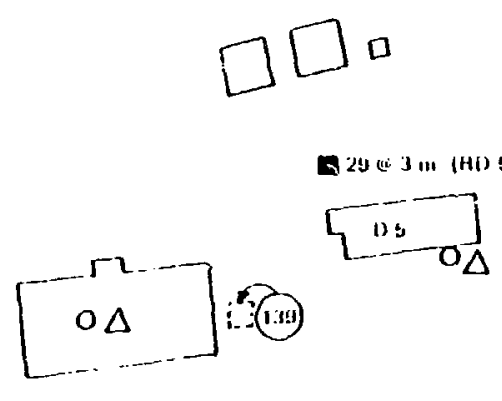

a

0

$42 \cos 7:$

0 $\square$

o

$\square$

[]

$O \triangle$

N

0

绝

$0^{0}$

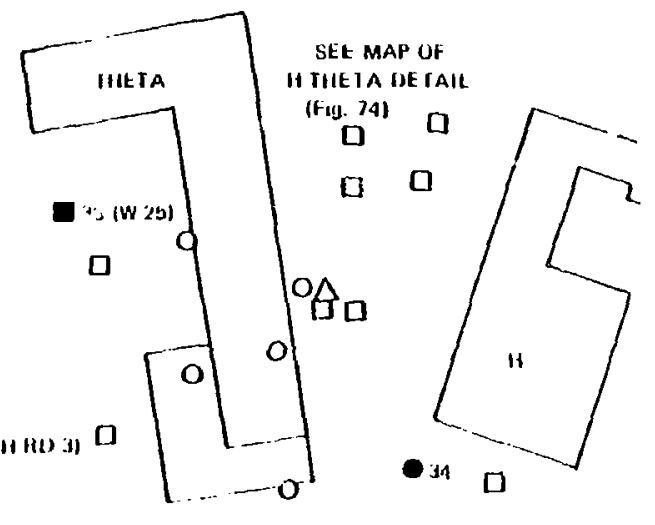

o

$0 \quad 0$
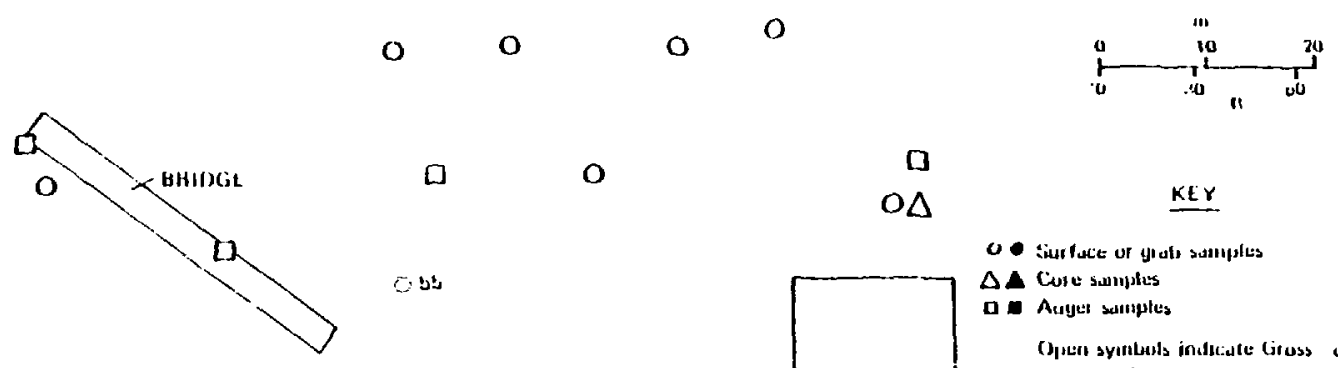

$\square$

o

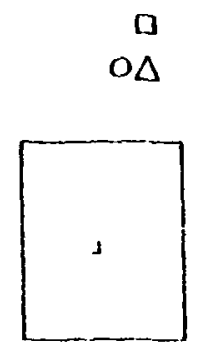

0

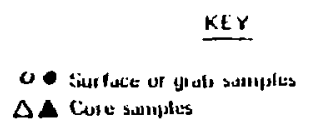

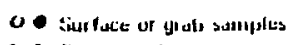

$\Delta A$ Cune Sumples

Optor symbers inducate Gouss a

- 20 HC: $1 / \mathrm{s}$ Silltel symbols

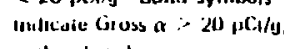

with valere sliuwi

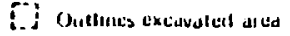

as Sturn dian

O

Fig. 89.

Survey locations and results from south of Sigma Building and in the H-Theta surface drainage area. 


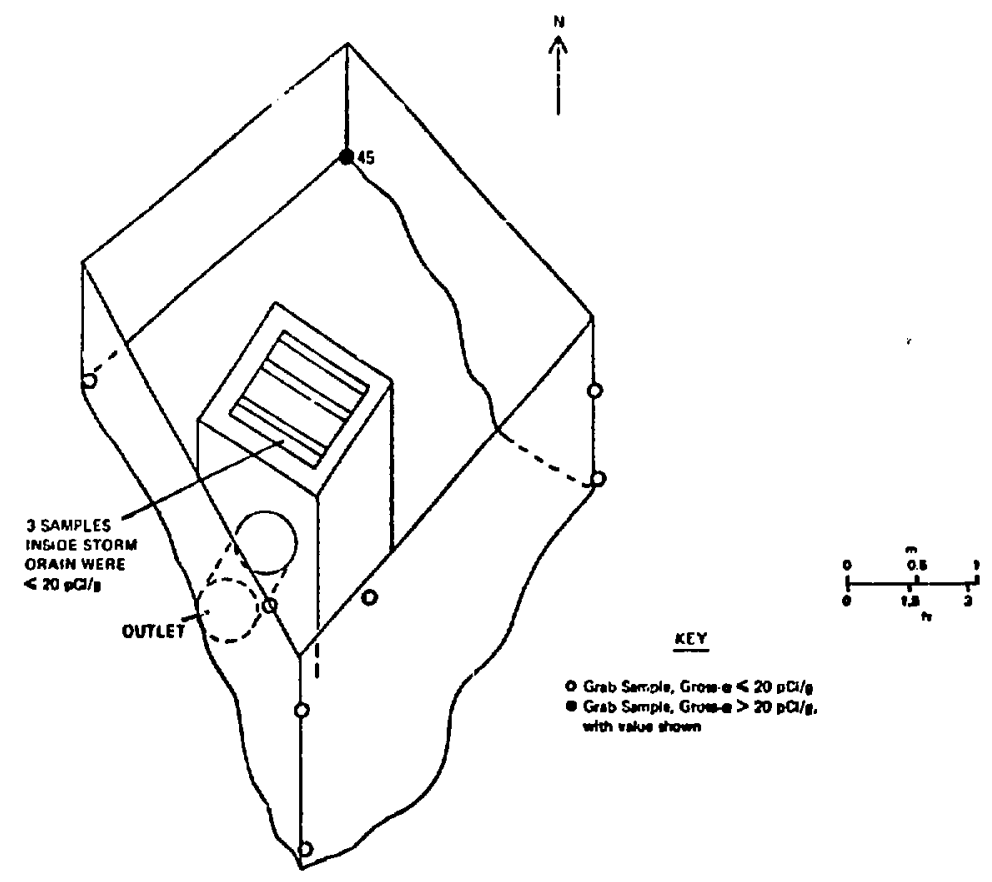

Fig. 90.

Schematic showing soil-sampling results from around storm drain in H-Theia drainage area.

$\mathrm{pCi} / \mathrm{g}$ (maximum activity of a sample was $45 \mathrm{pCi} / \mathrm{g}$ ); and (3) the activity remaining was at the bottom of a $\sim 1.5$-m-deep trench.

Discussions with employees present at the time and information in an old progress report ${ }^{13}$ indicated that on September 5, 1957, a leak had developed in the acid-sewer line near the old apartments next to TA-1 and that this leak had bubbled to the surface. Phoswich survey point 8 showed ${ }^{137} \mathrm{Cs}$ contamination (see Secs. II.B.1 and III.D.8) and corresponded to the location of this leak. Therefore, it was decided to investigate more thoroughly the $\mathrm{J}-2$ acid-sewer trench in the vicinity of phoswich survey print 3 . The location of this excavation is shown in Fig. 110. The widened portion of the trench is the place from which ${ }^{137} \mathrm{Cs}$-contaminated soil (detectable by the phoswich) was remo:ed. Results of gross-alpha analyses of samples from the trench are shown in Fig. 111. In the wide portion of the trench the ${ }^{137} \mathrm{Cs}$ contamination on both sides was removed to below detection limits on the phoswich $(<200 \mathrm{pCi} / \mathrm{g})$. At the bottom of the trench ( $\sim 4 \mathrm{~m}$ deep), contamination was confined to a $10-\mathrm{cm}$-wide, soil-filled fracture starting in the center and running southeast. The fracture was oriented N30W and did not extend up the trench walls. Further excavation would have been deeper than was practicable with a backhoe. Activity to $168 \mathrm{pCi} / \mathrm{g}$ of ${ }^{197} \mathrm{Cs}$ is known to remain in the bettom of the trench. No phoswich-detectable activity was found in the trench in either direction from this spot.

At a meeting on $\mathrm{J} \cdot \mathrm{ly} 28,1976$ (Table III), this portion of the acid-sewer excavation was considered decontaminated because (1) the primary contamination was ${ }^{137} \mathrm{Cs}$; (2) the only phoswichdetectable activity was $\sim 4 \mathrm{~m}$ deep and localized along a fracture; (3) only 3 of 54 samples had grossalpha activity $>20 \mathrm{pCi} / \mathrm{g}$ (maximum activity of a sample was $41 \mathrm{pCi} / \mathrm{g}$ ); and (4) the excavation in each direction along the former acid-sewer line was extensive enough to include the region of the known leak. 


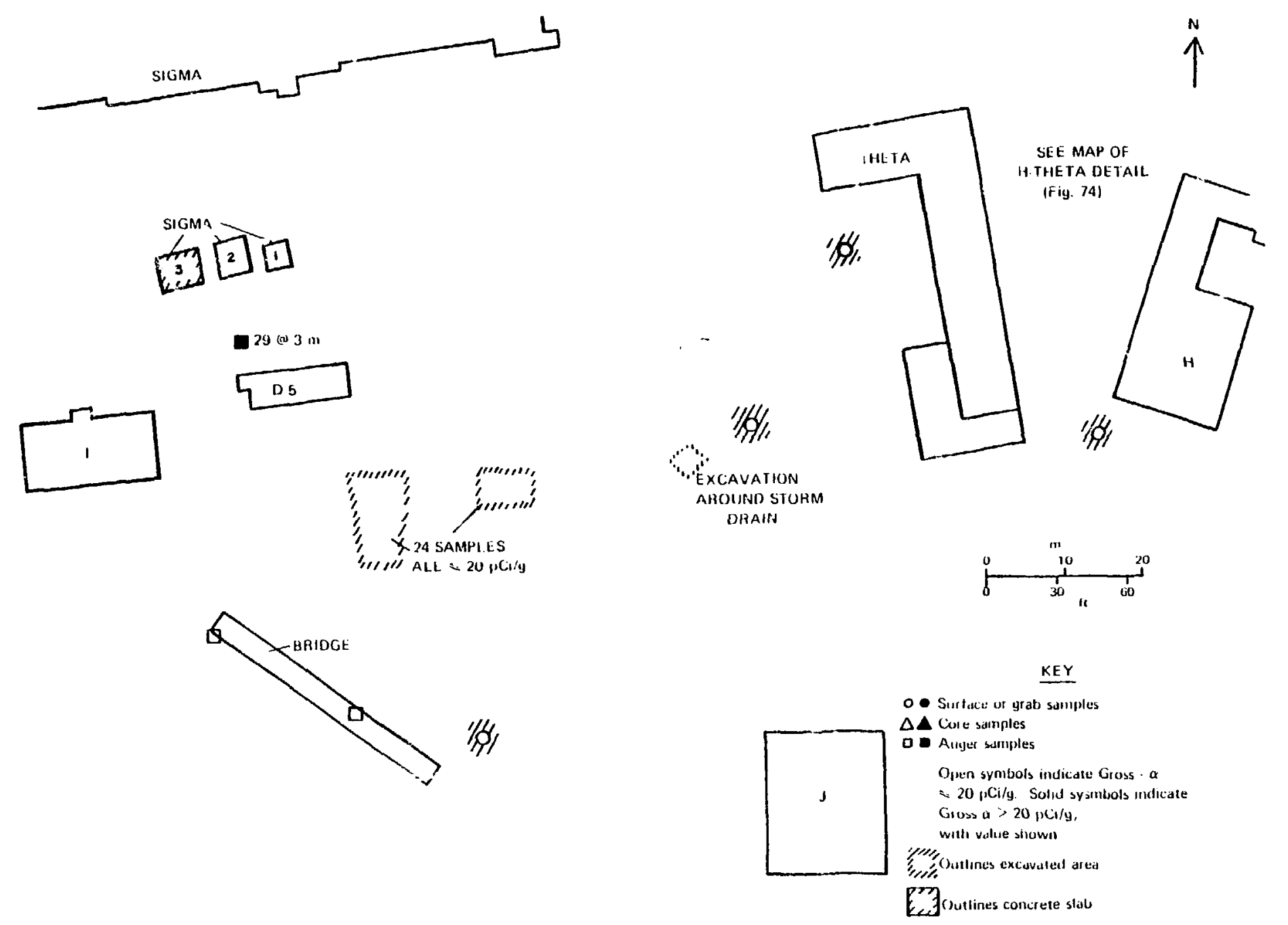

Fig. 91 .

Final sampling results from $H$-Theta surface arainuge area. (See Fig. 89.) 


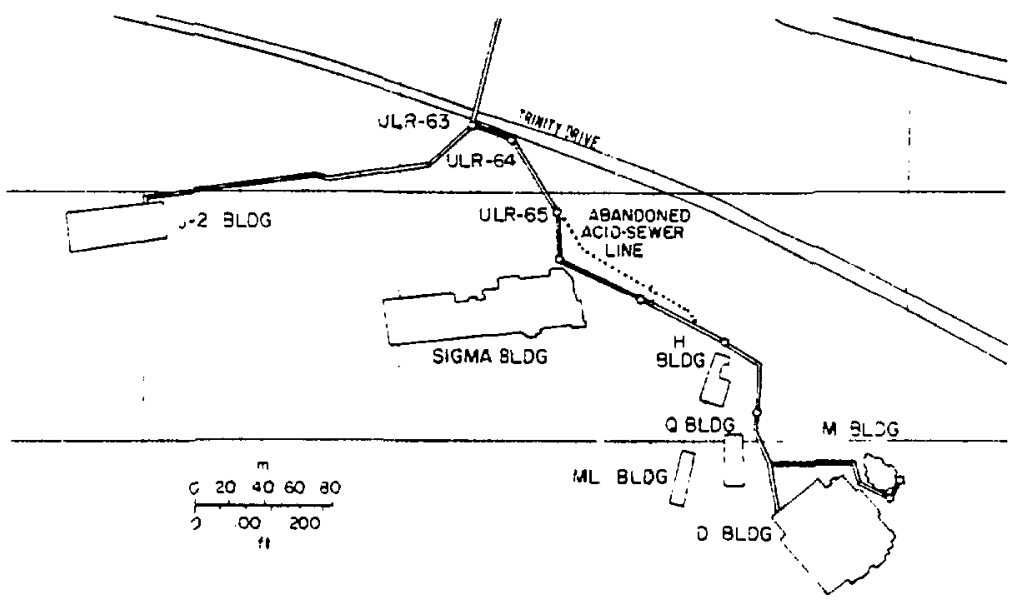

Fig. 92.

Locations of acid-sewer lines from $D$ Building to Trinity Drive.

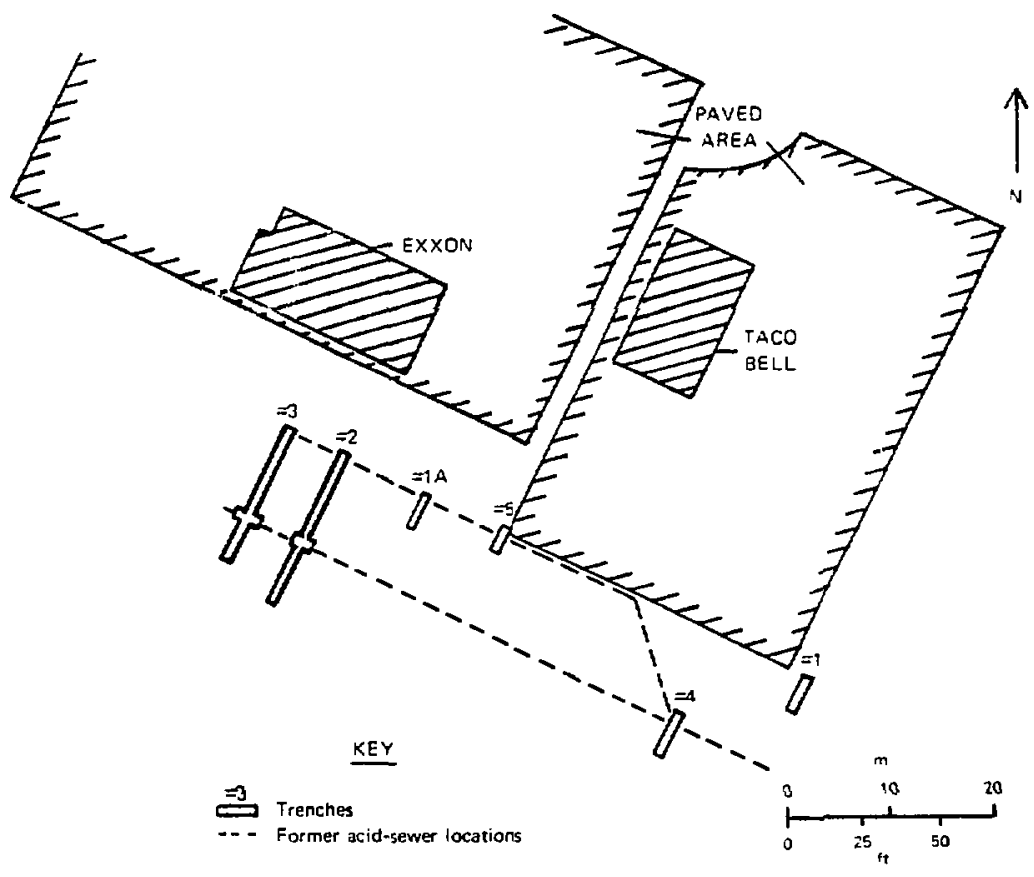

Fig. 93.

Locations of early exploratory trenches behind Taco Bell and Exxon station. 


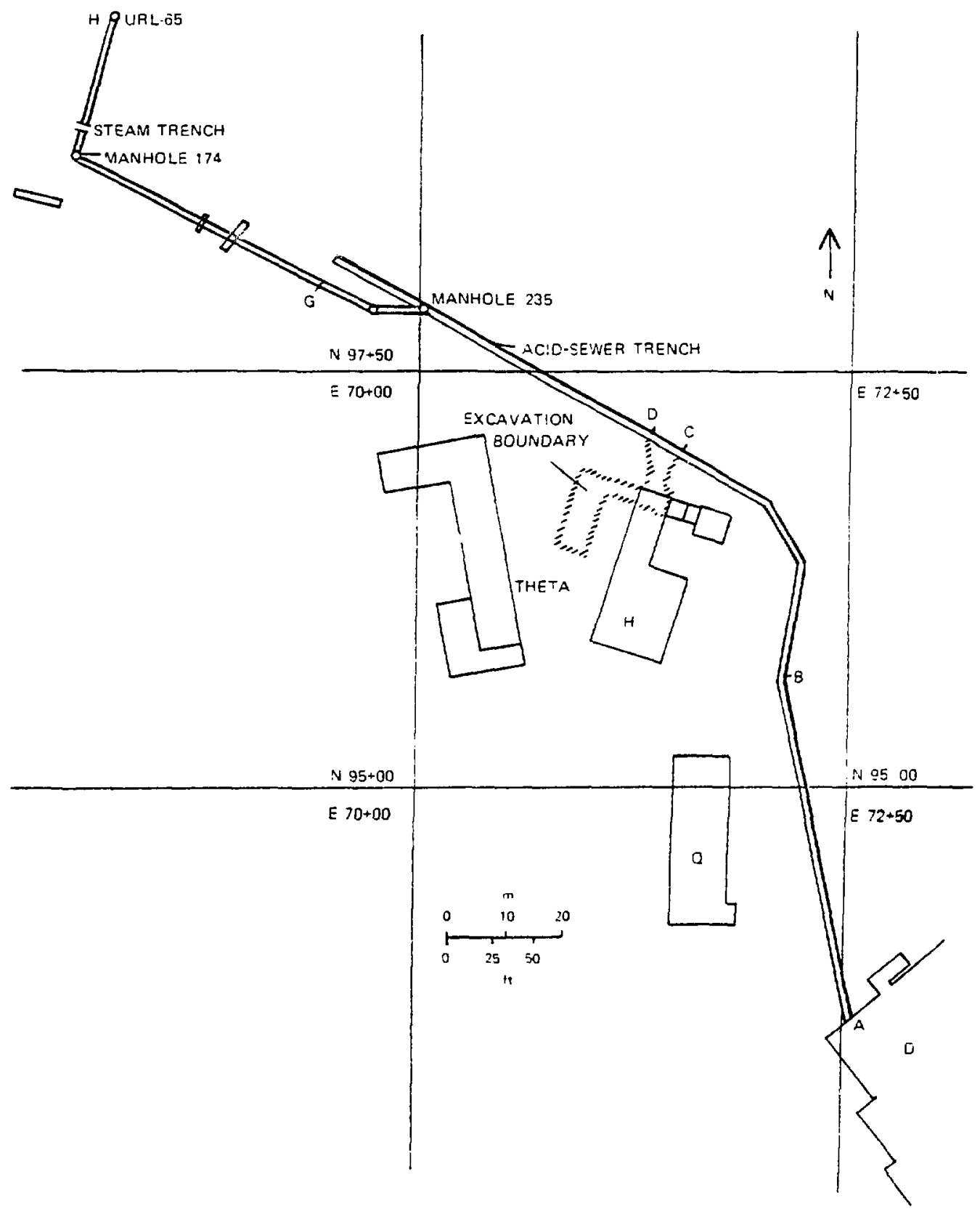

Fig. 94.

Acid-sewer trench (as dug) on undeveloped land south of Trinity Drive. 


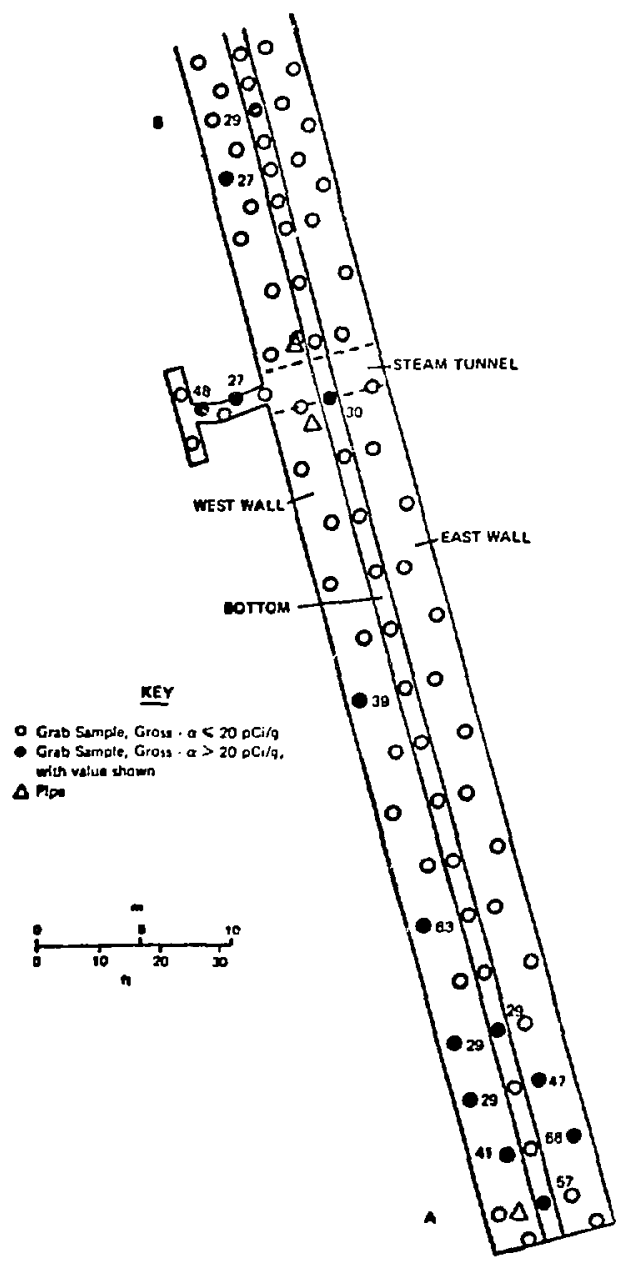

Fig. 95.

Flattened view of Section $A B$ of the acid-sewer trench, with initial soil-sampling results.

\section{Areas with Uranium as the Principal Contaminant}

1. Vicinity of Building HT. During the surfacedebris cleanup, a tuff outcrop just south of the former site of Building HT (a heat-treatment and machining facility for normal and enriched uranium) was found to read $1 \mathrm{mR} / \mathrm{h}$ (open shield) on a GM survey meter and $600 \mathrm{c} / \mathrm{min}$ on an alpha survey meter. The activity was identified by gamma spectroscopy as normal uranium. Exploration showed that the activity extended over a wide, shallow area; consequently, an area about $19 \mathrm{~m}$ wide

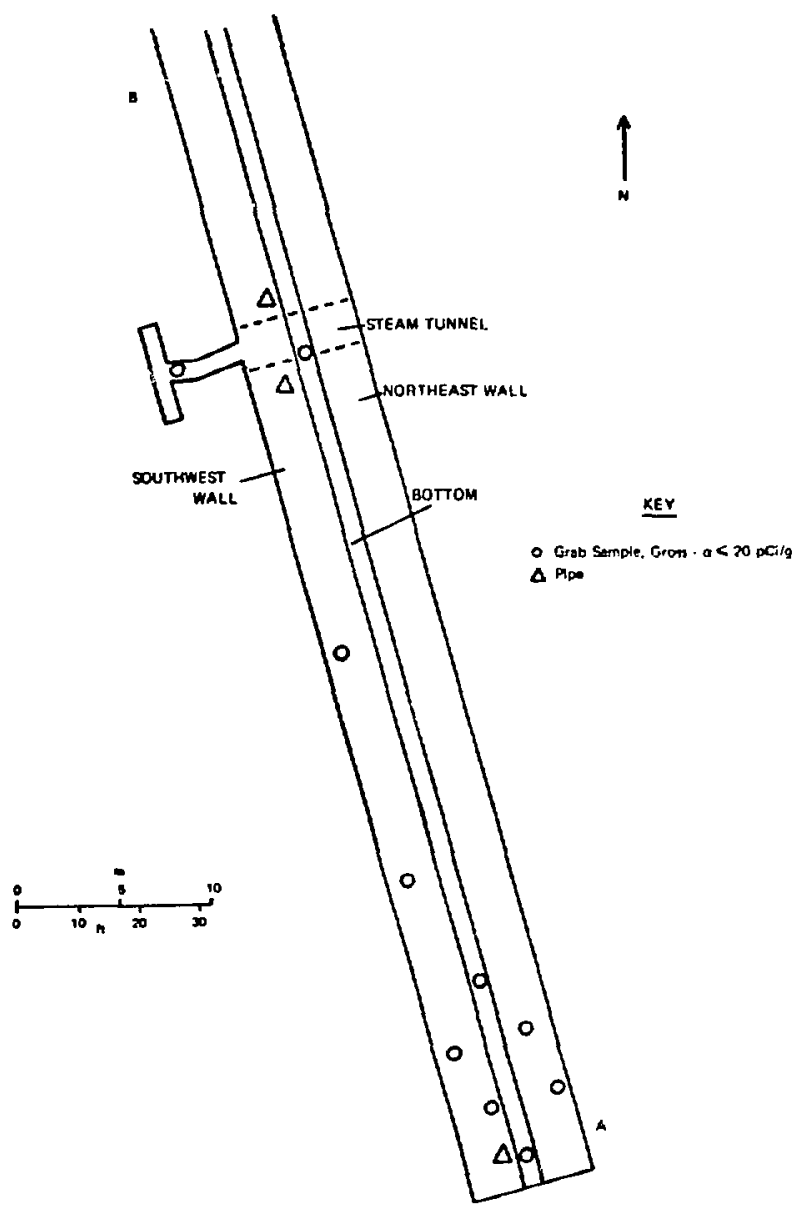

Fig. 96.

Flattened view of Section $A B$ of the acid-sewer trench, with final sampling results in areas where the excauation was enlarged.

by $22 \mathrm{~m}$ long and as deep as $0.76 \mathrm{~m}$ was excavated and $\sim 27 \mathrm{~m}^{3}$ of soil were removed until no further activity could be detected by the phoswich. Soil samples were then taken on a $6.1-\mathrm{m}$ grid. Sample locations and gross-alpha analysis results are given in Fig. 112.

At a meeting on November 4, 1975 (Table III), the HT excavation was determined to be decontaminated because (1) there was no phoswichdetectable activity in the excavation and (2) all 9 surface soil samples on the grid had gross-alpha activity $<20 \mathrm{pCi} / \mathrm{g}$. 


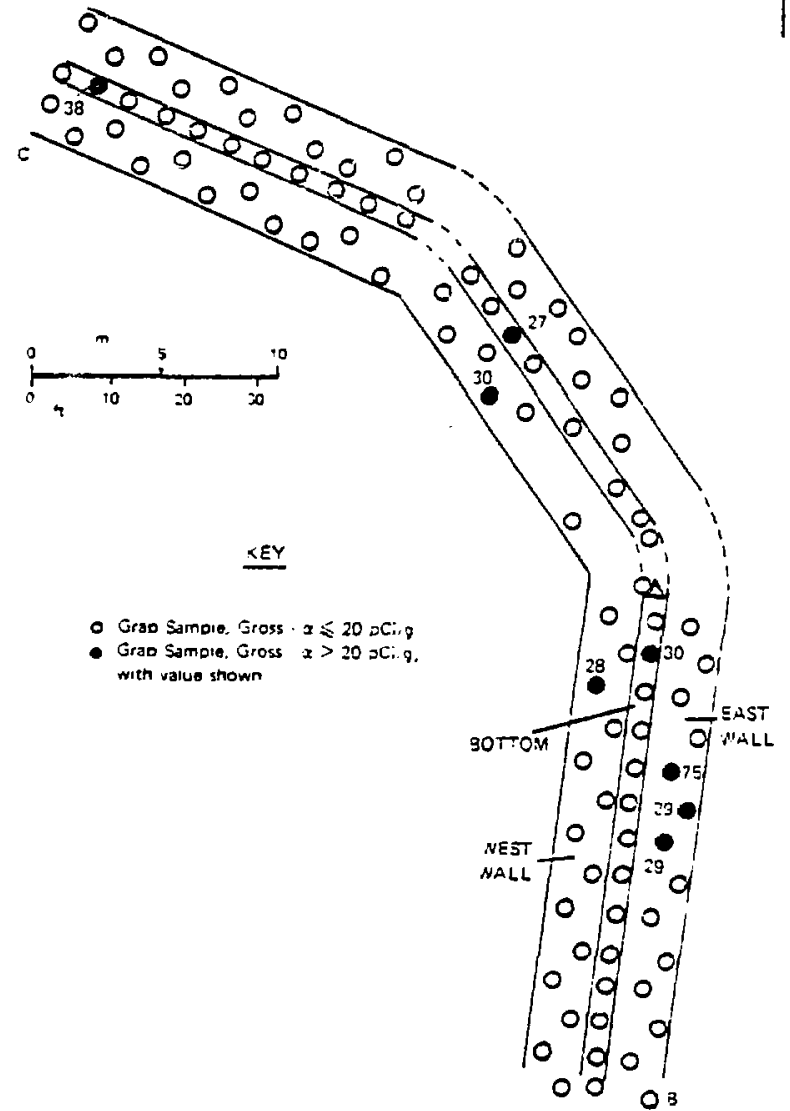

Fig. 97.

Flattened view of Section BC of the acid-sewer trench, with initial soil-sampling results.

2. Vicinity of Sigma Building. Surveys made during the cleanup of surface debris identified spots of uranium contamination on pipe shards (as much as 100 to $120 \mathrm{mR} / \mathrm{h}$ (open wirdow) on a GM survey meter) and in soil in the or cline of Sigma Building, which had been used for uranium and thorium casting, machining, and powder metallurgy. Because of the pipe shards, which probably came from break-up of laterals to the acid-sewer line during demolition, exploratory trenches were dug to determine whether the laterals from the Sigma and main acid-sewer lines had actually been removed. The trench locations and soil-sampling locations and results in the Sigma area are shown in Figs. 113 and 114 .

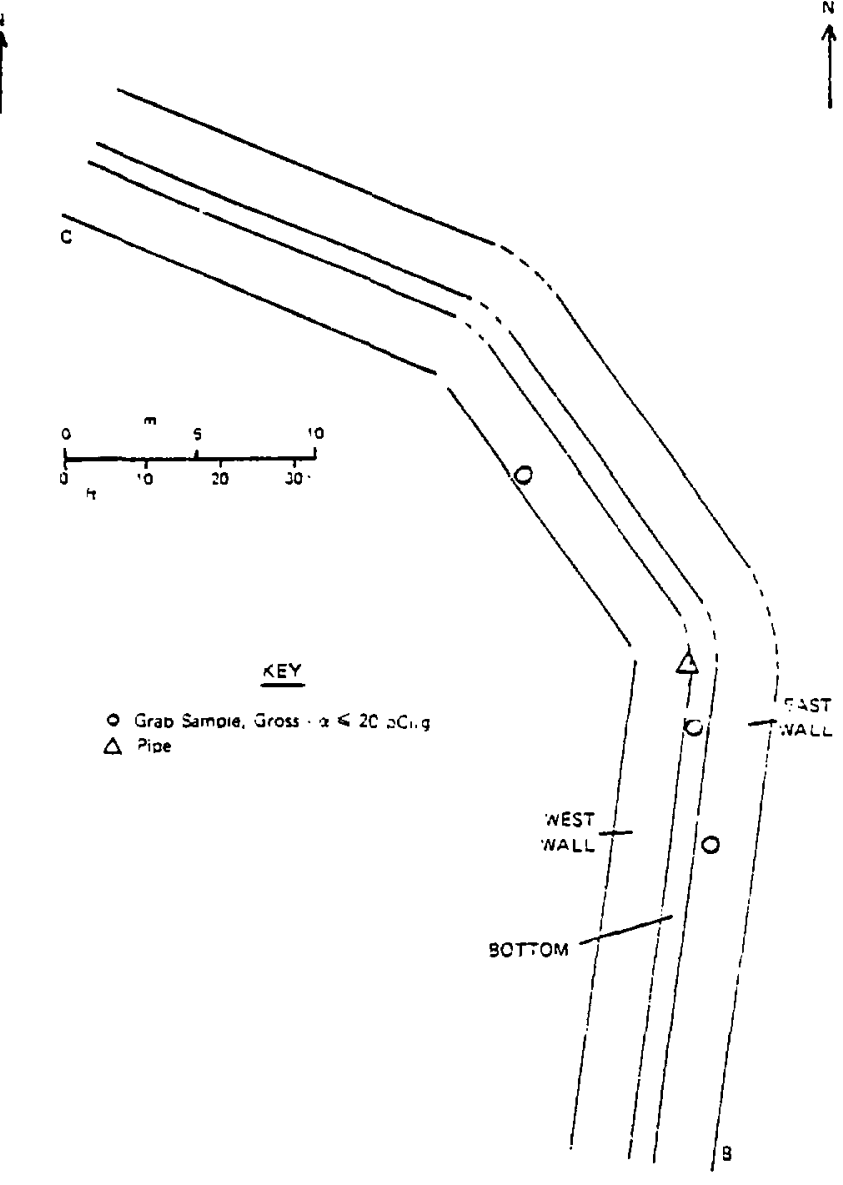

Fig. 98.

Flattened view of Section. BC of the acid-sewer trench, with final sampling results in areas where the excavation was enlarged.

Contamination uncovered during the trenching operations included soil and the corrugated-metal pipe (apparently a storm drain) indicated in Fig. 114. The contaminated materials were removed. No acid-sewer lines or laterals were found. In the areas where contaminated shards were found during the surface cleanup, soil samples W-1 and S-RC-1 indicated significant uranium contamination. Radiochemical analyses of these and other Sigmaarea samples are given in Table XVI; they confirmed that the predominant contamination was uranium. The discovery of numerous other contaminated pipe shards led to excavation of areas 1 and 2 shown in Fig. 115. These areas were excavated 


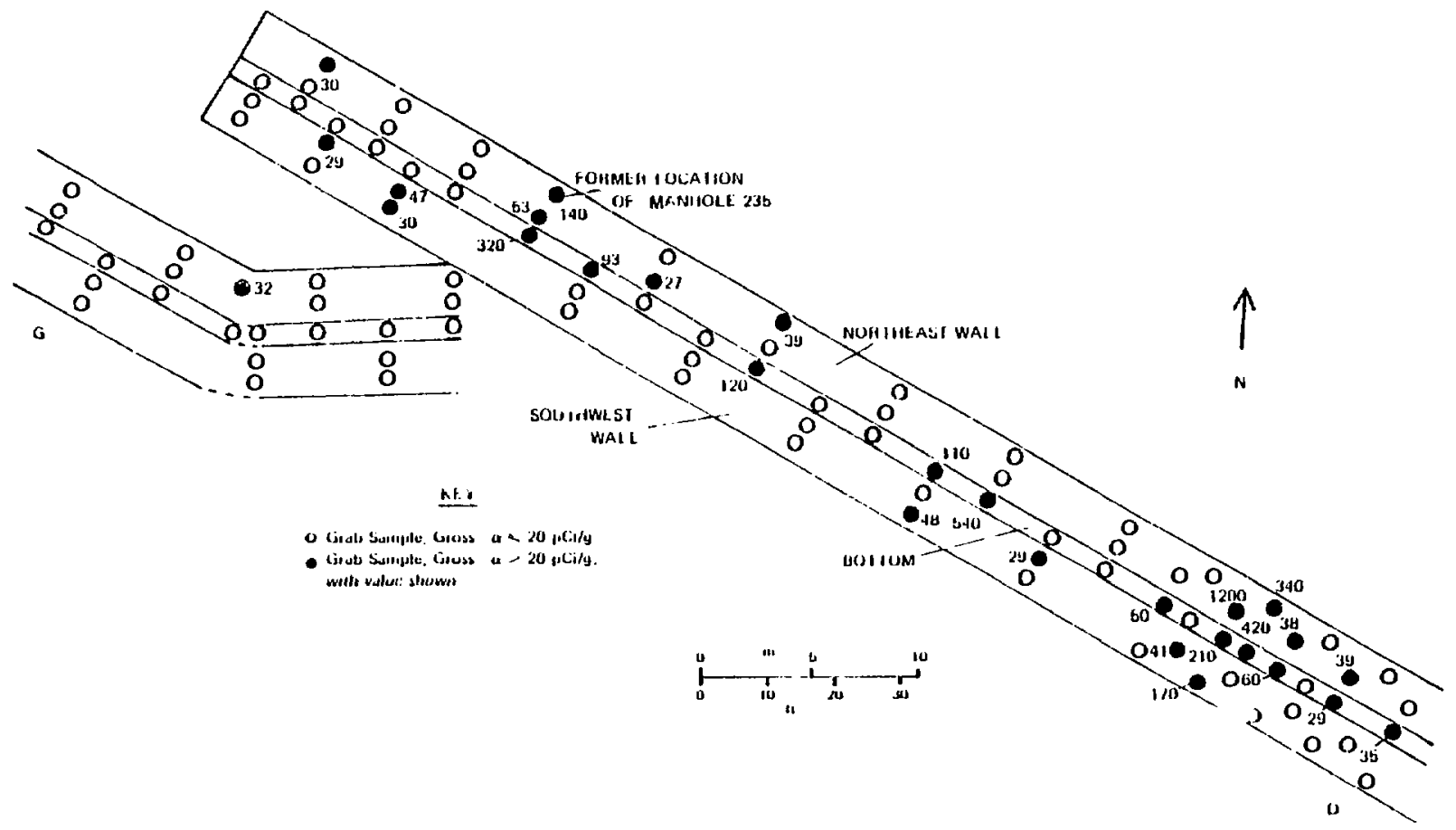

Fig. 99.

Flattened view of Section DG of the acid-sewer trench, with initial soil-sampling results.

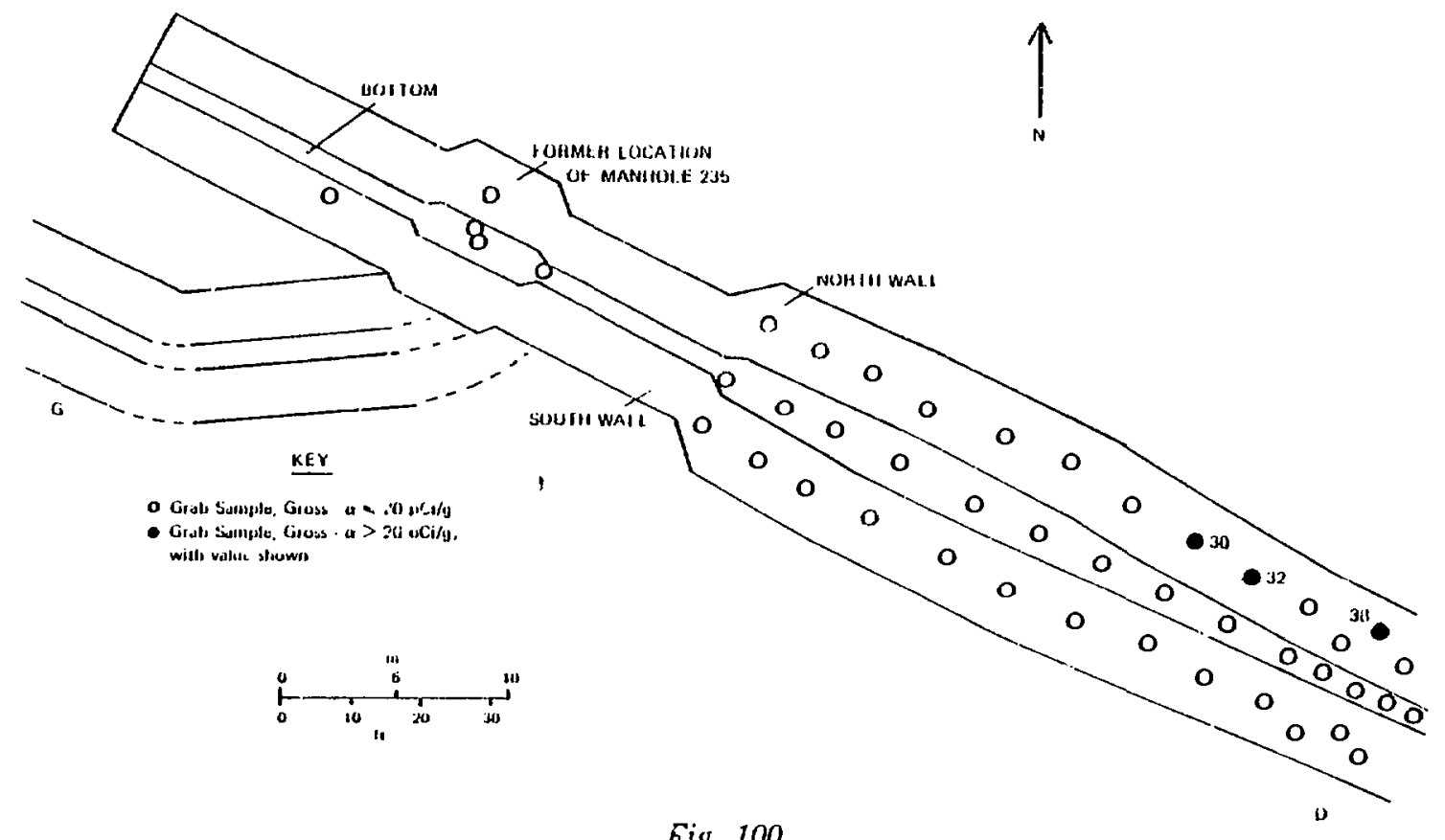

Fig. 100.

Flattened view of Section I)G of the acid-sewer trench, with final sampling results from areas where the excavation was enlarged. 


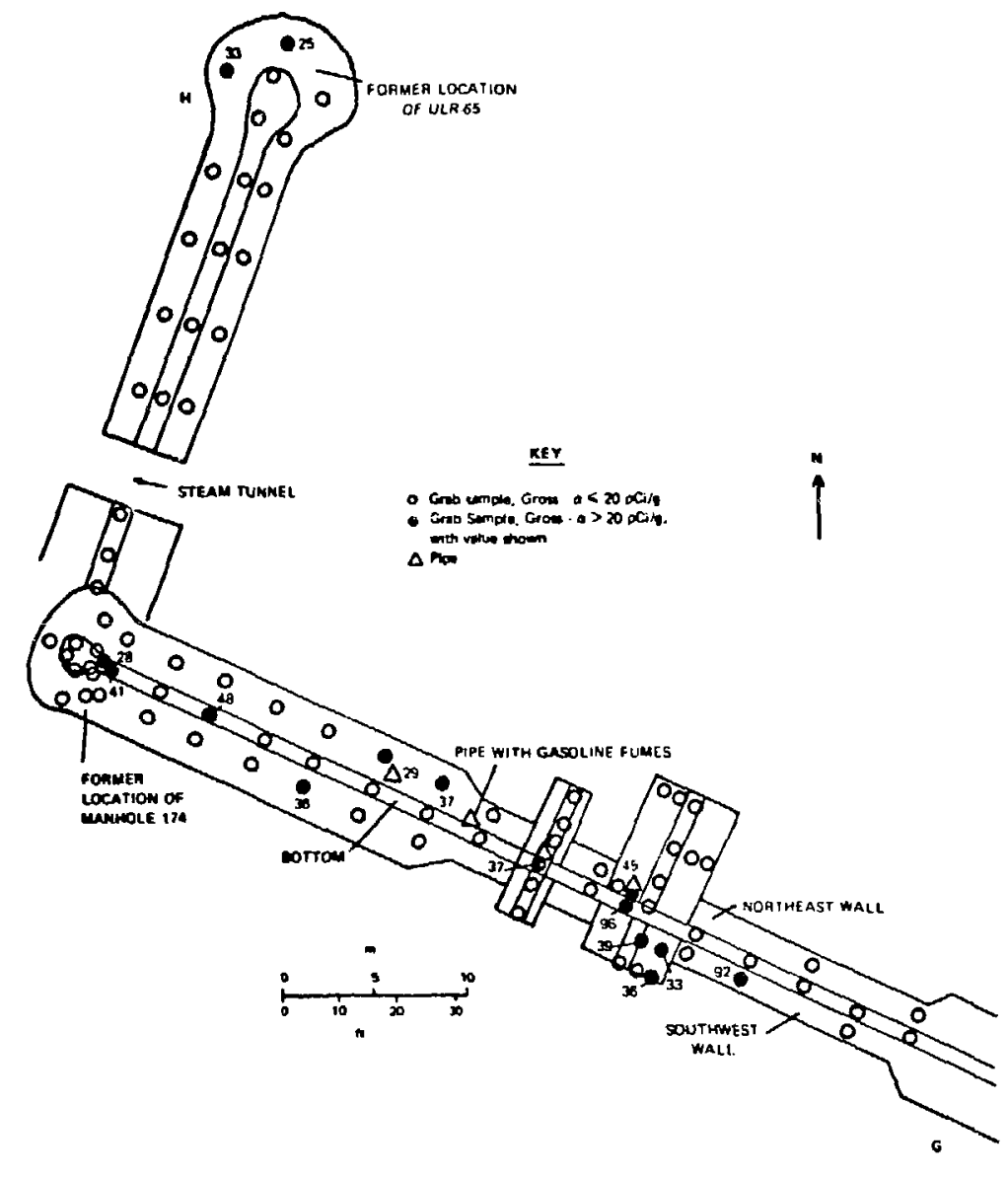

Fig. 101.

Flattened view of Section $G H$ of the acid-sewer trench, with initial soil-sampling results.

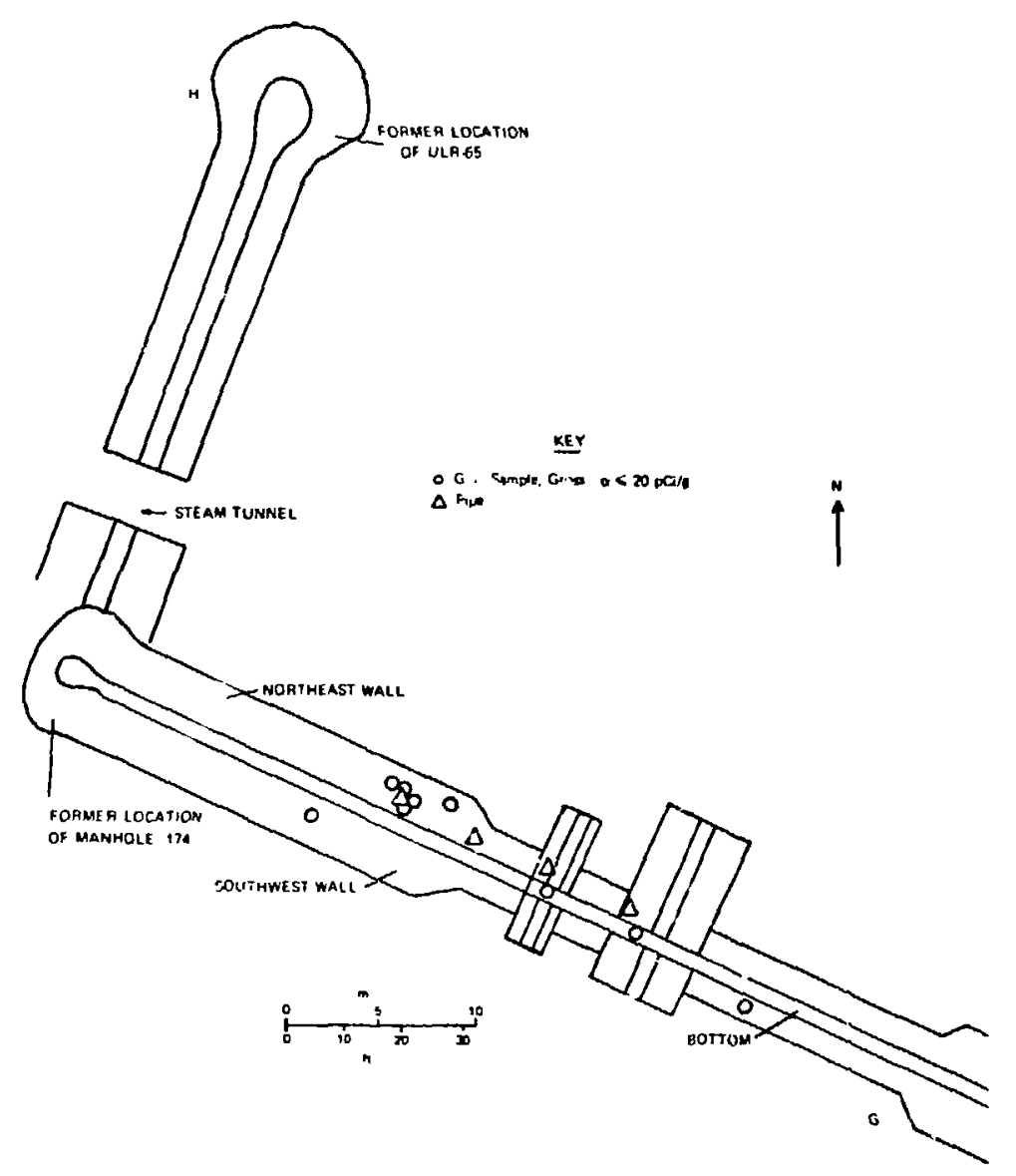

Fig. 102 .

Flattened view of Section $\mathrm{GH}$ of the acid-sewer trench, with final sampling results from areas where the excavation was enlarged. 


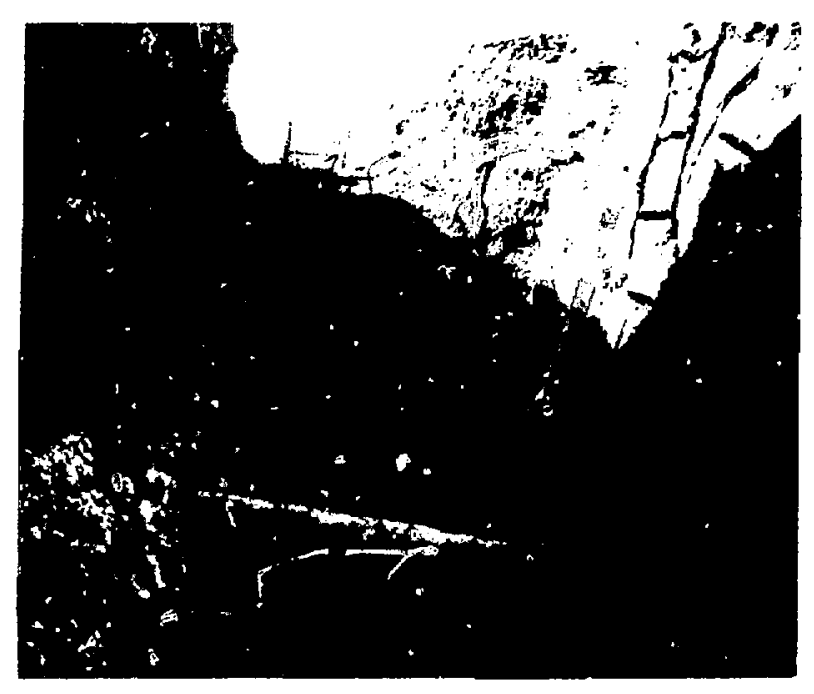

Fig. 103.

Pipes and steam tunnel in acid-sewer trench near $Q$ Building (looking south).

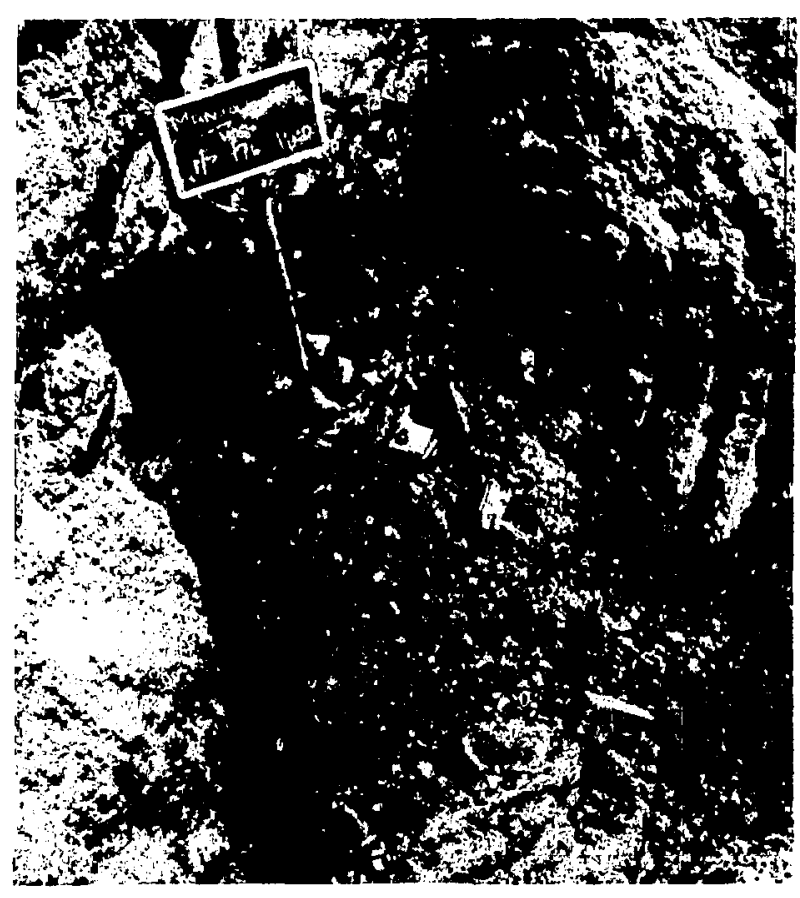

Fig. 105.

Remains of Manhole 174, as found.

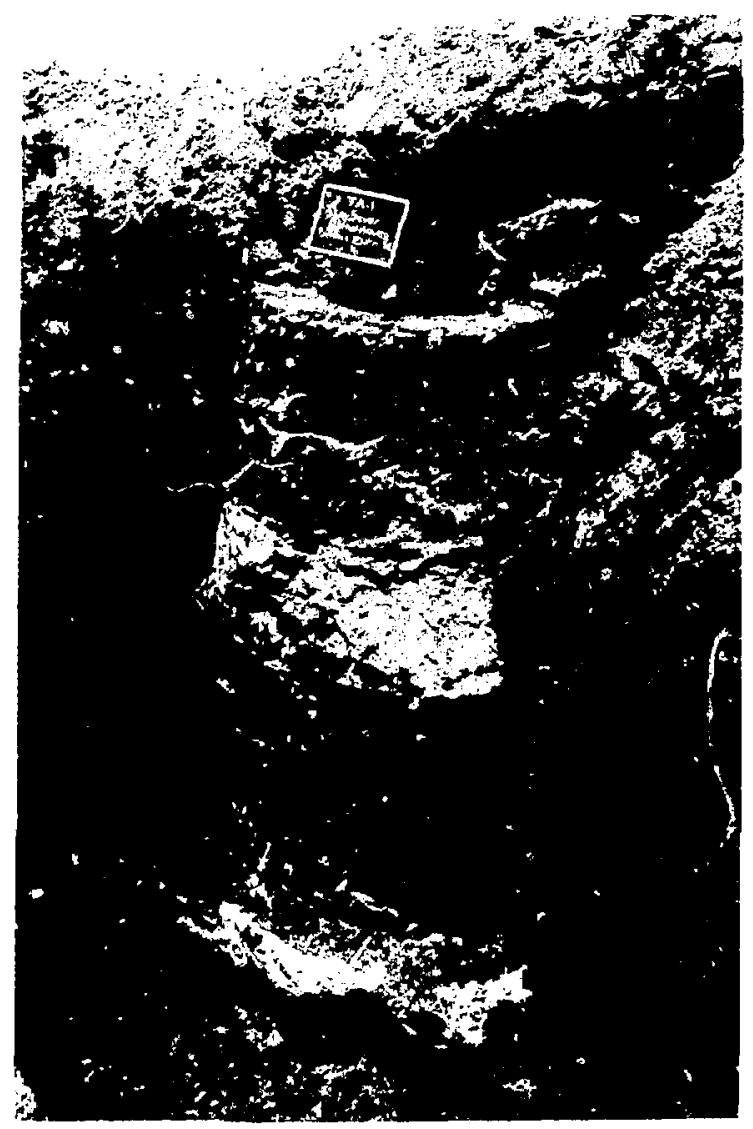

Fig. 104.

Manhole 235.

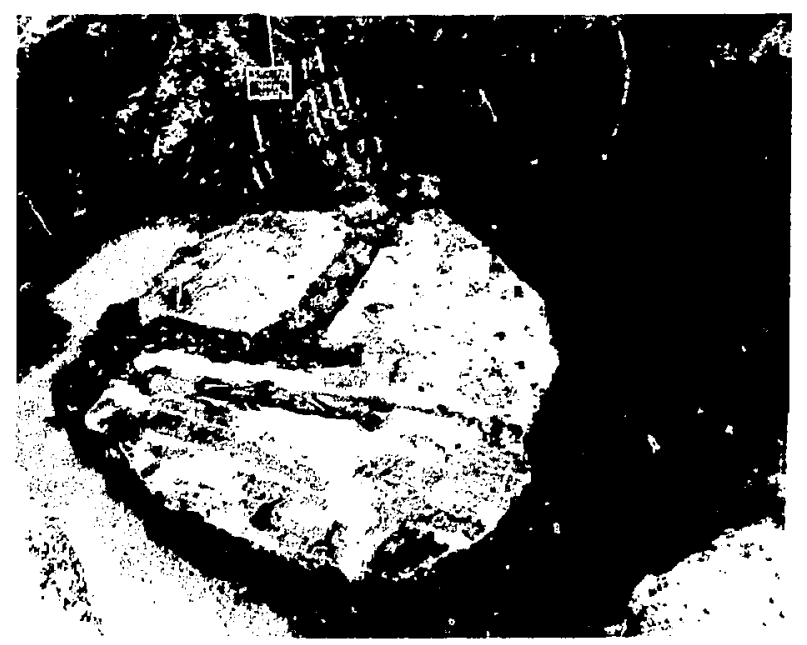

Fig. 106.

Base for Manhale 174 just before removal. 


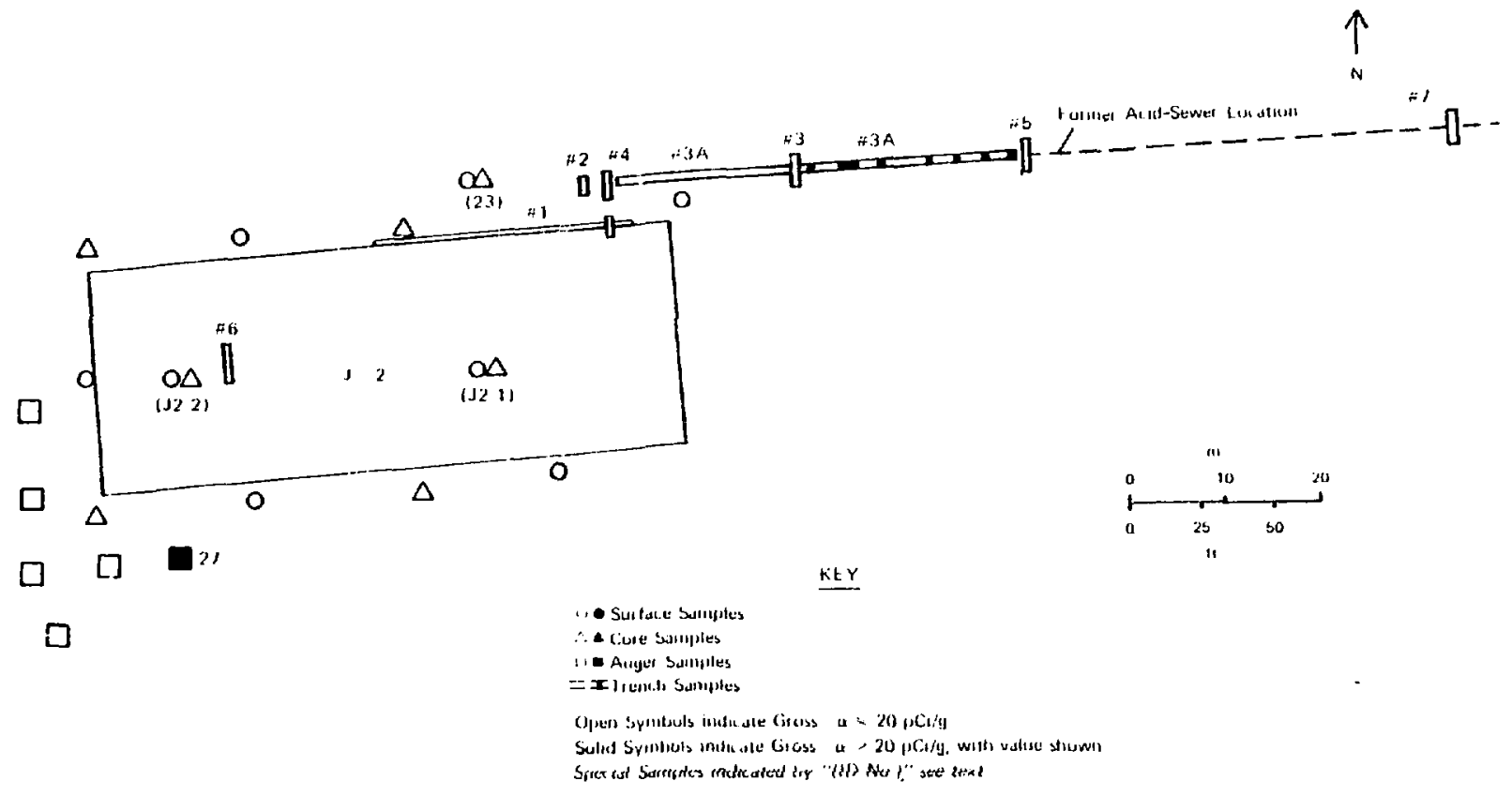

Fig. 107.

Trench locations along western portion of the acid-sewer line, with initia! sumpling results from there and from the vicinity of $\mathrm{J}-2$.

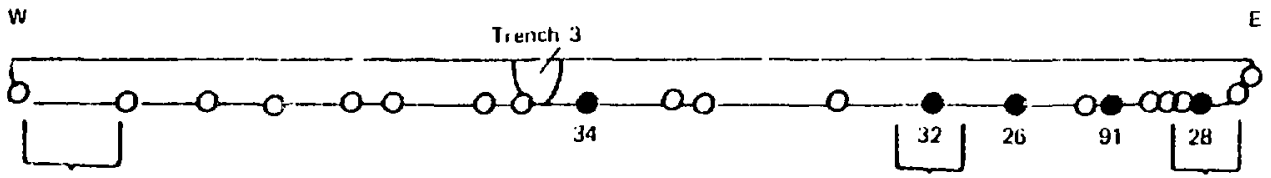

$\underline{\text { KEY }}$

$\checkmark$ Giab salmple, linuss - $\alpha \Leftarrow 20 \mu \mathrm{Ci} / \mathrm{g}$

- Grab sample, Gross - $a>20 \mathrm{pCi} / \mathrm{g}$, with vali:e shown

Brackets areas above buckujround

Gross $\gamma$ as coequsured by field instruments

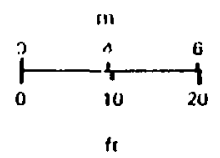

Fig. 108.

Cross section of Trench $3 A$ (looking north), with initial soil-sampling resuits.

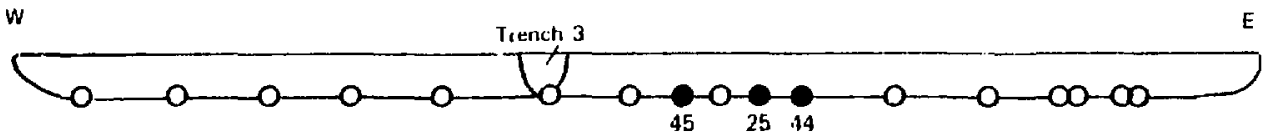

KEY
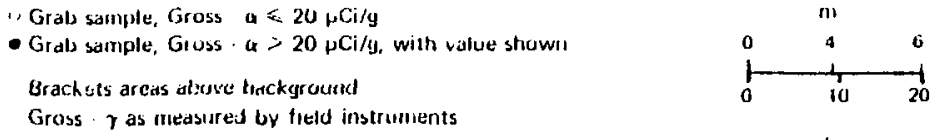

H

Fig. 109.

Cross section of Trench $3 A$ (looking north), with final soil-sampling results. 


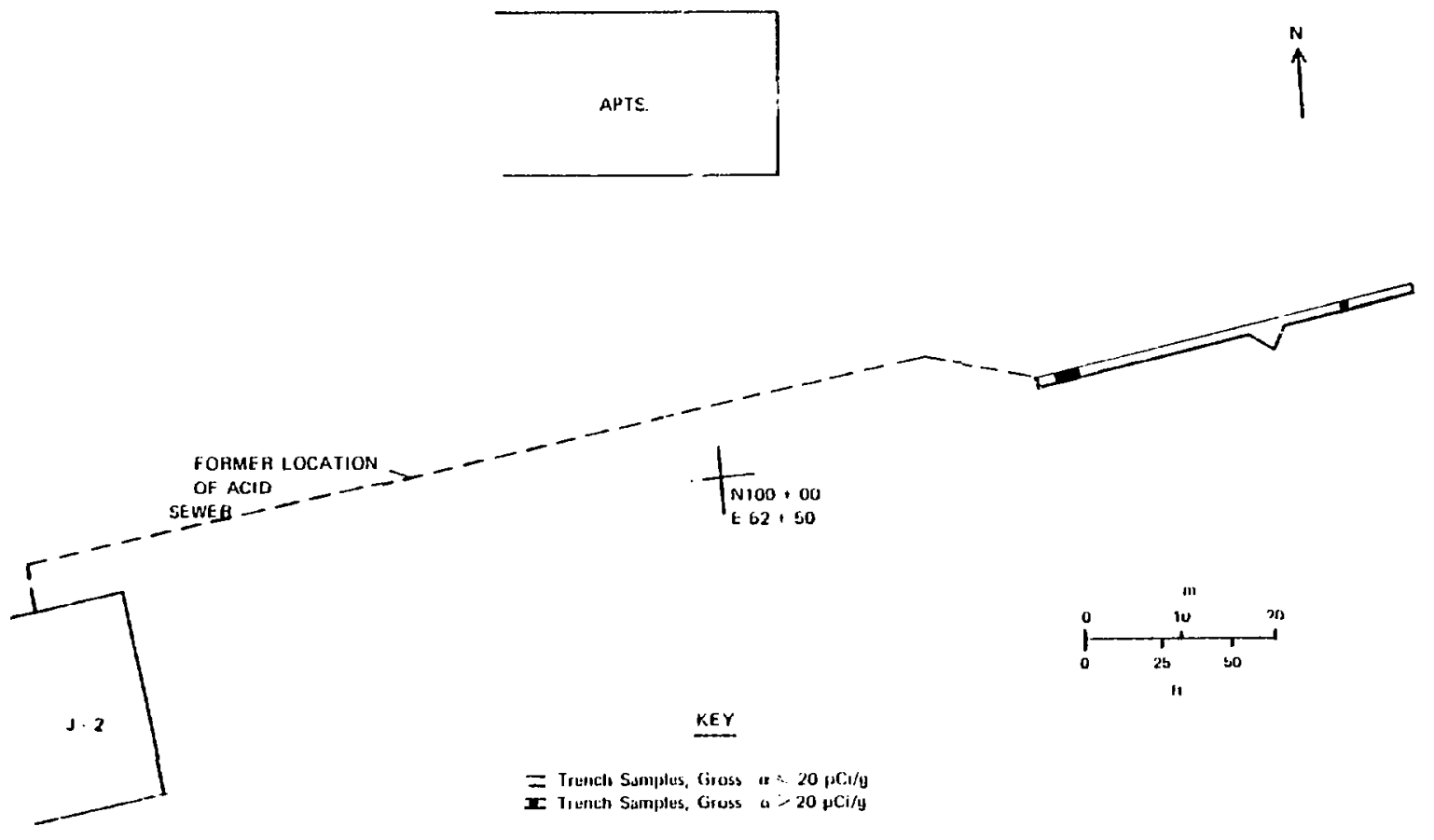

Fig. 110 .

Excavations around Phoswich Survey Point 8 (along western portion of acid-sewer line).

w

t.

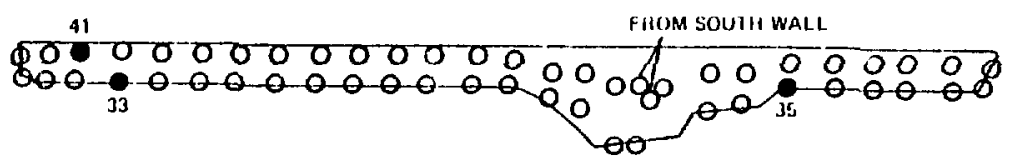

KEY

- Grab Sarinple, Gross a $<20 \mu \mathrm{Cl}_{1 / 4}$

- Gral Saniplt. Gross a $-20 \mathrm{NLi/4}$ wilh value shuwn

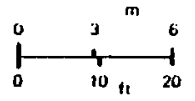

Fig. 111.

Cross section of trench excavation around Phoswich Survey Point 8, with final soil-sampling results. 


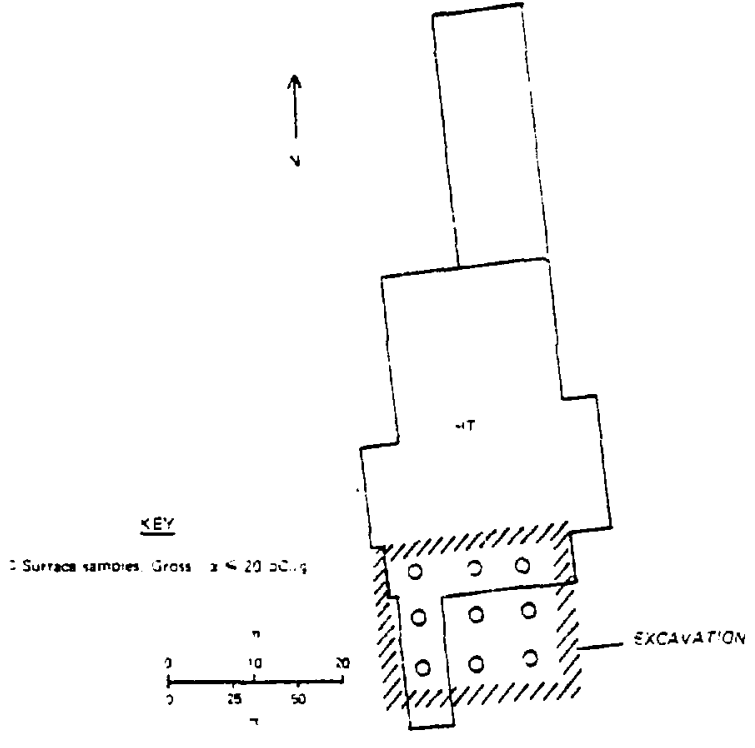

Fig. 112 .

Location and postdecontamination soilsampling results of the HT excavation. to below phoswich-detection limits and were then sampled for gross-alpha activity.

At a meeting on November 25, 1975 (Table III), areas 1 and 2 in the Sigma-Building outline were determined to be decontaminated because (1) the excavations were below the depth at which the pipe shards had been discovered; (2) no phoswichdetectable activity remained; and (3) 19 of 20 soil samples had gross alpha activity $<20 \mathrm{pCi} / \mathrm{g}$ (the positive sample had $28 \mathrm{pCi} / \mathrm{g}$ of gross alpha).

Survey data from the southwest portion of the Sigma-Building outline (Fig. 113) showed grossalpha activity ranging up to $46 \mathrm{pCi} / \mathrm{g}$. Three samples (in a water drainage channel) with slightly elevated gross-alpha activity 135,46 , and $44 \mathrm{pCi} / \mathrm{g}$ in Fig. 113) were of particular interest because chemistry results on sample $\mathrm{K}^{\prime}-10$ indicated $6 . \Omega \mathrm{pCi} / \mathrm{g}$ of ${ }^{239} \mathrm{Pu}$ (Table XVI). 'The immediate area was excavated in case these three samples were indicative of a larger suurce of ${ }^{239} \mathrm{Pu}$ contamination. After the first $0.6 \mathrm{~m}$ of soil was removed, 5 samples along the south edge.

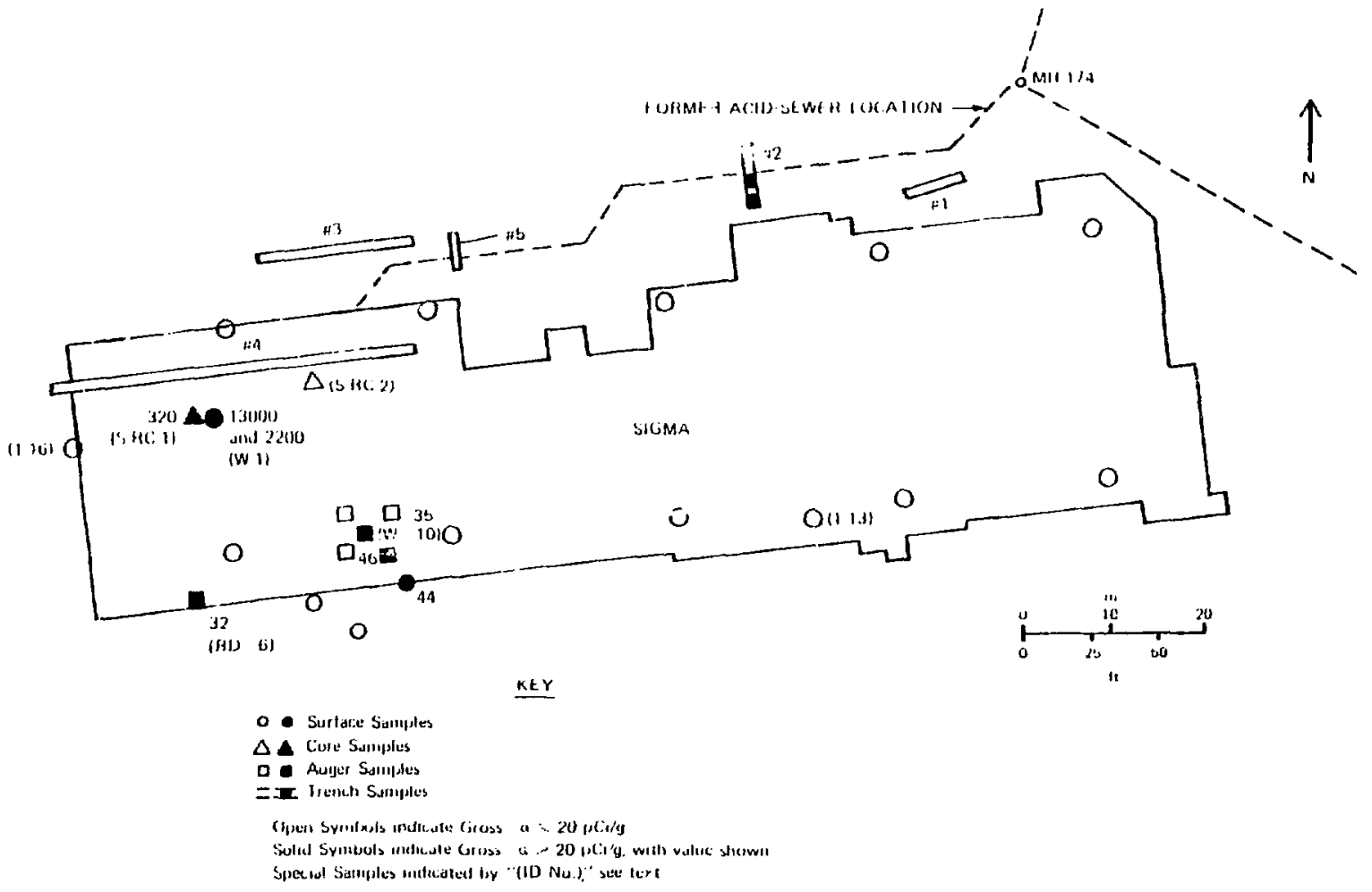

Fig. 113.

Sigma-Building trench and soil survey locations and sampling results. 


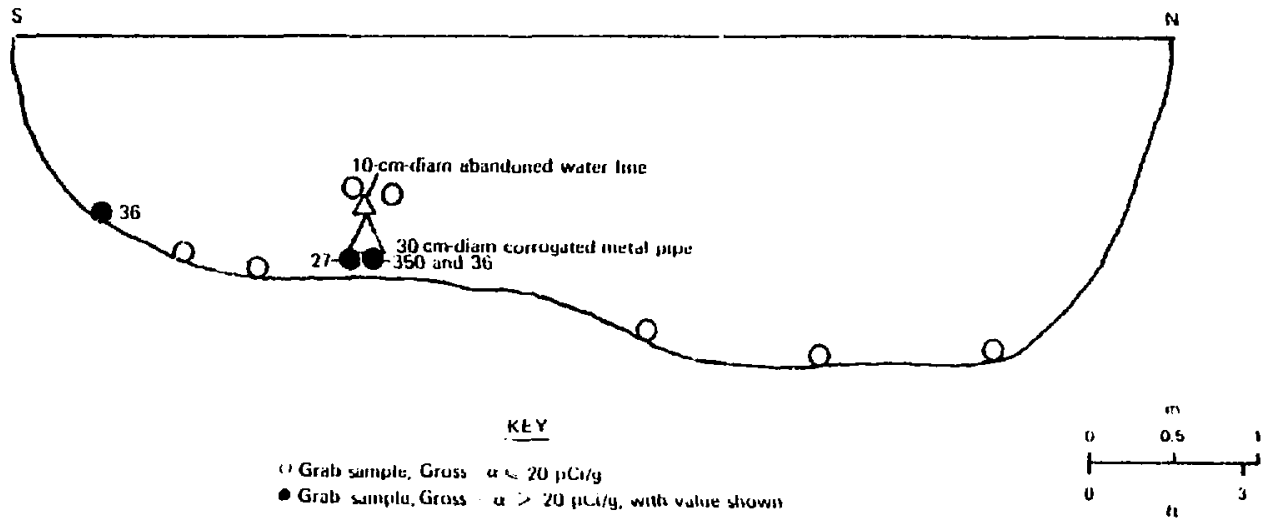

Fig. 114 .

Cross section of Sigma Trench 2 and associated soil-sampling results (looking west).

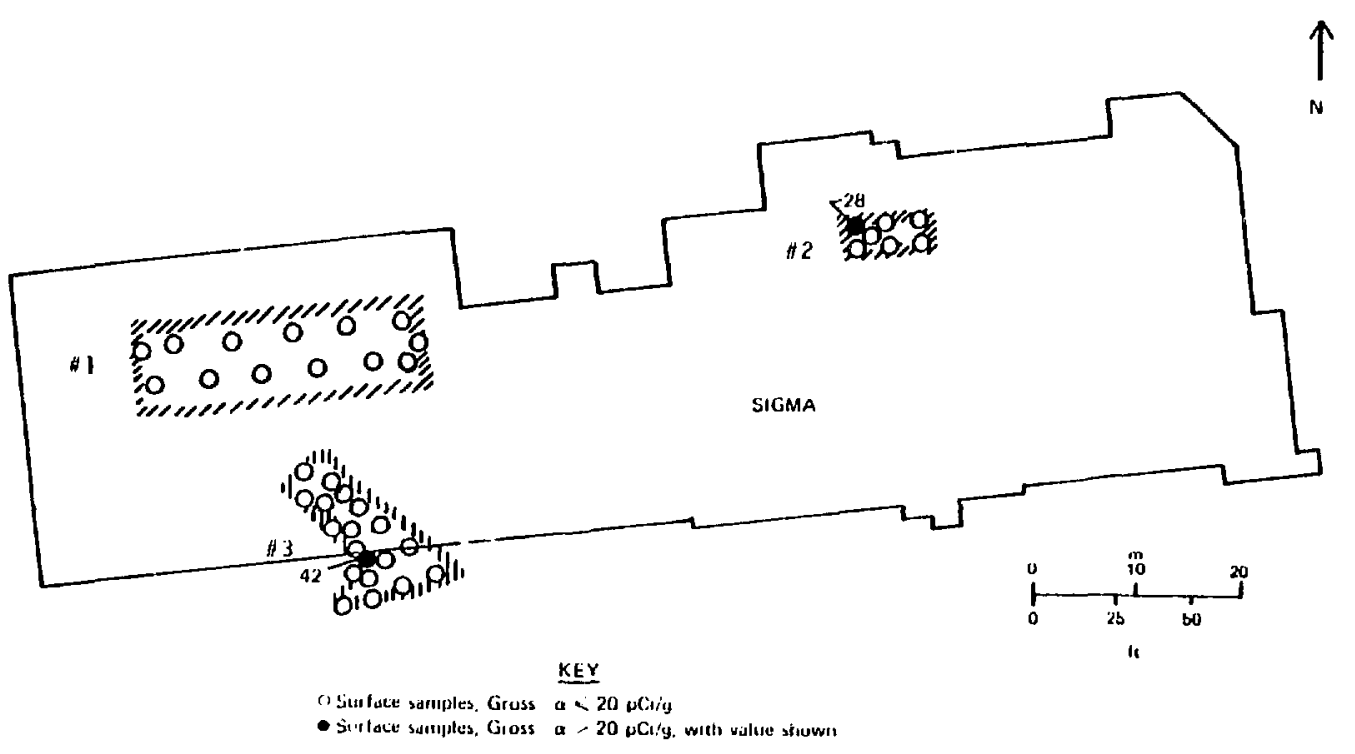

Fig. 115.

Sigma-Building excavation locations and postdecontaminatior soil-sampling results.

of the excavation had gross-alpha activity of 26 to 42 $\mathrm{pCi} / \mathrm{g}$. Another $0.3 \mathrm{~m}$ of soil was removed along that edge. (See Fig. 115, area 3, for location of the excavation and the final sampling results.)

At a meeting on July 28, 1976 (Table III), area 3 in the Sigma-Building outline was determined to be decontaminated because (1) no phoswichdetectable activity remained and (2) 18 of 19 soil samples had gross-alpha activity $<20 \mathrm{pCi} / \mathrm{g}$, with the only positive sample having $42 \mathrm{pCi} / \mathrm{g}$.
3. Vicinity of Delta Building. A small spot of uranium contamination $(200 \mathrm{pCi} / \mathrm{g})$ found on a surface sample near the west end of the Delta-Building location during early Fall 1975 was removed. (The contamination apparentiy was not related to past uses of the building, which had served primarily as a metting place and only briefly as a laboratory in which fission-product tracers were used. The slab on the west end of Delta Building became contaminated when debris from the Sigma-Building 
TABLE XVI

RADIOCHEMISTRY RESULTS FROM SIGMA-BUILDING AREA

\begin{tabular}{|c|c|c|c|c|c|c|c|}
\hline $\begin{array}{c}\text { Sample } \\
\text { Identification }\end{array}$ & $\begin{array}{c}\text { Depth } \\
\text { (m) }\end{array}$ & $\begin{array}{l}{ }^{293,234} \mathrm{U} \\
(\mathrm{pCi} / \mathrm{g})\end{array}$ & $\begin{array}{l}{ }^{236,236} \mathbf{U} \\
(\mathrm{pCi} / \mathrm{g})\end{array}$ & $\begin{array}{c}{ }^{239} \mathrm{U} \\
(\mathrm{pCi} / \mathrm{g})\end{array}$ & $\begin{array}{c}{ }^{238} \mathbf{P u} \\
(\mathbf{p C i} / \mathrm{g})\end{array}$ & $\begin{array}{c}{ }^{239} \mathbf{P u} \\
(\mathbf{p C i} / \mathbf{g})\end{array}$ & $\begin{array}{c}\text { Total } \\
\text { Uranium } \\
(\mu \mathrm{g} / \mathrm{g}) \\
\end{array}$ \\
\hline W-1 & & 2,00 & 100 & 1800 & & & \\
\hline S-RC-1 & $\begin{array}{l}0 \quad \text { to } 0.05 \\
0.05 \text { to } 0.10 \\
0.10 \text { to } 0.15 \\
0.15 \text { to } 0.20 \\
0.20 \text { to } 0.58\end{array}$ & $\begin{array}{l}0.69 \\
0.81 \\
0.82 \\
0.83 \\
48\end{array}$ & $\begin{array}{l}0.32 \\
0.045 \\
0.034 \\
0.052 \\
1.3\end{array}$ & $\begin{array}{l}0.67 \\
0.77 \\
0.76 \\
0.86 \\
1.2\end{array}$ & & & \\
\hline S-RC-2 & $\begin{array}{l}0 \quad \text { to } 0.05 \\
0.05 \text { to } 0.10 \\
0.10 \text { to } 0.15 \\
0.15 \text { to } 0.20 \\
0.20 \text { to } 0.58\end{array}$ & $\begin{array}{l}2.3 \\
7.0 \\
2.9 \\
3.4 \\
3.8\end{array}$ & $\begin{array}{l}0.069 \\
0.26 \\
0.095 \\
1.2 \\
0.087\end{array}$ & $\begin{array}{l}1.4 \\
3.8 \\
2.4 \\
2.3 \\
3.6\end{array}$ & & & \\
\hline RD. 6 & 0 to 0.6 & & & & 0.003 & 0.007 & 2.7 \\
\hline$W \cdot 10$ & 0.3 to 0.6 & & & & 0.018 & 6.8 & 2.9 \\
\hline TA-1-13 & & & & & 0.003 & 0.14 & \\
\hline TA-1-16 & & & & & 0.005 & 0.29 & \\
\hline
\end{tabular}

demolition was stacked there, and this probably was the sigurce of contamination.) Further sampling and an exploratory trench yielded only one sample of $>20 \mathrm{pCi} / \mathrm{g}$ in this area (Figs. 116 and 117). The chemical analysis of sample W-12 (south of Delta) indicated slightly elevated concentiations of uranium (to $8.6 \mu \mathrm{g} / \mathrm{g}$ ) and fallout levels of ${ }^{239} \mathrm{Pu}(0.09$ $\mathrm{pCi} / \mathrm{g})$. The gross-alpha activity of $>20 \mathrm{pCi} / \mathrm{g}$ in samples from south of Delta was, therefure considered at tributable to uranium (Fig. 116).

At a meeting on November 25, i975 (Table III), the Delta-Building excavation was determined to be decontaminated because (1) no phoswich. detectable activity was ever noted and (2) 14 of 15 soil samples from the trench had $<20 \mathrm{pCi} / \mathrm{g}$ of grossalpha activity, with the only positive sample having $26 \mathrm{pCi} / \mathrm{g}$. The area south of Delta did not require excavation because no phoswich-detectable activity was noted and the maximum surface sample showed $86 \mathrm{pCi} / \mathrm{g}$ of activity, believed to be from uranium.

4. Warehouse 19. During the surface cleanup and survey, a FIDLER located activity south of the Warehouse 19 slab. The source of contamination in this area is not known. Streaks of yellowish-green uranium oxide were later found at a depth of 15 to 30 $\mathrm{cm}$ in that area. The streaks continued downslope to the security patrol road and stopped. The uranium was identified as nornal uranium by mass spectrometry. ${ }^{14}$ (A bit of the sample used for the mass-spectroscopy analysis floated on water as if the uranium were associated with a speck of cardboard.) Ultimately, an area $22 \mathrm{~m}$ long, $15 \mathrm{~m}$ wide, and 0.15 to $1.1 \mathrm{~m}$ deep was excavated. Approximately $300 \mathrm{~m}^{3}$ of soil were $r \in$ moved. An open joint discovered in the tuff was $0.3 \mathrm{~m}$ long, $0.3 \mathrm{~m}$ 

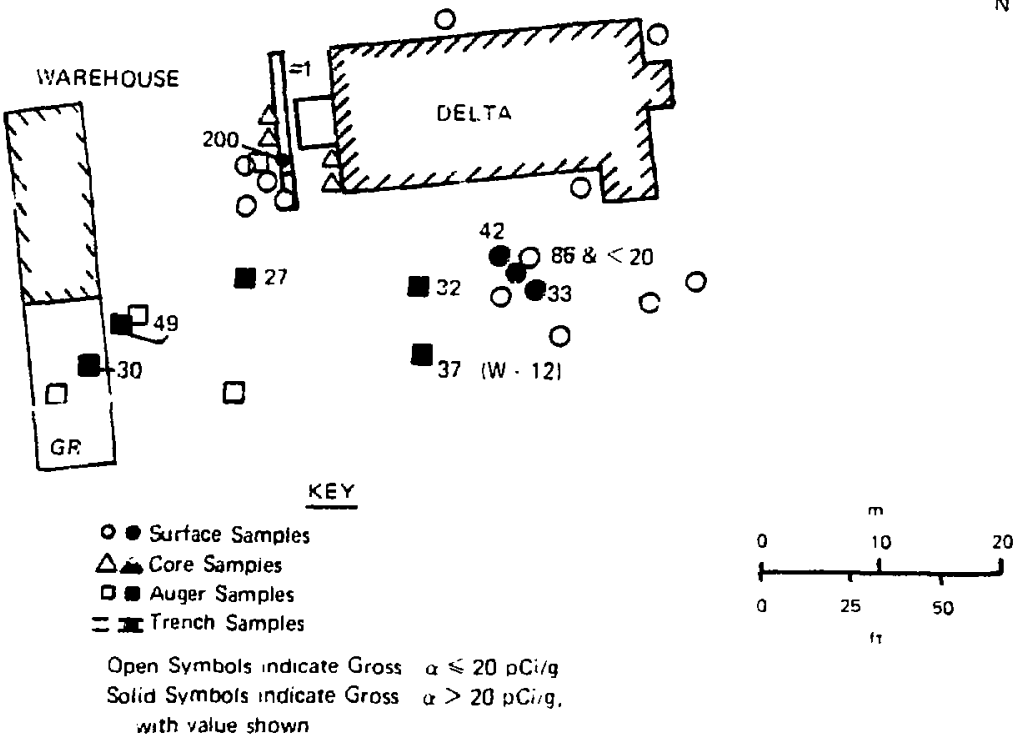

Fig. 116 .

Soil-sampling survey results from Delta-Building area.

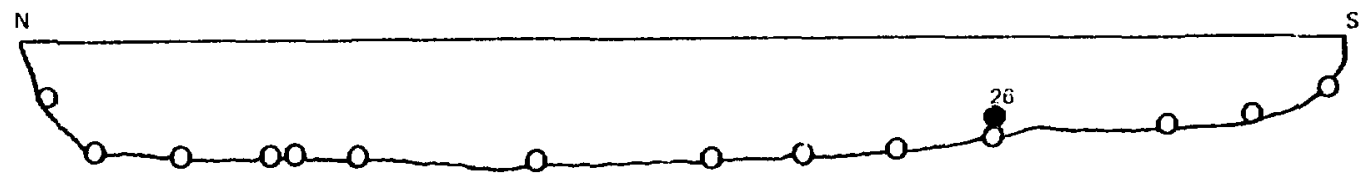

KEY

" Grab sample, Gross - $a \leqslant 20 \mu C_{1} / 9$

- Grab sumple, Gross - $a>20$ pCi/g, with value stiown

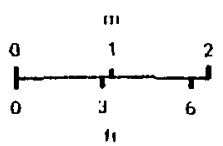

Fig. 117.

Cross section of Delta Trench 1 and associated soil-sampling results (looking east). 
wide, and $1.2 \mathrm{~m}$ deep. The excavation was enlarged and the $7-t 010-\mathrm{cm}$-wide cracks (soil-filled as well as open) extending from the main joint were strveyed. No radinactivity was found. Figure 118 shows the condition and orientution of some of the cracks. The location of the excavation and final sampling resulis are given in Fig. 119.

At a meeting on Novenber 4. 1975 (Table III), the Warehouse 19 excavation was determined to be decontaminated because (1) no phnswichcletectalile activity remained (implying that the streaks of uranium oxide were gone ) and (2) only 3 of 11 samples had gross-alpha activity $>20 \mathrm{pCi} / \mathrm{g}$, with the maximum being $64 \mathrm{pCi} / \mathrm{g}$.

5. Vicinity of TU and TU-1 Buildings. Soil samples taken during the 1974 survey showed slightly elevated uranium levels north of two small buildings formerly used for normal uranium processing (TU) and enriched-uranium storage and

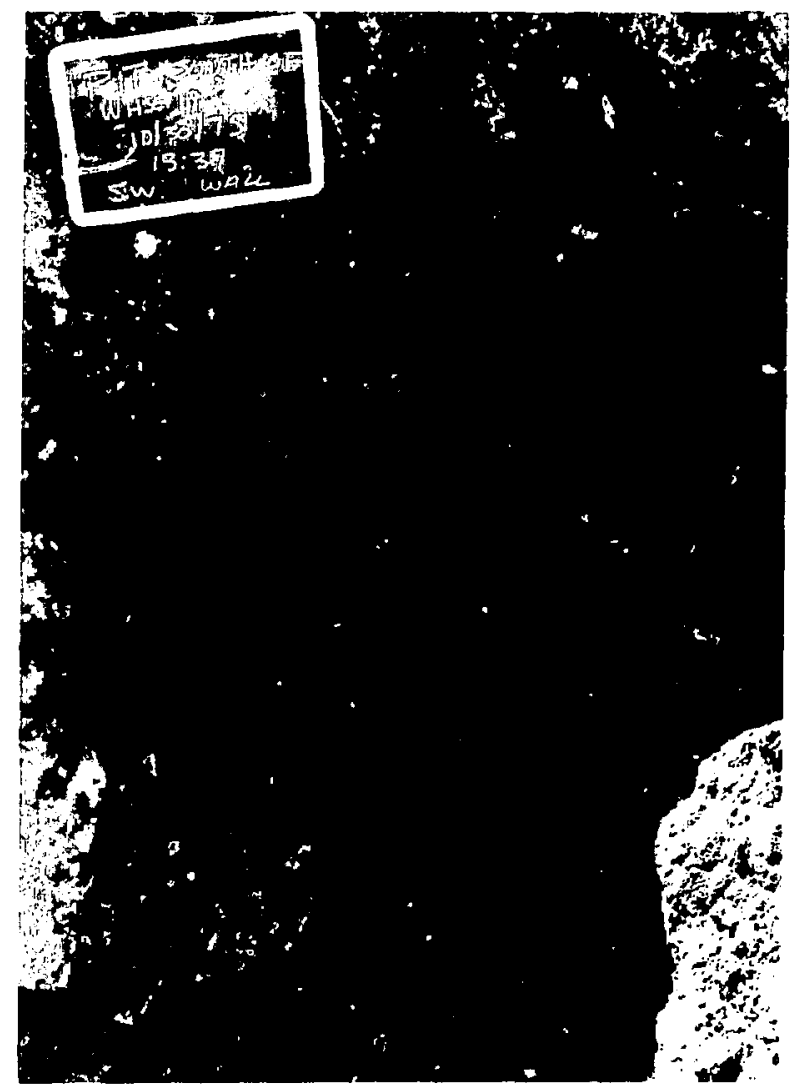

Fig. 118.

Cracks in tuff in the pit excavation just south of Warehouse 19. recovery (TU-1). The activity ranged from 11 to 28 $\mu \mathrm{g} / \mathrm{g}$ (against an average of $2.0 \mu \mathrm{g} / \mathrm{g}$ of uranium background for northern New Mexico locations). (See samples TA-1-17, TA-1-20, and TA-1-AS-2 in Appendix $\mathrm{E}$ for further detail.)

Suil-sampling and surveys during the surface cleanup operations showed uranium contamination near the TU-Building outline. Soil-sarnpling results are given in Fig. 120 and Tabie XVII. One small spot of soil contaminated by uranium oxide read $\sim 250000 \mathrm{c} / \mathrm{min}$ on the FIDLER.

A former TA-I employee recalled that drums of uranium stored outside of TU or TU-1 would ignite spontaneously. The fire would be extinguished by water from a fire hose placed in the cirums until water overflowed onto the ground. A January 8 , 1948 , memo ${ }^{15}$ describes results from one water sample and three soil samples collected in October 1947 after a fire at ' $\Gamma U$. The maximum contamination was $520 \mu \mathrm{g}{ }^{239} \mathrm{U}$ per gram of soil "just outside fence from below TU shop."

The establishti decontamination procedure ras planned-removal of soil to below detection limits on the phoswich, at which time documentation soil samples would be taken and analyzed for grossalpha activity.

As excavation and decontamination progressed, the situation became more complex. A follow-up on slightly positive phoswich readings often led to

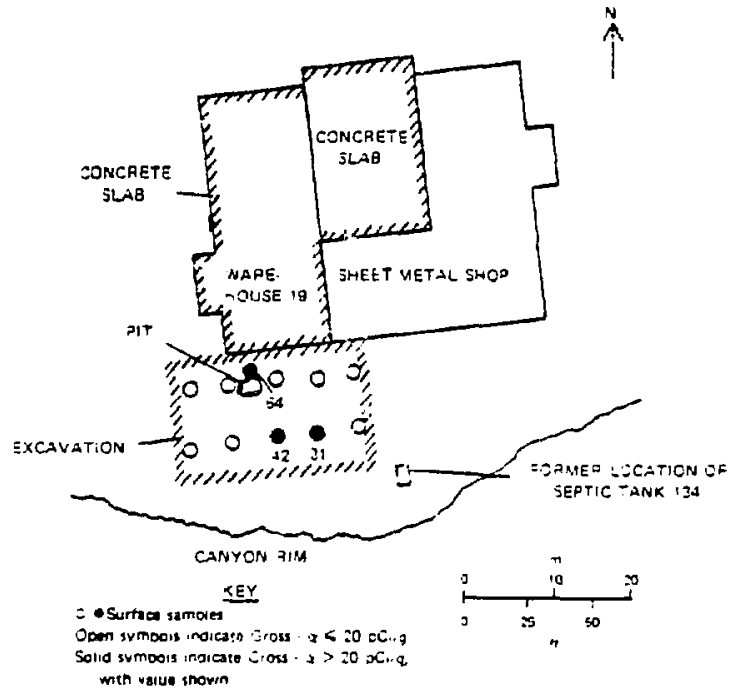

Fig. 119.

Lucation and final soil-sampling results of the Warehouse 19 excavation. 
deeper spots and veins of higher level uranium contamination. Numerous sewer lines, steam lines, storm sewers, and other pipe sections were removed. The highest level of contamination sent survey instruments off-scale and was found in a 3-m-long section of $0.3-\mathrm{m}$-diam corrugated-metal pipe buried 1.5 $\mathrm{m}$ deep. An uncontaminated metal septic tank, 1.22 $\mathrm{m}$ high and $1.22 \mathrm{~m}$ in diameter, was uncovered and removed from the vicinity of Septic Tank 143 (itself listed as having been removed). Because overburden could prevent the phoswich from detecting subsurface contamination, all potentially contaminated areas were excavated to a mininum depth of $0.6 \mathrm{~m}$. All sewer lines that were located were followed and removed, along with any associated contaminated soil. A total of $2815 \mathrm{~m}^{3}$ of soil was removed from the area. The extent of the excavation is depicted in Fig. 121, along with final sampling results. An elevation profile of the excavation is given in Fig. 122. Additional postexcavation drilling was undertaken to help define remaining contamination, and results are presented in Figs. 120 and 123. Two thin (10- to 20 -cm-thick) horizontal veins of uranium contamination showed up in a pit excavation in part of the decontamination area. The veins lie 1.2 and 3.0 $\mathrm{m}$ below the present ground surface in what appears io be a former water drainage area partially filled with soil. One sample from the $1.2-\mathrm{m}$-deep vein had $1200 \mathrm{pCi} / \mathrm{g}$ of gross-alpha activity. The veins were not completely removed pending further exploration to define their extent.

The lack of high activity in drill holes near the veins of contamination (TU-KD-1, $-2,-2 \mathrm{~A},-2 \mathrm{~B}$, and

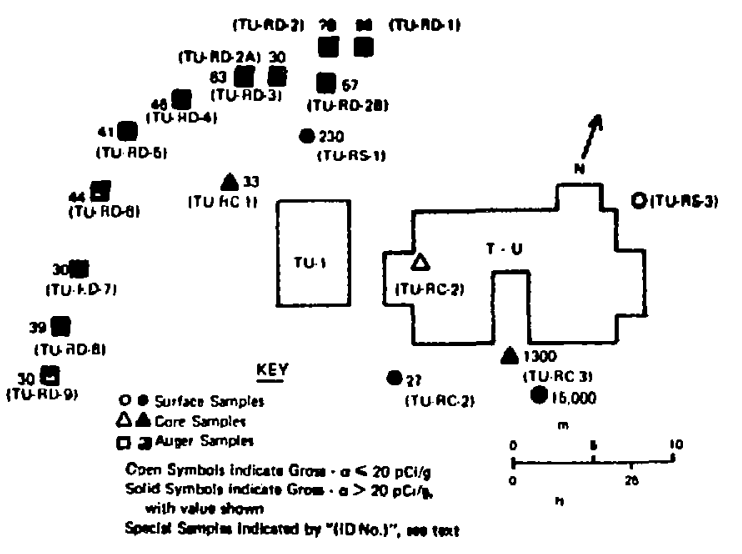

Fig. 120.

Soil-sampiing results from TU-Building area.
-3 in Fig. 123 and T'able XVII) indicated either that sufficient dilution occurred in 10.2 -cm-diam by 0.6 $\mathrm{m}$-long augered samples to greatly reduce the concentrations or that the extent of the contaminated veins is quite limited. Samples from additional holes made around the perimeter of the abovementioned excavation indicated $<20 \mathrm{pCi} / \mathrm{g}$ of grossalpha activity in most samples and a maximum of $46 \mathrm{pCi} / \mathrm{g}$.

At meetings on November 25, 1975, and April 23, 1976 (Table III), the excavation in the TU area was determined to be decontaminated because (1) except for the two known veins of contamination, no phoswich-detectable activity remained in the excavation (soil-filled and open joints in the tuff were surveyed carefully); (2) 30 of 31 soil samples from the excavation had $<20 \mathrm{pCi} / \mathrm{g}$ of gross-alpha activity, with the only positive sample having 40 $\mathrm{pCi} / \mathrm{g}$; and (3) the two veins of contamination were sufficiently thin and deep that any future projects would probably dilute the contamination to much lower concentrations.

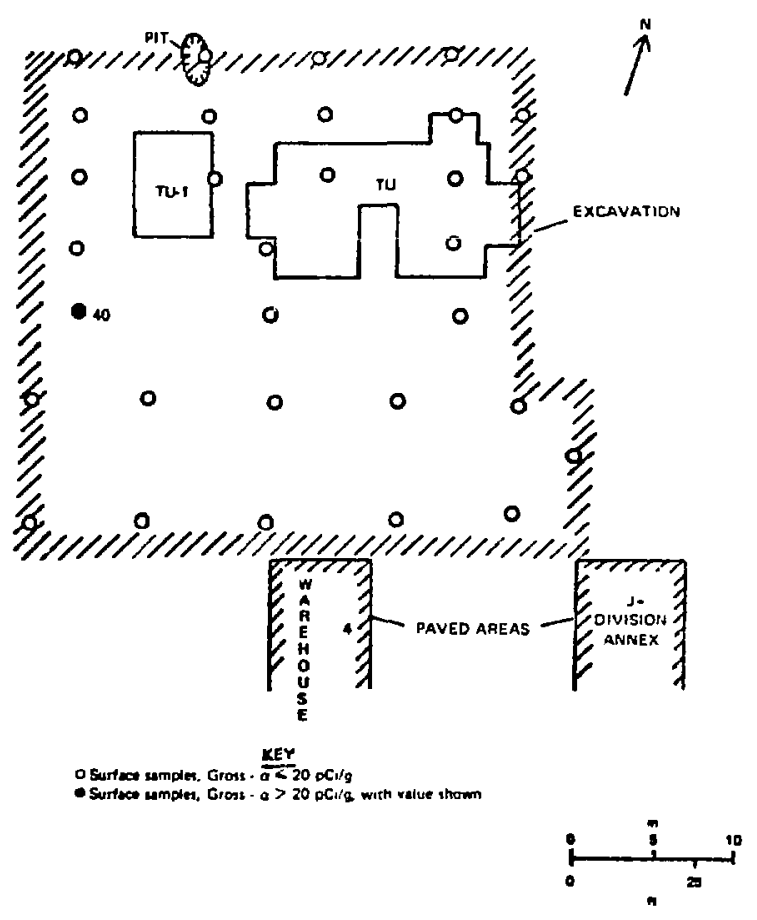

Fig. 121.

Excavation and postdecontamination soilsampling results at $T U$-Building area. 
TABI.F XVII

RADIOCHEMJSTRY HESULTS HROM TU-IBUIIDING AREA

\begin{tabular}{|c|c|c|c|c|c|c|c|c|c|}
\hline $\begin{array}{c}\text { Sample } \\
\text { Identification }\end{array}$ & $\begin{array}{c}\text { Depth } \\
\text { (m) }\end{array}$ & $\begin{array}{l}383.284 U \\
(\mathrm{pC} i / \mathrm{i})\end{array}$ & $\begin{array}{l}{ }^{288.230} \mathrm{U} \\
(\mathrm{pCi} / \mathrm{g})\end{array}$ & $\begin{array}{c}{ }^{288} \mathrm{U} \\
(\mathrm{pCi} / \mathrm{E})\end{array}$ & $\begin{array}{l}{ }^{238} \mathrm{Pu} \\
(\mathrm{pCi} / \mathrm{g})\end{array}$ & $\begin{array}{l}{ }^{298} \mathrm{Pu} \\
(\mathrm{pCi} / \mathrm{g})\end{array}$ & $\begin{array}{l}\text { Lab. } \\
\text { Gross } \\
\text { Alpha } \\
(\mathrm{pCi} / \mathrm{s})\end{array}$ & $\begin{array}{l}\text { Lab. } \\
\text { Gross } \\
\text { Beta } \\
\text { (pCi/g) }\end{array}$ & $\begin{array}{c}\text { Total } \\
\text { Uranium } \\
(\mu / g)\end{array}$ \\
\hline TU-RS-1 & & 120 & 3.0 & 110 & & & & & \\
\hline TU-RS-2 & & 60 & 2.8 & 58 & & & & & \\
\hline TU.KS-3 & & 0.81 & 0.01 & 0.85 & & & & & \\
\hline TU-RC-1 & $\begin{array}{lr}0 & \text { to } 0.05 \\
0.20 & \text { to } 0.63\end{array}$ & $\begin{array}{l}20 \\
34\end{array}$ & $\begin{array}{l}1.5 \\
0.38\end{array}$ & $\begin{array}{l}13 \\
33\end{array}$ & & & & & \\
\hline TU.RC-2 & $\begin{array}{l}0.05 \text { to } 0.10 \\
0.20 \text { tu } 0.60\end{array}$ & $\begin{array}{l}1.1 \\
2.0\end{array}$ & $\begin{array}{l}0.065 \\
0.070\end{array}$ & $\begin{array}{l}1.2 \\
2.2\end{array}$ & & & & & \\
\hline TU.RC-3 & $\begin{array}{l}0.05 \text { to } 0.10 \\
0.20 \text { to } 0.64\end{array}$ & $\begin{array}{r}160 \\
1000\end{array}$ & $\begin{array}{l}6.0 \\
360\end{array}$ & $\begin{array}{l}120 \\
820\end{array}$ & & & & & \\
\hline TU-RD-I & 0.6 to 1.2 & & & & 0.004 & 0.45 & 130 & 146 & 330 \\
\hline TU.RD.3 & 1.2 to 1.8 & & & & 0.002 & 0.027 & 17 & 13 & 24 \\
\hline
\end{tabular}

6. Septic Tank 140 (for Buildings HT and FP) and Vicinity. Septic Tank 140 served as the sanitary-sewer septic tank for Building HT and, for a while, for a foundry (FP) for nonradioactive, nonferrous metals.

Sludge found in the tank was contaminated with uranium. The sludge read $60000 \mathrm{c} / \mathrm{min}$ on the phoswich and the activity was identified as uranium by gamma spectroscopy. The sludge sample submitted for ${ }^{239} \mathrm{Pu}$ radiochemistry contained $0.62 \mathrm{pCi} / \mathrm{g}$ of ${ }^{238} \mathrm{Pu}$. The inlet and outlet lines to Septic Tank 140 were also contaminated.

The rectangular, concrete septic tank had been cast in place in the tuff. Because of the likelihood of tank breakup during removal, the $\sim 1.1$-m-deep sludge in the tank was removed by backhoe and loaded directly into a plastic-lined dump-truck bed. The tank and the inlet and outlet lines were then removed. Associated contaminated soil on private property was removed to below phoswich-detection limits. However, to the west of the outlet excavation (on ERDA property) steep terrain prevented removal of all known contamination. The final sampling results are given in Figs. 124 and 125.
At a meeting on January 30,1976 (Table III), the Septic Tank 140 excavations on private land were determined to be decontaminated because (1) no phoswich-detectable act ${ }^{\circ}$ ity remained in the pit or trenches and (2) of the 56 soil sainples, only 5 had gross-alpha activity $>20 \mathrm{pCi} / \mathrm{g}$, with the maximum being $48 \mathrm{pCi} / \mathrm{g}$.

7. General Wo rehouse Area. During the phoswich survey (Secs. III.A.3 and III.D.8) several significant spots of uranium contamination were located in the warehouse area east of HT Building. Along the western edge of the warehouse area, parallel to the slabs of Warehouses 4 and 5 , a $\sim 57$ $\mathrm{m}$-long drainage course or former trench contained visible yellow spots of uranium-oxide contamination. Soil samples from the suspect spots were analyzed for gross-alpha activity; the data are shown in Fig. 126. Considerable excavating was done to remove this contamination. (Two smaller spots of uranium contamination near Warehouses 6 and GR were also exc?vated.) Slightly positive phoswich readings between Warehouses 4 and 5 led to hand-digging which uncovered a $15.3-\mathrm{kg}$ cylinder 


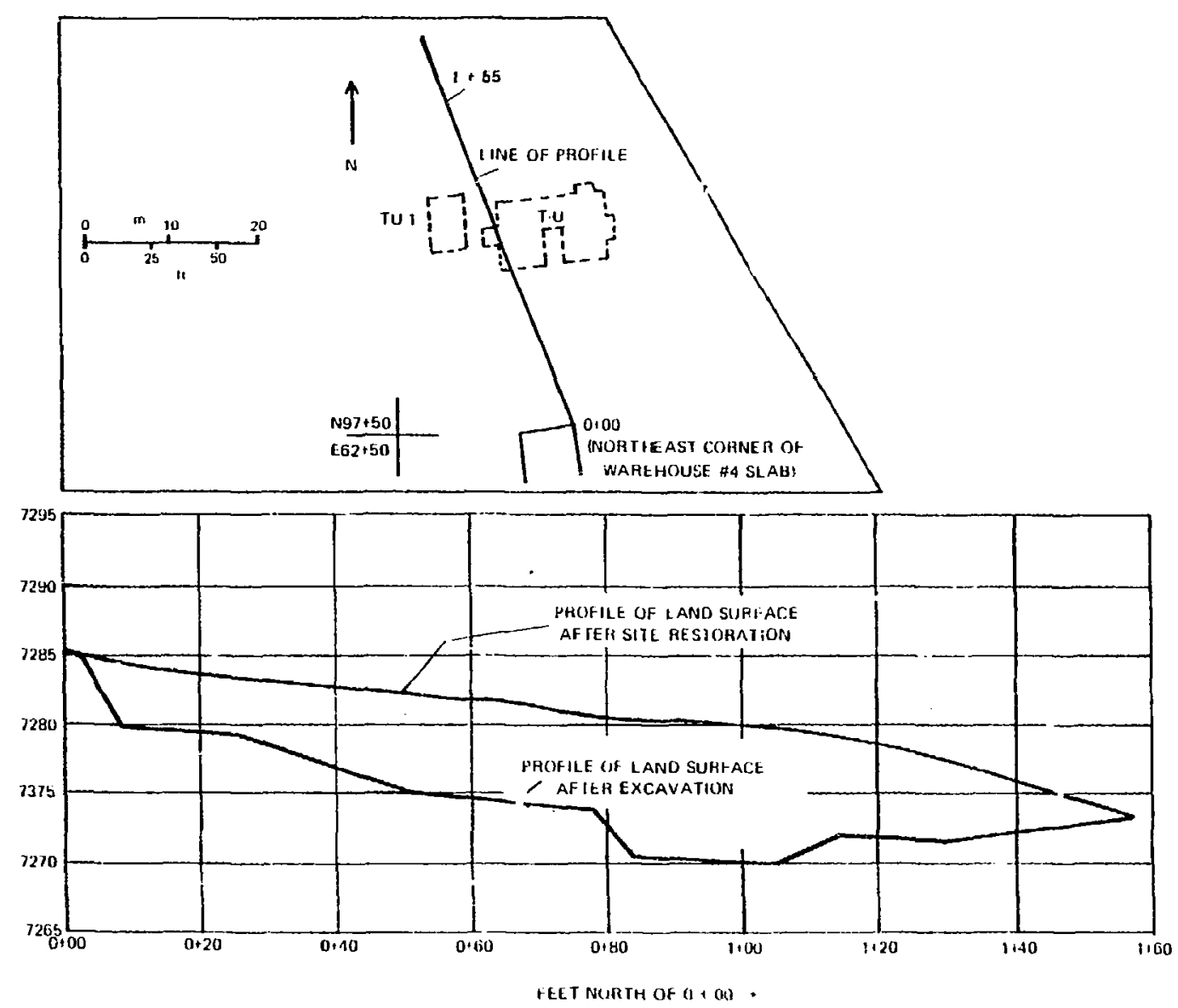

Fig. 122.

Profiles of the TU-area land surface after excavation (before backfilling) and after site restoration. 

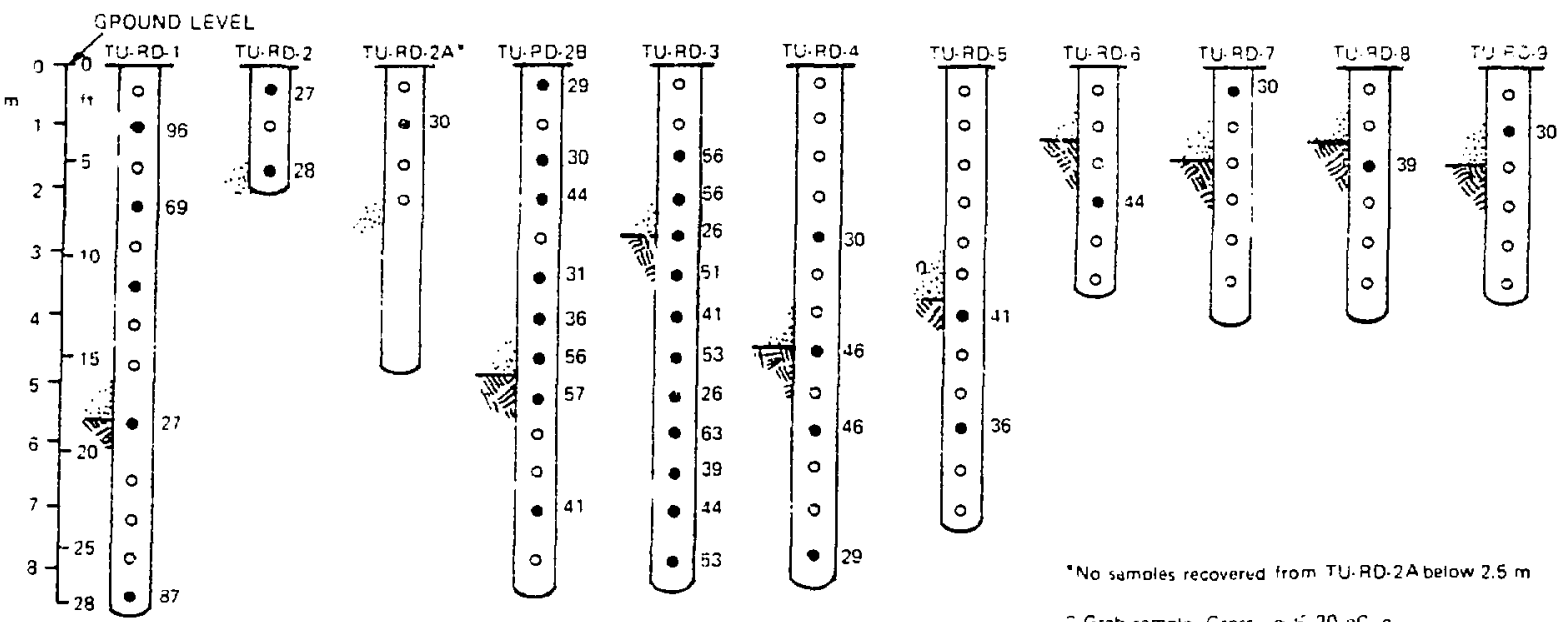

- No samoles recoverua from TU. RO.2A below $2.5 \mathrm{~m}$

- Grab samole. Gross a $200 \mathrm{DC} .9$

- Grab sampie. Gross a $>20$ DC i. with valup snown

$\therefore F \cdot I 1$

密Tutf

Fig. 123.

Depth profiles and soil-sampling results from $1 U-R D$ survey drill holes.

of normal uranium buried $\sim 0.6 \mathrm{~m}$ deep. The com . plete area was excavated, and final sampling results are given in Fig. 127.

At a meeting on June 8, 1976 ('Table III), the warehouse area excavations were determined to be decontaminated because (1) no phoswirhdetectable activity remained and (2) only 2 of 69 samples had gross-alpha activity $>20 \mathrm{pCi} / \mathrm{g}$, with the maximum $\mathrm{t}$.ng $36 \mathrm{pCi} / \mathrm{g}$.

8. Miscellaneous Small Areas. Seventeen contaminated spots (Table XVIII and Fig. 128) were located during the phoswich survey of the entire TA1 area in March-A pril 1976 undertaken to determine whether any spots of contamination had been missed in preceding cleanup operations. Initial hand-digging and dirt removal helped to show whether the contamination was on the surface or at depth. This initial exploration at sample locations $1-7,9,13$, and 15-17 (Fig. 128) showed no contamination that was not removable by handshoveling. Less than one dump-truck load of contaminated soil was put in plastic bags for disposal. The locations were resampled for gross-alpha activity (Table XVIII). On the basis of these results, the areas were determined to ke decontaminated at an April 23, 1976, meeting (Table III). Necessary ex- cavation at the other five locations (numbers 8,10 12, and 14 in Fig. 128) is discussed in detail in Secs. III.C. 1 and 3 and III.D.7.

\section{E. Septic Tank Removal}

The plans for intensive strvey and decontamination of TA-1 included the location and removal of all septic tanks thought to have been abandoned in place during the original demolition. Locations of these septic tanks are shown in Figs. 8 and 128 . Table XIX lists the type of tank, contamination status as found, and the date of removal. Table XX summarizes the findings for the uncontaminated tanks. Septic Tanks 137, 138, and 140 were discussed in previous sections of this report.

Septic Tank 139 was listed in the records as having been abandoned, but it was not located. An outlet pipe of the proper diameter and in the nroper location (according to drawings) was found where Septic Tank 139 was supposed to be. The earth was also softer in that location, as would be expected for fill. We therefore believe that the tank had been removed and that the records were incorrect.

When its outlet line was followed backward, Septic Tank 141 was found $18.3 \mathrm{~m}$ west of the loeation 


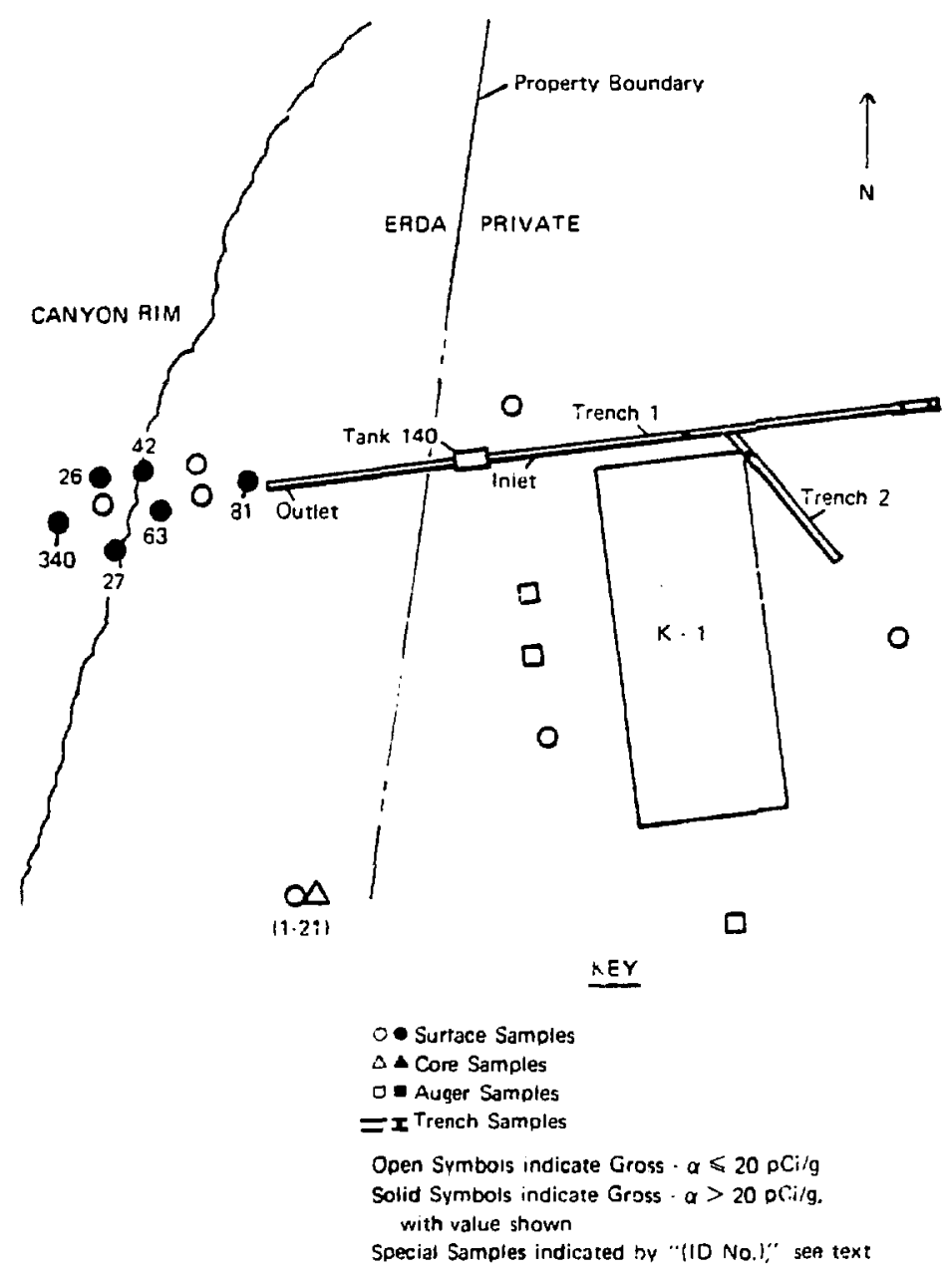

Fig. 124.

Septic Tank 140 excavation locations and postdecontamination soil-sampling results.

indicated on drawings. The outlet line and $\sim 46 \mathrm{~m}$ of inlet line were removed with the tank.

An unidentified, uncontaminated septic tank was removed during excavations of uraniumcontaminated soil in the TU area. It was near the map location of Septic Tank 143, listed in the records as having been removed. The tank removed may have been Septic Tank 143 .

Septic Tanks 268 and 269 were listed in one set of records as having been removed but there was no record of removal in another set of records. Tank 268 served TU Building and apparently had been removed because nothing was found at its map location within the TU excavation. Tank 269 served Building S-1 (a storage building) and was located in an area that is now a paved parking lot. Engineering records show that Tank 269 comprised three joints of sewer tile, $0.91 \mathrm{~m}$ long and $0.61 \mathrm{~m}$ in diameter. Because of its location and the fact that it served a storage building, no attempts were made to verify its removal.

Tank 275 was listed as having been abandoned but had not been located in earlier searches. The hillside location of Tank 275 had been bulldozed to below the level where the tank should have been; therefore, the tank probably had been removed. On the hillside below the vicinity of Tanks 269 and 275, an abandoned septic tank of the approximate dimensions of Tank 275 (as listed in the records) was found lying on its side, and may have been Tank 275. 

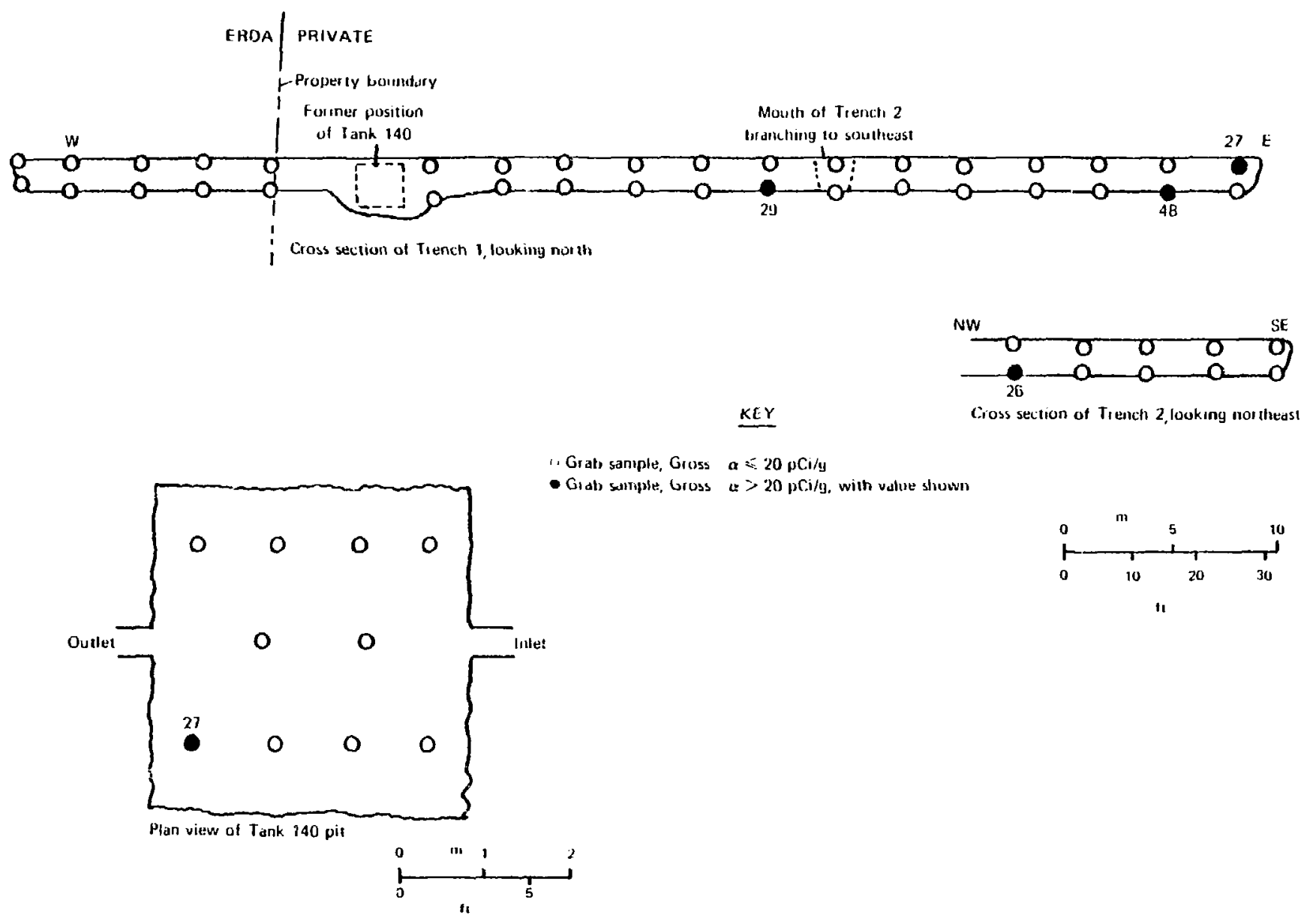

Fig. 125 .

Trench and pit soil-sampling results; postderontamination detail, Septic Tank 140. 

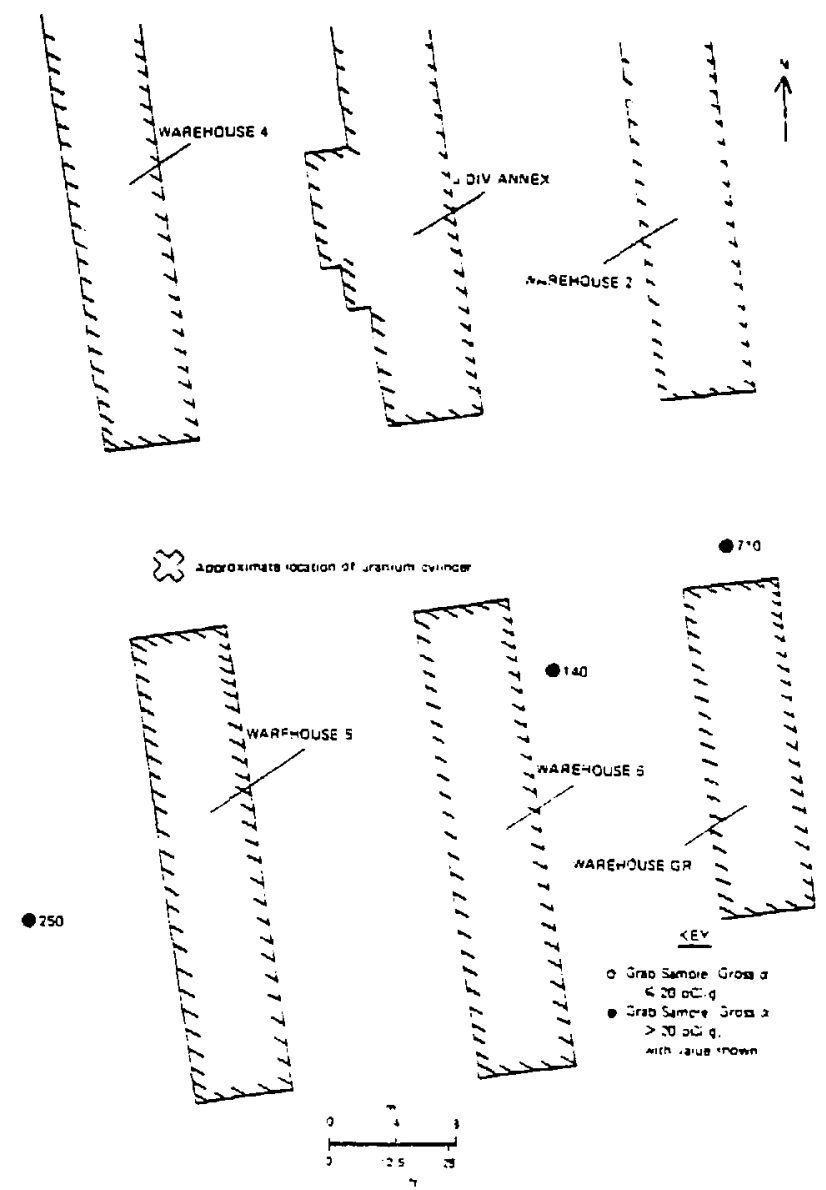

Fig. 126

Locations of soil-sampling surveys in the warehouse area.

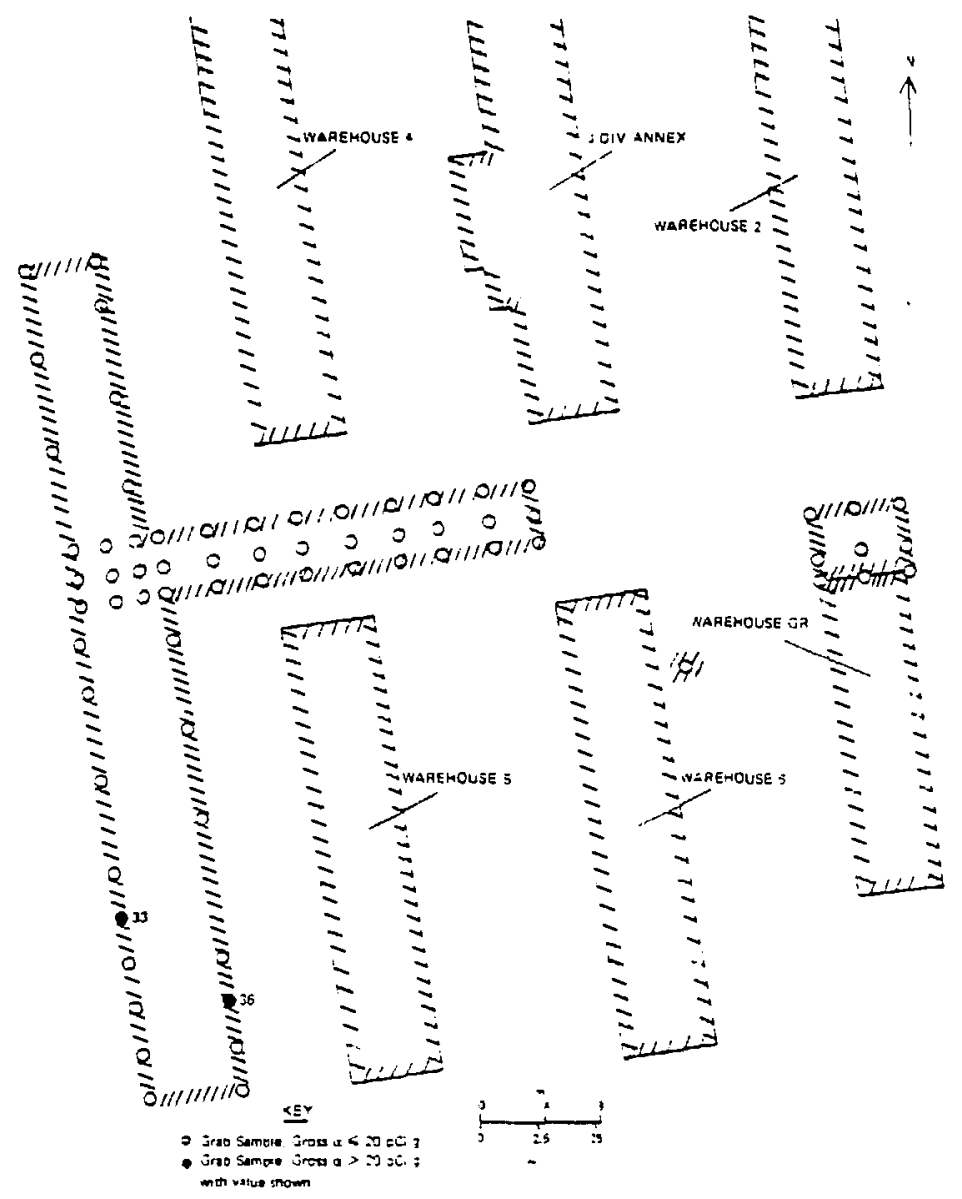

Fig. 127.

Excavation locations and postdecontamination soil-sampling results in the warehouse area. 
TABLE XVIII

SLRVEY AND DECONTAMINATION RESLLTS

\begin{tabular}{|c|c|c|c|c|c|c|c|}
\hline \multirow{3}{*}{$\begin{array}{l} \\
\text { Adrin. } \\
\text { Survey } \\
\text { Yo. }\end{array}$} & \multicolumn{5}{|c|}{ Initial Results } & \multirow{2}{*}{\multicolumn{2}{|c|}{ Postcleanup Sampling Results }} \\
\hline & \multirow[b]{2}{*}{ Location } & \multirow{3}{*}{ 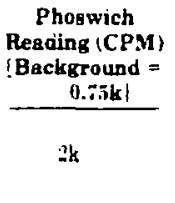 } & \multirow{3}{*}{$\begin{array}{c}\begin{array}{c}\text { Pancake G-.M } \\
\text { Reading (mR/h) } \\
\text { (Background = } \\
0.05 \mathrm{mR} / \mathrm{h} \text { ] }\end{array} \\
0.1\end{array}$} & \multirow{3}{*}{$\frac{\substack{\text { ZnS Gross } \\
\text { Alpha } \\
(\mathrm{pCV} / \mathrm{g})}}{\leq 20}$} & \multirow[b]{2}{*}{ Remarks } & & \\
\hline & & & & & & $\begin{array}{c}\text { ZnSGross } \\
\text { Alpha } \\
\text { (pCi/g) }\end{array}$ & Remarks \\
\hline : & $\begin{array}{l}X: 00+16 \\
\mathrm{E} \quad 61+-3\end{array}$ & & & & $\begin{array}{l}\text { No alpha: " }{ }^{\text {"IT }} \mathrm{C} \text { sus- } \\
\text { pected }\end{array}$ & $s$. & Some \\
\hline 2 & $\begin{array}{ll}\searrow & 98+90 \\
\mathrm{E} & 04+96\end{array}$ & $3 k$ & 0.3 & 340 & Below nutfall pipe & 90 & Sorge uram $2 \mathrm{~m}$ and ${ }^{13} \mathrm{Cs}$ \\
\hline 3 & $\begin{array}{ll}\stackrel{N}{*} 98+57 \\
\mathrm{E} & 64+23\end{array}$ & $2 k$ & 0.1 & $\leq 20$ & $\begin{array}{l}\text { Near TU: suspect } \\
\text { uranuum }\end{array}$ & 60 & \\
\hline$t$ & $\begin{array}{lr}\therefore \quad 98+42 \\
\mathrm{E} & 64+45\end{array}$ & $3 k$ & 0.2 & 130 & Same as No. 3 & $5: 20$ & $\begin{array}{l}\text { Some uranium in pre. } \\
\text { tleanup sample }\end{array}$ \\
\hline 5 & $\begin{array}{ll}\text { i } & 98+45 \\
\text { E } & 86 \div 49\end{array}$ & L5t & 5.0 & \pm 60 & $\begin{array}{l}\text { Vear Sigma: vetinite } \\
\text { uranium; yellow gputs } \\
\text { seen }\end{array}$ & 60 & $\begin{array}{l}\text { SLme uranilum by gamma } \\
\text { scan }\end{array}$ \\
\hline b & $\begin{array}{ll}\stackrel{N}{9} 98+53 \\
\overline{\mathrm{E}} & 66+66\end{array}$ & $3 k$ & i). 5 & 610 & Same as Yo. $\overline{\mathbf{j}}$ & 30 & $\begin{array}{l}\text { Lranium and thorium } \\
\text { by gamma scan }\end{array}$ \\
\hline$:$ & $\begin{array}{ll}N & 98+66 \\
E & 6 i-25\end{array}$ & 26 & 0.2 & 33 & Same aв Yo. 5 & 40 & \\
\hline 3 & $\begin{array}{lr}\therefore & 100-32 \\
E & 5+3+39\end{array}$ & $3 \mathbf{k}$ & 0.08 & $s 20$ & $\begin{array}{l}\text { Acrd sewer; no aipha: } \\
\text { outside the tence }\end{array}$ & $\begin{array}{l}\text { See Sec. } \\
\text { UII.C. } 3\end{array}$ & ${ }^{10} C_{s}$ definute \\
\hline 9 & $\begin{array}{ll}\therefore & 96+07 \\
\text { E } & 60+43\end{array}$ & $5 \mathbf{k}$ & $0 . \overline{1}$ & 980 & $\begin{array}{l}\text { Left over irom Tank } \\
\text { I } 40 \text { excavation? }\end{array}$ & $\leq 20$ & $\begin{array}{l}\text { Cranium in precieanup } \\
\text { sample }\end{array}$ \\
\hline 10 & $\begin{array}{ll}N & 95+55 \\
E & 62+90\end{array}$ & $10 k$ & 1.0 & 250 & $\begin{array}{l}\text { East of } \mathrm{HT} \text {; detinite } \\
\text { uranium; yellow spots } \\
\text { yeen }\end{array}$ & $\begin{array}{l}\text { See Sec. } \\
\text { III.D.7 }\end{array}$ & \\
\hline 11 & $\begin{array}{ll}N & 96+1) 6 \\
E & 64+\infty\end{array}$ & $20 k$ & 20 & 140 & $\begin{array}{l}\text { Single spot under } \\
\text { asphalt, yellow spot }\end{array}$ & $\begin{array}{l}\text { See Sec. } \\
\text { III.D.F }\end{array}$ & \\
\hline 12 & $\begin{array}{ll}X & 96-30 \\
\mathrm{E} & 64+39\end{array}$ & tk & 0.3 & 70 & $\begin{array}{l}\text { lmbedded in asphalt. } \\
\text { proobably uranium }\end{array}$ & $\begin{array}{l}\text { See Sec. } \\
\text { [L.D.7 }\end{array}$ & \\
\hline 13 & $\begin{array}{ll}\mathrm{N} & 94+41 \\
\mathrm{E} & 65-93\end{array}$ & $3 \mathbf{k}$ & 0.2 & 170 & $\begin{array}{l}\text { Area near Theta-1 on } \\
\text { surface only, un- } \\
\text { known composition }\end{array}$ & $\begin{array}{c}+ \text { oi } 8 \\
\text { samples } \\
>20 \mathrm{pCi} / \mathrm{g} \\
\operatorname{maz} 50 \\
\mathrm{pCi} / \mathrm{g}\end{array}$ & $\begin{array}{l}\text { L'sanium and }{ }^{\text {"MC }} \mathrm{C} \text { in } \\
\text { precleanup sample }\end{array}$ \\
\hline 14 & $\begin{array}{ll}N & 35+40 \\
E & 6 i+43\end{array}$ & $2 k$ & 0.2 & 380 & $\begin{array}{l}\text { Single spot on road, } \\
\text { unknown composition }\end{array}$ & $\begin{array}{l}\text { See sec. } \\
\text { III.C. } 1\end{array}$ & $\begin{array}{l}\text { Uranum and thorism } \\
\text { by gamma stan }\end{array}$ \\
\hline $1 \overline{0}$ & $\begin{array}{ll}X & 95+42 \\
E & 58+49\end{array}$ & $1.5 \mathrm{k}$ & 0.2 & 400 & $\begin{array}{l}\text { Below Sigma cooling } \\
\text { toser, unknown } \\
\text { Ersposition }\end{array}$ & 520 & Same as .No. 14 \\
\hline 16 & $\begin{array}{ll}\text { N } & 95+61 \\
E & 73+21\end{array}$ & Background & Beckgrourid & $\leq 20$ & $\begin{array}{l}\text { Suspicious, but \& } \\
\text { false alarm }\end{array}$ & & $\begin{array}{l}\text { Thorium daughter peaks } \\
\text { bsible in gamma scan: } \\
\text { no americium or pluton- } \\
\text { iun peaks vieible on } \\
\text { Lung Counter }\end{array}$ \\
\hline$: i$ & $\begin{array}{lr}\therefore \quad 95+19 \\
& 7 i+78\end{array}$ & Background & Background & $5: 0$ & Same as No. 16 & & \\
\hline
\end{tabular}




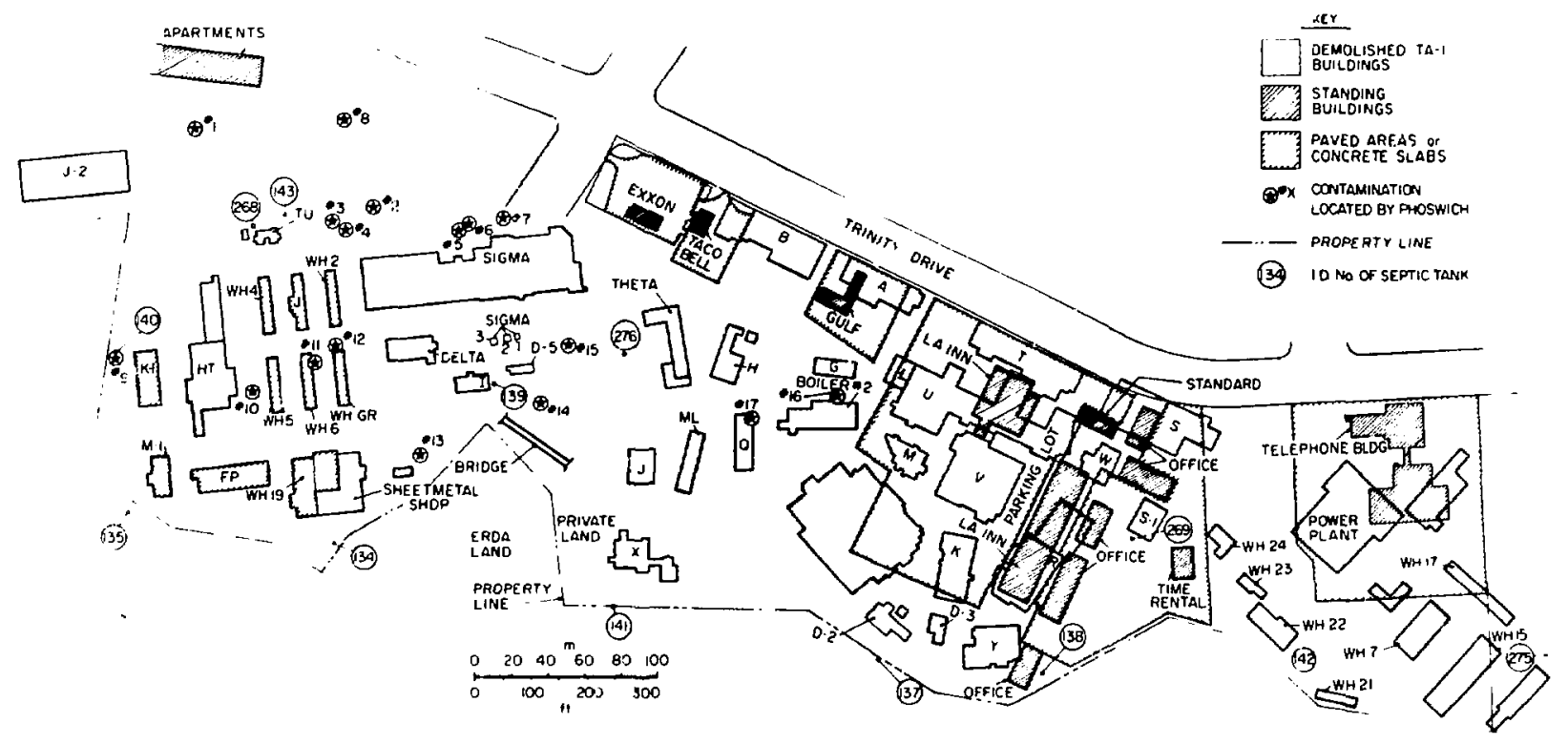

Fig. 128.

Locations of contamination located in March-April 1976 phoswich survey.

Septic Tank 276 served Theta Building, a warehouse with no known history of radioactivity. It was listed in one record as having been abandoned in 1946, in a later record as having been removed, and in another as not being locatable during the TA1 demolition in the 1960s. Because of this uncertainty a concerted effort was made to find the tank. Since the tank was not found in a trench (Trench 1 in Fig. 129) transecting its map location, two trenches (Trenches 2 and 3 in Fig. 129) were then dug to the west to find the outlet line. The line, first found in the third trench, consisted of $12.5-\mathrm{cm}$ diam, $30-\mathrm{cm}$-long joints of vitrified clay-tile pipes butted together. Portions of the line were excavated and ultimately the tank was found $\sim 4$ m east of the mapped iocation. The tank was cast-in-place concrete with a cast-iron inlet line. No contamination was associated with the line or tank; however, the tank and pipe were taken to the LASL radioactive waste disposal area. Some near-surface gross-alpha contamination was found at depths shallower than the line near the edge of the excavation for the tank and at one spot each in Trenches 1 and 2 (Fig. 129); the maximum level was $\sim 700 \mathrm{pCi} / \mathrm{g}$. These spots may have been related to the $H$-Theta acid-sewer overflow (see Sec. III.C.1 and Fig. 89). A total of 28 $\mathrm{m}^{3}$ of soil was excavated from these three spots. Documentary postcleanup samples showed no remaining contamination.

\section{F. Developed Areas with Contamination Potential}

Exploration and decontamination operations within the currently undeveloped portions of TA-1 indicated that some contamination might remain in already developed areas. The developed areas were investigated as thoroughly as was practicable without disturbing existing buildings or property improvements. Possibly contaminated regions included the vicinity of former Buildings $U$ and $W$ now under the Los Alamos Inn structures and parking lot (possible tritium contamination) and areas now under Trinity Drive (possible alpha-emitter and fission-product contamination). These areas had been decontaminated during original demolition in the 1950s and 1960s, extensively surveyed, and considered to be adequately decontaminated at that time (see Sec. I.B for the methods and 
SIMMARY AND DISPOSITION OF SEPTIC TANKS FROM TA-1 CLEANLP OPERATIONS

\begin{tabular}{|c|c|c|c|}
\hline $\begin{array}{c}\text { Tanks } \\
\text { Number }\end{array}$ & $\begin{array}{l}\text { Tank Material and } \\
\text { Outside Dimensiuns } \\
\text { (as found) or Status }\end{array}$ & Contamination Status & $\begin{array}{c}\text { Removal } \\
\text { Dote }\end{array}$ \\
\hline 134 & $\begin{array}{l}\text { Prefabricated concrete } \\
1.52 \mathrm{~m} \text { wide by } 2.79 \mathrm{~m} \\
\text { long by } 2.01 \mathrm{wh} \text { high }\end{array}$ & None (wag full of dirt) & $9,26,75$ \\
\hline 135 & $\begin{array}{l}0.10-\mathrm{ra} \text {-thick reinforced } \\
\text { concrete (prefabricated) } \\
1.07 \mathrm{~m} \text { wide by } 2.53 \mathrm{~m} \\
\text { long by } 1.73 \mathrm{~m} \text { high }\end{array}$ & $\begin{array}{l}\text { Yone (was full of } \\
\text { water) }\end{array}$ & $9 / 26,75$ \\
\hline $1: 37$ & $\begin{array}{l}\text { Cylindrical metal } 1.83-\mathrm{m} \\
\text { diam by } 1.22 \mathrm{~m} \text { high }\end{array}$ & $\begin{array}{l}\text { Trace of }{ }^{20} \mathrm{Pu} \text { in } \\
\text { water: } 114 \mathrm{pCig}{ }^{200} \mathrm{Pu} \\
\text { in sludge }\end{array}$ & $81117:$ \\
\hline 138 & $\begin{array}{l}\text { Cylindrical metal } 1.22-\mathrm{m} \\
\text { diam by } 1.22 \mathrm{~m} \text { high }\end{array}$ & $\begin{array}{l}\text { None in tunk sludge; } \\
\text { aspu in surrounding } \\
\text { soil }\end{array}$ & $10 / 16 / 75$ \\
\hline 139 & $\begin{array}{l}\text { Vot found: believed to } \\
\text { have been removed earlier }\end{array}$ & & \\
\hline 140 & $\begin{array}{l}\text { Reinforced concrete } \\
\text { (cast in place) } 1.32 \mathrm{~m} \\
\text { wide by } 3.04 \mathrm{~m} \text { long by } \\
1.51 \mathrm{~m} \text { high }\end{array}$ & $\begin{array}{l}\text { Uranium in sludge and } \\
\text { water }(60000 \mathrm{c} / \mathrm{min} \text { on } \\
\text { phoswich): trace of "Pu }\end{array}$ & $1 / 20 / 76$ \\
\hline 141 & 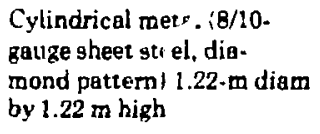 & None in tank sludge & $9 / 29 / 75$ \\
\hline$: 42$ & $\begin{array}{l}\text { Reinforced concrete } 1.52 \\
\text { m wide by } 3.04 \mathrm{~m} \text { long by } \\
1.83 \mathrm{~m} \text { high }\end{array}$ & None in tank siudge & $1,16 / 76$ \\
\hline $\begin{array}{l}\text { Cnkrown } \\
\text { (143?) } \\
\text { lin } T \text {. } \\
\text { area! }\end{array}$ & $\begin{array}{l}\text { Cylindrical metal } 1.22 \cdot \mathrm{m} \\
\text { diam by } 1.22 \mathrm{~m} \text { high }\end{array}$ & None in tank sludge & $11 / 10 / 75$ \\
\hline 268 & $\begin{array}{l}\text { Not found: location in. } \\
\text { cluded in TU excavation }\end{array}$ & & \\
\hline 269 & $\begin{array}{l}\text { No attempt to locate; } \\
\text { tan's in developed area }\end{array}$ & & \\
\hline 275 & $\begin{array}{l}\text { Vot found: location was } \\
\text { excavated }\end{array}$ & & \\
\hline 276 & $\begin{array}{l}\text { Concrete (cast in placel } \\
1.22 \mathrm{~m} \text { wide by } 1.83 \mathrm{~m} \text { long } \\
\text { by } 1.22 \mathrm{~m} \text { high }\end{array}$ & None (was full of dirt) & $8 / 30 / 77$ \\
\hline
\end{tabular}


TABLE XX

\section{SAMPLING RESULTS FROM EXCAVATIONS FOR REMOVAL OF UNCONTAMINATED SEPTIC TANKS}

\begin{tabular}{|c|c|c|c|}
\hline Septic Tank No. & $\begin{array}{c}\text { No. } \\
\text { Samples }\end{array}$ & $\begin{array}{c}\text { No. Samples } \\
\text { Containing } \\
>20 \mathrm{pCi} / \mathrm{g} \\
\end{array}$ & $\begin{array}{c}\text { Gross } \\
\text { Alpha } \\
\text { (pCi/g) }\end{array}$ \\
\hline 134 & 21 & $1^{\mathrm{a}}$ & 51 \\
\hline 135 & 22 & 0 & $\ldots$ \\
\hline 141 & 17 & 0 & $\ldots$ \\
\hline 142 & 4 & 0 & \\
\hline $\begin{array}{l}\text { Unl:nown tank, TU } \\
\text { area }^{\text {b }}\end{array}$ & 0 & \multicolumn{2}{|c|}{$\begin{array}{l}\text { Determined uncontaminated } \\
\text { (by instrumental survey) }\end{array}$} \\
\hline
\end{tabular}

findings). The present extensive development in these areas made it impracticable to attempt subsurface sampling for verification of decontamination. In fact, there was little likelihood of major contamination from the TA-1 buildings that were once located where development now exists, and mixing and dilution of any contamination during demolition and subsequent redevelcpment would probably have reduced levels to insignificant values. Therefore, aside from the sampling and theoretical evaluations described below, no exploratory excavation was conducted in developed areas.

\section{Vieinity of Buildings $U$ and $\boldsymbol{W}$. During the} latest survey and decontamination project, the southwest corner of the Los Alamos Inn parking lot was excavated to remove plutonium-contaminated soil. Also removed was fill soil that contained the highest concentrations of tritium in soil moisture (maximum sample $690 \mathrm{pCi} / \mathrm{ml}$ ) discovered in auger samples (Sec. III.B.2.a). The highest tritium concentrations in samples taken from other, unexcavated locations under the parking lot showed $\sim 120 \mathrm{pCi} / \mathrm{m} \ell$-values that are only a few percent of the ERDAM 0524 RCG value of $3000 \mathrm{pCi} / \mathrm{m} \ell$ for tritium in drinking water in uncontrolled areas. The tritium may have originated in the vicinity of $U$ and W Buildings and may have been moved with fill material that was pushed to the southwest riuring original demolition (see Sec. III.B.2.a). Samples of water from vegetation around the Los Alamos Iin in the vicinity of the $\mathrm{U}$ - and $\mathrm{W}$-Building locations did not show abnormal levels of tritium (see Sec. III.B.2.a and Fig. 52), indicating that although undiscovered tritium contamination may remain under existing structures and the parking lot, it is almost certainly low-level and is not mobile.

2. Trinity Drive Areas. Some contamination may exist in the fill material under Trinity Drive. Construction debris (concrete supports, steam-pipe insulation, etc.) in the fill in the D-Building area was contaminated. The topography is such that debris from other areas could have been pushed over D-Building debris. A former Zia Road Section Field Superintendent recalls that $\sim 1000$ to $2000 \mathrm{~m}^{3}$ of fili and debris from the southwestern portion of the filled area near Buildings D and D-2 were used for fill along Trinity Drive from the Los Alamos Inn to the Trinity Village Apartments during the 1966 


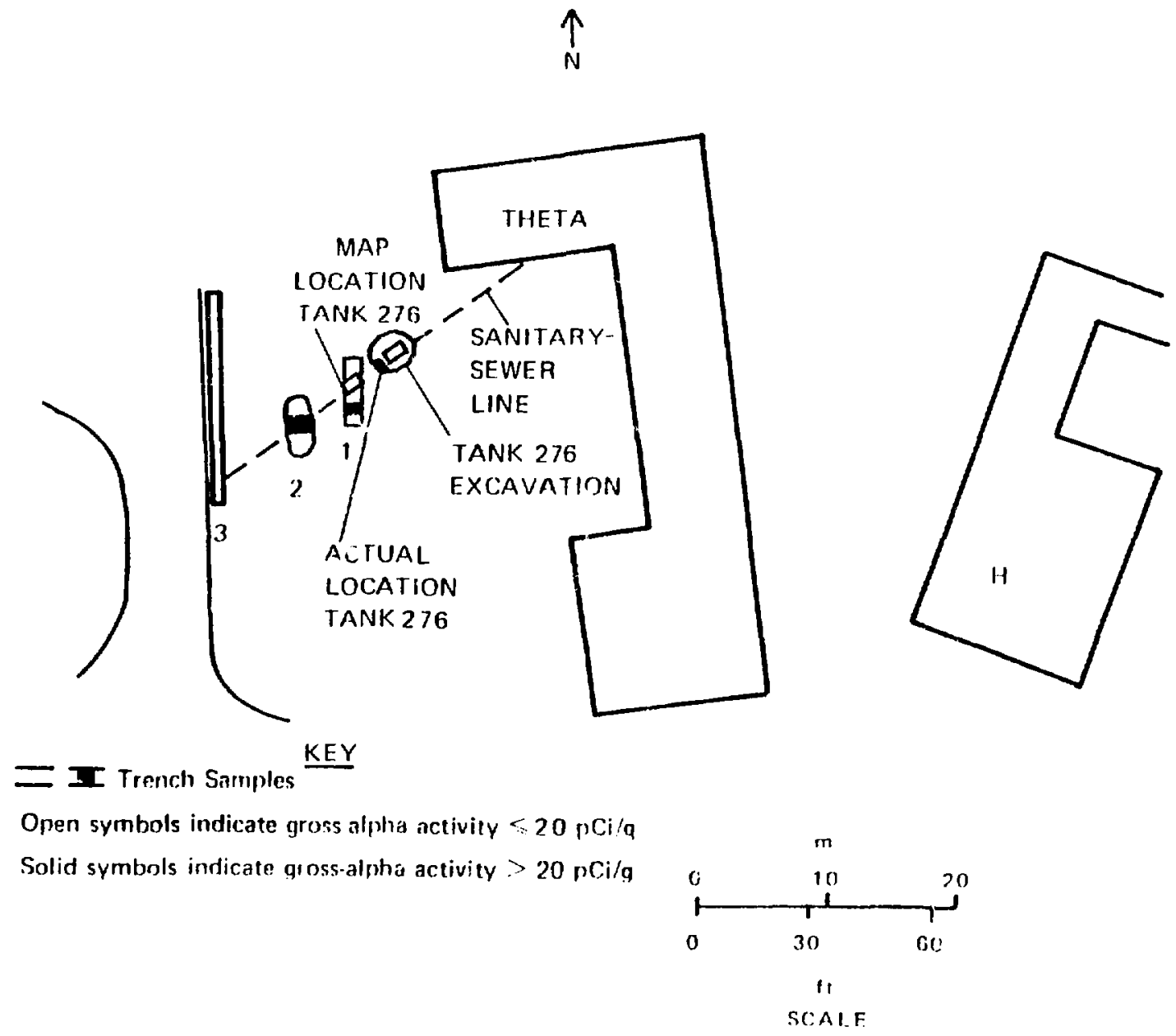

Fig. 129.

Septic Tank 276 trench and excavation locations.

widening/repaving project. On the basis of experience gained during this operation, any remaining pockets of highly contaminated soil would have been greatly diluted by the gathering and spreading of the backfill for road construction.

Portions of two contaminated manhole structures (ULR-64 and -65; see Fig. 92) may remain under Trinity Drive. Old drawings show two manholes on the TA- 1 acid-sewer line $\sim 56 \mathrm{~m}$ and $85 \mathrm{~m}$ north and west of Oppenheimer Drive under the widened por- tion of Trinity Drive. The bases for these manholes may well have been left in place, as was the case for the two removed during decontamination; thus, the county could inacivertently excavate, bring to the surface, and carry off one or both of the manhole bases as part of some future project. On the assumption that the manholes are no more contaminated than those already excavated (Sec. III.C.2), isolated soil spots cont aminated to $500 \mathrm{pCi} / \mathrm{g}$ probably would be mixed with clean soil and would either be hauled 
away or would be diluted and put back in the same excavation. If mixing were to occur, sampling might or might not find spots with activity $>20 \mathrm{pCi} / \mathrm{g}$. In addition to possible exposure of soil pipe contaminated internally in a few spots to levels $>10000$ $\mathrm{pCi} / \mathrm{g}$ might be exposed. There might be minor contamination to personnel if this pipe were manually handled. Earth-moving equipment might become slightly contaminated, but that would be difficult to detect. Airborne contamination would be most unlikely.

\section{G. Contamination Remaining on ERDA Property Adjacent to TA-1}

During decontamination operations, contamination was located on ERDA property adjacent to private land. These areas are identified elsewhere in this report. Section III.B.4 describes the contamination remaining on the hillside below Septic Tank 138. The regions of contamination remaining below the D and D-2 areas and Septic Tank 140 are described in Secs. LI.B.2.b and III.D.6, respectively. Low-level contamination from demolition in the western portion of TA-1 was bulldozed into the draw spanned by the former Bailey Bridge (Sec. I.A). Public access to each of these areas is restricted by the 2.4-m-high chain-link fence constructed in April 1976 (Sec. II.C.2).

\section{DISCUSSION}

Throughout the survey and decontamination operations at TA-1, an important and recurring question was: To what level should decontamination be carried? Neither recommendations for acceptable levels nor government standards for plutonium in soils were available. Individual recommendations for acceptable plutonium levels ${ }^{18.17}$ have been based primarily on considerations of surface contamination, whereas the majority of the plutonium contamination in the TA-1 area was subsurface. A study by Healy ${ }^{18}$ considered the inhalation of surface plutonium as well as the ingestion of plutonium, either casually or deliberately. The study recommended acceptable, subsurface plutonium levels of $509 \mathrm{dis} / \mathrm{min} / \mathrm{g}(225 \mathrm{pCi} / \mathrm{g})$ in any 1-cm-thick layer for particles smaller than $100-\mu \mathrm{m}$ diameter or a total of $100 \mathrm{dis} / \mathrm{min} / \mathrm{g}(450 \mathrm{pCi} / \mathrm{g})$ in all particle sizes.

No recommendations, standards, or individual studies have been made on acceptable levels of uranium in soils. However, uranium is ubiquitous in the earth's crust, and many areas have relatively high concentrations of uranium in the soil. For example, the St. Typpolyte shales in France contain $\sim 1200 \mathrm{ppm}(6000 \mathrm{pCi} / \mathrm{g})$, while in the US the copper marl phosphate in the Charleston, $\mathrm{SC}$, area contains $200 \mathrm{ppm}(960 \mathrm{pCi} / \mathrm{g})$ and the Miocene-Pliccene phosphate deposits in the Gulf Coastal plain of Florida contain $100 \mathrm{ppm}(480 \mathrm{pCi} / \mathrm{g})$. The specific activity of natural uranium is low, and the primary hazard is the chemical toxicity to the kidney following ingestion rather than the radiation dose to the lungs following inhalation. If very insoluble uranium cumpounds are encountered, the radiation dose to the lungs may he important; however, most uranium compounds have a significant degree of solubility. On the basis of the maximum permissible concentrations (MPCs) of uranium or the radioacuvity concentratıon guides promulgated by various national and international bodies on radia!ion protection, uranium is considerably less hazardous than plutonium, although it is difficult to derive an exact ratio of hazard without a more detailed study.

One approach to a contamination problem is to make a detailed site survey describing inventory, distribution, and nature of the contaminanis and to use these data in conjunction with land-use information and local meteorology to derive linits for each contaminant in the specific locality. Such an approach was impossible in this situation because the contamination was spotty and much of it was underground, either because it had seeped there from liquid sireams or because it had been covered or buried during demolition or construction activities. A good estimate of the true inventory and location of contaminants would have required many samples and probably years of time.--time that was not available because private !andowners were eager to proceed with land development.

As a result, it was decided to carry decontamination efforts to a point where the residual contamination was as low as could be achieved practicably, with no fixed upper level except that areas where several hundred $\mathrm{pCi} / \mathrm{g}$ remained would be 
scrutinized carefully to see if additional excavation would reduce the levels. The policy of "as low as practicable" was first enunciated by the National Council on Radiation Protection (NCRP) ${ }^{19}$ following their acceptance of an assumption (for standardsetting purposes) that radiation effects are linear with dose. This as-low-as-practicable policy has been accepted as a basic premise by other radiation bodies and is included in all regulations having to do with radiation protection. Essentially, any exposure to ionizing radiation should be held to the minimum level achievable in accordance with economic and practical realities.

The application of this principle requires definition of methods to achieve measurements below which one need not be concerned. Normal techniques include portable-instrument survey, field sampling, and chemical analysis of samples. For detecting alpha emitters in an environmental situation, the portable survey instruments are relatively insensitive because of the high absorption of alpha particles by overlying material. Sole reliance on portable instruments would mean that material with levels higher than several hundreds of $\mathrm{pCi} / \mathrm{g}$ would remain. Chemical analysis, involving either soil leaching, acid dissolution, or sulfate fusion, will detect small fractions of $1 \mathrm{pCi} / \mathrm{g}$, but the results represent only a small portion of the soil in the area, and the expense and time required are such that large numbers of samples could not be handled. Of primary importance here is the fact that survey and decontamination operations were done simultaneously-a contaminated area was located and soil removal began immediately. Frequent sampling was required to assess the progress and to indicate when the operation could be stopped, but chemical analyses require days to complete and crews would have io shift from one area to another or wait for results, thereby greatly increasing the cost and effort.

Therefor:, we decided to use a sampling and measurement technique for gross-alpha activity. The techmique had been tested in other cleanups and gave reasonable, reliable results when checked against radiochemical analyses. It was not as sensitive a technique as radiochemical analysis, but results became available in a relatively short time so that more samples could be taken and the crews could be directed promptly. In an attempt to over- come the sensitivity problem at least partially, excavations were usually dug somewhat beyond the point of gross-alpha detection in many samples. although some isolated areas with low positive levels remain.

Decisions about what is "as low as practicable" are difficult to make on a case-by-case basis because there are no fixed standards and decisions are largely judgmental. Early in the effort, ERDA's Division of Safety, Standards and Compliance, Headquarters, delegated responsibility for final decisions to ALO's Operational Safety Division. LASL's job was to carry out the operations and make recommendations on where to proceed and when to stop. In retrospect, it was an excellent method because it provided an independent check on the progress and necessitated frequent study and review of the data so that recommendations could be made.

Now that the work is finished, the question is: How complete was the decontamination and what are the health hazards that may remain? Considering that the contamination found was very spotty and that contamination was found in areas where no record of radioactivity work could be found, one cannot he certain that some small pockets of lowlevel uranium and plutonium contamination do not exist. Because measuring devices with relatively poor sensitivity were used (for reasons described above), above-background contamination may still exist. However, in view of the localized nature of the deposits found and the extensive surveys made in hoth contaminated and uncontaminated areas, the probability of encountering sizable pockets of high level contamination is low.

The possible public hazard in the TÁ-1 area is difficult to assess without qualification because of the widely accepted assumption that any amount of radiation, no matter how small, will result in some incremental hazard. Even in regions where background levels are much higher than any contamination remaining in TA-1, some people presume that there is some damage, although studies have not been able to detect it.

However, in the TA-1 area as it is today, most low-level residual contamination is buried under fill used to restore the area. Those pockets of contamination discovered during exploration and decontamination were relatively small, so that even 
if they were now on the surface the buildup of resuspension concentrations by winds would be lower than such buildup from a large area. Furthernore, no individual is likely to be in such a small area for a long period of time. Any excavation into these pockets would increase slightly the probability of contaminant inhalation, but it is very doubtful that the potential intake would be significant or that it could even be measured.

Any incremental risk to health from these low levels is really negligible compared with normal risks, as can be seen by comparing the existing levels in TA-1 with the levels mentioned in Refs. 16 19 and considering the small relative sizes of the areas and their locations. In this light, the presentday TA-1 area poses no risk to human health. In fact, before the survey and decontamination effort began the real risk was already low and even then was predicated largely upon the possibility of excavating a pocket of higher contamination. A station for continuous air-sampling established during this project will be operated for a reasonable period as part of LASL's routine monitoring network to document actual conditions.

\section{APPENDIX A}

\section{SUMMARY OF RECORDS SEARCH AND DISCUSSIONS WITH LASL PERSONNEL CONCERNING BUILDINGS AND DRAIN LINES IN TA-1 WHERE RADIOACTIVE MATERIALS WERE PROCESSED (Compiled August 1975)}

TA-1-5 (C Building). Completed September 25, 1943 , by N. M. Sundt \& Sons at a cost of $\$ 352654$. It was of wood-frame construction, $123 \mathrm{ft}$ wide by 176 ft long $x 24 \mathrm{ft}$ high, and was built on a large concrete pad. It burned in early 1945 and was rebuilt at a cost of $\$ 126000$. It was a normal machine shop with a uranium machine shop in the southeast section. Before removal, the building was monitored and found free of contamination except for the concrete pad. The building was removed by Los Alamos Transfer Co. in December 1964. The contaminated concrete pad was removed to the contaminated dump and the remaining concrete was placed in the canyon near the Bailey Bridge in 1965.

TA-1-6 (D Building) Completed in December 1943 by N. M. Sundt \& Sons with an annex added by R. E. McKee at a tota' cost of $\$ 809348$. It was of wood-frame construction, $50 \mathrm{ft}$ wide by $144 \mathrm{ft}$ long and was used for chemistry and metallurgy. Significant amounts of ${ }^{239} \mathrm{Pu}$ and ${ }^{235} \mathrm{U}$ were processed there, resulting in fairly high levels of contamination in sections of the building and in the drain lines. Demolition began on March 9, 1954, and was com- pleted on November 30,1954 . The work was done by Zia Co, with Group H-1 providing the health physics support. In addition to building removai, drain lines were removed to the nearest manholes and stubbed off. After removal of a large amount of dirt from the vicinity of the building, soil samples from the excavation ranged from 62 to $533 \mathrm{dis} / \mathrm{min} / \mathrm{g}$ of soil. ${ }^{6}$ The excavated area was backfilled with clean soil and brought to grade. Remaining drain lines were removed on a later work order that included the eastern half of TA-1.

TA-1-8 (D-2 Building). Built in July 1944 at a cost of $\$ 28345$. It was of wood-frame construction, $32 \mathrm{ft}$ wide by $80 \mathrm{ft}$ long by $9 \mathrm{ft}$ high, and was used as a laundry for contaminated clothing and glassware. The drain lines were shallow and emptied to an open area near the canyon rim. Three rooms were added and, after the laundry was moved to DP Site, D-2 was used for instrument repair. Later, D-Building pumps were decontaminated in part of the building. After the laundry facilities had been removed, a septic tank was added. All lines were left in place and some were rerouted to the septic tank. Thit building 
was monitored before its removal in October 1953 and found to be free of contamination except for the floor and attic where a few thousand $\mathrm{c} / \mathrm{min} / 55 \mathrm{~cm}^{2}$ of alpha activity were found. The doors and windows were salvaged and the remainder of the building was placed in the contaminated dump under the direction of $\mathrm{H}-1$. The plumbing was removed "as far down as the plumbers could reach," and the area was abandoned. Later soil sampling and counts taken with a FIDLER probe revealed pockets of ${ }^{239} \mathrm{Pu}$ contamination, and the sept ic tank and some plumbing were removed to the contaminated dump.

TA-1-11 (D-5 Sigma Vault). Built by R. E. McKee between No.ember 1944 and January 1945 at a cost of $\$ 28829$. It was of reinforced concrete, 20 ft wide by $41 \mathrm{ft}$ long by $13 \mathrm{ft}$ high, and was used for storage of ${ }^{239} \mathrm{Pu}$ and ${ }^{235} \mathrm{U}$. Minor spills in the building resulted in lasting low-level contamination on the concrete floors and shelving. It was demolished in December 1965 by $\mathrm{Zia} \mathrm{Co}$. and removed to the contaminated dump. No drain lines were connected to the building's storage area.

TA-1-21 (G Building). Built by hired labor in August 1943 at a cost of $\$ 16850$. It was of woodframe construction, $28 \mathrm{ft}$ wide by $74 \mathrm{ft}$ long by $13 \mathrm{ft}$ high. The middle section housed the Sigma Pile, which was coristructed of graphite and uranium. The concrete floor was slightly contaminated and a slight amount of cortamination was flushed down drains during decontamination of radium sources. The building itself was free of contamination and was removed by Los Alamos Transfer Co. in June 1959. The drains and concrete were taken to the radioactive waste dump.

TA-1-26 (H Building). Built by hired labor in February 1944. It was of wood-frame construction, $20 \mathrm{ft}$ wide by $92 \mathrm{ft}$ long. Additions included extensions of dimensions $\$ 5 \mathrm{ft}$ wide by $20 \mathrm{ft}$ long, $12 \mathrm{ft}, 4$ in. wide by $10 \mathrm{ft}$ lon , and $10 \mathrm{ft}, 6 \mathrm{in}$. wide by $10 \mathrm{ft}$ long at a cost of $\$ 65261$. The building initially was used for work with ${ }^{210} \mathrm{Po}$ and later was used by Group CMR-10 $f, r$ offices and work space. During the tenure of CMR-10, items contaminated with ${ }^{140} \mathrm{Ba}$ ${ }^{140} \mathrm{La}$ were used and stored in and under the building, with some resulting contamination. The material with short half-life decayed, but ${ }^{90} \mathrm{Sr}$ remained as a contaminant. During the 1957 TA-1 cleanup, the building was demolished by $\mathrm{Zia} \mathrm{C}_{\mathrm{O}}$. and removed to the dump. Drain lines from $\mathrm{H}$ Building were contaminated and were removed $t o$ the dump, as was a substantial amount of soil from under the building.

TA-1-29 (HT Building). Built by R. E. McKee during July and August 1945 at a cost of $\$ 169650$. It was of wood-frame construction, $62 \mathrm{ft}$ wide by $269 \mathrm{ft}$ long by $30 \mathrm{ft}$ high, with a basement $15 \mathrm{ft}$ wide by 69 ft long by $10 \mathrm{ft}$ high It was used by the Shops Department for processing normal and enriched uranium. Substantial levels of uranium contamination were found in the building, and it was demolished and hauled to the contaminated dump in December 1965. No drain lines other than sanitary-sewer lines connected with this building.

TA-1-30 (HT Barrel House). Built in July 1946 at a cost of $\$ 385$. It was of wood-frame construction, $8 \mathrm{ft}$ wide by $12 \mathrm{ft}$ long by $10 \mathrm{ft} \mathrm{high,} \mathrm{and} \mathrm{was} \mathrm{used} \mathrm{for}$ uranium storage and was moderately contaminated. It was demolished and hauled to the contaminated dump in July 1964 by Zia Co. No drains were associated with this building.

TA-1-32 (I Building). Built by US Post Engineers during June and July 1945, it was of wood-frame construction, $30 \mathrm{ft}$ wide by $60 \mathrm{ft}$ long by $16 \mathrm{ft}$ high, and was used for machining beryllium. It was sold to the Dog Obedience Club in 1958 and was moved to 1080 Airport Road. At that time it was discovered to be contaminated with nonradioactive beryllium, was repurchased by the government. demolished, and taken to the contaminated dump in 1959. No drain lines ot her than sanitary-sewer lines connected to this building.

TA-1-42 (ML Building). Built by hired labor during October and November 1945 at a cost of $\$ 26054$. It was of wood-frame construction, $27 \mathrm{ft}$ wide by $115 \mathrm{ft}$ long by $1.3 \mathrm{ft}$ high, and was used as a medical laboratory for many years by the groups later known as $\mathrm{H}-4$ and $\mathrm{H}-5$, who did sampling work to determine human uptake and excretion rates. After $\mathrm{H}-4$ and $\mathrm{H}-5$ moved out, the building was used by Group J-11 to process americium and curium. J11 personnel were involved in a spill of radioactive 
materiai that contaminated the northern $67 \mathrm{ft}$ of the building. Even after extensive decontamination, a moderate amount of contamination remained. The northern section of the building was demolished and taken to the contaminated dump by $\mathrm{Zia} \mathrm{Cu}$. in December 1958, and the southern part was taken to the Zia Surplus Yard. The only drain line associated with this building was the sanitary sewer which had an outfall west of $F$ Building. During the TA-1 cleanup, this line was found to be contaminated and was removed to the contaminated dump.

TA-1-43 (M Building). Built by N. M. Sundt \& Sons in April 1943 at a cost of $\$ 114874$. It was of wood-frame construction, $42 \mathrm{ft}$ wide by $83 \mathrm{ft}$ long by $24 \mathrm{ft}$ high. on a concrete slab and was used for processing and recovery of enriched uranium. The building (including the concrete) was remolished between September and December 1957 and was taken to the contaminated dump. The acid drain line was removed to the contaminated dump. No contamination was found in the sanitary-sewer line.

TA-1-45 (O Building). Built by hired labor in August 1943 at a cost of $\$ 4598$. It was of concrete construction, $10 \mathrm{ft}$ wide by $15 \mathrm{ft}$ long by $9 \mathrm{ft}$ high, and was used for the storage of radium and $\mathrm{Ra}-\mathrm{Be}$ sources, all of which were sealed. However, some leaked, and the building and adjacent walkway werc contaminated. Also, at the front of the building, radon was cnoked off radium sources on a hotplate before resoldering. The buildin was demolished and taken to the contaminated dump in November 1956. No drains connected with the building.

TA-1-49 (Q Building). Built by N. M. Sundt \& Sons in July 1943 at a cost of $\$ 95641$. It was of wood-frame construction, $32 \mathrm{ft}$ wide by $1.03 \mathrm{ft}$ long by $171 \mathrm{ft}$ high, and had a full basement. An addition was later placed on the south end. The building was used by the medical and health-monitoring group. Some film calibration was done in the north basement, where a small radium spill contaminated part of the north basement and part of the tunne! connecting $Q$ Building to Boiler House No. 2. The spill was cleaned up as thoroughly as was practicable, but some contamination remained. The building was removed by $\mathrm{H}$. C. Thompson in February 1959 . The concrete, including the tunnel and associated pipes and drains, was removed to the contaminated dump.

TA-1-56 (Sigma Building). Built by R. E. McKee and completed in September 1944. A major addition made by Haddock Engineers was completed in January 1950. The total cost was $\$ 1485$ 192.68. The building was of wood-frame construction, $93 \mathrm{ft}$ wide by $375 \mathrm{ft}$ long by $27 \mathrm{ft}$ average height, with a 100 -ft-wide by 133 -ft-long basement . The eastern part of the building was used to process normal uranium, and the western part was used to process enriched uranium. Parts of the building were moderately contaminated, and it was demolished by Zia Co. in December 196ij. The building and some of the concrete were hauled to the contaminated dump. The remaining concrete (either clean or having $<2500 \mathrm{c} / \mathrm{min}$ ) was taken to the canyon at the Bailey Bridge, dumped, and later covered with dirt.

TA-1-67 (TU Building). Built by hired labor and completed on August 15, 1945, at a total cost of $\$ 15721$. It was of wood-frame construction, $38 \mathrm{ft}$ lnng by $16 \mathrm{ft}$ wide by $12 \mathrm{ft}$ high, with a 7 -ft-long by 4 it-wide by 7 -ft-high compressor shed. It was used for processing normal uranium and was moderately containinated. It was removed to the contaminated dump in 1964 and burned. The sanitary sewer and septic tank were also removed.

TA-1-68 (TU-1 Building). Built in July 1948 at a cost of $\$ 1227$. It was of metal construction, $12 \mathrm{ft}$ wide hy $29 \mathrm{ft}$ long by $10 \mathrm{ft}$ high, with concrete floor and foundation. It was used for enriched-uranium storage and recovery. It was removed to the contaminated dump on July 27, 1964. There was no plumbing.

TA-1-70 (V Building). Built by N. M. Sundt and Sons and completed in July 1943 at a total cost of $\$ 153948$. It was of wood-frame construction, $64 \mathrm{ft}$ wide by $94 \mathrm{ft}$ long by $22 \mathrm{ft}$ high, with an addition 20 $\mathrm{ft}$ wide by $30 \mathrm{ft}$ long by $15 \mathrm{ft}$ high. lt was the original machine shop, and some uranium and beryllium were machired there. The building was free of contamination and was removed by Los Alamos Transfer Co. in February 1959. The concrete floor had contaminated spots and these were removed to 
the contaminated dump. The sanitary-sewer line showed no contamination.

TA-1-115 (J-2 Building). Built by R. E. McKee and completed on December 15,1949, at a cost of $\$ 516865$. It was of wood-frame constructic $\mathrm{n}, 73 \mathrm{ft}$ wide by $190 \mathrm{ft}$ long by $17 \mathrm{ft}$ average height, and was used by Group J-2 for radiochemistry work. Various materials were processed, but the ones of most concern were fission products and plutonium. The eastern half of the building was relatively free of contamination, but the western part was highly contaminated within the hoods, hot cells, and ductwork. A pipe trench rian east and west through the center of the floor. The building was demolished in 1958 and the acid drain line from the building to the junction at Trinity Brive was removed, along with some soil near the line where leaks had occurred. To save money, the sanitary sewer from the building north to Finch Street was not removed because the junction at Finch Street was not contaminated.
Acid-Sewer Lines and Manholes. Records state that all acid drain lines from the D-Building area to Trinity Drive, including the double line south of $\mathrm{C}$ Building, were removed and placed in the contaminated dump.

Many manholes were checked for contamination, and most were contamination-free. Some were filled with dirt, some were transferred to Los Alamos County, and some were just abandoned. Any that were found contaminated to any degree were removed to the contaminated dump, along with all asscciated plumbing. Minimal amounis of contamination may remain, but they would have been below the detection levels of instruments available at the time, and some surfaces may have been coated with dirt or moisture, making low-level counting impossible. Modern, sensitive equipment might pinpoint small deposits of radioarcivity in some areas. 


\section{APPENDIX B}

STRUCTURE IDENTIFICATION, REMOVAL DATE, AND

RADIOACTIVE-USE HISTORY OF TA-1

(Compiled August 1975 from Engineering Department

and Heal:h-Division Records)

\begin{tabular}{|c|c|c|c|}
\hline $\begin{array}{l}\text { Structure } \\
\text { Number }\end{array}$ & $\begin{array}{c}\text { Structure } \\
\text { Nomenclature }\end{array}$ & $\begin{array}{c}\text { Removal } \\
\text { Date } \\
\end{array}$ & $\begin{array}{c}\text { Radioactive Materials Used } \\
\text { und/or Structure Use }\end{array}$ \\
\hline TA-1-1 & A & $2 / 59$ & None. Administrative offices. \\
\hline ГА-1-2 & $\mathrm{B}$ & $2 / 59$ & $\begin{array}{l}{ }^{232} \mathrm{Th} \text { (small amounts), }{ }^{238} \mathrm{U}-{ }^{236} \mathrm{U} \text { foils. } \\
\text { Mostly administrative offices. }\end{array}$ \\
\hline TA-1-3 & B-1 & $7 / 23 / 46$ & ${ }^{210} \mathrm{Po}$ (sealed sources). \\
\hline TA-1-4 & $\begin{array}{l}\text { Boiler House } \\
\text { No. } 2\end{array}$ & $2 / 59$ & None. Supplied steam for TA-1. \\
\hline TA-1-5 & $\mathrm{C}$ & $12 / 64$ & $\begin{array}{l}{ }^{238} \mathrm{U} \text {. Shops Departmert (the first building } \\
\text { burned before May 1945). }\end{array}$ \\
\hline TA-1-6 & $\mathrm{D}$ & $\begin{array}{l}\text { Complete } \\
11 / 30 / 54\end{array}$ & $\begin{array}{l}{ }^{239} \mathrm{u},{ }^{230} \mathrm{U},{ }^{238} \mathrm{U},{ }^{3} \mathrm{H} \text {. Chemistry and } \\
\text { metallurgy. }\end{array}$ \\
\hline TA-1-7 & D-1 & $10 / 46$ & $\begin{array}{l}\text { Calcium metal storage; moved to north side } \\
\text { of DP road (TA-21). }\end{array}$ \\
\hline TA-1-8 & D.2 & $10 / 53$ & $\begin{array}{l}{ }^{239} \mathrm{Pu},{ }^{236} \mathrm{U} \text {. First use, contaminated laundry } \\
\text { and glassware decontamination; second use, } \\
\text { electronics shop; third use, decontamination } \\
\text { of D. Building equipment; fourth use, storage. }\end{array}$ \\
\hline TA-1-9 & D-3 & $6 / 56$ & $\begin{array}{l}\text { Count room for } \mathrm{H}-1(\mathrm{CM}-12) \text { filter papers } \\
\text { from room-air tests. }\end{array}$ \\
\hline TA-1-10 & D.4 & $1 / 12 / 54$ & None. Storage. \\
\hline TA-1-11 & $\begin{array}{l}\text { D-5 Sigma } \\
\text { Vault }\end{array}$ & $12 / 65$ & $\begin{array}{l}{ }^{236} \mathrm{U},{ }^{239} \mathrm{Pu}-\text { occasional spills were cleaned } \\
\text { up. Slight amount of contamination remained } \\
\text { on floors. }\end{array}$ \\
\hline TA-1-12 & D-6 & $1 / 54$ & None. Paint storaga. \\
\hline TA-1-13 & D-7 & $1 / 54$ & None. CMR HF gas analysis. \\
\hline TA-1-14 & D-8 Bınker & $1 / 54$ & None. Coffee shop for D Building. \\
\hline TA-1-15 & D-9 & $10 / 54$ & None. Moved to current technical area (TA-21) \\
\hline
\end{tabular}




\begin{tabular}{|c|c|c|c|}
\hline $\begin{array}{l}\text { Structure } \\
\text { Number }\end{array}$ & $\begin{array}{c}\text { Structure } \\
\text { Nomenclaiure }\end{array}$ & $\begin{array}{c}\text { Removal } \\
\text { Date }\end{array}$ & $\begin{array}{c}\text { Radioact: } \text { Materials Used } \\
\text { and/or Structure Use }\end{array}$ \\
\hline TA-1-16 & Delta & $4 / 65$ & $\begin{array}{l}{ }^{103} \mathrm{Ru},{ }^{106} \mathrm{Ru} \text {. Ceramic fixation of radioactive } \\
\text { waste; research; originally used for meeting } \\
\text { rooms. }\end{array}$ \\
\hline${ }^{\prime} \mathrm{A}-1-17$ & $\mathrm{E}$ & $3 / 58$ & None. T Division. \\
\hline TA-1-18 & $\mathrm{F}$ & $10 / 58$ & None. Film siorage. \\
\hline TA-1-19 & F-1 & $5 / 31 / 65$ & None. Storage. \\
\hline TA-1-20 & $\mathrm{FP}$ & $4 / 65$ & $\begin{array}{l}\text { None. Foundry for nonradioactive, nonferrous } \\
\text { metals. }\end{array}$ \\
\hline TA-1-21 & $\mathrm{G}$ & $6 / 59$ & $\begin{array}{l}\text { Uranium, }{ }^{226} \mathrm{Ra} \text {. Originally used for the } \\
\text { Sigma Pile (graphite); later used to leak- } \\
\text { test radium sources. }\end{array}$ \\
\hline 'ГА-1-22 & Gamma & $2 / 59$ & $\begin{array}{l}{ }^{210} \mathrm{Po},{ }^{197} \mathrm{Cs}-{ }^{137} \mathrm{C} . \quad \text { ontamination incident } \\
\text { occurred. }\end{array}$ \\
\hline TA-1-23 & Gamma 1 & $2 / 59$ & ${ }^{236} \mathrm{U},{ }^{239} \mathrm{Pu}$. Ice House; storage and assembly. \\
\hline TA-1-24 & $\mathrm{GC}$ & $9 / 46$ & Unknown. Location not identified. \\
\hline ТА-1-25 & Warehouse GR & $4 / 27 / 5 j$ & None. Equipment storage. \\
\hline TA-1-26 & $\mathbf{H}$ & $6 / 57$ & $\begin{array}{l}{ }^{140} \mathrm{Ba},{ }^{140} \mathrm{La},{ }^{80} \mathrm{Sr} \text {. Úriginally used for } \\
{ }^{210} \mathrm{Po} \text { source preparation. }\end{array}$ \\
\hline TA.1.27 & H Extension & $5 / 57$ & $\begin{array}{l}\text { None. Administrative offices: building was } \\
\text { removed to cont aminated dump. }\end{array}$ \\
\hline TA-1-28 & $\mathrm{H}-1$ & $6 / 59$ & $\begin{array}{l}{ }^{226} \mathrm{Ra} \text { (slight floor contamination), sealed } \\
\text { sources of }{ }^{80} \mathrm{Sr} \text {, no }{ }^{239} \mathrm{Pu} \text {. }\end{array}$ \\
\hline TA-1-29 & HT & $12 / 65$ & ${ }^{238} \mathrm{U},{ }^{235} \mathrm{~J}$. Heat treatment and machining. \\
\hline TA.1.30 & $\begin{array}{l}\text { HT Barrel } \\
\text { House }\end{array}$ & $7 / 64$ & ${ }^{2 s e} \mathrm{U}$. Storage. \\
\hline TA-1-31 & $\begin{array}{l}\text { HT Gas Stor- } \\
\text { age }\end{array}$ & $7 / 64$ & ${ }^{238} \mathrm{U}$ J. Storage. \\
\hline TA-1-32 & I & $7 / 59$ & $\begin{array}{l}\text { Beryllium. Building was purchased by the Dog } \\
\text { Obedience Club and found to have berllium } \\
\text { contamination. After repurchase by the AEC. } \\
\text { it was taken to the contaminated dump. }\end{array}$ \\
\hline TA-1-33 & Platform I & $3 / 55$ & None. Loading dock. \\
\hline
\end{tabular}




\begin{tabular}{|c|c|c|c|}
\hline $\begin{array}{l}\text { Structure } \\
\text { Number }\end{array}$ & $\begin{array}{c}\text { Structure } \\
\text { Nomenclature }\end{array}$ & $\begin{array}{c}\text { Removal } \\
\text { Date }\end{array}$ & $\begin{array}{c}\text { Radioactive Materials Used } \\
\text { and/or Structure Use }\end{array}$ \\
\hline TA-1-34 & $\mathbf{J}$ & $6 / 54$ & $\begin{array}{l}\text { Sealed sources, no plutonium. Offices and } \\
\text { laboratories. }\end{array}$ \\
\hline TA-1-35 & $\mathrm{J}-5$ & $\begin{array}{l}1950 \text { (by } \\
\text { windstorm) }\end{array}$ & $\begin{array}{l}\text { None. lnitially used for a medical labora- } \\
\text { tory; later used for storage. }\end{array}$ \\
\hline TA-1-36 & $\mathrm{J}-6$ & $6 / 54$ & $\begin{array}{l}\text { Sealed sources in lower hutment were used } \\
\text { for Health-Division film calibration with } \\
{ }^{22 \theta} \text { Ra sources. }\end{array}$ \\
\hline TÁ-1-37 & $\mathrm{J}-7$ & $6 / 54$ & None. Storage. \\
\hline TA-1-38 & $\mathrm{J}-8$ & $6 / 54$ & None. Storage. \\
\hline TA-1-39 & $\mathrm{J}-9$ & $6 / 54$ & None. Storage. \\
\hline TA-1-40 & $\mathrm{K}$ & $4 / 54$ & None. Stockroom. \\
\hline TA-1-41 & $\mathbf{L}$ & $1 / 47$ & Unknown. Location not identified. \\
\hline TA-1-42 & ML & $12 / 58$ & $\begin{array}{l}{ }^{298} \mathrm{Pu},{ }^{241} \mathrm{Am} \text {, curium. Medical laboratory for } \\
\text { urine assay; later use by J Division resulted } \\
\text { in contamination by americium and curium. }\end{array}$ \\
\hline TA-1-43 & $\mathbf{M}$ & $\begin{array}{l}\text { Complete } \\
12 / 6 / 57\end{array}$ & Enriched ${ }^{236} \mathrm{U}$. Metallurgy and recovery. \\
\hline TA-1-44 & $\mathbf{N}$ & $7 / 54$ & ${ }^{210}$ Po. Laboratory used by Enrico Fermi. \\
\hline TA-1-45 & 0 & $11 / 56$ & ${ }^{228} \mathrm{Ra}$. Source vault; leaking sources. \\
\hline TA-1-46 & $\mathbf{P}$ & $\begin{array}{l}2 / 59 \text { (east } \\
\text { portion) }\end{array}$ & None. Personnel offices. \\
\hline TA-1-47 & P-Prime & $12 / 65$ & None. Supply and Property offices. \\
\hline TA-1-48 & Paint Shop & $4 / 21 / 55$ & None. Paint storage and use. \\
\hline TA-1-49 & $\mathbf{Q}$ & $2 / 5 y$ & $\begin{array}{l}{ }^{22} \mathrm{Ra} \text { for calibration (there was a contami- } \\
\text { nated spill). }\end{array}$ \\
\hline TA-1-50 & $\mathbf{R}$ & $7 / 54$ & $\begin{array}{l}\text { None. Glass shop, cryogenics, model shop, } \\
\text { and carpenter shop. }\end{array}$ \\
\hline TA-1-51 & R-1 & $1 / 54$ & None. Lumber rack. \\
\hline TA-1-52 & R-2 & $1 / 7 / 54$ & None. Lead storage. \\
\hline TA-1-53 & $\mathbf{S}$ & $2 / 59$ & None. General stock warehouse. \\
\hline
\end{tabular}




\begin{tabular}{|c|c|c|c|}
\hline $\begin{array}{l}\text { Structure } \\
\text { Number }\end{array}$ & $\begin{array}{c}\text { Structure } \\
\text { Nomenclature }\end{array}$ & $\begin{array}{c}\text { Removal } \\
\text { Date }\end{array}$ & $\begin{array}{l}\text { Radioactive Materials Used } \\
\text { and/or Structure Use }\end{array}$ \\
\hline TA-1-54 & S-1 & $8 / 13 / 54$ & None. Storage. \\
\hline TA-1-55 & Saw Building & $2 / 53$ & None. Graphite sawing. \\
\hline TA-1-56 & Sigma & $12 / 65$ & $\begin{array}{l}{ }^{235} \mathrm{U},{ }^{289} \mathrm{U} \text {, thorium. Casting, machining. } \\
\text { and powder metallurgy. }\end{array}$ \\
\hline TA-1-57 & $\begin{array}{l}\text { Cooling } \\
\text { Tower } 57\end{array}$ & $2 / 65$ & None. Cooling water. \\
\hline TA- 1.58 & Sigma-1 & $4 / 22 / 55$ & None. Storage. \\
\hline TA-1-59 & Sigma-2 & $4 / 55$ & None. Storage. \\
\hline TA-1-60 & Sigma-3 & $4 / 55$ & None. Storage. \\
\hline TA-1-61 & Sigma-4 & $4 / 55$ & None. Storage. \\
\hline TA-1-62 & Steam Pit & $1 / 56$ & None. Heating steam. \\
\hline TA-1-63 & $\begin{array}{l}\text { Cooling } \\
\text { Tower } 63\end{array}$ & $2 / 59$ & None. Cooling water. \\
\hline TA-1-64 & $\mathrm{T}$ & $2 / 59$ & None. T-Division offices. \\
\hline TA-1-65 & Theta & $2 / 47$ & None. \\
\hline TA-1-66 & Theta-1 & $7 / 58$ & Norie. Storage. \\
\hline TA-1-67 & TU & $7 / 27 / 64$ & ${ }^{238} \mathrm{U}$ \\
\hline TA-1-68 & TU-1 & $7 / 27 / 64$ & $\begin{array}{l}{ }^{28} \mathrm{U} \text {. Contained furnace for burning rags, etc., } \\
\text { used in uranium recovery. }\end{array}$ \\
\hline TA-1-69. & $\mathrm{U}$ & $2 / 59$ & ${ }^{8} \mathrm{H},{ }^{238} \mathrm{U},{ }^{236} \mathrm{U},{ }^{14} \mathrm{C},{ }^{226} \mathrm{Ra}$ (sources). \\
\hline TA-1.70 & $\mathrm{v}$ & $2 / 59$ & $\begin{array}{l}\text { Beryllium, uranium alpha contamination. } \\
\text { Sheet metal storage. }\end{array}$ \\
\hline TA-1-71 & W & $2 / 59$ & Uranium, ${ }^{210} \mathrm{Po},{ }^{3} \mathrm{H}$. Van de Graaff. \\
\hline TA-1-72 & $\begin{array}{l}\text { Cooling } \\
\text { Tower } 72\end{array}$ & $2 / 59$ & None. Water cooling. \\
\hline TA-1.73 & Warehouse 1 & $8 / 48$ & None. Storage. \\
\hline TA-1-74 & Warehouse 2 & $9 / 54$ & None. Storage. \\
\hline
\end{tabular}




\begin{tabular}{|c|c|c|c|}
\hline $\begin{array}{l}\text { Structure } \\
\text { Number }\end{array}$ & $\begin{array}{c}\text { Structure } \\
\text { Nomenclature }\end{array}$ & $\begin{array}{c}\text { Removal } \\
\text { Date }\end{array}$ & $\begin{array}{c}\text { Radioactive Materials Used } \\
\text { and/or Structure Use }\end{array}$ \\
\hline TA-1-75 & $\begin{array}{l}\text { J-Division } \\
\text { Annex Ware- } \\
\text { house } 3\end{array}$ & $5 / 65$ & $\begin{array}{l}{ }^{228} \mathrm{Ra} \text {-some contamination from dust out of } \\
\text { a source storage pig. One end of building } \\
\text { was used for film calibration. }\end{array}$ \\
\hline TA-1-76 & Warehouse 4 & $9 / 54$ & None. Storage. \\
\hline $\mathrm{T} \dot{\mathrm{A}}-1-77$ & Warehouse 5 & $\mathbf{y} / 54$ & None. Storage. \\
\hline $\mathrm{TA}-1-78$ & Warehouse 6 & $9 / 10 / 54$ & $\begin{array}{l}\text { None. Originally used for repair of zquip- } \\
\text { ment from machine shops and later for } \\
\text { storage. }\end{array}$ \\
\hline $\mathrm{TA}-1-79$ & $\mathrm{X}$ & $6 / 54$ & $\begin{array}{l}\text { lnduced activity in cyclotron. Some } \\
\text { radioactive targets were used. }\end{array}$ \\
\hline TA-1-80 & $\begin{array}{l}\text { Cooling } \\
\text { Tower } 80\end{array}$ & $8 / 54$ & None. Water cooling. \\
\hline TA-1-81 & $\mathrm{Y}$ & $6 / 56$ & $\begin{array}{l}\text { Alpha contamination, }{ }^{3} \mathrm{H},{ }^{298} \mathrm{U} \text {. Physics } \\
\text { laboratory. }\end{array}$ \\
\hline TA-1-82 & $\begin{array}{l}\text { Cooling } \\
\text { Tower } 82\end{array}$ & $6 / 56$ & None. Cooling water. \\
\hline TA-1-83 & $\mathbf{Z}$ & $2 / 59$ & ${ }^{3} \mathrm{H}$. Cockcroft-Walton machine. \\
\hline TA-1-84 & $\begin{array}{l}\text { P-Prime } \\
\text { Annex }\end{array}$ & $10 / 65$ & None. Offices. \\
\hline TA-1-85 & $\begin{array}{l}\text { Sprinkler } \\
\text { House }\end{array}$ & $6 / 60$ & None. \\
\hline TA-1-86 & Platform & $8 / 48$ & None. Unloading duck for C Shop. \\
\hline TA-1.87 & $\begin{array}{l}87 \\
\text { Guard Station } \\
327\end{array}$ & $11 / 56$ & None. \\
\hline TA-1-88 & $\begin{array}{l}88 \\
\text { Guard Station } \\
210\end{array}$ & $1 / 59$ & None. \\
\hline TA-1-89 & $\begin{array}{l}89 \\
\text { Guard Station } \\
202\end{array}$ & $2 / 59$ & None. \\
\hline TA-1-90 & Guard Tower & $4 / 60$ & None. \\
\hline
\end{tabular}




\begin{tabular}{|c|c|c|c|}
\hline $\begin{array}{l}\text { Structure } \\
\text { Number }\end{array}$ & $\begin{array}{l}\text { Structure } \\
\text { Nomenclature }\end{array}$ & $\begin{array}{l}\text { Removal } \\
\text { Date }\end{array}$ & $\begin{array}{l}\text { Radioactive Materials Used } \\
\text { and/or Structure Use }\end{array}$ \\
\hline TA-1-91 & Warehouse 7 & 1956 & $\begin{array}{l}\text { None. Storage (sold to Junior National } \\
\text { Rifle Association). }\end{array}$ \\
\hline TA.1.92 & $\begin{array}{l}\text { Guard Tower } \\
92\end{array}$ & $7 / 51$ & None. \\
\hline TA-1-93 & $\begin{array}{l}\text { Guard Tower } \\
93\end{array}$ & Relocated & $\begin{array}{l}\text { None. Moved in } 1949 \text { to current technical } \\
\text { area (TA-18). }\end{array}$ \\
\hline TA-1-94 & $\begin{array}{l}\text { Guard Tower } \\
94\end{array}$ & Relocated & $\begin{array}{l}\text { None. Moved to current technical area } \\
\text { (TA-15). }\end{array}$ \\
\hline TA-1-95 & $\begin{array}{l}\text { Guard Tower } \\
95\end{array}$ & 1946 & None. \\
\hline TA-1-96 & M-1 & $3 / 65$ & $\begin{array}{l}\text { Originally used for machining lithium; } \\
\text { later for }{ }^{23} \text { U samples (no cont amination). }\end{array}$ \\
\hline TA-1-97 & Warehouse 13 & 1954 & None. Storage. \\
\hline TA-1-98 & $\mathrm{K}-1$ & $3 / 65$ & None. Machining graphite. \\
\hline TA-1-99 & Warehouse 15 & $12 / 7 / 55$ & None, Storage. \\
\hline TA-1-100 & Warehouse 16 & $12 / 7 / 55$ & None. Storage. \\
\hline TA-1-101 & Warehouse 17 & 1954 & None. St orage. \\
\hline TA-1-102 & Warehouse 18 & 1954 & None. Storage. \\
\hline TA-1-103 & Warehouse 19 & $3 / 65$ & None. Storage. \\
\hline TA-1-104 & $\begin{array}{l}\text { Sheet Metal } \\
\text { Shop }\end{array}$ & $3 / 65$ & ${ }^{238} \mathrm{U}$ (spill on concrete floor). \\
\hline TA-1-105 & Gamma-z & $8 / 64$ & None. Post office and storage. \\
\hline TA-1.106 & $\begin{array}{l}\text { Passageway } \\
106\end{array}$ & $2 / 59$ & None. \\
\hline TA-1-107 & $\begin{array}{l}\text { Passageway } \\
107\end{array}$ & $2 / 59$ & None. \\
\hline TA-1-108 & $\begin{array}{l}\text { Passageway } \\
108\end{array}$ & $2 / 59$ & None. \\
\hline TA-1-109 & $\begin{array}{l}\text { Passageway } \\
109\end{array}$ & $2 / 59$ & None. \\
\hline
\end{tabular}




\begin{tabular}{|c|c|c|c|}
\hline $\begin{array}{l}\text { Structure } \\
\text { Number }\end{array}$ & $\begin{array}{c}\text { Structure } \\
\text { Nomenclature }\end{array}$ & $\begin{array}{l}\text { Removal } \\
\text { Date }\end{array}$ & $\begin{array}{c}\text { Radioactive Materials Used } \\
\text { and/or Structure Use }\end{array}$ \\
\hline TA-1-110 & $\begin{array}{l}\text { Passageway } \\
110\end{array}$ & $2 / 59$ & None. \\
\hline TA-1-111 & $\begin{array}{l}\text { Passageway } \\
111\end{array}$ & $2 / 59$ & None. \\
\hline TA-1-112 & $\begin{array}{l}\text { Passageway } \\
112\end{array}$ & $3 / 59$ & None. \\
\hline TA-1-113 & $\begin{array}{l}\text { Passageway } \\
113\end{array}$ & $9 / 54$ & None. \\
\hline TA-1-114 & $\begin{array}{l}\text { Microscopy } \\
\text { Laboratory }\end{array}$ & 1953 & None. \\
\hline TA.1-115 & $\mathrm{J}-2$ & 1958 & $\begin{array}{l}{ }^{239} \mathrm{Pu},{ }^{23 \mathrm{~A}} \mathrm{U},{ }^{296} \mathrm{U} \text {, fission products, ameri- } \\
\text { cium, curium. Radiochemistry. }\end{array}$ \\
\hline TA-1-116 & $\mathrm{J}-3$ & $5 / 58$ & $\begin{array}{l}\text { None. Storage; moved to current technical } \\
\text { area (TA-3). }\end{array}$ \\
\hline TA-1-117 & Gas storage & $10 / 59$ & None. Storage. \\
\hline TA-1-118 & $\begin{array}{l}118 \\
\text { (latrine) }\end{array}$ & $4 / 5.3$ & None. \\
\hline TA-1-119 & Warehouse 21 & $4 / 53$ & None. Zia paint shop and storage. \\
\hline TA-1-120 & Warehouse 22 & $4 / 53$ & None. Zia carpenter shop and storage. \\
\hline TA-1-121 & Warehouse 23 & $4 / 53$ & None. Zia furniture repair shop and storage. \\
\hline TA-1-122 & Warehouse 24 & $4 / 53$ & None. Zia sign shop and storage. \\
\hline TA-1-123 & $\begin{array}{l}\text { Guard Tower } \\
123\end{array}$ & $\begin{array}{l}\text { Relocated } \\
7 / 46\end{array}$ & $\begin{array}{l}\text { None. Moved to current technical area } \\
\text { (TA-18). }\end{array}$ \\
\hline TA-1-124 & $\begin{array}{l}124 \\
\text { Guard Station } \\
304\end{array}$ & $6 / 3 / 58$ & None. \\
\hline TA-1-125 & $\begin{array}{l}125 \\
\text { Health and } \\
\text { Safety }\end{array}$ & $\begin{array}{l}\text { Released } \\
\text { to AEC } \\
2 / 25 / 52\end{array}$ & $\begin{array}{l}\text { None. Dormitories; later, Zia Co. health } \\
\text { and safety offices. }\end{array}$ \\
\hline TA-1-126 & Mesa Library & $4 / 53$ & $\begin{array}{l}{ }^{80} \mathrm{Sr} \text { (surface contaminated but cleaned up). } \\
\text { Library; later J-Division laboratories. }\end{array}$ \\
\hline TA-1-127 & AP & $11 / 15 / 65$ & None. Offices; formerly barracks. \\
\hline
\end{tabular}




\begin{tabular}{|c|c|c|c|}
\hline $\begin{array}{l}\text { Structure } \\
\text { Number }\end{array}$ & $\begin{array}{c}\text { Structure } \\
\text { Nomenclature }\end{array}$ & $\begin{array}{c}\text { Removal } \\
\text { Date }\end{array}$ & $\begin{array}{c}\text { Radioactive Materials Used } \\
\text { and/or Structure Use }\end{array}$ \\
\hline TA-1-128 & $\begin{array}{l}\text { Medical } \\
\text { Warehouse }\end{array}$ & 1953 & None. Used for old hospital. \\
\hline TA-1-129 & $\begin{array}{l}129 \\
\text { Guard Station } \\
239\end{array}$ & $3 / 58$ & None. \\
\hline TA-1-130 & 130 & $5 / 51$ & None. Guard station. \\
\hline TA-1-131 & Bailey Bridge & $1 / 65$ & None. \\
\hline TA-1-132 & Water Tower & Relocated & $\begin{array}{l}\text { None. Moved to current technical area } \\
\text { (TA-21). }\end{array}$ \\
\hline TA-1-133 & $\begin{array}{l}\text { Booster } \\
\text { Station }\end{array}$ & $3 / 66$ & None. Booster station for wilter. \\
\hline TA-1-134 & $\begin{array}{l}\text { Septic Tank } \\
\text { (sanitary) }\end{array}$ & $\begin{array}{l}\text { Abandoned } \\
1964\end{array}$ & None. Served Buildings 103 and 104. \\
\hline ТА-1-135 & $\begin{array}{l}\text { Septic Tank } \\
\text { (sanitary) }\end{array}$ & $\begin{array}{l}\text { Abandoned } \\
1964\end{array}$ & None. Served Building M-1. \\
\hline TA-1-136 & Platform 136 & $8 / 23 / 54$ & None. \\
\hline TA.1.137 & $\begin{array}{l}\text { Septic Tank } \\
\text { (sanitary) }\end{array}$ & $\begin{array}{l}\text { Abandoned } \\
1965\end{array}$ & $\begin{array}{l}{ }^{239} \mathrm{Pu} \text {. Served D-2 hutment; removed August } \\
1975 \text {. }\end{array}$ \\
\hline TA-1-138 & $\begin{array}{l}\text { Septic Tank } \\
\text { (sanitary) }\end{array}$ & $\begin{array}{l}\text { Abandoned } \\
1956\end{array}$ & $\begin{array}{l}\text { None. (Filled with dirt..) Served } \\
\text { Building } 4 .\end{array}$ \\
\hline TA-1-139 & $\begin{array}{l}\text { Septic Tank } \\
\text { (sanitary) }\end{array}$ & $\begin{array}{l}\text { Abandoned } \\
1965\end{array}$ & $\begin{array}{l}\text { Beryllium (?) or uranium (?). Served } \\
\text { Delta and D-5 Buildings. }\end{array}$ \\
\hline TA-1-140 & $\begin{array}{l}\text { Septic Tank } \\
\text { (sanitary) }\end{array}$ & $\begin{array}{l}\text { Abandoned } \\
1965\end{array}$ & Uranium. Served HT Building and Foundry. \\
\hline TA-1-141 & $\begin{array}{l}\text { Septic Tank } \\
\text { (sanitary) }\end{array}$ & $\begin{array}{l}\text { Abandoned } \\
1965\end{array}$ & None. (Filled with dirt.) Served X Building. \\
\hline TA-1-142 & $\begin{array}{l}\text { Septic Tank } \\
\text { (sanitary) }\end{array}$ & $\begin{array}{l}\text { Abandoned } \\
1953\end{array}$ & None. Served Building 118 (latrine). \\
\hline TA-1-143 & $\begin{array}{l}\text { Septic Tank } \\
\text { (sanitary) }\end{array}$ & $10 / 65$ & $\begin{array}{l}{ }^{296} \mathrm{U},{ }^{288} \mathrm{U} \text {. Served J-Division Annex and } \\
\text { TU Building. }\end{array}$ \\
\hline TA-1-144 & 144 & $10 / 53$ & None. \\
\hline
\end{tabular}




\begin{tabular}{|c|c|c|c|}
\hline $\begin{array}{l}\text { Structure } \\
\text { Number }\end{array}$ & $\begin{array}{c}\text { Structure } \\
\text { Nomenclature }\end{array}$ & $\begin{array}{c}\text { Removal } \\
\text { Date }\end{array}$ & $\begin{array}{c}\text { Radioactive Materials Used } \\
\text { and/or Structure Use }\end{array}$ \\
\hline TA-1-145 & 145 & $10 / 53$ & $\begin{array}{l}\text { (No history. Building had no plumbing and } \\
\text { is believed to liave been clean.) }\end{array}$ \\
\hline TA-1-146 & $\begin{array}{l}\text { Incinerator } \\
146\end{array}$ & $10 / 58$ & None. \\
\hline TA-1-147 & $\begin{array}{l}\text { Incinerator } \\
147\end{array}$ & $2 / 59$ & None. \\
\hline TA-1.148 & Platform 148 & $2 / 59$ & None. \\
\hline TA-1-149 & Tank 149 & $\begin{array}{l}\text { Relocated } \\
2 / 53\end{array}$ & $\begin{array}{l}\text { None. Moved to current technical area } \\
\text { (TA-3). }\end{array}$ \\
\hline TA-1-150 & 150 & $\begin{array}{l}\text { Relocated } \\
8 / 52\end{array}$ & $\begin{array}{l}\text { None. Moved to current technical area } \\
\text { (TA-21). }\end{array}$ \\
\hline TA-1-151 & 151 & $9 / 57$ & ${ }^{29 s} \mathrm{U}$. Part of $\mathrm{M}$-Building complex. \\
\hline TA-1-152 & $\begin{array}{l}\text { Transformer } \\
\text { Station }\end{array}$ & $10 / 64$ & None. \\
\hline TA-1-153 & $\begin{array}{l}\text { Transformer } \\
\text { Station }\end{array}$ & 1964 & None. \\
\hline TA-1-154 & $\begin{array}{l}\text { Transformer } \\
\text { Station }\end{array}$ & 1964 & None. \\
\hline TA-1-155 & $\begin{array}{l}\text { Transformer } \\
\text { Station }\end{array}$ & $10 / 64$ & None. \\
\hline TA-1-156 & $\begin{array}{l}\text { Transformier } \\
\text { Station }\end{array}$ & $10 / 64$ & None. \\
\hline TA-1-157 & $\begin{array}{l}\text { Transformer } \\
\text { Station }\end{array}$ & $8 / 54$ & None. \\
\hline TA-1-158 & $\begin{array}{l}\text { Transformer } \\
\text { Station }\end{array}$ & $6 / 60$ & None. \\
\hline TA-1-159 & $\begin{array}{l}\text { Transformer } \\
\text { Station }\end{array}$ & $6 / 60$ & None. \\
\hline TA-1-160 & $\begin{array}{l}\text { Transformer } \\
\text { Station }\end{array}$ & $6 / 60$ & None. \\
\hline TA-1-1.61 & $\begin{array}{l}\text { Transformer } \\
\text { Station }\end{array}$ & $\begin{array}{l}\text { Transferred } \\
\text { to county } \\
1 / 11 / 66\end{array}$ & None. \\
\hline
\end{tabular}




\begin{tabular}{|c|c|c|c|}
\hline $\begin{array}{l}\text { Structure } \\
\text { Number }\end{array}$ & $\begin{array}{c}\text { Structure } \\
\text { Nomenclature }\end{array}$ & $\begin{array}{c}\text { Removal } \\
\text { Date }\end{array}$ & $\begin{array}{l}\text { Radioactive Materials Used } \\
\text { and/or Structure Use }\end{array}$ \\
\hline TA-1-162 & $\begin{array}{l}\text { Transformer } \\
\text { Station }\end{array}$ & $\begin{array}{l}\text { Transferred } \\
\text { to county } \\
1 / 11 / 66\end{array}$ & None. \\
\hline TA-1-163 & $\begin{array}{l}\text { Transformer } \\
\text { Station }\end{array}$ & $6 / 60$ & None. \\
\hline TA-1-164 & $\begin{array}{l}\text { Transformer } \\
\text { Station }\end{array}$ & $6 / 60$ & None. \\
\hline TA-1-165 & $\begin{array}{l}\text { Transformer } \\
\text { Station }\end{array}$ & $6 / 60$ & None. \\
\hline TA-1-166 & $\begin{array}{l}\text { Transformer } \\
\text { Station }\end{array}$ & $6 / 60$ & None. \\
\hline TA-1-167 & $\begin{array}{l}\text { Transformer } \\
\text { Station }\end{array}$ & $6 / 60$ & None. \\
\hline TA-1-168 & $\begin{array}{l}\text { Manhole, } \\
\text { steam }\end{array}$ & $\begin{array}{l}\text { Abandoned } \\
1964\end{array}$ & None. (Filled with dirt.) \\
\hline TA-1-169 & $\begin{array}{l}\text { Manhole, } \\
\text { steam }\end{array}$ & $\begin{array}{l}\text { Abandoned } \\
1964\end{array}$ & None. (Filled with dirt.) \\
\hline TA-1-170 & $\begin{array}{l}\text { Manhole, } \\
\text { sprinkler }\end{array}$ & $\begin{array}{l}\text { Abandoned } \\
1964\end{array}$ & None. (Filled with dirt.) \\
\hline TA-1-171 & $\begin{array}{l}\text { Manhole, } \\
\text { sprinkler }\end{array}$ & $\begin{array}{l}\text { Abandoned } \\
1964\end{array}$ & None. (Filled with dirt.) \\
\hline T'A-1-172 & $\begin{array}{l}\text { Manhole, } \\
\text { electrical }\end{array}$ & $\begin{array}{l}\text { Abandoned } \\
1964\end{array}$ & None. (Filled with dirt.) \\
\hline TA-1-173 & $\begin{array}{l}\text { Manhole, } \\
\text { steam }\end{array}$ & $\begin{array}{l}\text { Abandoned } \\
1964\end{array}$ & None. (Filled with dirt.) \\
\hline TA-1-174 & $\begin{array}{l}\text { Manhole, } \\
\text { acid-sewer }\end{array}$ & 1964 & $\begin{array}{l}\text { Plutonium, uranium. Junction for Sigma } \\
\text { and D Buildings. }\end{array}$ \\
\hline TA-1.175 & $\begin{array}{l}\text { Manhole, } \\
\text { sprinkler }\end{array}$ & $\begin{array}{l}\text { Abandoned } \\
1964\end{array}$ & None. (Filled with dirt.) \\
\hline TA-1-176 & $\begin{array}{l}\text { Manhole, } \\
\text { sanitary- } \\
\text { sewer }\end{array}$ & $\begin{array}{l}\text { Transferred } \\
\text { to county } \\
1966\end{array}$ & None. Served A and B Buildings. \\
\hline TA-1-177 & $\begin{array}{l}\text { Manhole, } \\
\text { steam }\end{array}$ & $\begin{array}{l}\text { Abandoned } \\
1959\end{array}$ & None. \\
\hline
\end{tabular}




\begin{tabular}{|c|c|c|c|}
\hline $\begin{array}{l}\text { Structure } \\
\text { Number }\end{array}$ & $\begin{array}{c}\text { Structure } \\
\text { Nomenclature }\end{array}$ & $\begin{array}{c}\text { Removal } \\
\text { Date }\end{array}$ & $\begin{array}{c}\text { Radioactive Materials Used } \\
\text { and/or Structure Use }\end{array}$ \\
\hline TA-1-178 & $\begin{array}{l}\text { Manhole, } \\
\text { water }\end{array}$ & $\begin{array}{l}\text { Transferred } \\
\text { to county } \\
1966\end{array}$ & None. \\
\hline TA-1-179 & $\begin{array}{l}\text { Ianhole, } \\
\text { telephone }\end{array}$ & $\begin{array}{l}\text { Transferred } \\
\text { to county } \\
1966\end{array}$ & None. \\
\hline TA-1-180 & $\begin{array}{l}\text { Manhule, } \\
\text { sprinkler }\end{array}$ & $\begin{array}{l}\text { Abandoned } \\
1964\end{array}$ & None. \\
\hline TA-1-181 & $\begin{array}{l}\text { Manhole, } \\
\text { sanitary- } \\
\text { sewer }\end{array}$ & $\begin{array}{l}\text { Abandoned } \\
1959\end{array}$ & $\begin{array}{l}\text { Checked; no contamination found. Served } \\
V, M, D \text {, and A Buildings. }\end{array}$ \\
\hline TA-1-182 & $\begin{array}{l}\text { Manhole, } \\
\text { steam }\end{array}$ & $\begin{array}{l}\text { Transferred } \\
\text { to county } \\
1 / 11 / 66\end{array}$ & None. \\
\hline TA-1-183 & $\begin{array}{l}\text { Manhole, } \\
\text { steam }\end{array}$ & $\begin{array}{l}\text { Abandoned } \\
1964\end{array}$ & None. \\
\hline TA-1-184 & $\begin{array}{l}\text { Manhole, } \\
\text { steam }\end{array}$ & $\begin{array}{l}\text { Abandoned } \\
1959\end{array}$ & None. \\
\hline $1 \therefore-1-185$ & $\begin{array}{l}\text { Manhole, } \\
\text { steam }\end{array}$ & $\begin{array}{l}\text { Abandoned } \\
1959\end{array}$ & None. \\
\hline T.4.1.186 & $\begin{array}{l}\text { Manhole, } \\
\text { steam }\end{array}$ & $\begin{array}{l}\text { Abandoned } \\
1959\end{array}$ & None. \\
\hline TA-1-187 & $\begin{array}{l}\text { Manhole, } \\
\text { acid drain }\end{array}$ & 1960 & ${ }^{285} \mathrm{U}$. Served M Building. \\
\hline TA-1-188 & $\begin{array}{l}\text { Manhole, } \\
\text { sanitary- } \\
\text { sewer }\end{array}$ & 1960 & Uranium. Served $V$ and $M$ Buildings. \\
\hline TA-1-189 & $\begin{array}{l}\text { Manhole, } \\
\text { sanitary- } \\
\text { sewer }\end{array}$ & $\begin{array}{l}\text { Abandoned } \\
1959\end{array}$ & $\begin{array}{l}\text { None found. Served } \mathrm{V}, \mathrm{D} \text {, and } \mathrm{M} \text { Buildings } \\
\text { (was filled with dirt). }\end{array}$ \\
\hline TA-1-190 & $\begin{array}{l}\text { Manhole, } \\
\text { gas valve pit }\end{array}$ & $\begin{array}{l}\text { Abandoned } \\
1960\end{array}$ & None. \\
\hline TA-1-191 & $\begin{array}{l}\text { Manhole, } \\
\text { telephone }\end{array}$ & $\begin{array}{l}\text { Transferred } \\
\text { to county } \\
1 / 11 / 66\end{array}$ & None. \\
\hline TA-1-192 & $\begin{array}{l}\text { Manhole, } \\
\text { sprinkler }\end{array}$ & $\begin{array}{l}\text { Abandoned } \\
1960\end{array}$ & None. \\
\hline
\end{tabular}




\begin{tabular}{|c|c|c|c|}
\hline $\begin{array}{c}\text { Structure } \\
\text { Number }\end{array}$ & $\begin{array}{c}\text { Structure } \\
\text { Nomenclature }\end{array}$ & $\begin{array}{c}\text { Removal } \\
\text { Date }\end{array}$ & $\begin{array}{l}\text { Kadioactive Materials Used } \\
\text { and/or Structure Use }\end{array}$ \\
\hline TA-1-193 & $\begin{array}{l}\text { Manhole, } \\
\text { domestic } \\
\text { water }\end{array}$ & $\begin{array}{l}\text { Transferred } \\
\text { to county } \\
1 / 11 / 66\end{array}$ & None. \\
\hline TA-1.194 & $\begin{array}{l}\text { Manhole, } \\
\text { sprinkler }\end{array}$ & $\begin{array}{l}\text { Transferred } \\
\text { to county } \\
1 / 11 / 66\end{array}$ & None. \\
\hline TA-1-195 & $\begin{array}{l}\text { Manhole, } \\
\text { sanitary- } \\
\text { sewer }\end{array}$ & $\begin{array}{l}\text { Transferred } \\
\text { to county } \\
1 / 11 / 66\end{array}$ & None found. Served Gamma Building. \\
\hline TA-1-196 & $\begin{array}{l}\text { Manhole, } \\
\text { sanitary- } \\
\text { sewer }\end{array}$ & $\begin{array}{l}\text { Transferred } \\
\text { to county } \\
1 / 11 / 66\end{array}$ & None found. Served Gamma Building. \\
\hline TA-1-197 & $\begin{array}{l}\text { Manhole, } \\
\text { sanitary- } \\
\text { sewer }\end{array}$ & $\begin{array}{l}\text { Transferred } \\
\text { to county } \\
1 / 11 / 66\end{array}$ & None found. Served Gamma Building. \\
\hline TA-1-198 & $\begin{array}{l}\text { Manhoie, } \\
\text { sanitary- } \\
\text { sewer }\end{array}$ & $\begin{array}{l}\text { Transferred } \\
\text { to county } \\
1 / 11 / 66\end{array}$ & None found. Served Gamma Building. \\
\hline TA-1-199 & $\begin{array}{l}\text { Manhole, } \\
\text { sanitary- } \\
\text { sewer }\end{array}$ & $\begin{array}{l}\text { Transferred } \\
\text { to county } \\
1 / 11 / 66\end{array}$ & $\begin{array}{l}\text { None found. Served W, R, S, and T Buildings } \\
\text { and Mesa Library. }\end{array}$ \\
\hline TA-1-200 & $\begin{array}{l}\text { Manhole, } \\
\text { sanitary- } \\
\text { sewer }\end{array}$ & $\begin{array}{l}\text { Transferred } \\
\text { to county } \\
1 / 11 / 6 \dot{6}\end{array}$ & $\begin{array}{l}\text { Nine found. Served W, R, S, and } 7 \text { Buildings } \\
\text { aild Mesa Library. }\end{array}$ \\
\hline TA-1-201 & $\begin{array}{l}\text { Manhole, } \\
\text { sanitary- } \\
\text { sewer }\end{array}$ & $\begin{array}{l}\text { Transferred } \\
\text { to county } \\
1 / 11 / 66\end{array}$ & None found. Served W, R, S, and T Buildings. \\
\hline TA-1-202 & $\begin{array}{l}\text { Manhole, } \\
\text { sanitary- } \\
\text { sewer }\end{array}$ & $\begin{array}{l}\text { Abandoned } \\
1960\end{array}$ & $\begin{array}{l}\text { None found. Served W, R, S, and T Buildings } \\
\text { (was filled with dirt). }\end{array}$ \\
\hline TA-1-203 & $\begin{array}{l}\text { Manhole, } \\
\text { sprinkler }\end{array}$ & $\begin{array}{l}\text { Abandoned } \\
1964\end{array}$ & None. (Filled with dirt.) \\
\hline TA-1-204 & $\begin{array}{l}\text { Manhole, } \\
\text { domestic } \\
\text { water }\end{array}$ & $\begin{array}{l}\text { Abandoned } \\
6 / 59\end{array}$ & None. (Filled with dirt.) \\
\hline
\end{tabular}




\begin{tabular}{|c|c|c|c|}
\hline $\begin{array}{c}\text { Structure } \\
\text { Number }\end{array}$ & $\begin{array}{c}\begin{array}{c}\text { Structure } \\
\text { Nomenclature }\end{array} \\
\end{array}$ & $\begin{array}{c}\text { Removal } \\
\text { Date }\end{array}$ & $\begin{array}{c}\text { Radioactive Materials Used } \\
\text { and/or Structure Use }\end{array}$ \\
\hline TA-1-205 & $\begin{array}{l}\text { Manhole, } \\
\text { sprinkler }\end{array}$ & $\begin{array}{l}\text { Abandoned } \\
1964\end{array}$ & None. (Filled with dirt.) \\
\hline TA-1-206 & $\begin{array}{l}\text { Manhole, } \\
\text { sprinkler }\end{array}$ & $\begin{array}{l}\text { Abandoned } \\
1964\end{array}$ & None. (Filled with dirt.) \\
\hline TA-1-207 & $\begin{array}{l}\text { Manhole, } \\
\text { sanitary- } \\
\text { sewer }\end{array}$ & 1960 & None found. Served R Building. \\
\hline TA-1-208 & $\begin{array}{l}\text { Manhole, } \\
\text { sanitary- } \\
\text { sewer }\end{array}$ & $\begin{array}{l}\text { Abandoned } \\
1959\end{array}$ & $\begin{array}{l}\text { None. Served R Building (was filled wit } \\
\text { dirt). }\end{array}$ \\
\hline TA-1-209 & $\begin{array}{l}\text { Manhole, } \\
\text { sprinkler }\end{array}$ & $\begin{array}{l}\text { Transferred } \\
\text { to county } \\
1 / 11 / 66\end{array}$ & None. \\
\hline TA-1-210 & $\begin{array}{l}\text { Manhole, } \\
\text { sanitary- } \\
\text { sewer }\end{array}$ & $\begin{array}{l}\text { Abandoned } \\
1953\end{array}$ & None. \\
\hline TA-1-211 & $\begin{array}{l}\text { Manhole, } \\
\text { process }\end{array}$ & $\begin{array}{l}\text { Abandoned } \\
1953\end{array}$ & None. \\
\hline TA-1-212 & $\begin{array}{l}\text { Manhole, } \\
\text { sanitary- } \\
\text { sewer }\end{array}$ & $10 / 64$ & None. (Was pushed over canyon rim.) \\
\hline TA-1-213 & $\begin{array}{l}\text { Manhole, } \\
\text { electrical }\end{array}$ & $\begin{array}{l}\text { Transferred } \\
\text { to county } \\
1 / 11 / 66\end{array}$ & None. \\
\hline TA-1-214 & $\begin{array}{l}\text { Manhole, } \\
\text { electrical }\end{array}$ & $\begin{array}{l}\text { Transferred } \\
\text { to county } \\
1 / 11 / 66\end{array}$ & None. \\
\hline$T A-1-215$ & $\begin{array}{l}\text { Manhole, } \\
\text { electrical }\end{array}$ & $\begin{array}{l}\text { Transferred } \\
\text { to county } \\
1 / 11 / 66\end{array}$ & None. \\
\hline TA-1-216 & $\begin{array}{l}\text { Manhole, } \\
\text { electrical }\end{array}$ & $\begin{array}{l}\text { Transferred } \\
\text { to county } \\
1 / 11 / 66\end{array}$ & None. \\
\hline TA-1-217 & $\begin{array}{l}\text { Manhole, } \\
\text { electrical }\end{array}$ & $\begin{array}{l}\text { Transferred } \\
\text { to county } \\
1 / 11 / 66\end{array}$ & None. \\
\hline
\end{tabular}




\begin{tabular}{|c|c|c|c|}
\hline $\begin{array}{l}\text { Structure } \\
\text { Number }\end{array}$ & $\begin{array}{c}\text { Structure } \\
\text { Nomenclature }\end{array}$ & $\begin{array}{c}\text { Removal } \\
\text { Date }\end{array}$ & $\begin{array}{c}\text { Radioactive Materials Used } \\
\text { and/or Structure Use }\end{array}$ \\
\hline TA-1-218 & $\begin{array}{l}\text { Manhole, } \\
\text { electrical }\end{array}$ & $\begin{array}{l}\text { Transferred } \\
\text { to county } \\
1 / 11 / 66\end{array}$ & None. \\
\hline TA-1-219 & $\begin{array}{l}\text { Manhole, } \\
\text { telephone }\end{array}$ & $\begin{array}{l}\text { Transferred } \\
\text { to county } \\
1 / 11 / 66\end{array}$ & None. \\
\hline TA-1-220 & $\begin{array}{l}\text { Manhole, } \\
\text { electrical }\end{array}$ & $\begin{array}{l}\text { Transferred } \\
\text { to county } \\
1 / 11 / 66\end{array}$ & None. \\
\hline TA-1-221 & $\begin{array}{l}\text { Manhole, } \\
\text { teiephone }\end{array}$ & $\begin{array}{l}\text { Transferred } \\
\text { to county } \\
1 / 11 / 66\end{array}$ & None. \\
\hline TA-1-222 & $\begin{array}{l}\text { Manhole, } \\
\text { sanitary- } \\
\text { sewer }\end{array}$ & $\begin{array}{l}\text { Transferred } \\
\text { to county } \\
1 / 11 / 66\end{array}$ & None. \\
\hline TA-1-223 & $\begin{array}{l}\text { Manhole, } \\
\text { electrical }\end{array}$ & $\begin{array}{l}\text { Transferred } \\
\text { to county } \\
1 / 11 / 66\end{array}$ & None. \\
\hline TA-1-224 & $\begin{array}{l}\text { Manhole, } \\
\text { electrical }\end{array}$ & $\begin{array}{l}\text { Transferred } \\
\text { to county } \\
1 / 11 / 66\end{array}$ & None. \\
\hline TA-1-225 & $\begin{array}{l}\text { Manhole, } \\
\text { electrical }\end{array}$ & $\begin{array}{l}\text { Transferred } \\
\text { to county } \\
1 / 11 / 66\end{array}$ & None. \\
\hline TA-1-226 & $\begin{array}{l}\text { Manhole, } \\
\text { telephone }\end{array}$ & $\begin{array}{l}\text { Transferred } \\
\text { to county } \\
1 / 11 / 66\end{array}$ & None. \\
\hline TA-1-227 & $\begin{array}{l}\text { Manhole, } \\
\text { telephone }\end{array}$ & $\begin{array}{l}\text { Transferred } \\
\text { to county } \\
1 / 11 / 66\end{array}$ & None. \\
\hline TA-1-228 & $\begin{array}{l}\text { Manhole, } \\
\text { telephone }\end{array}$ & $\begin{array}{l}\text { Transferred } \\
\text { to county } \\
1 / 11 / 66\end{array}$ & None. \\
\hline TA-1-229 & $\begin{array}{l}\text { Manhole, } \\
\text { telephone }\end{array}$ & $\begin{array}{l}\text { Transferred } \\
\text { to county } \\
1 / 11 / 66\end{array}$ & None. \\
\hline
\end{tabular}




\begin{tabular}{|c|c|c|c|}
\hline $\begin{array}{l}\text { Structure } \\
\text { Number }\end{array}$ & $\begin{array}{c}\text { Structure } \\
\text { Nomenclature }\end{array}$ & $\begin{array}{c}\text { Removal } \\
\text { Date }\end{array}$ & $\begin{array}{c}\text { Radioactive Materials Used } \\
\text { and/or Structure Use }\end{array}$ \\
\hline TA-1-230 & $\begin{array}{l}\text { Manhole, } \\
\text { sanitary- } \\
\text { sewer }\end{array}$ & $\begin{array}{l}\text { 'Transferred } \\
\text { to county } \\
1 / 11 / 66\end{array}$ & None. Served Dental Clinic. \\
\hline TA-1-2 1 & $\begin{array}{l}\text { Manhole, } \\
\text { electrical }\end{array}$ & $\begin{array}{l}\text { Transferred } \\
\text { to county } \\
1 / 11 / 66\end{array}$ & None. \\
\hline TA-1-232 & $\begin{array}{l}\text { Manhole, } \\
\text { electrical }\end{array}$ & 1959 & None. \\
\hline 'ГА-1-233 & $\begin{array}{l}\text { Manhole, } \\
\text { electrical }\end{array}$ & $\begin{array}{l}\text { Transterred } \\
\text { to co'snty } \\
1 / 11 / 66\end{array}$ & None. \\
\hline TA-1-234 & $\begin{array}{l}\text { Manhole, } \\
\text { steam }\end{array}$ & $\begin{array}{l}\text { Abandoned } \\
1960\end{array}$ & None. \\
\hline TA-1-235 & $\begin{array}{l}\text { Manhole, } \\
\text { acid-sewer }\end{array}$ & 1965 & Plutonium, uranium. Served D Building. \\
\hline TA-1-236 & $\begin{array}{l}\text { Manhole, } \\
\text { sanitary- } \\
\text { sewer }\end{array}$ & $\begin{array}{l}\text { Abandoned } \\
1960\end{array}$ & None. (Located on Trinity Drive.) \\
\hline TA-1-237 & Drum storage & 1955 & None. \\
\hline TA-1-238 & Drum storage & $2 / 58$ & $\begin{array}{l}\text { None. Relocated to current technical area } \\
\text { (TA-3). }\end{array}$ \\
\hline TA-1-239 & Storage shed & 1955 & None. \\
\hline TA-1-240 & Fuel tank & $8 / 54$ & None. \\
\hline TA-1-241 & $\begin{array}{l}\text { Manhole, } \\
\text { steam }\end{array}$ & $\begin{array}{l}\text { Transferred } \\
\text { to county } \\
1 / 11 / 66\end{array}$ & None. \\
\hline TA-1-242 & $\begin{array}{l}\text { Manhole, } \\
\text { water }\end{array}$ & $\begin{array}{l}\text { Transferred } \\
\text { to county } \\
1 / 11 / 66\end{array}$ & None. \\
\hline TA-1-243 & $\begin{array}{l}\text { Manhole, } \\
\text { sanitary- } \\
\text { sewer }\end{array}$ & 1960 & None found. Served M Building. \\
\hline TA-1-244 & $\begin{array}{l}\text { Manhole, } \\
\text { sanitary- } \\
\text { sewer }\end{array}$ & $\begin{array}{l}\text { Abandoned } \\
1959\end{array}$ & $\begin{array}{l}\text { None found. Served MI, U, V, W, and T } \\
\text { Buildings. }\end{array}$ \\
\hline
\end{tabular}




\begin{tabular}{|c|c|c|c|}
\hline $\begin{array}{l}\text { Structure } \\
\text { Number }\end{array}$ & $\begin{array}{c}\text { Structure } \\
\text { Nomenclature }\end{array}$ & $\begin{array}{c}\text { Removal } \\
\text { Date } \\
\end{array}$ & $\begin{array}{c}\text { Radioactive Materials Used } \\
\text { and/or Structure Use }\end{array}$ \\
\hline TA-1-245 & $\begin{array}{l}\text { Manhole, } \\
\text { sanitary- } \\
\text { sewer }\end{array}$ & $\begin{array}{l}\text { Transferred } \\
\text { to county } \\
1 / 11 / 66\end{array}$ & $\begin{array}{l}\text { None found. Served A, B, C, D, G, M, and V } \\
\text { Buildings and Boiler House. }\end{array}$ \\
\hline TA-1-246 & $\begin{array}{l}\text { Manhole, } \\
\text { sanitary- } \\
\text { sewer }\end{array}$ & 1948 & None. Served Gamma Building. \\
\hline TA-1-247 & 247 & $12 / 45$ & (No information available.) \\
\hline TA-1-248 & $\begin{array}{l}\text { Transformer } \\
\text { Station }\end{array}$ & $7 / 46$ & None. \\
\hline TA-1-249 & $\begin{array}{l}\text { Transformer } \\
\text { Station }\end{array}$ & $2 / 45$ & None. \\
\hline TA-1-250 & $\begin{array}{l}\text { Transformer } \\
\text { Station }\end{array}$ & $7 / 46$ & None. \\
\hline TA-1-251 & $\begin{array}{l}\text { Transformer } \\
\text { Station }\end{array}$ & $\begin{array}{l}\text { Before } \\
1953\end{array}$ & (No information available.) \\
\hline TA-1-252 & $\begin{array}{l}\text { Transformer } \\
\text { Station }\end{array}$ & $7 / 46$ & None. \\
\hline TA-1-253 & $\begin{array}{l}\text { Transformer } \\
\text { Station }\end{array}$ & $7 / 46$ & None. \\
\hline TA-1-254 & $\begin{array}{l}\text { Transformer } \\
\text { Station }\end{array}$ & $7 / 46$ & None. \\
\hline TA-1-255 & 255 & $3 / 47$ & (No information available.) \\
\hline TA-1-256 & $\begin{array}{l}\text { Transformer } \\
\text { Station }\end{array}$ & $7 / 47$ & None. \\
\hline TA-1-257 & $\begin{array}{l}\text { Transformer } \\
\text { Station }\end{array}$ & $7 / 46$ & None. \\
\hline TA-1-258 & $\begin{array}{l}\text { Manhole, } \\
\text { sanitary- } \\
\text { sewer }\end{array}$ & 1960 & ${ }^{241} \mathrm{Am}$, curium. Served ML Building. \\
\hline TA-1-259 & Valve box & 1960 & None. \\
\hline TA-1-260 & $\begin{array}{l}\text { Retaining } \\
\text { wall }\end{array}$ & 1960 & None. \\
\hline
\end{tabular}




\begin{tabular}{|c|c|c|c|}
\hline $\begin{array}{l}\text { Structure } \\
\text { Number }\end{array}$ & $\begin{array}{c}\text { Structure } \\
\text { Nomenclature }\end{array}$ & $\begin{array}{c}\text { Removal } \\
\text { Date } \\
\end{array}$ & $\begin{array}{l}\text { Radioactive Materials Use } \\
\text { and/or Structure Use }\end{array}$ \\
\hline TA-1-261 & $\begin{array}{l}\text { Manhole, } \\
\text { acid-sewer }\end{array}$ & 1960 & ${ }^{239} \mathrm{Pu}$, uranium. Served D Building. \\
\hline TA-1-262 & Unassigned & Not used & $\cdots$ \\
\hline TA-1-263 & $\begin{array}{l}\text { Retaining } \\
\text { wall }\end{array}$ & 1965 & None. \\
\hline TA-1-264 & Unassigned & Not used & $\cdots$ \\
\hline TA-1-265 & Unassigned & Not used & $\cdots$ \\
\hline TA-1-266 & $\begin{array}{l}\text { Retaining } \\
\text { wall }\end{array}$ & $4 / 12 / 63$ & None. Removed to city dump. \\
\hline TA-1-267 & $\begin{array}{l}\text { Retaining } \\
\text { wall }\end{array}$ & 1965 & None. \\
\hline TA-1.268 & $\begin{array}{l}\text { Septic Tank, } \\
\text { sanitary }\end{array}$ & 1964 & ${ }^{238} \mathrm{U},{ }^{236} \mathrm{U}$. Served TU Building. \\
\hline TA-1-269 & $\begin{array}{l}\text { Septic tank, } \\
\text { sanitary }\end{array}$ & $8 / 54$ & None. Served Building S-1. \\
\hline TA-1-270 & Unassigned & Not used & $\cdots$ \\
\hline TA-1-271 & Pump house & $3 / 47$ & None. \\
\hline TA-1-272 & $\mathrm{TP}$ & Not built & $\cdots$ \\
\hline TA-1-273 & Tank 273 & Not built & $\cdots$ \\
\hline TA-1-274 & $\begin{array}{l}\text { Manhole, } \\
\text { sanitary- } \\
\text { sewer }\end{array}$ & $\begin{array}{l}\text { Abandoned } \\
1946\end{array}$ & Not located. \\
\hline TA-1-275 & $\begin{array}{l}\text { Septic tank, } \\
\text { sanitary }\end{array}$ & $\begin{array}{l}\text { Abandoned } \\
1946\end{array}$ & Not located. \\
\hline TA-1-276 & $\begin{array}{l}\text { Septic tank, } \\
\text { sanitary }\end{array}$ & $\begin{array}{l}\text { Abandoned } \\
1946\end{array}$ & $\begin{array}{l}\text { Not located; may have been removed. } \\
\text { Served Theta Building. }\end{array}$ \\
\hline TA-1-277 & $\begin{array}{l}\text { Transformer } \\
\text { Station }\end{array}$ & 1960 & None. \\
\hline TA-1-278 & $\begin{array}{l}\text { Manhole, } \\
\text { steam }\end{array}$ & $\begin{array}{l}\text { Abandoned } \\
1957\end{array}$ & None. (Filled with dirt.) \\
\hline TA-1-279 & Water ıank & 1947 & None. \\
\hline
\end{tabular}




\begin{tabular}{|c|c|c|c|}
\hline $\begin{array}{c}\text { Structure } \\
\text { Number }\end{array}$ & $\begin{array}{c}\text { Structure } \\
\text { Nomenclature }\end{array}$ & $\begin{array}{c}\text { Removal } \\
\text { Date }\end{array}$ & $\begin{array}{l}\text { Radioactive } 2 \text { aterials Used } \\
\text { and/or Structure Use }\end{array}$ \\
\hline TA-1-280 & Water tank & $3 / 47$ & None. \\
\hline TA-1-281 & Water tank & $3 / 47$ & None. \\
\hline TA-1-282 & Water tank & $3 / 47$ & None. \\
\hline TA-1-28.3 & $\begin{array}{l}\text { Retaining } \\
\text { wall }\end{array}$ & $12 / 64$ & (Removed to contaminated dump.) \\
\hline TA-1-284 & $\begin{array}{l}284 \\
\text { (Wingfoot) }\end{array}$ & $9 / 59$ & None. \\
\hline TA-1-285 & $\begin{array}{l}285 \\
\text { (Wingfoot) }\end{array}$ & $9 / 59$ & Pione. \\
\hline TA-1-286 & $\begin{array}{l}\text { Transformer } \\
\text { Station }\end{array}$ & 1965 & None. \\
\hline TA-1-287 & Guard Tower & $2 / 49$ & None. \\
\hline$T A-1-288$ & Guard Station & $8 / 59$ & None. \\
\hline TA-1.289 & $\begin{array}{l}\text { Office } \\
\text { Building }\end{array}$ & Not built & $\cdots$ \\
\hline TA-1-290 & Substation & 1965 & None. \\
\hline TA-1-291 & Guard House & $2 / 65$ & None. \\
\hline TA-1-292 & Substation & 1964 & None. \\
\hline
\end{tabular}




\section{APPENDIX C \\ LETTER DESCRIBING TA-1 CONTAMINATION STATUS AND H-DIVISION RECOMMENDATIONS, JANUARY 13, 1960}

TO: R. E. Dunning, Engineering and Construction

DATE: January 13, 1960

LAAO

T. L. Shipman, Health Division Leader. LASL

TA-1

$\mathrm{H}$

I have discussed with each of the groups in $\mathrm{H}$-Division which are involved-H-1, $\mathrm{H}-3$ and $\mathrm{H}$ 5 -the present condition of those parts of the TA-1 not enclosed by the fence around Sigma building and its surroundings. It is our considered opinion that there is at the present time no reason to prevent the utilization or the sale of this land for any purpose whatsoever. This includes the area formerly occupied by D-building.

It should be kept in mind that it undoubtedly would be possible at many points in this area to find detectable amounts of radioactive materials or chemicals. It is felt, however, that such materials are present in such small quantities and so widely dispersed, that they do not in any way constitute a health hazard to either grown-ups or children.

As you are aware, considerable time, effort and money went into getting this area cleaned up. All remaining pipe lines were surveyed, and those with any contamination were removed. In adidtion, considerable volumes of soil and concrete were removed. Unless there is a willingness to accept the degree of contamination still remaining, one might just as well agree that none of the area can ever again be used for anything. Such a conclusion obviously is unrualistic, but no more so than would be any further attempts to decontaminate to a zero level.

After the western part of TA-1 is abandoned and given the sanıe kind of treatment previously given to the eastern and, I can see absolutely no reason why it, too, should not be available for sale or any other utilization. The problem should not be as difficult as was the case with D. building and certainly no more difficult than cleaning up the remainder.

ORIGINAL SIGNED BY THOMAS L. SHIPMAN, M.D.

T. L. Shipman, M.D. Health Division Leader

TLS:rr
cc: N. E. Bradbury
D. Meyer
J. Bolton
H. S. Schulte
S. E. Russo
Roy Reider 


\section{APPENDIX D}

\section{INSTRUMENTATION AND METHODS USED IN THE 1974 SURVEY}

\section{In Situ Radiation Measurements}

In situ radiation measurements of $\mathrm{x}$ and gamma radiation were made at each of the 62 sampling locations by three different instrument systems: a micro- $R$ meter, a high-pressure ionization chamber (HPIC), and the FiDLER (Field Instrument for Detection of Low-Energy Radiation) LAFPHA (Los Alamos, Field Pulse Height Analyzer) system.

The micro- $\mathrm{R}$ meter is a Ludlum Model $12 \mathrm{~S}$ countrate meter in which a $\mathrm{NaI}(\mathrm{Tl})$ scintillation crystal is used as the detector. This detector has the advantage of being sensitive enough to read $\mu \mathrm{R} / \mathrm{h}$ directly. A disadvantage is that its response is quite dependent upon photon energy (Fig. D-1). The instrument was calibrated with a knowr flux of ${ }^{228} \mathrm{Ra}$ (and daughters) gamma rays. The measured response was normalized to thermoluminescent dosimeter (TLD) results (essentially independent of photon energy) frum the environmental dosimetry network.

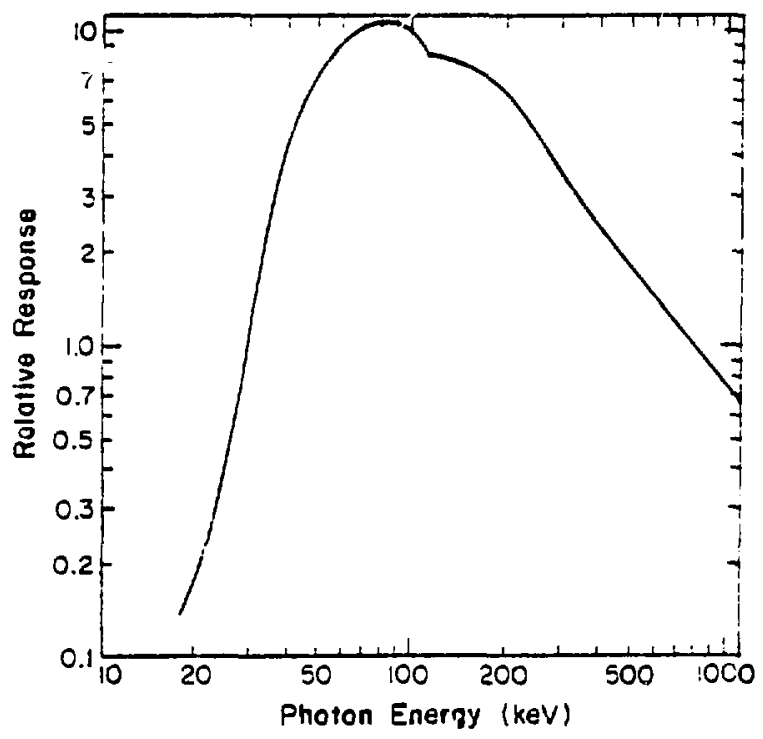

Fig. D-1.

Experimentally determined response curve of the Ludlum Model $12 S$ count-rate meter detector as a function of photon energy.
A Reuter-Stokes Model RSS-111 spherical, highpressure ionization chamber filled to $14 \mathrm{~atm}$ with pure argon was also used. Its calibrated-at-thefactory response was checked at various TLD measurement locations. In contrast to the micro- $R$ meter it has a flat energy response over a wide range of energies (Fig. D-2) and is thus well suited to make environmental gross-gamma measurements.

The FIDLER/LAFPHA system is designed to monitor the low-energy $x$ and gamma radiation from plutonium and americium. The FIDLER is a commercially available, thin, $\mathrm{NaI}(\mathrm{Tl})$ detector op. timized for photon energies $<100 \mathrm{keV}$. The LAFPHA is a field-portable, six-channel, pulse height analyzer. The channels on the LAFPHA were set to the foilowing energy bands:

\begin{tabular}{|c|c|}
\hline Channel & $\begin{array}{c}\text { Energy } \\
\text { Band } \\
\text { (keV) }\end{array}$ \\
\hline 1 & 5 to 9 \\
\hline 2 & 11 to 23 \\
\hline 3 & 25 to 37 \\
\hline 4 & 38 to 42 \\
\hline 5 & 54 to 66 \\
\hline 6 & 72 to 76 \\
\hline
\end{tabular}

Channel 2 was optimized to measure the $17 \cdot \mathrm{keV}$ $\mathrm{x}$-rays associated with ${ }^{238,239} \mathrm{Pu}$ and ${ }^{241} \mathrm{Am}$ decay. Channel 5 was optimized to mcasure the $59.5 \cdot \mathrm{keV}$ $x$ rays associated with ${ }^{241} \mathrm{Am}$ decay. The other four channels were used to measure peak widths of the 17 - and $59.5-\mathrm{keV}$ x rays. For a uniformly contaminated surface at the background counting rates normally encountered in the Los Alamos area, the detection limits of the FIDLER/LAFPHA system (detector $30 \mathrm{~cm}$ above the ground) for ${ }^{239} \mathrm{Pu}$ and ${ }^{241} \mathrm{Am}$ are $0.1 \mu \mathrm{Ci} / \mathrm{m}^{2}$ and $0.05 \mu \mathrm{Ci} / \mathrm{m}^{2}$, respectively, at the $95 \%$ level of confidence for a 10 -min count.

The results from the three systems of $x$ - and gamma-ray measurement showed no readings that could lead to a definitive statement about the presence of radioactive contamination. 


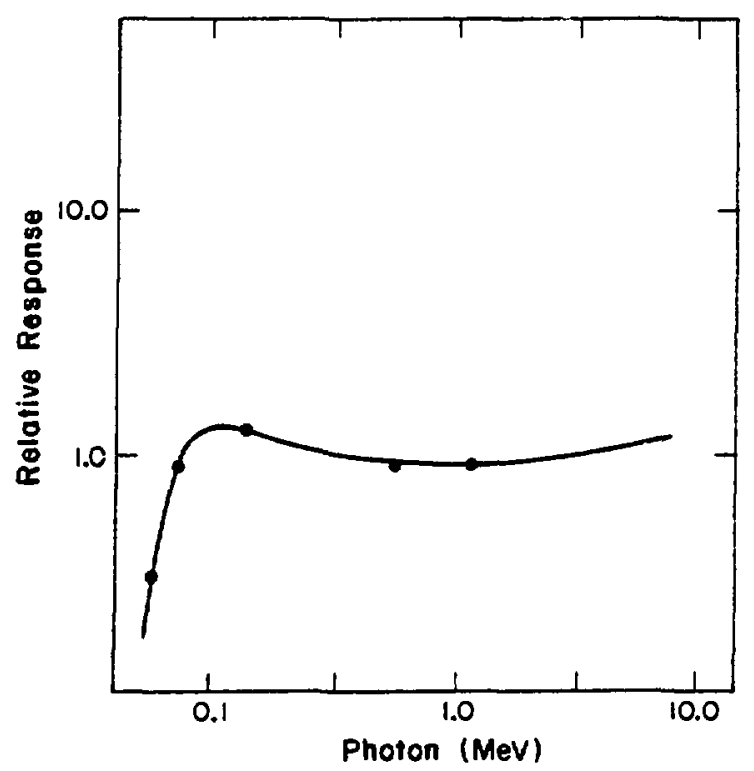

Fig. D.2.

Response of an RSS-111 monitor as a function of incident gamma-ray energy. Continuous line represents theoretical response. Circled points represent actual values measured with ${ }^{241} \mathrm{Am},{ }^{141} \mathrm{Ce}$, and NBS-traceable sources ${ }^{137} \mathrm{Cs}$ and ${ }^{60} \mathrm{Co}$.

\section{Sampling Methods}

For the 1974 survey, soil and vegetation samples for radiochemical analysis were collected at each sampling point. The soil samples consisted of five 7.6-cm-diam by 5.1-cm-deep core samples which were collected from the corners and the center of an area approximated by a $10-\mathrm{m}$ square. Each set of five soil samples was composited to form a sample representing a single sampling point. Soil samples collected from points designated as General Locations were submitted for the following analyses:

1. Gross-alpha and -beta activity.

2. ${ }^{137} \mathrm{Cs}$ and gross-gamma activity.

3. ${ }^{239} \mathrm{Pu}$ and ${ }^{239} \mathrm{Pu}$ activity.

4. Uranium (total) content.

Soil samples from Special Locations were submitted for appropriate analyses on the basis of available background information. The potential analyses for Special Locations included all of those enumerated for General Locations and the following additional analyses:
1. ${ }^{241} \mathrm{Am}$ activity.

2. ${ }^{228} \mathrm{Ra}$ activity.

3. Beryllium content.

To provide a complete set of reference values, soil samples from sites designated as TA-1 General Reference and Northern New Mexico Background Reference were submitted for all of the analyses listed for General Locations and Special Locations.

Vegetation samples consisted of a few hundred grams of native grass collected at each sampling point. Care was taken to exclude soil from the sample-grass samples were usually clipped off just above the roots. Vegetation samples were submitted for analyses only from those locations at which significant soil contamination was detected. The vegetation samples collected from reference locations (TA-1 General Reference and Northern New Mexico Background Reference) were, however, submitted for all tne analyses listed for the soil samples.

\section{Radiochemical Analytical Methods}

For soil analyses, the following methods were used:

1. Gross-alpha and -beta activity. Two grams were aliquoted from the soil sample and leached overnight in $5 \mathrm{~m} \ell$ of concentrated $\mathrm{HNO}_{3}$ and $5 \mathrm{~m} \ell$ of concentrated HF. The leachate was then evaporated onto a planchet and counted in a gas-flow proportional counter.

2. ${ }^{197} \mathrm{Cs}$ and gross-gamina activity. One hundred grams of soil were aliquoted into a plastic container and analyzed by direct gamma spectrometry. Cesium-137 activity determinations were based upon measurements of the $661.6-\mathrm{keV}$ gamma emission from ${ }^{137 \mathrm{~m}} \mathrm{Ba}$. Gross-gamma activity determinations were based upon the observed counting rate of each sample in the energy interval 0 to $2 \mathrm{Mev}$. Cesium-137 and gross-gamma measurements were made with a $\mathrm{NaI}(\mathrm{Tl})$ scintillation detector.

3. ${ }^{238} \mathrm{Pu}$ and ${ }^{239} \mathrm{Pu}$. Ten grams of soil were aliquoted into a polyethylene bottle and leached with concentrated $\mathrm{HNO}_{3}$ and $\mathrm{HF}$ acids The plutonium isotopes were isolated from the filtered leachate on ion exchange columns and subsequently electrodeposited onto counting planchets. The plated samples were analyzed by alpha spectrometry.

4. Uranium (total). Two grams of soil were aliquoted into a plastic container and leached with $1 \%$ 
$\mathrm{HF}$ in $7.2 \mathrm{~N} \mathrm{HNO}_{3}$ solution for $20 \mathrm{~h}$ at ambient temperatui'e. A portion of the extracted sample was analyzed fluorometricaliy for total uranium concentration.

5. ${ }^{241} \mathrm{Am}$ and ${ }^{226} \mathrm{Ra}$. The soil-sample aliquot that was used for the ${ }^{137} \mathrm{Cs}$ and gross-gamma activity deterininations was also used for ${ }^{241} \mathrm{Am}$ and ${ }^{226} \mathrm{Ra}$ analyses. Data for these analyses were collected with a $\mathrm{Ge}\left(\mathrm{Li}_{i}\right)$ detector. Activity determinations were based on raeasurements of the $59.5-\mathrm{keV}$ and $609-\mathrm{keV}$ photon emissions from the decay of ${ }^{241} \mathrm{Am}$ and ${ }^{214} \mathrm{Bi}$ (a daughter of ${ }^{220} \mathrm{Ra}$ ), respectively.

6. Beryllium. An aliquot of the soil sample was treated with concentrated $\mathrm{H}_{2} \mathrm{SO}_{4}-\mathrm{HNO}_{3}$ and ashed with repeated additions of $\mathrm{HNO}_{3}$. This procedure was aimed at putting the surface beryllium into soluble form rather than dissolving the soil itself. Beryllium concentration was measured by atomic absorption using a $\mathrm{N}_{2} \mathrm{O}$-acetylene flame.
The vegetation samples submitted for analyses were oven-dried and weighed before dry-ashing at $500^{\circ} \mathrm{C} .^{*}$ The dry-ashed samples were dissolved in concentrated $\mathrm{HNO}_{3}$ i.nd $\mathrm{HF}$ acids. Cesium-137 and ${ }^{241} \mathrm{Am}$ activity determinations were performed on the total dissolved sample by direct gamma spectrumetry with a $\mathrm{Ge}(\mathrm{Li})$ detector system. Aliquots were then taken, as necessary, from the dissolved samples for the measurement of gross alpha and beta, ${ }^{238} \mathrm{Pu}$ and ${ }^{239} \mathrm{Pu}$, and total uranium concentrations. Procedures for these radiochemical analyses, although somewhat different in technique, are analogous to those described for the analysis of soi] samples.

*Tie oven-drying step for the seven Northern New Mexico Background Reference samples was omitted by mistake.

\title{
APPENDIX E
}

RADIOCHEMICAL DATA FROM 1974 ENVIRONMENTAL SURVEY OF TA-1

\author{
TABLE E-I
}

GROSS-ALPHA AND -BE'TA ACTIVITIES IN SOIL

\begin{tabular}{|c|c|c|}
\hline Location & $\begin{array}{c}\text { Gross Alpha } \\
(\mathrm{pCi} / \mathrm{g})\end{array}$ & $\begin{array}{c}\text { Gross Beta } \\
(\mathrm{pCi} / \mathrm{g})\end{array}$ \\
\hline \multicolumn{3}{|l|}{ General Locations } \\
\hline TA-1-1 & $3.1( \pm 0.7)$ & $15.7( \pm 1.3)$ \\
\hline TA-1-2 & $2.5( \pm 0.6)$ & $15.0( \pm 1.3)$ \\
\hline TA-1-3 & 2.]. $( \pm 0.6)$ & $13.3( \pm 1.2)$ \\
\hline TA-1-4 & $2.3( \pm 0.6)$ & $17.9( \pm 1.5)$ \\
\hline TA-1-5 & -.- & ... \\
\hline TA-1-6 & $\ldots$ & $\ldots$ \\
\hline TA-1-7 & $3.1( \pm 0.6)$ & $20.0( \pm 1.6)$ \\
\hline TA-1-8 & $3.0( \pm 0.6)$ & $17.5( \pm 1.4)$ \\
\hline TA-1-9 & $2.6( \pm 0.6)$ & $15.9( \pm 1.4)$ \\
\hline TA-1-10 & $2.8( \pm 0.6)$ & $18.5( \pm 1.5)$ \\
\hline
\end{tabular}


TABLE E-I (cont)

Location

General Locations (cont)

TA-1-11

TA-1-12

TA-1-13

TA-1-14

TA-1-15

TA-1-16

TA-1-17

TA-1-18

TA-1-19

TA-1-20

TA $1-21$

TA-1-22

TA-1-23

TA-1-24

TA-1-25

TA-1-26

\section{Special Locations}

TA-1 AS-1

TA-1 AS-2

TA-1 BB-1

TA-1 BB-2

TA. 1 BB-3

TA-1 BB-4

TA-1 BB-5

TA-1 BB-6

TA-1 D-1

TA-1 D.2

TA-1 D-3

TA-1 D2-1

TA-1 D2-2

TA-1 D2-3

TA-1 D5-1

TA-1 H-1

TA-1 H-2

TA-1 H7-1

TA-1 I-1

TA-1 J2-1

\section{Gross Alpha \\ (pCi/g)}

Gross Beta

$(\mathrm{pCi} / \mathrm{g}$ )
$4.3( \pm 0.8)$

$1.8( \pm 0.5)$

$3.1( \pm 0.6)$

$2.8( \pm C .6)$

$2.6( \pm 0.6)$

$2.3( \pm 0.6)$

$2.5( \pm 0.6)$

$3.2( \pm 0.7)$

$3.5( \pm 0.7)$

$3.7( \pm 0.7)$

$2.2( \pm 0.6)$

-.-

$4.0( \pm 0.7)$

$4.0( \pm 0.7)$

$3.4( \pm 0.7)$

$2.5( \pm 0.6)$

$4.8( \pm 0.8)$

$3.1( \pm 0.6)$

$2.2( \pm 0.6)$

$1.5( \pm 0.5)$

$1.3( \pm 0.5)$

$1.6( \pm 0.5)$

$1.1( \pm 0.5)$

$9.0( \pm 1.1)$

$1.7( \pm 0.6)$

$2.1( \pm 0.6)$

$2.7( \pm 0.6)$

$14.7( \pm 1.4)$

$23.9( \pm 1.8)$

$2.8( \pm 0.6)$

$3.0( \pm 0.6)$

$3.3( \pm 0.7)$

$4.2( \pm 0.7)$

$2.7( \pm 0.6)$

$1.9( \pm 0.5)$
$26.1( \pm 2.0)$

$16.1( \pm 1.3)$

$18.3( \pm 1.5)$

$24.3( \pm 1$ )

$15.7(+1.3)$

$: 8.4( \pm 1.5)$

$17.8( \pm 1.4)$

$17.6( \pm 1.4)$

$27.8( \pm 2.1)$

$38.0( \pm 2.7)$

$17.5 \overline{( \pm 1.4)}$

- -

$33.8( \pm \pm .4)$

$314( \pm 2.2)$

$31.6( \pm 1.7)$

$21.2( \pm 1.6)$

$32.9( \pm 1.2)$

$23.1( \pm 1.8)$

$11.2( \pm 1.0)$

$11.3( \pm 1.0)$

$10.8( \pm 1.0)$

$11.4( \pm 1.0)$

$10.1( \pm 1.0)$

$23.2( \pm 1.8)$

$16.3( \pm 1.4)$

$14.9( \pm 1.2)$

$14.0( \pm 1.2)$

$26.1( \pm 2.0)$

$35.4( \pm 2.6)$

$18.4( \pm 1.5)$

$17.3( \pm 1.4)$

$21.6( \pm 1.7)$

24.1 ( \pm 1.9$)$

$18.0( \pm 1.5)$

$14.2( \pm 1.2)$ 


$\frac{\text { Location }}{\text { Special Locations (cont) }}$

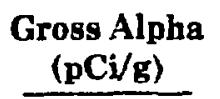

\section{Gross Beta} (pCi/g)

TA-1 J2-2

TAं-1 j2-C-1

TA-1 J2-C-2

TA-1 ML-1

TA-1 ML-2

TA-1 0-1

TA.1 O-2

TA-1 Q-1

TA-1 Q-2

\section{TA-1 Drilling Samples}

$\begin{array}{llll}\text { TA-1 D-1 } & 0 \quad \text { to } 0.61 \mathrm{~m} \text { deep } & 2.3( \pm 0.6) & 13.2( \pm 1.2) \\ \text { TA-1 D-1 } & 0.61 \text { to } 1.22 \mathrm{~m} \text { deep } & 3.2( \pm 0.7) & 16.3( \pm 1.4) \\ \text { TA-1 D-1 } & 1.22 \text { to } 1.83 \mathrm{~m} \text { deep } & 1.7( \pm 0.6) & 12.0( \pm 1.1) \\ \text { TA-1 D-1 } & 1.83 \text { to } 2.44 \mathrm{~m} \text { deep } & 1.9( \pm 0.6) & 10.9( \pm 1.0) \\ \text { 1A-1 D-1 } & 2.44 \text { to } 3.05 \mathrm{~m} \text { deep } & 2.3( \pm 0.6) & 18.3( \pm 1.5) \\ & & & \\ \text { TA-1 D-1 } & 3.05 \text { to } 3.66 \mathrm{~m} \text { deep } & 1.0( \pm 0.5) & 9.3( \pm 0.9) \\ \text { TA-1 D-2 } & 0 \quad \text { to } 0.61 \mathrm{~m} \text { deep } & 1.6( \pm 0.5) & 8.6( \pm 0.9) \\ \text { TA-1 D-2 } & 0.61 \text { to } 1.22 \mathrm{~m} \text { deep } & 3.2( \pm 0.7) & 13.7( \pm 1.2) \\ \text { TA-1 D-2 } & 1.22 \text { to } 2.44 \mathrm{~m} \text { deep } & 1.8( \pm 0.6) & 17.3( \pm 1.4) \\ \text { TA-1 D-2 } & 2.44 \text { to } 305 \text { m deep } & 1.5( \pm 0.5) & 13.0( \pm 1.2) \\ & & & \\ \text { TA-1 D-2 } & 3.05 \text { to } 3.66 \mathrm{~m} \text { deep } & 1.9( \pm 0.6) & 15.8( \pm 1.3) \\ \text { TA-1 D-3 } & 0 \quad \text { to } 0.61 \mathrm{~m} \text { deep } & 1.9( \pm 0.6) & 16.7( \pm 1.4) \\ \text { TA-1 D-3 } & 0.61 \text { to } 1.22 \mathrm{~m} \text { deep } & 2.6( \pm 0.6) & 14.5( \pm 1.2) \\ \text { TA-1 D-3 } & 1.22 \text { to } 1.83 \mathrm{~m} \text { deep } & 1.6( \pm 0.5) & 15.5( \pm 1.3) \\ \text { TA-1 D-3 } & 1.83 \text { to } 2.44 \text { m deep } & 2.2( \pm 0.6) & 13.5( \pm 1.2) \\ & & & \\ \text { TA-1 D-3 } & 2.44 \text { to } 3.05 \mathrm{~m} \text { deep } & 1.9( \pm 0.5) & 11.9( \pm 1.1) \\ \text { TA-1 D-3 } & 3.05 \text { to } 3.66 \mathrm{~m} \text { deep } & 1.4( \pm 0.5) & 10.0( \pm 1.0)\end{array}$

\section{Northern New Mexico Background Reference}

\begin{tabular}{lll}
\multicolumn{1}{l}{ Northern New Mexico Background Reference } & \\
Abiquiu & $2.0( \pm 0.6)$ & $17.3( \pm 1.4)$ \\
Cochiti No. 1 & $2.8( \pm 0.6)$ & $20.0( \pm 1.6)$ \\
Cochiti No. 2 & $2.1( \pm 0.6)$ & $17.8( \pm 1.4)$ \\
Ponderosa & $4.0( \pm 0.8)$ & $32.4( \pm 2.4)$ \\
Santa Cruz & $1.8( \pm 0.6)$ & $17.2( \pm 1.4)$ \\
& & \\
Santa Fe & $2.6( \pm 0.6)$ & $22.9( \pm 1.8)$ \\
Taos & $3.0( \pm 0.6)$ & $21.6( \pm 1.7)$
\end{tabular}

$13.2( \pm 1.2)$
$30.8( \pm 2.2)$
$48.7( \pm 3.4)$
$13.5( \pm 1.2)$
$16.5( \pm 1.4)$
$13.7( \pm 1.2)$
$19.8( \pm 1.6)$
$16.5( \pm 1.4)$
$13.6( \pm 1.2)$

$2.0( \pm 0.6)$

$3.6( \pm 0.7)$

$4.2( \pm 0.8)$

$3.1( \pm 0.6)$

$3.3( \pm 0.7)$

$3.9( \pm 0.7)$

$2.3( \pm 0.6)$

$13.2( \pm 1.2)$
$16.3( \pm 1.4)$
$12.0( \pm 1.1)$
$10.9( \pm 1.0)$
$18.3( \pm 1.5)$

$9.3( \pm 0.9)$

$13.7( \pm 1.2)$

$17.3( \pm 1.4)$

$13.0( \pm 1.2)$

$15.8( \pm 1.3)$

$16.7( \pm 1.4)$

$15.5( \pm 1.3)$

$13.5( \pm 1.2)$

$10.0( \pm 1.0)$
$2.6( \pm 0.6)$ 
TABLE E-II

${ }^{19}$ C6 AND GAMMA ACTIVITY IN TA-1 SOIL

\begin{tabular}{|c|c|c|}
\hline Location & $\begin{array}{c}{ }^{\mathrm{In}} \mathrm{Cs} \\
(\mathrm{pCV} / \mathrm{s})\end{array}$ & $\begin{array}{c}\text { Gross Gamms } \\
(\mathrm{pCV} / \mathrm{g})\end{array}$ \\
\hline \multicolumn{3}{|c|}{ General Locutione } \\
\hline $\begin{array}{l}\text { TA-1-1 } \\
\text { TA-1-2 } \\
\text { TA-1-3 } \\
\text { TA-1-4 } \\
\text { TA-1-5 }\end{array}$ & $\begin{array}{c}0.59( \pm 0.28) \\
0.64( \pm 0.30) \\
0.27( \pm 0.24) \\
1.4 \quad( \pm 0.4) \\
\ldots\end{array}$ & $\begin{array}{l}1.5( \pm 1.0) \\
4.2( \pm 1.0) \\
2.4( \pm 1.0) \\
5.2( \pm 1 . C) \\
\ldots\end{array}$ \\
\hline $\begin{array}{l}\text { TA-1-6 } \\
\text { TA-1-7 } \\
\text { TA-1-8 } \\
\text { TA-1-9 } \\
\text { TA-1-10 }\end{array}$ & $\begin{array}{c}\cdots \\
0.80( \pm 0.32) \\
0.89( \pm 0.34) \\
0.80( \pm 0.32) \\
0.58( \pm 0.28)\end{array}$ & $\begin{array}{c}\ldots . . \\
5.6( \pm 1.0) \\
5.3( \pm 1.0) \\
3.4( \pm 1.0) \\
3.6( \pm 1.0)\end{array}$ \\
\hline $\begin{array}{l}\text { TA-1-11 } \\
\text { TA-1-12 } \\
\text { TA-1-13 } \\
\text { TA-1-14 } \\
\text { TA-1-15 }\end{array}$ & $\begin{array}{l}1.9( \pm 0.6) \\
0.86( \pm 0.34) \\
0.37( \pm 0.26) \\
1.3 \quad( \pm 0.4) \\
1.7 \quad( \pm 0.6)\end{array}$ & $\begin{array}{l}4.9( \pm 1.0) \\
3.8( \pm 1.0) \\
5.6( \pm 1.0) \\
4.3( \pm 1.0) \\
6.1( \pm 1.0)\end{array}$ \\
\hline $\begin{array}{l}\text { TA-1-16 } \\
\text { TA-1-17 } \\
\text { TA-1-18 } \\
\text { TA-1.19 } \\
\text { TA-1.20 }\end{array}$ & $\begin{array}{l}0.53( \pm 0.28) \\
4.6 \quad( \pm 1.2) \\
0.64( \pm 0.30) \\
0.44( \pm 0.26) \\
2.1 \quad( \pm 0.6)\end{array}$ & $\begin{array}{l}4.4( \pm i .0) \\
6.6( \pm 1.0) \\
4.8( \pm 1.0) \\
5.5( \pm 1.0) \\
9.2( \pm 1.0)\end{array}$ \\
\hline $\begin{array}{l}\text { TA-1-21 } \\
\text { TA-1-22 } \\
\text { TA-1-23 } \\
\text { TA-1-24 } \\
\text { TA-1-25 } \\
\text { TA-1-26 }\end{array}$ & $\begin{array}{ll} & \cdots \\
1.1 \quad( \pm 0.4) \\
\quad \cdots \\
2.1 \quad( \pm 0.4) \\
1.46( \pm 0.32) \\
1.60( \pm 0.34)\end{array}$ & $\begin{array}{c}2.7( \pm 1.0) \\
\ldots \\
9.0( \pm 1.4) \\
8.1( \pm 1.4) \\
7.7( \pm 1.2)\end{array}$ \\
\hline
\end{tabular}

Special Locationo

TA-1 AS-1 $12.5( \pm 2.0)$

TA.1 AS-2 $\quad 1.20( \pm 0.30)$

TA-l BB-1 $\quad 0.76( \pm 0.26)$

TA-1 BB-2 $\quad 0.45( \pm 0.22)$

TA.1 B日-3 $\quad 0.34( \pm 0.22)$

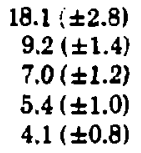

\begin{tabular}{|c|c|c|}
\hline Location & $\begin{array}{c}{ }^{13 x} \mathrm{Cs} \\
(\mathrm{pCi} / \mathrm{g})\end{array}$ & $\begin{array}{c}\text { Gross Gamma } \\
\text { (pCi/g) }\end{array}$ \\
\hline \multicolumn{3}{|c|}{ Special Locations (cont) } \\
\hline $\begin{array}{l}\text { TA-1 BB-4 } \\
\text { TA-1 BB-5 } \\
\text { TA-1 BB-6 } \\
\text { TA-1 D-1 } \\
\text { TA-1 D-2 }\end{array}$ & $\begin{array}{l}0.28( \pm 0.22) \\
0.29( \pm 0.22) \\
0.26( \pm 0.22) \\
0.81( \pm 0.26) \\
0.51( \pm 0.26)\end{array}$ & $\begin{array}{l}2.7( \pm 0.6) \\
5.4( \pm 1.0) \\
2.8( \pm 0.6) \\
9.4( \pm 0.8) \\
7.9( \pm 0.6)\end{array}$ \\
\hline $\begin{array}{l}\text { TA-1 D.3 } \\
\text { TA-1 D2-1 } \\
\text { TA-1 D2-2 } \\
\text { TA-1 D2-3 } \\
\text { TA-1 D5-1 }\end{array}$ & $\begin{array}{l}0.65( \pm 0.26) \\
0.74( \pm 0.26) \\
1.28( \pm 0.28) \\
2.58( \pm 0.32) \\
0.53( \pm 0.24)\end{array}$ & $\begin{array}{r}7.6( \pm 0.6) \\
8.0( \pm 0.6) \\
9.3( \pm 0.8) \\
11.2( \pm 0.8\} \\
5.7( \pm 1.2)\end{array}$ \\
\hline $\begin{array}{l}\text { TA-1 H-1 } \\
\text { TA-1 H-2 } \\
\text { TA-1 HT-1 } \\
\text { TA-1 I-1 } \\
\text { TA-1 J2-1 }\end{array}$ & $\begin{array}{l}1.16( \pm 0.30) \\
1.22( \pm 0.30) \\
0.69( \pm 0.24) \\
0.88( \pm 0.26) \\
1.48( \pm 0.32)\end{array}$ & $\begin{array}{l}8.8( \pm 1.4) \\
8.6( \pm 1.4) \\
8.2( \pm 1.4) \\
8.1( \pm 1.4) \\
7.8( \pm 1.2)\end{array}$ \\
\hline $\begin{array}{l}\text { TA-l J2-2 } \\
\text { TA-1 J2-C-1 } \\
\text { TA-1 J2-C-2 } \\
\text { TA-1 ML-1 } \\
\text { TA-1 ML-2 }\end{array}$ & $\begin{array}{l}0.91( \pm 0.26) \\
1.96( \pm 0.36) \\
1.23( \pm 0.30) \\
1.16( \pm 0.30) \\
1.17( \pm 0.30)\end{array}$ & $\begin{array}{r}6.8( \pm 1.2) \\
11.6( \pm 1.8) \\
8.3( \pm 1.4) \\
6.8( \pm 1.2) \\
7.3( \pm 1.2)\end{array}$ \\
\hline $\begin{array}{l}\text { TA-1 } 0-1 \\
\text { TA-1 } 0-2 \\
\text { TA-1 } \\
\text { TA-1 } \\
\text { Q-2 }\end{array}$ & $\begin{array}{l}1.79( \pm 0.36) \\
1.59( \pm 0.34) \\
1.49( \pm 0.32) \\
0.46( \pm 0.22)\end{array}$ & $\begin{array}{r}14.1( \pm 1.1) \\
9.8( \pm 1.6) \\
8.4( \pm 1.4) \\
7.1( \pm 1.2)\end{array}$ \\
\hline
\end{tabular}

Northern New Mexico Background Reference

$\begin{array}{llr}\text { Abiquiu } & 1.15( \pm 0.26) & 5.1( \pm 0.6) \\ \text { Cochiti No. } 1 & 1.30( \pm 0.28) & 11.3( \pm 0.8) \\ \text { Cochiti No. } 2 & 2.03( \pm 0.30) & 9.2( \pm 0.8) \\ \text { Ponderosa } & 2.53( \pm 0.32) & 15.1( \pm 1.0) \\ \text { Santa Cruz } & 1.33( \pm 0.28) & 8.1( \pm 0.6) \\ & & \\ \text { Santa Fe } & 2.39( \pm 0.32) & 9.8( \pm 0.8) \\ \text { Taos } & 1.67( \pm 0.28) & 8.3( \pm 0.6)\end{array}$


TABLE E-III

PLUTONIUM ACTIVITY IN TA-1 SOIL

\begin{tabular}{|c|c|c|}
\hline Location & $\begin{array}{c}{ }^{2 s} \mathrm{Pu} \\
(\mathrm{pCi} / \mathrm{g})\end{array}$ & $\begin{array}{c}{ }^{2 s} \mathrm{Pu} \\
(\mathrm{pCl} / \mathrm{g})\end{array}$ \\
\hline \multicolumn{3}{|c|}{ General Locations } \\
\hline $\begin{array}{l}\text { TA-1-1 } \\
\text { TA-1.2 } \\
\text { TA-1.3 } \\
\text { TA-1.4 } \\
\text { TA.1.7 }\end{array}$ & $\begin{array}{l}0.196( \pm 0.020) \\
0.076( \pm 0.010) \\
0.186( \pm 0.020) \\
1.15 \quad( \pm 0.08) \\
48.3 \quad( \pm 2.2)\end{array}$ & $\begin{array}{l}0.004(<0.005) \\
0.004(<0.005) \\
0.005(<0.005) \\
0.022( \pm 0.006) \\
0.18 \quad( \pm 0.04)\end{array}$ \\
\hline $\begin{array}{l}\text { TA-1-6 } \\
\text { TA-1-7 } \\
\text { TA-1-8 } \\
\text { TA-1-9 } \\
\text { TA-1-10 }\end{array}$ & $\begin{array}{l}1.00 \quad( \pm 0.07) \\
0.392( \pm 0.025) \\
1.40 \quad( \pm 0.012) \\
0.50 \quad( \pm 0.04) \\
0.373( \pm 0.008)\end{array}$ & $\begin{array}{l}0.015( \pm 0.006) \\
0.005(<0.005) \\
0.107( \pm 0.004) \\
0.008( \pm 0.004) \\
0.003(<0.005)\end{array}$ \\
\hline $\begin{array}{l}\text { TA-1-11 } \\
\text { TA-1-12 } \\
\text { TA-1-13 } \\
\text { TA-1-14 } \\
\text { TA-1-15 }\end{array}$ & $\begin{array}{l}2.16 \quad( \pm 0.16) \\
0.232( \pm 0.022) \\
0.135( \pm 0.016) \\
0.164( \pm 0.008) \\
0.148( \pm 0.016)\end{array}$ & $\begin{array}{l}0.011( \pm 0.004) \\
0.005(<0.005) \\
0.003(<0.005) \\
0.005(<0.005) \\
0.003(<0.005)\end{array}$ \\
\hline $\begin{array}{l}\text { TA-1-16 } \\
\text { TA-1-17 } \\
\text { TA-1-18 } \\
\text { TA-i-19 } \\
\text { TA-1-20 }\end{array}$ & $\begin{array}{l}0.029( \pm 0.006) \\
0.069( \pm 0.010) \\
0.276( \pm 0.022) \\
0.012( \pm 0.004) \\
0.726( \pm 0.029)\end{array}$ & $\begin{array}{l}0.005(<0.005) \\
0.002(<0.005) \\
0.005(<0.005) \\
0.001(<0.005) \\
0.009( \pm 0.004)\end{array}$ \\
\hline $\begin{array}{l}\text { TA-1.21 } \\
\text { TA-1.22 } \\
\text { TA-1-23 } \\
\text { TA-1-24 } \\
\text { TA-1.25 } \\
\text { TA-1.26 }\end{array}$ & $\begin{array}{l}0.074( \pm 0.010) \\
0.234( \pm 0.026) \\
4.03 \quad( \pm 0.030) \\
0.137( \pm 0.018) \\
0.166( \pm 0.022) \\
0.148( \pm 0.018)\end{array}$ & $\begin{array}{l}0.000(<0.005) \\
0.003(<0.005) \\
0.066( \pm 0.088) \\
0.007( \pm 0.004) \\
0.003(<0.005) \\
0.006( \pm 0.002)\end{array}$ \\
\hline \multicolumn{3}{|c|}{ Special Locations } \\
\hline $\begin{array}{l}\text { TA-1 AS-1 } \\
\text { TA-1 AS-2 } \\
\text { TA-1 BB-1 } \\
\text { TA-1 BB-2 } \\
\text { TA-1 BB-3 }\end{array}$ & $\begin{array}{l}1.29 \quad( \pm 0.08) \\
0.105( \pm 0.010) \\
1.89 \quad( \pm 0.016) \\
0.249( \pm 0.022) \\
0.437( \pm 0.036)\end{array}$ & $\begin{array}{l}0.009( \pm 0.004) \\
0.006( \pm 0.002) \\
0.012( \pm 0.004) \\
0.002(<0.005) \\
0.008( \pm 0.002)\end{array}$ \\
\hline
\end{tabular}

\begin{tabular}{|c|c|c|}
\hline Locetion & $\begin{array}{c}{ }^{2 s 9} \mathrm{Pu} \\
(\mathrm{pCl} / \mathrm{g})\end{array}$ & $\begin{array}{c}{ }^{3}+\mathrm{Pu} \\
(\mathrm{DCV} / \mathrm{g})\end{array}$ \\
\hline \multicolumn{3}{|c|}{ Special Locations (cont) } \\
\hline $\begin{array}{l}\text { TA-1 BB-4 } \\
\text { TA-1 BB-5 } \\
\text { TA-1 BB-6 } \\
\text { TA-1 D-1 } \\
\text { TA-1 D-2 }\end{array}$ & $\begin{array}{c}0.309( \pm 0.024) \\
0.209( \pm 0.020) \\
0.769( \pm 0.040) \\
39.9 \quad( \pm 1.1) \\
0.124( \pm 0.030)\end{array}$ & $\begin{array}{l}0 . C \sim 3(<0.005) \\
0.002(<0.005) \\
0.006( \pm 0.002) \\
0.14( \pm 0.06) \\
0.001(<0.005)\end{array}$ \\
\hline $\begin{array}{l}\text { TA-1 D-3 } \\
\text { TA-1 D2-1 } \\
\text { TA-1 D2-2 } \\
\text { TA-1 D2-3 } \\
\text { TA-1 D5-1 }\end{array}$ & $\begin{aligned} 0.133 & ( \pm 0.006) \\
4.49 & ( \pm 0.24) \\
105.4 & ( \pm 1.8) \\
224 \quad( \pm 8) & \\
0.152 & ( \pm 0.016)\end{aligned}$ & $\begin{array}{l}0.003(<0.005) \\
0.063( \pm 0.022) \\
2.17 \quad( \pm 0.12) \\
0.8 \quad( \pm 0.2) \\
0.007 \quad( \pm 0.002)\end{array}$ \\
\hline $\begin{array}{l}\text { TA-1 H-1 } \\
\text { TA-1 H-2 } \\
\text { TA-1 HT-1 } \\
\text { TA-1 I-1 } \\
\text { TA-1 J2-1 }\end{array}$ & $\begin{array}{l}0.019( \pm 0.604) \\
4.09( \pm 0.22) \\
0.011( \pm 0.004) \\
0.135( \pm 0.012) \\
0.245( \pm 0.020)\end{array}$ & $\begin{array}{l}0.001(<0.005) \\
0.015( \pm 0.002) \\
0.002(<0.005) \\
0.003(<0.005) \\
0.005(<0.005)\end{array}$ \\
\hline $\begin{array}{l}\text { TA-1 J2-2 } \\
\text { TA-1 J2-C-1 } \\
\text { TA-1 J2-C-2 } \\
\text { TA-1 ML-1 } \\
\text { TA-1 ML-2 }\end{array}$ & $\begin{array}{l}0.237( \pm 0.018) \\
0.398( \pm 0.040) \\
0.207( \pm 0.018) \\
0.056( \pm 0.008) \\
0.594( \pm 0.048)\end{array}$ & $\begin{array}{l}0.003(<0.005) \\
0.005(<0.005) \\
0.004(<0.005) \\
0.004(<0.005) \\
0.009( \pm 0.004)\end{array}$ \\
\hline $\begin{array}{l}\text { A. } 1 \text { O.1 } \\
\text { TA-1 } 0.2 \\
\text { TA-1 } \\
\text { TA-1 } \\
\text { Q. } \\
\end{array}$ & $\begin{aligned} 0.203( \pm 0.016) \\
0.545( \pm 0.044) \\
27.5 \quad( \pm 1.8) \\
0.275( \pm 0.026)\end{aligned}$ & $\begin{array}{l}0.003(<0.005) \\
0.007( \pm 0.002) \\
0.50 \quad( \pm 0.04) \\
0.003(<0.005)\end{array}$ \\
\hline
\end{tabular}

Northorn New Mexico Background Reference

$\begin{array}{lll}\text { Abiquiu } & 0.019( \pm 0.006) & 0.001(<0.005) \\ \text { Cochiti No. 1 } & 0.010( \pm 0.004) & 0.001(<0.005) \\ \text { Cochiti No. 2 } & 0.032( \pm 0.008) & 0.001(<0.005) \\ \text { Ponderosa } & 0.034 \pm 0.006) & 0.001(<0.005) \\ \text { Santa Cruz } & 0.017( \pm 0.006) & 0.000(<0.005) \\ & & \\ \text { Santa Fe } & 0.025( \pm 0.008) & 0.002(<0.005) \\ \text { Taos } & 0.028( \pm 0.008) & 0.001(<0.005)\end{array}$


TABLE E-IV

PLUTONIUM IN SOIL OF TA-1 MRILLINC SAMPLES

\begin{tabular}{|c|c|c|c|c|c|}
\hline \multicolumn{2}{|r|}{ Location } & \multicolumn{2}{|c|}{$\begin{array}{l}{ }^{230} \mathrm{Pu} \\
(\mathrm{pCi} / \mathrm{g})\end{array}$} & \multicolumn{2}{|c|}{$\begin{array}{l}{ }^{238} \mathbf{P u} \\
(\mathrm{pCi} / \mathrm{g})\end{array}$} \\
\hline TA-1 D-1 & 0 to $0.61 \mathrm{~m}$ deep & 28.3 & $( \pm 1.8)$ & 0.11 & $( \pm 0.10)$ \\
\hline TA-1 D.1 & 0.61 to $1.22 \mathrm{~m}$ deep & 9.0 & $( \pm 0.8)$ & 0.04 & $(<0.10)$ \\
\hline TA-i D-1 & 1.22 to $1.83 \mathrm{~m}$ deep & 4.9 & $( \pm 0.6)$ & 0.0 & $(<0.10)$ \\
\hline TA-1 C-1 & 1.23 to $2.44 \mathrm{~m}$ deep & 3.5 & $( \pm 0.4)$ & 0.13 & $( \pm 0.16)$ \\
\hline TA-1 D-1 & 2.44 to 3.05 .2 desp & 0.42 & $( \pm 0.08)$ & 0.01 & $(<0.10)$ \\
\hline TA-1 D-1 & 3.05 to $3.66 \mathrm{~m}$ deep & 0.24 & $( \pm 0.12)$ & 0.02 & $(<0.10)$ \\
\hline TA-1 D.2 & 0 to $0.61 \mathrm{~m}$ deep & 1.26 & $( \pm 0.07)$ & 0.003 & $1<0.006)$ \\
\hline TA-1 D-2 & 0.61 to $1.22 \mathrm{~m}$ deep & 070 & $( \pm 0.13)$ & 0.01 & $(<0.05)$ \\
\hline TA-1 D-2 & 1.22 to 2.44 in deep & 0.061 & $( \pm 0.026)$ & 0.0028 & $3( \pm 0.0026)$ \\
\hline TA-1 D-2 & 2.44 to 3.05 m deep & 0.015 & $( \pm 0.006)$ & 0.004 & 0.00181 \\
\hline T. -1 D.2 & 3.05 to $3.66 \mathrm{~m}$ deep & 0.021 & $( \pm 0.013)$ & 0.009 & $( \pm 0.005)$ \\
\hline
\end{tabular}

TABLE E- $Y$

URANIUM IN TA-1 SOIL

\begin{tabular}{|c|c|c|c|}
\hline Location & $\begin{array}{c}\text { Total Uranium } \\
(\mu g / B)\end{array}$ & Locetion & $\begin{array}{c}\text { Total Uraniun } \\
(\mu \mathrm{B} / \mathrm{B})\end{array}$ \\
\hline \multicolumn{4}{|c|}{ General Locations } \\
\hline $\begin{array}{l}\text { TA-1-1 } \\
\text { TA-1-2 } \\
\text { TA-1-3 } \\
\text { TA-1.4 } \\
\text { TA-1-5 }\end{array}$ & $\begin{array}{c}10.3( \pm 2.2) \\
2.6( \pm 0.4) \\
2.3( \pm 0.4) \\
3.9( \pm 0.6) \\
\ldots\end{array}$ & $\begin{array}{l}\text { TA-1-14 } \\
\text { TA-1-15 } \\
\text { TA-1-16 } \\
\text { TA-1-17 } \\
\text { TA-1-18 }\end{array}$ & $\begin{array}{c}3.8( \pm 1.6) \\
11( \pm 5) \\
8.7( \pm 3.6) \\
11.1( \pm 3.8) \\
14( \pm 6)\end{array}$ \\
\hline $\begin{array}{l}\text { TA-1-6 } \\
\text { TA-1-7 } \\
\text { TA-1-8 } \\
\text { TA-1-9 } \\
\text { TA-1-10 }\end{array}$ & $\begin{array}{c}3.1( \pm 0.4) \\
3.0( \pm 0.2) \\
1.6( \pm 0.4) \\
4.0( \pm 1.4)\end{array}$ & $\begin{array}{l}\text { TA-1-19 } \\
\text { TA-1-20 } \\
\text { TA-1-21 } \\
\text { TA-1-22 } \\
\text { TA-1-23 }\end{array}$ & $\begin{array}{cl}16 & ( \pm 6) \\
28 & ( \pm 10) \\
& \ldots \\
12 & ( \pm 4) \\
4.0 & ( \pm 1,4)\end{array}$ \\
\hline $\begin{array}{l}\text { TA-1-11 } \\
\text { TA-1-12 } \\
\text { TA-1-13 }\end{array}$ & $\begin{array}{r}7.6( \pm 2.8) \\
7.6( \pm 2.8) \\
14 \quad( \pm 6)\end{array}$ & $\begin{array}{l}\text { TA-1.24 } \\
\text { TA-1.25 } \\
\text { TA-1-26 }\end{array}$ & $\begin{array}{l}8.0( \pm 3.2) \\
4.7( \pm 1.2) \\
5.4( \pm J .2)\end{array}$ \\
\hline \multicolumn{4}{|c|}{ Special Locations } \\
\hline $\begin{array}{l}\text { TA-1 AS-1 } \\
\text { TA-1 AS-2 } \\
\text { TA-1 BB-1 } \\
\text { TA-1 BB-2 } \\
\text { TA-1 BB-3 }\end{array}$ & $\begin{array}{c}6.2( \pm 0.6) \\
16.8( \pm 2.8) \\
6.1( \pm 1.4) \\
11( \pm 4) \\
6.6( \pm 1.6)\end{array}$ & $\begin{array}{l}\text { TA-1 D2-1 } \\
\text { TA-1 D2-2 } \\
\text { TA-1 D2-3 } \\
\text { TA-1 D5-1 } \\
\text { TA-1 J2-1 }\end{array}$ & $\begin{array}{l}3.1( \pm 0.6) \\
3.6( \pm 0.6) \\
8.8( \pm 1.8) \\
5.7( \pm 1.4) \\
3.6( \pm 1.0)\end{array}$ \\
\hline $\begin{array}{l}\text { TA-1 BB-4 } \\
\text { TA-1 BB-5 } \\
\text { TA-1 BB-6 } \\
\text { TA-1 D-1 } \\
\text { TA-1 D.2 } \\
\text { TA-1 D.3 }\end{array}$ & $\begin{array}{l}4.0( \pm 1.6) \\
2.5( \pm 0.6) \\
2.4( \pm 0.6) \\
3.1( \pm 0.6) \\
2.5( \pm 0.6) \\
3.1( \pm 0.6)\end{array}$ & $\begin{array}{l}\text { TA-1 J2-2 } \\
\text { TA-1 J2-C-1 } \\
\text { TA-1 J2-C-2 } \\
\text { TA-1 HT-1 } \\
\text { TA-1-13 } \\
\text { TA-1-16 }\end{array}$ & $\begin{array}{c}2.1( \pm 0.6) \\
55( \pm 14) \\
31 \quad( \pm 4) \\
6.6( \pm 1.0) \\
14( \pm 5) \\
8.7( \pm 3.6)\end{array}$ \\
\hline
\end{tabular}

Northern New Mesico Background Referonce

$\begin{array}{llll}\text { Abiquiu } & 1.7( \pm 0.6) & \text { Ponderosa } & 1.4( \pm 0.6) \\ \text { Cochiti No. 1 } & 2.9( \pm 0.6) & \text { Santa Cruz } & 2.4( \pm 0.6) \\ \text { Cochiti No. 2 } & 2.5( \pm 0.6) & \text { Santa Fe } & 1.4( \pm 0.6) \\ & & \text { Taos } & 1.4( \pm 0.6)\end{array}$


TABLE E-VI

AMERICIUM IN TA-I SOIL

\begin{tabular}{|c|c|c|c|}
\hline Location & $\begin{array}{c}{ }^{24} \mathbf{A m} \\
(\mathrm{pCi} / \mathrm{g})\end{array}$ & Location & $\begin{array}{c}{ }^{241} \mathbf{A m} \\
(\mathrm{pCi} / \mathrm{g})\end{array}$ \\
\hline \multicolumn{4}{|c|}{ TA-1 general locations not analyzed for ${ }^{241} \mathrm{Am}$} \\
\hline \multicolumn{4}{|c|}{ Special Locations } \\
\hline TA-1 AS-1 & $0.012(<0.18)$ & TA-1 D2-1 & $0.22( \pm 0.26)$ \\
\hline TA-1 AS-2 & $-0.10 \quad(<0.18)$ & TA-1 D2-2 & $0.88( \pm 0.30)$ \\
\hline TA-1 BB-1 & $0.11 \quad(<0.18)$ & TA-1 D2-3 & $1.83( \pm 0.34)$ \\
\hline TA-1 BB-2 & $-0.15 \quad(<0.18)$ & TA-1 J2-C-1 & $0.06(<0.18)$ \\
\hline TA-1 BB-3 & $-0.06 \quad(<0.18)$ & TA-1 J2-C-2 & $0.06(<0.18)$ \\
\hline TA-1 BB-4 & $0.18 \quad(<0.18)$ & TA-1 ML-1 & $0.08(<0.18)$ \\
\hline TA-1 BB-5 & $0.6 \bar{u}(<0.18)$ & TA-1 ML-2 & $0.08(<0.18)$ \\
\hline TA-1 BB-6 & $-0.12 \quad(<0.18)$ & TA-1 Q-1 & $2.4( \pm 0.4)$ \\
\hline$T A-1 D-1$ & $0.74 \quad( \pm 0.28)$ & $T A-1 Q-2$ & $0.02(<0.18)$ \\
\hline TA-1 D-2 & $-0.02 \quad(<0.18)$ & & \\
\hline TA-1 D-3 & $0.27( \pm 0.24)$ & & \\
\hline
\end{tabular}

\section{TA-1 General Reference}

TA-1-1.

TA-1-3

TA-1-11

$$
\begin{aligned}
-0.01 & (<0.18) \\
-0.02 & (<0.18) \\
0.16 & (<0.18)
\end{aligned}
$$

TA-1-17

TA-1-18

TA-1-22
$0.11(<0.18)$

$0.43( \pm 0.26)$

$-0.04(<0.18)$

Northern New Mexico Background Reference

$\begin{array}{lrllr}\text { Abiquiu } & 0.01 & (<0.18) & \text { Ponderosa } & -0.47( \pm 0.28) \\ \text { Cochiti No. 1 } & -0.12 & (<0.18) & \text { Santa Cruz } & 0.09(<0.18) \\ \text { Cochiti No. 2 } & 0.08 & (<0.18) & \text { Santa Fe } & -0.11(<0.18) \\ & & & \text { Taos } & 0.11(<0.18)\end{array}$


TABLE E-VII

RADICM IN TA-1 SOIL

\begin{tabular}{|c|c|c|c|}
\hline Location & $\begin{array}{c}{ }^{226} \mathbf{R a} \\
(\mathrm{pCi} / \mathrm{g})\end{array}$ & Location & $\begin{array}{c}{ }^{226} \mathbf{R a} \\
(\mathrm{pCi} / \mathrm{g})\end{array}$ \\
\hline & & Location & \\
\hline
\end{tabular}

TA-1 general locations not analyzed for ${ }^{\mathrm{n}} \mathrm{Ra}$

Special Locationg

$\begin{array}{llll}\text { TA-1 BB-1 } & 2.0( \pm 0.4) & \text { TA-1 } Q-1 & 1.9( \pm 0.4) \\ \text { TA-1 BB-2 } & 1.9( \pm 0.4) & \text { TA-1 } Q-2 & 2.11 \pm 0.4) \\ \text { TA-1 BB-3 } & 1.4( \pm 0.4) & \text { TA-1 O-1 } & 5.2( \pm 0.8) \\ \text { TA-1 BB-4 } & 0.75( \pm 0.34) & \text { TA-1 O-2 } & 2.2( \pm 0.4) \\ \text { TA-1 BB-5 } & 1.7( \pm 0.4) & \text { TA-1 D2-1 } & 2.3( \pm 0.4) \\ \text { TA-1 BB-5 } & 1.26( \pm 0.38) & \text { TA-1 D2-2 } & 2.1( \pm 0.4) \\ & & \text { TA-1 D2-3 } & 2.5( \pm 0.4)\end{array}$

TA-1 General Reference

$\begin{array}{llll}\text { TA.1.1 } & 1.8( \pm 0.4) & \text { TA-1.17 } & 2.0( \pm 0.4) \\ \text { TA-1.3 } & 1.8( \pm 0.4) & \text { TA-1-18 } & 2.9( \pm 0.4) \\ \text { TA. }-11 & 2.1( \pm 0.4) & \text { TA- }-22 & 1.8( \pm 0.4)\end{array}$

Northern New Mexico Background Reference

\begin{tabular}{lllll}
\hline Abiquiu & 1.6 & $( \pm 0.4)$ & Ponderosa & $1.7 ; \pm 0.4)$ \\
Cochiti No. 1 & 2.3 & $( \pm 0.4)$ & Santa Cruz & $2.4( \pm 0.4)$ \\
Cochiti No. 2 & $2.8( \pm 0.41$ & Santa Fe & $1.8( \pm 0.4)$ \\
& & & Taos & $3.9( \pm 0.6)$
\end{tabular}

TABLE E-VIII

BERYLLIUM IN SOIL

$\underline{\text { Location }} \quad \underline{\begin{array}{c}\text { Beryllium } \\ (\mu \mathrm{g} / \mathrm{g})\end{array}} \quad \underline{\text { Location }} \quad \begin{gathered}\text { Beryllium } \\ (\mu \mathrm{g} / \mathrm{g})\end{gathered}$

TA-1 general locations not analyzed for beryllium

Special Locations

TA-1 I-1 $2.94( \pm 0.13)$

TA-1 General Reference

\begin{tabular}{|c|c|c|c|}
\hline $\begin{array}{l}\text { TA-1-1 } \\
\text { TA-1-3 } \\
\text { TA-1-11 }\end{array}$ & $\begin{array}{ll} & \cdots \\
1.6 & ( \pm 0.6) \\
1.2 & ( \pm 0.3)\end{array}$ & $\begin{array}{l}\text { TA-1.17 } \\
\text { TA-1-18 } \\
\text { TA-1.22 }\end{array}$ & $\begin{array}{l}0.99(\div 0.15) \\
1.1 \quad( \pm 0.2) \\
0.86( \pm 0.17)\end{array}$ \\
\hline \multicolumn{4}{|c|}{ Northem Now Mexico Background Reference } \\
\hline $\begin{array}{l}\text { Abiquiu } \\
\text { Cochiti No. I } \\
\text { Cochiti No. } 2\end{array}$ & $\begin{array}{l}0.58( \pm 0.06) \\
1.0( \pm 0.4) \\
1.2( \pm 1.0)\end{array}$ & $\begin{array}{l}\text { Fonderosa } \\
\text { Santa Cruz } \\
\text { Santa Fe } \\
\text { Taos }\end{array}$ & $\begin{array}{l}1.1 \quad( \pm 0.6) \\
1.01( \pm 0.04) \\
0.91( \pm 0.09) \\
0.91( \pm 0.04)\end{array}$ \\
\hline
\end{tabular}


TABLE E-IX

PLUTONIUM IN TA-1 VEGETATION (Concentrations are $\mathrm{fCi} / \mathrm{g}$ dry weight unless other xise noted)

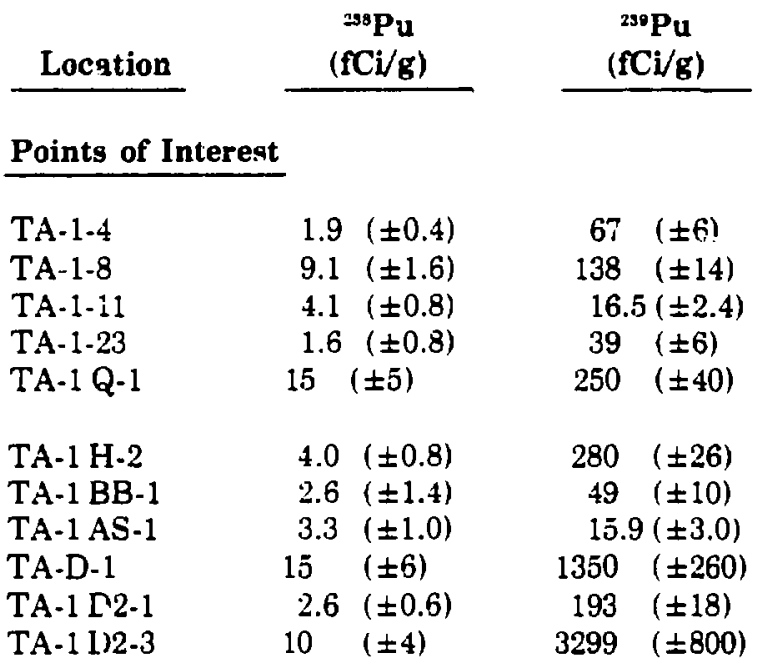

TA-1 General Reference

$\begin{array}{lllc}\text { TA-1-1 } & 6.8( \pm 1.8) & 65( \pm 8) \\ \text { TA-1-11 } & 4.1( \pm 0.8) & 16.5( \pm 2.4) \\ \text { TA-1-17 } & 2.8( \pm 1.2) & 4.3( \pm 1.6) \\ \text { TA-1-18 } & 7.5( \pm 1.2) & 32( \pm 4) \\ \text { TA-1-22 } & 5.0( \pm 1.6) & 1-9( \pm 3.4)\end{array}$

Northern New Mexico Background Reference ${ }^{a}$

$\begin{array}{lcc}\text { Abiquid } & 0.3( \pm 1.0) & 4.3( \pm 2.0) \\ \text { Cochiti No. 1 } & 0.0(<0.15) & 3.7( \pm 1.0) \\ \text { Cochiti No. } 2 & 0.22(<0.23) & 2.8( \pm 0.8) \\ \text { Ponderosa } & --- & \cdots \\ \text { Santa Cruz } & 0.36( \pm 0.20) & 5.6( \pm 1.0) \\ & & \\ \text { Santa Fe } & 0.5( \pm 0.8) & 18( \pm 4) \\ \text { Taos } & 0.03(<0.09) & 2.1( \pm 0.8)\end{array}$

"Concentrations are $\mathrm{fCi} / \mathrm{g}$ wet weight.
TABLE E-X

AMERICIUM IN TA-1 VEGETATION (Concentrations are $\mathrm{pCi} / \mathrm{g}$ dry weight unless otherwise noted)

Location

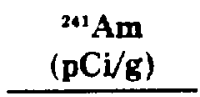

Points of Interest

TA-1 D2-3

$0.19( \pm 0.20)$

TA-1 Q-1

$0.00(<0.06)$

TA-1 General Reference

TA-1-1

$-0.13(<0.23)$

TA-1-3

$\ldots$

TA-1-11

$-0.10( \pm 0.12)$

TA-1-17

$-0.02(<0.08)$

TA-1-18

$0.00(<0.05)$

TA-1.22

$0.02(<0.11)$

Northern New Mexico Background Reference

Abiquiu

Cochiti No. 1

$0.08( \pm 0.10)$

Cochiti No. 2

$-0.01(<0.04)$

Ponderosa

$0.03(<0.07)$

Santa Cruz

$0.04(<0.07)$

$-0.01(<0.05)$

Senta Fe

Taos

$0.00(<0.12)$

$0.00(<0.03)$

- Concentrations are $\mathrm{pCi} / \mathrm{g}$ wet weight. 
TABLE E-XI

" ${ }^{3}$ Cs IN TA-I VEGETATION

(Concentrations are $\mathrm{pCV} / \mathrm{g} d r y$

weight unless otherwise noted)

Location

${ }^{\text {'s' Cs }}$

$(\mathrm{pCl} / \mathrm{g})$

Points of Interest

TA-1-17

$1.08( \pm 0.30)$

TA-1 AS-1

$1.07( \pm 0.36)$

TA-1 General Reference

TA-1-1

TA-1-11

TA.1-17

TA-1-18

$0.9( \pm 0.4)$

$0.18( \pm 0.22)$

$1.08( \pm 0.30)$

$1.16( \pm 0.24)$

TA.1-22

$1.60( \pm 0.42)$

Northern New Mexico Background Reference

Abiquiu
Cochiti No. 1
Cochiti No. 2
Ponderosa
Santa Cruz
Santa Fe
Taos

$0.95( \pm 0.24)$

$0.69( \pm 0.18)$

$0.75( \pm 0.26)$

$0.92( \pm 0.26)$

$0.87( \pm 0.22)$

$2.9( \pm 0.6)$

$0.45( \pm 0.12)$

- Concentrations are $\mathrm{pCi} / \mathrm{g}$ wet weight.

TABLE E-XII

URANIUM IN TA-1 VEGETATION

(Concentrationa are dry weight of

sample unless otherwise noted)

\begin{tabular}{|c|c|c|c|}
\hline Location & $\begin{array}{l}\text { Total Uranium } \\
(\mu \sigma / \delta)\end{array}$ & Location & $\begin{array}{c}\text { Total Urarium } \\
(\mu \mathrm{g} / \mathrm{g})\end{array}$ \\
\hline \multicolumn{4}{|c|}{ Points of Interesc } \\
\hline $\begin{array}{l}\text { TA-1-1 } \\
\text { TA-1-13 } \\
\text { TA-1-15 } \\
\text { TA-1-17 } \\
\text { TA-1-18 } \\
\text { TA-1-19 }\end{array}$ & $\begin{array}{l}0.134( \pm 0.026) \\
0.023( \pm 0.004) \\
0.78 \quad( \pm 0.16) \\
0.016( \pm 0.004) \\
0.117( \pm 0.024) \\
1.29 \quad( \pm 0.26)\end{array}$ & $\begin{array}{l}\text { TA-1-20 } \\
\text { TA-1-22 } \\
\text { TA-1 AS-2 } \\
\text { TA-1 BB-2 } \\
\text { TA-1 J2-C-1 } \\
\text { TA-1 J2-C-2 }\end{array}$ & $\begin{array}{ll}1.07 \quad( \pm 0.22) \\
0.48 \quad( \pm 0.10) \\
0.033( \pm 0.006) \\
1.66 \quad( \pm 0.34) \\
0.37 \quad( \pm 0.08) \\
2.1 \quad( \pm 0.42)\end{array}$ \\
\hline
\end{tabular}

TA-1 Genoral Reference

TA-1.11 $0.188( \pm 0.038)$

Northern New Mexico Background Reference*

$\begin{array}{lcll}\text { Abiquiu } & 9.060( \pm 0.012) & \text { Ponderosa } & 0.140( \pm 0.028) \\ \text { Cochiti No. 1 } & 0.020( \pm 0.004) & \text { Santa Cruz } & 0.016( \pm 0.004) \\ \text { Cochiti No. } 2 & <0.012 & \text { Santa Fe } & 0.062( \pm 0.012) \\ & & \text { Taog } & 0.030( \pm 0.006)\end{array}$

- Concentrations are wet weight of sampie. 
TABLE E-XIII

\section{GROSS-GAMMA FIELD MEASUREMENTS}

\begin{tabular}{|c|c|c|c|c|c|}
\hline Locration & $\begin{array}{c}\operatorname{Mod} 12 S^{\mu} \\
(\mu \mathrm{R} / \mathrm{h}) \\
\end{array}$ & $\begin{array}{c}\text { Mod RSS-111 } \\
(\mu R / h)\end{array}$ & Location & $\begin{array}{c}\operatorname{Mod} 12 S^{\mu} \\
(\mu R / h)\end{array}$ & $\begin{array}{c}\text { Mod RSS-11 } \\
(\mu \mathrm{R} / \mathrm{h}) \\
\end{array}$ \\
\hline \multicolumn{6}{|c|}{ General Locations } \\
\hline TA-1-1 & 15 & 14 & TA-1-14 & 14 & 15 \\
\hline TA-1-2 & 17 & 14 & TA-1-15 & 18 & 16 \\
\hline TA-1-3 & 17 & 14 & TA-1-16 & 25 & 15 \\
\hline TA-1-4 & 15 & 15 & TA-1-17 & 17 & 16 \\
\hline TA-1-5 & 14 & 14 & TA-1-18 & 18 & 16 \\
\hline TA-1-6 & 15 & 15 & TA-1-19 & 21 & 16 \\
\hline TA-1-7 & 16 & 15 & $\mathrm{TA}-1-20$ & 15 & 15 \\
\hline TA-1-8 & 17 & 15 & T'A-1-21 & 18 & 16 \\
\hline TA-1-9 & 14 & 15 & TA-1-22 & 20 & 16 \\
\hline TA-1-10 & 15 & 15 & TA-1-23 & 15 & 16 \\
\hline TA-1-11 & 17 & 16 & TA-1-24 & 17 & 17 \\
\hline TA. $1-12$ & 15 & 14 & TA-1-25 & 15 & 17 \\
\hline TA-1-13 & 15 & 14 & TA-1-26 & 15 & 9 \\
\hline \multicolumn{6}{|c|}{ Special Locations } \\
\hline TA-1 D-1 & 14 & 15 & TA-1 ML-1 & 15 & 16 \\
\hline TA-1 D-2 & 14 & 14 & TA-1 ML-2 & 15 & 15 \\
\hline TA-1 D-3 & 13 & 14 & TA-1 O-1 & 16 & 16 \\
\hline TA-1 D2-1 & 14 & 15 & TA-1 O-2 & 17 & 16 \\
\hline TA-1 D2-2 & 14 & 16 & TA-1 Q-1 & 16 & 15 \\
\hline TA-1 D2-3 & 15 & 9 & TA-1 Q-2 & 16 & 16 \\
\hline TA-1 D5-1 & 15 & 15 & TA-1 AS-1 & 15 & 17 \\
\hline TA-1 H-1 & 17 & 16 & TA-1 AS-2 & 15 & 16 \\
\hline TA-1 H-2 & 17 & 16 & TA-1 BB-1 & 15 & 15 \\
\hline TA-1 HT-1 & $1 . j$ & 15 & TA-1 BB-2 & 16 & 14 \\
\hline TA-1 I-1 & 15 & 15 & TA-1 BB-3 & 17 & 15 \\
\hline ГА-1 J2-1 & 14 & 16 & TA-1 BB-4 & 18 & 17 \\
\hline TA-1 J2-2 & 14 & 17 & TA-1 BB-5 & 18 & 18 \\
\hline TA-1 J2-C-1 & 28 & 18 & TA-1 BB-6 & 28 & 20 \\
\hline TA-1 J2-C-2 & 28 & 19 & & & \\
\hline
\end{tabular}

Northern New Mexico Background Reference

$\begin{array}{llllll}\text { Abiquiu } & 14 & 13 & \text { Ponderosa } & 25 & 18 \\ \text { Cochiti No. } 1 & 18 & 16 & \text { Santa Cruz } & 14 & 18 \\ \text { Cochiti No. } 2 & 15 & 14 & \text { Santa Fe } & 13 & 14 \\ & & & \text { Taos } & 15 & 15\end{array}$

a Normalized to response of environmental TLDs. 
TABLE E-XIV (cont)

\begin{tabular}{|c|c|c|c|c|c|c|c|c|c|}
\hline \multirow[b]{2}{*}{ Location } & \multirow[b]{2}{*}{ Ch 1} & \multirow[b]{2}{*}{ Ch 2} & \multirow[b]{2}{*}{ Ch 3} & \multirow[b]{2}{*}{ Ch 4} & \multirow[b]{2}{*}{$\mathrm{Ch} 5$} & \multirow[b]{2}{*}{ Ch 6} & \multirow{2}{*}{$\begin{array}{c}\text { Sum of } \\
\text { Ch } 2 \\
\text { through } \\
\text { Ch } 6\end{array}$} & \multicolumn{2}{|c|}{ Ratios } \\
\hline & & & & & & & & $\frac{2}{4}$ & $\frac{5}{(4+6)}$ \\
\hline \multicolumn{10}{|c|}{ Special Locations (cont) } \\
\hline TA-1 D2-3 & 335 & 618 & 695 & 294 & 2212 & 631 & 4450 & 2.10 & 2.39 \\
\hline TA-1 D5-1 & 336 & 481 & 558 & 241 & 2112 & 499 & 3891 & 2.00 & 2.85 \\
\hline TA-1 I-1 & 357 & 545 & 587 & 258 & 2328 & 568 & 4286 & 2.11 & 2.82 \\
\hline TA-1 H-1 & 381 & 550 & 601 & 245 & 2093 & 590 & 4079 & 2.24 & 2.51 \\
\hline TA-1 H-2 & 386 & 533 & 585 & 248 & 2050 & 580 & 3996 & 2.15 & 2.48 \\
\hline TA-1 HT-1 & 393 & 528 & 532 & 254 & 2170 & 577 & 4061 & 2.08 & 2.61 \\
\hline TA-1 J2-1 & 349 & 482 & 559 & 228 & 2151 & 511 & 3934 & 2.11 & 2.91 \\
\hline TA-1 J2-2 & 328 & 461 & 531 & 232 & 2060 & 480 & 3765 & 1.99 & 2.89 \\
\hline TA-1 J2-C-1 & 396 & 902 & 1013 & 472 & 4302 & 1085 & 7774 & 1.01 & 2.76 \\
\hline TA-1 J2-C-2 & 368 & 854 & 885 & 418 & 3790 & 928 & 6875 & 2.04 & 2.82 \\
\hline TA-1 ML-1 & 307 & 519 & 584 & 255 & 2143 & 586 & 4087 & 2.04 & 2.55 \\
\hline TA-1 ML-2 & 311 & 493 & 550 & 242 & 2025 & 561 & 3871 & 2.04 & 2.52 \\
\hline TA-1 O-1 & 355 & 544 & 601 & 242 & 1962 & 604 & 3953 & 2.25 & 2.32 \\
\hline TA-1 O-2 & 342 & 500 & 542 & 226 & 1792 & 546 & 3606 & 2.21 & 2.32 \\
\hline TA-1 Q-1 & 289 & 493 & 580 & 251 & 2061 & 564 & 3949 & 1.96 & 2.53 \\
\hline TA-1 Q-2 & 291 & 496 & 563 & 253 & 2094 & 572 & 3978 & 1.96 & 2.53 \\
\hline TA-1 AS-1 & 316 & 510 & 585 & 258 & 2285 & 557 & 4195 & 1.98 & 2.80 \\
\hline TA-1 AS-2 & 329 & 617 & 712 & 320 & 2918 & 697 & 5264 & 1.93 & 2.87 \\
\hline TA-1 BB-1 & 293 & 477 & 570 & 257 & 2364 & 553 & 4221 & 1.86 & 2.92 \\
\hline TA-1 BB-2 & 301 & 446 & 503 & 214 & 1973 & 467 & 3603 & 2.08 & 2.90 \\
\hline TA-1 BB-3 & 305 & 469 & 534 & 222 & 2035 & 473 & 3733 & 2.11 & 2.93 \\
\hline TA-1 BB-4 & 383 & 570 & 654 & 271 & 2556 & 610 & 4661 & 2.10 & 2.90 \\
\hline TA-1 BB-5 & 415 & 628 & 742 & 322 & 2937 & 719 & 5348 & 1.95 & 2.82 \\
\hline TA- 1 BB- 6 & 387 & 664 & 792 & 352 & 3263 & 795 & 5866 & 1.89 & 2.84 \\
\hline
\end{tabular}

Northern New Mexico Background Reference

\begin{tabular}{|c|c|c|c|c|c|c|c|c|c|}
\hline Abiquiu & 233 & 346 & 333 & 139 & 1127 & 349 & 2294 & 2.49 & 2.31 \\
\hline Cochiti No. 1 & ... &.- & $\ldots$ & $\ldots$ & --- & $--\cdot$ & -.. & $\cdots$ & $\cdots$ \\
\hline Cochiti Ne. 2 & $\cdots$ & $\cdots$ & -- & $\cdots$ & $\cdots$ & $\cdots$ & $\cdots$ & $\cdots$ & $\cdots$ \\
\hline Ponderosa & $\cdots$ & $\cdots$ & --- & $\cdots$ & $\cdots$ & -- & $\cdots$ & $\cdots$ & $\cdots$ \\
\hline Santa Cruz & 293 & 408 & 459 & 184 & 1403 & 435 & 2889 & 2.22 & 2.27 \\
\hline Santa Fe & 302 & 396 & 364 & 140 & 1268 & 390 & 2558 & 2.82 & 2.39 \\
\hline Taos & 322 & 454 & 496 & 191 & 1557 & 461 & 3159 & 2.38 & 2.39 \\
\hline
\end{tabular}




\section{DEPTH DISTRIBUTIONS OF PLUTONIUM IN SOIL}

\section{Location \\ General Locations}

TA-1-23

\section{Special Locations}

TA-1 AS-1

TA-1 Q-1

TA-1 Q-1

Replicate

TA-1 D-1

TA-1 D2-1

\author{
Core Section \\ (cm)
}
${ }^{239} \mathrm{Pu}$
$(\mathrm{pCi} / \mathrm{g})$

$5.16 \pm 0.09$

$4.73 \pm 0.08$

$2.36 \pm 0.06$

$0.181 \pm 0.010$

$0.095 \pm 0.008$
0 to 2.5
2.5 to 5.1
5.1 to 10.2
10.2 to 20.3
Remainder

0 to 2.5

2.5 to 5.1

5.1 to 10.2

10.2 to 20.3

Remainder

$$
\begin{gathered}
0 \text { to } 2.5 \\
2.5 \text { to } 5.1 \\
5.1 \text { to } 1.0 .2 \\
10.2 \text { to } 20.3 \\
\text { Remainder }
\end{gathered}
$$

0 to 2.5

2.5 to 5.1

5.1 to 10.2

10.2 to 20.3

Remainder

$$
\begin{gathered}
0 \text { to } 2.5 \\
2.5 \text { to } 5.1 \\
5.1 \text { to } 10.2 \\
10.2 \text { to } 20.3 \\
\text { Remainder }
\end{gathered}
$$

$$
\begin{aligned}
& 0 \text { to } 2.5 \\
& 2.5 \text { to } 5.1 \\
& 5.1 \text { to } 10.2 \\
& 10.2 \text { to } 20.3 \\
& \text { Remainder }
\end{aligned}
$$

$$
\begin{aligned}
& 0.081 \pm 0.009 \\
& 0.067 \pm 0.010 \\
& 0.067 \pm 0.008 \\
& 0.035 \pm 0.004 \\
& 0.013 \pm 0.004
\end{aligned}
$$

$$
\begin{aligned}
& 6.33 \pm 0.13 \\
& 9.09 \pm 0.16 \\
& 3.06 \pm 0.08 \\
& 3.08 \pm 0.07 \\
& 0.55 \pm 0.03
\end{aligned}
$$

$$
\begin{aligned}
& 3.29 \pm 0.16 \\
& 4.45 \pm 0.10 \\
& 2.93 \pm 0.08 \\
& 3.46 \pm 0.08 \\
& 0.47 \pm 0.03
\end{aligned}
$$

$18.4 \pm 0.3$

$24.5 \pm 0.4$

$11.4 \pm 0.2$

$45.0 \pm 0.6$

$145.8 \pm 1.8$

$$
\begin{aligned}
10.13 & \pm 0.20 \\
7.09 & \pm 0.17 \\
10.47 & \pm 0.20 \\
9.96 & \pm 0.19 \\
40.1 & \pm 0.6
\end{aligned}
$$


TABLE E-XV (cont)

\section{Location}

Special Locations (cont)

TA-1 D2-3

TA-1 D2-3

Replicate
Core Section (cm)

\author{
0 to 2.5 \\ 2.5 to 5.1 \\ 5.1 to 10.2 \\ 10.2 to 20.3 \\ Remainder
}

0 to 2.5

2.5 to 5.1

5.1 to 10.2

10.2 to 20.3

Remainder

$\begin{array}{r}{ }^{299} \mathrm{Pu} \\ (\mathrm{pCi} / \mathrm{g}) \\ \hline\end{array}$

$275 \pm 3$

$664 \pm 8$

$200 \pm 2$

$75.2 \pm 1.0$

$179 \pm 2$

$302 \pm 4$

$223 \pm 3$

$145 \pm 2$

$83.4 \pm 1.0$

$104 \pm 1$

Northern New Mexico Background Reference

Ponderosa
0 to 2.5

2.5 to 5.1

5.1 to 10.2

10.2 to 20.3

Remainder

$$
\begin{array}{r}
0.022 \pm 0.007 \\
0.025 \pm 0.004 \\
0.005 \pm 0.002 \\
-0.001 \pm 0.001 \\
0.000 \pm 0.002
\end{array}
$$




\section{APPENDIX F \\ RADIOLOGICAL INSTRUMENTATION USED DURING TA-1 CLEANUP}

Routine radiological survey meters were used at TA-1 during the surface cleanup (Sec. III.A.1) and on other occasions as appropriate. The instruments were used to identify contamination but were not used to determine whether decontamination had been completed to ALAP levels.

GM counters were used for beta-gamma surveys. The standard GM counter measures beta $(>0.15$ $\mathrm{MeV}$ ) and gamma radiation when the rotating shield is removed from the side of the tube that provides an "open window" in the shield. In this report, open-window readings are indicative of the magnitude of the meter response to beta-gamma radiation and do not indicate a true dose rate. When the rotating shield completely surrounds the GM tube (closed window), the instrument responds only to gamma radiation and gives a good approximation to the actual gamma dose rate. (Calibration is a closed-window calibration to a ${ }^{60} \mathrm{Co}$ gamma source.)

For a more sensitive response to beta and lowenergy gamma radiation, thin-window GM tubes were used. A thin window of mica ( 1.5 to $\left.2 \mathrm{mg} / \mathrm{cm}^{2}\right)$ in the end of cylindrical GM tubes or on one side of a pancake-shaped GM probe permits detection of $\sim 0.04-\mathrm{MeV}$ betas. The pancake-shaped probe provides a greater surface area (and thus better detection) than is available with the normal GM instrument. As with the readings on open windows of standard GM instruments, rearlings on the thinwindow GM instruments indicate relative response to beta-gamma radiation and not a true dose rate.
For alpha monitoring, air proportional counters having a $60-\mathrm{cm}^{2}$ detection area were used. These instruments respond only to alpha radiation. Because of the low penetrating power of alpha particles, the probe needs to be within $2 \mathrm{~cm}$ of the contaminated surface, which ideally would be dry and smooth. Obviously, in a situation like that at TA-1, the air proportional counter was of limited value. The instrument indicates the magnitude of the probe response in counts per minute.

A FIDLER probe connected to a count-rate meter was of much greater value in surveying surface contamination because it responds to low-energy $x$ and gamma rays (such as those associated with TA-1 contaminants) from a much wider urea than do GM or alpha probes. (Appendix D has a more detailed explanation of a FIDLER probe.)

Because a phoswich detector has a lower background (and thus limit of detection) than a FIDLER, two phoswich detectors were adapted for use as field survey instruments for the TA-1 operations. These detectors and the gross-alpha analysis done with $\mathrm{ZnS}$ scintillation detectors are described in detail in the paper that follows at the end of this appendix. The paper was presented at the Annual Meeting of the Health Physics Society in San Francisco, CA, July 1, 1976, and a version of the paper has been accepted for publication in Health Physics. The phoswic! 1 and the $\mathrm{ZnS}$ detector were the primary means used for documenting contamination levels. 
RECENT DEVELOPMENTS FOR FIELD MONITORING OF

ALPHA-EMITTING CONTAMINANSS IN THE ENVIRONMENT

by

A. John Ahlquist, C. John Umbarger, and Alan K. Stoker

Los Alamos Scientific Laboratory

P.O. Box 1663, MS 490

Los Alamos, New Mexico 87545

\section{INTRODUCTION}

Two field methods have been adapted by the Los Alamos Scientific Laboratory to rapidly assess locations and concentrations of alphaemitting contaminants in soil. They are 1) a gross-alpha measurement of soil samples using a ZnS alpha scintillator and 2) a portable phoswich detector used as a field survey instrument to detect low-energy $x$ and gamma rays associated with alpha decay. These methods have proven useful for directing decontamination operations of soils contaminated with alpha emitters ( $\sin 77$; He77).

\section{ZnS DETECTION SYSTEM}

The technique of making quantitative gross-alpha measurements on soil and rock samples was first used in the 1930 s by R. D. Evans to measure uranium and thorium (Ev33; Ev34a; Ev34b; Fi35). In adapting this technique, a commercially available $10 \mathrm{~cm}$ diam $\mathrm{ZnS}$ alpha scintillator probe was used with a single-channel analyzer equipped with a timer-scaler and HV supply. The system can be powered either by line or internal

*The Los Alamos Scientific Laboratory request.s that the publisher identify this article as work performed under the auspices of the USERDA, Contract W-7405-ENG. 36 . 
battery.

Soil samples are placed in plastic bags that are massaged to sufficiently homogenize the samole. Enough soil $(\sim 75 \mathrm{~g})$ is taken to fill an 88-mm dian x 13-mm deep plastic petri dish. The soil surface is leveled off even with the top of the petri dish; small rocks and debris are removed. The soil aliquot is dried under a heat lamp and allowed to cool before counting. If a sample is very wet, it is dried, ground up with a mortar and pestle to break up aggregates and then returned to the petri dish for redrying to remove residual moisture. If a sample is not dry enough, moisture tends to condense on the mylar face of the probe during counting, reducing detector sensitivity.

The petri dish is then placed in a depression in a black wooden holder and the probe is plased on top of the dish. The holder is black in order to minimize scattered 1 ight, as the $1 \mathrm{mg} / \mathrm{cm}^{2}$ aluminized mylar covering the detector face is not completely opaque to light. Integral ribs on the probe provide a consistent $1.6 \mathrm{~mm}$ spacing between the top of the soil sample and the probe face. Samples are nominally counted for 5 unin. Total elapsed time from receipt of sample to measurement results can be as litt.le as $30 \mathrm{~min}$.

The system is calibrated using a carefully homogenized soil sample spiked to $2000 \mathrm{pCi} / \mathrm{g}$ with ${ }^{239} \mathrm{Pu}$. This sample gives $0.135 \mathrm{c} / \mathrm{m}$ per pCi/g. The 1-sigma statistical error on the calibration factor is less than $3 \%$ for a 5-min count on samples $\geq 2000 \mathrm{pCi} / \mathrm{g}$. System background (using an empty petri dish) is $0.5-1.0 \mathrm{c} / \mathrm{m}$. Natural alpha emitters in Los Alamos area soils result in background counting rates of 4 to $8 \mathrm{c} / \mathrm{m}$. An uncontaminated soil sample of the soil type being measured is used to determine the natural alpha background. 
System calibration-scability checks made with a $7.5-\mathrm{cm}$ diam plated 239

Pu source, and system background checks are made diily. Blank and calibration checks are made periodically.

Table I lists the various detection limits attainable with this system, as a function of gross counts for soil background, for a 5-min counting time. This count time was selected as a compromise between desired detection limits and speed and ease of analysis. A $99.7 \%$ confidence level was chosen for operational use so as to minimize the Type I error (stating activity is present when it is not).

The risults of gross-alpha analyses on selected soil samples known to have predominantly ${ }^{239} \mathrm{Pu}$ contamination were compared to ${ }^{239} \mathrm{Pu}$ radiochemistry results on aliquots of soil from the petri dish used for the gross-alpha analysis (Fig. 1). Note that $73 \%$ of the $\mathrm{ZnS}$ measurements are within a factor of 2 of the radiochemistry results. This is considered to be good agreement since samples were not sieved, ground, or milled to ensure homogeneity and since the $\mathrm{ZnS}$ "sees" $<0.5 \mathrm{~g}$ of soil, whereas $10 \mathrm{~g}$ are used for radiochemistry. Four samples had gross-alpha $\mathrm{ZnS}$ to ${ }^{239} \mathrm{Pu}$ (radiochemistry) ratios of $0.07,19,27$, and 30 belicved to be due to sampling inhomogeneities.

In conclusion, this technique permits rapid assessment of alphaemitter contamination in soils to low enough concentrations to efficiently direct large field operations. Due to sample inhomogeneity, however, the gross-alpha analysis may not compare favorably to radiochemistry on the same sample (although the majority of our comparisons are within a factor of 2). We feel this disadvantage is more than offset by the advantage of being able to analyze large numbers of samples in a relatively short time. 


\section{PHOSWICH SYSTEM}

To locate spill boundaries or hot spots of alpha contamination that could be missed by soil sampling, a phoswich detector has been adapted for use as a field survey instrument because it can detect lower levels of radioactivity than can the more commonly used FIDLER probe.

The FIDLER probe (Ti67; Ti68) uses a thin inorganic scintillator, NaI(Tl), which preferentially absorbs photons up to a desired maximum energy. Higher energy photons then leave little or no energy in the crystal. However, Compton scattering of high-energy gamma rays in the crystal or surrounding medium will cause a low-energy-like response in the crystal that appears as increased background. By using a phosphor sandwich, (phoswich) detector commonly used in low-level counting laboratories, (in our case a $1 \mathrm{~mm}$ thick $\times 103 \mathrm{~cm}^{2}$ surface area NaI(Tl) crystal backed by a $38 \mathrm{~mm}$ thick CsI(Na) crystal of the same surface geometry) and pulse shape nalysis on the different signal decay times of the two crystals, one can discriminate between photon interactions occurring only in the front thin crystal and those occurring in both crystals. Hence, the contribution to background from compton scattering of high-energy gamma rays in the thin crystal can be substantially reduced by proper -nticoincidence gating.

The electronics for the field phoswich are shown in Fig. 2. The probe is connected by a 30-m long umbilical cord to standard NIM electronics carried in a truck, and is powered by a power inverter operated off the truck battery. The readout devices on the probe consist of a visual count-rate meter and a separate aural popper (Wo75) which squeaks when an event is detected. The rate and the frequency (pitch) of the squeak vary with the average count rate to give the operator an audible, semiquanti- 
tative indication of activity, compared to background. The system electronics are calibrated with an energy window of 12-40 keV which allows detection of plutonium, americium, thorium (using the daughter $I$ $\mathbf{x}$ rays of these alpha emitters), and ${ }^{137} \mathrm{Cs}$ by way of its daughter $32 \mathrm{keV}$ $\mathrm{K} \times$ rays. The bremsstrahlung from ${ }^{90} \mathrm{Sr}$ can also be detected with this energy window.

Crude concentration measurements (e.g., pci/g in soil) can be made for samples held to the detector face or when the detector is placed on the spot of interest on the ground. For our instruments the plutonium concentration in $\mathrm{pCi} / \mathrm{g}$ is about 2.5 times the net count rate above background (as determined with spiked homogenous $75 \mathrm{~g} 0.8-\mathrm{cm}$ thick soil samples). Assuming one needs twice the $500 \mathrm{c} / \mathrm{m}$ background for true detection (i.e., detection is possible when the signal equals the background level), the detection limit is $21200 \mathrm{pCi} / \mathrm{g}$.

A 3-mm brass plate can be placed over the probe to shield the detector face to increase directionality. The probe is surrounded by 2.5 cm of polyurethane foam for thermal-and mechanical-shock protection. The whole system is enclosed in two plastic bags to prevent probe contamination. The field survey systems have been operated in an ambient temperature range of $0^{\circ}-30^{\circ} \mathrm{C}$ with no significant change or drift in the electronics or the detection efficiency observed. Care was taken, however, to keep the trucks and electronics in a heated garage overnight during the winter and to keep the probes in a warm place (e.g., truck cab) when not in use in the field.

Comparing FIDLER to phoswich backgrounds, for well-shielded detectors the phoswich background is 4 to 9 times lower than that for a 
FIDLER. Actual reduction depends on the specific detectors and energy region chosen. For the unshielded field phoswich, however, the background reduction over a FIDLER is only a factor of 2 to 3 . For field work, this type of reduction provides an equivalent reduction (improvement) in detection limit if one uses the concept that detection is possible when the net count rate is equal to the background count rate.

Two truck-based phoswich detectors have been in continuous operation at IASI for over 18 months. They have operated reliably with very little maintenance in all weather conditions and with superior detection limits compared to a field FIDLER. Their restricted mobility, due to the umbilical cord, is being overcome by ruggedized and miniaturized field electronics which will allow the phosvich to be truly portable. A prototype is now being tested (UM7x).

\section{ACKNOWLEDGMEINTS}

J. W. Healy, W. E. Goode, and W. J. Smith, II made significant contributions to the evolution of the field $\mathrm{ans}$ system. R. F. Smale, J. A. Vigil, and R. J. Elliot routinely used the field phoswich system and provided encouragement and constructive criticism. We wish to thank J. L. Horney for drawing the figure of the field phoswich system. Los Alamos Scientific Laboratory A. John Ahlquist

P.O. Box 1663, MS 490

C. John Umbarger

Los Alamos, NM 87545

Alan K. Stoker

REFEREIICES

Ev33 Evans, R. D., 1933, "Uranium and Thorium Content of Rocks Determined from their Surface Radiation," abstract in Phys. Rev., 44, 129. 
Ev34a Evans, R. D., 1934, "The Measurements of Natural Alpha Particles Ejected from Solids," Phys. Rev., $\underline{45}, 29$.

Ev34b Evans, R. D., 1934, "The Radioactive Radiations from the Surfaces of So?ids and the Measurements of the Thorium Content of Rocks," Phys. Rev. , 45,38 .

Fi35 Finney, G. D. and Evans, R. D., 1935, "The Radioactivity of Solids Determ_ned by Alpha-Ray Counting," Phys. Rev., 48, 503.

He77 Health Division Staff, 1977, "Radiological Survey and Decontamination of the Former Main Technical Area (TA-I) at Los Alamos, New Mexico," Los Alamos Scientific Laboratory Report to be published.

Sm77 Smith, W. J., II, Fowler, E. G., and Stafford, R. G., 1977, "Experience in the Cleanup of Plutonium Contaminated Land," Los Alamos Scientific Laboratory Report LA-6731-MS.

Tif7 Tinney, J. F., and Koch, J. J., 1967, Lawrence Livermore L.zboratory Progress Report UCRL-50007-67-3, 6 .

Ti68 Tinney, J. F., 1968, Lawrence Livermore Laboratory Procress Report UCRL-50007-68-2, 24.

Um7x Umbarger, C. J., and Wolf, M. A., "A Portable Field Phoswich Detector," to be submitted to Nucl. Inst. and Methods.

Wo75 Wolf, M. A., 1975, "LASL \# $2 \mathrm{H}$ Count Rate Meter," Los Alamos Scientific Laboratory Drawing No. $4 \mathrm{Y} 168446$. 


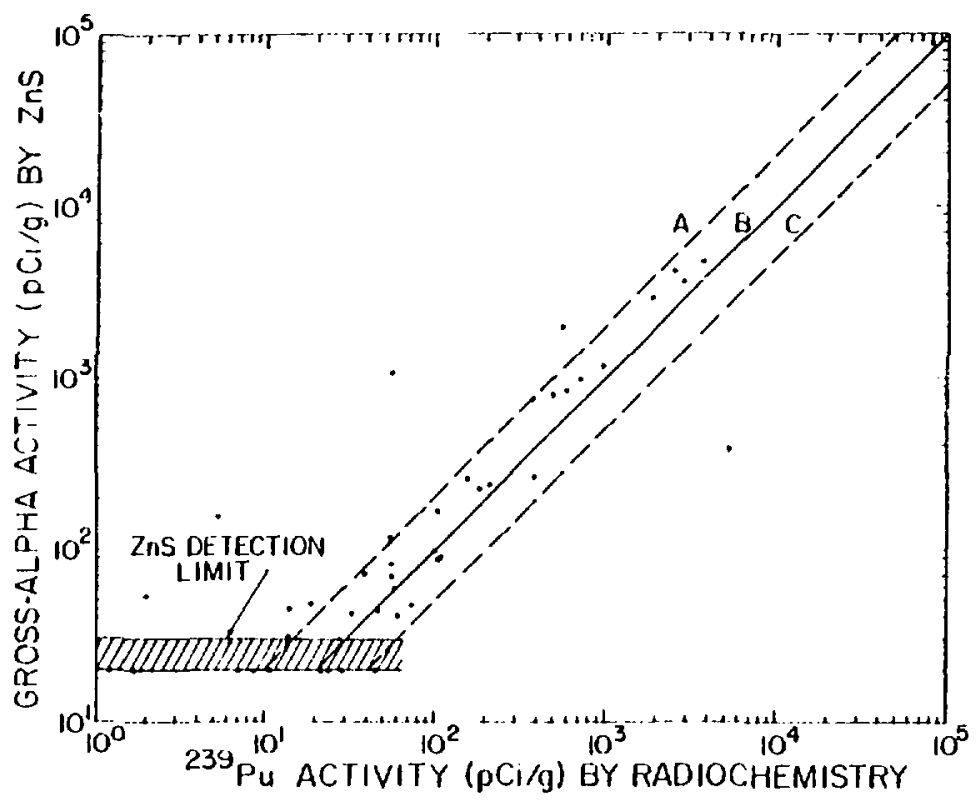

Fig. 1.

Comparison of $Z n S$ gross-alpha results to ${ }^{238} P$ radiochemistry results on the same samples. Curve $A$ indicates a $Z n S$ resull two times that of radiochemistry. Curve B indicates a $Z n S$ response equal to the radiochemistry result. Curve $C$ indicates a $Z n S$ response one-half that of radiochemistry. The detection limit indicated is for a 5-min count for a range of natural soil backgrounds. The actual limits depend upon the parameters used.
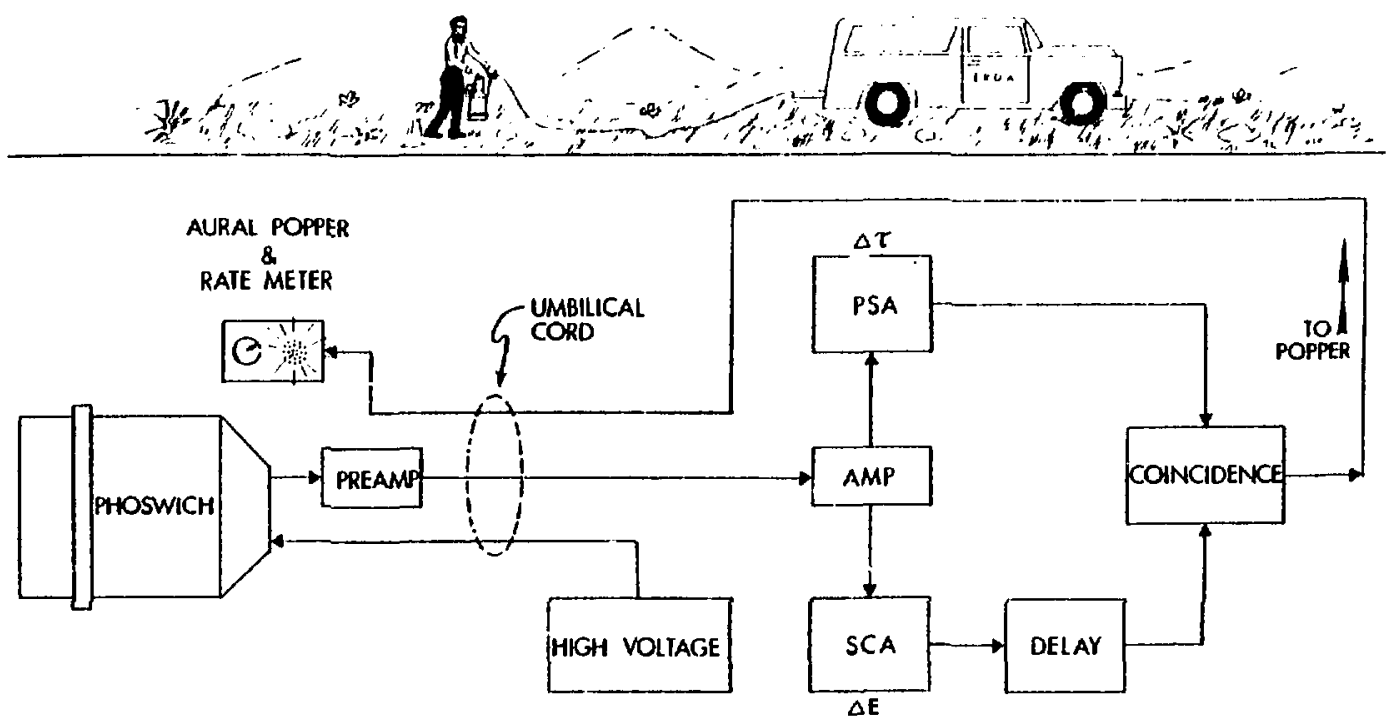

Fig. 2.

Schematic of the field phoswich detector. The pulse shape analyzer (PSA) selects only pure $\mathrm{NaI}$ signals while the single-channel analyzer (SCA) selects the photon energy region of interest. 


\section{TABLE I}

Gross-Alpha Activity Detection Limits for 5-Minute Sample Counts as a Function of Background Count Rate and Probability of Detection

Soil Background Count Rate $(\mathrm{c} / 5 \mathrm{~min})$

20

30

40

Gross-Alpha Activity Detection Limit (pCi/q)

95\% Confidence (a) $99.7 \%$ Confidence

14

21

15

26

(a) Given for reference. 


\section{APPENDIX G \\ DETAILED RESULTS OF ENVIRONMENTAL AIR SAMPLING}

To document the radiologica! impact of the TA-1 operations, air-sampling stations were established at three nearby commercial establishments: the Gulf Station, Los Alamos Inn, and Trinity Square Plaza (Fig. G-1). The sampling station nearest the major excavations in the $D$ and D-2 areaz was the station at the Trinity Square Plaza, which was also at approximately the same elevation as the original surface of most of the excavation. The other two stations were 4.5 to $6.0 \mathrm{~m}$ above the major excavations and were shielded froñi unitect view of most of the excavations.

Results of air sampling for gross alpha, gross beta, ${ }^{238} \mathrm{Pu}$, and ${ }^{238} \mathrm{Pu}$ and comparison of the results to the 26-station air surveillance network are given in Tables G-I and G-II. The plutonium results are plotted in Fig. G-2. Sampling at the three TA-1 stations was stopped for $\sim 1$ month during a lull in activity (see Sec. II.B). Because the restoration in the $D$ and D-2 areas was complete, the Trinity Square Plaza station was not restarted. Sampling at the Los Alamos Inn station was stopped on August 30, 1976. The Gulf Station sampling station has been incorporated into the routine environmental surveillance network.
Sampling results in Table G-I indicate no significant differences between the environmental surveillance net and the TA-1 stations for gross-alpha and -beta activity. Results from Table G-II indicate some differences in plutonium activity between the TA-1 stations and the surveillance network stations. The most notable example is for ${ }^{239} \mathrm{Pu}$ at Trinity Square Plaza for the period October 27 to November 11,1975 . [During this time trenching explorations to locate contamination were being condu'ted nearby ( $\sim 80 \mathrm{~m}$ distant) in the D-2 area.) The value of $463 \mathrm{x}$ $10^{-18} \mu \mathrm{Ci} / \mathrm{cm}^{3}$ for this 2 -wk period corresponds to the maximum values encountered for 6 -wk periods in the environmental surveillance net during 1973 . 1976. The values measured during the period when no decontamination was being conducted (February 2 to March 29, 1976) are higher than the values seen on the air surveillance net during that period. We do not know if this is a real phenomenon or if it represents a difference caused by analyzing each filter separately as opposed to analyzing composite samples as is done on the air net. 


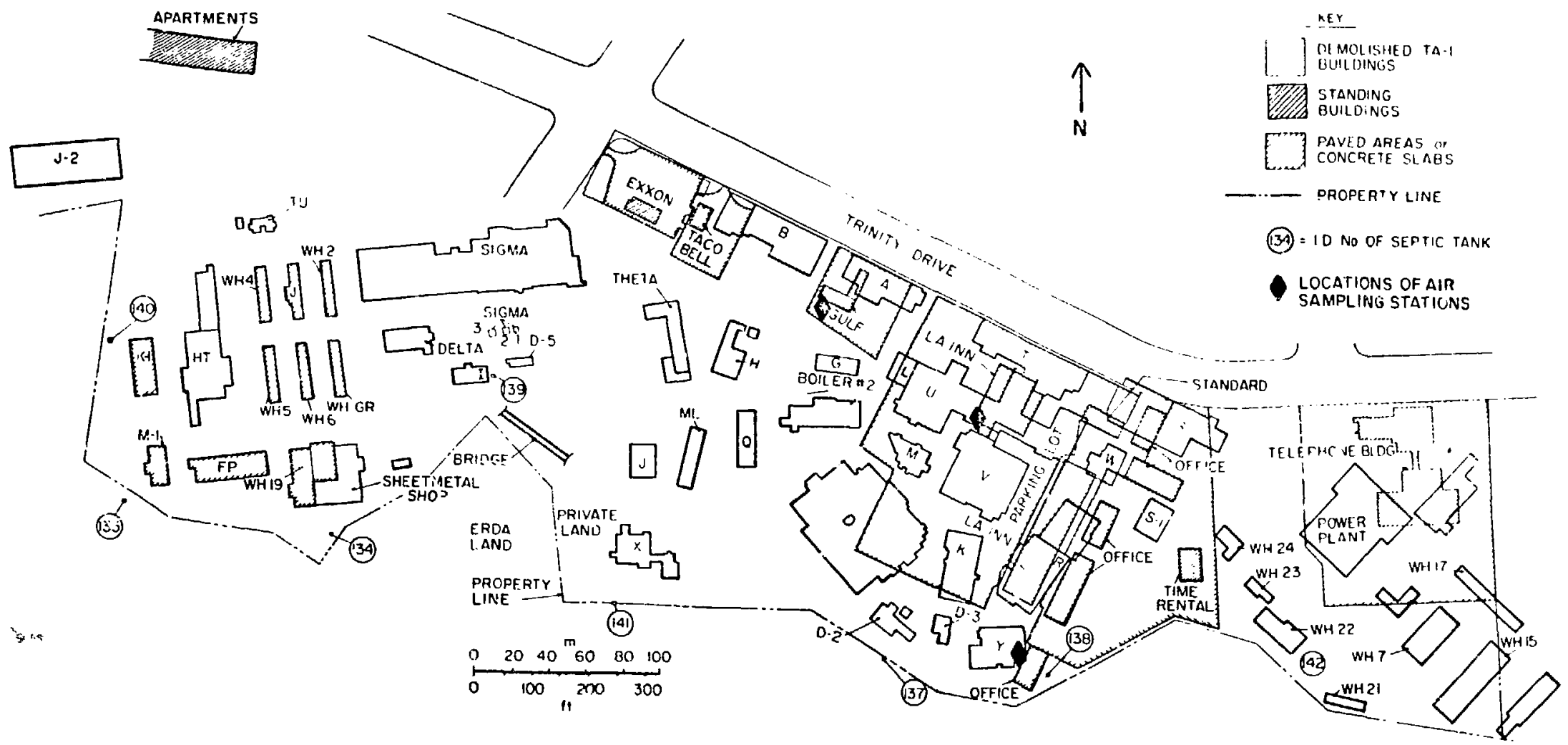

Fig. $(i-1$.

Air sumplers in TA-l area during decontamination operations. 


\section{TABLE G-I}

GROSS-ALPHA AND -BETA AIR-SAMPLING RESULTS ${ }^{a}$

(In $\mathbf{f C l} / \mathbf{m}^{3}$ )

\begin{tabular}{|c|c|c|c|c|c|c|c|c|c|c|}
\hline \multirow[b]{3}{*}{ Period } & \multirow{2}{*}{\multicolumn{2}{|c|}{ Gulf Station }} & \multirow{2}{*}{\multicolumn{2}{|c|}{ Los Alamos Inn }} & \multirow{2}{*}{\multicolumn{2}{|c|}{$\begin{array}{c}\text { Trinity Square } \\
\text { Plaza }\end{array}$}} & \multicolumn{4}{|c|}{ (26 Stations) } \\
\hline & & & & & & & \multicolumn{2}{|c|}{ Average } & \multicolumn{2}{|c|}{ Range } \\
\hline & Eipha & Beta & Alpha & Beta & Alpha & Beta & Alpha & Beta & Alpha & Beta \\
\hline $10 / 28$ to $11 / 10 / 75$ & $1.8 \pm 0.4$ & $26 \pm 3$ & $1.9 \pm 0.4$ & $28 \pm 3$ & $1.9 \pm 0.4$ & $25 \pm 3$ & $1.6 \pm 0.3$ & $25 \pm 3$ & $1.1-2.3$ & $18-31$ \\
\hline $11 / 10$ to $11 / 24$ & $1.6 \pm 0.4$ & $21 \pm 3$ & $1.8 \pm 0.4$ & $21 \pm 3$ & $2.1 \pm 0.5$ & $26 \pm 3$ & $1.3 \pm 0.2$ & $21 \pm \dot{z}$ & $1.0-1.9$ & $19-26$ \\
\hline $11 / 24$ to $12 / 8$ & $1.1 \pm 0.3$ & $15 \pm 2$ & $0.9 \pm 0.2$ & $12 \pm 2$ & $0.9 \pm 0.2$ & $14 \pm 2$ & $1.0 \pm 0.2$ & $17 \pm 3$ & $0.7-1.3$ & $12-20$ \\
\hline $12 / 8$ to $12 / 22$ & $1.1 \pm 0.3$ & $20 \pm 3$ & $1.6 \pm 0.4$ & $26 \pm 3$ & $0.9 \pm 0.2$ & $17 \pm 2$ & $1.3 \pm 0.2$ & $24 \pm 5$ & $1.0-1.7$ & $18-40$ \\
\hline $12 / 22$ to $1 / 5 / 76$ & $1.3 \pm 0.3$ & $18 \pm 2$ & $2.0 \pm 0.4$ & $24 \pm 3$ & $1.7 \pm 0.4$ & $23 \pm 3$ & $1.5 \pm 0.3$ & $24 \pm 4$ & $0.9-1.9$ & $18 \cdot 32$ \\
\hline $1 / 5$ to $1 / 19$ & $1.0 \pm 0.2$ & $15 \pm 2$ & \pm 0.2 & $17 \pm 2$ & $1.1 \pm 0.2$ & $15 \pm 2$ & $1.0 \pm 0.3$ & $18 \pm 3$ & 2.0 & $14-25$ \\
\hline $1 / 19$ to $2 / 2$ & $1.2 \pm 0.3$ & $21 \pm 3$ & $1.2 \pm 0.3$ & $20 \pm 3$ & $0.9 \pm 0.2$ & $18 \pm 2$ & $=0.2$ & & $.7-1.6$ & $17-26$ \\
\hline $2 / 2$ to $2 / 17$ & $0.9 \pm 0.2$ & $17 \pm 2$ & $0.8 \pm 0.2$ & $15 \pm 2$ & $1.0 \pm 0.2$ & $19 \pm 2$ & $1.0 \pm 0.2$ & $18 \pm 4$ & $0.7-1.3$ & $13-33$ \\
\hline $2 / 17$ to $3 / 1$ & $1.1 \pm 0.3$ & $20 \pm 3$ & $1.2 \pm 0.3$ & $19 \pm 2$ & $1.4 \pm 0.3$ & $17 \pm 2$ & $1.1 \pm 0.2$ & $22 \pm 4$ & $0.7-1.4$ & $1-35$ \\
\hline $3 / 1$ to $3 / 15$ & $1.2 \pm 0.3$ & $22 \pm 3$ & $1.1 \pm 0.3$ & $22 \pm 3$ & $1.0 \pm 0.2$ & $19 \pm 2$ & $1.2 \pm 0.3$ & $23 \pm 4$ & $0.7-2.1$ & $16-32$ \\
\hline $3 / 15$ to $3 / 29$ & $1.1 \pm 0.3$ & $19 \pm 2$ & $0.8 \pm 0.2$ & $16 \pm 2$ & $0.9 \pm 0.2$ & $14 \pm 2$ & $0.9 \pm 0.2$ & $17 \pm 3$ & $0.6-1.4$ & $14-27$ \\
\hline $3 / 29$ to $4 / 12$ & $0.8 \pm 0.2$ & $16 \pm 2$ & ...' & -.- & -.. & ... & $1.0 \pm 0.2$ & $19 \pm 4$ & $0.6-1.5$ & $15-28$ \\
\hline $4 / 12$ to $4 / 26$ & $1.1 \pm 0.2$ & $16 \pm 2$ & -.. & ... & $\ldots$ & ... & $1.0 \pm 0.2$ & $17 \pm 4$ & $0.1-1.2$ & $1-19$ \\
\hline $4 / 26$ to $5 / 10$ & $1.5 \pm 0.3$ & $21 \pm 3$ & $1.5 \pm 4$ & $23 \pm 3$ & $\cdots$ & ... & $1.2 \pm 0.4$ & $19 \pm 4$ & $0.1-1.7$ & 9.25 \\
\hline $5 / 10$ to $5 / 24$ & $1.1 \pm 0.3$ & $16 \pm 2$ & $1.0 \pm 0.2$ & $20 \pm 3$ & --. & $\ldots$ & $1.1 \pm 0.4$ & $18 \pm 4$ & $0.1-2.2$ & $8-23$ \\
\hline $5 / 24$ to $6 / 7$ & $1.1 \pm 0.2$ & $16 \pm 2$ & $1.0 \pm 0.2$ & $20 \pm 3$ & -.- & $\ldots$ & $1.2 \pm 0.5$ & $19 \pm 4$ & $0.5-3.3$ & $8-30$ \\
\hline $6 / 7$ to $6 / 21$ & $1.0 \pm 0.2$ & $27 \pm 4$ & $0.9 \pm 0.2$ & $16 \pm 2$ & ... & $\ldots$ & $1.2 \pm 0.2$ & $19 \pm 3$ & $0.8-1.6$ & $17-24$ \\
\hline $6 / 21$ to $7 / 5$ & $1.2 \pm 0.3$ & $19 \pm 2$ & $0.9 \pm 0.2$ & $16 \pm 2$ & ... & $\ldots$ & $1.0 \pm 0.2$ & $18 \pm 3$ & $0.8 \cdot 1.4$ & $13-30$ \\
\hline $7 / 6$ to $7 / 19$ & $0.9 \pm 0.2$ & $15 \pm 2$ & $1 . n \pm 0.2$ & $19 \pm 2$ & $\ldots$ & $\cdots$ & $1.2 \pm 0.8$ & $17 \pm 2$ & $0.8-5.3$ & $13-21$ \\
\hline $7 / 19$ to $8 / 2$ & $0.8 \pm 0.2$ & $12 \pm 2$ & $0.9 \pm 0.2$ & $14 \pm 2$ & $\ldots$ & $\ldots$ & $0.8 \pm 0.1$ & $13 \pm 3$ & $0.6 \cdot 1.1$ & $9-26$ \\
\hline $8 / 2$ to $8 / 16$ & $0.9 \pm 0.2$ & $12 \pm 2$ & $1.0 \pm 0.2$ & $14 \pm 2$ & ... & ... & $1.0 \pm 0.3$ & $14 \pm 2$ & $0.7-2.0$ & $11-17$ \\
\hline $8 / 16$ to $8 / 30$ & $1.1 \pm n .3$ & $15 \pm 2$ & $0.9 \pm 0.2$ & $15 \pm 2$ & ... & $\ldots$ & $1.0 \pm 0.2$ & $14 \pm 3$ & $0.8-1.3$ & $10-25$ \\
\hline
\end{tabular}

a For comparison, the RCG for unknown gross-alpha activity is $20 \mathrm{fCi} / \mathrm{m}^{3}$ and for gross-beta activity it is $100000 \mathrm{fCi} / \mathrm{m}^{3}$.

"No snmples taken. 
TABLE G-II

PLITONIIM CONCENTKATIONS IN AIR*

(In $\mathrm{a}\left(\mathrm{Ci} / \mathrm{m}^{1}\right)$

\begin{tabular}{|c|c|c|c|c|}
\hline \multirow[b]{2}{*}{ Period } & \multicolumn{2}{|c|}{ Gulf Station } & \multicolumn{2}{|c|}{ Los Alamos Inn } \\
\hline & ${ }^{209} \mathrm{Pu}$ & ${ }^{209} \mathrm{Pu}$ & ${ }^{2 \mathbf{s s}} \mathbf{P u}$ & ${ }^{230} \mathrm{Pu}$ \\
\hline $10 / 27 \tan 11 / 10 / 75$ & $1.5 \pm 4.0$ & $17 \pm 5$ & $1.5 \pm 3.6$ & $46 \pm 8$ \\
\hline $11 / 10$ to $\mathrm{i} 1 / 24$ & $0.2 \pm 1.2$ & $19 \pm 4$ & $1.8 \pm 1.5$ & 50 \pm 6 \\
\hline $11 / 24$ to $12 / 7$ & $-0.4 \pm 2.3$ & $30 \pm 6$ & $2 . ? \pm 2.3$ & $10 \pm 3$ \\
\hline $12 / 8$ to $12 / 22$ & $17 \pm 2.3$ & $52 \pm 9$ & $-0.5 \pm 2.3$ & $21 \pm 5$ \\
\hline $12 / 22$ to $1 ; 5 / 76$ & $0.5 \pm 1.2$ & $17 \pm 3$ & $10.8 \pm 3.1$ & $17 \pm 3$ \\
\hline 1/s to $1 / 19$ & $1.2 \pm 2.1$ & $29 \pm 4$ & $0.1 \pm 1.2$ & $31 \pm 4$ \\
\hline $1 / 19$ to $2 / 2$ & $-0.9 \pm-1.6$ & $27 \pm 4$ & $-0.8 \pm-0.9$ & $21 \pm 3$ \\
\hline $2 / 2$ to $2 / 17$ & $-0.2 \pm-2.4$ & $33 \pm 7$ & $0 . \overline{1} \pm 1.4$ & $29 \pm 4$ \\
\hline $2 / 17$ to $3 / 1$ & $-0 . \overline{5} \pm 0.8$ & $22 \pm i$ & $1.9 \pm 1.9$ & $32 \pm 8$ \\
\hline $3 / 1$ to $3 / 15$ & $0.0 \pm 0.8$ & $0.8 \pm 0.8$ & $-0 . \therefore \pm 0.8$ & $36 \pm 5$ \\
\hline $3 / 15$ to $3 / 29$ & $-0.5 \pm 0.5$ & $5 \pm 2$ & $-1.8 \pm 1 . x$ & $10 \pm 5$ \\
\hline $4 / 26$ to $5 / 10$ & $\ldots-{ }^{b}$ & $\cdots$ & $-3.2 \pm 4.5$ & $-10.1 \pm 4$ \\
\hline $5 / 10$ to $5 / 24$ & $\cdots$ & $\cdots$ & $-0.2 \pm 2.4$ & $1: 2 \pm 4$ \\
\hline $5 / 24 \operatorname{tn} 6 / 7$ & $\cdots$ & $\cdots$ & $-1.6 \pm 1.6$ & $3 i \pm 6$ \\
\hline $6 / 7$ to $6 / 21$ & $\cdots$ & $\cdots$ & $-0.6 \pm 2.6$ & $9.1 \pm 4.1$ \\
\hline $6 / 21$ to $8 / 2$ & $-1.2 \pm 0.9$ & $13 \pm 3$ & $0.4 \pm 0.7$ & $10 \pm 2$ \\
\hline $8 / 2108 / 30$ & $-1.0=1.1$ & $1.3 \pm 1.7$ & $-0.5 \pm 0.7$ & $4.6 \pm 1.4$ \\
\hline
\end{tabular}

\begin{tabular}{|c|c|}
\hline \multicolumn{2}{|c|}{ Trinity Square Pluza } \\
\hline${ }^{25 *} \mathrm{Pu}$ & ${ }^{2 n} \mathrm{FJ}$ \\
\hline $6 \pm 5$ & $463 \pm 257$ \\
\hline$-(1.2 \pm 1.2$ & $\pi \pm 6$ \\
\hline$\| \pm 1$ & $15 \pm 3$ \\
\hline$-10.2 \pm 1.6$ & $33 \pm 6$ \\
\hline $1.8 \pm 2.2$ & $16 \pm 4$ \\
\hline $0 . \bar{i} \pm 1 . \bar{x}$ & $3 x \pm 5$ \\
\hline$-0.5 \pm-1.3$ & $16 \pm 3$ \\
\hline $1.8 \pm 1.4$ & $14 \pm 2$ \\
\hline$-1 . .5 \pm(0.5$ & $4 \pi \pm \pi$ \\
\hline $0.8 \pm(i .8$ & $9 \pm 3$ \\
\hline $5.6 \pm 4.3$ & 5) \pm 5 \\
\hline$\cdots$ & $\cdots$ \\
\hline$\cdots$ & $\cdots$ \\
\hline$\cdots$ & $\ldots$ \\
\hline$\cdots$ & $\ldots$ \\
\hline$\cdots$ & $\ldots$ \\
\hline
\end{tabular}

\begin{tabular}{|c|c|c|c|c|c|}
\hline \multicolumn{6}{|c|}{ Environmental Surveillance Net (26 Stations) } \\
\hline \multicolumn{3}{|c|}{${ }^{21} \mathrm{Pu}$} & \multicolumn{3}{|c|}{${ }^{219} \mathrm{Pu}$} \\
\hline Median & Average & Range & Median & Average & Hange \\
\hline 0.15 & $0.4 \pm 1.4$ & $-1.0+07.0$ & 4.9 & $f i t \pm 11$ & $-11.310+6)$ \\
\hline 0.3 & $11: 11.9$ & -1.9402 .3 & $\therefore: 2$ & $5.2 \pm 1 . x$ & $2.6 \operatorname{tos} 3.6$ \\
\hline 0,0 & $0.1 \pm 0.5$ & $-0 . x+1.5$ &.$: 2$ & $-2 \pm 1.9$ & +610124 \\
\hline 0.3 & $0.2 \pm 0.9$ & $-0.9+02.2$ & 6.4 & $6.6 \pm 2.2$ & $1.7+n \mid 2.1$ \\
\hline 0.2 & $0.3 \pm 1.0$ & $-0.8+0.2 .6$ & 7.4 & $7.7 \pm 3.0$ & 3.01018 .8 \\
\hline 0.0 & $-10.9 \pm 5.1$ & $-2+1+26$ & .19 & 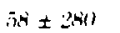 & $0.70,1.0010$ \\
\hline-0.6 & $-0.2 \pm 2.1$ & -1.5102 .3 & 1.3 & $4.3 \pm 22$ & $0.11+0 \%$ \\
\hline
\end{tabular}

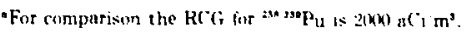

Sio snmples taken. 


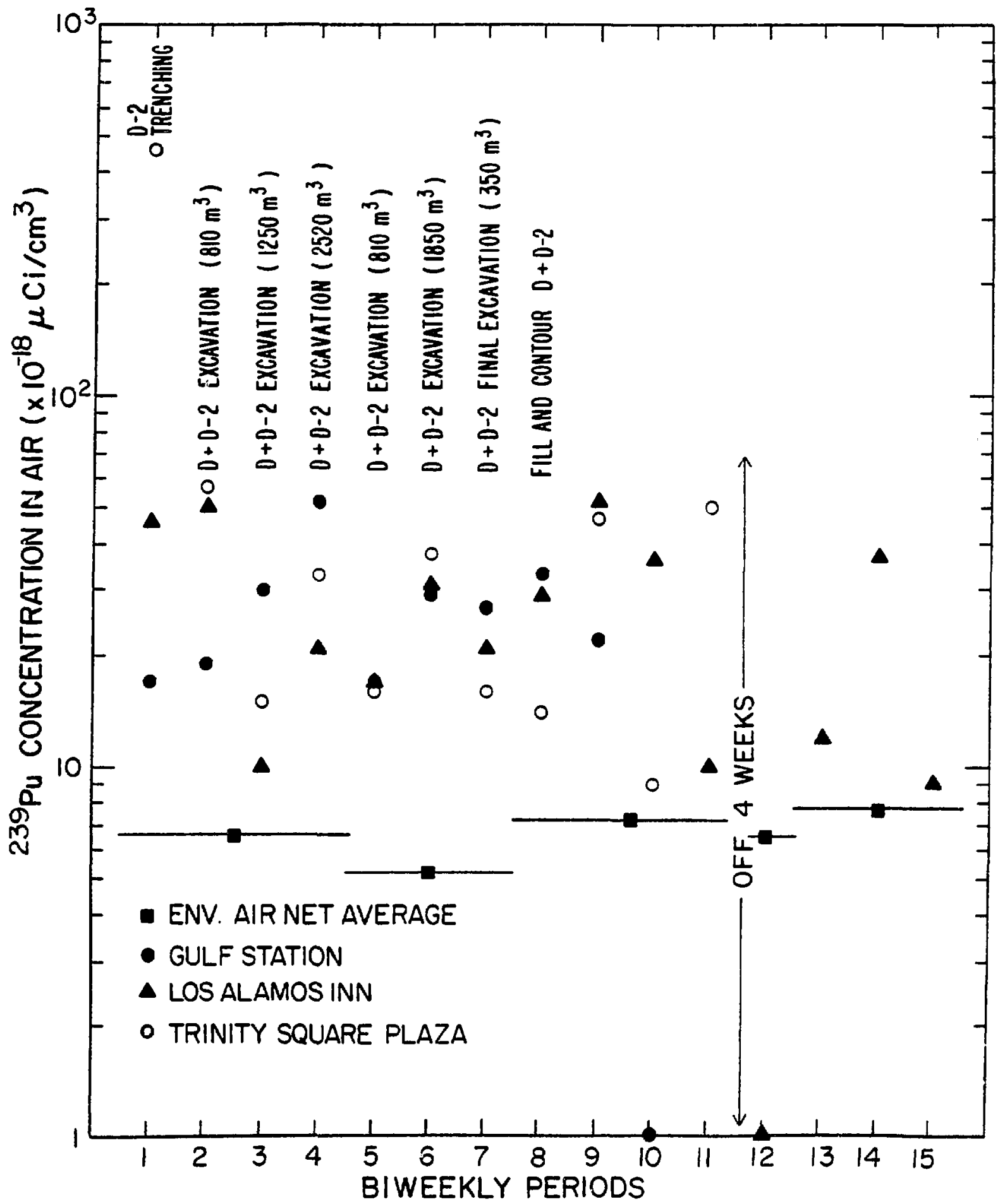

Fig. G-2.

Plutonium concentrations in air measured during TA-1 decontamination operations. 


\section{ACKNOWLEDGMENTS}

The radiological and survey and decontamination operations required the participation and support of a number of yeople too numerous to identify individually. The principal organizations involved were the Albuquerque Operations Office and Los Alamos Area Office of ERDA; the Health Division and Engineering and Information Services Department of LASL (with upper level Laboratory management support); and Zia Co. ERDA responsibilities included financial support, outside liaison, and final ALAP decisions. The responsibilities of the Health Division Office, Environmental Studies Group, Health Physics Group, Waste Management Group, and Safety Group included project management, health physics, safety, waste disposal, inst rumentation development, sample collection and analysis, and report writing. The Engineering Department Office, Construction Group, Records Management Group, and Long Range Planning Group provided records, operations direction, and surveys, and were the prime interface with Zia Co., which provided the equipment and personnel to move the soil and debris. The Information Services Department Office, Illustration Services Group, Technical Information Group, and Graphic Arts Group also provided support.

\section{REFERENCES}

1. Carl W. Buckland to Dean D. Meyer, "Summary of Records Search for Radioactivity Remaining in TA-1, Acid Waste lines, TA-10, TA-45, and Acid Canyon Below TA-45," personal communication, February 16, 1973.

2. Carl W. Buckland to Joe Hill, "Final Radioactive Contamination Fealth Clearances of the Eastern Sector of TA-1 South of Trinity Drive and the J-2 Area," personal communication, September $15,1959$.

3. John Enders to Dean Meyer, "Report on the Dımolition of D-Building," personal communicatinn, December 29, 1954.
4. B. F. Schnap to W. R. Kennedy, "Pu Assay of Soil on Ground of Former D-Building," personal communication, September 1, 1954.

5. B. F. Schnap to W. R. Kennedy, "Pu Assay of Soil Samples Taken 6 Feet Below Surface of Location of Former D-Building," personal communication, September 8, 1954.

6. B. F. Schnap to W. R. Kennedy, "Pu Assay of Soil Samples," personal communication, October 26, 1954.

7. John A. Erlewine, Assistant General Manager for Operations, USAEC, to $H$. C. Donnelly, Manager, Albuquerque Operations Office, USAEC . "Contamination Clearance of Land at the Los Alamos Scientific Laboratory," personal con. munication, September 14, 1971.

8. H. Jack Blackwell, Manager, Los Alamos Area Office, USAEC , to Harold M. Agnew, Director, Los Alamos Scientific Laboratory, "Management of Contaminated Real Property," personal communication, November 17, 1971.

9. Los Alamos Scientific Laboratory, "Removal of Acid Sewer, Contaminated Sanitary Sewer, and Contaminated Concrete," LASL Drawing No. ENG. R-202 (September 22, 1959).

10. Los Alamos Scientific Laboratory, "Main Technical Area," LASL Drawing No. ENG-R-537, March 3, 1959.

11. W. L. Kingsley to J. F. Tribby, "Overflowed Sewer," personal communication, June 19, 1946.

12. G. W. Knobeloch to C. I. Browne, "Alpha Pulse Analysis of TA-1 Soil Samples," personal communication, April 11, 1976.

13. H-1 General Monitoring Section, "Monthly Progress Report August 21, 1957, through September 20, 1957," Los Alamos Scientific Laboratory internal report. 
14. G. 'י. Knobeloch to C. I. Browne, "TA-1 Uranium," personal communication, October 2, 1975.

15. B. F. Schnap to J. F. Tribby, "Analysis of Dirt and Water Samples for Uranium," personal communication, January 8, 1948.

16. W. H. Langham, "Biological Considerations of Noonuclear Incidents Involving Nuclear Warhcads, " Lawrence Livermore Laboratory report UCRL-50639 (April 1969).
17. R. L. Kathren, "Towards Interim Acceptable Surface Contamination for Environmental $\mathrm{PuO}_{2}$," Battelle Pacific Northwest Laboratory report BNWL-SA-1510 (April 1968).

18. J. W. Healy, "A Proposed Interim Standard for Plutonium in Soils," Los Alamos Scientific Laboratory report LA-5483-MS (January 1974).

19. National Council on Radiation Protection and Measurements, "Permissible Dose from External Sources of Ionizing Radiation," National Bureau of Standards Handbook No. 59 (September 24, 1954). 


\section{GLOSSARY}

Acid sewer

Alpha particle

Beta particle

Curie

Fracture

Gamma ray

Gross alpha

Joint

Normal uranium

pCi (picu Curie)

$\mathbf{R}$

RCG (Radioactivity Concentration Guide)
A sewer system designed to receive wastes from laboratory-related activity, including liquids contaminated with hazardous chemicals and radioactivity, for transmission to industrial waste treatment facilities or other discharge points.

A charged particle emitted from the nucleus of certain radioactive atoms having a charge and mass equal in magnitude to those of a helium nucleus, i.e., two protons and two neutrons.

A charged particle emitted from the nucleus of certain radioactive atoms having a charge and mass equal to those of the electron.

The special unı of radioactivity. One curie equals $3.70 \times 10^{10}$ nuclear transformations per second (abbreviated $\mathrm{Ci}$ ).

Any break in a rock.

Short-wavelength elect romagnetic radiation of nuclear origin (has no mass or charge).

The total amount of measured alpha activity above natural alpha activity levels.

A plane of fracture in a rock.

Uranium having the isotopic content of uranium in nature $199.27 \%$ $\left.{ }^{239} \mathrm{U}, 0.72 \%{ }^{235} \mathrm{U}, 0.0057 \%{ }^{234} \mathrm{U}\right)$.

One millionth of a millionth of a curie ( $\mathrm{Ci}$ ). It is equivalent to 2.22 nuclear transformations per minute.

The symbol for the roentgen, the unit of radiation exposure. It applies only to the amount of charge produced by $x$ or gamma radiation in air. $1 \mathrm{R}=2.58 \times 10^{-4}$ coulombs per kilogram (exactly).

The concentration of radioactivity in the environment that is determined to result in whole-body or organ doses equal to the Radiation Protection Standards for external and internal exposures. 
TABLE E-XIV

LOW-ENERGY FIELD RADIATION MEASUREMENTS

(In gross counts per minute)

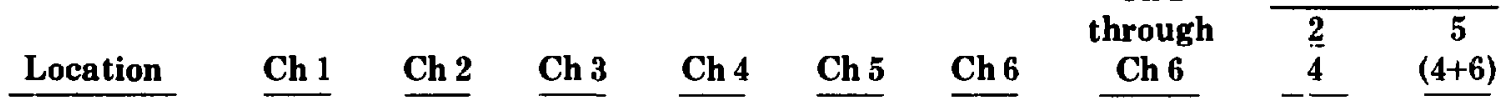

General Locations

\begin{tabular}{|c|c|c|c|c|c|c|c|c|c|}
\hline TA-1-1 & 304 & 503 & 554 & 233 & 1813 & 528 & 3935 & 2.16 & 2.38 \\
\hline TA-1-2 & 292 & 485 & 544 & 236 & 1823 & 516 & 3896 & 2.06 & 2.43 \\
\hline ТA-1-3 & 276 & 429 & 475 & 202 & 1600 & 463 & 3445 & 2.12 & 2.41 \\
\hline TA-1 $-4^{\mathrm{a}}$ & 2449 & 726 & 746 & 254 & 1833 & 901 & 4460 & 2.86 & 1.59 \\
\hline TA-1-5 & 334 & 466 & 516 & 217 & 1778 & 460 & 3437 & 2.15 & 2.63 \\
\hline TA-1-6 & 321 & 472 & 541 & 213 & 1789 & 536 & 3550 & 2.22 & 2.39 \\
\hline TA-1-7 & 340 & 546 & 587 & 226 & 1960 & 583 & 3902 & 2.42 & 2.42 \\
\hline TA-1-8 & 323 & 499 & 580 & 256 & 2092 & 561 & 3988 & 1.95 & 2.56 \\
\hline TA-1-9 & 314 & 476 & 515 & 216 & 1810 & 509 & 3526 & 2.20 & 2.50 \\
\hline TA-1-10 & 309 & 494 & 532 & 222 & 1905 & 519 & 3672 & 2.23 & 2.57 \\
\hline TA-1-11 & 306 & 504 & 607 & 254 & 2091 & 581 & 4037 & 1.98 & 2.50 \\
\hline TA-1-12 & 281 & 500 & 568 & 262 & 2332 & 537 & 4199 & 1.91 & 2.92 \\
\hline TA-1-13 & 293 & 428 & 492 & 212 & 1862 & 442 & 3436 & 2.02 & 2.85 \\
\hline TA-1-14 & 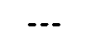 & $\ldots$ & $\ldots$ & $\ldots$ & ... & ... & -.. & -.. & -.. \\
\hline TA-1-15 & 361 & 522 & 548 & 244 & 2023 & 525 & 3862 & 2.14 & 2.63 \\
\hline TA-1-16 & 284 & 488 & 545 & 226 & 1818 & 506 & 3583 & 2.16 & 2.48 \\
\hline TA-1-17 & $\ldots$ & $\ldots$ & $\cdots$ & -.- & --- & $\cdots$ & $\ldots$ & $\cdots$ & $\cdots$ \\
\hline TA-1-18 & 343 & 567 & 601 & 265 & 2238 & 571 & $424 ?$ & 2.14 & 2.68 \\
\hline TA-1-19 & 307 & 534 & 605 & 248 & 2167 & 582 & 4136 & 2.15 & 2.61 \\
\hline TA-1-20 & $\cdots$ & --- & -- & $\cdots$ & --- & --- & -.. & --- & --- \\
\hline TA-1-21 & 331 & 549 & 615 & 274 & 2190 & 558 & 4186 & 2.00 & 2.63 \\
\hline TA-1-22 & 304 & 497 & 581 & 256 & 2057 & 532 & 3923 & 1.94 & 2.61 \\
\hline TA-1-23 & 366 & 484 & 567 & 246 & 2174 & 516 & 3987 & 1.97 & 2.85 \\
\hline TA-1-24 & 343 & 642 & 734 & 333 & 2960 & 705 & 5374 & 1.93 & 2.85 \\
\hline TA-1-25 & 357 & 591 & 709 & 321 & 2795 & 679 & 5095 & 1.84 & 2.80 \\
\hline TA-1-26 & 355 & 542 & 598 & 275 & 2365 & 602 & 4382 & 1.97 & 2.70 \\
\hline
\end{tabular}

Special Locations

$\begin{array}{lrllllllll}\text { TA-1 D-1 }^{\mathrm{a}} & 2340 & 695 & 733 & 255 & 1808 & 882 & 4373 & 2.73 & 1.59 \\ \text { TA-1 D-2 }^{\mathrm{a}} & 2256 & 702 & 721 & 263 & 1756 & 873 & 4315 & 2.67 & 1.55 \\ \text { TA-1 D-3 }^{\mathrm{a}} & 2424 & 719 & 729 & 255 & 1811 & 897 & 4411 & 2.82 & 1.57 \\ \text { TA-1 D2-1 } & 303 & 500 & 534 & 237 & 1850 & 525 & 3646 & 2.11 & 2.43 \\ \text { TA-1 D2-2 } & 285 & 525 & 565 & 232 & 1823 & 498 & 3643 & 2.26 & 2.50\end{array}$

-These measurements were zade with a different system. 
rem

\section{Sanitary sewer}

Tuff
The unit of dose equivalence used for radiation protection applications. It is the product of the absorbed radiation dose (D), the quality factor $\mathbf{Q}$ (which accounts for differences in biological effect between various types of ionizing radiation), and $\mathrm{N}$ the product of any other modifying factors (such as dose distribution in orga.ıs). rem $=\mathrm{DQN}$.

A sewer system designed to receive wastes from normal human activities, exclusive of iaboratory-generated wastes, for example, wastes from rest rooms, lavatories, showers, and fooa-handling activities, for transmission to septic tanks, treatment facilities, or other discharge points.

A compacted, extrusive, igneous rock comprising volcanic ash and dust.

\section{ACRONYMS}

AEC

ALAP

ALO

c

CPM

dis

ERDA

FIDLER

HPIC

LAAO

LAFPHA

LASL

MFP

MPC

NCRP

pCi

RCG

rem

TLD

$\mathrm{ZnS}$
Atomic Energy Commission

as low as practicable

Albuq'1erque Operations Office

counts

counts per minute

disintegrations

Energy Research and Development Administration

Field Instrument for Detection of Low inergy Radiation

high-pressure ionization chamber

Los Alamos Area Office

Los Alamos Field Pulse Height Analyzer

Los Alamos Scientific Laboratory

mixed fission producis

maximum permissible concentration

National Council on Radiation Protection

pico curie

Radioactivity Concentration Guide

roentgen equivalent man

thermoluminescent dosimeter

zinc sulfide 


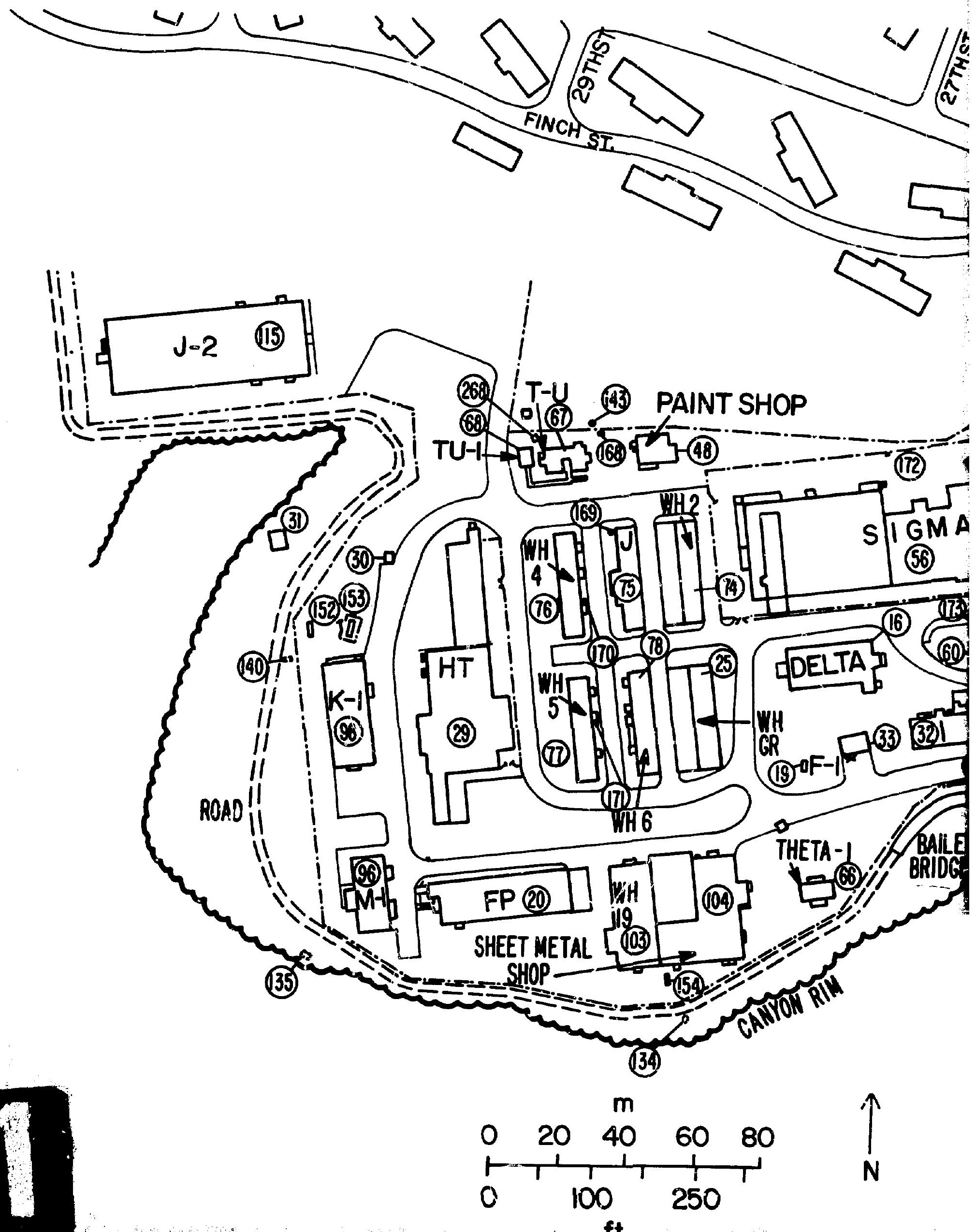




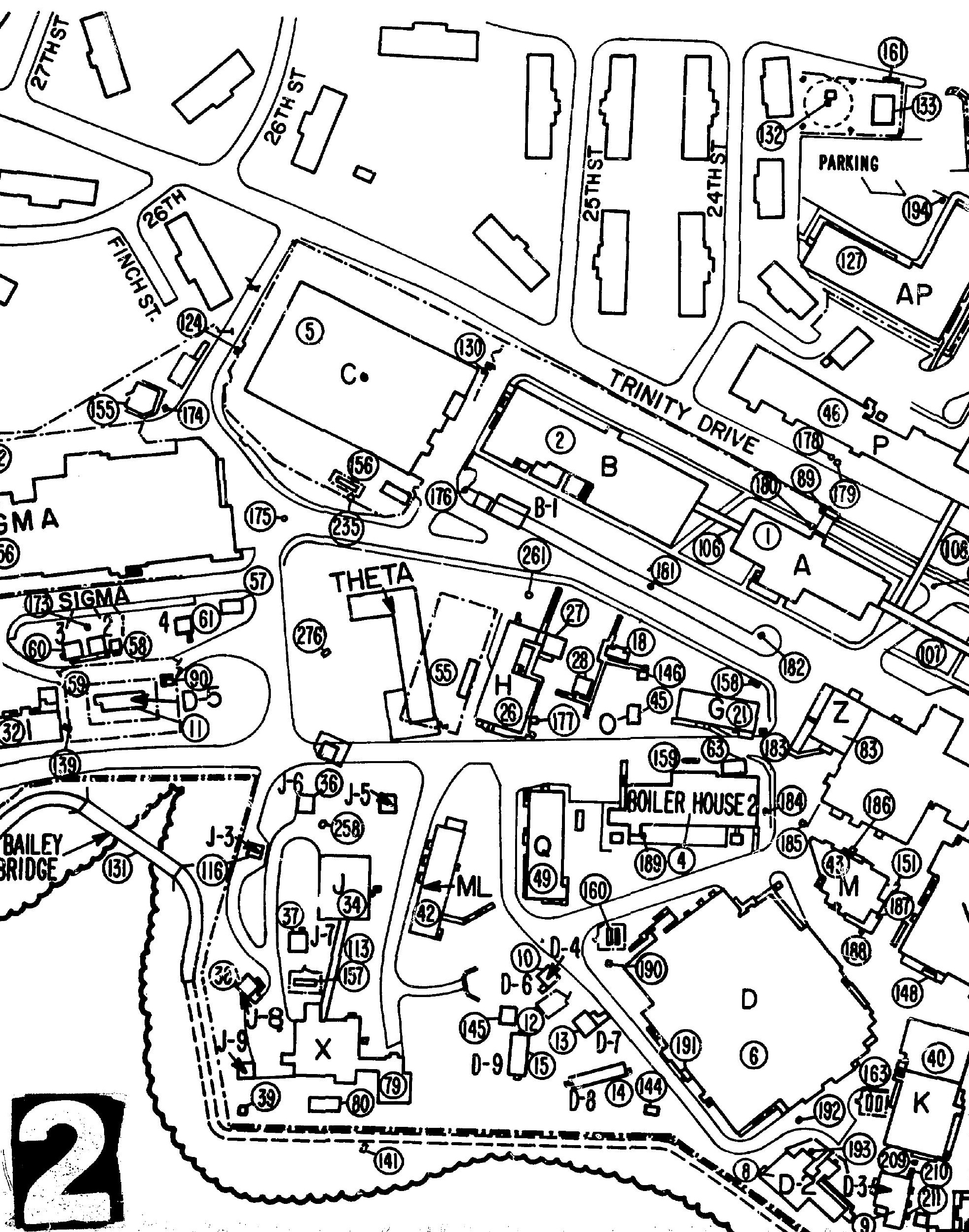




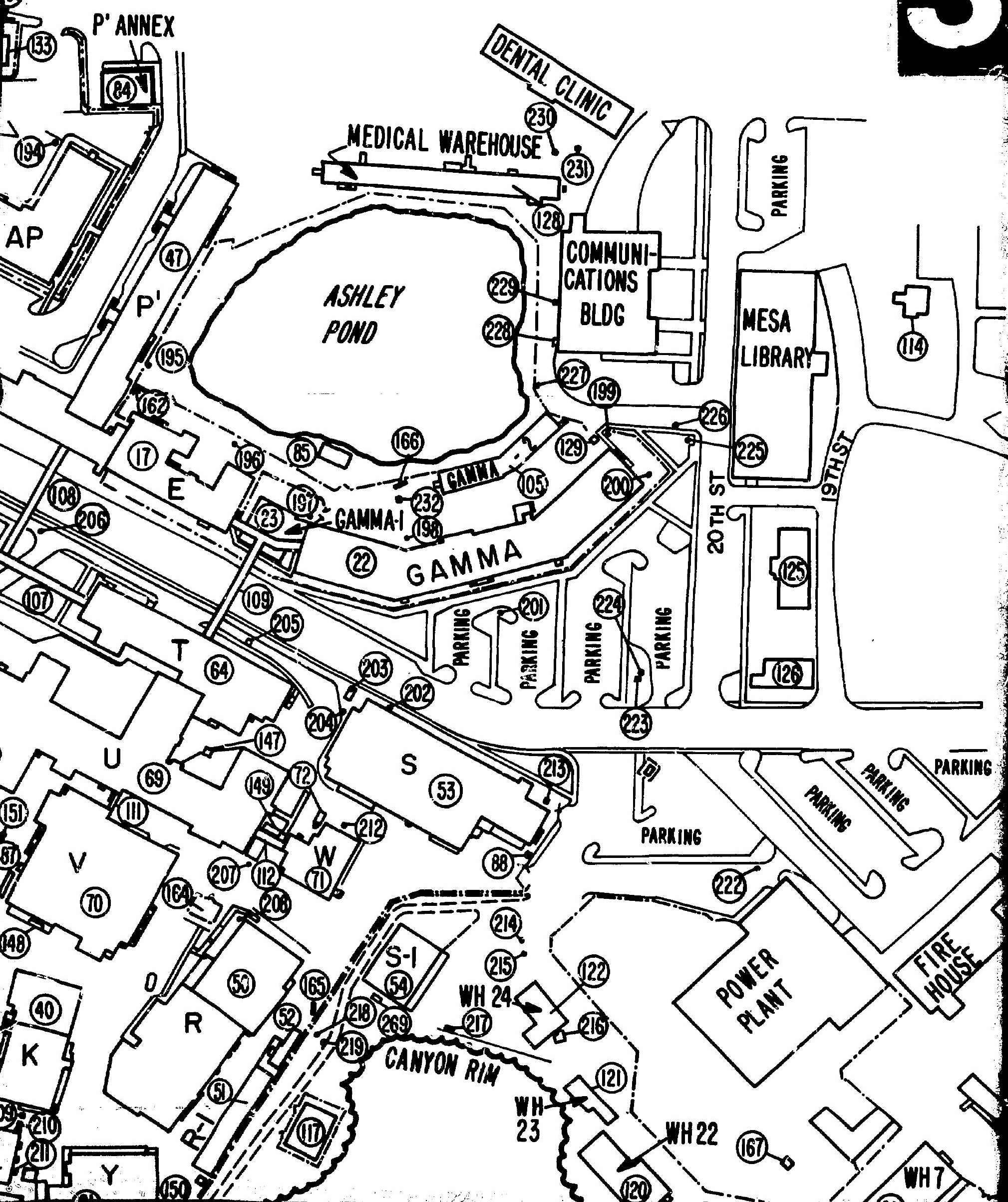




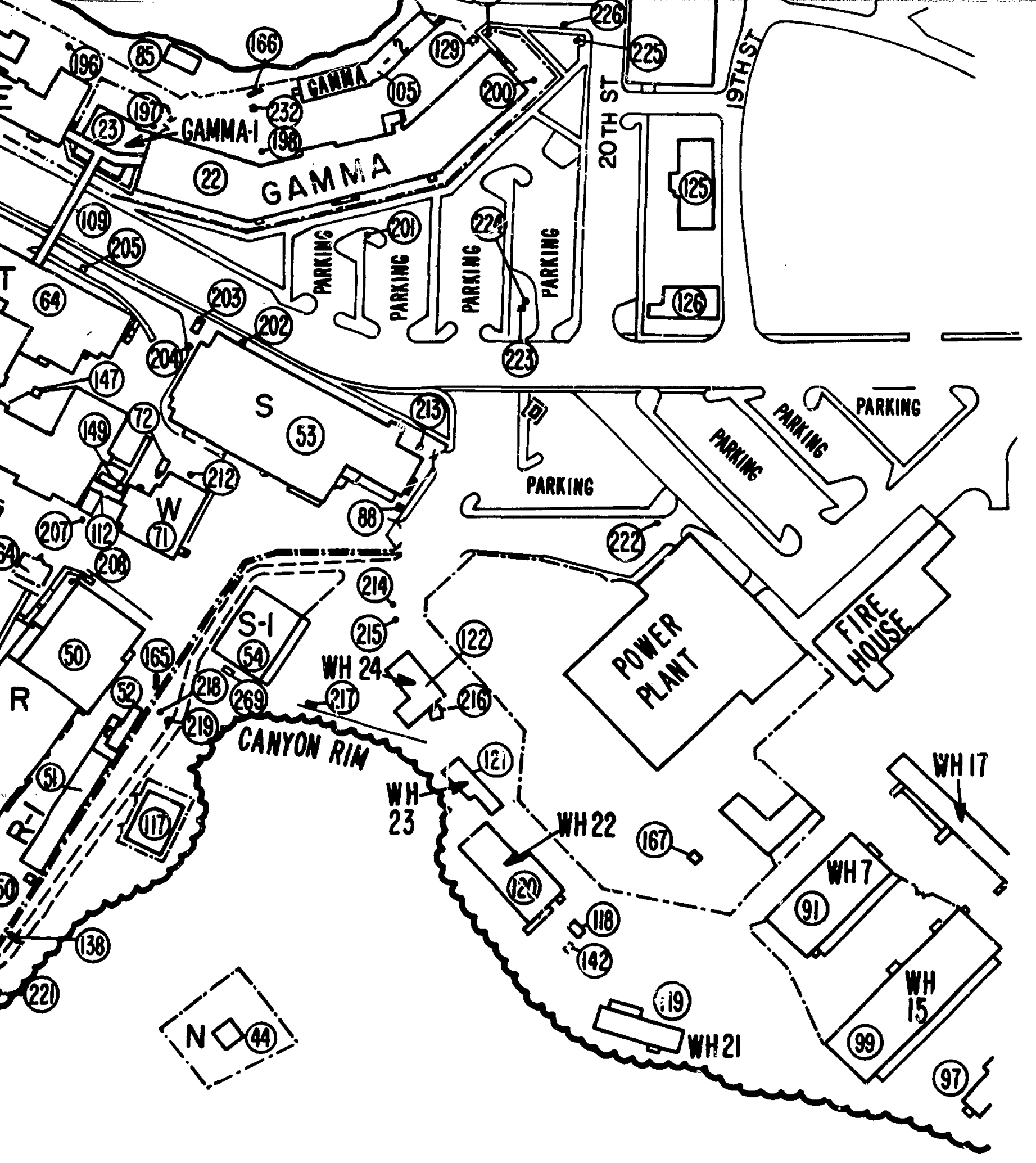




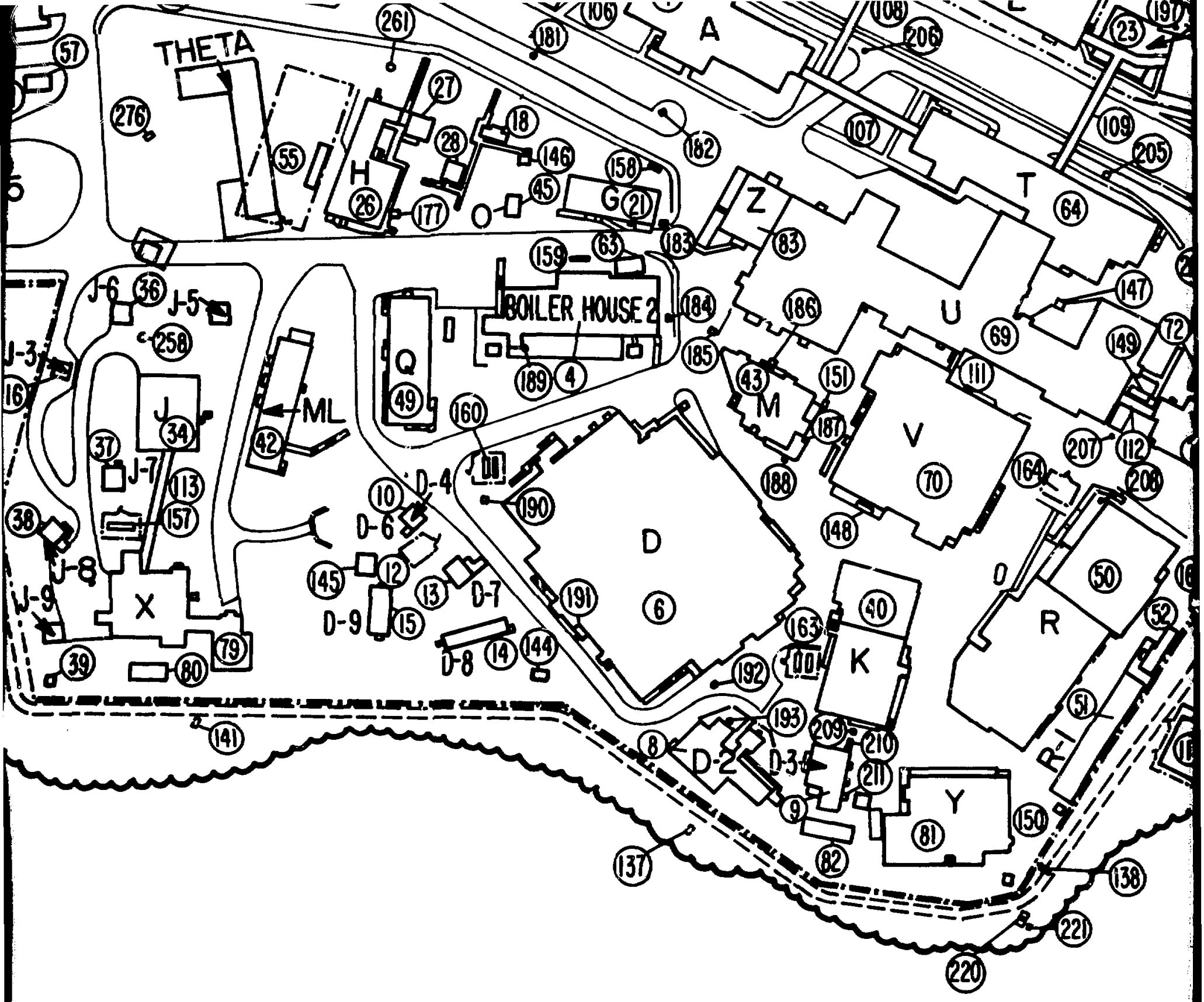

Fig. 8. TA-I, circa 1955 
$a_{(1-26)}$

0

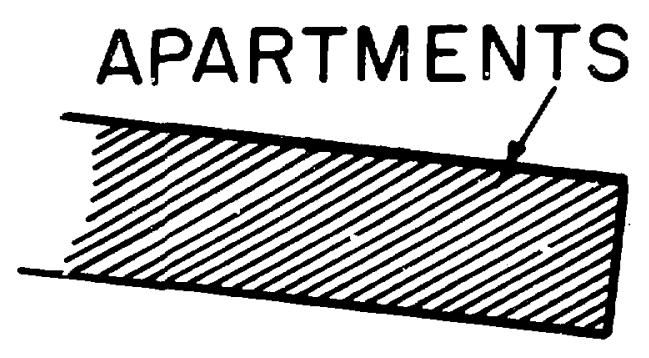

0

$$
(w-4) \quad(1-23)
$$

$O(1-25)$

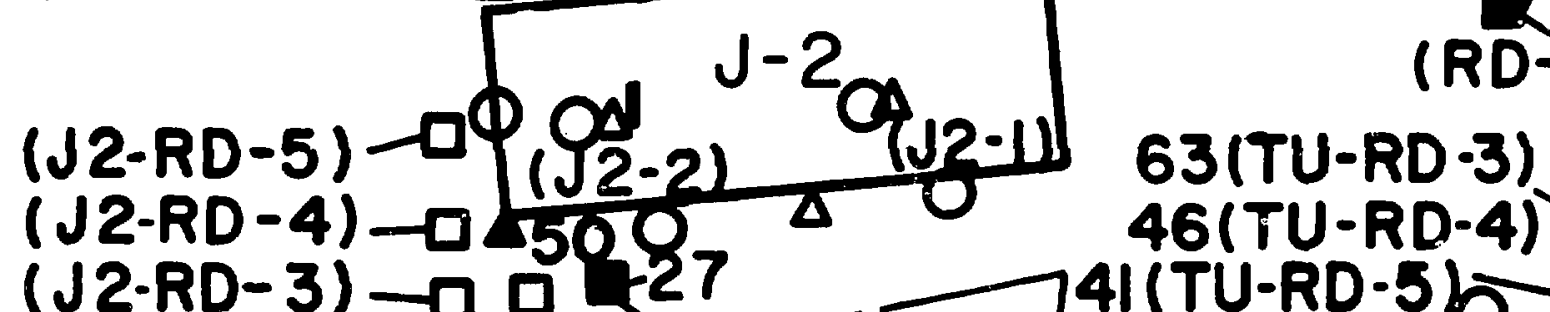

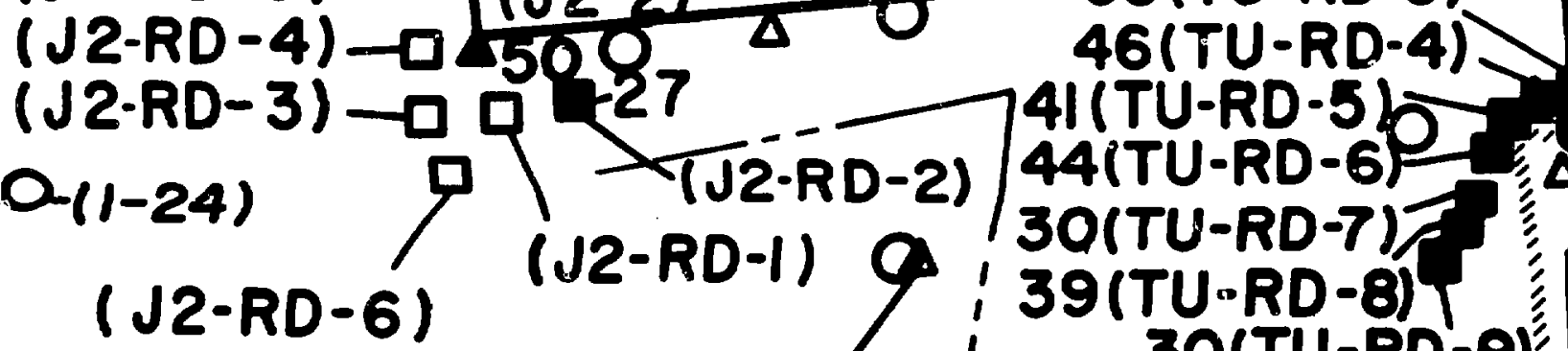

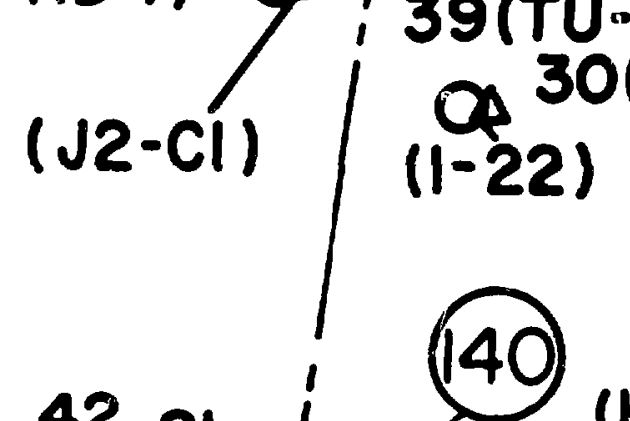

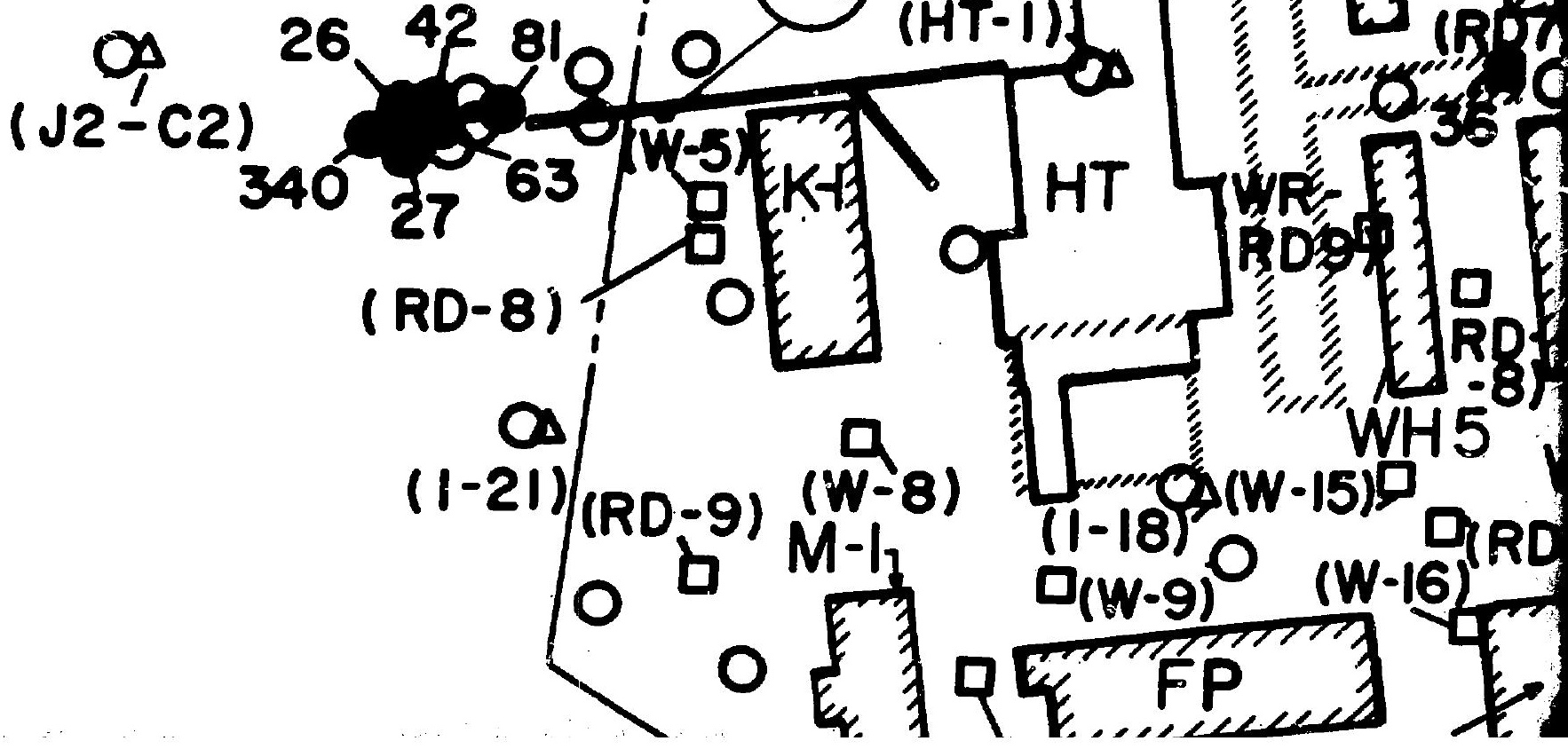





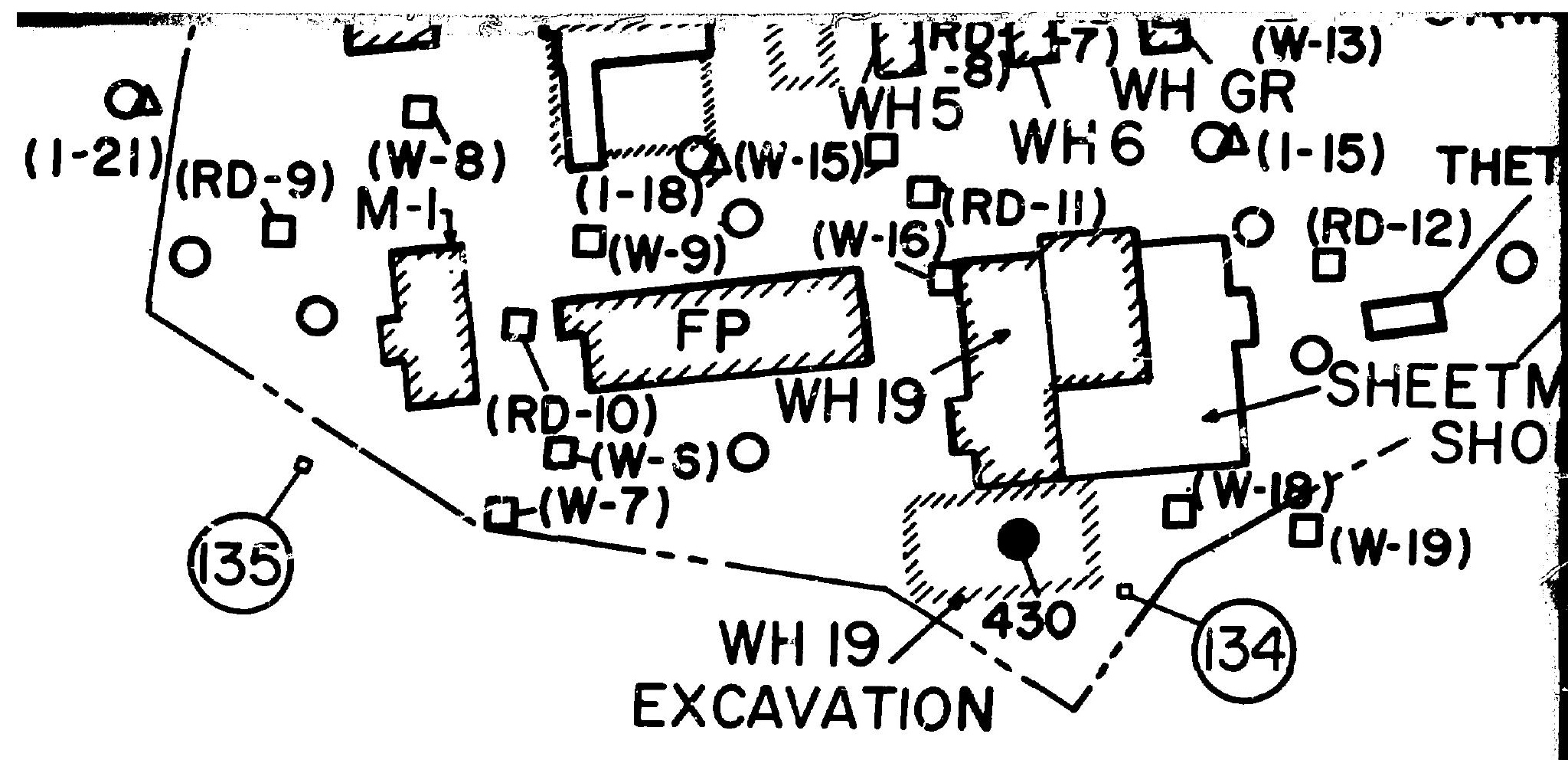

OA

(BB

Od

$(B B-6)$ 


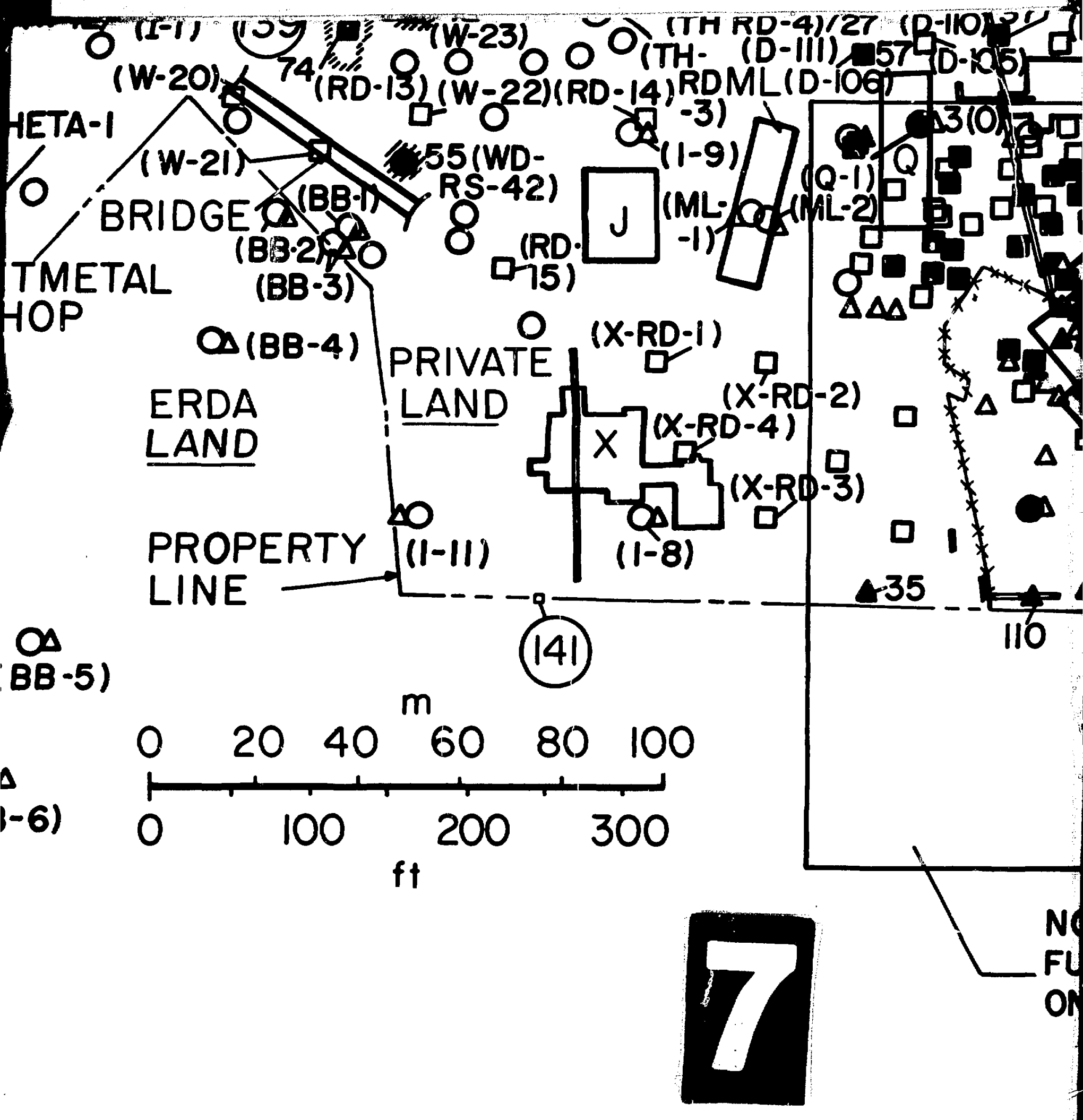




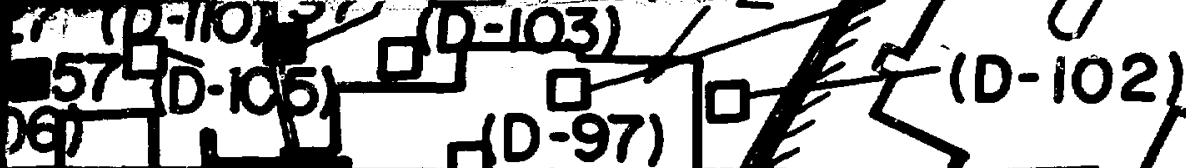
2) P

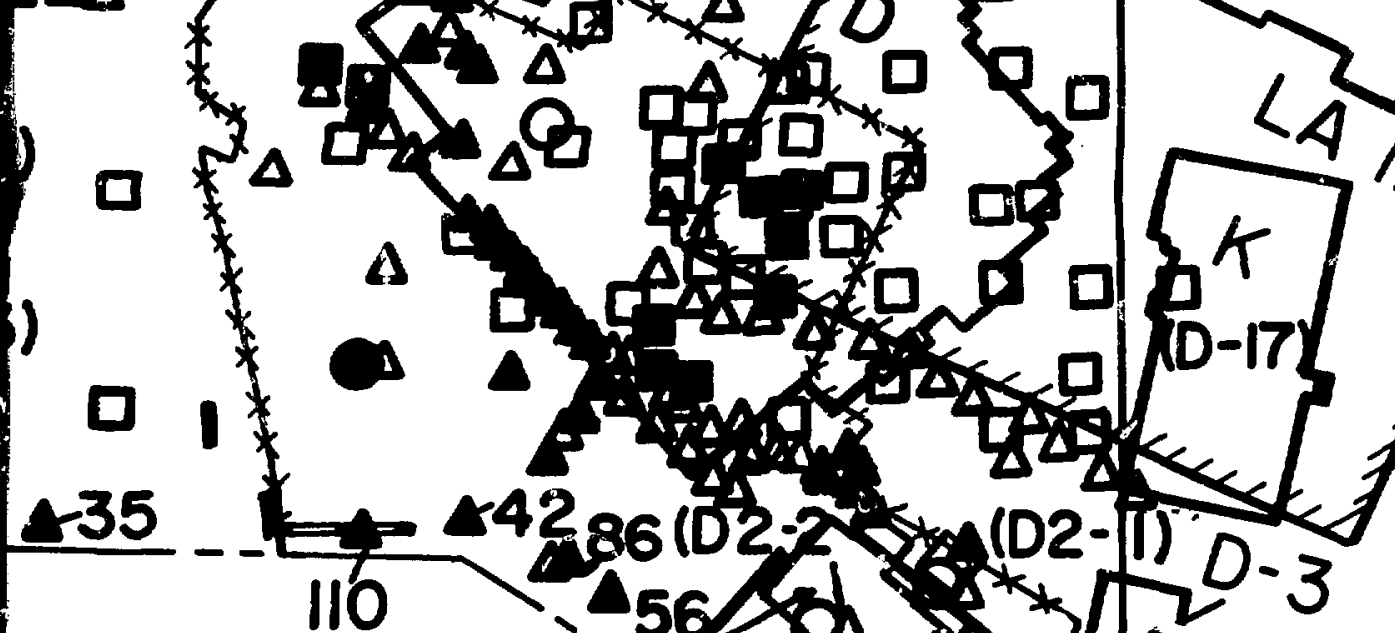
110 - $56<2+0.3$ 0.2

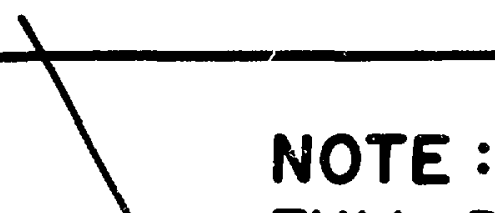

FULL DETAIL FOR THIS AREA ON ALTERNATE MAPS

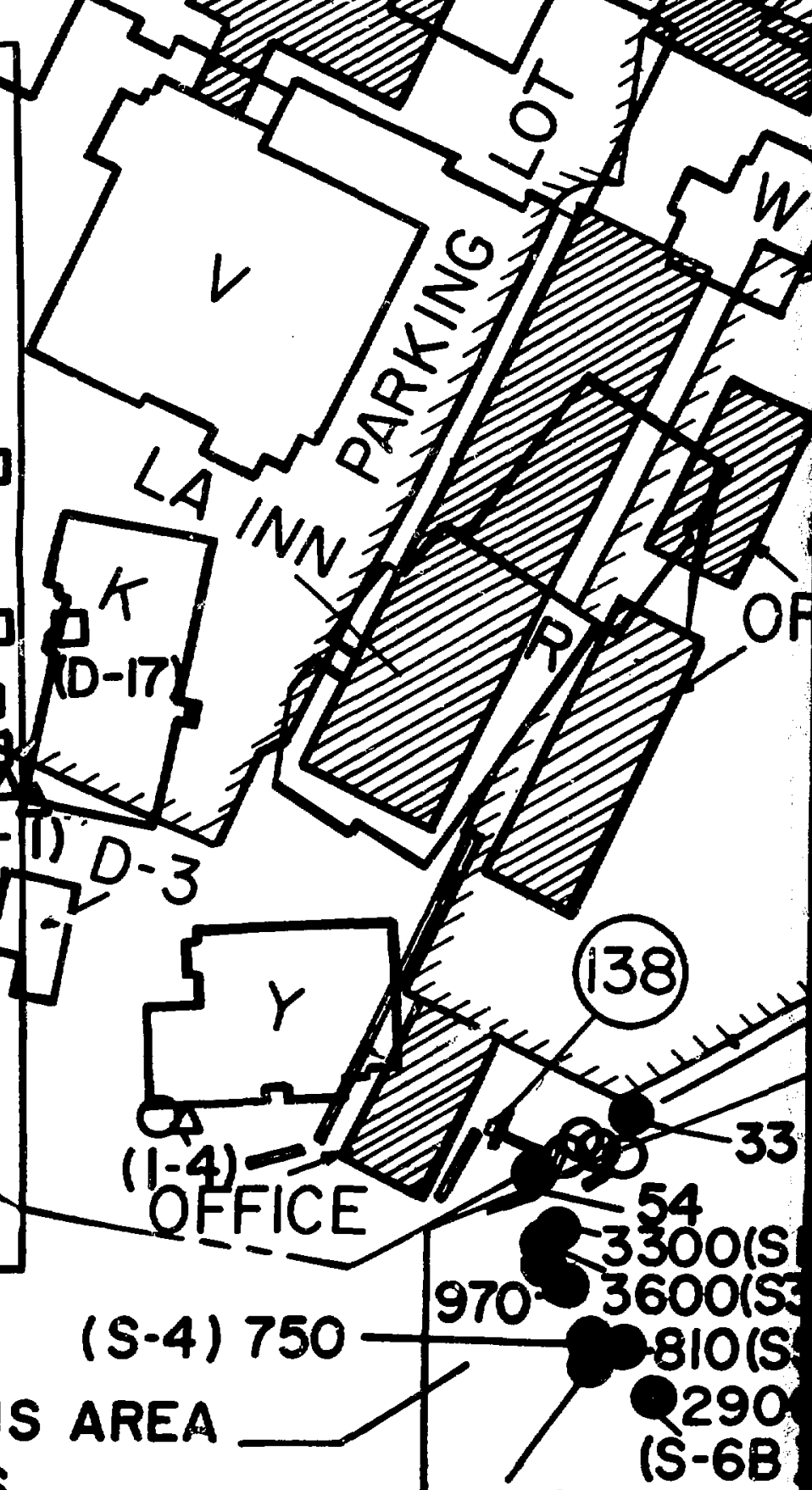

$(S-6) 2000$

area survey results at $T A-1$ 


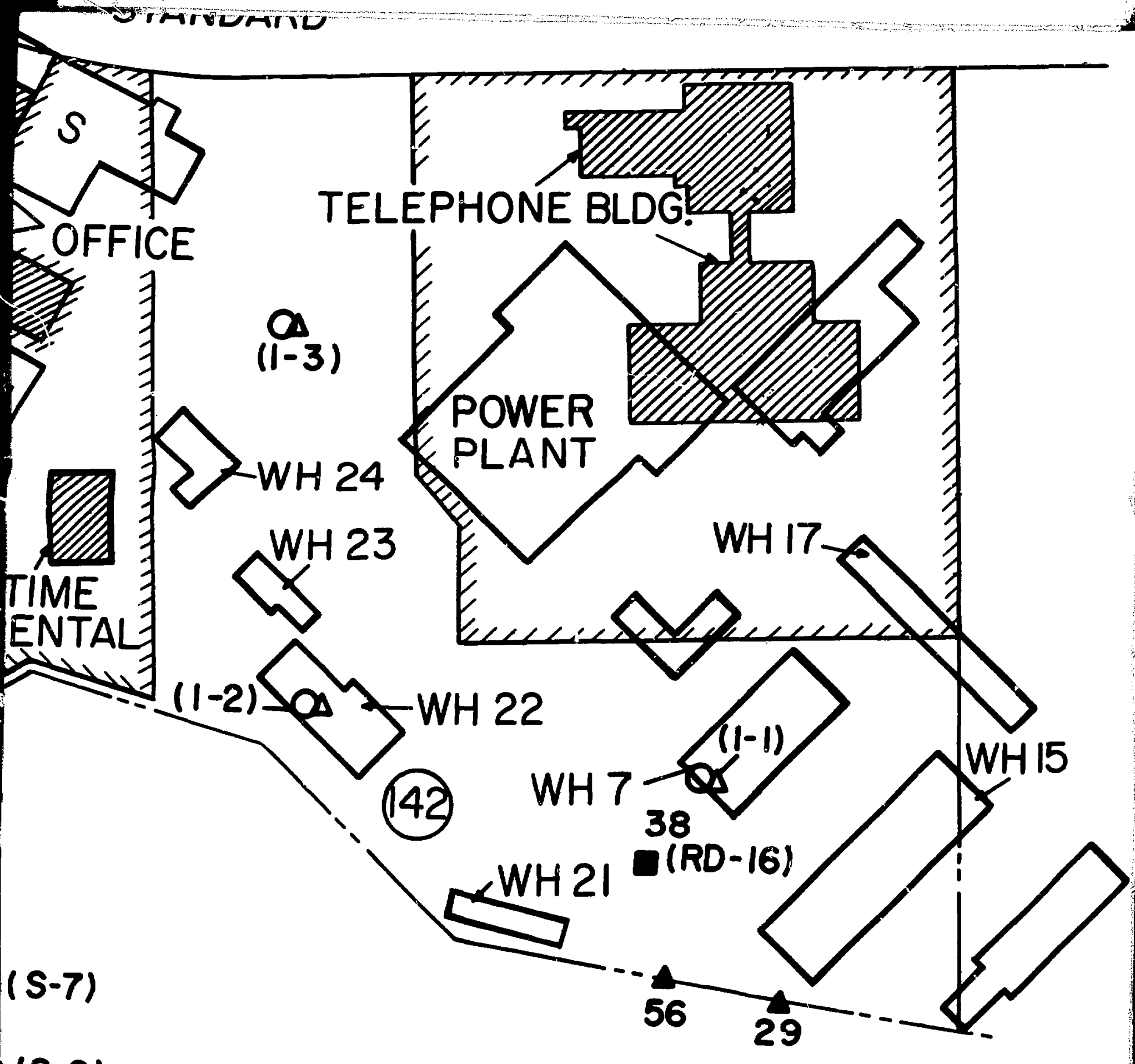

